UNIVERSIDAD NACIONAL DE LA PLATA

FACULTAD DE HUMANIDADES Y CIENCIAS DE LA EDUCACIÓN SECRETARÍA DE POSGRADO

\title{
Catolicismo liberacionista y militancias contestatarias en Bahía Blanca: sociabilidades y trayectorias en las ramas especializadas de Acción Católica durante la efervescencia social y política de los años ' 60 y '70
}

\author{
Virginia Lorena Dominella
}

Tesis para optar por el grado de Doctora en Historia

Director: Dr. Aldo Ameigeiras (UNGS - CONICET)

Codirector: Dr. Daniel Lvovich (UNGS - UNLP - CONICET)

La Plata, 8 de junio de 2015 


\section{RESUMEN}

Diversos autores han llamado la atención sobre la influencia del cristianismo liberacionista en los acontecimientos más importantes de las últimas décadas en América Latina. Esta investigación, que se enmarca teórica y metodológicamente en el campo de la Historia Reciente, tiene por objetivo comprender las relaciones entre catolicismo liberacionista y política en el escenario de la efervescencia social y de las tensiones entre religión y política de los años sesenta y setenta en Argentina, a partir de la historización y análisis de ese proceso en la ciudad de Bahía Blanca. En particular, se detiene en el cruce entre la religión y la política en las trayectorias de los integrantes de la Juventud Universitaria Católica (JUC), la Juventud Estudiantil Católica (JEC) y la Juventud Obrera Católica (JOC) en el período 1968-1975.

En este sentido, reflexiona en torno a una serie de interrogantes, a saber: ¿qué afinidades podemos reconocer entre el catolicismo liberacionista y diversas opciones de compromiso?, ¿de qué forma el paso por los grupos de reflexión cristianos marcó las trayectorias militantes de los actores?, ¿cómo influyeron tanto los nuevos documentos eclesiales y los teólogos de la liberación como la materialidad constitutiva de las relaciones sociales?, ¿en qué medida el fenómeno del catolicismo integral aporta elementos para comprender el compromiso temporal de los jóvenes católicos en los años sesenta y setenta?, ¿cuáles fueron sus espacios de construcción social y política?, ¿por qué algunos canalizaron su compromiso cristiano a través de la militancia políticapartidaria?, ¿por qué buena parte de ellos eligió el peronismo revolucionario?, ¿qué debates, dilemas y opciones planteó la cuestión de la violencia y la lucha armada entre estos militantes?, ¿en qué medida la militancia de los jóvenes católicos tenía peculiaridades que permitían identificarla dentro de la militancia revolucionaria bahiense?, ¿qué particularidades asumió este proceso para los estudiantes secundarios, los universitarios y los trabajadores?, ¿cómo impactó en los grupos de revisión de vida el "contacto con el mundo" de sus miembros?, ¿en qué medida se planteó la necesidad de optar entre la estructura eclesial y la militancia política? ¿Hubo distintas formas de integrar la fe y la política?

Para llevar adelante este abordaje, se ha optado por la investigación cualitativa y, en este sentido, por la utilización de diversas estrategias, desde entrevistas en profundidad (ahondando en trayectorias y relatos de vida) hasta el análisis de distintas fuentes empíricas (que incluyen testimonios éditos, producciones literarias de los 
actores, prensa, informes de inteligencia, volantes, fotografías, etc.), apelando a estrategias de triangulación para lograr una comprensión en profundidad del problema en cuestión.

El desarrollo de la tesis se organiza en siete capítulos. El primero busca ubicar a la JUC, la JOC y la JEC bahienses en su contexto histórico, social, político y eclesial. El capítulo 2 trata sobre las tres ramas de Acción Católica que funcionaron en Bahía Blanca a fines de los años sesenta y primera mitad de los años setenta, y sus antecedentes a nivel nacional y local. El capítulo 3 se propone ubicar a estas organizaciones laicales en relación a otros espacios de sociabilidad y referentes del catolicismo liberacionista de la ciudad, del país y de América Latina, así como a la jerarquía y a los sectores eclesiales locales renuentes a aceptar la renovación eclesial. El capítulo 4 procura dar cuenta del proceso mediante el cual los jucistas, jecistas y jocistas se acercaron a la sociedad y a la política. Los siguientes dos capítulos estudian la acción política de los militantes en vistas a concretar lo que entendían como un proyecto de construcción de un Hombre Nuevo y una sociedad más justa. Así, el capítulo 5 se ocupa de las iniciativas emprendidas colectivamente por los grupos identificados con el catolicismo liberacionista para denunciar las situaciones que consideraban injustas, mientras el capítulo 6 se centra en las múltiples formas de intervención social y política asumidas por los jóvenes en diversos ámbitos. El capítulo 7 atiende a los conflictos experimentados por los militantes y por los movimientos especializados de juventud bahienses a partir de su compromiso "temporal".

PALABRAS CLAVES: catolicismo liberacionista, militancias contestatarias, Bahía Blanca, años sesenta y setenta. 


\section{AGRADECIMIENTOS}

Esta tesis es el producto de muchos años de trabajo y ha tomado forma gracias a distintas personas que de diversas maneras me ofrecieron su presencia, compañía, aliento y ayuda. Quisiera agradecer, en primer lugar, a los protagonistas de esta historia por brindarme sus testimonios, por abrirme las puertas de su casa, de su historia y de su corazón para compartir sus experiencias y vivencias, muchas veces dolorosas, y en este sentido, por animarse a hablar, tal vez por primera vez, de aspectos de su vida silenciados y olvidados -en ese "olvido necesario" para seguir viviendo, al decir de Elizabeth Jelin-; por su disponibilidad para responder a mis dudas por mail y por teléfono; por contactarme con otros actores y facilitar los siguientes encuentros; por abrirme sus archivos y prestarme sus fotos, sus cartas, sus informes de la DIPPBA, sus apuntes, sus revistas, sus libros, sus volantes o sus cancioneros. Quiero recordar especialmente al padre "Pepe" Zamorano, quien partió en septiembre de 2012 y con quien compartí dos intensos encuentros en Moreno y uno durante su último viaje a Bahía Blanca, en los que me cautivó con su sencillez, su coherencia, su lucidez, la sabiduría que le daban sus 80 años y la juventud de su espíritu y sus ideas. También quiero traer a los integrantes de la JEC y de la JUC asesinados y desaparecidos por las Fuerzas Armadas y de seguridad durante la última dictadura militar, quienes, junto a los sobrevivientes de la violencia represiva, escribieron esta historia pero, a diferencia de los entrevistados, no han podido contarla con su propia voz aunque han dejado su testimonio vital y su entrega. Eduardo Ricci, María Clara Ciocchini, Ely Frers, Horacio Russin, Néstor Junquera, María Eugenia González, Alberto Paira ¡PRESENTES!

Quiero agradecer a mis directores Aldo Ameigeiras y Daniel Lvovich, por confiar en mí y aceptar acompañar mi propuesta sin conocerme, por la lectura atenta, seria, minuciosa de mis textos, por ayudarme en la cocina de la investigación, formándome en los aspectos metodológicos, por su disposición a atender mis dudas y a reunirse conmigo entre mate y mate siempre que lo necesité, y fundamentalmente, por la calidez humana con la que hacen su trabajo, por entenderme y alentarme en los momentos en que la vida personal se volvía intensa y cambiante.

A Silvina Jensen, mi directora de tesina y co-directora de beca, quien también es una referente clave en mi recorrido de investigación, al ser quien me acercó al campo de la historia reciente y la historia oral, me formó en el oficio, me ofreció generosamente 
sus libros, su tiempo, su experiencia y su lucidez intelectual para leer incisivamente mis producciones y ayudarme organizar mi cronograma de trabajo.

A las instituciones estatales en las que estudié o que respaldaron mi formación, permitiéndome trabajar de lo que me gusta durante todos estos años: la Universidad Nacional del Sur, la Universidad Nacional de La Plata, la Comisión de Investigaciones Científicas y, especialmente, el Consejo Nacional de Investigaciones Científicas y Técnicas.

A las personas e instituciones que me posibilitaron el acceso a la documentación: a Marina Huentenao y la gente de Cáritas Bahía Blanca; a Julieta Ferragine y Pamela Alarcón del Archivo Histórico Salesiano de la Patagonia; a Emma Vila, secretaria-canciller del Arzobispado; a Sergio Boada de la Biblioteca del Colegio Máximo de San Miguel; a los trabajadores del Archivo de la Comisión Provincial por la Memoria.

A mis compañeras de la UNS, con las que pensamos juntas la historia reciente local: Ana Vidal, Julia Giménez, Ana Inés Seitz, Andrea Rodríguez, Belén Zapata, Florencia Fernández Albanesi y Lorena Montero, especialmente a Ana, Julia, Ana Inés y Andrea por su amistad, por leer mis borradores y elaborar devoluciones siempre inteligentes, comprometidas, sinceras, por su disposición para encontrarnos por skype y por mail para charlar sobre los textos y la vida, por recopilar material para mí, por hospedarme en sus casas. A Alejandra Pupio y Romina Frontini, por la escucha y los consejos que desde otra especialidad me brindaron durante todo el recorrido investigativo.

A otros colegas y profesores, que me compartieron material, o leyeron versiones preliminares de algunas partes de esta tesis cuando tenían la forma de ponencias o trabajos finales de seminario, brindándome devoluciones que enriquecieron mi perspectiva.

A la familia Migliorisi, por apoyarme y acompañarme en estos años de investigación: a Pedro por su contención y compañía; a Beto e Inés, por los mates y los almuerzos, por darme un lugar en su auto para ir y volver de Buenos Aires, prestarme materiales y facilitarme los contactos con los entrevistados; a Laura y a Leandro por hospedarme con tanto cariño mientras hacía cursos de posgrado, asistía a las jornadas científicas o me reunía con Aldo y con Daniel, y a Fermín por alegrar mis estadías con sus juegos, sus canciones, sus cuentos y sus abrazos. 
A Olga y Andrés, mis vecinos y amigos de Villa Ventana, por su generosidad, por tenerme en cuenta siempre que viajaban a Buenos Aires y por la hospitalidad con la siempre me tratan en San Isidro.

Y muy especialmente, quiero agradecer a los "pilares" afectivos, las personas en las que hoy me apoyo y que constituyen mi refugio, las responsables de que transite la vida -incluido el trabajo-, con felicidad, llenándola de sentido. A mis padres, Carlitos y Silvia, por su amor incondicional, por sostenerme en todos los sentidos, por regalarme la libertad para elegir los rumbos de mi vida y aceptarme incluso sin estar necesariamente de acuerdo, y su disposición a acompañarme en este trabajo, desde su paciencia para aguantar mis cambios de humor, hasta los gestos más cotidianos como llevarme e ir a buscarme a la terminal. A mi hermano Leo, por su amor y su generosidad, por darme un lugar en su casa en los períodos en que estudiaba en Buenos Aires y La Plata. A Luna, Zamba, el Negro y Roberto, también integrantes de la familia, por su leal y divertida compañía. A mis sobrinos -Felipe, Camilo-, por alegrarme los días con sus ojos de universo nuevo.

A mis amigos, que son mis otros hermanos, por celebrar la vida desde el compromiso, la autenticidad, la sonrisa, la música y la utopía. Por su amistad infinita. En especial a Fredy por acercarme a la historia de los "cristiancuhis" y prestarme sus libros; a Fran López Corral, por compartir los ratos de estudio en las bibliotecas de la universidad y en nuestras casas y las angustias del proceso de escritura de las tesis; a Ana Dorado, por hacerme sentir en casa en mis días de trabajo en Buenos Aires; a Valeria, por animar nuestra convivencia durante el 2010, cuando era casi nómade y empezaba a transitar el doctorado; a Noelia, Anita, Julieta, Ana, Sabrina, Mayra, Emilce, Clara, Maju, por hacer de la "reunión de chicas" un espacio para poner en común las alegrías y los sinsabores de los trabajos y los días.

A mi hijo, Facundo, que está llegando al mundo, que me inspiró, me dio impulso y me acompañó haciendo olas desde la panza estos últimos siete meses intensos, de cambio y crecimiento.

A Alejandro, el papá de Facu, por enseñarme que no soy "la tesis", que se puede poner el corazón a la tarea y al mismo tiempo ubicar las prioridades en disfrutar de la vida y el amor, incluso, sin importar qué pase mañana. Y a Santi, por alegrar con sus aventuras mis descansos de escritura. 


\section{ÍNDICE}

\section{INTRODUCCIÓN}

1) Presentación del tema................................................ 10

2) Marco teórico y estado de la cuestión................................14

3) Objetivos, hipótesis y precisiones conceptuales.........................24

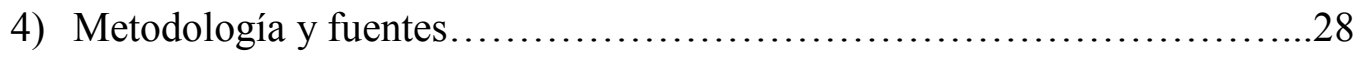

5) Organización de los capítulos.......................................

\section{CAPÍTULO 1: El marco interpretativo del acercamiento a la sociedad y a la política}

1) La efervescencia social y política de los años sesenta y setenta..............38

2) Cambios y continuidades del catolicismo argentino y latinoamericano......47

a) La matriz del catolicismo integral...............................56

b) El aggiornamento eclesial y sus implicancias sociales y políticas

i) Los documentos eclesiales: una nueva concepción de la Iglesia y de su relación con el mundo.

ii) La lectura de los Sacerdotes para el Tercer Mundo y de Cristianismo y Revolución: fe, política y revolución...................65

c) La teología de la liberación: repensar la fe desde América Latina.....72

\section{CAPÍTULO 2: Las ramas especializadas de Acción Católica en Bahía Blanca.....85}

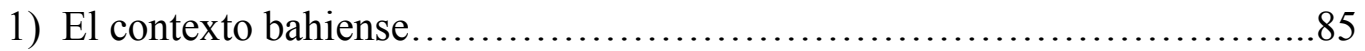

2) La JUC, la JOC y la JEC

a) Orígenes y desarrollo en Argentina.

b) Antecedentes locales

i) La Juventud Obrera Católica

ii) La Acción Católica Universitaria.

iii) Los Círculos y Centros de Estudiantes Secundarios de la Acción Católica.

c) Los grupos en el período 1967-1975

i) Los asesores. .129

ii) Los grupos de "revisión de vida" 
CAPÍTULO 3: Espacios de sociabilidad y redes sociales del catolicismo liberacionista en Bahía Blanca.............................................. 148

1) Grupos y referentes

a) Los laicos. 149

b) Los sacerdotes "tercermundistas"...............................153

c) Las religiosas............................................. 157

2) Vínculos e interacciones

a) Los lazos tejidos entre los católicos liberacionistas en el espacio local......................................................... 160

b) Los grupos de la renovación católica y otros sectores eclesiales en la ciudad......................................................... 172

i) Cruces y conflictos..................................179

c) La articulación con otros ámbitos del catolicismo liberacionista a nivel nacional e internacional..............................192

i) MSTM, CUT, Cristianismo y Revolución...................192

ii) Las redes jocistas......................................194

iii) El MIEC-JECI......................................... 197

iv) Las influencias de los teólogos latinoamericanos..........209

CAPÍTULO 4: De la revisión de vida al despertar del compromiso cristiano.....215

1) Ver, Juzgar y Actuar............................................2217

2) Una nueva forma de vivir la fe....................................228

3) El descubrimiento de "la realidad" y el impulso al compromiso..........234

CAPÍTULO 5: La denuncia profética....................................263

1) Los sectores liberacionistas se defienden.............................264

2) La oposición a la dictadura de Onganía..............................271

3) Iniciativas frente a los atropellos policiales..........................273

4) El repudio a la Masacre de Trelew.................................274

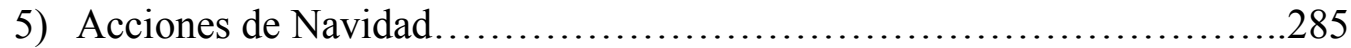

6) La lucha contra el Camino de Cintura...............................287

CAPÍTULO 6: El anuncio del Reino de Dios. Espacios y prácticas de la militancia católica. .300 
1) La acción pastoral.................................................301

a) E1 MIEC-JECI y la JOC .....................................302

b) Scouts y Guías................................................ 308

c) La liturgia y la catequesis.................................. 310

2) El trabajo social

a) El voluntariado de Cáritas......................................313

b) La presencia en los barrios periféricos. El caso de Villa Nocito.......315

3) La militancia en el lugar de trabajo....................................320

4) La militancia estudiantil: la escuela secundaria y la universidad.............327

5) La militancia política y las opciones político-partidarias..............................341

a) El "encanto y desencanto" con agrupaciones marxistas..............346

b) La opción por el peronismo revolucionario

i) ¿Por qué el peronismo?.........................................................350

ii) Las redes católicas y la militancia política.....................367

iii) Las afinidades entre catolicismo liberacionista y

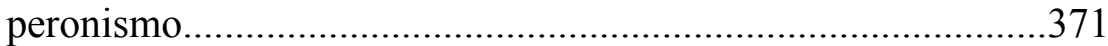

c) La lucha armada como forma de hacer política....................376

\section{CAPÍTULO 7: Las tensiones entre catolicismo liberacionista y militancias}

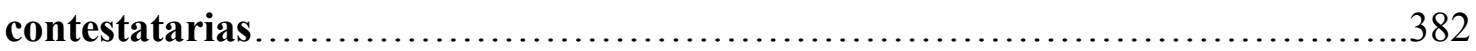

1) La preponderancia de la militancia política............................383

2) La convivencia entre diversas opciones ideológico-políticas...............388

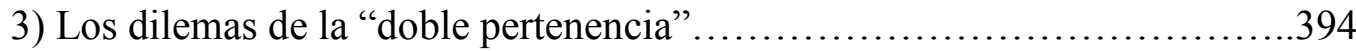

a) Militantes políticos en los grupos cristianos......................395

b) "Cristianuchis" en las agrupaciones políticas.....................403

c) Militantes católicos y/o activistas políticos.....................406

4) Debates y conflictos en torno a la vía armada...........................421

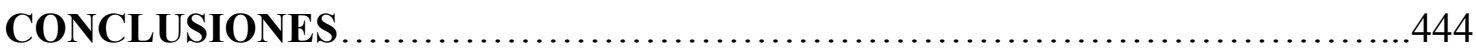

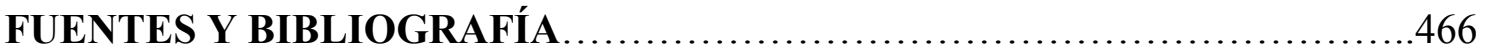

ANEXO METODOLÓGICO (en CD adjunto) 


\section{INTRODUCCIÓN}

\section{SUMARIO}

1) Presentación del tema

2) Marco teórico y estado de la cuestión

3) Objetivos, hipótesis y precisiones conceptuales

4) Metodología y fuentes

5) Organización de los capítulos

\section{1) Presentación del tema}

Esta investigación se centra en la Juventud Universitaria Católica (JUC), la Juventud Obrera Católica (JOC) y la Juventud Estudiantil Católica (JEC) en Bahía Blanca. Estos movimientos especializados de juventud, constituidos en Argentina en las décadas de 1940 y 1950, desarrollaban su acción pastoral en ámbitos particulares (el mundo del trabajo y el estudiantil), haciendo de ese "apostolado" en el propio “ambiente" su razón de ser (Mallimaci, 1992) ${ }^{1}$. Se trataba de grupos de jóvenes que se reunían semanalmente, en pequeñas comunidades y con la compañía de un sacerdote asesor, a reflexionar mediante el ritmo de Ver, Juzgar y Actuar -práctica encuadrada en la metodología de la "revisión de vida", que comenzó a usarse en la Acción Católica, especialmente en los orígenes de la JOC, y que la encíclica Mater et Magista del Papa Juan XXIII constituyó en el modo fundamental de analizar la realidad enmarcada en la Doctrina Social de la Iglesia- ${ }^{2}$. Los grupos en los que se centra esta tesis surgieron en Bahía Blanca hacia 1967 (JUC), 1968 (JOC) y 1972 (JEC), y funcionaron hasta 1975. La rama universitaria llegó a reunir alrededor de 40 jóvenes; la JOC, a 18; y la JEC, a unos 30. Las tres organizaciones compartían el asesor, espacios de encuentro y acción, e iniciativas públicas, y sus miembros estaban unidos por relaciones afectivas y de parentesco. Los intercambios y vínculos entre los grupos, así como las dimensiones que adquirieron en la ciudad, permiten el abordaje conjunto.

Estos movimientos se identificaron con la renovación eclesial y, más aún, con el "catolicismo liberacionista", pero estaban enraizados en el desarrollo del movimiento católico en las décadas previas. En efecto, sin negar la influencia de los cambios del catolicismo en los años sesenta, es necesario adoptar una mirada de largo plazo y ligar

\footnotetext{
${ }^{1}$ En el capítulo 2 me detendré en sus orígenes y desarrollo a nivel nacional y local.

${ }^{2}$ Mencionaré esta metodología en el capítulo 1 y 2, y la analizaré en profundidad en el capítulo 4.
} 
esta corriente eclesial con un modo particular de concebir y de vivir el catolicismo, el "catolicismo integral". Así, a partir del paso por la JUC, la JEC y la JOC, sus integrantes asumieron diversas formas de acción que incluyeron un tipo de militancia de carácter contestatario, que se explicitaba en el cuestionamiento al orden vigente y en la búsqueda de su transformación, en un contexto histórico marcado por la efervescencia social y política.

Esta investigación está estrechamente ligada a mi historia y búsquedas personales. Entre mis 15 y mis 21 años participé de un oratorio salesiano que visitaba semanalmente el barrio periférico Stella Maris de Bahía Blanca, para realizar actividades recreativas y educativas con niños y adolescentes de entre 3 y 18 años. En aquel momento, esa experiencia significó para mí un descubrimiento de una fe encarnada, cuya esencia era el mandamiento del amor al prójimo y, en particular, lo que llamábamos "opción preferencial por los pobres", y una imagen de Dios no ya como aquel ser lejano que juzga y castiga y con el que la comunicación se da a través de la oración y el cumplimiento de preceptos, sino como un padre cercano, amoroso, misericordioso, que nos había creado libres e iguales y nos había dado el mismo "jardín” para todos, y con el que nos comunicábamos necesariamente a través de las "obras", saliendo al encuentro del otro. Esa fe era además vivida en comunidad, en el marco de una continua reflexión sobre la práctica, de un profundo cuestionamiento al asistencialismo -que ubicaba a las personas pobres como objetos de caridad y no como sujetos de su propio destino-, de estudio y formación, de una elección por una vida sencilla y austera, y de una constante búsqueda de coherencia. Así tuve mi primer contacto con algunos documentos eclesiales y con la teología de la liberación, además de con la historia de referentes cristianos y mártires que habían dado su vida en lo que entendían como el seguimiento de Jesús. Esa experiencia en el Movimiento Juvenil Salesiano (MJS) debía en parte estas características a la impronta del fundador del oratorio Stella Maris, el entonces salesiano Ramiro Gagiotti Menna Lanzilotto, hijo de los militantes del Partido Revolucionario de los Trabajadores-Ejército Revolucionario del Pueblo (PRT-ERP) Domingo Menna y Ana María Lanzilotto, desaparecidos desde julio de 1976 junto a su hermano o hermana aún en gestación; de otros religiosos que acompañaron al grupo de jóvenes en el que me encontraba, como "Tony” de Bernardín, Carlos Gartner y la hermana Nancy Ciucio; de algunos jóvenes un tanto más grandes, de gran claridad intelectual y compromiso, como Juliana Segatori, Valeria Bilbao, Rosita Rodríguez -que fue de las primeras alumnas de la Escuela Nuestra Señora de la Paz en 
Villa Nocito, a la que me referiré más adelante- y Horacio Pezzutti. Después de esa experiencia, seguida de dos años de trabajo en el equipo inspectorial del movimiento ${ }^{3}$, mi relación con la Iglesia se transformó al calor de mi formación universitaria -que me aportaba una visión fuertemente crítica de la institución-, de ciertos desencuentros con otros referentes del MJS ubicados en otras líneas eclesiales, que contradecían las convicciones y maneras de pensar y vivir el catolicismo que yo había "mamado" en aquel espacio en los años anteriores. De allí que no volviera a tener militancia dentro de la Iglesia, si bien reivindicaba la vivencia del oratorio.

A mediados de 2007, mi amigo "Fredy" Herrero, ex guía oratoriano con una larga trayectoria en las Comunidades Eclesiales de Base, me habló por primera vez de la historia de la JUC, en la que habían participado Héctor, Susana, Patricia y Eduardo, los padres de tres amigos del oratorio. A los pocos meses, conocí personalmente a los dos últimos gracias a la intermediación de su hijo, quien por entonces se había convertido en mi compañero. A partir de allí, Patricia, Eduardo y yo comenzamos a construir un vínculo de profunda confianza y afecto, alimentado por la cotidianeidad del hogar, que se mantiene en el presente a pesar de la ruptura del lazo familiar. Un día de otoño de 2008 les pregunté sobre la JUC e improvisamos una primera entrevista en el living de su casa, que hasta principios de los años ochenta había sido la casa parroquial de Nuestra Señora del Carmen, en el barrio de Sánchez Elía, y donde la Triple A había perpetrado un atentado con bomba dirigido al padre José "Pepe" Zamorano 33 años antes. Ese día ni siquiera contaba con un grabador -Patricia aportó el propio aunque no pudimos hacerlo funcionar durante la primera parte de la charla- ni un cuestionario definido. Sin embargo, esa conversación informal me introdujo en el mundo de los jucistas y de la militancia de los años sesenta y setenta en Bahía Blanca: Ver, Juzgar y Actuar, compromiso, vincular la vida con la realidad para transformarla, "Pepe", Emilio Flores, Néstor Navarro, Norma Gorriarán, la escuela de Villa Nocito, La Pequeña Obra, las Guías, los Scouts, la JOC, la JEC, el Secretariado Latinoamericano del Movimiento Internacional de Estudiantes Católicos- Juventud Estudiantil Católica Internacional (MIEC-JECI), el Concilio Vaticano II, el Che, la Revolución Cubana, Camilo Torres,

\footnotetext{
${ }^{3}$ Entre abril de 2005 y febrero de 2007 formé parte del Equipo del MJS correspondiente a la Inspectoría Patagonia Norte "San Francisco Javier", que comprendía el sur de la provincia de Buenos Aires, Río Negro, Chubut y Neuquén. El equipo estaba integrado por jóvenes laicos, un cooperador salesiano, un religioso salesiano y una hermana de María Auxiliadora. Su finalidad era la coordinación de diversas actividades, destinadas a los jóvenes animadores del MJS, tales como organización de retiros, cursos, encuentros y asambleas, y elaboración de materiales de formación y comunicación de las distintas zonas de la Inspectoría.
} 
los Campamentos Universitarios de Trabajo, el peronismo revolucionario, la Juventud Peronista, Montoneros...

Allí empecé a construir el objeto de mi tesina de Licenciatura. Decidí entonces abordar la historia de la JUC y las trayectorias de sus militantes que los habían llevado del mundo religioso al compromiso "temporal", intentando identificar las marcas de lo local en dicho proceso. Con ello, buscaba contribuir a elucidar las relaciones entre catolicismo liberacionista -aunque entonces utilizaba la expresión "catolicismo postconciliar"- y los complejos fenómenos de contestación de los años sesenta y setenta. Para ello, me propuse comprender en qué medida la praxis contestataria de los jucistas bahienses se nutrió de su fe; reconstruir los diversos recorridos de esos jóvenes identificando formas y espacios de militancia, y opciones ideológico-políticas; analizar el lugar de la JUC en la Iglesia de las décadas de 1960 y 1970 y en los conflictos que la atravesaron, con sus implicancias teológicas, eclesiales, políticas y sociales; identificar las características peculiares de la militancia católica en el conjunto del activismo bahiense; analizar las afinidades y conflictos entre pertenencia institucional y compromiso temporal; y comenzar a reconstruir las redes articuladas en torno al catolicismo liberacionista en la ciudad.

En efecto, a lo largo de la tesina constaté, en primer lugar, que el paso por los grupos de revisión de vida de la JUC influyó en forma decisiva en las trayectorias militantes de una parte de los jóvenes bahienses que, en los años sesenta y setenta, se comprometieron con la transformación social, política y económica desde diversos espacios y modalidades de acción y múltiples opciones político-ideológicas. Esa influencia adoptó distintas formas y se extendió tanto a los jóvenes que asumieron su identidad religiosa antes y después de su participación en los grupos cristianos, como a aquellos que no compartían la fe católica. En segundo lugar, mostré que los itinerarios ideológico-políticos de los militantes católicos en Bahía Blanca no se redujeron a una opción exclusiva por el peronismo sino que fueron diversas e incluso cambiantes. Sin embargo, la adscripción al peronismo revolucionario se constituyó en el posicionamiento político mayoritario. Por otra parte, las trayectorias políticas en otras agrupaciones, -PRT y Partido Comunista Revolucionario (PCR) -, derivaron más frecuentemente en una mayor desvinculación de los ámbitos eclesiales. Por último, confirmé que la represión a los católicos “contestatarios” comenzó en Bahía Blanca al menos un año antes del golpe de estado de 1976, siendo uno de los blancos privilegiados de la Triple A. 
Tomando como punto de partida las conclusiones de la tesina, en la investigación doctoral he continuado explorando las relaciones entre catolicismo liberacionista y política en el marco de la efervescencia social y de las tensiones entre religión y política de los años sesenta y setenta en Argentina, a partir de la historización y análisis de ese proceso en la ciudad de Bahía Blanca. Para ello, decidí abordar en conjunto los ámbitos de sociabilidad y las trayectorias de los jóvenes pertenecientes a las tres ramas especializadas de Acción Católica que funcionaron en la ciudad en aquellos años.

\section{2) Marco teórico y estado de la cuestión}

Esta investigación se enmarca teórica y metodológicamente en el campo de la Historia del Tiempo Presente o Historia reciente (Aróstegui, 1998; Franco y Levín, 2007; Bohoslavsky et al., 2010), cuya especificidad está dada por un régimen de historicidad basado en diversas formas de coetaneidad entre pasado y presente (supervivencia de los protagonistas, existencia de una memoria social viva sobre ese pasado, la contemporaneidad entre la experiencia del historiador y el pasado del que se ocupa) y un predominio de problemas vinculados a procesos sociales "traumáticos" (guerras, genocidios, dictaduras, crisis sociales, etc.), con fuertes implicancias en el presente. En consecuencia, el historiador está en permanente diálogo con otros profesionales y actores, y se enfrenta a las tensiones derivadas de las peculiaridades y disponibilidad de sus fuentes, del complejo diálogo Historia-Memoria, de su rol como "actor", como testigo, como "parte" de los temas que estudia (la tensión entre el compromiso y el distanciamiento del investigador), de las incumbencias políticas inmediatas de sus estudios, de múltiples demandas sociales y dilemas éticos que se le plantean.

Como afirma Águila (2012), el pasado reciente ha sido objeto de interés y de abordajes muy diversos, constituyéndose como un campo de estudios multidisciplinar. Sociólogos, cientistas políticos, antropólogos sociales e incluso juristas y economistas, han analizado ese tramo del pasado al que la Historia llegó tardíamente. En efecto, en los últimos años, se ha afirmado como territorio propio de la Historia como disciplina. Precisamente, una de las principales novedades en el panorama historiográfico argentino es el auge de la Historia reciente, verificado en el sostenido crecimiento de la producción académica y de los espacios donde se debate y se investiga sobre el pasado 
más cercano. La multiplicidad de jornadas, mesas temáticas, proyectos de investigación, instancias de formación de posgrado, así como la creciente cantidad de tesis doctorales y publicaciones que se centran en el estudio de las últimas décadas de la Historia argentina demuestran la vitalidad de este campo de estudios.

En los años 2000, los estudios sobre el pasado cercano, además de multiplicarse, comenzaron a abarcar temáticas cada vez más diversas (luchas obreras, mundo cultural y artístico, procesos económicos, organizaciones políticas y armadas, movimientos sociales, problemas de géneros, "derechas", modalidades y efectos de la represión, Estado y partidos políticos, actitudes sociales y vida cotidiana, memorias y usos del pasado, etc.). En cuanto al marco temporal, las investigaciones se centran en un período inaugurado por el golpe de estado de 1955 o bien por "los "60", y se extienden "hasta nuestros días" o "la actualidad". Sin embargo, la atención de los estudiosos se ha focalizado en dos momentos significativos: los años sesenta y primeros setenta y la dictadura militar de 1976/83. Así, entre los temas privilegiados figuran aquellos que habían sido relegados a los márgenes de la Historia profesional, hasta no hace mucho cuestionados por su carácter "militante" y deslegitimados: la conflictividad social y las luchas populares de las décadas de 1960 y 1970, los trabajadores y el mundo del trabajo, las expresiones de la "nueva izquierda" y las organizaciones armadas, la militancia "setentista" o las memorias de las víctimas de la dictadura. Por otra parte, otro de los énfasis de la Historia reciente es la primacía de una Historia social que sitúa en primer plano a los sujetos, sus relaciones, prácticas y experiencias. En este sentido, la difusión de metodologías de análisis cualitativo y la centralidad del uso de fuentes orales imprimieron un sesgo particular a las indagaciones sobre las últimas décadas, otorgando una especial atención a las memorias y culturas militantes, las experiencias, identidades y subjetividades de distintos actores sociales y políticos o a las memorias $\mathrm{y}$ representaciones de ese pasado atravesado por la violencia política y el terror dictatorial (Águila, 2012).

Esta investigación recupera esta vasta y creciente producción académica, especialmente aquella que versa sobre luchas sociales y políticas, las militancias revolucionarias y la violencia política, en tanto ofrecen un marco que permite contextualizar y problematizar el objeto de estudio.

Por otra parte, esta tesis se basa en los trabajos que han abordado la relación religión y política en el siglo $\mathrm{XX}$, y especialmente en las últimas décadas, tanto en América Latina como en Argentina. Entre los primeros, resultan particularmente 
significativos los que se han interrogado sobre el papel de la religión en los procesos de contestación y cambio social (Levine, 1996, 2006, 2011, 2012; Löwy, 1999). En Argentina, los estudios sobre la Iglesia católica (Soneira, 1989a; Di Stefano y Zanatta, 2000), el catolicismo integral y las relaciones entre poder militar y poder eclesial (Mallimaci, 1988, 1992, 1995), o las imbricaciones entre catolicismo y nacionalismo (Mallimaci, Cucchetti y Donatello, 2006) establecieron un marco general para comprender los nexos entre catolicismo, política y Estado en nuestro país. Otros abordajes que se han centrado en las vinculaciones institucionales, políticas, simbólicas, ideológicas y de cuadros entre la Iglesia Católica (Bianchi, 1990; Caimari, 1994; Zanatta, 1999) o el catolicismo (Forni, 1987; Cucchetti, 2005) y el primer peronismo con excepción de Forni que extiende su análisis al período 1955-1969-, contribuyen a pensar, en el largo plazo, la opción por el peronismo de muchos militantes católicos de los años setenta.

En efecto, esta investigación entiende que las relaciones entre fe y militancia en las trayectorias de los jóvenes católicos bahienses deben comprenderse atendiendo tanto a una mirada de corto plazo como de largo plazo. De allí, que abreve en la tradición de estudios que, interesados en el cruce entre religión y política en la Argentina de las últimas décadas, reconocen las rupturas que supusieron las transformaciones del catolicismo en los años sesenta y, al mismo tiempo, hacen hincapié en las continuidades con la matriz común del catolicismo integral (Donatello, 2002, 2003, 2005 у 2010; Cucchetti, 2005, 2007, 2010; Morello, 2003; Touris, 2005).

Asimismo, este estudio es deudor de aquellos que abordan las interacciones entre el mundo religioso y el político en la historia reciente teniendo en cuenta diversas dimensiones no reductibles al factor ideológico. Como plantea Donatello (2010), el lugar de la socialización religiosa en las trayectorias de los militantes es un fenómeno tan significativo como la dimensión ideológica y, sin embargo, ha sido descuidado. En esta línea, se inscriben los aportes que, a partir de diversos referentes empíricos, reconstruyen y analizan trayectorias, espacios de sociabilidad católicos y redes articuladas en torno a ellos y su rol en la participación de los militantes en múltiples formas de acción (los citados de Donatello y de Cucchetti; Catoggio, 2010a; Donatello y Catoggio, 2010; Soneira, 2008; Touris, 2008, 2012a). En este sentido, creo que para dar cuenta del acercamiento a la militancia social y política de los jóvenes bahienses es necesario considerar no sólo una serie de ideas sobre la Iglesia y su relación con el mundo sino también la materialidad constitutiva de las relaciones sociales. Subyace aquí 
la idea, demostrada por Agulhon (2009) para otros procesos y períodos, de que las relaciones entre los individuos forman parte del entramado implícito en los fenómenos históricos.

Existe un cuerpo de publicaciones centradas en la renovación católica en Argentina u otros países latinoamericanos, que incluyen investigaciones generales sobre el tema (Moyano, 1992; Politi, 1992; Touris, 2012a; Mallimaci y Donatello, 2012) o recopilaciones de historias de vida (Lanusse, 2007b; Diana, 2013) y trabajos referidos a grupos o problemas particulares, que constituyen antecedentes importantes para mi tesis. Por un lado, están los estudios que, interesados en movimientos laicales, han observado sus repercusiones políticas o directamente se han interrogado sobre las interacciones de estos grupos con la esfera política, como las indagaciones de Bidegain $(1979,2009)$ sobre los movimientos de juventud obreros y universitarios en Brasil y Colombia, el trabajo de Gómez de Souza (1984) sobre la problemática política en la JUC brasileña entre 1950 y 1968, las investigaciones sobre la JOC en Argentina (Soneira, 1989b, 2002, 2008; Bottinelli, et al., 2001; Blanco, 2010, 2011) o en otros países (Levenson, 2007), y sobre el Movimiento Rural de Acción Católica y la formación de las Ligas Agrarias (Archetti, 1988; Lasa, 1987; Roze, 2011). La tesis de Touris (2012a) constituye una referencia para esta investigación porque no sólo refleja la heterogeneidad interna de la red socio-religiosa "tercermundista", abarcando a los agentes eclesiásticos y también a los laicos, sino que además su interés principal se focaliza en los actores que privilegiaron la acción en ambientes populares ejerciendo un trabajo de base.

Por otro lado, están los abordajes que tematizan otros referentes del catolicismo liberacionista, como el Movimiento de Sacerdotes para el Tercer Mundo (MSTM) (Martín, 2010, basado en entrevistas publicadas en Martín, 2013; Pontoriero, 1991; Touris, 2005, 2012b) o el constituido en torno a la revista Cristianismo y Revolución (Lenci, 1998; Morello, 2003; Campos, 2010). Asimismo, las investigaciones sobre el vínculo catolicismo y lucha armada en Argentina, a partir del caso de Montoneros (Donatello, 2002, 2005 y 2010; Lanusse, 2007a) o el recién citado de Cristianismo y Revolución, aportan interrogantes y reflexiones para repensar los itinerarios bahienses. Morello ha llamado la atención sobre la relación entre creencia religiosa y praxis política de los cristianos, señalando la dimensión teológica de dicha praxis y las implicancias políticas de la religión en los orígenes intelectuales de la guerrilla. Donatello, por su parte, aporta conceptos que pueden contribuir al análisis del fenómeno 
del compromiso católico en múltiples ámbitos de militancia y opciones políticoreligiosas, incluso por fuera de la opción insurreccional. Han sido menos trabajadas las relaciones entre catolicismo y organizaciones armadas de izquierda no peronista a excepción de un artículo sobre la apropiación perretista de la imaginería católica (Carnovale, 2005).

Por otra parte, esta investigación privilegia la escala local y se centra en una comunidad específica que, por otra parte, está ubicada territorialmente "lejos" de la capital. El abordaje, si bien no es de tipo microhistórico, tiene en cuenta los aportes de la microhistoria como práctica historiográfica que, tomando lo particular como punto de partida, busca revelar fenómenos más generales y factores anteriormente no observados para dar cuenta de la complejidad de la realidad (Levi, 1991). Así, la reducción de la escala de observación permite comprender la diversidad de espacios, actores y realidades que le otorgan especificidad a un objeto de estudio (Jensen, 2010). Esta tesis parte de considerar que la comunidad es una unidad socio-espacial localizada constituida históricamente a partir de las experiencias y prácticas sociales, y que no es una unidad homogénea ni está ajena a disputas, por lo que se vuelve ineludible identificar qué es lo que la unifica y la vuelve heterogénea. Asimismo, piensa lo local como parte de realidades más amplias (lo nacional, lo transnacional) y también más pequeñas (el barrio, la familia, la comunidad). De ahí que este estudio se plantee la necesidad de analizar la dinámica de relación entre estos niveles y escalas (Del Pino y Jelin, 2003; Fernández, 2007).

La consideración del problema de las escalas de análisis toma especial relevancia cuando se trata de reconstruir experiencias individuales y colectivas, localizadas e históricamente cambiantes, de dar explicaciones históricas concretas que den cuenta de las acciones humanas y el sentido que sus protagonistas les atribuyen, y de historizar las redes y lazos sociales que permiten valorar tanto el rol y las estrategias individuales como los constreñimientos y limitaciones del entorno. Así, este análisis en una escala reducida no busca ser ejemplo de, ni laboratorio donde verificar hipótesis, conceptos e interpretaciones elaboradas para otras escalas, ni un simple estudio de caso de procesos amplios y estructurales; por el contrario, se propone descubrir nuevas dimensiones del conflicto social o de la acción colectiva, comprender en su complejidad $\mathrm{y}$ sus rostros humanos determinadas dinámicas del pasado reciente argentino, y poner entre paréntesis explicaciones de carácter macro y periodizaciones eficientes para el acontecer nacional. En este sentido, esta investigación, en cuanto está asentada en el 
rescate de las marcas locales, muestra desincronías o velocidades diferentes, poniendo entre paréntesis los hitos y cesuras de la cronología nacional y alumbrando una temporalidad diferente en los procesos en cuestión (Jensen, 2010).

De esta manera, lo local no es para mí un dato ni un escenario; emerge como escala de observación privilegiada para entender la tensión entre acción humana y estructuras, entre experiencia subjetiva y determinación material, entre conciencia social y ser social, y como herramienta analítica fecunda para dotar de inteligibilidad al pasado en la complejidad de sus tramas sociales y en la heterogeneidad de trayectorias vitales que lo componen. Pienso lo local como unidad de análisis que aspira a proporcionar explicaciones que apuran/tensan/matizan/contextualizan verdades macro y de tipo general, intentado a la vez una reconstrucción pormenorizada de los múltiples y heterogéneos contextos de la acción colectiva en un espacio específico, reconociendo tanto los actores copresentes como aquellos que no reúnen esas condiciones pero con los que se establecen interacciones decisivas a la hora de producir dinámicas sociales en la localidad. Pretendo construir así, una historia local y no de localismos; de lo propio pero no de lo parroquial, de lo peculiar pero no de la rareza; una historia de un espacio concreto, pero no porque esa unidad espacial tenga algún sentido en sí mismo, sino porque lo que interesa es analizar las relaciones sociales localmente situadas. El propósito no es sólo ni principalmente analizar la localidad, sino estudiar determinados problemas en la localidad, en tanto lo local tiene algo que lo hace irrepetible, que lo hace específico y que pone en cuestión evidencias defendidas desde la historia general. En otras palabras, la preocupación no se agota en elucidar prácticas locales, interacciones sociales situadas, sentidos localizados historias vividas en contextos heterogéneos y cambiantes, sino que combina parafraseando a Serna y Pons (2001: 104) la formulación de "preguntas generales a objetos reducidos", "de tal modo que esos objetos menudos, lejanos y extraños cobren una dimensión universal, sin dejar de ser a la vez irrepetibles y locales" (Jensen, 2010).

En este sentido, esta investigación se inscribe en los recorridos que en el último lustro han protagonizado algunos jóvenes investigadores por las parcelas del pasado reciente bahiense, guiados por un interrogante amplio: ¿qué implicaba vivir en Bahía Blanca en los activos y convulsos años setenta?, así como por una manera de abordar lo local. Si bien Bahía Blanca ha sido su punto de partida, estos historiadores han sido conscientes que el pasado bahiense involucra niveles y escalas disímiles, cambiantes y que por tanto la búsqueda desde la comunidad de Bahía Blanca no implica hacer una 
historia de los localismos. Estos trabajos de manera más o menos reflexiva hacen uso del potencial teórico-metodológico de las nuevas formas de hacer Historia regional y local para abordar problemas ligados a las prácticas de lucha social, las identidades colectivas, la indagación de los ámbitos de sociabilidad en un contexto urbano, los procesos de recordación y de instalación de marcas territoriales y de disputas en torno al pasado de luchas, represión y guerra, sobre las tramas de control y persecución durante la dictadura, haciendo eje en un concepto analítico clave como es el de experiencia y su análisis en sus heterogéneos y cambiantes contextos (Jensen, 2010). Así, para comprender el marco particular en el que se desarrollan los procesos que pretendo abordar, esta tesis recupera los aportes de estos investigadores locales, en especial aquellos en los que se ha prestado atención a las distintas formas de militancia estudiantil, artística, religiosa, obrera, gremial, barrial, social, política y ligada a la defensa de los derechos humanos en los años sesenta y setenta (Orbe, 2007; Zapata, 2008, 2014a; Giménez, 2008, 2009; Vidal, 2013 a, b y c, 2014a y b; Seitz, 2010, 2014; Montserrat, 2013).

En particular, como mencioné en el apartado anterior, la presente investigación tiene como antecedente mi tesina de Licenciatura en Historia titulada "El fermento en la masa. La Juventud Universitaria Católica en Bahía Blanca, entre la efervescencia política y la oleada represiva de la Triple A (1968-1975)”, realizada bajo la dirección de la Dra. Silvina Jensen y defendida en la UNS en marzo de 2010. Por último, este estudio se basa en los propios avances de investigación durante los últimos años, que se han plasmado en diversos artículos publicados en actas de congresos y revistas (Dominella, 2008; 2010a, b y c; 2011; 2012 a y b; 2014a, b, c).

Anclada en estos antecedentes historiográficos, la contribución de esta tesis puede resumirse de la siguiente forma. En principio, busca contribuir, desde un enfoque local, al conocimiento y comprensión de un tema y un actor de escasa atención entre los historiadores: los movimientos especializados de Acción Católica, que en los años sesenta y setenta experimentaron importantes cambios que los ubicaron dentro de la renovación católica e, incluso, del catolicismo liberacionista, y sus afinidades y tensiones con el mundo de la política y diversas opciones de militancia contestataria.

Di Stefano y Mallimaci han señalado el relativo atraso de la historiografía argentina en relación al desarrollo que ha logrado la "historia de las religiones" en otros países, y el predominio de una concepción muy restringida de lo que significa el estudio histórico de los fenómenos religiosos. Es decir, la manera predominante de analizar 
estos temas se traduce en privilegio no sólo del catolicismo por encima de otras confesiones, sino además de la jerarquía católica -conferencia episcopal, obispos y prensa "oficial"- por sobre otras realidades como grupos, comunidades y personajes menos notorios cuyas vicisitudes forman parte también de la historia del catolicismo. Lo institucional se complementa con una visión "mayoritarista" de lo religioso: lo que cuenta es la mayoría católica, y dentro de ella, los sectores que hegemonizaron el catolicismo, mientras que los "otros" -protestantes, ortodoxos, grupos y corrientes disidentes de la misma Iglesia Católica- no cuentan porque no influyeron, aparentemente, en el desarrollo de esa trama principal protagonizada por cardenales, obispos católicos y partidos políticos, etc. Para estos autores, esta idea de que hay que reservar los esfuerzos para estudiar "lo que cuenta" o "lo que influye", proviene de una historiografía que tradicionalmente ha prestado atención casi exclusiva a los grandes acontecimientos en detrimento de la vida concreta y cotidiana, de las percepciones, ilusiones y auto-percepciones de los hombres y mujeres “de la calle" (2001: 10).

En este contexto, se justifica la necesidad de estudiar el catolicismo liberacionista, en tanto corriente eclesial con gran influencia en los fenómenos sociales y políticos de la época, que fue temprana y crecientemente marginada y silenciada al interior de la Iglesia por el Vaticano y la jerarquía eclesiástica en favor de los sectores más conservadores o moderados, a la vez que condenada y perseguida por quienes implementaron el terror paramilitar y estatal en Argentina.

Por otra parte, desde la mirada historiográfica hegemónica, el estudio de los movimientos laicales aparece como un campo poco explorado, a pesar del rol clave de la Acción Católica en la configuración de los catolicismos latinoamericanos. En este marco, resultan valiosas contribuciones para comprender estos movimientos y su rol en la Iglesia y la sociedad argentinas los estudios sobre las trayectorias de dirigentes de la Acción Católica en los años treinta y cuarenta (Mallimaci, 1991) y las formas de organización del laicado católico en el siglo XX (Giménez Béliveau, 2005). Este escaso interés por los laicos, se reitera en el caso de las indagaciones sobre el catolicismo liberacionista, donde en muchos casos, la pluralidad y heterogeneidad de actores que integraban la red de católicos comprometidos con la problemática social y política aparece como un aspecto minimizado. Como plantea Touris (2011), pese al rol que tuvo el MSTM, no debe soslayarse la inclusión de las religiosas, los religiosos y una gran cantidad de grupos laicales. 
Si en las últimas décadas, diversos estudios han llamado la atención sobre la importancia del factor religioso en la comprensión de fenómenos políticos $y$, concretamente, han revitalizado la discusión en el seno de las ciencias sociales sobre las relaciones entre el catolicismo liberacionista y la política en los años sesenta, en América Latina y en Argentina, el interés se ha centrado en las relaciones entre catolicismo y el fenómeno insurreccional en Argentina. Sin embargo, como afirma Touris (2011), existieron múltiples experiencias generadas en el clima de renovación eclesial, que llevaron a diversas formas de inserción y de compromiso social que no desembocaron en la opción por la violencia, y que es necesario incorporar al análisis.

Pero, dejando de lado las indagaciones que tematizan las relaciones entre religión y política, incluso para la militancia de los años setenta como objeto de investigación, el énfasis está puesto en las organizaciones guerrilleras. Otras militancias -como el lento y paciente trabajo en un barrio, la disputa de la comisión interna con la dirección del gremio, las iniciativas por la defensa de presos políticos, etc.- están totalmente ensombrecidas por el centro que ocupa la acción armada en los estudios sobre el pasado reciente (Pittaluga, 2010). En este sentido, esta investigación busca contribuir a elucidar experiencias diversas de acción contestataria, que sin excluirla van más allá de la opción armada, y que encuentran en el catolicismo liberacionista un origen e impulso particular.

Por otro lado, frecuentemente, la historia de las últimas décadas argentinas está escrita en clave pretendidamente nacional pero encierra una perspectiva “porteñocéntrica". La Historia reciente continúa sosteniendo la asimilación entre lo nacional y lo porteño, o cuanto más pampeano o de las grandes ciudades litorales (Jensen, 2010). Como señala Águila, la mayoría de los trabajos sobre el pasado reciente “están construidos desde una mirada nacional o, más bien, centrada en la realidad bonaerense y que proyectándola como explicación general, ha minusvalorado el análisis de otros espacios regionales o locales" (2008: 20). Sin embargo, la agenda de la Historia reciente va mostrando un creciente interés por matizar explicaciones globales de la historia argentina y por ver cómo determinados procesos sociales han sido experimentados localmente. Lentamente se van sumando aportes anclados en lo local o regional que intentan o bien complejizar la Historia nacional de "los setenta", poniendo entre paréntesis verdades aceptadas, o bien elucidar el significado de prácticas concretas en sus contextos locales e históricamente cambiantes (Jensen, 2010). En este sentido, el enfoque aquí elegido permite aportar a la reconstrucción de un proceso histórico más 
vasto, ampliar el horizonte de comprensión de esta historia desde diferentes aspectos, enriqueciendo la mirada y cuestionando lugares comunes de las producciones historiográficas sobre nuestro pasado reciente argentino.

Existen múltiples obras que abordan la historia de Bahía Blanca y hacen foco en distintos aspectos y períodos (por ejemplo, Weinberg, 1978, 1988; Cernadas de Bulnes, 1999, 2001, 2003, 2006; Cernadas de Bulnes y Marcilese, 2012; Silva, 1987; Errazu de Mendiburu, Rey y Abraham, 1970; Crespi Valls, 1955; Agesta, 2009, 2013; Bracamonte, 2011, 2012; Buffa, 1994; Caviglia, 1993, 2003; Cabezas, 2012; Fanduzzi, 2007; Fernández, 2007; David, 2006; Llull, 2005; López Pascual, 2009, 2014; Marcilese, 2008, 2009; Miravalles, 2013; Randazzo, 2007; Ribas, 2008; Zanetto, 2014). Sin embargo, como afirma Jensen (2010), los trabajos que estudian la historia reciente de esta localidad y su región son muy escasos. Recién en los últimos 5 años comenzaron a hacerse visibles investigaciones desde/en/sobre/de Bahía Blanca sobre dinámicas fundamentales de los años setenta, desde los procesos de activación social y lucha política hasta la represión paraestatal y estatal (Bonavena, 2010; Dominella y Montero, 2007; Dominella, Fernández Albanesi, Montero, Rodríguez, Seitz, Vidal y Zapata, 2009; Dominella, Giménez, Montero, Seitz y Vidal, 2010; Pupio y Dominella, 2013; Giménez, 2014; Zapata, 2012, 2014b; Seitz, 2013; Montero, 2010, 2014; Visotsky y Gattari, 2004) y las luchas por la memoria de la dictadura desde 1983 al presente (Dominella, 2013; Montero, 2006; Montero, 2009; Seitz, 2011; Vidal, 2010, 2013d). Así, el interés historiográfico por las décadas de 1960 y 1970 en la ciudad es relativamente nuevo. En particular, la historia de la militancia bahiense de las décadas de 1960 y 1970, con pocas excepciones, está marcada por los silencios en los ámbitos historiográfico, periodístico y artístico. De allí que el presente estudio se proponga contribuir a llenar esos "huecos", si bien, como expuse en los párrafos anteriores, intenta hacer una contribución que trasciende el conocimiento relativo a Bahía Blanca.

Por último, entiendo que la recuperación de las historias de militancia y los proyectos de aquellos cuyas vidas fueron marcadas definitivamente por la desaparición, el asesinato, la cárcel o el exilio resulta fundamental para la comprensión del pasado reciente atravesado por el terrorismo de Estado y la violencia paramilitar, así como también para revertir la impunidad con la que actuaron los perpetradores y evitar la "realización simbólica de las prácticas genocidas", es decir, la culminación de esas prácticas en una etapa siguiente a su realización material, que se ve facilitada con la 
articulación de procesos tales como la negación de la identidad de las víctimas en la figura del "inocente" (Feierstein, 2000).

\section{3) Objetivos, hipótesis y precisiones conceptuales}

Esta investigación se propone, en primer lugar, analizar el cruce entre catolicismo liberacionista y política en la JUC, la JEC y la JOC bahienses en el período 1968-1975, reconociendo sus características comunes y peculiares. Siguiendo a Löwy (1999), defino el catolicismo liberacionista como un amplio movimiento social-religioso surgido a principios de los años sesenta, que incluye tanto la cultura religiosa como la red social, la fe y la praxis, y cuya expresión intelectual es la teología de la liberación. Una serie de principios básicos permiten reconocerlo: la lucha contra los "nuevos ídolos de la muerte" (el mercado, la civilización occidental y cristiana, la seguridad nacional, etc.); la liberación humana histórica como anticipación de la salvación final; la crítica a la teología dualista tradicional y una nueva lectura de la Biblia; una aguda denuncia del capitalismo como pecado estructural; el recurso al marxismo como instrumento socialanalítico; la opción preferencial por los pobres y la solidaridad con su lucha de autoliberación. En realidad, Löwy aborda el fenómeno más amplio del “cristianismo liberacionista" y Donatello (2005) delimita el concepto dentro del mundo católico. En sus trabajos más recientes (2010), sin embargo, este autor prefiere las expresiones "renovación católica" y "catolicismo contestatario", porque considera que el concepto de liberacionista en general se encuentra ligado a un fenómeno intelectual, la teología de la liberación, que no ha sido el rasgo más singular del caso argentino.

El camino de investigación recorrido entre la tesina de licenciatura y la actual tesis doctoral me llevó a replantearme el uso de estos conceptos. De esta manera, opté por evitar la noción de "catolicismo post-conciliar" por ser la utilizada por los propios actores, además de imprecisa. En efecto, si después del Concilio Vaticano II todo el catolicismo es formalmente "post-conciliar", a partir de este acontecimiento clave se manifestaron perfiles y tendencias claramente definidos que dan cuenta de los distintos posicionamientos respecto del mismo. Frente al espectro del catolicismo conservador con sus distintas variantes, renuente a aplicar las recomendaciones conciliares, surgía un heterogéneo conjunto de tendencias renovadoras, vinculadas con el replanteo conciliar (Ameigeiras, 2008; Di Stefano y Zanatta, 2000). Así, para referirme a estos sectores identificados con el aggiornamento eclesial prefiero la expresión "renovación católica". 
Dentro de este universo, ubico el "catolicismo liberacionista" porque se ajusta a los actores en los que se centra esta tesis. Más allá de lo que ocurrió en otras partes del país, donde fue más significativa la incidencia de la llamada teología argentina o escuela argentina de teología y conocida por algunos como teología de la cultura, teología desde la praxis de los pueblos latinoamericanos (Scannone, 1987) o teología populista (Mugica, 1985 citado en Tamayo Acosta, 1989), -de la mano de Juan Carlos Scannone y Lucio Gera-, los jucistas, jocistas y jecistas bahienses se vieron influidos de múltiples maneras por las teologías de la liberación -las más directas se vinculan a la pertenencia de los universitarios y secundarios al MIEC-JECI-, y en especial por la línea que continuaba la perspectiva abierta por Gustavo Gutiérrez, a la vez que se propusieron contribuir desde su práctica al nuevo intento de inteligencia de la fe inserta en la realidad latinoamericana.

Más allá de sus particularidades, entiendo que la corriente liberacionista comparte con otros tipos eclesiales -incluso con aquellos que se colocan en sus antípodas- un sustrato común, que Mallimaci denomina "catolicismo integral" (1988, 1992). Este fenómeno, cuyo desarrollo comenzó a hacerse visible a partir de la década de 1920, constituía la respuesta del catolicismo argentino al avance secularizador del liberalismo y el socialismo, que intentaba constreñirlo al ámbito privado. Así, el catolicismo integral buscó integrar las instancias de lo social, lo político, lo religioso, lo público y lo privado, y avanzar sobre la sociedad y el Estado ${ }^{4}$.

En relación con el primer objetivo, la tesis se plantea, en segundo lugar, comprender en qué medida la praxis contestataria de los jóvenes católicos bahienses se nutrió de su fe, y en particular, de qué modo influyeron en el acercamiento a la sociedad y a la política de estos militantes bahienses los cambios que experimentó el catolicismo a nivel nacional, latinoamericano y mundial desde los años cincuenta, así como las continuidades con la matriz católica integral.

Al mismo tiempo que hago foco en los factores ideológicos, me interesa reconstruir los espacios de sociabilidad ligados a la renovación católica en Bahía Blanca -que incluyen a la JUC, la JEC y la JOC-, y las redes sociales que éstos articularon, y analizar los modos en que actuaron en la generación de iniciativas comunes y en la participación de los actores en diversos ámbitos de acción social y política. Así, incorporo la reconstrucción no sólo de los espacios de sociabilidad, sino también de las

\footnotetext{
${ }^{4}$ Sobre el catolicismo liberacionista y el catolicismo integral véase el capítulo 1.
} 
redes sociales para dar cuenta de distintas dimensiones del universo relacional del catolicismo liberacionista. El objeto sociabilidad fue introducido en el terreno de la historiografía por Agulhon (1966), y en la historia política latinoamericana, por Guerra (1985), renovando así dicho campo. Hoy tiene un vasto desarrollo en la disciplina, abarcando diversas temáticas y períodos. Con González Bernaldo de Quirós (2008) entiendo que la sociabilidad apunta a analizar las formas a partir de las cuales un grupo de individuos entra efectivamente en relación y el papel que juegan esos vínculos, y que la dimensión afectiva es un componente de la interacción y elemento que condiciona, aunque no determina, la acción. Por otra parte, la red remite a espacios de interacción social que no implican que todos los individuos que participan en ella se conozcan o que compartan espacios de sociabilidad.

Dentro del espacio local, a la vez que busco ubicar a la JUC, la JOC y la JEC en una amplia y heterogénea red socio-religiosa identificada con las novedades del Concilio, de Medellín y de los teólogos de la liberación, procuro analizar el lugar de las ramas especializadas de la Acción Católica en el marco de la Iglesia bahiense, en la que convivían diversas líneas teológicas y pastorales, por lo que se vio atravesada por diversas tensiones en esos años.

El acento en las sociabilidades y redes enriquece el abordaje de las trayectorias religiosas y políticas. En efecto, la tesis intenta historizar las trayectorias de los militantes, identificando diversas y complejas experiencias en cuanto a las formas y espacios de construcción social y política, y a las opciones político-partidarias tomadas. Una vez reconstruidos estos itinerarios, me interesa analizar las afinidades y tensiones entre catolicismo liberacionista y las diversas opciones de "compromiso" asumidas. Por otra parte, en cuanto los jucistas, jocistas y jecistas aspiraban a ser "fermento en la masa", esto es, a no segregarse de los demás sino unirse a todos aquellos hombres y mujeres de "buena voluntad" comprometidos en la transformación social, aspiro a identificar los rasgos particulares de los activistas católicos en el conjunto de la militancia contestataria bahiense.

Finalmente, propongo una serie de interrogantes y la hipótesis de trabajo que vertebran el análisis. Los interrogantes son los siguientes: ¿qué afinidades podemos reconocer entre el catolicismo liberacionista y diversas opciones de compromiso?, ¿de qué forma su paso por los grupos de reflexión cristianos marcó las trayectorias militantes de los actores?, ¿cómo influyeron tanto los nuevos documentos eclesiales y los teólogos de la liberación como la materialidad constitutiva de las relaciones 
sociales?, ¿en qué medida el fenómeno del catolicismo integral aporta elementos para comprender el compromiso temporal de los jóvenes católicos en los años sesenta y setenta?, ¿cuáles fueron sus espacios de construcción social y política?, ¿por qué algunos canalizaron su compromiso cristiano a través de la militancia políticapartidaria?, ¿por qué buena parte de ellos eligió el peronismo revolucionario?, ¿qué debates, dilemas y opciones planteó la cuestión de la violencia y la lucha armada entre estos militantes?, ¿en qué medida la militancia de los jóvenes católicos tenía peculiaridades que permitían identificarla dentro de la militancia revolucionaria bahiense?, ¿qué particularidades asumió este proceso para los estudiantes secundarios, los universitarios y los trabajadores?, ¿cómo impactó en los grupos de revisión de vida el "contacto con el mundo" de sus miembros?, ¿en qué medida se planteó la necesidad de optar entre la estructura eclesial y la militancia política? ¿Hubo distintas formas de integrar la fe y la política?

Por otra parte, la hipótesis general de la que parto es: en el contexto de efervescencia social y política de las décadas de 1960 y 1970 en Argentina, el cruce entre catolicismo liberacionista y acción social y política contestataria en las trayectorias de los integrantes de la JOC, la JUC y la JEC bahienses asumió una marca de identidad. Para dar cuenta de esas particularidades, planteo una serie de hipótesis específicas.

En primer lugar, que estos ámbitos de sociabilidad ligados al catolicismo liberacionista influyeron en el acercamiento a la sociedad y a la política de sus miembros de distintas formas. Por un lado, fueron una instancia fundamental en la profundización de su compromiso "con la sociedad", a partir de la identificación con determinadas ideas sobre la Iglesia y su relación con el mundo y una cierta forma de vivir la fe. Esas concepciones y modalidades compartidas pueden explicarse atendiendo a las transformaciones que experimentó el catolicismo desde fines de los años cincuenta (que se plasmaron en documentos del Concilio Vaticano II, del magisterio de la Iglesia y en los desarrollos de la teología de la liberación); y una matriz católica integral, hegemónica en Argentina desde los años treinta. Por otro lado, se constituyeron en espacios de formación que les brindaron a sus militantes una serie de herramientas relacionales y organizativas que fueron claves en el mundo de la política. Por último, forjaron vínculos personales que facilitaron la articulación de denuncias públicas, la generación de iniciativas políticas, el pasaje de un tipo de militancia eclesial o social a otra política-partidaria y el ingreso a las organización revolucionarias. 
En segundo lugar, postulo que el compromiso de estos jóvenes con la "transformación de la realidad" implicó un amplio abanico de alternativas en cuanto a tipos de intervención (eclesial, social, barrial, gremial, estudiantil, política, armada) y opciones político-partidarias. En este sentido, las trayectorias políticas de los militantes católicos en Bahía Blanca no se redujeron a una opción exclusiva por el peronismo sino que fueron diversas e incluso cambiantes en el período 1968-1975. Sin embargo, la adscripción al peronismo revolucionario se constituyó en el posicionamiento político mayoritario. Aún así, la común adscripción a este movimiento tomó diferentes variantes (Juventud Peronista -JP- Montoneros o Peronismo de Base -PB-). Por otra parte, los itinerarios políticos en otras agrupaciones (PRT, PCR) derivaron más frecuentemente en una mayor desvinculación de los ámbitos eclesiales.

En tercer lugar, propongo que las formas de integrar la fe, la pertenencia eclesial y la militancia fueron complejas, variadas (en relación con los tipos y ámbitos de acción; el grado de responsabilidad en las organizaciones revolucionarias, en el caso de los militantes políticos; las adscripciones partidarias; el contexto político inmediato; las trayectorias religiosas previas) y no estuvieron exentas de conflictos y tensiones.

\section{4) Metodología y fuentes}

Esta tesis se enmarca en la investigación cualitativa, que es interpretativa, inductiva, reflexiva y multimetódica (Vasilachis de Gialdino, 2006). En este sentido, opta por la utilización de diversas estrategias, desde entrevistas en profundidad (ahondando en trayectorias y relatos de vida) hasta el abordaje de distintas fuentes empíricas (que incluyen testimonios éditos, producciones literarias de los actores, prensa, informes de inteligencia, volantes, fotografías, etc.), apelando a estrategias de triangulación con el objetivo de superar los sesgos propios de una determinada metodología y lograr una comprensión en profundidad del problema en cuestión.

La construcción de fuentes orales (Vilanova, 1998) o la adopción de la tradición de la historia de vida y los métodos biográficos (Mallimaci y Giménez Béliveau, 2006) se justifica en tanto permite visualizar lo subjetivo, lo experiencial, lo cotidiano; profundizar en el mundo de los significados, los valores, las representaciones y los motivos personales de las elecciones vitales; descubrir las prácticas de vida y las identidades ignoradas; explicitar la noción de proceso y rastrear las trayectorias de las personas a lo largo del tiempo y en las redes sociales que las sostienen. En este sentido, 
la historia de vida brinda información no sólo sobre un sujeto individual sino también sobre las sociabilidades en los que esta persona está inserta y que contribuye a generar con sus acciones. Asimismo, esta perspectiva de análisis es sensible para abordar individuos y grupos sociales frecuentemente silenciados desde otras tradiciones epistemológicas, así como para trabajar con una nueva escala o dimensión de análisis (individual o "micro") y entender cómo convergen en las trayectorias concretas varios niveles de la vida social (Berteaux, 1996).

En este marco, realicé las entrevistas a partir de una guía abierta o semiestructurada que permitiera indagar la experiencia objetiva, subjetiva, simbólica y relacional de los actores (Mallimaci y Giménez Béliveau, 2006). Entonces, construí un cuestionario general, siempre tentativo, flexible y abierto, que estaba estructurado en diversas etapas (la previa al ingreso a la JUC, la JOC o la JEC, la referente a la participación en las ramas especializadas y en espacios de militancia, y el período posterior a la irrupción de la violencia represiva y la desestructuración de esos ámbitos de pertenencia), con preguntas descriptivas, de experiencias o de ejemplos (Ameigeiras, 2006), esto es, que tenían que ver con sus vivencias, emociones, percepciones, aunque también con cuestiones factuales. Cada uno de los temas era abordado a partir de una pregunta general (“Contame de...”, por ejemplo, tu familia/ la JUC/el trabajo en el barrio/ el exilio...), y luego profundizado mediante preguntas específicas, en algunos casos, pensadas de antemano y, en otros, surgidas al calor de la charla. Antes de comenzar a grabar, procuré dedicar un tiempo para hacer algunas aclaraciones relativas a cuál era el objetivo del encuentro y cómo se vinculaba a mi investigación; a la necesidad de aludir a los momentos previos y posteriores de su vida para comprender esa etapa sobre la que buscaba detenerme en profundidad; a la búsqueda de la experiencia, los sentimientos, los significados, las anécdotas personales más que de fechas o nombres de sitios y personas; al modo en que iba a ser usada la información que compartiéramos en esas horas, lo que implicaba la sugerencia de que el entrevistado explicitara aquello que no debía ser publicado; a mi intención de resguardar la identidad de las personas, unido al pedido de que eligiera un nombre con el que prefería aparecer citado. Así, a excepción de las figuras públicas cuya identificación resulta inevitable, a lo largo de la tesis los nombres de los protagonistas fueron cambiados, obedeciendo al pedido explícito de algunos de ellos en este sentido y a la necesidad de unificar los criterios de identificación. 
Una vez que finalizaba cada sesión y me retiraba del punto de encuentro (en general, las mismas casas de los entrevistados o de sus familiares o amigos, aunque también sus lugares de trabajo, cafés o, incluso, la terminal de ómnibus) intentaba describir en detalle el lugar físico (con esquema gráfico incluido), los objetos, los gestos, las posturas corporales del entrevistado, las acciones realizadas, lo compartido una vez apagado el grabador, así como -en un espacio diferenciado- mis impresiones, intuiciones, sensaciones, interrogantes, cuestiones que habían llamado mi atención y temas a (re)pensar sobre el objeto de investigación y la metodología utilizada. Con la habilitación de estas notas y diario de campo (Ameigeiras, 2006) buscaba, por un lado, complementar la información recabada a través del grabador, y por el otro, generar un espacio de reflexión sobre mis elecciones metodológicas y mi implicación personal en el tema de investigación. En cuanto al primer aspecto, opté por descartar el uso de una cámara filmadora y registrar sólo la voz de los actores, mediante un mp3 primero, y un grabador de mano más tarde, esto es, un aparato de pequeño porte, que colocado entre la persona y yo pronto era olvidado por ambos, facilitando que la conversación transcurriera del modo más espontáneo posible. Con la misma intención, obvié tomar notas durante las sesiones, a excepción de algunas "notas en bruto" o "de señalamiento" aisladas en momentos muy precisos (Ameigeiras, 2006), consistes en una frase, una palabra, una imagen que pudiera activar la memoria y me permitiera más tarde una tarea de recuperación y de profundización. Esto fue así porque me parecía fundamental mantener el contacto visual con la persona y evitar gestos que la distrajeran o la hicieran sentir incómoda o incluso juzgada/evaluada, en orden a priorizar la generación de empatía con ella. En relación a la segunda cuestión, como plantea Ameigeiras para la investigación etnográfica, en el diario de campo se hace explícita la necesidad de tener en cuenta que el instrumento básico de investigación "es el propio investigador, sus apreciaciones y experiencias, lo que siente y lo que le pasa, distintas situaciones y acontecimientos vividos que confluyen en el proceso de construcción social de conocimiento" (2006: 136).

Una vez registrado cada audio, procuré transcribirlo los días o semanas posteriores, evitando que mediara demasiado tiempo entre el encuentro y la entrega de la entrevista en papel o en Word a los actores. En este sentido, entendía que le debía al entrevistado este primer y mínimo gesto de devolución por el tiempo que me había dedicado y por la disposición a recibirme en su casa y a compartir/exponer/revivir su historia. 
La predilección de la investigación cualitativa por la profundidad y la inducción a partir de casos significativos implica que la representatividad de la muestra no reside en una cantidad determinada de relatos sino en la posibilidad de abarcar múltiples trayectorias. Así, opté por una "muestra según propósitos” (Maxwell, 1996), con el criterio de garantizar que los entrevistados dieran cuenta de un rango amplio de experiencias. Para abarcar la riqueza del universo de análisis, consideré distintas variables, como el origen familiar (en términos de tradiciones políticas y religiosas, y de condición socioeconómica), el sector de la Iglesia a la que pertenecían (esto es, si se trataba de laicos, sacerdotes, religiosas o de integrantes de la jerarquía), la rama especializada de Acción Católica en la que participaron y el período en el que lo hicieron, los tipos y espacios de militancia, las trayectorias ideológico-políticas, los caminos recorridos a partir del comienzo de la violencia política (por ejemplo, el exilio externo, el exilio en otras ciudades del país, el exilio interno en la misma Bahía Blanca, la cárcel, la detención-desaparición), y la vinculación actual con el mundo católico.

Entre marzo de 2008 y mayo de 2013 realicé 64 entrevistas a 19 integrantes de la JUC, a 18 de la JEC, a 12 de la JOC y al sacerdote asesor de los tres grupos, así como a 5 personas cercanas a esos espacios pero que no pertenecían a los mismos (compañeros de militancia política y una alumna de la escuela de Villa Nocito). Por otra parte, he conversado con 4 laicos, 4 sacerdotes o ex sacerdotes y 1 ex religiosa vinculados a otros grupos identificados con el catolicismo liberacionista, con el objetivo de reconstruir los espacios de sociabilidad y las redes sociales de la renovación católica en Bahía Blanca. Las entrevistas tuvieron lugar en Bahía Blanca, Punta Alta, Río Colorado, Mar del Plata, Santa Fe, Neuquén, Moreno y Ciudad Autónoma de Buenos Aires. La gran mayoría de éstas fueron individuales -sólo en 5 casos, entrevisté a matrimonios-, y frecuentemente compartimos más de un encuentro con los entrevistados. Es por ello que realicé un total de 85 sesiones, que fueron grabadas, además de 2 entrevistas vía e-mail. Entre las sesiones mencionadas, 5 fueron llevadas a cabo vía skype Bahía BlancaOrrefors (Suecia).

Asimismo, analicé otros registros subjetivos de las experiencias de los actores, como los testimonios éditos de ex miembros de la JUC, la JEC o la JOC o de otros espacios de la renovación católica bahiense (entrevistas aparecidas en la prensa nacional y en publicaciones periódicas católicas e historias de vida compiladas en obras de edición local); las grabaciones de entrevistas radiales realizadas a ex integrantes de las ramas especializadas de Acción Católica ( $F M$ de la Calle, Bahía Blanca) y de 
entrevistas llevadas a cabo por los integrantes de Abuelos Relatores por la Identidad, la Memoria y la Inclusión Social ${ }^{5}$ a ex estudiantes residentes del Pensionado Católico en los años sesenta y setenta; las filmaciones de entrevistas realizadas a los actores por alumnos de la Escuela Normal Superior, en el marco del Proyecto Jóvenes y Memoria ${ }^{6}$; y la producción literaria de los protagonistas (cuentos breves, poesías, etc.).

Paralelamente, recopilé fuentes periodísticas: diarios locales (La Nueva Provincia, El Eco, El Sureño), diarios nacionales (La Nación, La Opinión), revistas locales y nacionales (Graphos, Reporte. La revista puntaltense, Nuevo Hombre, Así, Cristianismo y Revolución, entre otros). Al mismo tiempo, revisé publicaciones católicas oficiales, especialmente las editadas por el Secretariado Latinoamericano del MIEC-JECI (JEC Boletín Secundario, Boletín Spes, Boletín América Latina y Servicio de Documentación), y el Boletín Eclesiástico del Arzobispado de Bahía Blanca.

Por otra parte, tuve en cuenta las fuentes escritas disponibles en diferentes repositorios, a saber:

- el Archivo de la Dirección de Inteligencia de la Policía de la Provincia de Buenos Aires (DIPPBA), actualmente a disposición de la Comisión Provincial por la Memoria, que incluye informes que describen actividades, iniciativas, acontecimientos que involucran a los sujetos de esta historia (conferencias, homilías, distribución de declaraciones, atentados, etc.), acompañados en muchos casos de recortes periodísticos, volantes o revistas, como Pablo -editada por un grupo de laicos liberacionistas del Instituto salesiano Juan XXIII-. Dejando de lado su innegable aporte a las causas judiciales contra los responsables de delitos de lesa humanidad y la averiguación de datos sobre las víctimas de la represión, creo necesario destacar la importancia histórica de este fondo documental para la reconstrucción del pasado reciente. El accionar clandestino de las organizaciones sindicales, políticas, estudiantiles, barriales, etc. y la persecución política de la que fueron objeto sus integrantes redundó en el secuestro, la fragmentación y la destrucción de gran parte de sus materiales. En este sentido, el

\footnotetext{
${ }^{5}$ Se trata de un programa impulsado por PAMI en colaboración con Abuelas de Plaza de Mayo. Su objetivo es promover la reflexión acerca de la historia reciente de nuestro país, mediante espacios de encuentro entre los adultos mayores, niños y jóvenes. En Bahía Blanca funcionó a través del taller literario "Relatar" desde octubre de 2010 hasta diciembre de 2013, bajo la coordinación de la Lic. Elsa Calzetta, y contó con mi asesoramiento en la elaboración de fuentes orales y recopilación bibliográfica sobre la historia local, así como sobre la historia argentina de las últimas décadas.

${ }^{6}$ En particular, las entrevistas llevadas a cabo en 2010 para el video "La Peque", que aborda uno de los espacios más significativos del catolicismo liberacionista en Bahía Blanca, el centro pastoral La Pequeña Obra, durante los años sesenta y setenta, y el proceso de persecución que sufrieron sus militantes. Participé de la elaboración del video a través de una entrevista y del asesoramiento en la reconstrucción del contexto histórico y eclesial, y tuve acceso al material recopilado por los alumnos.
} 
archivo se constituye en un acervo privilegiado para el estudio de una parte importante de los movimientos sociales, políticos y culturales de la segunda mitad del siglo XX, incluyendo los actores abordados en esta tesis, en cuanto permite la consulta de materiales que de otro modo serían inaccesibles. El relevamiento para esta investigación se llevó adelante a través de la búsqueda realizada por los referencistas del archivo a partir de tres pedidos de información que efectué, siguiendo las normas del archivo, a partir de la confección de formularios donde explicité el tema de interés delimitado con la mayor precisión posible. Debido al carácter sensible de los documentos, la accesibilidad a los mismos se halla limitada por la protección de los datos personales, es decir, los administradores del archivo deben disociar - por medio del tachado- los nombres que aparezcan en los documentos públicos que entreguen a los interesados ${ }^{7}$.

- el Archivo del Arzobispado de Bahía Blanca, donde me permitieron consultar, además del Boletín Oficial, el libro de designaciones de la Escuela "Nuestra Señora de la Paz" de Villa Nocito;

- el Archivo de Cáritas Arquidiocesana de Bahía Blanca, donde encontré documentación sobre sus orígenes, su historia, sus articulaciones a nivel nacional, y sobre otros grupos católicos locales, así como publicaciones periódicas de la institución -Horizontes-;

- el Archivo Histórico Salesiano, que reúne crónicas, revistas -como la llamada Carácter, perteneciente al Colegio Don Bosco de Bahía Blanca-, folletos o boletines relativos a las instituciones, comunidades, grupos y asociaciones salesianas, además de los legajos de los religiosos que integraban el grupo de consagrados identificados con el aggiornamento eclesial, que incluyen su epistolario, cuadernos con apuntes personales, escritos, conferencias, etc. Al igual que en el caso de Cáritas y de la Curia, estos materiales me resultaron significativos para reconstruir las redes de la renovación católica en la ciudad, así como para contextualizar las trayectorias de los jucistas, jecistas y jocistas bahienses que transitaron por estos espacios.

- la Biblioteca del Colegio Máximo de San Miguel, que conserva boletines del MIEC-JECI;

- el Archivo del Área Cultura, Sociedad y Religión, CEIL-PIETTE, CONICET, donde encontré un documento del comando de operaciones navales de la Base Naval Puerto Belgrano, fechado en 1970, sobre el MSTM;

\footnotetext{
${ }^{7}$ Sobre el archivo, véase http://www.comisionporlamemoria.org/archivo/?page id=3
} 
Por último, consulté los archivos personales de los entrevistados que incluyen fotografías (sobre el Pensionado Católico, los encuentros y campamentos de grupos de revisión de vida, de otros grupos eclesiales y del clero, los Scouts de "San Jorge" y "San Pío X", las Guías "Santa Juana de Arco", las ordenaciones sacerdotales, los cumpleaños, los casamientos), filmaciones sobre el movimiento Guía-Scout de La Pequeña Obra, cancioneros utilizados en las misas compartidas, postales y cartas personales, volantes (elaborados por los grupos que integraban las redes de renovación católica en la ciudad y otros anónimos que atacaban a esos grupos), apuntes de reuniones de reflexión, informes elaborados por la DIPPBA, folletos sobre los Campamentos Universitarios de Trabajo, publicaciones del MIEC-JECI, el primer boletín de El mensajero de la JOC de Grünbein y libros.

Llevé a cabo el análisis e interpretación de la información durante el transcurso del trabajo de campo, a partir de la sistematización y clasificación del material relevado mediante las diversas formas de registro, de "estrategias de categorización" y "de contextualización" de la información (Maxwell, 1996). En este sentido, acompañé el proceso de transcripción con una primera instancia de procesamiento de las fuentes orales construidas, mediante la habilitación de las notas de campo mencionadas y de fichas analíticas donde reconstruía y resumía lo conversando, discriminando la trayectoria familiar, religiosa, educativa, laboral de la persona, sus vivencias en relación a la rama especializada a la que había pertenecido, su opción de compromiso social, las relaciones entre el espacio de "revisión de vida" o la pertenencia eclesial con la participación social o política, y su itinerario posterior hasta la actualidad. Al mismo tiempo, apuntaba las dudas e interrogantes abiertos o aspectos a profundizar en un segundo encuentro. Por otra parte, fui elaborando fichas temáticas (por ejemplo, relativas a cada uno de los grupos -formación, integrantes, actividades, modo de ingreso, etc.-, a los vínculos con otros espacios, a las trayectorias de los actores, a la metodología del Ver, Juzgar y Actuar, a los espacios de militancia, a las tensiones experimentadas en el cruce entre fe/pertenencia eclesial y acción social o política, etc.) y otro tipo de memos sobre asuntos metodológicos, éticos y conceptuales.

\section{5) Organización de los capítulos}

La tesis está organizada en siete capítulos. En el primero busco ubicar a la JUC, la JOC y la JEC bahienses en su contexto histórico, social, político y eclesial. En primer 
lugar, hago referencia a los elementos que configuraron la efervescencia social y política que tuvo lugar en nuestro país en las décadas de 1960 y 1970, y que condicionaron las relaciones entre religión y política. En segundo lugar, me centro en las realidades propias del catolicismo. Dado que para comprender el paso a la acción de los actores en cuanto cristianos en diversos espacios de compromiso se vuelve necesario explorar el marco ideológico y doctrinario de este proceso, reviso los documentos eclesiales vinculados a la renovación católica -encíclicas de Juan XXIII y Pablo VI, constituciones del Concilio Vaticano II (1962-1965), Documento Final de la II Conferencia episcopal latinoamericana reunida en Medellín (1968), el Documento elaborado por los obispos argentinos en San Miguel (1969)-, focalizando la atención en sus implicancias sociales y políticas. A continuación, me adentro en las lecturas que hicieron de dichos documentos los Sacerdotes para el Tercer Mundo y Cristianismo y Revolución -dos referentes del catolicismo liberacionista en Argentina con los que los grupos locales tejieron vínculos, como veremos en el capítulo 3-. Por otra parte, resumo los ejes vertebradores de la teología de la liberación. Asimismo, abordo el fenómeno del "catolicismo integral", porque entiendo, como adelanté anteriormente, que una mirada de largo plazo es ineludible para dar cuenta de este proceso de "avance sobre la sociedad" que protagonizan los católicos liberacionistas.

El capítulo 2 trata sobre las tres ramas de Acción Católica que funcionaron en Bahía Blanca a fines de los años sesenta y primera mitad de los años setenta. Para comprender su desarrollo, considero necesario repasar brevemente las características de la ciudad en esos años, así como detenerme en los antecedentes de estos movimientos a nivel nacional y local.

En el capítulo 3 me propongo ubicar a la JUC, la JOC y la JEC en relación a otros espacios de sociabilidad del catolicismo liberacionista, así como a los sectores eclesiales renuentes a aceptar la renovación eclesial. Para ello, reconstruyo la red de grupos laicales, sacerdotes, religiosos y religiosas que actuaron en la ciudad y los vínculos e intercambios que articularon en Bahía Blanca, en Argentina y en América Latina con otros referentes liberacionistas. Por otra parte, me detengo en las interacciones de estos actores con la jerarquía y otros sectores de la Iglesia local.

En el capítulo 4 procuro dar cuenta del proceso mediante el cual los integrantes de las ramas especializadas bahienses se acercaron a la sociedad y a la política. Me interesa comprender en qué medida la fe movió a estos militantes a asumir un compromiso concreto en sus propios ámbitos, y en ese caso, de qué tipo de vivencia 
religiosa se trataba, qué papel tuvo la "pedagogía" del Ver, Juzgar y Actuar en este proceso; en suma, de qué forma su paso por los equipos de la JUC, la JOC y la JEC marcó sus trayectorias militantes.

En los siguientes dos capítulos estudio la acción política de los militantes jucistas, jocistas y jecistas en vistas a concretar lo que entendían como un proyecto de construcción de un hombre nuevo y una sociedad más justa. Así, el capítulo 5 se ocupa de la denuncia del orden vigente, considerado injusto, emprendida colectivamente como movimiento de JUC, JOC o JEC, o bien como conjunto de grupos identificados con la renovación conciliar- mientras el sexto se centra en el anuncio de otro mundo posible, entendida como venida del Reino de Dios y asumido por cada uno de los militantes en diversos ámbitos. En el primer caso, me interesa reflexionar en torno a las situaciones que motivaron la intervención pública de los actores, los canales elegidos para concretarla y los "otros" construidos en ese proceso. Y en el segundo, analizo los modos de inserción y compromiso de los militantes católicos, atendiendo a un amplio abanico de prácticas, espacios y adscripciones político-partidarias. En este sentido, exploro las afinidades entre el catolicismo liberacionista y estas múltiples posibilidades de participación, e intento historizar y explicar la opción política de una parte de los jucistas, jocistas y jecistas, la vinculación con agrupaciones marxistas, así como la identificación mayoritaria con el peronismo revolucionario. Por otra parte, si para dar cuenta de la militancia social y política de los jóvenes bahienses en el capítulo 1 considero una serie de ideas sobre la Iglesia y la relación con el mundo, a lo largo de los capítulos 5 y 6 retomo la cuestión de las redes de la renovación católica -descriptas en el capítulo 3-, y analizo la función política de los vínculos de sociabilidad, esto es, el papel de la materialidad constitutiva de las relaciones sociales en el impulso y la concreción de la acción contestataria.

El capítulo 7 atiende a los conflictos experimentados por los militantes y por los movimientos especializados de juventud bahienses a partir de su compromiso "temporal" en un contexto marcado por la efervescencia social y política. Específicamente, me centro en las tensiones suscitadas al interior de los grupos por la coexistencia de múltiples maneras de entender y llevar adelante el compromiso cristiano, y por la convivencia de diversas adscripciones político-partidarias; los dilemas que enfrentaron los militantes políticos por su participación simultánea en la comunidad cristiana y en las organizaciones político-militares, atendiendo a las demandas planteadas en uno y otro espacio, y a las formas en que resolvieron la cuestión; y por 
último, los debates y contradicciones suscitadas frente a la alternativa de tomar las armas y pasar a la clandestinidad.

En las conclusiones, intento recuperar las líneas de reflexión desplegadas a lo largo de la tesis sobre los cruces entre catolicismo liberacionista y política en Bahía Blanca a fines de los años sesenta y principios de los setenta, procurando señalar los matices cronológicos, las particularidades de cada uno de los grupos y las complejidades de las opciones político-religiosas de los militantes.

En el anexo describo los detalles de la construcción metodológica. Por un lado, incluyo una serie de fichas temáticas con el propósito de mostrar el modo en que se ha sistematizado la información para un análisis que permitiera tener una aproximación comparativa de los temas emergentes en las entrevistas. Por otro lado, presento las trayectorias de los entrevistados, así como de aquellos ex integrantes de las tres ramas especializadas de Acción Católica bahienses que fueron asesinados y desaparecidos durante la última dictadura militar. Por último, agrego, a modo de ejemplo de la construcción de fuentes orales, el cuestionario correspondiente a la última entrevista realizada, así como las notas de campo que elaboré con posterioridad al encuentro. 
CAPÍTULO 1: El marco interpretativo del acercamiento a la sociedad y a la política

SUMARIO

1) La efervescencia social y política de los años sesenta y setenta

2) Cambios y continuidades del catolicismo argentino y latinoamericano

a) La matriz del catolicismo integral

b) El aggiornamento eclesial y sus implicancias sociales y políticas

i) Los documentos eclesiales: una nueva concepción de la Iglesia y de su relación con el mundo

ii) La lectura de los Sacerdotes para el Tercer Mundo y de Cristianismo y Revolución: fe, política y revolución

c) La teología de la liberación: repensar la fe desde América Latina

\section{1) La efervescencia social y política de los años sesenta y setenta}

Distintos autores, como Gilman (2003) y Devés Valdés (2003), coinciden en considerar los "sesenta" como época, es decir, como un período con entidad histórica, temporal y conceptual propia, que se extiende entre la Revolución Cubana (1959) y el comienzo de las dictaduras militares de los años setenta en el Cono Sur. Los "sesenta" en América Latina estuvieron marcados por la expectativa revolucionaria, consistente en la percepción compartida de la transformación inevitable y deseada de las instituciones, la subjetividad, las costumbres, las mentalidades, los regímenes políticos, el arte, la cultura, la sociedad. De allí un conjunto de rasgos estructurales de la "sensibilidad sesentista", tales como la difusión del marxismo; la renovación del pensamiento cristiano; la valorización de la política y la exaltación del compromiso político; el utopismo; la búsqueda de formas de vida alternativas a las convencionales hippismo, orientalismo, protoecologismo-; la modernización cultural; la configuración de la idea de América Latina y de una identidad latinoamericana; el pensamiento político caracterizado por el antiimperialismo, el anticolonialismo, el anticapitalismo, los afanes integracionistas y liberacionistas y su posición popular; la aparición del dependentismo y del liberacionismo en el ámbito de las ideas. El contexto internacional, en general, parecía revelar una suerte de "marca revolucionaria del Tercer Mundo": luchas de descolonización en África; guerra de Vietnam; rebelión antirracista en Estados Unidos; brotes de rebeldía juvenil en distintos puntos del planeta; Revolución 
Cubana, intensificación de las luchas sociales, aparición de movimientos guerrilleros y crisis de legitimidad del sistema político en América Latina.

La fe en la revolución había recobrado toda su carga mesiánica: sólo la revolución permitiría edificar el mundo del pueblo liberado y del Hombre Nuevo. Para Ernesto "Che" Guevara, él era la semilla de la nueva sociedad y el resultado de la relación dialéctica entre sociedad y ser humano, mediante la que cual éste último transformaba su entorno al tiempo que era transformado por aquél. La criatura resultante de este proceso se caracterizaba por su solidaridad, voluntarismo, honestidad, desprendimiento, humildad y conciencia colectiva. De esta manera, se constituyó en referente para los movimientos de liberación nacional de la época. Como afirma Cruz Feliciano (2012) para el caso del Frente Sandinista de Liberación Nacional, la idea del Hombre Nuevo, precisamente encarnado en la figura del "Che", contribuyó a la dimensión mística del proyecto sandinista, proveyendo a los jóvenes de la década de 1980, un modelo a seguir e imitar, e impulsando a muchos de ellos a incorporarse a la experiencia revolucionaria.

El violento cambio social y político del continente estaba también vinculado a la industrialización bajo hegemonía del capital multinacional, que promovió una mayor dependencia y profundizó las diferencias sociales y regionales (Löwy, 1999). En este marco, en el campo de las ciencias sociales se formularon las teorías de la dependencia ${ }^{8}$, que se constituyeron en un elemento clave para una nueva toma de conciencia de la realidad latinoamericana y su transformación, esto es, para articular teoría y política. Esta interpretación surgió en ruptura con y a partir de la crítica profunda a los enfoques desarrollistas y modernizadores que habían dirigido sus expectativas a la industrialización, y que habían demostrado su ineficacia para interpretar la evolución económica de América Latina. El desarrollismo suponía que las diferencias entre países subdesarrollados y desarrollados eran sólo de grado o etapas. El subdesarrollo implicaba "ausencia de desarrollo" y el "atraso" de estas sociedades era explicado por las debilidades que en ellas existían para su modernización, por lo cual, estaban obligadas a repetir la experiencia histórica de las naciones desarrolladas (Beigel, 2005).

\footnotetext{
8 Afirmamos con Beigel (2005) que es conveniente hablar en plural de enfoques y teorías de la dependencia, para expresar con más propiedad al conjunto complejo y heterogéneo de los trabajos publicados a partir de 1965, por autores como Osvaldo Sunkel, Enzo Faletto, Fernando Henrique Cardoso, Andre Gunder Frank, Fernando Velasco Abad, Aníbal Quijano, Ruy Mauro Marini, Celso Furtado, Theotonio Dos Santos, Vania Bambirra, Franz Hinkelammert, entre otros.
} 
Las teorías de la dependencia, en cambio, dilucidaban las condiciones de explotación en que vivían nuestros países frente a los poderes hegemónicos del sistema capitalista como resultado de un proceso histórico; entendían que la polarización entre centros y periferias era inmanente a la expansión mundial del capital. El mismo desenvolvimiento capitalista era el que iba desarrollando y subdesarrollando a las naciones, según el papel que les tocara jugar; eran dos polos del mismo proceso. La dependencia aparecía como una relación que se establecía en una situación específica, y en la que se articulaba lo económico y lo político. Por lo tanto, resultaba inviable el desarrollo autónomo latinoamericano dentro del marco del sistema capitalista vigente. Sólo una revolución social podía permitir el paso a una sociedad distinta (Beigel, 2005). De este modo, caracterizar a América Latina como continente dominado y "oprimido", conducía a hablar de liberación ${ }^{9}$ económica, social, política, cultural (Gutiérrez, 1971; Tamayo Acosta, 1989).

Asimismo, América Latina, como gran parte del mundo occidental, asistía en esos años a una revolución cultural que involucró a las actividades artísticas e intelectuales, y a todo un modo de vida, costumbres y comportamiento. Como parte del mismo proceso, al cuestionamiento de la tradicional superioridad del hombre sobre la mujer se sumó el de la superioridad de los adultos sobre los jóvenes. La juventud, sujeto de esta revolución, se convirtió en un grupo social independiente, lo que implicó la resignificación del ser joven: ya no era una etapa de transición entre la niñez y la adultez sino el momento culminante del desarrollo humano (Burkart, 2007). Así, los jóvenes se convirtieron en un nuevo sujeto social que ocupó el centro de la escena en el campo cultural y político, se constituyeron en el sujeto que encarnaba la expectativa y la esperanza revolucionaria, y dentro de la Iglesia -como veremos en las páginas siguientes-, adquirían protagonismo y autonomía como laicos que estaban llamados a desempeñar un rol fundamental en el camino de liberación.

\footnotetext{
${ }^{9}$ Para Gutiérrez (1971), tres niveles de significación se interpenetran recíprocamente en este término. En primer lugar, liberación expresa las aspiraciones de los pueblos y sectores oprimidos y subraya el aspecto conflictual del proceso económico, social y político que opone a los pueblos y grupos opulentos. El término desarrollo, en cambio, falsea una realidad trágica y conflictual. En segundo lugar, concebir la historia como un proceso de liberación del hombre supone percibirlo como una conquista histórica, que no se realiza sin lucha contra todo lo que oprime al hombre y que implica no sólo mejores condiciones de vida, un cambio radical de estructuras, una revolución social, sino también la creación continua de una nueva manera de ser hombre. Finalmente, en este proceso se halla presente una problemática teológica; hablar de liberación nos conduce a las fuentes bíblicas que inspiran la presencia y el actuar del hombre en la historia. Así, liberación no es un concepto sociopolítico moderno ajeno al campo teológico, sino una palabra central en la proclamación bíblica que expresa, junto a "salvación", la acción de Dios y la misión de Jesús, así como la vocación del hombre a construir con Dios el Reino (Segundo, 1990a).
} 
Así, la irrupción, hacia fines de los años sesenta, de una cultura juvenil en la Argentina asumió un tono general crítico frente al orden social y político, que se expandió en esos años, apoyado en tradiciones diversas e incluso contradictorias que, sin embargo, lograron articularse en el imaginario juvenil, sosteniendo prácticas y actitudes. Esta nueva cultura juvenil no se agotaba en la militancia en organizaciones políticomilitares, sino que implicó una amplia gama de "modos de sociabilidad, de establecer relaciones afectivas y sexuales, de enfrentar a la autoridad en el grupo familiar y fuera de él", planteos cuestionadores que daban cuenta de la existencia de convicciones comunes y generales, que serían la base de la resignificación de la categoría "juventud" (Cataruzza, 1997: 106).

Los años sesenta fueron, al mismo tiempo, el momento de repliegue y renovación de "las derechas", proceso que cristalizó en la instalación de regímenes dictatoriales de carácter contrarrevolucionario en el Cono Sur. Las dictaduras de Brasil (1964-1985), Uruguay (1973-1985), Chile (1973-1990) y Argentina (1976-1983) compartieron una intención fundacional o refundacional, que se expresó en la articulación de proyectos de transformación profunda de las sociedades de los respectivos países, desde fundamentos ideológicos-doctrinarios comunes basados en la Doctrina de la Seguridad Nacional ${ }^{10}$. El punto de partida de estos proyectos de cambio fue la percepción de la existencia de una crisis de los valores de fundamentación última del sistema de producción/reproducción social vigente, en que se legitimaban los intereses de los grupos dominantes. De allí, la implantación, a través de las dictaduras, de un sistema de dominación que era excluyente en lo económico, con una distribución del ingreso fuertemente regresiva, y en lo político, a través de la implementación de medidas represivas a gran escala. Estas características, sumadas a la participación institucional permanente de las Fuerzas Armadas, orientada a concretar la transformación del sistema político, dan cuenta de la presencia de un "nuevo autoritarismo" en América Latina (Rico, 2009). En la práctica, ese carácter conservador y antiobrero llevó a la institucionalización de la coordinación represiva entre los distintos regímenes dictatoriales y, a partir de fines de 1975, al surgimiento de la

\footnotetext{
${ }^{10}$ La forma específica que asumió la Doctrina de la Seguridad Nacional en América Latina enfatizaba la "seguridad interna" del país frente a la amenaza de "acción indirecta" del comunismo. Según esta lógica, la bipolaridad del mundo llevaba a la desaparición de las guerras convencionales y a su reemplazo por guerras ideológicas disputadas dentro de las fronteras nacionales, en todos los frentes en los que actuaba la subversión: militar, político, económico, cultural, ideológico. En este nuevo contexto, las Fuerzas Armadas debían prepararse para un enfrentamiento no convencional (Ansaldi, 2004).
} 
“Operación Cóndor”, un plan secreto que realizó tareas de inteligencia, persecución y asesinato de disidentes (Markarian, 2009; Rico, 2009; Ansaldi, 2004).

Durante los años sesenta y setenta, se desarrolló en Argentina un proceso de protesta social y efervescencia política que sumergió a la sociedad en una etapa de contestación generalizada. Un clima de malestar creciente tendía a cuestionar el ordenamiento habitual de la vida social y las formas tradicionales de ejercicio de la autoridad y de la representación. La oposición social y política desbordaba hacia los fundamentos mismos de la organización social y la dominación estatal. Diversos sectores provenientes del peronismo, la izquierda, el nacionalismo y el catolicismo ligado a la teología de la liberación convergieron en la crítica al "sistema" y se percibieron como parte del campo popular y revolucionario. Esta heterogénea "Nueva Izquierda" se volvió particularmente amenazante para los sectores dominantes a partir de la eclosión social de 1969 y del crecimiento de la guerrilla, pero su presencia se venía manifestando sostenidamente a lo largo de la década anterior (Tortti, 1999a y b).

El golpe de 1955 había abierto un período de continua crisis e inestabilidad políticas derivadas de la proscripción del peronismo (O’Donnell, 1982). Para Amaral (1993), la caída de Juan Domingo Perón abrió una crisis de legitimidad debida al rechazo del sistema político por Perón y el peronismo y al de éstos por los otros actores políticos. La historia política argentina posterior estuvo marcada por la necesidad de reintegrar al sistema político las fuerzas sociales que se expresaban a través del peronismo, lo que sólo pudo alcanzarse cuando todos los otros actores aceptaron el reingreso de Perón al sistema. En este marco, paulatinamente, emergió un sistema político dual en el cual los mecanismos parlamentarios coexistieron con modalidades extra-institucionales de hacer política. En consecuencia, el sector popular-privado de toda representación tanto en las instituciones parlamentarias semidemocráticas como en la maquinaria institucional del Estado-, y los sectores burgueses y de clase media rara vez compartieron la misma arena política para la resolución de los conflictos (Cavarozzi, 2004). Según Portantiero (1977), la inestabilidad crónica de la Argentina, su condición de sociedad "ingobernable", tenía que ver con una situación de "empate hegemónico" entre fuerzas alternativamente capaces de vetar los proyectos de las otras, pero sin recursos suficientes para imponer, de manera perdurable, los propios. Así, las clases dominantes se mostraban incapaces para construir alguna forma de dominación legítima sobre una sociedad progresiva y dramáticamente desintegrada. La crisis de hegemonía se articulaba con un nuevo modelo de acumulación de capital -basado en 
una situación de poder económico compartido entre distintas fracciones de la burguesíay la complejización de las contradicciones entre clases.

El autoritarismo del régimen militar inaugurado en 1966 fue decisivo en la efervescencia de los últimos años sesenta. El intento de Juan Carlos Onganía de eliminar el juego político terminó por producir el efecto contrario y enfrentó al gobierno con una crisis de dominación social en la que se superponían las contestaciones antiautoritarias, los cuestionamientos a las políticas económicas liberales, los reclamos de democratización con elecciones sin proscripciones y los planteos de insurrección popular para instaurar un orden social y político alternativo (Cavarozzi, 2004). La agitación estudiantil, de los trabajadores y las organizaciones gremiales, el descontento de los sectores nacionalistas y la oposición de la gran burguesía pronto dejaron al gobierno extrañado de la sociedad (O’Donnell, 1982). Un foco de oposición enérgica a la "Revolución Argentina" fue la CGT de los Argentinos que, nacida en 1968 y liderada por Raimundo Ongaro, expresó una ruptura en la columna vertebral de la burocracia sindical peronista y comenzó a promover nuevas formas de protesta y resolución de los conflictos que permitieron la real participación de las bases sindicales y la vinculación con los estudiantes (Altamirano, 2001a; Gordillo, 2003).

En efecto, entre los actores protagonistas de la oposición a la dictadura también figuran los sectores estudiantiles y los intelectuales. Siguiendo a Gillespie (1987), se puede decir que el gobierno de Onganía significó un duro golpe para las clases medias ya que atentó contra sus principales "cotos privados": la universidad y el mundo de la cultura en general. Las universidades nacionales fueron intervenidas, se atacó su autonomía y la libertad de cátedra, se prohibió la actividad política de los estudiantes y se anuló su derecho a participar en el sistema tripartito de gobierno universitario. Pero como ocurría a nivel nacional y en otras instituciones sociales, el autoritarismo del régimen militar y su intento de anular la política actuaron como caldo de cultivo de un proceso de "radicalización" (Gillespie, 1987) o de "politización" de los sectores medios y del estudiantado (Barletta y Tortti, 2002), produciendo, en definitiva, el efecto contrario al que se proponían.

A la oposición a la "Revolución Argentina" se sumaron los sectores católicos renovadores y los grupos armados de distintas vertientes político-ideológicas, para las cuales el Onganiato actuó como precipitador (Gordillo, 2003). Se multiplicaron, también, las prácticas políticas no violentas de los jóvenes en partidos, sindicatos, asociaciones barriales, centros culturales, etc. 
Si la oposición a la dictadura de Onganía fue el catalizador de este proceso de activación política que incluyó a los jóvenes como uno de sus protagonistas privilegiados, por otra parte, para la "Revolución Argentina", esta cultura juvenil emergente tenía una configuración sospechosa. Como señala Pujol, para el gobierno, “eran los jóvenes los que atentaban contra 'la sexualidad íntima, nuestra, no perversa'. Eran los jóvenes los que alentaban modos de vida reñidos con la moral 'occidental y cristiana'. Eran los jóvenes, al fin y al cabo, los principales provocadores" (2003: 315).

El año 1969 marcó un punto de inflexión y el comienzo del fin del gobierno de Onganía. La protesta obrera se transformó en rebelión popular con el estallido de insurrecciones urbanas -cuyo episodio más significativo fue el "Cordobazo"(Cavarozzi, 2004; Altamirano, 2001a; Gordillo, 2003), que expresaron y fueron el disparador de tensiones acumuladas desde la implantación del régimen ( $\mathrm{O}^{\prime}$ Donnell, 1982). Por otra parte, florecieron las experiencias más extremas de cuestionamiento del orden social, político y económico: el sindicalismo clasista en Córdoba (Brennan, 1996) y las organizaciones armadas, que después del "Cordobazo" y durante siete años ocuparon el espacio público argentino (Altamirano, 2001a; Gordillo, 2003).

Ese cuestionamiento al sistema respondía a las vicisitudes de la historia política y social argentina, pero también estaba asociada a la esperanza revolucionaria que era alentada por la experiencia cubana. Cuba introdujo un nuevo horizonte para el conjunto de la izquierda latinoamericana -los jóvenes de una "nueva izquierda" comenzaron a concebir el futuro en términos de una ruptura radical- al tiempo que devino puente entre izquierda, nacionalismo y peronismo (Altamirano, 2001a; Sigal, 2002).

A fines de la década de 1960, una serie de rupturas y escisiones en los partidos tradicionales de la izquierda dieron origen a grupos revolucionarios marxistas que no descartaban la lucha armada como medio para acceder al poder. Tal fue el caso de Vanguardia Comunista -escisión del Partido Socialista Argentino de Vanguardia-, el PCR y el PRT (Lanusse, 2007a). El PCR surgió a principios de 1968, a partir de ex militantes del Partido Comunista Argentino (PCA) que denunciaron que el "revisionismo" del partido había traicionado la política revolucionaria marxistaleninista. Simpatizaban con el maoísmo y estaban a favor de una estrategia insurreccionalista. Un grupo de militantes del PCR organizó las Fuerzas Armadas de Liberación (FAL) en 1969 (Seoane, 1993; Gordillo, 2003). El PRT fue fundado en 1965 luego de la unión de dos organizaciones: Palabra Obrera -de tendencia trotskista, nacida en las urbes industriales- y el Frente Revolucionario Indoamericano y Popular - 
nacionalista y antiimperialista, abocado a las problemáticas de los trabajadores del norte argentino. En el V Congreso partidario, celebrado en 1970, un sector del PRT conocido como PRT El Combatiente fundó el ERP (Seoane, 1993) ${ }^{11}$.

La convergencia entre peronismo y socialismo fue, desde comienzos de los años sesenta, una de las expresiones más significativas que acompañó el crecimiento de la efervescencia política de la sociedad argentina. Grupos y activistas, provenientes de corrientes marxistas que reinterpretaban el peronismo o bien de figuras del peronismo que incorporaron concepciones del marxismo, procesaron dicha confluencia como una nueva identidad política, protagonizando el nacimiento del peronismo revolucionario o izquierda peronista. Bajo la influencia de John William Cooke, el peronismo revolucionario planteó la necesidad de la transformación del movimiento y la "radicalización" de su programa, tomando el socialismo como horizonte estratégico y la opción revolucionaria -insurreccionalismo y preparación de la lucha armada- como vía para la conquista del poder. Ya en la década de 1960 pueden reconocerse diversas vertientes del peronismo revolucionario, constituidas por los comandos de la resistencia peronista, los activistas sindicales y la juventud (Bozza, 2001). A finales de la década y principios de la siguiente, se sumaron los sindicatos rebeldes de Córdoba, el PB, y organizaciones armadas como las Fuerzas Armadas Peronistas (FAP), las Fuerzas Armadas Revolucionarias (FAR) y Montoneros, así como diversas ramas juveniles (De Riz, 1987). Luego, en el contexto de "montonerización" ocurrido entre 1972 y 1973 se formó un frente de masas, sintetizado en la "Tendencia Revolucionaria", que incluía a JP, la Juventud Universitaria Peronista (JUP), la Unión de Estudiantes Secundarios (UES), la Juventud Trabajadora Peronista (JTP), el Movimiento de Villeros Peronistas (MVP), la Agrupación Evita (AE) y el Movimiento de Inquilinos Peronistas (MIP) (Svampa, 2003).

Así, dentro del peronismo revolucionario convivían vertientes disímiles. Las FAP y el PB por un lado, y Montoneros y su frente de masas, por el otro, tenían importantes diferencias ideológicas, organizativas y metodológicas. La existencia de las FAP se dio a conocer en octubre de 1968, cuando un número importante de sus integrantes fueron descubiertos por una patrulla de la gendarmería en la localidad tucumana de Taco Ralo cuando realizaban tareas de reconocimiento del terreno. Después de la captura de este destacamento, las FAP no volvieron a intentar otro ensayo

\footnotetext{
${ }^{11}$ Para profundizar sobre los debates y rupturas en los partidos Comunista y Socialista en la década previa, ver Tortti, C. (1999b, 2002).
} 
de guerrilla rural (Raimundo, 2004). El PB era una organización política de orientación clasista que aglutinó a militantes obreros combativos, sindicatos y comisiones de base en importantes fábricas y centros urbanos del país. Su surgimiento estuvo ligado a la reconstitución de las FAP después de Taco Ralo, que apuntó a la construcción de una organización político-militar que habría de consolidarse en el desarrollo de una "guerra popular y prolongada" como estrategia para la toma del poder -de la mano del abandono del foco rural y la adopción de los procedimientos de la guerrilla urbana- y en la mayor gravitación del trabajo en los frentes de masas (Bozza, 2001).

Por otra parte, Montoneros era una organización político-militar que se dio a conocer públicamente en mayo de 1970 con el secuestro y asesinato del ex presidente de facto, Teniente General Pedro Eugenio Aramburu. En su conformación, la influencia de las redes sociales de la renovación católica fue directa. Es decir, es posible explicar el surgimiento de Montoneros partiendo de las sociabilidades católicas y de las redes erigidas en torno a ellas en Buenos Aires, Santa Fe, Córdoba, Tucumán, Corrientes o Chaco. Desde el punto de vista organizativo, se distinguen diversas etapas en el período (Donatello, 2010). Una constante en la historia de Montoneros es su carencia de una ideología y un programa definidos (Gillespie, 1987). Sin embargo, hubo dos elementos permanentes del discurso montonero: el llamado a conformar un ejército popular y la necesidad de una guerra integral, para cambiar la sociedad. En su diagnóstico de la misma, la desigualdad social se combinaba con la existencia de una oligarquía al servicio de la dominación transnacional. Nuevamente, el proyecto de sociedad presentaba indefinición. Las retóricas del Hombre Nuevo y el socialismo nacional se combinaban con la teoría de la dependencia y las hermenéuticas del propio Perón, y concurrían en la necesidad de legitimarse como vanguardia armada (Donatello, 2010).

En este marco en el cual el peronismo comenzó a ser valorado como una alternativa auténticamente revolucionaria, la efervescencia de aquellos años a menudo estuvo acompañada de "peronización". Este proceso atravesó diversos espacios e instituciones sociales, incluidos los gremios profesionales, las organizaciones estudiantiles y la vida universitaria en general (Gillespie, 1987; Barletta y Tortti, 2002).

El catolicismo liberacionista fue uno de los protagonistas del movimiento social y actor político al que denominamos "Nueva Izquierda" (Tortti, 1999a y b). El proceso que experimentó la Iglesia Católica, sumado a la evolución de la izquierda y el peronismo revolucionario, resulta fundamental para comprender la efervescencia política de los años sesenta y setenta $\mathrm{y}$, en particular, el desarrollo del movimiento 
estudiantil universitario (Altamirano, 2001b) y la historia de Montoneros (Gillespie, 1987; Lanusse, 2007a; Morello, 2007).

\section{2) Cambios y continuidades del catolicismo argentino y latinoamericano}

Desde finales de la Segunda Guerra Mundial, se desarrollaron nuevas corrientes teológicas en Alemania y Francia, nuevas formas de cristianismo social y una creciente apertura a las preocupaciones de la filosofía moderna y de las ciencias sociales, que fueron sistematizadas y legitimadas por el pontificado de Juan XXIII (1958-1963) y el Concilio Vaticano II (Löwy, 1999). En este sentido, la presencia de una amplia disposición al cambio en el catolicismo latinoamericano fue ampliada, aunque no creada ex novo, por las encíclicas del "Papa bueno" y por los documentos conciliares (Levine, 1996). Estos hitos, sumados el pontificado de Pablo VI (1963-1978), la II Conferencia General del Episcopado Latinoamericano en Medellín y la II Asamblea Extraordinaria del Episcopado Argentino en San Miguel marcaron la renovación eclesial en diversos ejes, a saber: una apertura al mundo, una atención preferencial a los pobres y un espíritu más horizontal y participativo, que remitían al compromiso histórico por la "liberación nacional y social" que se perfilaba como ideal para grandes sectores de la juventud argentina (Politi, 1992: 121).

A partir del Concilio comenzaron a hacerse evidentes tensiones emergentes de la coexistencia de perspectivas eclesiológicas y formas de acción socio-religiosas diversas. En este sentido, las décadas de 1960 y 1970 están marcadas por una doble dinámica: por un lado, de aggiornamento en lo teológico y pastoral de algunos sectores; y por otro, de resistencias y reacción dentro de la institución (Ameigeiras, 2008).

La corriente renovadora incluía a una infinidad de organizaciones, grupos, experiencias e intereses disímiles, así como caminos dispares de búsqueda intelectual, reflexión teológica, compromiso político y social (Habegger, 1970). Dentro de este universo, en América Latina surgió el cristianismo liberacionista, del que la teología de la liberación era expresión/producto espiritual/reflejo, al tiempo que lo legitimaba, le proporcionaba una doctrina religiosa coherente y, así, contribuía a que se extendiera y reforzara. Este movimiento, que apareció muchos años antes de la nueva teología, abarcaba a sectores importantes de la Iglesia, movimientos religiosos laicos, comunidades eclesiales de base y organizaciones populares que, inspirados en la fe y la tradición católica, se unían a la causa de los explotados (Löwy, 1999). 
En este sentido, dicho fenómeno tuvo consecuencias políticas trascendentales. Siguiendo a Löwy (1999), religión y política se vincularon en este movimiento a partir de una "afinidad electiva" (Weber, 1967) ${ }^{12}$ basada en una matriz común de creencias religiosas y políticas en torno a las prácticas de transformación social. De este modo, un creciente número de cristianos se convirtieron en activos partícipes de las luchas populares. Probablemente, la revolución sandinista en Nicaragua haya sido el ejemplo extremo de la interacción entre política y religión, interacción que condujo a una fuerte simbiosis cultural, influencia mutua y convergencia práctica entre ética cristiana y esperanza revolucionaria. Curas extranjeros, órdenes religiosas y laicos tuvieron un papel clave en el movimiento. Por otra parte, la insurgencia popular en El Salvador se caracterizó por el papel prominente del obispo Oscar Arnulfo Romero y la absorción de la religión por la política, a partir de la participación de cristianos en los movimientos guerrilleros y en las bases de masas del Frente de Liberación Farabundo Martí que lanzó la ofensiva contra el ejército.

En este proceso, católicos de distintos puntos del continente descubrieron el marxismo como llave para la comprensión de la realidad social, así como una guía para cambiarla. De este modo, se dio el pasaje de grupos políticos cristianos al marxismo (Löwy, 1999; Ridenti, 2002). Este es el caso de la Acción Popular (AP) en Brasil, cuya trayectoria hunde sus raíces en la JUC de fines de la década de 1950-principios de la década de 1960, y está marcada por la influencia de la Revolución Cubana, la adhesión al marxismo-leninismo y, particularmente, a una interpretación maoísta del marxismo en 1968, la pérdida de identidad propia y la integración de la mayor parte de la organización al Partido Comunista de Brasil en 1973. La afinidad entre el romanticismo revolucionario -entendido como crítica a la civilización capitalista moderna, la búsqueda en el pasado de elementos para la construcción de un Hombre Nuevo y el énfasis en la práctica de transformación- presente en los idearios de la Revolución Cubana y del maoísmo y en el de la JUC, permiten explicar la aproximación de la AP a esas experiencias marxistas. Así, guevarismo y maoísmo parecían adecuados para expresar la voluntad de transformación de los jóvenes jucistas que ya no podían canalizarla por los estrechos límites de la institución eclesial. A partir de la disolución

\footnotetext{
${ }^{12}$ Löwy (1999) toma el concepto de La ética protestante y el espíritu del capitalismo de Max Weber, donde el autor lo utiliza para designar la relación existente entre ciertas formas religiosas y el estilo de vida capitalista. Si bien Weber no define lo que entiende por "afinidad electiva", Löwy deduce que se trata de una relación de atracción y refuerzo mutuo, que en ciertos casos conduce a una especie de simbiosis cultural.
} 
de lo que quedaba de la AP en 1981, muchos de sus miembros se integraron a las fuerzas que formaron el Partido de los Trabajadores, donde se encontraron con otros militantes católicos (Ridenti, 2002) ${ }^{13}$.

Por otra parte, en el marco de la renovación católica, nacieron en nuestro país las experiencias del diálogo entre católicos y marxistas, los Curas obreros, el MSTM, los Campamentos Universitarios de Trabajo (CUT) y la revista Cristianismo y Revolución. Quisiera detenerme en estas últimas porque, tal como veremos en el capítulo 3, resultaron especialmente significativas para los actores bahienses.

Los curas obreros nacieron en Francia en las décadas de 1940 y 1950, y más tarde crearon misiones en otros países. Pío XII los suprimió en 1954 y fue el Concilio el que los rehabilitó en 1965. En Argentina, Monseñor Jerónimo Podestá brindó la diócesis de Avellaneda para la primera experiencia de curas dispuestos a vivir y trabajar como los "no privilegiados". La estrategia que primaba dentro del grupo no era la de realizar acción pastoral dentro del mundo obrero sino la de comprometerse junto a los trabajadores en su medio, viviendo su misma vida. Estos sacerdotes tuvieron protagonismo en la organización sindical, lo que motivó el despido de varios de ellos de las fábricas en las que trabajaban, generando tensiones al interior de la Iglesia (Habegger, 1970; Donatello, 2010).

En segundo lugar, siguiendo a Martín (2010), el MSTM comenzó a estructurarse en 1968 a partir de la adhesión de sacerdotes de distintos puntos del país al Manifiesto de 18 obispos del Tercer Mundo, y reunió a más de 500 presbíteros, que constituían el 9\% del clero -y el 20\% del clero de 30 a 40 años-, eran predominantemente diocesanos aunque en Bahía Blanca hubo una participación importante de hombres de instituciones religiosas-, y al menos un tercio se había formado durante el Concilio Vaticano II. Las diócesis fueron el lugar de articulación para el movimiento, de la mano de nuevas experiencias de asociación y de reuniones colegiadas de sacerdotes -ya sea impulsadas por directivas oficiales o por nucleamientos espontáneos de presbíteros interesados en la renovación- frente a las cuales el MSTM se colocó en una línea de continuidad,

\footnotetext{
${ }^{13}$ El catolicismo liberacionista tuvo una influencia decisiva en las luchas populares en Brasil de otras maneras y en procesos posteriores. El Movimiento de campesinos Sin Tierra tuvo un origen católico, a partir de la pastoral de la Tierra, en el contexto de la influencia de la teología de la liberación. Ésta, a su vez, era heredera de la izquierda católica brasileña de los años sesenta, que encarnó la JUC y la AP. Otros nuevos movimientos populares brasileños de la redemocratización de los años ochenta son también producto de actividades de bases de cristianos comprometidos, agentes pastorales laicos y comunidades cristianas de base (Löwy, 1999; Ridenti, 2002).
} 
absorbiendo en su devenir algunas de esas formas asociativas, influyendo en el eclipse de otros y potenciando energías latentes en el clero argentino.

Según Martín, el MSTM “es una formación sociológica argentina, que nace, se desarrolla y se disuelve sin lazos organizativos determinantes con instancias, homólogas o diversas, de otros países" (2010: 43). Su estructura interna, mínima y flexible, se definió en el I Encuentro, de mayo de 1968, con un "responsable general", 3 o más integrantes de un "secretariado", los "coordinadores", que abarcaban zonas del país con varias diócesis, y los encargados de la promoción y el enlace en cada diócesis, llamados "delegados" o "responsables". Las líneas y las acciones del MSTM se decidían en reuniones en las que participaban el secretario general, el secretariado, los coordinadores $\mathrm{y}$, en ocasiones, algunos "delegados". Estas figuras no estaban claramente delimitadas y había zonas que tenían hasta tres "coordinadores". En 1968 y 1969 se establecieron seis regiones en el país, ampliadas a ocho más tarde. Sin embargo, lo decisivo de la actuación del MSTM estaba en los grupos diocesanos. Éstos se reunían con diversa frecuencia y metodología, hacían declaraciones públicas locales o en coordinación con iniciativas nacionales, y decidían formas de acción pastoral muy definidas, lo que traía en sí el germen de inevitables tensiones en sus diócesis (Martín, 2010).

Al intensificar su inserción entre los sectores obreros y marginados, el MSTM se relacionó frecuentemente con el gremialismo o con grupos de base organizados (CGT de los Argentinos, SITRAC-SITRAM en Córdoba, FOTIA en Tucumán, etc.). En cuanto a los vínculos con la Iglesia, éstos fueron complejos. El MSTM nunca se planteó actuar fuera de ella. Se consideró una instancia asociativa legítima dentro de la misma. Los obispos, por su parte, si bien criticaron en varias oportunidades aspectos del movimiento y por momentos tuvieron con él relaciones tormentosas, omitieron cuidadosamente el planteo de su ilegitimidad. La mayor tensión se expresó en las relaciones del MSTM con las Fuerzas Armadas, por razones sociopolíticas y de seguridad. El ideal del socialismo latinoamericano y la denuncia de la violencia "institucionalizada" con los que el movimiento inauguró su presencia histórica, hicieron que aquéllas no pudieran no sentirse aludidas ${ }^{14}$. La idea sobre el MSTM que terminó

\footnotetext{
${ }^{14}$ A esto se suman las relaciones del movimiento con las organizaciones armadas que, siguiendo a Martín (2010), se pueden dividir en cuatro capítulos principales: a) el contacto de origen entre miembros del MSTM y de la guerrilla en grupos de militantes católicos anteriores y contemporáneos a la génesis de ambas formaciones; b) la cercanía ideológica del MSTM con grupos políticos que sustentaban la tesis de la toma del poder por medios revolucionarios y en el horizonte de América Latina, y las diversas ideas
} 
por dominar en el ámbito castrense fue la sostenida por el sacerdote Julio Meinville, quien lo ubicaba en la expansión de la subversión marxista de tipo argelino y, dogmáticamente, en la corriente del "neomodernismo" (Martín, 2010).

Según el Comando de Operaciones Navales de la Base Naval de Puerto Belgrano, el MSTM era una organización que tenía por finalidad instaurar en el poder político un gobierno "socialista marxista, sirviéndose, como medio de la dialéctica marxista con todo lo que ésta supone: lucha de clases, lavado de cerebro, violencia y revolución”. Así, desde la perspectiva militar, los presbíteros cometían un doble error: por un lado, "pretender que la finalidad primordial de la Iglesia sea solucionar directamente los problemas materiales económico-sociales"; y por el otro, "que lo hagan con un sistema inmoral, ya rechazado desde mucho tiempo atrás, y cuya aplicación causaría mayores males que los que se pretende sanar”. Según el documento, al chocar con la falta de apoyo de la jerarquía, aquellos sacerdotes fundaban de hecho una "Iglesia paralela", bajo el argumento de que los obispos debían gobernar de acuerdo a la voluntad del pueblo y arrogándose los clérigos la identidad del mismo. Por otra parte, desde la óptica castrense, los "tercermundistas" representaban el "triste papel de agitadores sociales" en cuanto tumulto se presentaba con el "patente propósito de impedir la paz interna y mantener la agitación, que, según la dialéctica, posibilitará la ascensión del marxismo al poder" ${ }^{\prime 15}$.

Dentro del apretado lapso en el que actuó el MSTM, es posible reconocer diversas etapas: a) nacimiento y consolidación del movimiento (octubre 1967-junio 1970), cuya cuestión clave era probar la validez de la autopresentación del MSTM como obediencia al magisterio de la Iglesia, en especial al Concilio, a la Populorum Progressio, a Medellín y al documento de San Miguel; b) crecimiento de la tensión política y religiosa en todo el país (julio 1970-noviembre 1972), en el que el MSTM ocupó frecuentemente el centro de la escena pública argentina y se acercó al peronismo; c) actuación en la escena política (diciembre 1972-agosto 1973), que comenzó con la reunión con Perón en su residencia de Vicente López, e inició la declinación del movimiento; d) fractura interna (agosto 1973-marzo 1976), que empezó en el VI Encuentro Nacional, ligada a la cuestión del peronismo (a partir de entonces, el MSTM

que se expresaban en el movimiento sobre la licitud y la conveniencia de la protesta armada; c) las relaciones concretas del MSTM con diversas organizaciones y actos armados, y las distintas opciones en 1969, 1973 y 1976; d) la participación de algunos STM en el accionar de esas organizaciones.

${ }^{15}$ Comando de Operaciones Navales. Base Naval Puerto Belgrano (1970), ¿Qué es el Movimiento de Sacerdotes para el tercer Mundo?, Bahía Blanca. Archivo del Área Cultura, Sociedad y Religión, CEILPIETTE, CONICET. 
se manifestó a través de acciones regionales); e) retracción global y exilio (marzo 1976diciembre 1976), el MSTM dejó toda actividad pública (en los dos últimos períodos, 47 sacerdotes emigraron del país, 16 fueron asesinados y desaparecidos) (Martín, 2010).

Por otra parte, los Campamentos Universitarios de Trabajo surgieron a partir de una serie de experiencias del jesuita José María "Macuca" Llorens en el barrio San Martín de Mendoza capital, que tuvieron lugar en febrero de 1964 y en enero de 1965, y reunieron a 50 universitarios de 6 provincias y a 140 jóvenes de 13 provincias respectivamente. Con el tiempo, la propuesta atrajo a un número creciente de estudiantes que, divididos en grupos, trabajaron en campamentos simultáneos. Por ejemplo, en 1966 los participantes se repartieron entre Reconquista y Fortín Olmos (Santa Fe), y al año siguiente, se montaron seis campamentos con un total de 200 universitarios en las villas inestables de Neuquén y el Alto Valle del Río Negro ${ }^{16}$. Así, si los CUT se realizaron siempre durante el verano -concretamente, en el mes de enero-, los lugares fueron cambiando año a año, abarcando, además de los sitios mencionados, las provincias de Chaco, Corrientes ${ }^{17}$, Tucumán, Santiago del Estero o Catamarca. Allí se trabajaba en la cosecha de productos masivos como el tabaco, el algodón o la fruta, en jornadas que frecuentemente iban "de sol a sol".

De esta manera, la experiencia se basaba en la inmersión del universitario en el mundo de los marginados, la participación en sus vidas, la convivencia con ellos y el trabajo en común (Habegger, 1970). Según los protagonistas, este trabajo tenía una triple dimensión: el diálogo, como "comunicación existencial"; el conocimiento de la realidad de un pueblo marginado por la escasez de vivienda y la inestabilidad de trabajo; y la "toma de conciencia de esta realidad y de la realidad de que el futuro de nuestro país y de América Latina depende de hombres comprometidos". En este sentido, se buscaba cooperar en la "transformación auténtica en las estructuras" a partir de la

\footnotetext{
16 "Campamento Universitario de Trabajo", volante s/f (hacia 1966), Archivo personal de Julio e Irene.

17 Siguiendo a Healey (2003), las provincias del Nordeste no fueron una prioridad para el gobierno nacional. En los años sesenta, las crisis de las economías regionales provocaron un fuerte éxodo de la región, especialmente de las provincias de Formosa, Corrientes y Chaco. En el marco de las crisis del agro, de la poca eficacia de organizaciones cooperativas y gremiales tradicionales y del avance de la Iglesia católica -fundamentalmente, de los laicos- en los intentos de organización, surgieron, a principios de los años setenta, las Ligas Agrarias. Éstas, que se hicieron fuertes en Chaco, Formosa, Misiones y Corrientes, mostraron gran capacidad para articular grupos e intereses antes dispersos. Sus protagonistas fueron los hijos de los colonos o pequeños agricultores locales. Así, en ellas confluyeron las estrategias de acumulación o mera supervivencia de los pequeños productores con la ideología radicalizada de la juventud católica. La agenda de las ligas fue diversa según el modo en que la crisis general del agro afectaba la producción del algodón, la yerba mate o el tabaco en las distintas provincias. Sobre las Ligas Agrarias y el papel de la rama rural de Acción Católica en su surgimiento véase Archetti, 1988; Lasa, 1987; Roze, 2011.
} 
convicción de que "no hay verdadero cambio de estructura sino cambiamos antes las estructuras de nuestro ser personal"18. Así, se planteaba como un reto a la mentalidad del "no comprometerse", al asistencialismo y al paternalismo. Para quienes provenían en su mayoría de la clase media, compartir las labores diarias y las condiciones de vida de la gente trabajadora significaba dejar de lado las propias comodidades y seguridades materiales, experimentar la rudeza del trabajo manual, la incomodidad de la vivienda, las injusticias de la pobreza y la explotación. Después de vivir en carne propia y comprender profundamente los sufrimientos de los marginados ya no se podía seguir siendo igual. Así, los Campamentos se constituían en una experiencia de conversión, es decir, de cambio personal auténtico. En este sentido, contribuyeron a la "toma de conciencia de la realidad" y de la necesidad de transformarla por parte de muchos jóvenes que, al volver a sus lugares de origen, eligieron comenzar o profundizar su militancia (Habegger, 1970).

En particular, los CUT aspiraban a formar profesionales involucrados con su comunidad. Partiendo de la idea de que era el pueblo el que sostenía las universidades, los futuros científicos y técnicos debían devolverle a aquél lo que les había dado para promoción de todos, especialmente los que vivían “en condiciones menos humanas”. Se trataba de que descubrieran que la profesión, lejos de ser un medio para ganarse la vida, encontraba sentido en el servicio como "deber ineludible de justicia"19.

Por último, siguiendo a Lenci (1998, 2000) y a Morello (2003, 2007), Cristianismo y Revolución fue publicada entre 1966 y 1971, bajo la dirección de Juan García Elorrio -hasta su muerte en febrero de 1970- y luego, de Casiana Ahumada compañera de García Elorrio y financiadora de la revista-, con una frecuencia irregular, llegándose a editar 30 números, más 3 especiales -dedicados al Che Guevara, a Camilo Torres y a la Revolución Cubana. La revista, nacida como órgano de oposición a la dictadura de Onganía, tenía como tema central el rol de los cristianos en la lucha revolucionaria, basándose en dos consignas: "el deber de todo católico es ser revolucionario" -tomada de Camilo Torres- y "el deber de todo revolucionario es hacer la revolución" -tomada del Che Guevara. En efecto, estas dos figuras, sumadas a la de Juan Domingo Perón, fueron configurando las bases de los acuerdos con que los miembros de la revista construyeron su identidad política. Sus destinatarios incluían

\footnotetext{
18 "Campamento Universitario de Trabajo", volante s/f (hacia 1966), Archivo personal de Julio e Irene.

19 "Campamento Universitario de Trabajo", volante s/f (hacia 1966), Archivo personal de Julio e Irene.
} 
desde los cristianos disconformes con la institución eclesial hasta todos los hombres y mujeres que buscaban la transformación de la realidad argentina y del Tercer Mundo.

De su contenido, sobresalían la difusión del pensamiento post-conciliar, el apoyo al peronismo revolucionario, la coincidencia con la experiencia de la CGT de los Argentinos, la defensa de la lucha armada como vía para la toma del poder y respuesta a la "violencia institucionalizada" del sistema, y la adhesión a las organizaciones armadas, especialmente, las peronistas. Sin embargo, no hubo una rigurosa homogeneidad entre los números. Si el acercamiento al peronismo fue inicial, fue en el número 10 donde se explicitó el apoyo al mismo, y gradualmente las editoriales y los panoramas políticos se transformaron en una caja de resonancia de los acontecimientos que producía el peronismo revolucionario. Además, apareció una columna sobre el mismo, a cargo de Jorge Gil Solá. Por otra parte, con el tiempo, la revista dedicó más notas sobre revolución y menos de contenido cristiano, aunque esas cuestiones nunca se abandonaron. En efecto, una de las características de la publicación fue el intento de dar opciones de participación en la vida de la Iglesia a los cristianos que se identificaban con la renovación católica. Así, es notable la presencia de toda experiencia de transformación de las estructuras eclesiales a nivel mundial, latinoamericano y nacional. La reflexión teológica y el nuevo papel del laicado era una preocupación evidente. También aparecían en primer plano las experiencias de compromiso concreto de sectores católicos con los pobres y con el pueblo. A medida que la revista se fue "radicalizando", las referencias a la Revolución Cubana y las discusiones sobre las estrategias revolucionarias en el continente se hicieron cada vez más frecuentes, a la vez que se dio un mayor acercamiento del director y los colaboradores al gobierno cubano a través del John W. Cooke y se multiplicaron las notas referidas a la compatibilidad entre el socialismo cubano y la fe católica (Lenci, 2000).

Entre sus secciones -que eran más cambiantes en el período de García Elorrio mientras se volvieron fijas y se mantuvieron en el de Ahumada- se encontraban la nota editorial firmada, que bajo la segunda dirección fue sustituida por el panorama político; material sobre la Iglesia en Argentina y América Latina, referido a los grupos comprometidos o bien a críticas de la jerarquía -en este sentido, la publicación funcionaba como espacio de expresión de los sectores anti- statu quo también en el interior de la Iglesia-; ensayos teológicos destinados a presentar las novedades del Concilio, a cargo de sacerdotes pertenecientes al MSTM; informes especiales sobre la realidad argentina -por ejemplo, de Tucumán, Chaco, etc.-; análisis de la actualidad 
nacional; columna dedicada a la cuestión gremial; sección "Universidad"; noticias del Tercer Mundo; notas sobre los movimientos revolucionarios en América Latina; columna sobre economía con análisis de la estructura y coyuntura económica; reportajes y monografías sobre grupos armados del país y del mundo; comunicados de las organizaciones armadas; notas sobre las cárceles, denuncias y reclamos por los presos políticos; columna sobre peronismo revolucionario; documentos -de la Revolución China, de los obispos del Tercer Mundo, etc.

El grupo que hacía la revista era estrecho -solamente en el número 2-3 publicó su staff- pero muy relacionado con un colectivo más amplio conformado por al menos tres organizaciones conducidas por García Elorrio: el Centro de Estudios Teilhard de Chardin, el Centro de Documentación del Tercer Mundo y el Comando Camilo Torres vinculado al Encuentro Latinoamericano Camilo Torres, organización internacional de grupos cristianos "radicalizados". El fundador y primer director de la revista -quien había sido seminarista-, así como otros colaboradores -entre ellos, integrantes de la JEC y de la JOC-, tenían fuertes vinculaciones institucionales con la Iglesia. Por otro lado, parte del grupo se integró a Montoneros (Lenci, 1998; Morello, 2003; 2007).

Al tiempo que surgieron nuevas experiencias como las anteriormente mencionadas, se renovaron grupos eclesiales enraizados en el desarrollo del movimiento católico de las décadas previas, como es el caso de los movimientos especializados de Acción Católica (Mallimaci, 1992). En este sentido, sin negar las transformaciones que experimentó el catolicismo en esos años, es necesario adoptar una mirada de largo plazo y ligar esta corriente católica liberacionista con una matriz común: el catolicismo integral. Este fenómeno, caracterizado por la vocación por la intervención política, la aspiración a moldear al conjunto social, la consigna de llevar el catolicismo "a toda la vida", aparece como sustrato común de tipos eclesiales tan distanciados como el catolicismo liberacionista o el "nacionalismo exagerado" de orientación católica (Mallimaci, 1992). De esta manera, "los católicos contestatarios eran, en el sentido de la relación público-privado, tan integrales como sus antecesores" (Donatello, 2010: 67). Esta particular estructuración del campo religioso -que nos impide pensarlo como una red institucional cerrada, separada de la política-, sumado a las peculiaridades de la política nacional, ayuda a comprender el hecho de que, históricamente, los católicos argentinos rara vez desarrollaron fuerzas políticas autónomas y, por el contrario, gestaron afinidades positivas con diversas opciones que eran a la vez religiosas y políticas (Donatello, 2005a: 78). 
Fue en este marco interpretativo que muchos cristianos liberacionistas -categoría en la que pueden incluirse los integrantes de la JUC, la JOC y la JEC bahienses entre los años 1967 y 1975, en virtud de las convicciones que los animaban y las prácticas que llevaban a cabo- se acercaron a la sociedad y a la política. Este apartado aborda las ideas/ las maneras de pensar y vivir el catolicismo que impulsaron ese acercamiento. En este sentido, se plantea una serie de interrogantes que guían la reflexión en sus cuatro secciones: en primer lugar, ¿qué elementos aporta el fenómeno del catolicismo integral para comprender el compromiso "temporal" de los jóvenes católicos en los años sesenta y setenta? En segundo lugar, ¿en qué medida los nuevos lineamientos propuestos por el Papa y los obispos impulsaron la acción política de los fieles y los acercaron a la idea de revolución? Y por otro lado, ¿cómo vivieron el aggiornamento eclesial otros grupos, conformados tanto por laicos como por especialistas religiosos ${ }^{20}$, que se constituyeron en referentes fundamentales de esta nueva forma de entender la fe, no sólo en nuestro país en general, sino también para los jucistas, jecistas y jocistas bahienses, en particular? En otras palabras, ¿cómo entendieron ese compromiso los Sacerdotes para el Tercer Mundo y la revista Cristianismo y Revolución, y qué ideas claves sustentaron su pensamiento político? Para ello, se analizan las directivas de la jerarquía eclesial constituciones del Concilio Vaticano II, encíclicas papales, documentos del episcopado latinoamericano y argentino-, así como documentos del MSTM y de Cristianismo y Revolución -que, en tanto nexo del catolicismo contestatario argentino es una fuente ineludible para analizar la "radicalización" de los católicos (Lenci, 1998; Morello, 2007). En tercer lugar, ¿de qué hablamos cuando hablamos de teología de la liberación? ¿Cuáles son sus principios básicos? Así, se busca plantear brevemente una primera definición y caracterización de la nueva teología, y a la vez, avanzar sobre sus principales planteos, destacando aquellos aspectos vertebradores con mayores implicancias sociales y políticas.

\section{a) La matriz del catolicismo integral}

Es necesario hacer referencia a un tipo de catolicismo, el catolicismo integral (Mallimaci, 1988, 1992), en cuanto manera histórica de comprender el rol que debe

\footnotetext{
${ }^{20}$ Esta categoría comprende a los miembros de la jerarquía eclesiástica, sacerdotes, religiosos y religiosas, quienes ocupan una posición privilegiada en el espacio social como parte de una institución de larga tradición y legitimidad para amplios sectores de la sociedad argentina (Catoggio, 2010a).
} 
cumplir lo religioso/la Iglesia en la sociedad. Este catolicismo se caracteriza por la convicción de que la fe cristiana es el principio de verdad absoluta y que la Iglesia es la única garante de esa unidad trascendente, y se define, fundamentalmente, por el rechazo a que lo religioso quede relegado a la sacristía o al templo. Por el contrario, parte de la convicción de que la religión, lejos de ser un asunto privado, de culto, o un problema individual de conciencia, debe tener presencia pública, visible, "temporal" en la sociedad. En este sentido, niega la autonomía entre las instancias de lo social, lo político, lo religioso, lo público y lo privado; por el contrario, aspira a integrarlas y a avanzar sobre la sociedad y el Estado. Se trata de un movimiento de acción, de penetración /transformación/restauración/infiltración en la sociedad. Promueve modelos de vida, quiere estar presente en la vida diaria, cotidiana, ser aplicado a todas las necesidades de la sociedad contemporánea. Es, por esencia, un catolicismo social. Sus lemas son "recristianizar la Argentina", "que Cristo reine en nuestra patria", "viva Cristo Rey" o "restaurar todo en Cristo".

Este fenómeno fue la respuesta del catolicismo argentino de principios del siglo $\mathrm{XX}$ al avance secularizador del liberalismo y el socialismo, que buscaban constreñirlo al ámbito privado. Liberalismo y socialismo se constituyeron en sus enemigos principales en cuanto cada uno contaba con un proyecto totalizador de la sociedad. El catolicismo integral rechazaba de plano la modernidad, era antiliberal, porque le atribuía al liberalismo todos los males, como el desorden, la pérdida de identidad cultural y del ser nacional, y el hecho de engendrar la subversión socialista. En los años treinta, en un contexto de crisis de la Argentina liberal y del proyecto agroexportador, y del temor al avance del comunismo, el catolicismo comenzó a ser percibido por sectores cada vez más amplios de la sociedad como un remedio. El derrumbe del Estado liberal creó un ambiente social y cultural propicio para la expansión del catolicismo integral, que aspiraba a dar respuesta a la crisis. Si desde comienzos de la década de 1920, éste tendría cada vez más gravitación en la vida política y cultural del país, a partir de la década de 1930 se convirtió en hegemónico; ya no se podrá comprender la realidad argentina sin contarlo como uno de sus interlocutores. Se asistió así, al pasaje de un catolicismo de conciliación, defensivo o subalterno del Estado liberal a otro de integralidad, ofensivo y parte central del nuevo Estado. En este sentido, la estrategia implementada coincidía con la impulsaba desde Roma pero acondicionada a la realidad local. Al mismo tiempo, se producía la homogeneización de una gran parte del catolicismo argentino en la nueva matriz del integralismo. 
El catolicismo integral inició un movimiento de penetración en la sociedad multifacético y multisectorial, cultural y social. A través de actos, celebraciones, congresos, reuniones y marchas procuró ocupar la calle. De esta manera, buscó presencia masiva, ganarse a los hombres y a las mujeres, a los jóvenes, a los niños y a los adultos, a las clases medias, a los intelectuales y a los sectores populares -entre ellos, especialmente a los pobres y obreros, amenazados por los "errores" del mundo moderno y el crecimiento del "peligro socialista". El proyecto era recristianizar la sociedad, no sólo un sector o a un grupo, sino a todas las instituciones y espacios sociales -salud, educación, recreación, comunicación, etc. Pero no se trataba de crear universidades, escuelas, sindicatos o partidos católicos, sino de formar cuadros católicos que dirigieran las distintas organizaciones existentes.

Este proceso encontró una herramienta fundamental en la Acción Católica Argentina (ACA), nacida en 1931, al calor del impulso desde Roma de movimientos laicales que llegaran a nuevos grupos sociales y promovieran la presencia social del catolicismo. Esta organización invitaba a los jóvenes a trabajar para transformar "esa sociedad de pecado y restaurarla en Cristo", a adquirir un compromiso individual, familiar, profesional pero sobre todo público, callejero, visible. El dispositivo integralista contó además con otros canales. Los Cursos de Cultura Católica -que funcionaban desde 1922- se constituyeron en un lugar privilegiado de reflexión y de acción de los sectores altos de la reacción católica antiliberal. Por otra parte, la revista Criterio -creada en 1928- pretendía propagar la doctrina católica en toda su integridad y se convirtió en un lugar de encuentro, discusión y síntesis del catolicismo integral.

Este intento de conquistar espacios sociales, culturales e ideológicos, se completó con un lento y eficiente trabajo a nivel de las Fuerzas Armadas. En este sentido, las vicarías, las capellanías y la presencia mutua en actos públicos permitieron un contacto estrecho. Por otro lado, los movimientos de Acción Católica se abrieron a los militares y las ceremonias litúrgicas incluyeron cada vez más a jefes y a tropas (Mallimaci, 1988: 23).

En 1930 el movimiento católico comenzó a descubrir la necesidad de influir políticamente sobre el Estado. Se consolidó entonces una comprensión del trabajo pastoral que hacía de la presencia y cercanía del Estado su principal eje de acción. A partir del golpe de 1943, la catolización que se estaba produciendo en la sociedad penetró en las principales instituciones estatales: las Fuerzas Armadas, la justicia, la burocracia, la educación, el trabajo, etc. Para todo un sector del catolicismo argentino en 
alianza con los militares, había llegado el momento de hacer católico no sólo la sociedad sino el Estado. La restauración católica se convertía en plataforma del gobierno. Con los gobiernos peronistas, el Estado y la sociedad asumieron como propios los principios católicos. El catolicismo invadió la sociedad y se transformó en sustrato de la nacionalidad y en parte central de la nueva cultura. En esta nueva situación, para la institución eclesial era más fácil la relación con el poder del Estado que una inserción en la sociedad a partir de movimientos apostólicos. Distintos sectores de la Iglesia colaboraron y cooperaron con el nuevo gobierno "católico". Las medidas que éste tomó les permitieron a los católicos solidarizarse con el peronismo. El Estado buscaba moldear una Iglesia que apoyara y legitimara sus acciones mientras la Iglesia, que aspiraba a mantener distancia al tiempo que complacer, obtenía mayor presencia en las esferas estatales. Esta posibilidad de acceso al poder, comenzada en $1930 \mathrm{y}$ consolidada con el golpe de 1943, creó maneras de actuar y pensar donde la penetración en el aparato estatal se desarrolló más que la presencia en la sociedad (Mallimaci, 1992).

En relación con lo anterior, en esos años se consolidó la identificación entre Patria, Fuerzas Armadas y catolicismo, entre Estado y catolicismo, entre nación e Iglesia. Los procesos de militarización y clericalización de la sociedad argentina iban de la mano. Lo católico aparecía como uno de los pilares de la "argentinización", el símbolo de la "argentinidad", auténtico sostén de la nacionalidad, dador de identidad a la nueva Argentina, y, de este modo, pasaba a ser un elemento constitutivo de la cohesión social (Mallimaci, 1988, 1992). Las Fuerzas Armadas, por su parte, hicieron suya la defensa de la Patria Católica, produciéndose una simbiosis que ha perdurado hasta el fin de la última dictadura militar. El mito de la "nación católica", cristalizado en la década de 1930, legitimó el poder castrense, en cuanto Iglesia y Ejército se erigían como instituciones tutelares de la identidad nacional (Zanatta, 2008).

Sin embargo, el proceso de legitimación católica del Estado por parte del gobierno de turno tomó largos años. Si en la proclama del golpe cívico-militar de 1930 no había ninguna mención a lo religioso, la del golpe de 1943 contenía por primera vez una referencia cristiana explícita. En 1945 la legitimidad católica fue utilizada tanto por la Unión Democrática como por el Partido Laborista y en especial, por la figura del Coronel Perón, al manifestar que su ideología era la cristiana y su programa el de la Doctrina Social de la Iglesia. En el período 1945-1955, la legitimidad católica cubrió el conjunto de las instituciones. Durante el golpe de la "Revolución Libertadora", los 
aviones de los militares presentaron cruces pintadas en sus fuselajes: "Cristo Vence". La proclama del general Eduardo Lonardi no sólo hablaba de Dios como la de 1943 sino que directamente se legitimaba en términos católicos y marianos. Nuevamente un grupo de católicos integrales aparecían como personal de recambio en un nuevo gobierno militar. A partir de la década de 1940 entonces, la legitimación católica se incorporó al lenguaje del Estado, siendo mucho más acentuada en los gobiernos cívico-militares siguientes, pero sin estar completamente ausente en los democráticos. Una de las consecuencias de la identificación de la Argentina como Estado católico, a partir de los años treinta y cuarenta, fue que, desde entonces, las tensiones al interior de la Iglesia repercutieron en el propio Estado, al tiempo que los conflictos sociales y políticos impactaron en el seno del catolicismo (Mallimaci, 1988, 1992).

La mentalidad integral dominante permitía la existencia de grupos distintos al interior del movimiento católico, ligados al proyecto de recristianizar la sociedad. Si la idea de que la religión católica debía estar en la base de la restauración de la nueva Argentina concitaba el consenso de los católicos integrales, fue frente al problema de cómo construir el nuevo orden cristiano, así como de los medios a utilizar, donde aparecieron las discrepancias. El catolicismo integral se dividió en cuanto a la actitud a tomar frente al cambio histórico y sus resultados. En este sentido, como explica Mallimaci, "en el catolicismo integral no se discutía si se hacía política o no, sino qué tipo de política se llevaba adelante a partir de los principios cristianos" (1992: 344). De allí que de esta matriz común surgieran católicos "sociales", que acentuaban la idea del trabajo social a largo plazo, de lograr la restauración católica por consenso y desde la sociedad, y católicos "integristas" que insistían en la eficacia inmediata, en la coacción, en apoderarse del Estado y ligarse a los diversos grupos de poder. Esta vertiente se proclamó defensora de la tradición y la ortodoxia católica, se caracterizó por el rechazo de toda innovación dentro de la propia Iglesia, por un espíritu de cruzada y por la búsqueda de conciliación con los regímenes autoritarios, a partir de una concepción dogmática, elitista y de relación privilegiada con las Fuerzas Armadas. Al mismo tiempo, otros grupos católicos apoyaron los procesos democráticos. En síntesis, el catolicismo integral ha sido a partir de entonces, la matriz común de de tipos eclesiales diversos (Mallimaci, 1988, 1992). Fue también la matriz común de víctimas y victimarios del terrorismo estatal de 1976-1983 (Donatello, 2008). Como afirma Mallimaci, la llegada del Vaticano II abrió las puertas para nuevas comprensiones y actitudes al interior del cuerpo católico, pero 
la mentalidad construida durante los últimos 50 años no será fácilmente desterrada. La fascinación del asalto al poder del Estado aquí y ahora dándole al accionar legitimidad católica sea del signo que fuere y la duda sobre la eficacia de la democracia, estará de una u otra manera presente. La tentación de la violencia a un paso (1992: 365).

\section{b) El aggiornamento eclesial y sus implicancias sociales y políticas}

\section{i) Los documentos eclesiales: una nueva concepción de la Iglesia y de su relación con el mundo}

A partir de los años sesenta, la Iglesia Católica pretendió volverse hacia el hombre contemporáneo consciente de que "para conocer a Dios es necesario conocer al hombre" 21 y de que existía una unidad profunda entre "la historia de la salvación y la historia humana", "entre el proyecto salvífico de Dios y las aspiraciones del hombre", "entre la Iglesia, pueblo de Dios, y la experiencia del hombre" ${ }^{22}$. Entendió, entonces, que la fidelidad al Evangelio exigía dedicarse al servicio terreno de los hermanos, como preparación de la trama del Reino de los $\operatorname{Cielos}^{23}$. Desde esta perspectiva, la esperanza de esa nueva tierra no debía anular sino animar la preocupación por la transformación de este mundo. El progreso temporal, si bien no debía confundirse con el Reino de Cristo, interesaba en gran medida a este último. El mismo Jesús había reclamado el amor de sus discípulos hacia los pobres y enseñado a aceptar la cruz que la carne y el mundo imponían en la búsqueda de la justicia y la paz $^{24}$. De este modo, la fe que conducía a la salvación final comprometía desde entonces en la acción por el desarrollo integral del hombre ${ }^{25}$.

Se partía de una serie de principios que postulaban la dignidad sagrada de la persona, de la que se desprendían derechos y deberes inalienables; el hombre como fundamento, sujeto y fin de todas las instituciones sociales; la exigencia de la justicia y la equidad, de una convivencia fundamentada en la verdad, el amor, la solidaridad, la igualdad y la libertad, de la correspondencia entre desarrollo económico y progreso social; la consolidación de la paz en el mundo como fruto de la justicia, el respeto de la

\footnotetext{
${ }^{21}$ Documentos Finales, 1968: 12.

${ }^{22}$ Documentos Finales, 1968: 104.

${ }^{23}$ Mater et Magistra, 1961.

${ }^{24}$ Gadium et Spes, 1965; Documentos Finales, 1968.

${ }^{25}$ Documento de San Miguel, 1969.
} 
dignidad de los demás hombres y el ejercicio de la fraternidad ${ }^{26}$. Por otra parte, se insistía en que el mismo Dios había creado la tierra y todo lo que hay en ella para uso de todos los hombres y de todos los pueblos, de modo que los bienes creados pudieran llegar a todos en forma justa ${ }^{27}$.

Al mismo tiempo, los documentos eclesiales planteaban la constatación de la existencia de disparidades hirientes en el nivel de vida, el goce de los bienes y el ejercicio del poder entre distintos sectores sociales y diversas regiones y países, de estructuras opresoras, de explotación de los trabajadores, de miseria, de un sistema económico -el "capitalismo liberal"- que era causa de injusticia y atentaba contra la dignidad de la persona en tanto consideraba el provecho como motor esencial del progreso económico y a la propiedad privada como derecho absoluto sin límites ni obligaciones ${ }^{28}$. En América Latina -afirmaban- se hacía evidente la realidad del subdesarrollo, que conjugaba hambre y miseria, mortalidad infantil, analfabetismo, marginalidad, escasa participación del pueblo en la gestión del bien común, alienación, dependencia económica y cultural, etc. A esto se sumaba la opresión de sectores dominantes que intentaban mantener sus privilegios a través del uso de la fuerza para reprimir los intentos de reacción ${ }^{29}$. Estas situaciones eran pensadas como un problema colectivo: el pecado se cristalizaba en las estructuras injustas ${ }^{30}$ y era todo el pueblo el que estaba en situación de pecado cuando se cometía injusticias, se las consentía o no se las reparaba ${ }^{31}$.

En este contexto, para la Iglesia, el combate contra la miseria se tornaba urgente y necesario pero, al mismo tiempo, insuficiente ${ }^{32}$. Las injusticias clamaban al Cielo y volvían imperiosas las transformaciones audaces y profundas. Para Pablo VI y los obispos latinoamericanos, esa situación hacía comprensible la tentación del uso de la violencia; no obstante, ésta, salvo en caso de "tiranía evidente y prolongada”, encerraba

\footnotetext{
${ }^{26}$ Mater et Magistra, 1961; Pacem in Terris, 1963; Gadium et Spes, 1965; Documentos Finales, 1968.

${ }^{27}$ Gadium et Spes, 1965; Documentos Finales, 1968.

${ }^{28}$ Mater et Magistra, 1961; Populorum Progressio, 1967; Documentos Finales, 1968; Documento de San Miguel, 1969.

${ }^{29}$ Documentos Finales, 1968.

${ }^{30}$ Documentos Finales, 1968.

${ }^{31}$ Documento de San Miguel, 1969.

${ }^{32}$ Mater et Magistra, 1961. Las encíclicas Rerum Novarum de León XIII y Quadragesimo Anno de Pío XI ya habían planteado el derecho y el deber de la Iglesia de aportar a la solución de los "urgentes y gravísimos problemas sociales que angustian a la familia humana" (Mater et Magistra, 1961: 12), a partir de una serie de principios y directivas históricas que debían guiar a los cristianos para juzgar la "cuestión social" y asumir la correspondiente responsabilidad.
} 
nuevas injusticias ${ }^{33}$. De este modo, la responsabilidad con los hermanos se cumplía promoviendo el mejoramiento de la vida de los hombres y de los pueblos ${ }^{34}$, la cada vez mayor adecuación de la realidad social a las exigencias bíblicas de la justicia ${ }^{35}$, la realización del bien común ${ }^{36}$, y la consumación del verdadero desarrollo integral. Se trataba de construir un mundo donde todo hombre pudiera vivir una vida plenamente humana $^{37}$. Y en esa tarea eran los hombres y los pueblos los sujetos de su propio desarrollo $^{38}$.

No obstante, se entendía que el continente latinoamericano ya estaba en el umbral de una nueva época histórica llena de un anhelo de emancipación total y de liberación de toda servidumbre. Se evidenciaba una progresiva toma de conciencia de los sectores "oprimidos". La Iglesia quería comprometerse con sus pueblos, acompañando el proceso de cambio con la luz de los valores evangélicos. En este sentido, le correspondía denunciar con firmeza las realidades que constituían una afrenta al espíritu del Evangelio, a la vez que estimular todo intento de vencer las grandes dificultades existentes ${ }^{39}$.

De acuerdo a lo que sostenían los obispos, este proceso de profundo cambio de la sociedad encontraba en la renovación interior/conversión del hombre una dimensión complementaria. Ambos confluían en el desarrollo de un orden social fundado en la verdad, la justicia y el amor, que asegurara la dignidad de las personas ${ }^{40}$ : "No tendremos un continente nuevo, sin nuevas y renovadas estructuras; sobre todo, no habrá continente nuevo sin hombres nuevos" ${ }^{41}$.

En esta misión, se afirmaba, les cabía a los laicos, y entre ellos a los jóvenes, un papel fundamental, ya que lo típicamente laical estaba constituido por el compromiso en la historia. Los seglares, en virtud de estar ocupados habitualmente en actividades económicas, sociales, profesionales, debían asumir la renovación del orden temporal y penetrar de espíritu cristiano la mentalidad, las costumbres, las leyes, las instituciones y las estructuras de su comunidad ${ }^{42}$. Los movimientos laicos, presentes en diversos

\footnotetext{
${ }^{33}$ Populorum Progressio, 1967; Documentos Finales, 1968.

${ }^{34}$ Gadium et Spes, 1965.

${ }^{35}$ Pacem in Terris, 1963.

${ }^{36}$ Mater et Magistra, 1961; Pacem in Terris, 1963.

${ }^{37}$ Populorum Progressio, 1967; Documentos Finales, 1968.

${ }^{38}$ Pacem in Terris, 1963; Populorum Progressio, 1967; Documentos Finales, 1968.

${ }^{39}$ Documentos Finales, 1968.

${ }^{40}$ Gadium et Spes, 1965.

${ }^{41}$ Documentos Finales, 1968.

${ }^{42}$ Mater et Magistra, 1961; Gadium et Spes, 1965; Populorum Progressio, 1967; Mensaje de 18 obispos del Tercer Mundo, 1967; Documentos Finales, 1968; Documento de San Miguel, 1969.
} 
ambientes, prestaban un servicio clave a la promoción humana y estaban en condiciones de abrazar el compromiso liberador y humanizador ${ }^{43}$. En esta opción, el laico gozaba de autonomía y responsabilidad propias ${ }^{44}$. De allí que la Iglesia se propusiera promover con especial énfasis y urgencia la creación y el apoyo de movimientos laicos en los ambientes donde se elaboraba y decidía en gran parte el proceso de liberación y humanización de la sociedad ${ }^{45}$.

Por su parte, la juventud tenía un papel decisivo en la transformación de América Latina y en la misión profética de la Iglesia, en cuanto constituía no sólo el grupo más numeroso de la sociedad latinoamericana, sino fundamentalmente, un nuevo cuerpo social, portador de sus propias ideas, valores y dinamismo interno, que buscaba participar activamente, asumiendo nuevas responsabilidades y funciones, dentro de la comunidad latinoamericana ${ }^{46}$. Se destacaba que "la juventud, particularmente sensible a los problemas sociales, reclama cambios profundos y rápidos que garanticen una sociedad más justa" ${ }^{47}$. En este marco, la Iglesia debía dar respuesta a los reclamos pastorales de los jóvenes, reconocer la autonomía propia de los seglares a los movimientos católicos de juventud y estimular su acción en la transformación de las personas y las estructuras.

En este sentido, se planteaba que la situación del mundo y la importancia de la edificación de una sociedad más humana imponían a los cristianos una entrega completa y sacrificio, por amor a sus hermanos, a la vez que la unión con todos los hombres de buena voluntad, creyentes y no creyentes, en esta tarea ${ }^{48}$. Los cristianos debían ser así "un fermento que vivifique toda la masa" 49 .

En suma, a partir de los pontificados de Juan XXIII y Pablo VI y del Concilio Vaticano II, la Iglesia Católica afirmó que se sentía íntimamente unida con el hombre y su historia, en cuanto ésta era considerada escenario de la revelación divina y anticipo del Reino de los Cielos. Entonces, manifestó una preocupación renovada por las exigencias del vivir diario de los hombres y la "cuestión social" ${ }^{50}$. El Papa y los obispos exhortaron a los cristianos a que cumplieran sus deberes temporales. Ante la

\footnotetext{
${ }^{43}$ Documentos Finales, 1968.

${ }^{44}$ Gadium et Spes, 1965; Documentos Finales, 1968.

${ }^{45}$ Documentos Finales, 1968.

${ }^{46}$ Documentos Finales, 1968; Documento de San Miguel, 1969.

${ }^{47}$ Documentos Finales, 1968: 74.

${ }^{48}$ Mater et Magistra, 1961; Pacem in Terris, 1963; Gadium et Spes, 1965; Populorum Progressio, 1967; Documentos Finales, 1968; Documento de San Miguel, 1969.

${ }^{49}$ Pacem in Terris, 1963: 73.

${ }^{50}$ Mater et Magistra, 1961; Gadium et Spes, 1965.
} 
inadecuación de la situación política, social y económica con lo expresado en el texto bíblico, y sin subestimar las formas asistenciales de acción social, plantearon que la pastoral de la Iglesia debía orientarse hacia un compromiso en la reforma de las estructuras socio-económicas ${ }^{51}$. De este modo, la Iglesia asumía como misión salvar integralmente al hombre y entendía que la evangelización comprendía necesariamente el ámbito de la promoción humana. Así, se tornaba deber de los cristianos trabajar por la liberación total del hombre e iluminar el proceso de cambio de las estructuras opresoras generadas por el pecado. Urgidos por el Evangelio, le correspondía asumir la defensa de los derechos de los marginados, cooperar en la eliminación de las amenazas de la paz social -desigualdades, opresiones, abusos de poder, etc.-, y denunciar proféticamente las situaciones que atentaban contra el desarrollo de los hombres ${ }^{52}$. Siguiendo el ejemplo de Cristo, pensado como encarnado en cada hombre doliente, la Iglesia defendía a los pobres y se solidarizaba con su causa ${ }^{53}$. En este proceso, los laicos y, en particular, los jóvenes estaban llamados a cumplir un rol fundamental.

\section{ii) La lectura de los Sacerdotes para el Tercer Mundo y de Cristianismo} y Revolución: fe, política y revolución

Los principios trazados por la jerarquía de la Iglesia Católica a nivel global, latinoamericano y nacional, tenían resonancias políticas. Así lo interpretaron diversos actores de la red social del catolicismo liberacionista en nuestro país. Entre ellos, el MSTM y la revista Cristianismo y Revolución.

Para el presbítero Carlos Mugica -integrante del movimiento sacerdotal-, a partir del Concilio, los cristianos comenzaban a cuestionarse por las dimensiones políticas de la existencia porque empezaban a interesarse por este mundo, al descubrir que Dios se revelaba en la historia y que el Reino de Dios se iniciaba aquí abajo. Los documentos eclesiales hacían un llamamiento a la acción política en cuanto exhortaban a los cristianos a destruir las estructuras injustas y a sumarse, desde su originalidad, a la lucha por transformar la sociedad. Sin embargo, al decir de Mugica, la preocupación de los seguidores de Jesús por la política se desprendía del mismo mandamiento del amor al prójimo: el compromiso de amor a los demás era un compromiso político. Quien quería

\footnotetext{
${ }^{51}$ Documentos Finales, 1968.

${ }^{52}$ Documento de San Miguel, 1969.

${ }^{53}$ Mensaje de los 18 obispos del Tercer Mundo, 1967; Documentos Finales, 1968; Documento de San Miguel, 1969.
} 
asumir el Evangelio y al hombre de carne y hueso descubría que el compromiso político no era optativo sino obligatorio, y que era además, un compromiso revolucionario. Desde este punto de vista, el cristiano no podía quedarse tranquilo ante la situación de violencia institucionalizada; debía emprender una acción política eficaz para disminuir el índice de mortalidad infantil, para que cesaran las torturas, etc. No se trataba de la acción partidista, incompatible con la función de pastor en el caso de los sacerdotes, sino de tomar postura frente al sistema capitalista liberal vigente, hablar y actuar frente a sus consecuencias, identificarse con la defensa de los seres humanos pisoteados en su dignidad y acompañarlos en la lucha por su liberación. Desde esta perspectiva, entonces, para el que quería ser fiel a Cristo, conversión del corazón y acción política que buscaba la conversión de la sociedad resultaban inseparables (Mugica, 1973).

Similares argumentos encontramos desplegados en la revista que se proponía reflejar el sentido, la urgencia, las formas y los momentos del compromiso cristiano revolucionario, asumido por convicción religiosa ${ }^{54}$ : si Jesús vivió entre los pobres y perseguidos y encarnó un mensaje de redención, seguirlo suponía solidarizarse con el hombre "oprimido": "partir el pan con los indigentes y sufrir con los hambrientos" Por otra parte, del análisis de la realidad se desprendía un continente de opresión, subdesarrollo, mal reparto de los bienes, desigualdad e injusticia, lo que suponía, siguiendo a los obispos reunidos en Medellín, una situación de pecado. Por ello, según Cristianismo y Revolución, la Iglesia no podía permanecer indiferente. Su misión exigía la lucha por la liberación del hombre, la realización de "los cielos nuevos en nuestra misma tierra" 56 .

Por otra parte, los Sacerdotes para el Tercer Mundo, plantearon una serie de grandes cuestiones en el terreno político o "modelos políticos" (Martín, 2010). En primer lugar, el MSTM descubría y asumía el rol profético, subordinando a éste el sacerdocio $^{57}$. Si el sacerdocio debía ir unido a la realización de la justicia y la caridad, la palabra debía priorizarse al rito. No se trataba de abandonar lo religioso para fondear lo político sino de relacionar ambas esferas, de desplazar el interés en los actos consagratorios hacia la denuncia profética cuyo objeto era la política. Así, el sentido de

\footnotetext{
${ }^{54}$ Cristianismo y Revolución, 1, septiembre 1966.

${ }^{55}$ Cristianismo y Revolución, 6-7, abril 1968.

${ }^{56}$ Cristianismo y Revolución, 2-3, octubre-noviembre 1966.

${ }^{57}$ Según un antiguo tópico de la teología católica, el rol del presbítero entre los fieles se asemejaba al de Jesús, quien reunió en su persona las tres funciones de los enviados divinos del Antiguo Testamento: la profecía, el sacerdocio y el reino, esto es, el poder de anunciar, conducir y consagrar (Martín, 2010).
} 
la acción del MSTM se comprendía como una absorción de lo político en un pathos religioso (Martín, 2010).

Desde la perspectiva de estos sacerdotes, la función interpretativa o profética que se arrogaba la Iglesia en el proceso político de liberación del hombre consistía en denunciar injusticias, dar principios y formar conciencias ${ }^{58}$. Si a la Iglesia y al presbítero no les incumbía directamente la elaboración de proyectos específicamente políticos o económicos, sí les correspondía discernirlos a la luz del Evangelio ${ }^{59}$. De este modo, el MSTM se definía explícitamente como un movimiento profético y no político: "no es un partido político y rechaza convertirse en un grupo revolucionario para la toma del poder político". De allí que el movimiento como tal se prohibía opinar y tomar posiciones acerca de tácticas, estrategias o tendencias de grupos y organizaciones, respetando la libertad de opción de sus propios miembros ${ }^{60}$.

Al mismo tiempo, el MSTM entendía que había que ingresar en la construcción del Reino. Es decir, era necesaria la intervención en política de la Iglesia. En otras palabras, el MSTM "quiere establecer y vivir un modelo de catolicismo que, partiendo de la función profética, llegue a la función política mediante la crítica a las prácticas del templo" (Martín, 2010: 147) y a diversos actores y aspectos de lo temporal, que entraban en contradicción con la propuesta de Dios y su justicia.

Para los sacerdotes, asumir una actitud política prescindente contradecía el Evangelio y se tornaba, de hecho, en apoyo al sistema. Por el contrario, el movimiento declaraba estar comprometido con el pueblo en su proceso de liberación ${ }^{61}$. La acción a favor de la justicia y la participación en la transformación del mundo se presentaba claramente como una dimensión constitutiva de la predicación del Evangelio, es decir, de la misión de la Iglesia. El compromiso político radicaba en asumir la realidad de la Iglesia en el mundo y la opción por los “oprimidos". La conciencia de la necesidad de ese compromiso desde la misión sacerdotal surgía de varias vertientes, a saber: una renovada concepción de las mutuas relaciones entre la Iglesia y el mundo; el descubrimiento de la misión profética de la Iglesia y del sacerdote, como denuncia de toda clase de injusticia, apoyo concreto a las iniciativas que significaban pasos en el camino de liberación y participación real en la construcción de un hombre y mundo

\footnotetext{
${ }^{58}$ Política y Pastoral, 4/1969.

${ }^{59}$ Nuestra Reflexión, 11/10/1970.

${ }^{60}$ Informe del secretariado para discutir en los grupos del movimiento sobre "Peronismo y Socialismo" y "conflictos eclesiásticos", 10/12/1970.

${ }^{61}$ Documento final del Quinto Encuentro Nacional, 19/10/1972.
} 
nuevos; la vigencia de la contradicción radical entre "opresores y oprimidos"; y las necesidades y exigencias del pueblo ${ }^{62}$.

Un segundo modelo que aparece como sostén del pensamiento de los Sacerdotes para el Tercer Mundo es el de la revolución latinoamericana (Martín, 2010). Según los actores, declararse solidarios del Tercer Mundo y servidores de sus necesidades significaba adherir al proceso revolucionario en marcha en Latinoamérica en búsqueda del socialismo, que implicaba necesariamente la socialización de los medios de producción, del poder económico, político y de la cultura, y el rechazo al sistema capitalista y al imperialismo ${ }^{63}$. Entendían la revolución social como un hito en el proceso de liberación y la definían en los mismos términos de Pablo VI en la Populorum Progressio: transformaciones audaces y urgentes que renovaran radicalmente las estructuras. La socialización de los medios de producción se suponía necesaria porque el capitalismo oprimía al pueblo, por lo que había que buscar un nuevo sistema social que erradicara toda explotación del hombre por el hombre. Por otro lado, las líneas evangélicas no eran contrarias a una solución socialista, a juzgar por el mensaje de Cristo y la experiencia de las primeras comunidades cristianas ${ }^{64}$. Por el contrario, el socialismo aparecía como una forma de vida social más conforme con el espíritu del Evangelio. Adhiriendo a la intervención del patriarca Máximo IV en el Concilio, decían: "el verdadero socialismo es el cristianismo integralmente vivido, en el justo reparto de los bienes y la igualdad fundamental de todos"65. En suma, los Sacerdotes para el Tercer Mundo defendían un socialismo nacional -que respondiera a nuestras auténticas raíces-, popular -donde el pueblo participara y decidiera su propio destino-, latinoamericano -que nos hiciera solidarios de los países hermanos-, humanista -que posibilitara a cada hombre una vida creadora- y crítico - que se renovara permanentemente ${ }^{66}$.

También Cristianismo y Revolución concebía la revolución como un imperativo cristiano. Al respecto, la revista sostenía que en aquella hora de América los cristianos se veían enfrentados con urgencia a la opción "de luchar con los pobres o contra los pobres, de servir al Dios del dólar o de servir al Señor de la Liberación" ${ }^{67}$. Un católico

\footnotetext{
62 Documento de trabajo preparado por los grupos que proponen un nuevo encuentro nacional, 22/8/1974.

${ }^{63}$ Coincidencias Básicas, 3/5/1969.

${ }^{64}$ Nuestra Reflexión, 11/10/1970.

${ }^{65}$ Mensaje de 18 obispos del Tercer Mundo, 1967; Mugica, 1973.

${ }^{66}$ Nuestra Reflexión, 11/10/1970; Mugica, 1973.

${ }^{67}$ Cristianismo y Revolución, 9, septiembre 1968.
} 
coherente con su fe, afirmaban, debía comprometerse sin miedo ni medida en las angustias y esperanzas de sus hermanos ${ }^{68}$ y formar parte de su marcha hacia la Nueva Humanidad $^{69}$. Esto era parte de su vocación de servicio al prójimo. Pero los cristianos se incorporaban a la lucha, no la inventaban ni la conducían, porque veían en ella, como Camilo Torres, la única manera eficaz y amplia de realizar el amor para todos ${ }^{70}$. En resumen, como mencionamos anteriormente, desde la perspectiva de Cristianismo y Revolución, "el deber de todo cristiano es ser revolucionario. Y el deber de todo revolucionario es hacer la revolución" ${ }^{, 71}$. Así, los sectores de la jerarquía católica que se aliaban o eran cómplices de los poderes políticos, económicos y militares eran vistos como traidores del Evangelio, el Concilio, la Populorum Progressio y Medellín ${ }^{72}$.

Para la revista, si la revolución tenía como finalidad terminar con el sistema, sus instituciones y sus privilegios (Morello, 2003), suponía necesariamente la violencia: los sectores dominantes no cederían el poder fácilmente, por lo que no dejaban otro camino al pueblo que sufría hambre, desocupación, falta de vivienda digna, hospitales y educación ${ }^{73}$. Además, el gobierno de Onganía reprimía brutalmente al pueblo ${ }^{74}$, dando muestras de que se iba transformando en lo que Pablo VI describía en la Populorum Progressio, como una "tiranía evidente y prolongada" "75: "Frente a este cuadro de violencia se terminan las palabras. Es la hora de los hechos, la hora de la violencia revolucionaria de los pueblos" 76 . De esta manera, "el pueblo no elige la violencia, lucha por la justicia"77.

Esta empresa, se aseveraba, requería a todos los hombres de buena fe (cristianos, marxistas y todos los elementos progresistas) y la solidaridad continental. La revolución podía hacerse por diversos caminos mientras la clase explotada fuera la protagonista del proceso. En su marcha hacia el poder, el pueblo contaba con un conjunto de aliados que tenían una responsabilidad revolucionaria y hacían -o debían hacer- su aporte a la lucha popular, entre los que se encontraban los intelectuales, los artistas, los universitarios y los sacerdotes. Al mismo tiempo, se enfrentaba con sus enemigos: el Imperio, los

\footnotetext{
${ }^{68}$ Cristianismo y Revolución, 2-3, octubre-noviembre 1966.

${ }^{69}$ Cristianismo y Revolución, 20, septiembre-octubre 1969.

${ }^{70}$ Cristianismo y Revolución, 1, septiembre 1966; 4, marzo 1967.

${ }^{71}$ Cristianismo y Revolución, 5, noviembre 1967.

${ }^{72}$ Cristianismo y Revolución, 13 y 14, abril 1969; 15, mayo 1969.

${ }^{73}$ Cristianismo y Revolución, 4, marzo 1967.

${ }^{74}$ Cristianismo y Revolución, 16, mayo 1969; 17, junio 1969.

${ }^{75}$ Cristianismo y Revolución, 18, julio 1969.

${ }^{76}$ Cristianismo y Revolución, 8, julio 1968.

${ }^{77}$ Cristianismo y Revolución, 20, septiembre-octubre 1969.
} 
grandes capitalistas y el ejército, vanguardia del imperialismo, que despreciaba al pueblo, torturaba a los revolucionarios y censuraba a los que denunciaban la situación. También se le oponían la dirigencia sindical, sectores jerárquicos de la Iglesia, aliados de los poderosos, y parte de los partidos revisionistas de izquierda (Morello, 2003).

Desde esta perspectiva, la exigencia revolucionaria de los cristianos estaba unida con la opción por el socialismo: "luchamos por una sociedad socialista. Una sociedad donde la explotación del hombre por el hombre constituya uno de los delitos más graves", y "cuyas estructuras hagan imposible esa explotación"78. Cristianismo y Revolución defendía el socialismo en los mismos términos en que lo hacía el MSTM. Para la revista, esta idea no pasaba por Moscú, sino que nacía de Marx y se entroncaba con las luchas revolucionarias de América, con Fidel y el Che. Se trataba de la única posibilidad para los pueblos del Tercer Mundo, la vía para superar la injusticia y la miseria, la garantía para los trabajadores de su participación en el poder. De allí que muchos cristianos estuvieran dispuestos a luchar por la destrucción de la propiedad privada de los medios de producción, el aprovechamiento racional de la riqueza del país, la distribución de los bienes según el aporte de cada uno al proceso productivo, y la construcción de la sociedad como ámbito del Hombre Nuevo (Morello, 2003).

En suma, en el marco de estos lineamientos marcados por la institución eclesial y de una matriz católica común de socialización, de pensamiento y de acción que impulsaba a vivir la fe fuera del "templo", distintos grupos católicos descubrieron las conexiones entre el amor cristiano y la política, y encontraron en ella una dimensión de la fe. Las creencias religiosas daban significado y coherencia a la experiencia subjetiva, nutriendo la praxis política. Creemos con Morello (2003) que si los católicos hacen la revolución desde la fe, esta integración con la política tiene una dimensión teológica. Y la religión, en tanto que implica praxis, no es sólo una interrogación en el plano teológico o moral sino que es también un problema político.

Ese "deber cristiano" de intervenir en la lucha por la liberación tenía un carácter político. Política y religión estaban estrechamente unidas en la misión de denuncia profética y en las acciones en favor de la justicia y la transformación del mundo. Si bien a la Iglesia no le correspondía la elaboración de programas y estrategias concretas, los militantes católicos creían que debían sumarse a todos "los hombres de buena voluntad"

\footnotetext{
${ }^{78}$ Cristianismo y Revolución, 18, julio 1969.
} 
en el cambio del orden temporal. Este proyecto político alternativo podía ser abrazado desde diversos espacios y formas de militancia social y política.

De este modo, referentes y grupos del catolicismo liberacionista entendieron este compromiso político obligado del cristiano como un compromiso revolucionario. La lucha era a favor de un cambio radicalmente innovador y rápido de un orden social, económico, político y cultural antiguo, hacia otro orden nuevo de profunda significación humana. Así, la exigencia revolucionaria los llevó a la opción por el socialismo, esto es, por una forma de vida social que entendían más coherente con el espíritu del Evangelio y con el modelo del cristianismo primitivo. Este cambio podía realizarse por diversos caminos siempre que se tuviera presente que es "a los pueblos pobres y a los pobres de los pueblos" a los que corresponde su propia liberación ${ }^{79}$.

Ahora bien, del análisis anterior se desprende que entre las directivas de la jerarquía católica y las concepciones de los referentes del catolicismo liberacionista en Argentina había tanto continuidades como rupturas. Siguiendo a Martín (2010), pueden darse varios ejemplos para el caso de los Sacerdotes para el Tercer Mundo. En materia económica, el movimiento se distanció de la Populorum Progressio. Su tesis de la eliminación de la propiedad privada de los medios de producción, que mantuvo en sus documentos principales, fue uno de los blancos más firmes de ataque por parte de sus oponentes, precisamente, porque la propiedad privada había sido reconocida como lícita y conveniente por el magisterio católico antes y después de Juan XXIII. Por otra parte, el MSTM introdujo un nuevo modelo para pensar las relaciones entre religión y política, que compartía elementos con el planteado por el Concilio y el de Medellín, a la vez que trascendía sus límites. Así, mientras los documentos eclesiásticos trataban de relacionar "revolución" con "violencia" y distinguirla de "transformación", a la que preferían, los STM, en cambio, elegían el término "revolución", lo intentaban distanciar de "violencia" y lo ubicaban en el espacio donde cabía "transformación". Del mismo modo, al juicio general de la urgencia de la acción a favor de la justicia el MSTM añadió determinaciones políticas concretas ${ }^{80}$. Y a la consideración general de la legítima defensa de los pueblos, agregó argumentaciones morales, históricas y políticas que dejaron el camino abierto para aquellos que optaron por la toma del poder por las armas. En otras palabras, el MSTM y Cristianismo y Revolución no sólo pusieron en práctica

\footnotetext{
${ }^{79}$ Mensaje de 18 obispos para el Tercer Mundo, 1967.

${ }^{80}$ Véase el apartado del capítulo 6 dedicado a analizar la opción por el peronismo.
} 
los documentos eclesiásticos, sino que en ocasiones fueron más allá de sus planteos, en el marco de los ideales y las esperanzas actuantes en la sociedad a la que pertenecían.

\section{c) La teología de la liberación: repensar la fe desde América Latina}

La teología de la liberación es un cuerpo de escritos (Löwy, 1999) que surgió en América Latina hacia 1970, en un período particular -como hemos mencionado-, marcado por transformaciones, controversias y conflictos (Levine, 1996). Una serie de circunstancias crearon las condiciones de posibilidad para su surgimiento. Se trató de una convergencia de cambios que tuvieron lugar desde fines de los años cincuenta tanto dentro como fuera de la Iglesia Católica y desde la periferia al centro de la institución (Löwy, 1999). Desde la perspectiva de los protagonistas, la situación de pobreza estructural del continente agudizada con las políticas desarrollistas, la irrupción del Tercer Mundo en la historia y la "toma de conciencia" de los pueblos latinoamericanos de su situación de dependencia, el nacimiento de los movimientos populares de liberación, la presencia activa de los cristianos en los procesos revolucionarios, el aggiornamento eclesial y el compromiso de la Iglesia latinoamericana en la defensa de las mayorías populares ${ }^{81}$ ejercieron una influencia decisiva en la génesis de la teología de la liberación (Tamayo Acosta, 1989).

Entre sus referentes más conocidos se encuentran Gustavo Gutiérrez (Perú), Rubem Alves, Hugo Assmann, Carlos Mesters, Leonardo y Clodovis Boff, Frei Betto (Brasil), Jon Sobrino, Ignacio Ellacuría (El Salvador), Segundo Galilea, Ronaldo Muñoz, Pablo Richard (Chile), José Míguez Bonino, Juan Carlos Scannone, Rubén Dri, Enrique Dussel (Argentina), Juan Luis Segundo (Uruguay), Samuel Silva Gotay (Puerto Rico).

\footnotetext{
${ }^{81}$ En esta arena social, se destacaron, en primer lugar, los movimientos católicos laicos, los movimientos educacionales populares (Brasil), las Federaciones de campesinos cristianos (El Salvador) y las comunidades eclesiales de base. Otro grupo de laicos que jugó un papel clave en la formación del cristianismo liberacionista fueron los equipos de especialistas que trabajaban para los obispos y conferencias episcopales, que introdujeron en la institución los avances de las ciencias sociales, concretamente de la sociología y la economía marxistas (teoría de la dependencia). En segundo lugar, estaban los grupos sacerdotales como el Movimiento sacerdotal ONIS (Perú) o el grupo de Golconda (Colombia). El caso más conocido de "radicalización" de los círculos clericales fue probablemente el de Camilo Torres, quien se sumó al movimiento guerrillero castrista de Colombia. Por su parte, curas y religiosos españoles, franceses, norteamericanos que llegaron como misioneros a América Latina, en contacto con esta realidad y a partir de experiencias previas con curas obreros o movimientos especializados de Acción Católica, se sumaron a los movimientos populares. En tercer lugar, las órdenes religiosas estaban a la vanguardia de la nueva práctica y pensamiento teológico (Löwy, 1999; Gutiérrez, 1971).
} 
Los teólogos la han presentado como una "nueva manera de hacer teología" (Gutiérrez, 1971: 33), un "nuevo espíritu teológico" o un "nuevo estilo de teologizar" (Boff, 1990: 89). Es decir, la teología de la liberación no se autocomprende como una "teología del genitivo" -como las desarrolladas en Europa después de la Segunda Guerra Mundial (teología del trabajo, de la cultura, etc.)- que busca ampliar los temas de reflexión cristiana incorporando el de la liberación, sino como una teología fundamental/global/integral, que se ocupa de repensar todo el contenido de la revelación desde su concreción histórica latinoamericana (Tamayo Acosta, 1989; Boff, 1990; Segundo, 1990a). Para Ellacuría (1990b) y Sobrino (1990), es una "teología del Reino de Dios": su objeto central es todo lo que atañe al Reino, sólo que enfocándolo con atención muy especial a su dimensión liberadora, se sitúa desde la opción por los pobres y tiene como finalidad la liberación, esto es, que las virtualidades del Reino se pongan al servicio de la salvación histórica del hombre. En este sentido, es "teología" porque su raíz última, su óptica principal y su punto de partida final es la fe/la revelación/la Palabra de Dios; y es “de la liberación” porque su óptica particular, su punto de partida material es la experiencia del "oprimido", la praxis y el proceso de opresión-liberación (Boff, 1990).

Algunos autores la ubican dentro de la familia de las "teologías políticas", esencialmente críticas del orden establecido desde la reserva escatológica. La teología política se mueve en un horizonte hermenéutico que considera lo político como el ámbito más abarcador y decisivo de la existencia humana. En este sentido, tiene en cuenta la dimensión política de la vida y sus condicionamientos sociales y las posibilidades de cambio de la realidad. Y desde ahí intenta comprender e interpretar el Evangelio, descubriendo en él -así como en la fe, la revelación, la salvación- su dimensión política/crítica/pública/liberadora, que es valorada como necesaria e ineludible. La política entra así en el marco hermenéutico del quehacer teológico latinoamericano y forma parte del proceso de reflexión teológica. Por otra parte, la teología de la liberación asume su relación con la política a otro nivel: toma partido y opta por la "liberación de los oprimidos" (Tamayo Acosta, 1989).

En Teología de la liberación, Gustavo Gutiérrez la definió como "reflexión crítica de la praxis histórica a la luz de la fe" (1971: 31), "reflexión, a la luz de la fe, sobre el complejo proceso de liberación", esfuerzo de inteligencia de la fe que "deberá partir de la presencia y acción de los cristianos, en solidaridad con otros hombres, en el mundo de hoy, en particular, en la perspectiva de su participación en el proceso de 
liberación que se opera en América Latina" (1971: 61). De ello se desprende que, para los actores, es la injusticia de la pobreza de las mayorías latinoamericanas la "experiencia fundante" que vuelve a los cristianos a la causa de los pobres y empuja a la reflexión teológica "a la luz de la fe". En otros términos, el punto de partida de la teología de la liberación es la palabra "interpelante" de los "oprimidos", cuya respuesta es la opción por los pobres y la praxis liberadora que tiende a la construcción de una sociedad nueva. En este sentido, la teología de la liberación es un acto segundo; el acto primero lo constituye la situación de los explotados y sus anhelos, el accionar humano y eclesial orientado a la liberación en un contexto de injusticia (Gutiérrez, 1971; Scannone, 1987; Oliveros, 1990; Segundo, 1990a). Así, según Boff (1990), el encuentro con el pobre es la novedad radical y la condición epistemológica indispensable para hacer teología de la liberación. De esta manera, si toda teología se funda desde el lugar de la fe y el lugar de la realidad social dentro del cual se vive la fe, el "desde donde" de la teología de la liberación lo constituye el pobre y la praxis de liberación en América Latina (Tamayo Acosta, 1989).

Pero esta teología latinoamericana también se piensa a sí misma como "acción histórica del pueblo de Dios en el seguimiento de Jesús" (Ellacuría, 1990a), se define por la "fusión de comprensión religiosa, análisis social y militancia" (Levine, 1996), por tener una "funcionalidad históricamente liberadora" (Lois, 1990). En otros términos, también pretende estar indisolublemente unida a la praxis histórica por su intencionalidad práctica: no se limita a pensar el mundo sino que busca situarse en "el proceso a través del cual el mundo es transformado" (Gutiérrez, 1971: 34). En este sentido, si su horizonte mayor es el plano de la salvación, su horizonte segundo es el proceso histórico de liberación, se dirige a la praxis de transformación social (Boff, 1990).

Ahora bien, en su desarrollo histórico se distinguen diversas etapas:

1. Preparación, búsqueda (Scannone, 1987) o gestación (Oliveros 1990) (década del 1960). Se asistió a los primeros intentos de pensar teológicamente la realidad del continente. En este sentido, la elaboración de la teoría de la dependencia, la concreción del Concilio Vaticano II, la celebración en 1964 en Petrópolis (Brasil) de un encuentro de teólogos que se proponía investigar teológicamente la problemática de la Iglesia latinoamericana -en el que participaron Gustavo Gutiérrez, Juan Luis Segundo y Lucio Gera-, y la Conferencia de Medellín, constituyeron hitos fundamentales. 
2. Creación (Scannone, 1987) o génesis (Oliveros, 1990) (1969-1971). La obra de Gutiérrez (1971), que dio cauce a los esfuerzos teológicos de los años sesenta, significó un punto de inflexión en la teología latinoamericana. Algunos aportes importantes marcaron la dirección de la teología posterior: enriquecimiento del método teológico, elaboración de conceptos fundamentales (pobreza/pobre, liberación, utopía, salvación, etc.), reorientación “desde la praxis de liberación” de los grandes temas de la existencia cristiana, etc.

3. Sedimentación (desde 1972) (Scannone, 1987) o crecimiento (1972-1979) seguido de consolidación (1979-1987) (Oliveros, 1990). En este período, se multiplicaron las comunidades eclesiales de base y las experiencias apostólicas que apuntaban a "cambios audaces" - a los que invitaban los obispos en Medellín-, al tiempo que se profundizó la reflexión en la fe de la mano de una "segunda generación" de teólogos de la liberación que se sumó a los primeros. De este modo, se avanzó en el método teológico y la hermenéutica bíblica, y en la elaboración de diversas temáticas del quehacer teológico, tales como: la cristología, la eclesiología, Dios, la opción por los pobres, la espiritualidad enraizada en la misión liberadora, la historia de la Iglesia “desde la praxis de liberación”, o la escatología (Oliveros, 1990; Scannone, 1987; Tamayo Acosta, 1989).

Al mismo tiempo, los años setenta y ochenta estuvieron marcados por las persecuciones a cristianos y no cristianos comprometidos en los movimientos populares, y por la presión y los ataques a la teología de la liberación, provenientes de ciertos teólogos, de un sector de la jerarquía y del Vaticano. En la Conferencia de Obispos Latinoamericanos celebrada en Puebla (1979) hubo un intento de tomar el control de las cosas, a partir de la prohibición del Consejo Episcopal Latinoamericano (CELAM) de la participación de los teólogos de la liberación -que, no obstante, ejercieron influencia en los debates por intermedio de algunos obispos-, y de la matización de la expresión “opción por los pobres" mediante el adjetivo "preferencial”. La descalificación se puso de manifiesto con especial beligerancia en la Instrucción sobre algunos aspectos de la teología de la liberación (1984), publicada por la Sagrada Congregación para la Doctrina de la Fe -presidida por el entonces cardenal Joseph Ratzinger-, el silencio impuesto a Leonardo Boff y el acoso a Gustavo Gutiérrez. En 1985, una nueva instrucción, Libertad cristiana y liberación, retomaba temas de la teología de la liberación espiritualizándolos. Al mismo tiempo, Juan Pablo II reconoció la legitimidad de esta teología latinoamericana. Sin embargo, desde Roma ha continuado el intento por 
marginar las corrientes radicales y reafirmar su control sobre las conferencias episcopales (Oliveros, 1990; Tamayo Acosta, 1989; Löwy, 1999).

Por otra parte, ya a partir de 1972 comenzó a notarse que la teología de la liberación no era un todo monolítico y uniforme. En tanto se asumía como reflexión sobre la praxis cristiana, surgían matices y diferencias en función de las diversas experiencias históricas, situaciones regionales, coyunturas culturales y socio-políticas, y opciones ideológicas, por la cual, se hizo conveniente hablar en plural, de "teologías de la liberación" (Scannone, 1987; Tamayo Acosta, 1989). Han sido varias las tipologías o clasificaciones que se han construido para dar cuenta de esta multiplicidad de enfoques. Entre el conjunto de vertientes de este movimiento teológico, podemos distinguir:

La que Scannone (1987) llama teología desde la praxis pastoral de la Iglesia institucional, que acentúa el carácter integral y evangélico de la liberación, enfocándola desde una perspectiva bíblica y eclesial, sin entrar a reflexionar directamente sobre los aspectos sociopolíticos. El objeto de la reflexión teológica es toda la Iglesia. Utiliza la mediación ético-antropológica, si bien tiene en cuenta los datos que le proporcionan las ciencias sociales. Su óptica coincide con la de una parte importante del episcopado latinoamericano. Siguiendo a Scannone (1987), se trataría entonces de una teología de la liberación tomada en sentido amplio, sobre todo porque aborda la liberación como tema teológico y con una intención explícitamente liberadora en el plano histórico.

- La representada por Hugo Assman, Pablo Richard -principalmente en sus escritos de los años setenta- y los Cristianos por el Socialismo, que reflexiona teológicamente "desde y para la praxis de los grupos cristianos comprometidos en la acción revolucionaria”. Para leer la realidad, utiliza el análisis marxista, aunque no acepta el materialismo dialéctico a nivel filosófico. Según Scannone (1987), esta vertiente, a la que denomina teología desde la praxis de grupos revolucionarios, se distancia de la jerarquía al mismo tiempo que del pueblo, tiende al elitismo y a vaciarse de contenido teológico, desdibujando la diferencia entre Iglesia y mundo.

- La teología desde la praxis de los pueblos latinoamericanos (Scannone, 1987) o teología populista (Mugica, 1985 citado en Tamayo Acosta, 1989: 126), representada por los teólogos argentinos Juan Carlos Scannone y Lucio Gera, se distingue en la comprensión de "pueblo" y su posición ante el análisis marxista. 
Si otras corrientes entienden pueblo ante todo como clase, esta última lo concibe como sujeto comunitario de una historia y una cultura. Para analizar la realidad, usa la mediación de la historia, la filosofía y la antropología. El sujeto de la praxis liberadora son los pueblos en los que está inculturado el Pueblo de Dios. Tiene especial cuidado de la dimensión religiosa de la praxis liberadora y presta especial atención a la capacidad "redentora" de la religiosidad popular. En consecuencia, recalca lo específicamente cristiano en la praxis de liberación. Plantea la evangelización de la cultura como proyecto pastoral global y urgente para América Latina. Revaloriza, así, la historia concreta de los pueblos y de su evangelización, y la cultura de los mismos. Por todo ello, se explica que esta corriente estime que las categorías sacadas de la historia y la cultura latinoamericanas son más apropiadas que las marxistas para interpretar la propia realidad (Scannone, 1987).

- La línea que continúa las perspectivas abiertas por Gustavo Gutiérrez, llamada por Scannone (1987) teología desde la praxis histórica, da gran relevancia a la reflexión de la praxis liberadora de los cristianos y considera a las comunidades eclesiales de base los sujetos de dicha reflexión teológica. Acentúa la unidad de la historia y el carácter determinante de la espiritualidad. Se destaca por su consideración del pobre como lugar teológico y clave epistemológica, y por su utilización, crítica pero decidida, de la mediación de las ciencias sociales, y más en concreto del análisis socio-estructural. Según Scannone (1987), esta corriente es radical en sus planteamientos de transformación estructural de la sociedad latinoamericana, pero conscientemente desea ser fiel a la Iglesia y a la tradición teológica. Y al tiempo que se ocupa de la praxis pastoral y política de los sectores cristianos más concienciados y politizados, procura evitar los elitismos. Sin embargo, al decir de Scannone, algunos autores de esta tendencia comprenden en forma acotada lo específicamente cristiano de la praxis y el valor religioso del cristianismo.

- La teología del cautiverio, representada por Leonardo Boff, se propone como una nueva estrategia a seguir en los tiempos de "cautividad", como aquellos vividos en América Latina en los años setenta, con el predominio de la Doctrina de la Seguridad Nacional (Tamayo Acosta, 1989).

Más allá de las diferencias entre los teólogos liberacionistas, en sus escritos puede detectarse una serie de principios básicos que permiten caracterizar esta corriente 
intelectual. Como mencioné en la introducción, algunos de los más importantes son: la lucha contra los "nuevos ídolos de la muerte" (la riqueza, el mercado, la civilización occidental y cristiana, la seguridad nacional, etc.); la liberación humana histórica como anticipación de la salvación final en Cristo, el Reino de Dios; la crítica a la teología dualista tradicional que separaba historia humana y divina; una nueva lectura de la Biblia que da atención significativa a pasajes como el Éxodo, tomado como paradigma de la lucha por la liberación de un pueblo esclavizado; una aguda denuncia moral y social del capitalismo como pecado estructural; el recurso al marxismo como instrumento social-analítico para comprender las causas de la pobreza, las contradicciones del capitalismo y la lucha de clases; la opción por los pobres y la solidaridad con su lucha de autoliberación; y el desarrollo de comunidades cristianas de base entre los pobres como una nueva forma de Iglesia (Löwy, 1999).

Según Löwy (1999), si hubiera que resumir la idea central de la teología de la liberación en una frase, ésta sería "opción por los pobres" -que fue afirmada y definida con precisión en Medellín (Tamayo Acosta, 1989). La teología de la liberación se propone como un intento de lectura del "signo de los tiempos" 82 que significa la irrupción de los "oprimidos" en el mundo actual como sujetos de su propio destino (Gutiérrez, 1990). Así, como ya mencionados, los marginados son los principales inspiradores y el sujeto histórico de esta teología (Tamayo Acosta, 1989). Siguiendo a los protagonistas, este esfuerzo de inteligencia de la fe parte de los pobres como "lugar epistemológico, hermenéutico y teológico" (Sobrino, 1990) por excelencia, espacio privilegiado de la presencia y revelación de Dios (Richard, 1990) y, por lo tanto, de encuentro con Él (Lois, 1990), "sacramento de Cristo" y lugar social de la Iglesia (Tamayo Acosta, 1989).

Como explica Levine (1996), la preocupación por los marginados no es nueva en la perspectiva cristiana pero ahora cambia el papel que se promueve para ellos en la sociedad, la política y la Iglesia (de objeto de acciones y programas pasan a ser pensados como sujetos activos) y el modo como la pobreza es explicada.

En este sentido, la teología de la liberación plantea la distinción asumida por Medellín, entre la pobreza real como un mal, es decir, no deseada por Dios, y entonces, inhumana, antievangélica, sinónimo de muerte, injusticia y violencia institucionalizada;

\footnotetext{
${ }^{82}$ La necesidad de escrutar los "signos de los tiempos" -esto es, los nuevos fenómenos culturales, sociales, políticos y económicos- fue estimulada por el Concilio, rompiendo así con las distinciones tradicionales entre la "Iglesia" y el "mundo", lo que conllevaba implicancias para los vínculos entre la religión y la política (Levine, 1996).
} 
la pobreza espiritual, en tanto "disponibilidad a la voluntad del Señor"; y la solidaridad con los pobres y protesta por la situación que sufren (Gutiérrez, 1971, 1990). En su primera acepción, la pobreza es pensada como una realidad socioeconómica, colectiva, estructural, y como un hecho social, histórico, no natural sino producido, en relación dialéctica con la riqueza. Al mismo tiempo, los pobres constituyen una fuerza social y política (Tamayo Acosta, 1989; Ellacuría, 1990a).

Por otra parte, desde esta perspectiva, la pobreza espiritual, cuya esencia se expresa en las "Bienaventuranzas", consiste en ser discípulo/testigo de Jesús. Ahora bien, Jesús es concebido como el "mediador definitivo del Reino de Dios", en tanto anuncia su venida y su presencia a los pobres, pone a su servicio su hacer transformador, lucha contra el antirreino y entrega su vida por esa realidad salvíficoliberadora. Así, para estos teólogos, su cruz tiene una dimensión crítico-profética y una significación político-liberadora/salvífico-redentora, mientras que su resurrección aparece como irrupción anticipada de la liberación definitiva, confirmación de la vida y causa de Jesús, e invitación apremiante a su seguimiento. En esta lógica, el Jesús histórico no es aquel del que se espera la salvación sino alguien que envía a proseguir su misión. De este modo, el seguimiento de Jesús en América Latina encuentra en el Reino su motivación y contenido; “abrazar la cruz de Jesús” implica expresar la acogida del Reino de Dios en la solidaridad fraterna con los pobres reales, esto es, la opción por los pobres y el compromiso por la transformación liberadora (Sobrino, 1990; Lois, 1990).

Esto supone una solidaridad profunda y permanente, una inserción cotidiana en el mundo de los marginados, la lucha por la justicia y la liberación (Gutiérrez, 1990; Levine, 1996). Desde este punto de vista, la opción por los pobres tiene así consecuencias políticas ineludibles. A esta opción -de carácter "libre y comprometedor", aunque no facultativo (Gutiérrez, 1990: 309)-, se le da una fundamentación bíblico-teológica: en el Éxodo, Dios aparece como liberador de los “oprimidos”, pero además Jesús se hace pobre, se identifica con su causa y anuncia el Reino desde el mundo de los olvidados, constituyéndolos en destinatarios privilegiados y portadores de su mensaje. De este modo, para los teólogos de la liberación, "el problema de los pobres es, en definitiva, el problema de Dios y de Jesús" (Tamayo Acosta, 1989: 66).

Desde la misma perspectiva, la Iglesia debe ser una "Iglesia de los pobres", encarnada en los “oprimidos", dedicada a ellos y a su salvación. Esto supone, por un lado, que la fe cristiana signifique algo real y palpable en la vida de los marginados, esto 
es, la historia de salvación debe ser también de salvación "aquí y ahora"; por el otro, que la fe cristiana se convierta en principio de liberación del corazón humano y de la persona, frente a estructuras opresoras (Ellacuría, 1990a).

La cuestión de cómo se relacionan los esfuerzos humanos por la liberación histórica, incluso sociopolítica, de las "mayorías oprimidas" con la salvación cristiana/la instauración del Reino de Dios anunciado por Jesús, cobra una importancia fundamental en la teología de la liberación, no sólo para la comprensión de la fe sino también para la eficacia de la praxis de los cristianos que, urgidos por su fe, participan en la lucha de su pueblo (Gutiérrez, 1971; Ellacuría, 1990b). Para Gutiérrez, la salvación -a la que define como "comunión de los hombres con Dios y comunión de los hombres entre ellos" (1971: 187)-, que comprende a todo el hombre y a todos los hombres, es también una realidad intrahistórica; orienta, transforma y lleva la historia a su plenitud. Desde esta perspectiva, salvación histórica y salvación cristiana pueden diferenciarse pero no separarse; por el contrario, debe buscarse la unidad entre ellas. La dimensión sociopolítica es pensada como parte esencial de la historia de la salvación aunque no la agota. En palabras de Gutiérrez, "el hecho histórico, político liberador es crecimiento del Reino, es acontecer salvífico pero no es la llegada del Reino, ni toda la salvación" (1971: 228). Para los actores, en la situación de opresión del Tercer Mundo, la realización histórica de la salvación se presenta predominantemente como liberación (Ellacuría, 1990a). Y aquí el hombre tiene un papel protagónico como copartícipe de su propia salvación. Así, "la lucha por una sociedad justa se inscribe plenamente y por derecho propio en la historia salvífica" (Gutiérrez, 1971: 216).

Estos planteos encuentran su fundamento en la tesis que sostiene que no hay dos historias, una profana/del hombre/del mundo y una sagrada/de salvación/de Dios, sino que se trata de un solo devenir humano asumido por Cristo (Gutiérrez, 1971), una sola historia, la historia de Dios, que engloba a ambas historias, mutuamente determinadas. Desde este punto de vista, tanto el Antiguo como el Nuevo Testamento ponen de manifiesto que la trascendencia cristiana no reside en salirse de la historia del pueblo y sus luchas sino, por el contrario, en potenciarlas. En consecuencia, se afirma que a diferencia de otros pueblos que se acercan a Dios a través de la naturaleza o del ámbito interior, los cristianos lo hacen en la historia; Dios es trascendente porque se hace libremente presente, irrumpe/interviene/se revela/se manifiesta y se dona permanentemente en la historia y de modo privilegiado, en la praxis histórica de salvación (Ellacuría, 1990b; Richard, 1990). Por tanto, desde la óptica liberadora, la 
diferencia no está entre lo natural y lo sobrenatural sino entre gracia y pecado, entre mayor o menor presencia de vida divina. El problema entonces es discernir qué hay de gracia y de pecado en una coyuntura histórica. Y el pecado es visto como una realidad histórica, social, colectiva, una traba para que la vida humana llegue a su plenitud, lo que implica una ruptura en la comunión con Dios y entre los hombres (Gutiérrez, 1971). Para los actores, en América Latina, el pecado se presenta bajo la forma de la pobreza y la injusticia, y los pobres son el lugar preferido del amor de Dios. Así, la opción por los pobres y la acción liberadora son concebidas como el camino en que se hace más visible la trascendencia histórica cristiana, la máxima posibilidad de manifestación objetiva de la voluntad de Dios. Esto lleva a asumir compromisos políticos que, sin embargo, se distinguen de la opción puramente cristiana en favor de los pobres (Ellacuría, 1990b).

De la tesis que postula que Dios se revela de modo privilegiado en el mundo de los explotados, los autores deducen que la tarea teológica central -y una dimensión específica de la práctica histórica de liberación- en nuestro continente no es probar la existencia de Dios sino discernir el Dios verdadero de los ídolos falsos, rescatando la crítica anti-idolátrica de la tradición bíblica. Se afirma entonces que la fe en Dios se enfrenta fundamentalmente, no con el ateísmo sino con la idolatría, que consiste tanto en la manipulación del Dios verdadero como en su sustitución por otros dioses creados por el ser humano (dinero, ley, saber, poder, prestigio, instituciones, funciones, etc.). Para los liberacionistas, la idolatría, raíz del pecado social, está al servicio del sistema económico, político, cultural dominante, para aumentar su poder, así como para dominar espiritualmente a las personas y a la sociedad (Richard, 1990).

Otra de las marcas distintivas de la teología de la liberación es su método. Los autores reconocen tres "mediaciones" o instrumentos principales de construcción teológica: la "mediación práctica", la "mediación socio-analítica" y la "mediación hermenéutica" -las últimas de carácter teórico. Se explica que la primera contempla el lado de la acción e intenta descubrir las líneas operativas para superar la opresión de acuerdo al plan de Dios. Como mencionamos anteriormente, la teología de la liberación aspira a salir de la acción y, desde el análisis de la realidad del pobre, pasar a través de la Palabra de Dios para llegar finalmente a la práctica concreta: acción por la justicia, conversión, transformación de la sociedad. En este sentido, se propone como una teología militante, comprometida, que conduce a la plaza pública, porque entiende, en palabras de Boff, que la forma actual de la fe en el Tercer Mundo "es también y sobre todo política" (1990: 112). 
Se afirma que la "mediación socio-analítica" contempla el lado del mundo del “oprimido", a través de una labor de discernimiento que procura conocer profundamente la realidad latinoamericana, develar sus complejidades y conflictos, explicitar las condiciones materiales de existencia, entender las causas, formas y mecanismos de la opresión. Para ello, recurre a las ciencias sociales pero también incorpora la sabiduría popular, esto es, toda la interpretación que hacen los pobres de su mundo (Boff, 1990; Tamayo Acosta, 1989).

Es en este momento interno central del "discurso de la fe", así como en los movimientos populares, donde la teología de la liberación se encuentra con el marxismo. Esta teología pretende interrogar al marxismo a partir y en función de los pobres, utilizarlo como herramienta para el análisis de la realidad socio-histórica, y hacerlo de modo instrumental, tomando las indicaciones metodológicas que considera fecundas -las categorías de clase, conflicto y explotación, la importancia de factores económicos, la atención a la lucha de clases, el poder mistificador de las ideologías, incluidas las religiosas, etc. Sin embargo, la teología de la liberación no considera la infraestructura económica como único factor significativo responsable de las transformaciones sociales, y se interesa por otros planos de la opresión social -racial, étnica o sexual. Al mismo tiempo, el préstamo conceptual no requiere la identificación con la filosofía e ideología marxista. De allí que rechace su ateísmo, su materialismo dialéctico calificado de "ingenuo", su "economicismo" y su "dogmatismo abstracto" (Boff, 1990; Tamayo Acosta, 1989; Levine, 1996; Dussel, 1990). En otros términos, la teología de la liberación asume el marxismo por las necesidades que plantea su opción práctica, y lo hace de una determinada manera, que considera no incompatible con los fundamentos de la fe. Se trata de un cierto tipo de marxismo y de una utilización con distintos acentos y posiciones: algunos teólogos tienen una postura más claramente "clasista", otros más cercanamente "populista"; algunos usan sólo el instrumental de la crítica ideológica, otros social, y aun propiamente económica; algunos también se oponen al marxismo globalmente; algunos se inspiran en una corriente más francesa, otros en la italiana o alemana, y en la mayoría de los casos, en varias de ellas simultáneamente; todos se sirven, sin embargo, de la tesis de la dependencia que "latinoamericanizó" el marxismo (Dussel, 1990).

Más allá de esta diversidad de posibilidades, el encuentro entre teología de la liberación y marxismo ha sido una de las cuestiones más controvertidas, en tanto los críticos de la primera la han acusado de estar teñida de ideas marxistas y subordinada a 
sus programas y políticas. Por otra parte, algunos autores consideran problemática la comprensión del pobre como clase por sus consecuencias para la interpretación de la praxis liberadora de los cristianos (según esa determinada concepción de la lucha de clases), de la opción por los pobres (como opción clasista), del amor cristiano, la misión de Cristo y de la Iglesia, la unidad de la Iglesia y los conflictos dentro de ella, la misma comprensión de Dios, etc. Asimismo, cuestionan la posibilidad real de separar el análisis marxista de la interpretación global (filosófica) del hombre y de la historia que él presupone, señalando los riesgos de la "ideologización de la teología" (Scannone, 1987: 60).

Por último, se dice que la "mediación hermenéutica", contempla el lado del mundo de Dios, procurando ver el proceso de opresión-liberación a la luz de la fe (Boff, 1990). En este momento de construcción teológica, la teología de la liberación se mueve en un círculo hermenéutico que incluye dos fases metodológicas: 1) la lectura de realidad histórica y política concreta a la luz de la Palabra, en la que se desvela el sentido trascendente de la acción liberadora, la dimensión salvífica de los acontecimientos políticos; 2) la relectura de la Biblia desde la praxis histórica, en la que se redescubre el sentido histórico, político, conflictivo y transformativo del mensaje cristiano. La primera fase reproduce el ritmo del Ver, Juzgar y Obrar, propuesta por el Concilio a través de la constitución Gadium et Spes, como manera distinta de enfocar teológicamente la realidad. La segunda, supone la recomprensión, conceptualización y sistematización de las afirmaciones centrales de la fe desde la opción por los pobres y las mediaciones práctico-pastorales, volviendo al nivel del Obrar (Scannone, 1987).

De este modo, la teología de la liberación plantea una novedad en el modo en que se hace la lectura bíblica, procurando dejar atrás la lógica deductiva y axiomática hasta convertirse en una disciplina interpretativa (Levine, 1996). Se entiende, por un lado, que la revelación no es conjunto de respuestas ya hechas, válidas de una vez y para siempre, sino que supone libertad, fe, hombres en una búsqueda convergente y una comunidad que interpreta y transmite; por el otro, que esta comunidad forma parte de la revelación y que la praxis condiciona la posibilidad de que la revelación revele algo en realidad (Segundo, 1990b). En este sentido, el punto de partida hermenéutico son las "mayorías oprimidas", la opción por los pobres y su liberación integral. Así, el mensaje bíblico es releído desde la situación histórica, cultural, religiosa, social, económica y política en que vive el pueblo y desde la vivencia comunitaria de la fe del mismo. De allí que la exégesis popular se plantea como un "acto creativo de interpretación 
transformadora" (Tamayo Acosta, 1989). Esta hermenéutica se caracteriza por buscar interpretar la vida según las Escrituras; descubrir y activar la "energía transformadora" de los textos bíblicos en términos de la persona (“conversión”) y de la historia ("revolución"); acentuar el contexto social del mensaje para hacer una traducción no literal al propio escenario histórico, descubriendo el significado de la revelación aquí y ahora; y querer hacerse junto a los pobres, incorporando la lectura popular de la Biblia.

El retorno del pueblo a las fuentes bíblicas, que tomó su fuerza de las reformas del Concilio Vaticano II, tiene un enorme impacto en las comunidades cristianas con mayorías pobres y analfabetas, convirtiéndose en factor de igualdad. El énfasis está puesto en las imágenes del Antiguo Testamento, que muestran a Dios como presencia activa en el mundo y resaltan los roles proféticos de crítica contra la injusticia y de lucha por una sociedad mejor; en los Evangelios, por el carácter central de Jesús, su mensaje del Reino, su preocupación por la justicia, su práctica liberadora, su muerte y resurrección como sentido absoluto de la historia; en los Hechos de los apóstoles, que retratan el ideal de una comunidad cristiana libre y libertadora; y en el Apocalipsis, que describe en términos colectivos y simbólicos la lucha contra los "monstruos de la historia" (Levine, 1996; Boff, 1990).

En este marco de cambios, dados por el aggiornamento eclesial y la expansión de la teología de la liberación, así como de continuidades, ligadas a un modo particular "integralista"- de comprender y vivir el catolicismo, se desplegó el accionar de los movimientos católicos de juventud en Bahía Blanca durante la efervescencia social y política de los años sesenta y setenta. En el próximo capítulo presentaré a estos grupos, atendiendo al contexto local, así como a sus antecedentes. 


\section{CAPÍTULO 2: Las ramas especializadas de Acción Católica en Bahía Blanca}

\section{SUMARIO}

1) El contexto bahiense

2) La JUC, la JOC y la JEC

a) Orígenes y desarrollo en Argentina

b) Antecedentes locales

i) La Juventud Obrera Católica

ii) La Acción Católica Universitaria

iii) Los Círculos y Centros de Estudiantes Secundarios de la Acción Católica

c) Los grupos en el período 1967-1975

i) Los asesores

ii) Los grupos de "revisión de vida".

El objetivo del presente capítulo es caracterizar las ramas especializadas de Acción Católica en Bahía Blanca. Para ello, presentaré a la JEC, la JUC y la JOC, dando cuenta de sus orígenes en Argentina, de sus antecedentes locales, del proceso de su formación en esta ciudad a partir de 1967, de sus formas de organización y funcionamiento, de sus actividades, de sus espacios de encuentro y, especialmente, de las trayectorias de sus miembros (en cuanto al origen familiar, inserción barrial e itinerarios educativos y laborales). Sin embargo, antes me detendré en algunos datos de la historia social y política de Bahía Blanca en los años sesenta y setenta.

\section{1) El contexto bahiense}

Bahía Blanca es una ciudad de dimensiones intermedias ubicada en el sur de la provincia de Buenos Aires, a 700 km. de la ciudad de Buenos Aires. Fundada en 1828, para los años setenta rondaba los 182 mil habitantes y tenía gran relevancia a nivel regional desde el punto de vista económico, militar, cultural y eclesial.

El desarrollo de la ciudad como nodo regional se puede rastrear a fines del siglo XIX, momento en que Bahía Blanca logró incorporarse exitosamente al proyecto nacional de la "generación del ' 80 ”, mediante una transformación económica y política de gran envergadura. En esa época, la construcción del muelle portuario-que motivó un fuerte desarrollo de las actividades comerciales y financieras-, sumado a la llegada del ferrocarril en 1884 -que permitió comunicar a la ciudad con el resto del país-, la 
instalación de establecimientos industriales medios y la revolución agrícola regional, hicieron de Bahía Blanca un centro comercial, financiero y de servicios de significativa gravitación en el sudoeste bonaerense, en La Pampa y en otros territorios patagónicos. Este crecimiento fue favorecido por el incremento poblacional, producto de las colonias de inmigrantes que se asentaron en la ciudad y acompañaron el proceso de urbanización local. Además, por su estratégica localización geográfica como puente que vincula Buenos Aires y la Patagonia, nudo de comunicaciones terrestres, marítimas y aéreas entre el norte y sur de país, la ciudad pretendió erigirse también en un polo político clave a nivel nacional: diversos proyectos de fines del siglo XIX y principios del siglo XX que proponían a la localidad como capital de la provincia de Buenos Aires o como cabecera de una nueva provincia dan cuenta de ese ascendiente económico y político de Bahía Blanca en la región.

Para la década de 1960, en reconocimiento al rol dinamizador de la región que Bahía Blanca venía cumpliendo desde el siglo anterior, desde el punto de vista comercial -el complejo portuario era ya uno de los principales del país-, del tránsito entre regiones, demográfico -en materia poblacional, el partido crecía considerablemente- e incluso industrial -se multiplicaban las empresas dedicadas a la manufactura de alimentos y a la construcción-, y a raíz de algunos estudios de organismos oficiales y privados, la ciudad fue designada como polo de desarrollo de una amplia zona que nucleaba a quince partidos bonaerenses, un vasto territorio al que se añadía su proyección regional sobre las provincias de La Pampa, Río Negro y Neuquén (Orbe, 2006).

Por otra parte, desde fines del siglo XIX, la ciudad se convirtió en asiento de diversas guarniciones militares y de organismos de defensa y de seguridad, que para mediados de la década de 1970 incluían: la Base Naval Puerto Belgrano, creada en 1896, que era la más importante del país y una de las más grandes de Latinoamérica desde allí partieron los aviones que en 1955 bombardearon la Plaza de Mayo- y con la que estuvo ligada la fundación de la localidad de Punta Alta dos años después; la Base Aeronaval Comandante Espora; la Base Naval de Infantería de Marina; el Comando del V Cuerpo del Ejército que, erigido en 1960, extendía su jurisdicción a toda la Patagonia, y bajo el cual fueron unificadas las unidades que se habían formado previamente; la Compañía de Intendencia 181, el Batallón de Comunicaciones 181, la Policía Militar y el Destacamento de Inteligencia Militar 181, que establecidas a lo largo de la década de 1960 y principios de 1970, estaban subordinadas a este Comando; la Delegación Sur de 
Gendarmería Nacional; la Prefectura Naval Argentina; la Delegación de la Secretaría de Inteligencia del Estado (SIDE); la Delegación de la Policía Federal Argentina; la Brigada de Investigaciones y la Unidad Regional Quinta de la Policía de la Provincia de Buenos Aires.

Al mismo tiempo, la ciudad era cabecera de la Arquidiócesis de Bahía Blanca. La elevación a sede episcopal ocurrió en 1934. En marzo de 1935, el primer obispo, Leandro Astelarra, tomó posesión del cargo, el que desempeñó hasta su fallecimiento en agosto de 1943. En su reemplazo, y durante la vacancia de la diócesis, se nombró a José Alonso Vicario Capitular y Ecónomo. Finalmente, en marzo de 1947, Germiniano Esorto asumió como nuevo obispo. Diez años más tarde, la diócesis fue elevada a arquidiócesis, quedando Monseñor Esorto al frente de la sede arzobispal. Cuando, en 1961, Juan XXIII reordenó las provincias eclesiásticas de la nación, por bula "Nobilis Argentina", la de Bahía Blanca constaba de la sede metropolitana del mismo nombre y las diócesis sufragáneas de (Comodoro) Rivadavia, Santa Rosa, Viedma y Río Gallegos -erigida en esa misma oportunidad. En 1972, Monseñor Esorto presentó su renuncia, según las nuevas normas pontificias, al cumplir los 75 años de edad, sucediéndolo Jorge Mayer -primer obispo de Santa Rosa (1957-1972)-, quien se desempeñó como arzobispo hasta mayo de 1991. En septiembre de 1970, la arquidiócesis contaba con más de 525 mil habitantes, distribuidos en un territorio de poco más de 82 mil km2 que comprendía los partidos bonaerenses de Bahía Blanca, Coronel Rosales, Tres Arroyos, Coronel Suárez, Patagones, Coronel Pringles, Coronel Dorrego, Villarino, Adolfo Alsina, Puán, Saavedra, González Chaves, Daireaux, Guaminí, Tornquist y San Cayetano ${ }^{83}$.

Paralelamente a la evolución socioeconómica, la ciudad experimentó en las primeras décadas del siglo XX un importante crecimiento en lo que a instituciones culturales y educativas se refiere. En 1903 fue inaugurada la Escuela Nacional de Comercio y tres años después abrieron sus puertas la Escuela Normal y el Colegio Nacional. En la actividad cultural, el aporte de la población inmigrante -que para 1914 constituía la mitad de los 70 mil habitantes- fue esencial, a partir de la creación de numerosas instituciones y organizaciones. Entre ellas, la Biblioteca Bernardino Rivadavia, inaugurada en 1882, o el Teatro Municipal, cuya construcción data de 1913. Por otra parte, el desarrollo socioeconómico y cultural de la ciudad generó tempranamente en los sectores dirigentes y la ciudadanía el anhelo por contar con una

\footnotetext{
${ }^{83}$ Arzobispado de Bahía Blanca, 1997; y Boletín Eclesiástico, Bahía Blanca, septiembre de 1943, marzo de 1947, marzo-abril de 1957, abril-mayo-junio de 1961, octubre-diciembre de 1971.
} 
institución de carácter universitario. Al ser Bahía Blanca el principal centro urbano del sur del país, la presencia de instituciones educativas de carácter universitario era fundamental para los estudiantes secundarios de una amplia zona de influencia. Así, desde 1924 se sucedieron diversos proyectos que, con diferente éxito, impulsaron su creación. Finalmente, en 1948 se fundó el Instituto Tecnológico del Sur y en 1954, la Facultad Bahía Blanca de la Universidad Obrera Nacional -luego Universidad Tecnológica Nacional (UTN)-, dos entidades educativas de nivel superior con orientación técnica e industrial, que respondían más a la intención de promover la producción industrial que a la existencia de un cinturón fabril que requiriese de un número importante de ingenieros especializados ${ }^{84}$ (Marcilese, 2006). Finalmente, con la "Revolución Libertadora", se produjo el cierre del Instituto y la creación de la Universidad Nacional del Sur (UNS) -por decreto-ley del 5 de enero de 1956-, siendo la octava universidad nacional del país. La nueva institución adoptó un gobierno autónomo, un régimen cuatrimestral de cursado y la estructura departamental, siendo los primeros ocho departamentos los de Contabilidad, Economía, Física, Geología y Geografía, Humanidades, Ingeniería, Matemática y Química (Orbe, 2006).

Además de la UNS y de la UTN, desde mediados de la década de 1950, Bahía Blanca albergaba una serie de institutos terciarios, como el Instituto Superior de Profesorado Juan XXIII o la Escuela de Servicio Social, convirtiéndose, así también, en un centro educativo de nivel superior. El Instituto Juan XXIII, dirigido por una comunidad de salesianos, inició sus actividades el 29 de marzo de 1960. Para 1968, el número de alumnos era de 600, el de egresados, de 263, y el de profesores, de 52. En el establecimiento funcionaban los departamentos de Literatura y Castellano, Matemáticas y Cosmografía, Física, Filosofía y Psico-pedagogía, Geografía, e Inglés. Cada una de las carreras incluía una hora semanal de Teología católica como materia ${ }^{85}$.

Estas instituciones de educación superior figuraron entre los espacios bahienses que en los años sesenta y setenta fueron escenario de una intensa movilización social y política. Este proceso, al igual que en el resto del país, fue protagonizado por los sectores medios y populares, en particular, en oposición a la dictadura militar liderada por Onganía, primero, y ligados a la vuelta del peronismo al poder, más tarde, y se manifestó en la conformación de diversos ámbitos de militancia: barrial, sindical,

\footnotetext{
${ }^{84}$ Al promediar el siglo XX, el perfil económico de Bahía Blanca estaba más próximo al de una ciudad ligada a la actividad mercantil y financiera, siendo el desarrollo industrial bahiense más un proyecto a concretarse que una realidad constatable (Marcilese, 2006).

${ }^{85}$ Boletín Eclesiástico, Bahía Blanca, julio-septiembre de 1968.
} 
estudiantil, entre otros. Este proceso de movilización social tuvo un punto de inflexión en 1974, cuando la violencia política de la Triple $\mathrm{A}^{86}$ comenzó a desatarse con fuerza en la ciudad, alcanzando a víctimas de trayectorias disímiles.

En este repaso por el escenario bahiense, no puedo eludir la referencia a $L a$ Nueva Provincia (LNP), diario fundado en 1898 por Enrique Julio, propiedad de la familia Massot, y que se edita hasta la actualidad. A lo largo de su trayectoria como medio de comunicación, y bajo la dirección de distintos miembros de la familia, fue incrementando su gravitación como actor político a nivel local y provincial. En el campo periodístico bahiense, fue acrecentando su capital económico, político y simbólico (Llull, 2005). La empresa fue ampliada, en 1958, con la adquisición de una radio AM -LU2 "Radio Bahía Blanca"- y, en 1965, de un canal de televisión -LU80 Canal 9 "Telenueva"-, convirtiéndose de ese modo en la voz periodística hegemónica en la ciudad (Zapata, 2008).

La continuidad de la tirada se vio interrumpida cuando, en el año 1950, el gobierno de Perón decidió su cierre. En su carácter de ferviente opositor al peronismo, el diario logró su reapertura en 1955, de la mano de la Marina con la llamada "Revolución Libertadora". Luego, el maridaje entre este medio y las fuerzas militares sería cada vez más evidente. En 1956, la nieta del fundador, Diana Julio de Massot, se puso al frente de la empresa. Guiada por la convicción de que los medios de comunicación no sólo debían informar sino, fundamentalmente, "formar conciencia respecto de determinados valores e ideas", procuró que $L N P$ se destacara "por su compromiso indeclinable con la defensa de las más profundas tradiciones nacionales y de los fundamentos de la cultura occidental: el principio de autoridad, la seguridad jurídica y la libertad responsable de las personas". Convencida de sus razones, defendió la legitimidad del golpe de Estado que derrocó a Perón en 1955, apoyó “críticamente” la autodenominada "Revolución Argentina" y asumió "su mejor perfil combativo" frente a las organizaciones armadas considerándolas "enemigos de la Nación”

En efecto, inumerables páginas de $L N P$ fueron dedicadas a la efervescencia social y política del país en los años sesenta y setenta. El diario se pronunció firmemente en contra del "comunismo ateo", del "marxismo apátrida", de los recintos universitarios como "epicentros de extremistas izquierdistas", de sectores del peronismo y del sacerdocio "tercermundista". Monolíticamente, LNP señalaba en lo anterior al

\footnotetext{
${ }^{86}$ Véase el capítulo 3 y 7.

87 "Falleció anoche la señora Diana Julio de Massot", LNP, 26/8/2009.
} 
"enemigo subversivo" y alertaba sobre el peligro que suscitaba un potencial "infierno bolchevique" en Bahía Blanca y en el país, generando un discurso pro-golpista y militarista. Según el diagnóstico de los editorialistas, la amenaza subversiva se corporizaba en dos ámbitos privilegiados, el mundo sindical y el campo educativo, y por tanto en ellos había que concentrar los esfuerzos para lograr la destrucción del enemigo.

Una de las páginas más oscuras del diario la encontramos luego de los conflictos laborales que la empresa mantuvo con el sindicato de Artes Gráficas de la ciudad entre los años 1973 y 1976, que culminaron con los asesinatos de dos de sus trabajadores más combativos, Enrique Heinrich y Miguel Ángel Loyola, ya en contexto dictatorial. Al entender de las fuerzas de seguridad, LNP era un "medio periodístico fundamental" para la ciudad. Por lo tanto se debía "ralear" de su interior a su "soviet" interno ${ }^{88}$. En efecto, la connivencia empresarial/militar no sólo se vio expresada en las ayudas brindadas desde el diario a los servicios de inteligencia para señalar a sus obreros gráficos (Zapata, 2008), sino también en el modo en el que LNP festejó la llegada de los militares al poder en 1976, hecho que reconoce y defiende en el presente, como puede verse en la editorial del 26 de agosto de 2009: "en medio de aquel proceso disolvente que afectaba a la República" -representado por el tercer gobierno peronista- "el 24 de marzo de 1976 Diana Julio de Massot consideró que era un deber ineludible respaldar la acción militar de las Fuerzas Armadas" ${ }^{\prime 89}$. Así $L N P$ reivindicó el accionar represivo y se convirtió en portavoz de la versión de los hechos que sostenía el V Cuerpo de Ejército ${ }^{90}$. Por esta participación activa en la trama civil de la represión en la ciudad se ha abierto una causa que investiga a su director y propietario, Vicente Massot, imputado por crímenes de lesa humanidad $^{91}$.

\section{2) La JUC, la JOC y la JEC}

\footnotetext{
${ }^{88}$ Informe Servicio de Inteligencia de la Prefectura Naval Argentina (SIPNA) Memorandum 8687-IFINro27 "ESC"/76, 22 de marzo de 1976, citado en Zapata, 2008.

89 "Falleció anoche la señora Diana Julio de Massot", LNP, 26/8/2009.

90 Sin embargo, esta complacencia y este apoyo se encontraban supeditados al cumplimiento de los imperativos que exigía una verdadera "revolución nacional" ( $L N P, 24 / 3 / 1976)$. Según el diario, las Fuerzas Armadas se encontraban frente a una coyuntura única, en la que era posible reencauzar los destinos del país o conducirlo a una crisis aún más profunda. Por ello debían asumir la responsabilidad de llevar adelante algo más que un simple golpe, debían afrontar una nueva etapa que superaría todo lo anterior y que necesariamente debía encontrar sustento en la opinión pública. Sobre el discurso de $L N P$ respecto del tercer gobierno peronista y del golpe de estado del 24 de marzo de 1976, puede consultarse Montero, 2006 y 2008. Volveré sobre LNP en el capítulo 5.

${ }^{91}$ Véase http://juiciobahiablanca.wordpress.com/page/2/. Consultado el 23/5/2014.
} 


\section{a) Orígenes y desarrollo en Argentina}

Las ramas especializadas intentaban ocupar el lugar de organizaciones como la Acción Católica Argentina, que -tal como mencionamos en el capítulo anterior- habían sido motores de la "restauración católica" en los años treinta, pero década y media después se encontraban en una profunda declinación y crisis con la llegada de un gobierno democrático ${ }^{92}$. Las nuevas experiencias apostólicas, fundadas en la concepción del modelo belga de la $\mathrm{AC}$-en la que los militantes se nucleaban según su pertenencia a diferentes ambientes de la sociedad civil-, convivieron con la ACA que, siguiendo el modelo italiano, agrupaba a sus militantes en ramas según sexo y edad. En otras palabras, la JUC, la JEC o la JOC no eran parte de la ACA, y por lo tanto, no dependían de las decisiones de su Junta Central (Bottinelli et al., 2001). Sin embargo, al igual que aquélla, el surgimiento de los movimientos especializados de juventud se inscribía en el marco de la estrategia del catolicismo integral de penetrar en diversos espacios de la sociedad y el Estado y conquistar una presencia pública (Mallimaci, 1992).

En esta cruzada recristianizadora, la JOC venía a invitar al movimiento obrero a participar de la construcción de un nuevo orden social cristiano. Y en la medida en que se lograra atraer a este actor a la doctrina católica, se daría su esperado alejamiento de posturas radicales. De allí que la JOC se haya constituido en un actor central para la corriente hegemónica del catolicismo argentino.

Más allá de nuestro país, la JOC constituyó la apuesta más comprometida de la Iglesia de acercarse a la clase obrera. Sus orígenes en Bélgica estaban ligados a las experiencias de su creador, el sacerdote Joseph Cardijn, en la búsqueda de proveer a los jóvenes obreros de una formación que les permitiera tanto luchar por mejores condiciones de trabajo como llevar una vida privada acorde con los valores cristianos. Bajo la influencia de Cardijn, la JOC reconocía en el obrero no a un "instrumento de trabajo y producción, sino a un ser humano dotado de inteligencia y creado a imagen de Dios" (Cardijn, citado en Levenson, 2007: 86), y en oposición al capitalismo y al

\footnotetext{
${ }^{92}$ Siguiendo a Mallimaci (1992), varios de los militantes de la ACA fueron llamados a ocupar puestos en el gobierno peronista, otros abandonaron las filas por falta de "motivaciones" (se había obtenido la enseñanza religiosa, se había vencido a los liberales y comunistas, se trataba de un gobierno que se consideraba "católico"), otros veían una "excesiva politización” y desgastes personales que no hacían más que clericalizar y dar un cariz cada vez más eclesial a la organización. Para la institución eclesial, en esta nueva situación, era más fácil y menos conflictiva la relación con el poder del Estado que una inserción en la sociedad a partir de movimientos apostólicos.
} 
comunismo, buscaba la transformación de su situación material y moral. A diferencia de los católicos que durante el siglo XIX se habían volcado a la evangelización de los trabajadores sustrayéndolos de su lugar cotidiano, la JOC buscaba llevar la religión a sus vidas diarias, atrayéndolos a la estructura de la Iglesia como apóstoles laicos.

La JOC fue reconocida como organización especializada de la AC por el Episcopado belga en 1924 y pronto se transformó en un movimiento internacional. Tuvo un rápido crecimiento en Bélgica y en toda Europa. Desde principios de la década de 1930, se desarrolló en América y particularmente, en América Latina, siendo Colombia el país pionero. En Brasil, surgieron grupos de JOC desde mediados de la década, aunque fue en 1947 que empezó a ser un movimiento nacional vinculado oficialmente con la JOC internacional. En ese mismo año, se inició la organización en Guatemala (Levenson, 2007). Fue más tardía la evolución en México, donde se lanzó el movimiento a nivel nacional en 1961 (Soneira, 2002).

En Argentina, la asociación tuvo orígenes y trayectorias divergentes de acuerdo a las distintas diócesis. En la mayoría de los casos, fue promovida por la Juventud de Acción Católica (JAC) de la ACA. Luego de meses de preparación, en diciembre de 1940, la JOC argentina fue fundada oficialmente, con la aprobación de sus estatutos por parte del Episcopado, y reconocida como organización autónoma de la ACA. En ese momento, se oficializaron experiencias jocistas preexistentes en Salta -primera JOC del país, fundada en 1938- y en Córdoba -constituida en septiembre de 1940 por auto del arzobispo-, se formaron otras en Buenos Aires (1940), La Plata (1940), San Juan (1942) y Catamarca (1943). En 1944, la JOC también aparecía mencionada en Santa Fe, Tucumán, Santiago del Estero, Mendoza, La Rioja y Chaco, y en 1946, en Entre Ríos y Chubut (Blanco, 2010).

La nueva organización se superponía con estructuras preexistentes con presencia en los sectores trabajadores: los Círculos Católicos de Obreros -fundados en $1892-{ }^{93}$ y, específicamente, su rama juvenil, las Vanguardias Obreras -creadas en 1933- (Soneira,

\footnotetext{
${ }^{93}$ Los Círculos, inspirados por el Padre Federico Grote y animados por obreros e intelectuales católicos sensibilizados por la temática social, se organizaron en las grandes ciudades del país y crecieron fundamentalmente, durante las dos primeras décadas del siglo, hasta que en los años veinte las transformaciones del catolicismo afectaron el crecimiento de esta organización. Frente al "liberal positivismo" y a la influencia del socialismo, buscaban ganar las masas obreras para la Iglesia a través del socorro mutuo, la enseñanza gratuita, las diversiones, la atención médica y jurídica, etc. Más tarde, también buscaron promover las leyes sociales que respondieran a las necesidades de los trabajadores. En cuanto buscaban la "armonía de clases", en sus filas convivían profesionales y obreros, siendo los primeros, mayoría en los cargos directivos. Por otra parte, al calor de las luchas sociales, los sectores dominantes comenzaron a apoyar, incluso monetariamente, la tarea de los Círculos al ver en ellos un espacio donde arraigar "buenas costumbres" en los obreros (Mallimaci, 1992).
} 
2002). La superposición se manifestaba de diversas maneras. Por ejemplo, los miembros de la JOC salteña se reunían en el mismo local que los de los Círculos, aunque se indicaba que éstos continuaban con sus funciones mutualistas, mientras que la JOC bregaba por la formación de sindicatos dirigidos por la Iglesia salteña. En el caso de Córdoba, los Círculos y la JOC compartían miembros, el local e incluso la asistencia mutua a los actos organizados por ambas asociaciones, que se complementaban en su funciones (Blanco, 2010).

Al mismo tiempo, la JOC planteaba una ruptura con respecto a estas formas de apostolado católico en el movimiento obrero. Si los Círculos buscaron cambiar la situación de los trabajadores, respondían más al paternalismo que al intento por brindarles herramientas para que ellos mismos lucharan por mejoras en sus condiciones de vida. En otras palabras, "fueron más una obra de Iglesia para los obreros católicos que una obra de obreros de inspiración católica en el movimiento obrero" (Bottinelli et al., 2001: 85), tal como se propuso la JOC. En este sentido, este movimiento respondió al llamado de la encíclica Quadragesimo Anno (1931): "los primeros apóstoles de los obreros serán los obreros" (Bottinelli et al., 2001: 86).

La JOC se proponía agrupar a los jóvenes con un triple fin: formarlos integralmente, transformar el medio obrero y representarlos en la manifestación de sus inquietudes y defensa de sus intereses. En otras palabras, se planteaba constituirse al mismo tiempo en escuela, servicio social y cuerpo representativo (Soneira, 1989b).

Según sus estatutos, los miembros de la JOC debían ser varones solteros, de entre 14 y 25 años, en edad de elegir oficio asalariado; alumnos de escuelas profesionales e industriales, de artes y oficios; trabajadores de fábricas y talleres, empleados de oficinas, tiendas y almacenes, etc. (Soneira, 1989b; Blanco, 2010). La JOC contemplaba a las mujeres en su rama femenina, que tenía su reunión semanal separada de la de los hombres, separación que respondía a la concepción del catolicismo de la relación entre los sexos y de la perspectiva según la cual la auténtica vocación de la mujer era ser "madre y esposa de un hogar obrero y cristiano" (Blanco, 2010; Bottinelli et al., 2001). Había varias formas de vincularse a la organización, que incluían al simpatizante (que participaba en algunas actividades), el militante (el que era admitido, pagaba su cuota, participaba de un círculo de estudios y colaboraba en el reclutamiento de nuevos miembros), el jefe de equipo (quien había formado su propio equipo), el dirigente (que había sido elegido para ocupar algún cargo) y el permanente (dedicado a tiempo completo a la organización) (Soneira, 1989b). 
Como movimiento nacional, la JOC se constituyó en Argentina como Federación Nacional, dirigida por la Comisión central; la Organización federal, que agrupaba a varias organizaciones de zonas y estaba a cargo de la Comisión federal; la Organización por zona, que reunía varias secciones y era dirigida por una Comisión de zona; la Sección, de carácter parroquial, interparroquial o existía al margen de la parroquia, y estaba a cargo de una Comisión Directiva; y el equipo jocista, a cargo de un jefe de equipo. Las distintas instancias organizativas tenían sus correspondientes asambleas y asesores espirituales, quienes se reunían periódicamente en las "semanas de los asesores". Otras actividades que involucraban al movimiento eran las asambleas generales mensuales, que congregaban a militantes y simpatizantes para el reclutamiento de nuevos miembros; retiros trimestrales y ejercicios anuales para fortalecer la vida espiritual, que contaban con la presencia de alguna autoridad eclesiástica (Soneira, 1989b). Como movimiento internacional, integraba a las distintas federaciones nacionales. Existía también una instancia de encuentro, representada por los congresos internacionales, donde militantes y asesores jocistas de todo el mundo compartían sus experiencias (Soneira, 1989b; Bottinelli et al., 2001).

En cuanto a la relación con la jerarquía, existen controversias entre los autores que se han dedicado al tema. Según Mallimaci (1992), el movimiento no fue reconocido oficialmente por el Episcopado Argentino, mostrando la dificultad de aceptar la "cuestión obrera" como algo central para la actividad pastoral. Por su parte, Zanatta (1996) plantea que con la aprobación de los estatutos de la JOC, el Episcopado cumplió el esfuerzo más acabado con relación al apostolado dirigido a la clase obrera. Para Bottinelli et al. (2001), no es posible hablar de una relación unidireccional ni de un vínculo institucional ni tampoco de una autonomía absoluta por parte de la JOC -más allá de que los actores percibían su horizonte de acción como más amplio del estipulado por la autoridad-; por el contrario, es más acertado pensarla como una relación dinámica, que daba lugar a rupturas y tensiones; concebir la jerarquía como una unidad monolítica o la subordinación total de la JOC resulta empobrecedor a la hora de ver las especificidades de la organización y de su propuesta. Por otra parte, algo similar podría decirse respecto de la relación con los asesores. Según los Estatutos, esta figura era siempre nombrada por la jerarquía, y la relación con los militantes aparecía como autoritaria y antidemocrática. Sin embargo, los actores tuvieron en la práctica mayor protagonismo y autonomía en el movimiento. 
El apostolado de los jocistas en sus ámbitos cotidianos se llevaba a cabo sobre la base del método Ver, Juzgar y Obrar que, desde sus raíces belgas, era una de las notas identitarias de la JOC. Esta "revisión de vida", llevada adelante en las reuniones semanales del equipo jocista, consistía en "ver" las situaciones que tenían lugar en la fábrica, el barrio, la calle, la parroquia; analizar sus causas y consecuencias, juzgarlos de acuerdo a la doctrina cristiana -lo que en general se hacía bajo la orientación del asesor-; y resolver conjuntamente cómo actuar individual y colectivamente para cambiarlos. Así, la propuesta partía de la experiencia misma de los trabajadores que a su vez se resignificaba en la reflexión con otros compañeros que vivían la misma realidad. La prioridad estaba en la acción en los espacios cotidianos; los militantes debían comprometerse en su medio e intervenir en su transformación. Lejos de seguir directivas a priori que definieran posturas de antemano, los jocistas discutían en cada reunión cuestiones concretas para definir soluciones específicas en cada caso (Mallimaci, 1992).

La evolución de la organización se vio fuertemente marcada por el peronismo y sus relaciones con la Iglesia. Por lo menos hasta 1951, como institución, puede afirmarse que la JOC apoyó al gobierno militar de 1943-1946 y a la primera presidencia de Perón. Hubo jocistas que se incorporaron a los gobierno peronistas (Caimari, 1994). Por otra parte, fue concreta la intención de la organización de constituirse como asociación asesora del gobierno (Zanatta, 1999; Blanco, 2012) ${ }^{94}$. La JOC creyó que podía tener un espacio de intervención, a través de la guía de iniciativas relacionadas con los sectores trabajadores. Así, la propuesta recurrente de participación en los asuntos públicos y el pedido de legitimación del Estado para que la reconociera como interlocutora válida entre éste y los obreros se constituyó en la característica política sobresaliente de la asociación hasta el golpe de 1955 (Blanco, 2012). En la segunda presidencia de Perón y hasta 1954, la JOC -como ocurrió con la Iglesia en generalsiguió mostrando una clara predisposición al gobierno ${ }^{95}$ (Soneira, 1989b, 2002, 2008). Sin embargo, en este período, las críticas de la asociación cobraron mayor espacio y se

\footnotetext{
${ }^{94}$ Según Zanatta (1999), ya en septiembre de 1943, durante la asamblea de la JOC en La Plata, la asociación ambicionaba ser colaboradora del gobierno. Al promulgarse, en junio de 1944, el decreto-ley de creación de una Comisión Nacional de Aprendizaje y Orientación Profesional para promover la formación de los jóvenes trabajadores, Perón destacó su inspiración socialcristiana, mientras que la JOC y las Vanguardias Obreras Católicas compitieron por adjudicarse su espíritu y asesoramiento, en un intento de apropiación de la medida.

${ }^{95}$ Según Caimari (1994), los católicos decepcionados del peronismo comenzaron a retirarle su apoyo antes de 1952. Para Blanco (2012), en cambio, éste no habría sido el caso para la mayoría de los militantes jocistas.
} 
orientaron a denunciar la centralización estatal, el manejo político de los sectores trabajadores, el relajamiento moral de las costumbres obreras y la postura difusa de Perón hacia el catolicismo (Blanco, 2012). Según Zanatta (1996), el respaldo que la JOC dio a la política social inaugurada por Perón fue retribuido con la promoción obispal de dos de los referentes eclesiásticos de la organización, Emilio Di Pasquo y Enrique Rau.

Muchos militantes jocistas se identificaron con el peronismo entendiendo que no había solución de continuidad entre la lucha que ellos venían desarrollando en la mejora de las condiciones de vida y de trabajo de los obreros y las banderas enarboladas por Perón ${ }^{96}$. Según Caimari (1994) y Zanatta (1996), el contexto laboral de reivindicaciones atendidas y la metodología de la asociación (autonomía e inserción en el medio de acción) constituyeron factores que inclinaron a muchos de sus miembros a abandonar el apartidismo aconsejado por el Episcopado y a involucrarse con el peronismo. Este movimiento político respondía al modelo social que ambicionaban la jerarquía y la JOC, cuyos elementos incluían un movimiento obrero sindicalizado y articulado por el Estado, justicia social, tercera posición, nacionalismo económico sustentado en la moral católica del pueblo, al tiempo que rechazaba el liberalismo y el comunismo. Este movimiento político construyó un imaginario que conjugaba elementos católicos con una fuerte identidad obrera, y tomó imágenes y resignificaciones de las concepciones católicas propias de la JOC. De esta manera, los jocistas vieron en él la concreción de muchas de sus aspiraciones (Bottinelli et al., 2001).

La afinidad con el peronismo de los jocistas, basada en coincidencias a nivel ideológico, social, político y religioso, se produjo fundamentalmente por su identidad laboral y su posición social, no por su condición religiosa, más allá de que los actores justificaran su identificación política por la "inspiración católica” del gobierno; de allí su coincidencia con acciones políticas contrarias a la doctrina de la Iglesia, como es el caso del sindicato único ${ }^{97}$ (Blanco, 2012). En este proceso, dentro de la JOC apareció

\footnotetext{
96 De un modo más general, como afirma Zanatta (1999), las medidas tomadas desde la Secretaría de Trabajo y Previsión -como la rebaja de alquileres o la campaña para el abaratamiento de los productos de primera necesidad-, recibieron el apoyo de la prensa católica, que avizoró en ellas la iniciación de una política social cristiana. En el capítulo 1 hemos abordado brevemente la relación entre catolicismo y gobierno militar inaugurado en 1943, y entre catolicismo y peronismo, sobre la que volveremos en el capítulo 6 .

${ }^{97}$ Unos meses después de que Perón asumiera al frente de la cartera de Trabajo, en diciembre de 1943, Monseñor Caggiano ya alertaba a la ACA acerca de que el proyecto sobre el sindicato único era contrario a la doctrina católica. En julio de 1944, Monseñor Miguel De Andrea, titular de la Federación de Asociaciones Católicas de Empleadas (FACE), se opuso públicamente al proyecto. Como respuesta a esta postura, Gustavo Franceschi escribía en la revista Criterio que la política social del gobierno venía a
} 
un nuevo tipo de tensiones: por un lado, quienes admitían públicamente su adhesión al peronismo, y por el otro, aquellos que no consideraban posible participar en otro movimiento como medio para alcanzar sus objetivos católicos, dado que aquel era también integral y, por lo tanto, exigía también un compromiso en todos los aspectos de la vida del militante (Mallimaci, 1992; Bottinelli et al., 2001).

El conflicto entre la Iglesia y Perón, que encerró un enfrentamiento mayor y más profundo entre peronistas y antiperonistas -quienes encontraron en la Iglesia un factor aglutinante, perfilándose una identidad definida por oposición a Perón, basada en el discurso antiperonista católico (Caimari, 1994)- repercutió en la JOC. Entre los hitos de la ruptura, la quema de las iglesias produjo en los jocistas una tensión imposible de eludir entre la identidad católica y la afinidad política peronista. Este hecho constituyó un punto de inflexión donde la convivencia entre ambas pertenencia se volvió irreconciliable. En el caso de algunos militantes, los habilitó incluso para actuar en el golpe de Estado. Sin embargo, siguiendo a Blanco (2012), la suspensión de la lealtad peronista fue sólo provisoria ya que ésta no tardó en volver a ocupar un espacio relevante en la trama identitaria de los sujetos. Según los testimonios recogidos por Soneira (1989b), muchos jocistas vivieron intensamente la ruptura como una opción entre el pueblo y la jerarquía. En efecto, la visualización que los sectores obreros y populares hicieron de la Iglesia como la causante de la caída de un gobierno que tanto los había favorecido, marcó los conflictos entre dirigentes y asesores, y entre éstos y la jerarquía, y dificultó cualquier apostolado católico en el movimiento obrero durante años (Mallimaci, 1992; Soneira, 1989b; Bottinelli et al., 2001).

A pesar de esta dificultad de establecer una presencia de los sectores populares después del conflicto, estando el sindicalismo peronista trabado en su accionar, la JOC tuvo una mayor intervención en los problemas gremiales, las huelgas y las comisiones paritarias. Así, en octubre de 1955, sobre la base de un amplio grupo de dirigentes de la

cubrir deficiencias de una acción social católica ineficaz basada en la promoción de instituciones amorfas, mezcla heterogénea de clases y profesiones, como los Círculos Obreros y la FACE (Zanatta, 1999). Sumándose a la polémica, los militantes de la JOC reiteraban que el sindicarse era un derecho natural de los trabajadores que el Estado no podía prohibir y se proclamaban por la posibilidad de existencia de varios sindicatos de distintas tendencias dentro de la misma profesión. Sin embargo, al mismo tiempo, defendían el sindicato único como opción realista para obligar a los trabajadores a que defendieran sus derechos. Finalmente, el decreto del 2 de octubre de 1945, implantaba el sindicato industrial, que significaba el monopolio de la representación para un solo sindicato, e impedía que las socias de la FACE y los sindicatos confesionales impulsados por los Círculos de Obreros y la ACA obtuvieran personería como tales. Los pregoneros social-católicos y la FACE se pronunciaron contra el decreto. La JOC, en cambio, justificó la medida del gobierno como un mal necesario que había redundado en el fortalecimiento de los sindicatos (Blanco, 2012). 
JOC y de la Acción Católica, se fundó la Acción Sindical Argentina (ASA) ${ }^{98}$. El derrotero de la JOC después de 1955 también está marcado por otras intervenciones de carácter más eclesial, como las movilizaciones por la enseñanza libre -que también involucraron, como veremos, a los militantes de la JUC-, y la preocupación por la "infiltración comunista" en las fábricas, los sindicatos y el mundo obrero, que atravesaba a toda la institución eclesial (Soneira, 1989b, 2002, 2008) ${ }^{99}$.

Este proceso se enmarca en un contexto mayor signado por las políticas de los gobiernos de Eduardo Lonardi y Pedro Eugenio Aramburu respecto del peronismo y el surgimiento de la Resistencia peronista. Siguiendo a James (1990), Lonardi, apoyado por los sectores nacionalistas católicos, llevó adelante una política conciliadora con el sindicalismo peronista. El sector de Lonardi admitía que el peronismo conservara el dominio de la clase trabajadora y sus instituciones con la condición de que, tras una breve depuración de los más implicados en la corrupción del régimen, los sindicatos se avinieran a respetar como esferas claramente demarcadas la acción del gobierno, por un lado, y la representación de los trabajadores, por otro, y restringieran su actividad a esta última. Para el ala nacionalista del antiperonismo, por su parte, el movimiento dirigido

\footnotetext{
${ }^{98}$ Se proponía la estructuración de un auténtico sindicalismo basado en la doctrina social cristiana. En su primera etapa, en lo gremial, buscaba la defensa del pluralismo sindical, la creación de conciencia social y solidaridad en la clase trabajadora, con exclusión de todo partidismo político, además de la formación de militantes y dirigentes; en lo ideológico, condenaba las diversas formas de explotación de los trabajadores por el capitalismo y se oponía a toda concepción materialista y atea; en lo político, se declaraba democrática y pluralista. Para esta generación, el gremialismo era una forma tradicional de apostolado y de presencia en "lo temporal". En una segunda etapa, ASA levantó la bandera de la Central Única de Trabajadores y permaneció en su seno como corriente social-cristiana (Habegger, 1970). Si su objetivo fundacional era reemplazar la dirigencia peronista de los sindicatos cuando fueron intervenidos por la "Revolución Libertadora", en la medida en que el gobierno de facto viró su política, ASA fue acercando sus posiciones al peronismo y a la CGT (Donatello, 2010). Asimismo, defendió el "cambio de estructuras" y "la revolución social" en América Latina, se opuso a las políticas económicas de Frondizi, Guido, Illia, y participó del Plan de Lucha de la CGT. En 1967, se unificó con el Movimiento Sindical Demócrata Cristiano. ASA nucleó a militantes de distintos sindicatos hasta el golpe de Estado de 1976 (Oberlin Molina, $\mathrm{s} / \mathrm{f})$.

${ }^{99}$ El congreso mundial de la JOC celebrado en Roma en agosto de 1957 se vio alterado por un mensaje de los jóvenes comunistas que planteaba la necesidad del entendimiento entre "el mundo católico y el mundo socialista". Sin embargo, los jocistas lo rechazaron, argumentando que en los países socialistas se pisoteaba la personalidad humana. Por otro lado, la Radio Vaticana subrayaba las diferencias del encuentro que se llevaba a cabo en Roma con el Festival de la Juventud realizado en Moscú: si los compromisos tomados en ambos casos con la Fraternidad, el Amor y la Paz parecían identificarse, no podían esconder la oposición de las ideas: "de un lado, estas palabras están dicadas por el materialismo; del otro por el Espíritu de Dios”. De este modo, la acogida hecha al mensaje comunista por los obreros cristianos debía ser un "símbolo sin equívoco de la imposibilidad de todo compromiso entre la Juventud de Moscú y la Juventud de Roma" ("Noticioso de AICA. Maniobra comunista en el Encuentro Mundial de la JOC" y "Juventud en Moscú y Juventud en Roma", Boletín Eclesiástico, Bahía Blanca, julio-agosto de 1957). En efecto, los orígenes mismos de la JOC se vinculaban estrechamente con la posibilidad de hacer de esta organización un instrumento eficaz para atraer a los trabajadores a la Doctrina de Cristo y hacia "soluciones católicas" del problema obrero, y al mismo tiempo, sustraerlos del comunismo (Bottinelli et al., 2001; Blanco, 2010).
} 
por Perón era un baluarte contra el comunismo, en cuanto apelaba al ideal de armonía y orden sociales. Si los sindicatos admitían la necesidad de mantenerse en su propia esfera, y si podía eliminarse la corrupta demagogia de los personajes más estrechamente comprometidos con Perón, los sindicatos conducidos por peronistas tenían un importante papel que desempeñar en la Argentina posterior a 1955, como órganos de control social y canales de expresión de las masas trabajadoras. Sin embargo, el modus vivendi entre el gobierno y los sindicatos pronto se volvió difícil de sostener. La CGT dudaba de la capacidad del gobierno para impedir los ataques de los comandos civiles a los locales sindicales y para cumplir las medidas proclamadas, más allá de las buenas intenciones. Por otro lado, la resistencia de las bases no les dejaba las manos libres a los dirigentes para negociar con el gobierno porque daba cuenta de que no tenían bajo control a los afiliados. Con el reemplazo de Lonardi por Aramburu a la cabeza de la "Revolución Libertadora", se planteó una nueva política respecto de la clase trabajadora y el peronismo. Ésta se basó en el supuesto de que el peronismo constituía una aberración que debía ser borrada de la sociedad argentina, y siguió tres líneas principales: ante todo, se intentó proscribir un estrato entero de dirigentes sindicales peronistas para apartarlos de toda futura actividad; en segundo término, se llevó a cabo una persistente represión e intimidación del sindicalismo y sus activistas en el plano más popular y básico, a través de los intentos de controlar y debilitar a las comisiones internas, y socavar el poder de los delegados gremiales; finalmente, hubo un esfuerzo concertado entre el gobierno y los empleadores en torno del tema de la productividad y la racionalización del trabajo, proceso que marcó de la mano con un intento de frenar los salarios y reestructurar el funcionamiento del sistema de negociaciones colectivas.

Por otra parte, desde el comienzo de la rebelión militar, surgió de modo espontáneo, instintivo, confuso, acéfalo y atomizado en las bases peronistas una fuerte resistencia a las nuevas autoridades, a la toma de los sindicatos por dirigentes gremiales libres y a los arrestos de gremialistas, a lo que más tarde se sumaría la respuesta defensiva a la represión y el hostigamiento en los lugares de trabajo y en los sindicatos, al abuso empresarial, al ataque a las condiciones laborales y a la organización obrera. Así, la política de Aramburu reforzó la identificación de Perón y el peronismo con las experiencias cotidianas de los trabajadores. Y las luchas salariales de fines de 1956 ayudaron a consolidar el creciente movimiento de resistencia (James, 1990).

Este movimiento, marcado por el repudio al gobierno militar y sus implicancias sociales y políticas, así como por la perspectiva de la vuelta de Perón, recurrió a canales 
de expresión muy distintos. La acción que tenía lugar en las fábricas para defender las condiciones de trabajo y organización obrera estaba indisolublemente ligada a la que se desarrollaba en otros terrenos. La primera respuesta a los actos del nuevo gobierno adoptó la forma de un terrorismo espontáneo. Así, una creciente actividad de sabotaje tuvo lugar en el sistema ferroviario y las plantas de electricidad, así como dentro de las fábricas. También se intensificó el uso de artefactos explosivos rudimentarios -hechos de sustancias químicas básicas alojadas en cascos improvisados- llamados "caños" contra objetivos militares y edificios públicos. Si bien parte de estos actos eran iniciativa individual, desde principios de 1956 ya existían gérmenes de una organización muy caótica y basada en grupos locales. En muchas zonas, grupos de trabajadores de una misma fábrica empezaron a reunirse regularmente y planificar acciones, y también existían células clandestinas en los barrios, integrados por distintas clases, que pintaban consignas y distribuían volantes. La no profesionalidad, el espíritu de sacrificio, la participación activa de gente común y la carencia de una elite burocrática que centralizara la organización caracterizaron a este proceso. Desde mediados de 1956, hubo una creciente diferenciación entre los comandos, que desarrollaban actividades clandestinas, y el movimiento de resistencia en los sindicatos, dedicado a recuperar las comisiones internas y los gremios (James, 1990).

En efecto, al calor de estas acciones en las fábricas y los talleres surgieron nuevos líderes sindicales que tendrán una estrecha identificación con los militantes de base, favoreciendo una mayor democratización y participación de en la práctica sindical. Por otra parte, durante 1957 se constituyeron estructuras formalizadas que contribuyeron a definir el perfil del movimiento en gran medida espontáneo de 1956: la Comisión Intersindical y las 62 organizaciones. La primera posibilitó cierta coherencia en la organización de las fuerzas peronistas en el ámbito gremial. La segunda confirmó la posición dominante de los peronistas en los gremios y les dio una entidad totalmente peronista mediante la cual podían actuar y presionar al gobierno desde el punto de vista sindical y político. Además, demostró que los sindicatos constituían la principal fuerza organizadora y la expresión institucional del peronismo en la era posterior a 1955 (James, 1990).

Volviendo a la JOC, en esos años, la crisis del movimiento también se manifestó en un problema organizativo, que se expresaba en la dificultad para reclutar nuevos miembros y en el alejamiento de los existentes. Finalmente, en 1958 los asesores de la JOC decidieron auto-disolverse debido a las presiones del Cardenal Antonio Caggiano, 
y los dirigentes concretaron la renuncia de las comisiones centrales femenina y masculina. Entre este hito y la disolución de la JOC como organización de la Iglesia a nivel nacional, por iniciativa del Episcopado en 1971, las experiencias jocistas, que ya no contaban con medios de elaboración y comunicación de ideas y experiencias ni reuniones periódicas de los asesores, se caracterizaron por un alto grado de heterogeneidad en cuanto a objetivos, métodos y orientación en las distintas diócesis. Tucumán fue la zona del interior con mayor presencia jocista, integrada por trabajadores de los ingenios ${ }^{100}$ y del servicio doméstico, con una metodología más tradicional y una impronta más eclesial. En cambio, la zona sur del Gran Buenos Aires, Rosario y Córdoba, la JOC reclutó jóvenes obreros industriales, con una metodología distinta, más centrada en el análisis de la realidad socio-política, con una orientación ideológica cercana al peronismo revolucionario y una identificación con el MSTM (Soneira, 2008).

En efecto, a fines de la década de 1960 y principios de la siguiente, algunos ex militantes y dirigentes de la JOC se sumaron a las organizaciones de la Tendencia Revolucionaria del peronismo. Según Bottinelli et al., la resignificación de lo católico que posibilitaron las prácticas apostólicas de la AC especializada tuvo una influencia significativa en estos jocistas que unieron la "espada y la cruz pero al servicio del pueblo" (2001: 110). Hacia fines de 1969 la sede central de la JOC en Buenos Aires fue allanada por la policía ante la sospecha de que era utilizada como lugar de reunión por Montoneros (Soneira, 2008). La vinculación de algunos jocistas en estas experiencias políticas decidió entonces a la jerarquía a quitar a la JOC todo apoyo. En algunas diócesis, como Tucumán o La Plata, la JOC continuó pero sin mayor gravitación. Y la

\footnotetext{
${ }^{100}$ Siguiendo a Healey (2003), el Tucumán moderno surgió a la sombra de los ingenios azucareros. Hacia mediados de los años cincuenta, se hizo evidente la contracción del sector. Después del golpe de 1966, Onganía anunció el "plan de transformación" de la provincia, que apuntaba a "racionalizar" tanto a los cañeros como a los ingenios, eliminando los subsidios y fortaleciendo a los productores más eficientes y concentrados. A partir de entonces, un buen número de ingenios cerraron sus puertas, miles de pequeños cañeros fueron empujados a la producción en negro, la tasa de desempleo subió a niveles inéditos, impulsando a decenas de miles de trabajadores a migrar hacia otras regiones del país. Esta destrucción de la industria azucarera, provocó una resistencia fragmentada, latente y difícil de sostener. Si hasta entonces la Federación Obrera de Trabajadores de la Industria Azucarera había sido baluarte de la resistencia comunitaria contra los recortes salariales, las demoras en el pago y los efectos de la crisis azucarera, al haber pasado a manos de una dirigencia menos combativa, la federación tomó una actitud más bien conciliatoria y sumisa hacia el gobierno. El colapso de la actividad gremial de la industria azucarera tuvo varios efectos. Por un lado, fragmentó la acción obrera en luchas de ingenios individuales y, a veces, en conflictos internos dentro de esos ingenios entre distintas tendencias políticas; y por el otro, unificó a la resistencia dentro de algunos ingenios, especialmente en los ingenios cerrados, donde comités de defensa, los curas -que luego participaron en el MSTM- y dirigentes vecinales cumplieron un papel destacado. Los sectores más combativos confluyeron en la CGT de los Argentinos.
} 
violencia represiva de las bandas paramilitares y de la dictadura militar de 1976-1983 terminó por aniquilar las últimas iniciativas jocistas ${ }^{101}$ (Bottinelli et al., 2001).

En cuanto a la JOC como movimiento internacional, éste se quebró hacia fines de los años sesenta, quedando, por un lado, la Juventud Obrera Cristiana Internacional (JOCI), con sede en Bruselas, alejada de la jerarquía y radicalizada políticamente, y por el otro, una JOC tradicional promovida y sostenida desde Roma (Soneira, 2008).

Respecto de la rama universitaria, en noviembre de 1941, se constituyó en La Plata el Centro Universitario de la $\mathrm{AC}^{102}$. Por entonces, la Comisión permanente del Episcopado Argentino exhortaba a "promover y consolidar los Círculos y Centros de Estudiantes Secundarios y Universitarios", así como a "dar impulso y organizar la penetración especializada, comenzando por preparar elementos dirigentes" ${ }^{\prime 103}$. A 20 años de constituida la ACA, los obispos argentinos insistían en la necesidad de aumentar la eficacia de la organización y ampliar sus cuadros a través de las nuevas asociaciones de profesionales, de estudiantes universitarios y de secundarios ${ }^{104}$. Por otra parte, en noviembre de 1959, la Asamblea Plenaria del Episcopado encargaba la coordinación de las juventudes de la AC (JAC, JEC y JUC), a partir de una reunión mensual en el seno de la JAC con asistencia de los presidentes de la JEC y la JUC y sus asesores. Y recomendaba que donde no hubiera consejo de la JEC o de la JUC, el consejo superior de la JAC pidiera a los consejos diocesanos que nombraran delegados para estos movimientos dentro del consejo JAC existente, para que procuraran promover la creación de centros JEC y JUC, debiéndose relacionarse con los consejos superiores de la JEC y de la $\mathrm{JUC}^{105}$.

\footnotetext{
${ }^{101}$ Uno de los militantes jocistas víctimas de la represión que tuvo vinculación con el grupo bahiense a principios de los años setenta y que ocupa un lugar destacado en la memoria de los actores, especialmente los cordobeses (Blanco, 2008), fue José "Pepe" Palacios. Nacido en San Juan y emigrado a Córdoba en 1944, José fue obrero metalúrgico en la Fábrica Militar de Aviones, donde fundó el Grupo de Acción en el Trabajo, de inspiración jocista. Luego, se trasladó a Caseros, donde comenzó a trabajar en Fiat y organizó un sindicato por empresa. Paralelamente, fue uno de los fundadores de la JOC en Córdoba, dirigente nacional y miembro del Secretariado Latinoamericano del Movimiento Obrero de Acción Católica (MOAC). Fue delegado de base y, en 1955, inició, junto al dirigente jocista Emilio Máspero, el Comité Intersindical Cristiano/Comité de Sindicalistas Cristianos, que nucleaba a los jocistas que eran delegados de los gremios, y que en octubre de ese mismo años se disolvió en la ASA. Fue secuestrado en Buenos Aires en diciembre de 1975 y continúa desaparecido (Blanco, 2008; Oberlin Molina, s/f).

${ }^{102}$ Boletín Eclesiástico, Bahía Blanca, diciembre de 1941.

103 "Disposiciones tomadas por la Comisión permanente del Venerable Episcopado Argentino en su reunión del 29 de diciembre de 1941”, Boletín Eclesiástico, Bahía Blanca, mayo de 1942.

104 "Carta Pastoral colectiva del Episcopado Argentino con motivo del vigésimo aniversario de la Acción Católica Argentina", Boletín Eclesiástico, Bahía Blanca, julio-agosto de 1951.

105 "Resoluciones de la Asamblea Plenaria del Episcopado (9 al 14-xi-1959)", Boletín Eclesiástico, Bahía Blanca, octubre-diciembre de 1959.
} 
Desde fines de la década de 1950, la JUC venía experimentando un proceso de cambio profundo a nivel nacional. Hasta ese momento, era un movimiento muy similar a las otras ramas de la Acción Católica tradicional, con una organización jerárquica y una concepción religiosa formal, donde lo más importante era "una buena capacitación teórica para enfrentar el error y una concepción eminentemente institucional del apostolado" (Habegger, 1970: 106). Pero en 1958 comenzó un movimiento de renovación en los universitarios que militaban en Acción Católica que culminó con el reconocimiento de la JUC como Acción Católica especializada. A partir de allí, inició un proceso de búsqueda y reflexión teológica e intelectual, que insistía cada vez más en el valor religioso de "lo temporal" y en la necesidad de una acción sobre las personas, las mentalidades y las instituciones. Así surgió la necesidad de un método que permitiera romper la dualidad entre el trabajo a realizar y la vida espiritual. Sin embargo, todavía la mayoría de sus militantes no participaba de una actividad política o estudiantil como eje de su militancia.

En 1963, la JUC, junto al Centro Argentino de Economía Humana (CAEH) ${ }^{106}$, la ASA y otros grupos, organizó el IV Encuentro de militantes cristianos, cuyo tema fue "La posibilidad de delinear un programa de cambio revolucionario". Además, participó del primer encuentro obrero-estudiantil, organizado por el CAEH y al que concurrieron también la ASA, el Movimiento Obrero de Acción Católica, el Centro de Estudiantes de la UCA, el Movimiento Sindical Paraguayo y el Humanismo de Farmacia (Armada, 1970: 214-215). Por otra parte, se llevó a cabo en Tandil un encuentro nacional de dirigentes de la JUC donde se planteó la necesidad de profundizar la propia misión, siendo la universidad el campo de acción. En ese sentido, se discutió sobre la universidad inserta en el país y América Latina y, particularmente, la exigencia de comprometerla en el proceso de transformación nacional. De este modo, "Tandil 63" marcó profundamente las experiencias y trayectorias de estos jóvenes católicos y abrió una nueva etapa para el movimiento. Según los actores, a partir de entonces se intentó “profundizar el misterio de la historia como revelación de Dios y asumir las exigencias

\footnotetext{
${ }^{106}$ Creado en 1963, era un centro de investigación formado por sociólogos y economistas de militancia humanista en la universidad y en la Acción Católica. A principios de la década de 1960 se vinculó a la CGT, promoviendo investigaciones, conferencias y cursos de capacitación. Asimismo, realizó encuentros entre obreros y estudiantes cristianos, con la finalidad de pensar el rol de los católicos en el cambio social. Editó la revista Cambio, que era dirigida por Gonzalo Cárdenas, integraba intelectuales que pasaron a participar en el Partido Demócrata Cristiano (PDC) y luego en el peronismo, y ayudó a promover las ideas del Concilio Vaticano II fuera del ámbito religioso. En sus páginas podía percibirse la gravitación de los pensadores franceses Joseph Lebret, Emmanuel Mounier y Pierre Theillard de Chardin (Habegger, 1970; Donatello, 2010). Volveré sobre estos autores y el PDC en las páginas siguientes.
} 
históricas de la Encarnación para encuadrar correctamente una acción pastoral de los laicos cuya presencia en el medio universitario les exige opciones constantes" (Habegger, 1970: 135). Esto empujó a los jóvenes a la búsqueda de nuevos métodos de apostolado, a través de caminos divergentes. Se establecieron diálogos y frentes de acción con agrupaciones reformistas y marxistas, en un intento de superar la antinomia Humanismo-Reforma, se introdujeron novedades como el diálogo católico-marxista y la consigna de trabajar con los no cristianos. El marxismo se presentaba como blanco inicial del movimiento de apertura y diálogo. De este modo, se produjo el ingreso de muchos jucistas en organizaciones de izquierda (Habegger, 1970).

En enero de 1965, se celebró en el Seminario "La Asunción” ${ }^{107}$ de Bahía Blanca un nuevo encuentro de dirigentes jucistas de todo el país, que tuvo como tema central el compromiso político de los militantes católicos. Un informe presentado en dicho encuentro por el grupo de Buenos Aires, versaba, justamente, sobre la inserción de los jucistas en agrupaciones universitarias, y analizaba los motivos que llevaban a los militantes a ingresar a una agrupación, así como los criterios empleados para la elección de la misma. Entre los primeros, se encontraban la búsqueda de un medio para ponerse al servicio de los demás, la necesidad de concretar en la práctica las ideas elaboradas teóricamente en la JUC y el intento de dar una respuesta como cristianos combatiendo el comunismo. Sin embargo, en este último caso, las posturas de los militantes cambiaban debido al nuevo sentido del diálogo. En la elección de la agrupación se privilegiaba, en algunos casos, la "eficacia", en otros, la coherencia de sus bases con la doctrina cristiana. Entre las conclusiones del documento, se resaltaba la importancia de que en las actividades políticas no se dejaran de lado los valores de la persona y la exigencia de la revisión del compromiso para no perder de vista el objetivo cristiano (Armada, 1970: 247-248).

Así, para los dirigentes de la JUC, en 1965 comenzó una etapa caracterizada por el afianzamiento de la corriente teológico-social que propugnaba el compromiso de los cristianos en la realidad de su tiempo, y la "radicalización política" de ciertos militantes. El proceso de "politización" tuvo como escenario los centros urbanos, precisamente en

\footnotetext{
${ }^{107}$ Desde 1936, el Seminario diocesano funcionó en el colegio Juan Elicagaray de González Chaves. Una vez consagrado obispo, Esorto decidió construir una nueva casa de formación en Bahía Blanca, por considerar que el edificio original no reunía las condiciones necesarias, además de distar $250 \mathrm{kms}$. de la sede episcopal En octubre de 1951 se concretó la bendición y colocación de la piedra fundamental del Seminario dedicado a Nuestra Señora de la Asunción y ubicado en el $\mathrm{km} 6$ del camino que unía Bahía Blanca con Punta Alta. El 19 de abril de 1959 fue inaugurado oficialmente, con la presencia del nuncio apostólico y otras autoridades eclesiásticas, además de las civiles y militares (Boletín Eclesiástico, Bahía Blanca, septiembre-octubre y noviembre-diciembre de 1951; abril-junio de 1959).
} 
las universidades de Buenos Aires, Bahía Blanca y Tucumán. Se planteaba que el militante cristiano no podía comprometerse sin asumir personalmente una visión ideológica, un compromiso a nivel personal. "La JUC respeta profundamente la opción política. Sólo pide y da elementos para que esa opción responda a todo un sentir nuevo de la teología" (Habegger, 1970: 136). La contracara de este proceso de profundización de la militancia política de los jucistas fue, de hecho, su alejamiento del movimiento. En distintos puntos del país, los grupos de universitarios católicos asistían a una crisis terminal a partir del éxodo de la militancia institucionalizada de los jóvenes que se planteaban cada vez más vigorosamente las exigencias de un compromiso temporal (Gera y Rodríguez Melgarejo, 1970), sumado a la situación de los asesores que dejaban el ministerio. De esta manera, según Politi, “esta fuerte politización (claramente desde 1968, peronización), huérfana de un acompañamiento pastoral, desquició a la JUC" (1992: 136).

Un informe preparado por la JUC de Buenos Aires para el encuentro de dirigentes nacionales realizado en Ramos Mejía, del 4 al 7 de febrero de 1967, planteaba un panorama de la vida del movimiento durante el año 1966 marcado por la crisis. Ésta se manifestaba en la renuncia del equipo Buenos Aires, que entonces fue reemplazado por una asamblea que pasó a funcionar como órgano máximo, pero cuya actividad pronto comenzó a decaer por falta de continuidad de sus promotores y asistentes “ocupados en otras actividades comprometidas". Para los dirigentes, las motivaciones de la inestabilidad de la JUC tenían que ver con las dificultades de conciliar su reflexión cristiana y su pertenencia eclesial, por un lado, con sus nuevas adscripciones ideológicas y variados canales de militancia política, por el otro, a pesar de que la experiencia jucista, en tanto que instancia de "descubrimiento de la realidad" por parte de los jóvenes católicos, había jugado un papel significativo en la asunción del compromiso temporal de sus miembros (Armada, 1970: 310-312).

En estos años, al igual que las otras organizaciones de Acción Católica, la JUC protagonizó enfrentamientos con la jerarquía. En 1963, las posturas esbozadas en las conclusiones del encuentro de Tandil llevaron al Cardenal Caggiano a remover a su asesor y a que la organización fuera excluida de la Junta Directiva de la Acción Católica. En 1966, a partir del apoyo a la huelga de los portuarios, Monseñor Adolfo Tortolo entregó un informe a la Comisión Permanente del Episcopado cuestionando a la JUC con todo el arsenal disponible para enfrentar a las tendencias liberacionistas (Donatello, 2005). 
Antes de abordar los antecedentes de la rama secundaria de Acción Católica, quisiera detenerme en los elementos del contexto nacional que nos permiten comprender los procesos analizados en los párrafos precedentes. En los orígenes de la JUC en nuestro país, el espacio universitario estuvo marcado por las nuevas políticas que en materia de instrucción pública llevaron adelante el gobierno militar inaugurado en 1943 y el peronismo, entre 1946 y 1955. Siguiendo a Buchbinder (2005), el primero se proponía refundar el sistema educativo sobe una matriz confesional, autoritaria y tradicionalista. Así, las universidades fueron intervenidas por figuras provenientes de grupos antiliberales que propugnaban la confesionalización de la enseñanza. En la mayoría de las casas de estudios se decretó la suspensión de las actividades de los centros estudiantiles, la separación de miembros del cuerpo docente y la expulsión de los estudiantes señalados por su militancia opositora. En respuesta, pronto comenzó un movimiento de oposición, protagonizado por los estudiantes, que exigía la normalización y la devolución de la autonomía a la universidad, lucha que continuaría en los años siguientes.

La llegada del peronismo al poder supuso profundos cambios en la vida universitaria. En primer lugar, implicó un recambio del personal científico y docente de gran envergadura, a través de la expulsión de una parte significativa del profesorado, y el desmantelamiento de grupos enteros de investigación. En segundo lugar, se impusieron nuevas formas de gobierno y administración de las casas de estudios, que quedaron sometidas al poder político y privadas de la autonomía. Estas medidas tuvieron diversas implicancias. Por un lado, el régimen cedió la cultura universitaria a intelectuales solidarios de los componentes de derecha y católicos del peronismo, incluso simpatizantes del franquismo. Por otro lado, la política invadió la esfera universitaria y se planteó una nueva forma de entender los vínculos entre la universidad y el sistema político, así como la fractura de la comunidad académica en dos sectores irreconciliables de acuerdo a la posición que asumían frente al nuevo régimen. Por último, sobrevivieron e incluso reforzaron sus lazos los círculos culturales no oficiales, integrados por científicos e intelectuales apartados de la universidad, mientras permanecieran en los márgenes del espacio público. En efecto, el peronismo no se proponía tanto acallar las voces opositoras como mantenerlas al margen de manera que la palabra adversa era admitida o ignorada mientras fuera públicamente inaudible (Buchbinder, 2005; Sigal, 2002). 
Sin embargo, más allá de las transformaciones institucionales, el nuevo gobierno no tenía una política cultural sistematizada. En el plano de la cultura docta, el peronismo carecía de una estrategia propia y ni siquiera contaba con una ideología que permitiera decidir en conflictos propiamente culturales. Así, en la universidad, ni los contenidos ni la orientación de la enseñanza experimentaron cambios significativos. Muchos de los profesores fueron reemplazados por sus discípulos (Buchbinder, 2005, Sigal, 2002). Por otra parte, uno de los aspectos más innovadores de la política universitaria de Perón fue la creación de la Universidad Obrera, que tenía como objetivo la formación profesional de la clase trabajadora. Asimismo, en esos años se produjo la masificación de la enseñanza superior (Buchbinder, 2005).

En cuanto a los estudiantes, el gobierno colocó fuera de la ley a sus organizaciones opositoras, impuso la presencia de policías de civil en las aulas y exigió un certificado policial de buena conducta para proseguir los estudios, a la vez que intentó politizar a los alumnos a través de los cursos de formación política y la creación de una central estudiantil, la Confederación General Universitaria (CGU), como alternativa a la Federación Universitaria Argentina (FUA). Sin embargo, esto chocó con la resistencia del estudiantado, que permaneció en su gran mayoría apegado a los principios de la Reforma, siendo la FUA la única organización capaz de movilizarlos. Hacia 1951, el movimiento estudiantil entró en una nueva fase de reorganización y politización de tono fuertemente opositor. Sin embargo, dentro de los reformistas surgieron disputas relevantes entre los grupos independientes, afines al radicalismo y al socialismo, y los comunistas. Por otro lado, en 1950, se conformó la Liga de Estudiantes Humanistas que, si bien valoraba la experiencia reformista, rechazaba la politización del activismo estudiantil y el gobierno tripartito e igualitario de profesores, egresados y estudiantes, y respaldaba la libertad de enseñanza y la posibilidad de la existencia de universidades libres. Los humanistas, si bien estaban vinculados con distintas vertientes cercanas a la Iglesia católica, no se concebían a sí mismos como una agrupación confesional. Al mismo tiempo, rechazaban el anticlericalismo de los reformistas. Con diversos matices, también se incorporaron a la coalición que se oponía a la política del régimen en la universidad y fuera de ella, especialmente durante la crisis entre la Iglesia y el gobierno, oposición que permitió olvidar lo que los separaba de la FUA (Buchbinder, 2005; Sigal, 2002).

Los cambios que experimentó la JUC desde finales de la década de 1950 y en la primera mitad del decenio siguiente se enmarcan en un proceso de renovación 
universitaria iniciado por la "Revolución Libertadora". El gobierno de facto procuró desperonizar las universidades. En ese proceso, otorgó un rol central como interlocutor a la dirigencia estudiantil reformista y caracterizada por una sensibilidad política predominantemente de izquierda. Tuvo lugar un nuevo proceso de cesantías masivas de profesores y personal administrativo comprometido con el régimen depuesto. Por otra parte, con el decreto 6403, la "Revolución Libertadora" amplió y fortaleció la autonomía universitaria, concediendo a sus autoridades la potestad para administrar su patrimonio y darse su estructura y planes de estudio, además de la libertad para organizar sus formas de gobierno y dictar sus estatutos (Buchbinder, 2005; Sigal, 2002).

Asimismo, mediante el artículo 28 del decreto mencionado, el nuevo gobierno abrió la posibilidad de creación, por parte de la iniciativa privada, de universidades con capacidad para expedir diplomas y títulos habilitantes. El artículo daba cuenta de la presencia dominante que los católicos de orientación liberal tenían en el régimen militar. Por otra parte, la medida chocaba con valores muy arraigados en la tradición educativa de la Argentina, basada en el predominio de la instrucción laica. Los opositores veían con preocupación que la iniciativa ahondase las diferencias culturales en el seno de la sociedad, que atentase contra la impronta gratuita e igualitaria del sistema educativo y que fragmentase al estudiantado entre ricos y pobres. A fines de 1958, el presidente constitucional Arturo Frondizi decidió avanzar en la reglamentación del artículo 28, enviando el proyecto al Parlamento, provocando la cerrada oposición de los universitarios. Entre el 4 y el 19 de septiembre se realizaron actos multitudinarios para oponerse a los proyectos del gobierno, mientras los partidarios de la enseñanza libre también llegaron a reunir una verdadera multitud en un acto en el Congreso Nacional. Finalmente, en febrero de 1959, la ley fue reglamentada. A partir de entonces aparecieron nuevas universidades, en su mayoría de origen confesional (Buchbinder, 2005; Sigal, 2002).

El período 1955-1966 también se caracterizó por la modernización del sistema universitario, aunque la transformación permaneció limitada a algunas facultades y disciplinas. El proyecto modernizador apuntaba en primer lugar, a resolver el problema derivado del aumento sustancial en el número de estudiantes que además optaban por carreras tradicionales; luego, a crear nuevas carreras, renovar las estructuras curriculares, los planes de estudio y los métodos de enseñanza; en tercer término, a fortalecer el perfil científico de la universidad y unir la docencia con la investigación; en cuarto lugar, a asegurar el pluralismo ideológico y político en la vida académica. Estos 
procesos fueron acompañados por cambios en la organización institucional de la universidad. Uno de ellos, concretado en la UNS, fue el reemplazo de la estructura basada en facultades por otra conformada a partir de departamentos, con el objetivo de unir a las mismas especialidades dentro de cada universidad y articular en forma estrecha a la docencia con la investigación. La extensión también estuvo involucrada en los intentos de conformar un nuevo sistema universitario (Buchbinder, 2005).

En los primeros años sesenta, los proyectos modernizadores fueron perdiendo fuerza e intensidad. A los conflictos originados en criterios de orientación curricular, pedagógica y científica o relativos al papel y las funciones de la universidad, se sumaron las disputas políticas. La comunidad académica se fragmentó a raíz de la "radicalización" política de una parte importante de sus integrantes. La juventud universitaria comenzó a participar entonces de un proceso de acelerada "politización". El impacto de la Revolución en Cuba provocó que creciera entre los universitarios el consenso a favor de las soluciones revolucionarias. Entonces, el espacio académico comenzó a estar cruzado permanentemente por las tensiones derivadas de la política nacional (Buchbinder, 2005).

En este marco, se dieron una serie de debates y cuestionamientos vinculados, por un lado, al contenido de la actividad académica y científica y, por el otro, a la función de las instituciones universitarias y sus actores. Respecto de lo primero, el modelo académico consolidado desde 1958 fue cuestionado por su carácter cientificista. En particular, se criticaba la concepción neutralista que se pretendía asignar a la actividad científica. Una parte relevante de los académicos, y sobre todo de los estudiantes, rechazaba la idea de que en estas condiciones la ciencia pudiese contribuir en forma decisiva a modificar la realidad social y elevar los niveles de vida de la población. Estas transformaciones sólo podían provenir ahora de un cambio radical de las estructuras sociales. Se proponía, entonces, una ciencia social que brindara los conocimientos para ser usados por los "sectores oprimidos" y que contribuyera a la lucha de éstos por la modificación de las estructuras de dominación. En lo que se refiere a las instituciones universitarias, se planteaba su carácter burgués y su función como instrumento de dominación. Para los universitarios radicalizados, resultaba necesario crear una universidad puesta al servicio de la transformación social, que encarnara un compromiso militante con los intereses "nacionales y populares" (Suasnábar, 2004; Buchbinder, 2005). 
Por último, en el período 1956-1966 se asistió a la formación de una nueva izquierda intelectual en el ámbito nacional. Ello implicó un cambio en el modelo de intelectual: si antes el núcleo principal de su identidad era la actividad científicocultural, ahora el intelectual propiamente dicho es un intelectual "comprometido" (Suasnábar, 2004) o, incluso, “orgánico” (Terán, 1991; Sigal, 2002). Siguiendo a Terán (1991), el primero hablaba a sus pares y a la sociedad mientras el segundo intentaba más bien dirigirse al pueblo o a la clase obrera para apoyarse sobre ellos y desempeñar su misión, pero ambos tipos podían superponerse y entrelazarse, definiendo identidades complejas. Este nuevo modelo -que se propagaba gracias a la difusión de los escritos de Gramsci, la Carta a los intelectuales de Fidel Castro y el rechazo del Che a las "formas congeladas de realismo"- legitimaba un nuevo lugar para los intelectuales, dando respuesta al debate subyacente sobre su rol y el de las ideas mismas: ¿eran necesarias las ideas y las discusiones? ¿Eran necesarios los intelectuales? (Sigal, 2002).

Así, la política se tornó una región dadora de sentido de las diversas prácticas, incluida, por cierto, la teórica. La política ofrecía fuera del campo intelectual el fundamento al vacío de legitimidad del propio quehacer; daba eficacia a la función cultural del intelectual, de ahora en más pensada íntimamente ligada a la suerte del resto de la comunidad. Crecía la conciencia de que toda actividad puramente intelectual estaba condenada a sufrir las consecuencias de un proceso del que más valía la pena ser actor, y se fortalecía la concepción de que aquella debía marchar estrechamente unida a la política. Pero, al mismo tiempo, este estilo de incidencia en la política negaba la intervención directa sobre el Estado. Se ofrecerían a partir de ello condiciones aptas para el perfilamiento más nítido de una zona cultural segregada institucionalmente del poder político y autolegitimada ideológicamente en dicha marginalidad (Terán, 1991).

En este marco, al intelectual no se le pedía obra comprometida sino compromiso de militancia personal. En este sentido, los primeros años de expansión del espacio cultural no estuvieron dominados por la idea de una determinación de los principios culturales por lo ideológico. Y conviene por lo tanto distinguirla de un segundo momento inaugurado por el "Cordobazo", que se caracterizó, en cambio, por el predominio del "todo es política". Durante esta primera fase, lo político está presente pero lo está, esencialmente, como santo y seña de una comunidad. Era más un modo de identificación y reconocimiento de los artistas que un criterio clasificatorio de las obras. La obra tomaba como garantía de su carácter revolucionario las posiciones de sus autores (Sigal, 2002). 
En estas posturas, se destacaban el tercermundismo, la oposición al neocolonialismo, la creencia en una crisis general del capitalismo, la identificación con las clases populares y la oposición al poder que los proscribía políticamente, la preocupación por los aspectos sociales y políticos de la realidad argentina y la solidaridad con Cuba. En efecto, la Revolución Cubana constituyó un acontecimiento clave en este proceso. Como mencionamos en el capítulo anterior, ella asumió el valor de un modelo alternativo a la dependencia imperialista y alentó la convicción de haber ingresado en una nueva época en la que era de veras posible superar todas las limitaciones. Al mismo tiempo, ofrecía un espacio donde parecía conciliarse pueblo e intelectuales, y un lenguaje común entre castrismo y peronismo, peronismo revolucionario y militantes de izquierda, Perón e intelectuales. Bajo el ala de esta revolución, la intelectualidad contestataria logró darse una base comunitaria y un rumbo revolucionario, y reforzar sus proyectos culturales (Terán, 1991; Sigal, 2002).

En este sentido, este actor intelectual diseñó un espacio de reflexión dentro del cual la nueva izquierda aprendió a pensarse. El amplio fenómeno de politización de la cultura fue siguiendo los mismos clivajes de radicalización que los enfrentamientos políticos. Fueron el golpe de Estado de 1966 y su ataque a los sectores y aspectos progresistas de la cultura argentina los que construyeron un nuevo campo de problematicidad acerca de las relaciones entre intelectuales, política y violencia, sobre el cual la tematización de la vía armada recién entonces alcanzaría un nivel de pertinencia hasta ese momento insospechado (Terán, 1991).

Por último, nos resta analizar brevemente los antecedentes de la rama estudiantil secundaria de la Acción Católica. La Juventud Estudiantil Católica surgió en 1953 como parte del plan de especialización. Sin embargo, en sus primeros años, se enfrentó a dos obstáculos: en primer lugar, la competencia con la organización alentada por el gobierno peronista para la militancia estudiantil, esto es, la Unión de Estudiantes Secundarios; en segundo lugar, la falta de voluntad de muchos obispos para promover nuevas organizaciones, que podían generar tensiones con el gobierno. Por ello, su expansión se produjo años después, de la mano de la renovación de la cúpula eclesiástica y los gobiernos posteriores a la "Revolución Libertadora", que vieron en la JEC un instrumento de socialización que podía alejar a los jóvenes del peronismo, así como de las nuevas ideologías de "izquierda". Fue entonces reconocida por la Iglesia y contó con una estructura de asesores a nivel nacional, provincial y local. La mayor parte 
de los colegios católicos y parroquias contaba con un asesor y un grupo jecista. Sus actividades consistían en jornadas de reflexión y encuentros pastorales. Con la renovación conciliar, se incorporaron campamentos en zonas postergadas del país que buscaban el conocimiento de la realidad de los pobres y que marcaban el avance hacia un mayor compromiso, y a la vez, la terminación de la etapa como estudiante secundario. El ingreso a la JEC, que era voluntario, se producía por invitación de un sacerdote o de un estudiante avanzado. Sus jerarquías internas eran determinadas por el nivel de compromiso y de trayectoria, sin que éstas adquirieran un grado de formalización (Donatello, 2010: 43-44).

\section{b) Antecedentes locales}

\section{i) La Juventud Obrera Católica}

En los años previos a la creación de la JOC en la Arquidiócesis de Bahía Blanca, la publicación del arzobispado difundió documentos pontificios y episcopales que ponían de manifiesto la preocupación de la jerarquía por la evangelización del mundo obrero. Sin embargo, el escaso número de publicaciones que hacen mención del asunto a lo largo de diez años da cuenta que no se trataba de un tema central para la máxima autoridad eclesial a nivel local. En primer lugar, las resoluciones del Episcopado Argentino en las conferencias de noviembre de 1938, por un lado, instaban a la Acción Católica a desarrollar una acción social en vistas a lograr una más justa remuneración del trabajo asalariado y a implantar el salario familiar; y por el otro, planteaban la necesidad de formar "organizaciones de clase” y resolvían que en todas las diócesis se estableciera la Juventud Obrera Católica, como institución adherida a la ACA, que debía atenerse a sus "fines culturales", con exclusión de los económicos o profesionales ${ }^{108}$. En segundo lugar, la Carta apostólica de Pío XI al Episcopado de las Islas Filipinas, dedicada a resaltar la importancia de la Acción Católica y a indicar las tareas que ésta debía desarrollar junto a la jerarquía, ponía de relieve la exigencia de atender a las urgencias espirituales y materiales de la clase trabajadora, frente a la cual "el apostolado del igual por el igual" resultaba el camino más eficaz, "de modo de obtener la salvación del obrero por el mismo obrero" ${ }^{109}$. En tercer lugar, en diciembre de 1940, los obispos

\footnotetext{
${ }^{108}$ Boletín Eclesiástico, Bahía Blanca, mayo de 1939.

${ }^{109}$ Boletín Eclesiástico, Bahía Blanca, octubre de 1939.
} 
argentinos dedicaban una pastoral colectiva a abordar las condiciones y el salario de los obreros, que culminaba con un llamamiento a la Acción Católica a "dar amplitud y firmeza a este movimiento en favor de la clase trabajadora"110. Por otro lado, el Boletín informó sobre el viaje del asesor general de la JOC, Cardijn, por América del Sur en $1946^{111}$. En dicho marco, los asesores y militantes de la Asociación de los Jóvenes de Acción Católica conocieron al fundador de la JOC y compartieron actividades con dicho movimiento y las Vanguardias Obreras Católicas, en la VI Asamblea Federal de los Jóvenes de la AC, celebrada en Buenos Aires en agosto de $1946^{112}$. Por último, publicó una carta del presidente del Consejo Superior de los Hombres de Acción Católica dirigida al presidente del Consejo Diocesano de dicha organización en Bahía Blanca, donde invitaba a intensificar la preparación para encarar un amplio apostolado externo en los ambientes, atendiendo a diversas metas, entre ellas: "cristianizar los ambientes de trabajo -apostolado en el lugar de trabajo o diversión"; "promover asociaciones católicas de clase -apostolado en la clase social", como la JOC y las asociaciones de jóvenes universitarios, siendo el Episcopado el encargado de determinar si éstas serían auxiliares o pertenecerían a la Acción Católica; "formar dirigentes sindicales apostolado en la profesión", frente "a la actividad sindical del enemigo" y en vistas a "hacer de cada socio un militante de la solución cristiana de los problemas de su gremio" $" 113$

Para entonces, existían en la diócesis otras asociaciones laicas que buscaban acercar la Iglesia a los sectores trabajadores, como el Círculo de Obreros Católicos León XIII -creado en la ciudad en 1891 y con presencia en Patagones, San Cayetano, Orense, Pigüé y San Miguel Arcángel- ${ }^{114}$, y la Vanguardia Obrera Católica ${ }^{115}$. Más tarde se sumaría la Federación de Asociaciones Católicas de Empleadas ${ }^{116}$.

\footnotetext{
${ }^{110}$ Boletín Eclesiástico, Bahía Blanca, febrero de 1941.

111 Boletín Eclesiástico, Bahía Blanca, agosto de 1946.

112 Boletín Eclesiástico, Bahía Blanca, agosto de 1946.

113 Boletín Eclesiástico, Bahía Blanca, febrero de 1947.

114 Boletín Eclesiástico, Bahía Blanca, enero de 1941. También véanse los números del Boletín de los años 1939, 1940, 1941, 1942, 1944, 1946, 1947, 1948, 1949, 1950, 1959, 1963, 1966, 1967, 1968, 1974.

115 Boletín Eclesiástico, Bahía Blanca, septiembre de 1940. La referencia alude a la autorización del obispo al cura párroco de Oriente para fundar el centro de jóvenes con el nombre de Vanguardia Obrera Católica.

${ }^{116}$ La primera mención de FACE en la publicación del arzobispado data de 1951, como integrante de la comisión organizadora de la festividad de Corpus Christi (Boletín Eclesiástico, marzo-abril 1951). A fines de la década de 1960 y principios de la de 1970, la organización funcionaba en el mismo edificio de Cáritas y del Seminario Catequístico, ubicado en Rodríguez 78 (Entrevista a Zulma, Bahía Blanca, 25/8/2010). La casona todavía conserva un cartel con sus iniciales. Sobre las trayectorias de los entrevistados, véase al anexo metodológico.
} 
Los indicios de la existencia de la JOC en Bahía Blanca resultan escasos y han podido reconstruirse a través de algunas referencias a la organización aparecidas en el Boletín Eclesiástico que se remontan a fines de la década de 1940 y principios de la década siguiente. Por ejemplo, en febrero de 1950 Monseñor Esorto otorgó "al presbítero Francisco Berisso y asistentes del Campamento Jocista de Saldungaray, dispensa del ayuno y abstinencia en los días 22 y 24 " de ese mes ${ }^{117}$. Por otra parte, encontramos que en los años 1949 y 1951, las comisiones organizadoras de la festividad de Corpus Christi, incluyeron entre sus integrantes al "presidente de la JOC, señor José Policano", junto a sacerdotes de la curia, las parroquias, las capellanías y los colegios religiosos, y a laicos referentes de las distintas ramas de Acción Católica (Asociación de Hombres de Acción Católica -AHAC- y Asociación de los jóvenes de Acción Católica JAC- en los dos años, y Asociación de Mujeres de Acción Católica -AMAC- y Asociación de las jóvenes de Acción Católica -AJAC- ${ }^{118}$, en 1951), del Círculo de Obreros Católicos León XIII, de la Federación de Empleadas Católicas, el Sindicato de Costureras Católicas, entre otros ${ }^{119}$. Asimismo, durante la primera fiesta mencionada, se llevó a cabo una misa en la "fábrica de pescados 'Antártida'” (sic), ubicada en el barrio de Grünbein. El acto, al que asistieron la mayoría de los obreros, fue precedido por la preparación del "ambiente espiritual", mediante charlas sobre el cumplimiento del precepto pascual y confesiones que tuvieron lugar en las instalaciones del mismo edificio. Durante la celebración, organizada por un equipo de la JOC Femenina, se hicieron presentes los símbolos que identificaban al movimiento:

En el mismo lugar del trabajo diario, adornado profusamente con banderas argentinas y pontificias, se erigió el altar del sacrificio, teniendo por fondo una hermosa bandera de seda de la fábrica y rodeada de banderines de la JOC [...] [las integrantes de la Juventud Obrera Católica Femenina] hicieron resonar en la fábrica sus cantos y cantaron con más entusiasmo que nunca: Hemos jurado: morir o vencer! La clase obrera a Cristo queremos devolver ${ }^{120}$.

Esta estrofa pone de relieve la estrategia jocista de penetración en el movimiento obrero, que estaba fuertemente determinada por las posturas integralistas. La JOC venía a ejercer su apostolado en un ambiente tradicionalmente difícil para el catolicismo en

\footnotetext{
${ }^{117}$ Boletín Eclesiástico, Bahía Blanca, febrero-marzo de 1950.

${ }^{118} \mathrm{La}$ constitución oficial de la ACA en la diócesis de Bahía Blanca data de septiembre de 1936. Por decreto, el entonces obispo Astelarra dejó establecidos los consejos diocesanos de las cuatro ramas, con sus correspondientes asesores, presidentes, vicepresidentes, secretarios, tesoreros y vocales, y la Junta Diocesana de la ACA, con representantes de cada asociación (Boletín Eclesiástico, Bahía Blanca, marzo de 1947; julio-septiembre de 1961).

${ }_{119}$ Boletín Eclesiástico, Bahía Blanca, junio de 1949 y marzo-abril de 1951.

${ }^{120}$ Boletín Eclesiástico, Bahía Blanca, agosto de 1949.
} 
vistas a "recristianizar la Argentina" y establecer el "reinado social de Jesucristo" (Mallimaci, 1992; Bottinelli et al., 2001). De esta manera, el movimiento participaba de la avanzada del catolicismo integral sobre la sociedad, a través de la "conquista" de los obreros "para Cristo", que se constituía en su único redentor.

Después de estas noticias, no aparecen otras menciones a la JOC bahiense en la publicación oficial de la diócesis. Por otra parte, las referencias de los entrevistados son más vagas y remiten a la existencia de la JOC en Bahía Blanca "años atrás" y a su posterior desaparición, para resaltar que la experiencia que protagonizaban se trataba de un “relanzamiento" o "reinicio" del movimiento ${ }^{121}$.

\section{ii) La Acción Católica Universitaria}

En las décadas previas al período que abarca esta investigación, la Acción Católica Universitaria se desarrolló en Bahía Blanca ${ }^{122}$, a partir de dos organizaciones, el Centro de Universitarios de la AC y el Círculo de Universitarias de la AC, más tarde conocidas como Juventud Universitaria Católica (JUC) y Asociación Universitaria de Acción Católica (AUDAC) respectivamente. En sus comienzos, eran ramas de la ACA y por lo tanto, estaban sujetas a sus estatutos. Así, cada una de las organizaciones contaba con un asesor y un presidente, que eran nombrados por el obispo/arzobispo. A estas autoridades se sumaron un delegado arquidiocesano del Consejo Superior de la $\mathrm{JUC}^{123}$ y los Consejos Arquidiocesanos de JUC y de AUDAC, constituidos en 1961, cuando la jerarquía consideró que, habiendo alcanzado la ACA su completa organización a nivel local con la conformación de los consejos diocesanos, las ramas universitarias habían logrado "un grado de madurez y responsabilidad necesarias para poder proveer a su organización definitiva" ${ }^{\text {124 }}$.

\footnotetext{
${ }^{121}$ Entrevistas a José Zamorano, Moreno, 19/9/2009 y 2/9/2011.

${ }^{122}$ La primera mención a un Círculo de Universitarias en Bahía Blanca la encontramos en el Boletín Eclesiástico para referir al pase de socias del Círculo de Estudiantes Secundarias de la AC a dicha agrupación en noviembre de 1939 (Boletín Eclesiástico, Bahía Blanca, junio de 1941). Luego, hallamos referencias al mismo y al Centro de Universitarios de la AC en el segundo semestre de 1949, a partir de la designación de sus asesores (Boletín Eclesiástico, Bahía Blanca, septiembre-octubre de 1949). En cuanto a las siglas JUC y AUDAC, aparecen mencionadas como sinónimos del Centro y el Círculo universitarios respectivamente, y como asociaciones integrantes de la AC bahiense a mediados de 1953 (Boletín Eclesiástico, Bahía Blanca, mayo-junio de 1953).

${ }_{123}$ Boletín Eclesiástico, Bahía Blanca, julio-agosto de 1957.

${ }^{124}$ Boletín Eclesiástico, Bahía Blanca, julio-septiembre de 1961.
} 
Esta primera experiencia jucista en la ciudad se desenvolvió bajo el impulso de diversos asesores, entre ellos, los presbíteros Norman Horacio Pipo y Juan Fabris ${ }^{125}$. Pipo, nacido en 1924 en Coronel Pringles y ordenado sacerdote en octubre de 1947, fue nombrado asesor del Círculo de Universitarias y del Centro de Universitarios del movimiento en 1952. Según los testimonios de integrantes de la JUC y de AUDAC, el sacerdote también se desempeñó como asesor de las dos ramas de la Acción Católica Universitaria en el período $1956-1958^{126}$ y de la JUC -ya con miembros de ambos sexos- en los años 1962-1967 ${ }^{127}$, siendo así el último presbítero que acompañó a esta organización antes de su disolución. A las mencionadas responsabilidades, se agregó su designación como secretario general y canciller de la diócesis, en septiembre de 1952 cargo que desempeñó hasta mediados de 1967-, y como vice-asesor del Movimiento Familiar Cristiano (MFC) ${ }^{128}$, en junio de $1964^{129}$. Por su parte, Juan Fabris, nacido en 1931 y ordenado en 1953, fue elegido asesor de los consejos arquidiocesanos de JUC y AUDAC para el trienio 1961-1964, después de haberse desempeñado como asesor de los y las estudiantes secundarios/as de la AC a partir de 1960. En la segunda mitad de esa década, también ocupó el cargo de vicerrector del Seminario Arquidiocesano "La Asunción" $" 130$.

Según recordaba Alberto, si bien formalmente la figura del asesor era la del “representante oficial de la jerarquía”, y, gracias a su formación, era el más capacitado

\footnotetext{
${ }^{125}$ Alberto Monge y Lucio Iurman, integrantes de la JUC en la segunda mitad de la década de 1950 y primera mitad de la de 1960, también recuerdan como asesores al Padre Silverio Rosso, quien era universitario y falleció a los 30 años en 1961 (Boletín Eclesiástico, Bahía Blanca, enero-marzo de 1961) y al salesiano Jaime De Nevares (Abuelos Relatores, 2012). Por otra parte, De Nevares figura en el Boletín Oficial de mayo-junio de 1953 como asesor del Centro de Profesionales de la AC. Alberto Integró la JUC entre 1956 y 1965 y fue presidente de la misma en el período 1959-1962. Vivió en el Pensionado Católico -véase el capítulo 3- entre 1957 y 1965. Lucio vivió en el Pensionado entre 1959 y 1963 . Entrevista a Alberto, Bahía Blanca, 29/8/2012, y Entrevista a Alberto Monge, Beto Migliorisi y Miguel Ponce de Léon, Bahía Blanca, 21/8/2012, entrevistadoras: Elsa Calzetta, Ana Germani y Virginia Dominella.

${ }^{126}$ Entrevista a Zulma, Bahía Blanca, 25/8/2010.

${ }^{127}$ Entrevista a Ángel, Buenos Aires, 8/10/2009. Y testimonio de Carlos Rígoli en: Abuelos Relatores, 2012. Rígoli participó de la JUC entre 1962 y 1968.

${ }^{128}$ Asociación católica integrada por matrimonios que procuraban "conocer, vivir y difundir los fines y riquezas naturales y sobrenaturales del matrimonio cristiano" (Boletín Eclesiástico, Bahía Blanca, agostodiciembre de 1964). En Bahía Blanca, fue constituido en junio de 1964 con la designación por parte del arzobispo de sus asesores, un matrimonio y una comisión promotora, que se abocó a la organización del movimiento en la arquidiócesis, logrando en poco tiempo constituir equipos en Bahía Blanca, Puerto Belgrano, Punta Alta, Tres Arroyos, González Chaves, Patagones, Mayor Buratovich y Teniente Origone. Además de las parejas, que se reunían en grupos de 8-10 para revisar la vida cristiana de la familia y que sumaban 100 a fines de 1965, el movimiento se dedicó a formar equipos de novios y grupos juveniles (Boletín Eclesiástico, Bahía Blanca, julio-septiembre de 1965).

${ }^{129}$ Boletín Eclesiástico, Bahía Blanca, agosto de 1939, enero de 1946, marzo de 1946, noviembre de 1947, mayo-junio de 1951, mayo-junio de 1952, septiembre-octubre de 1952, mayo-junio de 1953, enerojulio de 1964, agosto-diciembre de 1964, octubre-diciembre de 1965, abril-junio de 1967.

${ }_{130}$ Boletín Eclesiástico, Bahía Blanca, julio-septiembre de 1960, julio-septiembre de 1961, octubrediciembre de 1965, julio-septiembre de 1968.
} 
para orientar a los jóvenes en la reflexión teológica y en cuestiones doctrinales, de hecho, era "un integrante más del grupo". Sin embargo, tanto Fabris como Pipo antes de que fueran incorporando las novedades conciliares, eran percibidos como “ortodoxos”, lo que generaba no pocas discusiones con los jóvenes ${ }^{131}$. En cuanto a la relación con el obispo, más allá de que éste era el encargado de designar al asesor y a las autoridades de la AC Universitaria, no tenía un contacto frecuente con los universitarios, incluso ni siquiera los conocía ${ }^{132}$.

Según los estatutos de la $\mathrm{AC}$, las dos ramas de jóvenes universitarios funcionaban por separado, siguiendo la lógica de la división por sexos que distinguía las asociaciones de la Acción Católica entre hombres y mujeres, los y las jóvenes, los y las estudiantes secundarios/as. Sin embargo, para fines de la década de 1950 y principios de la de 1960 los dos grupos trabajaban en conjunto. Este cambio era parte de los aires de renovación eclesial que soplaba el Concilio Vaticano II. Alberto explicaba:

eran dos centros separados. Eso para los papeles, digamos, para la parte oficial. En la realidad nos juntábamos, porque no tenía sentido si estábamos juntos en la universidad, en el club, en todas partes, y después reunirse varones por un lado y mujeres por el otro. Entonces nos juntábamos como JUC ${ }^{133}$.

Entre sus actividades más importantes, se encontraba la misa semanal de los universitarios, que tenía lugar en la iglesia Nuestra Señora de Lourdes o en el colegio Don Bosco ${ }^{134}$, y las reuniones, tanto de los grupos directivos de JUC y AUDAC -que no tenían un calendario fijo sino una frecuencia variable según las actividades en cursocomo de todos los jóvenes, donde el acento estaba puesto en "la reflexión" "135. En estos encuentros, que generalmente se llevaban a cabo en la Curia en compañía del asesor, se debatían temas de actualidad $\mathrm{y}$, principalmente, de la problemática estudiantil. En palabras de Alberto: "la finalidad era la presencia evangelizadora de la Iglesia en el ambiente universitario y el análisis de los acontecimientos a la luz de la doctrina cristiana ${ }^{136}$.

Según Zulma y Alberto, en aquella reflexión ya comenzaba a utilizarse el método Ver, Juzgar y Actuar, lo que planteó una ruptura en el modo de funcionamiento tradicional de las ramas de la Acción Católica, marcado por el énfasis en la formación

\footnotetext{
${ }^{131}$ Entrevista a Alberto, Bahía Blanca, 29/8/2012.

${ }^{132}$ Entrevista a Alberto, Bahía Blanca, 29/8/2012. Entrevista a Zulma, Bahía Blanca, 25/8/2010.

${ }^{133}$ Entrevista a Alberto, Bahía Blanca, 29/8/2012. Y testimonio de Lucio Iurman, "Dos fundadores" en: Abuelos Relatores, 2012.

${ }^{134}$ Institución salesiana, fundada en 1890 y erigida en pleno centro de la ciudad.

${ }^{135}$ Entrevista a Zulma, Bahía Blanca, 25/8/210 y a Alberto, Bahía Blanca, 29/8/2012.

${ }^{136}$ Aclaraciones por escrito de Alberto a su entrevista del 29/8/2012, 4/10/2012.
} 
religiosa en detrimento de la acción efectiva. En palabras de Alberto: "formarse es necesario pero también vamos llevándolo a cosas concretas" "137. En efecto, en 1964 y 1965, al calor del Concilio, la misma ACA se planteó la tarea de "repensarse" y revisar su "acción apostólica", su "vida" y su "metodología"138. Así, la X Asamblea arquidiocesana del movimiento, celebrada en Bahía Blanca en octubre-noviembre de 1965, declaró que ninguna junta, centro o círculo podía carecer de una "obra concreta", y formuló la necesidad “de formarse con la renovación y ritmo que impone la Iglesia en la hora actual" y de usar "planes concretos de formación para la acción", así como "métodos reales de formación con preferencia el de Ver-Juzgar y Actuar"139.

Ángel, sin embargo, afirma que en las reuniones de la JUC todavía no hacían la revisión de vida, al menos tal y como después fue ejercitada en los equipos jucistas a partir de 1967, ni conversaban sobre su vida personal. Por el contrario, los encuentros, en los que se leía el Evangelio y el Padre Pipo acercaba las novedades del Concilio, tenían una impronta fundamentalmente "intelectual" y "teórica"140. Con todo, los testimonios concuerdan en la introducción por parte del asesor, de una reflexión que comenzaba a orientarse cada vez más a la acción.

La Acción Católica Universitaria también compartía otras actividades. En el medio local, tanto la JUC como la AUDAC celebraban asambleas cada tres años para renovar autoridades. Asimismo, iniciaron una práctica que sería continuada por la experiencia jucista de 1967-1975, consagrándose como el modo de ingreso al grupo: los encuentros periódicos, abiertos a gente nueva, organizados para captar militantes ${ }^{141}$. Por otra parte, los jucistas participaban de encuentros nacionales, como los llevados a cabo en Luján (hacia 1956/1957), en Tucumán (hacia 1960), en Tandil (enero de 1963), en Bahía Blanca (enero de 1965) o en Ramos Mejía (febrero de 1967). Al primero, asistieron tres militantes bahienses, entre ellos, Alberto, y al segundo, un grupo más numeroso y mixto de dirigentes locales. En ese encuentro, realizado en el centro universitario de Horco Molle ubicado en la ladera del cerro que lleva ese nombre, los jóvenes, entre los que ya había militantes del Humanismo, discutieron sobre la toma de postura frente a los movimientos estudiantiles universitarios $\mathrm{y}$, concretamente, frente a la Reforma de 1918. Una anécdota de Alberto ilustra el modo en que la renovación

\footnotetext{
${ }^{137}$ Entrevista a Alberto, Bahía Blanca, 29/8/2012.

${ }^{138}$ Boletín Eclesiástico, Bahía Blanca, agosto-diciembre de 1964.

${ }^{139}$ Boletín Eclesiástico, Bahía Blanca, octubre-diciembre de 1965.

${ }^{140}$ Entrevista a Ángel, Buenos Aires, 8/10/2009.

${ }^{141}$ Entrevista a Ángel, Buenos Aires, 8/10/2009.
} 
católica empezaba a impregnar algunos grupos laicales, como la JUC bahiense, y el contrate con otras corrientes eclesiales que convivían en el seno de la Iglesia:

habitualmente uno para tomar la comunión se arrodillaba en la misa [...] Nosotros allí por una cuestión de practicidad y de tiempo, tomábamos la comunión de pie, directamente íbamos pasando como se hace ahora ¿no? Y Monseñor Aramburu ${ }^{142}$ nos llamó la atención, que cómo íbamos a tomar la comunión así, era una falta de respeto...Bué, nosotros seguimos tomando la comunión de pie (risas) ${ }^{143}$.

La participación del grupo bahiense y su asesor fue fundamental en el encuentro de 1965, donde actuaron como anfitriones. Por último, la JUC local también envió tres representantes a Ramos Mejía, entre los cuales se encontraba Ángel y otro compañero, quienes serían el nexo con la nueva JUC bahiense, dando continuidad a la experiencia ${ }^{144}$. El contacto y el trabajo conjunto con otros grupos jucistas del país, especialmente con el de Buenos Aires, trascendían los encuentros nacionales y se alimentaban a través del intercambio de materiales ${ }^{145}$.

Por otro lado, en los años siguientes a la creación de la UNS, los jucistas asumieron como compromiso personal la tarea de servir de guía en la inserción de los ingresantes en la universidad. Para ello, visitaban los colegios secundarios de la ciudad, o incluso de sus pueblos de origen, para comentar qué carreras se dictaban y conseguir pensiones o casas para los estudiantes venidos de la zona. En este proceso, los jucistas bahienses y los que, oriundos de otras regiones, habían venido a estudiar a la universidad descubrieron la carencia de lugares de alojamiento y así surgió primero la idea de crear un Pensionado ${ }^{146}$ para estudiantes varones, y más tarde, uno para las jóvenes ${ }^{147}$, lo que pasó a ocupar un lugar central en las tareas y preocupaciones de la Acción Católica Universitaria.

\footnotetext{
${ }^{142}$ Fue nombrado por el Papa Pío XII obispo auxiliar de Tucumán el 7 de octubre 1946, y obispo de la misma sede, el 28 de agosto de 1953. Al elevarse la diócesis tucumana a la jerarquía de arquidiócesis, el 13 de marzo 1957, el prelado fue promovido a arzobispo. El 14 de junio de 1967, Pablo VI lo nombró Coadjutor con derecho de sucesión del Cardenal Caggiano, Arzobispo de Buenos Aires (http://m.aciprensa.com/noticia.php? $\mathrm{n}=6535$, consultado el 23/8/2013).

${ }^{143}$ Entrevista a Alberto, Bahía Blanca, 29/8/2012.

${ }^{144}$ Entrevista a Ángel, Buenos Aires, 8/10/2009.

${ }^{145}$ Entrevista a Alberto, Bahía Blanca, 29/8/2012.

${ }^{146}$ Hablaremos del Pensionado en el capítulo siguiente.

${ }^{147}$ En los primeros años sesenta, la JUC y AUDAC emprendieron el proyecto de abrir un pensionado para chicas, ya que muchas militantes eran de afuera. Así, alquilaron una casona en Alsina 265, pleno centro de la ciudad, que tenía capacidad para 18 camas, la amueblaron y la pusieron en funcionamiento bajo la administración de las universitarias católicas. La casona, en la que se destacaba una escalera de mármol y en general una arquitectura que Alberto recuerda como "más lujosa" que la del Pensionado de varones (Entrevista a Alberto, Bahía Blanca, 29/8/2012), contaba con la comodidad de una sala acondicionada como lugar de estudio, con mesas y veladores individuales.
} 
Buena parte de los integrantes de esta primera JUC bahiense y residentes del Pensionado eran militantes, e incluso fundadores, de la Liga de Estudiantes Humanistas del Sur (LEHS). Mientras algunos jóvenes continuaron perteneciendo a la Acción Católica Universitaria en paralelo al nuevo espacio de acción, otros se abocaron a la militancia en la universidad. Al respecto, Zulma decía: "la militancia en la Acción Católica se fue como diluyendo porque era prioritario el compromiso formal como centro de estudiantes en la universidad para controlar un poco lo que era la FUS"148.

Los humanistas constituían uno de los dos grandes grupos en los que se articuló el movimiento estudiantil bahiense en el período 1955-1966, enfrentados a los reformistas, aunque habían comenzado trabajando juntos. El reformismo estaba representado por la Federación Universitaria del Sur (FUS), surgida al calor de la lucha por la autonomía universitaria y articulada en torno a un proyecto universitario definido a partir de las principales banderas de la Reforma de 1918. La amplitud de estos principios permitió que a su alrededor orbitaran una serie fluctuante de tendencias políticas afines a las distintas vertientes del socialismo y del radicalismo, así como militantes cristianos e incluso peronistas. No obstante, hacia 1955 las divergencias internas precipitaron la ruptura de un importante grupo de estudiantes de sensibilidad cristiana (Orbe, 2007). Alberto recordaba que estos militantes, en tensión con planteos de la FUS que entendían como contrarios a la Iglesia, se enfrentaron a la disyuntiva de conformar una agrupación interna a la Federación o separarse definitivamente de ésta $^{149}$. Finalmente, a fines de ese año, se inclinaron por esta última opción y conformaron la Federación de Ateneos Universitarios del Sur (FAUS). Pronto comenzaron los contactos con el Humanismo -en especial, con militantes de Buenos Aires- y, en 1956, FAUS tomó el nombre de Liga de Estudiantes Humanistas del Sur.

La nueva organización estaba integrada, fundamentalmente, por militantes cristianos -mayoritariamente católicos y de JUC y AUDAC, que más tarde se sintieron interpelados por la renovación eclesial, y algunos metodistas-, lo que les valió el apodo de "cristianuchis" en la universidad ${ }^{150}$. Sus principios se sustentaban en el Humanismo Integral, cuyas bases ideológicas habían sido sentadas por el filósofo francés Jacques Maritain. Al mismo tiempo, se empezaron a formar con "el personalismo", movimiento y filosofía "militante" de raíz cristiana, cuyo inspirador y figura principal era Emmanuel

\footnotetext{
${ }^{148}$ Entrevista a Zulma, Bahía Blanca, 25/8/2010.

${ }^{149}$ Entrevista a Alberto, Bahía Blanca, 29/8/2012.

${ }^{150}$ Entrevista a Zulma, Bahía Blanca, 25/8/2010.
} 
Mounier (Mounier, 1962). Alberto parafraseaba a este autor: “'la revolución moral será económica o no será. La revolución económica será moral o no será nada' (risas y emoción a la vez). No podés hacer una sin la otra" ${ }^{151}$.

A partir de esa impronta, la Liga se guió por la adhesión a las premisas de autonomía universitaria, pluralismo gremial, libertad de enseñanza, participación estudiantil en el cogobierno, y apoliticidad de la universidad. Zulma explicaba las diferencias claves que mantenían con la FUS en relación a estas cuestiones:

Estábamos de acuerdo con la FUS en el gobierno tripartito [...] ellos pedían el gobierno tripartito paritario: que si habian 5 profesores, fueran 5 alumnos y 5 egresados. Y a nosotros nos parecía que el egresado como tal no podía tener el mismo compromiso con la vida universitaria que el alumno que lo estaba viviendo o el profesor que también lo estaba viviendo [...] Nosotros lo que pediamos era que las familias tuvieran la libertad para elegir la escuela para sus chicos, que el que quisiera elegir una escuela privada, confesional, la pudiera elegir y que el que quisiera elegir la escuela pública lo pudiera elegir. En cambio, ellos proponían la anulación de la escuela privada y que toda la enseñanza fuera laica, como pública ${ }^{152}$.

Esta polémica, "laica o libre", llegó a los claustros bahienses en agosto de 1958.

La LEHS reivindicaba el sistema de libertad de enseñanza que garantizaba la posibilidad de elección y se oponía al monopolio estatal en esta materia. En cambio, para la FUS, lo que se oponía era enseñanza “común, popular, igual para todos, sin restricciones por causas económicas, sociales o religiosas", y enseñanza "aristocrática para los grupos privilegiados", por lo que consideraban que todo el proceso de formación de profesionales debía estar en manos de una institución que representara a la sociedad, esto es, la universidad nacional. Ambas agrupaciones se lanzaron a difundir

\footnotetext{
${ }^{151}$ Entrevista a Alberto, Bahía Blanca, 29/8/2012. La frase aparece citada en Mounier, 1956: 20. Mounier insiste en este punto al desarrollar la teoría de la acción, que ocupa un lugar central en el personalismo, con sus cuatro requerimientos: que modifique la realidad exterior, que llama "económica", donde lo político se articula con la ética y que tiene su fin y medida en la eficacia; que nos forme en nuestras virtudes y unidad personal; que nos acerque a los hombres (dimensión colectiva, comunidad de trabajo o comunión espiritual como indispensables para su humanización integral); y que enriquezca nuestro universo de valores para que envuelva toda la actividad humana y las relaciones entre las cosas y entre los hombres. Así, ninguna acción es sana o viable si descuida o rechaza la preocupación por la efícacia o el aporte de la vida espiritual. La acción no mutilada es siempre dialéctica. De este modo, el compromiso se asienta en una base constituida por el campo que va del polo político al polo profético, que asegura la unión entre lo ético y lo económico, y entre ética y economía, respectivamente. Más adelante, al abordar algunas reglas de la estrategia personalista, el autor constata que la cristalización global de los desórdenes en el mundo contemporáneo ha llevado a algunos personalistas a llamarse revolucionarios. Y plantea la necesidad de despojar al término de toda facilidad pero no de agudeza: "una revolución es siempre una crisis mórbida y de ningún modo aporta soluciones automáticas. Revolucionario quiere decir simplemente desorden, pero quiere decir que el desorden de este siglo es demasiado íntimo y demasiado obstinado para ser eliminado sin trastueque, sin una revisión profunda de valores, sin una reorganización de estructuras y una renovación de las elites" (Mounier, 1962: 57).

${ }^{152}$ Entrevista a Zulma, Bahía Blanca, 25/8/2010.
} 
sus ideas y a conquistar adeptos, dentro de la universidad y fuera de ella. Casi diariamente, concentraciones, discursos altisonantes y marchas multitudinarias tenían lugar en las calles céntricas de la ciudad (Orbe, 2006).

Otro de los espacios de militancia política de los universitarios católicos fue la Democracia Cristiana. El Partido Demócrata Cristiano (PDC) surgió a mediados de 1954 a partir de una mayoría de militantes de la Acción Católica y del Humanismo que tenían el propósito común de contribuir al derrocamiento de Perón y formar una fuerza política de inspiración cristiana. En este sentido, es necesario resaltar que el hecho de que el catolicismo integral se hubiera convertido en la corriente hegemónica del catolicismo argentino hizo que los intentos por conformar un partido político confesional constituyeran una serie de opciones marginales. Sin embargo, el escenario abierto con la "Revolución Libertadora" pareció abrir las puertas para que esos esfuerzos se cristalizasen en una propuesta institucional (Donatello, 2010: 56). En su manifiesto liminar del 13 de junio de 1955, el PDC anticipó sus bases doctrinarias, su condena al liberalismo individualista, al marxismo colectivista y al peronismo, su apego a la constitución y su defensa del mundo del trabajo, a la vez que proclamó el mantenimiento de las conquistas sociales alanzadas por el pueblo trabajador. Así, el PDC apoyó el golpe de 1955 e integró la junta consultiva del gobierno de Aramburu, y se presentó para elecciones constituyentes en 1957. Por entonces, sus banderas eran representación proporcional, libertad de enseñanza e indisolubilidad del matrimonio.

Sin embargo, pronto los cuadros más jóvenes comenzaron a replantear la ubicación ideológica y política del movimiento y se hicieron evidentes las divisiones internas. En las elecciones de 1958 surgieron dos corrientes, ambas inspiradas en las ideas de Maritain: la lista encabezada por Horacio Sueldo y Lucas Ayarragaray, ganadora de la interna, que proponía un diálogo con el peronismo y una agenda que privilegiaba el problema sindical y la intervención del Estado en la economía; y la lista compuesta por Manuel Ordóñez y Messa Boeri, viejos militantes peronistas y cercanos a los círculos de poder económico. En 1959 se realizó la Convención de Bahía Blanca donde se produjeron nuevas definiciones en lo económico-social (se condenaba al plan económico del gobierno de Frondizi) y en lo político (se planteaba la "revolución comunitaria, pacífica y democrática de esencia social-cristiana y se valoraba al peronismo como hecho histórico). De esta manera, hacia 1960 tres corrientes surcaban la Democracia Cristiana: el "centrismo reformista" (antiperonistas, reformistas en lo social, democráticos en lo político); la "izquierda ideológica", que sustentaba el 
pensamiento socialista (socialización de la producción y distribución, planificación económica, etc.); y la "línea de apertura", "nacional y popular", al peronismo. Esta corriente tuvo su expresión en las elecciones de 1963 con la fórmula Matera-Sueldo.

En esos años, los militantes del PDC se comprometieron en las luchas sindicales, apoyaron la ocupación de fábricas dispuestas por la CGT, intervinieron en conflictos sociales y acompañaron los proyectos de reforma de la empresa (que en septiembre de 1964 proponía la transformación progresiva de las empresas capitalistas mediante la cogestión y la copropiedad efectiva para lograr la autogestión de los trabajadores) y reforma agraria, presentados por los legisladores nacionales. Asimismo, dieron origen a la rama juvenil -Juventud Demócrata Cristiana- y a la línea sindical en la estructura partidaria constituida por el Movimiento Sindical Demócrata Cristiano (Habegger, 1970; Donatello, 2010).

Una parte de los militantes de Acción Católica bahiense que se acercó a la Democracia Cristiana continuó integrando la Liga Humanista y/ o la Acción Católica. Los lazos personales que surcaban las dos últimas jugaron un papel importante en la participación de los militantes jucistas ya sea en la conformación de la DC en la ciudad, o en la intervención en algunas de sus actividades. Así, sin afiliarse directamente a aquella fuerza política, Alberto participó de alguna reunión y Zulma fue fiscal en las elecciones de 1958. La pertenencia común de los jucistas a estos grupos y las relaciones que entre ellos se establecieron hicieron que, como explica Alberto, se plantearan la necesidad de procurar que los referentes de las tres organizaciones estuvieran en una $u$ otra para evitar que se confundieran:

un poco tratamos de dividir las aguas, de decir "bueno, por este lado nosotros nos dedicamos a la Acción Católica, ustedes se dedican a Humanismo”, y otros por allá se dedicaron a Democracia Cristiana. Pero siempre éramos gente vinculada, toda gente conocida y que estaba más o menos en lo mismo ${ }^{153}$.

Los jucistas también se comprometieron en otros ámbitos, por fuera de las agrupaciones políticas. Algunos de ellos, como Alberto o Lucio, participaron también de la fundación del Club Universitario ${ }^{154}$. Para Alberto, la intervención en diversos

\footnotetext{
${ }^{153}$ Entrevista a Alberto, Bahía Blanca, 29/8/2012.

154 "Dos fundadores", en: Abuelos Relatores, 2012. El Club Universitario fue creado en 1951 por iniciativa de las autoridades del Instituto Tecnológico del Sur, con el objetivo de establecer un ámbito para la realización de actividades sociales y deportivas. La institución fue utilizada por los docentes, no docentes y alumnos, constituyéndose en un espacio propio de socialización. Funcionaba con un reglamento y una comisión directiva constituida por representantes de todos los claustros. El Club tenía sus instalaciones en un predio lindante al complejo de la Avenida Alem -que se comenzó a construir en 1951 y se finalizó en 1963, como sede del ITS y luego de la UNS-, y contaba con canchas de tenis y un
} 
espacios simultáneos -en el marco de la recién creada UNS- tenía que ver, por un lado, con ideas y disposiciones para la acción mamadas en el ámbito eclesial, tanto una "vocación de servicio que te inculcan desde la Iglesia", donde les "habían enseñado a que había que ocuparse de los demás, había que hacer”, como el hecho de estar “ideológicamente convencidos de una serie de cosas que queríamos cambiar”; y por el otro, con la existencia de toda una red de personas que se conocían, estaban surcadas por relaciones afectivas y mantenían vínculos cara a cara, todo lo cual facilitaba la acción común $^{155}$.

Como adelantamos anteriormente, el padre Pipo jugó un papel significativo en la difusión de las propuestas conciliares en el medio local y en la transformación de la JUC al calor de aquel aggiornamento. Así, en 1964, encabezó, junto al presbítero Hugo Segovia, una comisión arquidiocesana encargada de adaptar las normas sobre liturgia, arte y música sagradas, de acuerdo a la constitución promulgada por Pablo VI en la clausura de la segunda sesión del Concilio -en diciembre de $1963-{ }^{156}$, y una serie de conferencias, celebradas en la Curia y en la parroquia María Auxiliadora de Punta Alta, cuyos temarios se titularon "Hacia una nueva definición de la Iglesia" y "Concilio y mundo moderno"157. Asimismo, en esos años, Pipo comenzó a transmitir en la JUC las nuevas ideas plasmadas en las encíclicas de Juan XXIII y de Pablo VI, y en las constituciones conciliares, que implicaban una nueva forma de vivir la fe y de pensar la Iglesia y su relación con el mundo. Y de este modo, el asesor proveyó la base teórica para que los jóvenes dieran un "salto", en palabras de Ángel, "de la vivencia de yo con Dios solamente en vez de yo con mis semejantes" ${ }^{\prime 158}$.

Esto implicó, por un lado, un crecimiento cuantitativo del movimiento que empezó a resultar más atractivo para los jóvenes, llegando a sumar, para la primera mitad de la década de 1960, entre 30 y 40 integrantes ${ }^{159}$ que, siendo oriundos de Bahía Blanca o de varias ciudades de la zona, estudiaban en la universidad; por el otro, la profundización de la reflexión sobre las implicancias del compromiso concreto con los

\footnotetext{
amplio parque y una sede social que era usada como salón de fiestas por los estudiantes (Marcilese, 2006).

155 Entrevista a Alberto Monge, Beto Migliorisi y Miguel Ponce de Léon, Bahía Blanca, 21/8/2012, entrevistadoras: Elsa Calzetta, Ana Germani y Virginia Dominella.

${ }^{156}$ En mayo de 1967, esta comisión fue reemplazada por una nueva, integrada, entre otros, por los presbíteros Eriberto Baudry y Benito Santecchia (Boletín Eclesiástico, Bahía Blanca, abril-junio de 1967). Sobre Segovia, Baudry y Santecchia hablaremos en el próximo capítulo.

${ }^{157}$ Boletín Eclesiástico, Bahía Blanca, enero-julio y agosto-diciembre de 1964.

${ }^{158}$ Entrevista a Ángel, Buenos Aires, 8/10/2009.

${ }^{159}$ Entrevista a Ángel, Buenos Aires, 8/10/2009. Entrevista a Alberto, Bahía Blanca, 29/8/2012.
} 
demás y, particularmente, sobre la opción política. Siguiendo a Ángel: “desde el año '63 lo que te proponía [la JUC] era participar, transformar la sociedad a través del compromiso político" ${ }^{\prime 60}$. Este proceso, que, como mencionamos anteriormente, lejos de ser exclusivo de la JUC bahiense se desarrollaba en otros puntos del país, tuvo en los encuentros nacionales de Tandil y Bahía Blanca, dos hitos significativos. En este marco, surgió en la UNS, en 1964, el Movimiento Universitario Personalista (MUP), a partir de un desprendimiento de la Liga Humanista. Al respecto, Carlos Bonfiglio relataba:

en vísperas de una asamblea de la LEHS se planteó o ganar o salir con un grupo nuevo, para lo cual teníamos todo preparado, previendo la derrota electoral en aquélla asamblea. Así fue, los perdedores nos retiramos de la asamblea y al día siguiente repartimos por todos los ámbitos de la universidady el comedor universitario, folletos del MUP ${ }^{161}$.

El Movimiento, liderado por Ernesto Foix y María Cacciamani, integró en sus filas a sectores ligados a la JUC y a otros vinculados con el sindicalismo local. La agrupación se sumó al resto del movimiento universitario bahiense en la lucha por el aumento presupuestario y en expresión de la solidaridad obrero-estudiantil. En sus comienzos, se identificó con la vertiente filosófica personalista de Mounier, según Carlos Bonfiglio, "sobre todo en lo que atañe al diálogo con otras doctrinas y con no creyentes ${ }^{162}$. Sin embargo, pocos meses después, suscribió un documento en el que categóricamente anunciaba el abandono de "la línea de pensamiento de inspiración cristiana" para asumirse como vanguardia revolucionaria que perseguía "el fin de la burguesía occidental, el advenimiento de una estructura socialista y la organización del proletariado a nivel mundial". Con esta manifestación disolvió su identidad universitaria y a partir de entonces se limitó a participar en algunos actos políticos de carácter antiimperialista organizados por las entidades estudiantiles, como una agrupación combativa más que operaba en la ciudad (Orbe, 2007: 128-129).

En este sentido, el encuentro nacional de 1965, que continuó el camino iniciado por el celebrado en Tandil, significó una ruptura -tuvo impacto "explosivo", en palabras de Ángel- en la JUC bahiense. La urgencia por asumir un compromiso político llevó a muchos de los viejos militantes a optar por agrupaciones de izquierda $\mathrm{y}$, simultáneamente, a abandonar la JUC ${ }^{163}$. Al respecto, Ángel recordaba:

\footnotetext{
${ }^{160}$ Entrevista a Ángel, Buenos Aires, 8/10/2009.

161 "Carlos Bonfiglio", en: Abuelos Relatores, 2012: 81.

162 "Carlos Bonfiglio", en: Abuelos Relatores, 2012: 82.

163 Este fue el caso de Ernesto Foix, residente del Pensionado Católico, de quien Carlos Bonfiglio recordaba que "comenzó siendo un católico de misa y comunión diaria, casi de derecha" ("Carlos
} 
muchos de ellos se pasaron directamente al marxismo, se rebelaron contra la Iglesia pero en forma, viste cuando uno va como de un extremo al otro y entonces se pone...bien en contra, digamos ¿no? Se fueron a la extrema izquierda, al Partido Obrero, así...Y de golpe los que nos quedamos, nos quedamos un poco... acéfalos, por decir de alguna manera, desde que muchos de los que se fueron eran los dirigentes más importantes de Bahía Blanca ${ }^{164}$.

La profundización del compromiso político, incluso en organizaciones de izquierda, no siempre significó el quiebre con la comunidad cristiana, como lo demuestra la trayectoria de Ángel, quien empezó militando en la Liga Humanista, continuó en el MUP, y más tarde en las agrupaciones universitarias ligadas al PRT y al PCR, mientras siguió participando de la JUC, aunque ya se trataba de un nuevo grupo de jóvenes universitarios formado en 1967. Al respecto, Ángel decía que a diferencia de los que "se fueron a la izquierda", "yo me quedé con la izquierda también en ese momento pero nunca renuncié a la religión" ${ }^{165}$. Sin embargo, el éxodo abrupto de militantes en los años 1965-1966 sumergió a la JUC local en una crisis profunda, que duró dos años y se ahondó con el abandono del ministerio sacerdotal por parte de Pipo, determinando así el fin de la primera experiencia jucista en Bahía Blanca.

\section{iii) Los Círculos y Centros de Estudiantes Secundarios de la Acción Católica}

A diferencia de las otras dos ramas especializadas de Acción Católica, no encontramos indicios del desarrollo de la JEC en Bahía Blanca en los años previos al período que aborda esta investigación. Como antecedentes, puede mencionarse que desde mediados de la década de 1930, la ACA tenía presencia entre los niños y jóvenes estudiantes a través de sus círculos y secciones internas de las Asociaciones de los Jóvenes y las Jóvenes, con sus correspondientes asesores designados por el obispo/arzobispo, que funcionaban en diversos colegios religiosos, tanto de varones como de mujeres, de Bahía Blanca (como Don Bosco, La Piedad ${ }^{166}$, María

Bonfiglio", en: Abuelos Relatores, 2012: 81). Fue militante de la LEHS, luego, líder del MUP, y por último, dirigente de Política Obrera. Al ingresar a este partido -hacia 1965- rompió con la Iglesia y abandonó la ciudad para desarrollar su militancia en Córdoba, donde fue uno de los protagonistas del "Cordobazo" y murió pocos días después en un accidente automovilístico que nunca fue esclarecido. Sobre Política Obrera hablaremos en el capítulo 6.

${ }^{164}$ Entrevista a Ángel, Buenos Aires, 8/10/2009.

${ }^{165}$ Entrevista a Ángel, Buenos Aires, 8/10/2009.

${ }^{166}$ Parte de la obra salesiana emplazada en el barrio obrero Noroeste. Orientado a niños y jóvenes pobres, se inició como primario y desembocó luego en una escuela de artes y oficios, con la inauguración de 
Auxiliadora ${ }^{167}$, La Inmaculada ${ }^{168}$, Marina Coppa ${ }^{169}$ o San Vicente de Paul ${ }^{170}$ ) y de otras localidades de la arquidiócesis, entre ellos, Pigüé, Coronel Pringles, Coronel Suárez, Coronel Dorrego, Necochea, Lobería, Tres Arroyos, Carmen de Patagones, General Acha, González Chaves, Tornquist, Fortín Mercedes o Puán ${ }^{171}$. Por otra parte, a fines de los años treinta, dentro de la estructura de la ACA, y concretamente de la JAC y AJAC, se iniciaron otros círculos y centros que buscaban acercar la Iglesia a los estudiantes del nivel medio: las secundarias y los secundarios de la Acción Católica.

En junio de 1938, se inició la delegación diocesana de Estudiantes Secundarias y a partir de entonces, se comenzó a organizar el Círculo de Estudiantes Secundarias de la ciudad de Bahía Blanca. A mediados de 1939, el obispo Astelarra, a propuesta del consejo diocesano de la Asociación de las Jóvenes de AC, nombró oficialmente una delegada diocesana de la Asociación de Estudiantes Secundarias de la $\mathrm{AC}^{172}$. El Círculo de Estudiantes Secundarias de la diócesis comenzó a funcionar provisoriamente en abril de 1939 con 13 socias, y se oficializó cuatro meses después con 14 socias oficializadas y 6 socias provisorias, siendo el primero en el país ${ }^{173}$. La ceremonia de afiliación del primer "Centro de Estudiantes Secundarios", bajo la dirección del consejo diocesano de la Asociación de las Jóvenes de la AC, tuvo lugar en el colegio María Auxiliadora ${ }^{174}$.

talleres de alpargatería (1908), de zapatería (1914), de artes gráficas (1915) o de mecánica (1920). En 1946, pasó a ser Instituto politécnico y, a partir de 1961, fue incorporado a la enseñanza oficial. Entre 1914 y 1976 el colegio contó con alumnos pupilos, que eran jóvenes huérfanos o bien provenientes de la Patagonia que venían a recibir capacitación profesional (Boletín Eclesiástico, Bahía Blanca, mayo de 1944, marzo de 1947, julio-septiembre de 1968. Y “¿Quiénes somos?”, disponible en: http://www.arsomos.org.ar/itlp/q/, consultado el 26 de agosto de 2013).

${ }^{167}$ A cargo de las Hijas de María Auxiliadora, fue fundado el 23 de octubre de 1890 y emplazado en el centro de la ciudad. En 1947, el establecimiento contaba con cerca de 900 alumnas y abarcaba el jardín de infantes, la escuela primaria, los cinco años del curso normal incorporados a la Escuela Normal Mixta, cursos de lencería, bordado y cocina, y un instituto musical. En 1968, el colegio tenía alumnas externas e internas (Boletín Eclesiástico, Bahía Blanca, marzo de 1947; julio-septiembre de 1968).

${ }^{168}$ Fundado por las hermanas de la Compañía de María y emplazado en la zona céntrica de la ciudad. Las actividades educativas se iniciaron en marzo de 1913, abarcando una escuela primaria, un jardín de infantes y clases especiales de francés, música, pintura y labores (Bracamonte, Torre y Vila, 2004).

${ }^{169}$ A cargo de las Hijas de María Auxiliadora y ubicado en el barrio Noroeste.

${ }^{170}$ La institución, que consistía en una Escuela Taller y un asilo infantil, estaba a cargo de las Hijas de la Caridad de San Vicente de Paul, y fue fundada en 1918 en el entonces barrio obrero de Villa Mitre. A finales de la década de 1940, contaba con 150 alumnas distribuidas en los seis primeros grados y 50 niños menores a 6 años, y poseía un taller de bordado y corte y confección (Boletín Eclesiástico, Bahía Blanca, julio de 1943 y marzo de 1947). Hacia 1960, la escuela sufrió una importante reestructuración que modificó su perfil y sus destinatarios. En 1968, estaba dirigida a alumnas externas y contaba con jardín de infantes, primario, ciclo básico y magisterio (Boletín Eclesiástico, Bahía Blanca, julio-septiembre de 1968; Entrevista a Ema, Bahía Blanca, 27/9/2012).

${ }^{171}$ Boletín Eclesiástico, Bahía Blanca, 1939-1967.

${ }^{172}$ Este cargo se fue renovando entre las socias (Boletín Eclesiástico, Bahía Blanca, julio de 1939; mayo de 1942; marzo de 1944).

173 Boletín Eclesiástico, Bahía Blanca, junio de 1941.

${ }^{174}$ Boletín Eclesiástico, Bahía Blanca, septiembre de 1939. 
Una estadística general de la $\mathrm{AC}$ en la diócesis de diciembre de ese año incluye el Círculo Oficial de Estudiantes Secundarios de Bahía Blanca en la AJAC, con 17 socias oficializadas y 4 provisorias ${ }^{175}$.

Las primeras actividades del Círculo y de la delegación de Estudiantes Secundarias fue la organización de una campaña pro cumplimiento del precepto pascual, con conferencias para las estudiantes, y las misas del estudiante en el mes de noviembre. En 1940 la misma se celebró en la iglesia del Sagrado Corazón de Jesús ${ }^{176}$. En 1956 seguía celebrándose la fiesta del estudiante, a partir de una misa en aquella iglesia que contó con la asistencia de "un crecido número de estudiantes, testimoniando así su fe católica y su deseo apostólico de ver a Cristo reinando en el ambiente estudiantil" "177. Asimismo, en 1941, la delegada diocesana y algunas socias del Círculo participaron de la II asamblea y jornada de oración y estudio del Consejo Diocesano de la Asociación de las Jóvenes de $\mathrm{AC}^{178}$.

La constitución de un Centro de Estudiantes Secundarios dependiente de la JAC es más tardía. Si bien no hemos dado con la fecha cierta de su fundación, sabemos que para marzo de 1947 existía uno en la diócesis que funcionaba en Bahía Blanca con el nombre de "Santo Tomás de Aquino", y que se había designado un delegado de Centro de Estudiantes Secundarios, que al mismo tiempo era delegado de los Centros Internos, y que integraba el Consejo Diocesano de los Jóvenes. En cuanto al Círculo de Estudiantes Secundarios de la AJAC, para entonces, había uno en la ciudad que se reunía en la parroquia Santa Teresita y contaba con una nueva delegada de Estudiantes Secundarias ${ }^{179}$.

En los años siguientes, pueden rastrearse en el Boletín Eclesiástico algunas menciones a estas organizaciones que, sin embargo, resultan escasas y se centran, fundamentalmente, en la designación de sus asesores y referentes laicos a través de su

\footnotetext{
${ }^{175}$ Boletín Eclesiástico, Bahía Blanca, abril de 1940.

176 Allí, el sacerdote -Feliciano López, director del colegio Don Bosco- destacó "la misión de los estudiantes y el deber que como tales contraen con Dios y con la sociedad de forjar su inteligencia y su voluntad en principios sanos y nobles que los ayudarán para mantenerse limpios de alma y de conciencia". Luego de la celebración, se inició una manifestación encabezada por el padre Julián Fernández, asesor del Círculo, y por una representación de los y las estudiantes socios/as con alumnos del Colegio Normal, Nacional y Don Bosco, que saludaron a Monseñor Astelarra, quien invitó "a la juventud estudiosa a seguir adelante por el camino del bien llevando siempre en alto el ideal de la Patria y de la Religión" (Boletín Eclesiástico, Bahía Blanca, enero de 1941).

${ }^{177}$ Boletín Eclesiástico, Bahía Blanca, septiembre-diciembre de 1956: 69.

${ }^{178}$ Boletín Eclesiástico, Bahía Blanca, abril de 1941.

${ }^{179}$ Boletín Eclesiástico, Bahía Blanca, marzo de 1947.
} 
elección en las asambleas diocesanas de la AC y su nombramiento oficial por la jerarquía local cada tres años ${ }^{180}$.

\section{c) Los grupos en el período 1967-1975}

\section{i) Los asesores}

Es imposible comprender la historia de las ramas especializadas de Acción Católica en Bahía Blanca sin hacer referencia a los asesores. A diferencia de la Acción Católica tradicional, éstos no eran nombrados por el obispo sino propuestos por los mismos jóvenes y designados por el movimiento. Muchos de los sacerdotes más "avanzados" de la Argentina, desde el punto de vista del aggiornamento eclesial, fueron asesores de la JUC: por ejemplo, en diferentes facultades de la UBA estaban Carlos Mugica, Alejandro Mayol, Rodolfo Ricchiardelli (Politi, 1992: 136). Bahía Blanca no sería la excepción. Los presbíteros José Zamorano y Emilio Flores marcaron profundamente a estos grupos bahienses -particularmente el primero, quien acompañó a los equipos durante todo el período-, a partir de sus experiencias, personalidades y postura eclesial. También lo hizo Hugo Segovia, quien durante un tiempo acompañó a un equipo jucista.

\footnotetext{
180 Así, Monseñor Esorto nombró asesores del Centro de Estudiantes Secundarios de la AC diocesana/arquidiocesana en junio de 1947, julio de 1948, julio de 1952 (al presbítero Jorge Koenig), junio de 1953 (nuevamente a Koenig) y julio de 1960 (a Juan Fabris); del Centro de Estudiantes Secundarios de la AC de la Escuela de Comercio de Bahía Blanca, en agosto de 1949 (a Raúl Entraigas); y de la Asociación de las/el Círculo de Estudiantes Secundarias de la AC diocesana/arquidiocesana en julio de 1948, julio de 1952 (a Jorge Koenig), junio de 1953 (al salesiano Osvaldo Francella) y julio de 1960 (a Juan Fabris) (Boletín Eclesiástico, Bahía Blanca, junio de 1947, julio de 1948, septiembreoctubre de 1949, julio-agosto de 1952, mayo-junio de 1953, julio-septiembre de 1960).
} 


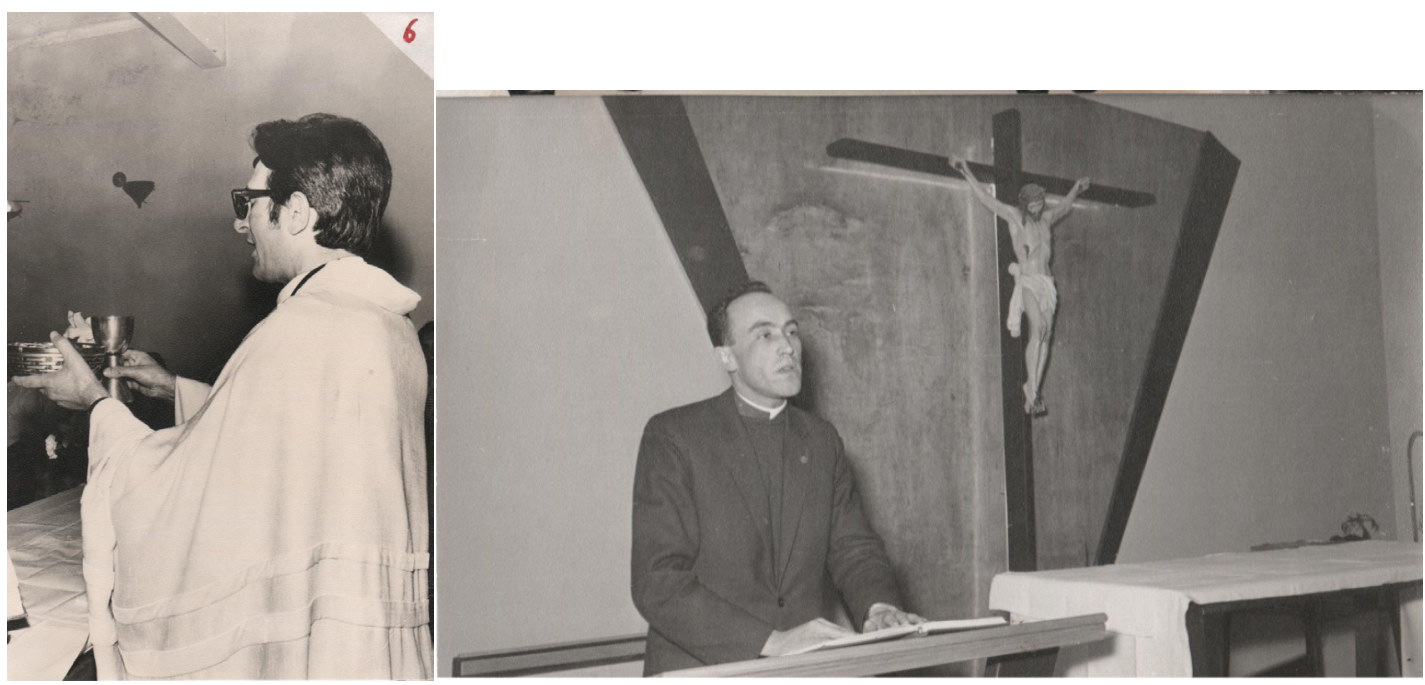

José Zamorano y Emilio Flores.

Los primeros eran oriundos de España: “Pepe” nació en $1932^{181}$ y Emilio, en 1937. Llegaron a la Argentina a través de la Obra de Cooperación Sacerdotal Hispanoamericana (OCSHA), un organismo creado a fines de los años cuarenta y patrocinado por el episcopado español, que institucionalizaba el envío de misioneros diocesanos durante un tiempo -en principio, 7 años- a América Latina para fortalecer las Iglesias que se enfrentaban al problema de la escasez de vocaciones sacerdotales ${ }^{182}$. Los misioneros eran o bien sacerdotes ya ordenados, que hacían un curso de tres meses donde se informaban sobre la realidad latinoamericana, o bien seminaristas de distintas diócesis de España que, dispuestos a prestar un servicio en América Latina y contando con la autorización de su obispo, completaban su formación teológica en el Seminario Hispanoamericano en Madrid, como fue el caso de "Pepe" y Emilio entre 1957 y 1961.

A diferencia de los "sacerdotes ya hechos" que conservaban "lo más rancio del estilo español de vida religiosa", los seminaristas del Colegio Hispanoamericano se caracterizaban por una "acrisolada crítica hacia los modos de dominación y sometimiento que arrastraban el régimen político y las estructuras eclesiales" (Mayol, 1970: 65-66). De esta manera, como mencionamos en el capítulo anterior, una vez en Latinoamérica, estos actores, así como otros misioneros provenientes de Europa, en

\footnotetext{
181 "Pepe" falleció en España el 9 de septiembre de 2012.

${ }^{182}$ En efecto, en 1960, los medios católicos ponían de manifiesto su preocupación por esta cuestión: "el continente latinoamericano, que cuenta con 167 millones de católicos, o sea el 34\% de la población católica mundial, no tiene sino 35 mil sacerdotes para asegurar la función religiosa, o sea a un 9 y $1 / 2 \%$ de los sacerdotes del Universo. Y si se tiene en cuenta las distancias y la dificultad de comunicaciones en territorios tan extensos, se estima que 40 mil centros de población están totalmente privadas (sic) de toda asistencia sacerdotal ("Noticias de AICA y FIDES. América Latina carece de sacerdotes", Boletín Eclesiástico, Bahía Blanca, abril-mayo-junio de 1960).
} 
contacto con la nueva realidad y a partir de experiencias previas con curas obreros o movimientos especializados de Acción Católica, se sumaron a los movimientos populares. Además, los sacerdotes de la OCSHA tuvieron un gran protagonismo en los conflictos de la Iglesia Latinoamericana, hasta el punto que algunos fueron expulsados de las diócesis de San Martín, San Isidro y Rosario - por citar sólo ejemplos en Argentina- frente a la reticencia de algunos obispos a aceptar las novedades conciliares y de Medellín, y a sus intentos de encuadrar a los curas españoles en su propia visión teológica y pastoral. Como consecuencia de estos conflictos, que se repitieron en otros países del subcontinente, el episcopado español acabó cerrando el Seminario Hispanoamericano, hacia el año 1967.

"Pepe" destacaba la influencia de su formación en una "teología histórica", que se encontraba en la corriente de renovación que se consagró poco después en el Concilio Vaticano II, y en ese marco, el contacto indirecto con los movimientos especializados de juventud. Éste se dio a través de su director espiritual -el Padre Fernando Urbina-, quien acompañaba a la JOC y tenía una estrecha ligazón con las bases trabajadoras, y de algunos profesores, que se desempeñaban como asesores nacionales de la JUC y de la JOC. Por otra parte, los misioneros formaron equipos por destino, donde ejercitaron y asumieron la metodología de la "revisión de vida" desde su realidad de estudio. En este proceso, fueron identificándose, al decir del sacerdote, con "una mirada pastoral distinta": "una mirada ya a la sociedad y como un descubrimiento de lo que es la misión de la Iglesia, de los cristianos en el mundo, en la sociedad ¿no? Por ello, el espiritu de la levadura en la masa" ${ }^{183}$.

Estas trayectorias se comprenden en el marco del cambio que experimentó la Iglesia católica española a mediados del siglo XX, al calor de las transformaciones económicas, sociales y de mentalidades operadas en la sociedad franquista. Siguiendo a Montero García (2006), este cambio, que implicó el "despegue" de la institución respecto del régimen de Francisco Franco y su conversión a los valores democráticos, se produjo en dos fases. En la primera, que abarcó el período 1956-1966, la renovación se manifestó en las bases, y de manera destacada en el clero y los laicos. Como ocurrió a nivel general, el Concilio Vaticano II fue el acelerador y legitimador de unas actitudes y posiciones que, aunque minoritarias, estaban ya presentes en el catolicismo español y, en particular, en algunos sectores de la Iglesia. Así, desde comienzos de los años

${ }^{183}$ Entrevista a José Zamorano, Moreno, 2/9/2011. 
cincuenta, la Acción Católica obrera experimentó una transformación, que luego se difundió y extendió a las otras ramas, y estaba marcada por el valor del "compromiso temporal" como tarea ineludible. En este proceso, el método de la revisión de vida ocupó un rol central, en cuanto favoreció el reconocimiento de los problemas reales, el descubrimiento en ellos de los principios evangélicos y el diálogo con otras militancias fuera de las organizaciones católicas, formando directa o indirectamente a los jóvenes en actitudes críticas y democráticas. En general, toda la evolución del conjunto de la AC especializada española de los años sesenta tenía una dimensión y proyección política claramente democrática y, en ese sentido, contraria al régimen de Franco. Por otra parte, muchos militantes católicos se unieron a la militancia antifranquista. Esto provocó la reacción del gobierno, que aumentó la censura y la represión contra las organizaciones y los militantes, y de la jerarquía eclesiástica, en ese momento mayoritariamente identificada con Franco, incrementándose las tensiones y el conflicto intraeclesial cuya expresión más significativa fue la llamada "crisis" de la AC de los años 1966-1968. Esta crisis, que tenía un carácter político, marcó el fin de una experiencia renovadora. Habría que esperar unos años (1969-1975), en vísperas del final del franquismo, para que las posiciones favorables a la renovación eclesial $-\mathrm{y}$, ligadas a ellas, a la democratización social y política-, se manifestaran a nivel institucional o de la jerarquía, difundiéndose entonces desde la Conferencia Episcopal, bajo el impulso y las directrices de Pablo VI. En este marco, la Iglesia pudo jugar un papel decisivo en el proceso de transición democrática.

Volviendo al caso que nos ocupa, en la zona, la llegada de los primeros misioneros españoles se produjo en los primeros años de la década de 1960. A principios de 1961, Fidel Panera García arribó a la diócesis de Santa Rosa, previo trámite de su obispo, Jorge Mayer, ante la OCSHA ${ }^{184}$. En 1962, los padres Zamorano y Flores llegaron a la Arquidiócesis de Bahía Blanca, que también había presentado la correspondiente solicitud al organismo español ${ }^{185}$. En 1964, Javier Jordán finalizó sus estudios en el Seminario Hispanoamericano de Madrid como seminarista de la Arquidiócesis y una vez ordenado, desarrolló sus tareas pastorales en Coronel Suárez y Coronel Pringles ${ }^{186}$.

\footnotetext{
184 “Arribo de un sacerdote español”, Boletín Eclesiástico, Bahía Blanca, enero-febrero-marzo de 1961. 185 "Dos nuevos sacerdotes", Boletín Eclesiástico, Bahía Blanca, enero-febrero-marzo de 1963.

${ }^{186}$ Boletín Eclesiástico, Bahía Blanca, enero-julio de 1964, octubre-diciembre de 1965, julio-septiembre de 1968, abril-junio de 1970. Jordán se unió tempranamente al MSTM, siendo uno de los 270 primeros presbíteros que firmaron su adhesión al Mensaje de los 18 obispos del Tercer Mundo (Bresci, 1994).
} 
El primer destino de "Pepe" y Emilio fue la parroquia de Coronel Suárez, donde desarrollaron trabajo pastoral en una iglesia del centro de la ciudad -en la que predominaban las familias de los dueños de las estancias de la zona-, tratando de renovar la liturgia y la Acción Católica tradicional ${ }^{187}$, y crearon un grupo Scout -en contacto con la hermana Kotska de La Pequeña Obra de Bahía Blanca.

Tres años y meses después, Monseñor Esorto atendió el pedido de los presbíteros de que se les asignara un "lugar más misionero" "188, y los dejó a cargo de la capilla de "la loma": Nuestra Señora del Carmen" ${ }^{189}$, en Villa Sánchez Elía, en Bahía Blanca, desde marzo de 1966. Este barrio, emplazado a 30 cuadras del centro de la ciudad, era en aquellos años fundamentalmente de suboficiales de Marina y de trabajadores. Por entonces, "Pepe" también comenzó a celebrar misa en el Pequeño Cottolengo "Monseñor José Nascimbeni"190, de las Pequeñas Hermanas de la Sagrada Familia, ubicado a dos cuadras de la casa parroquial.

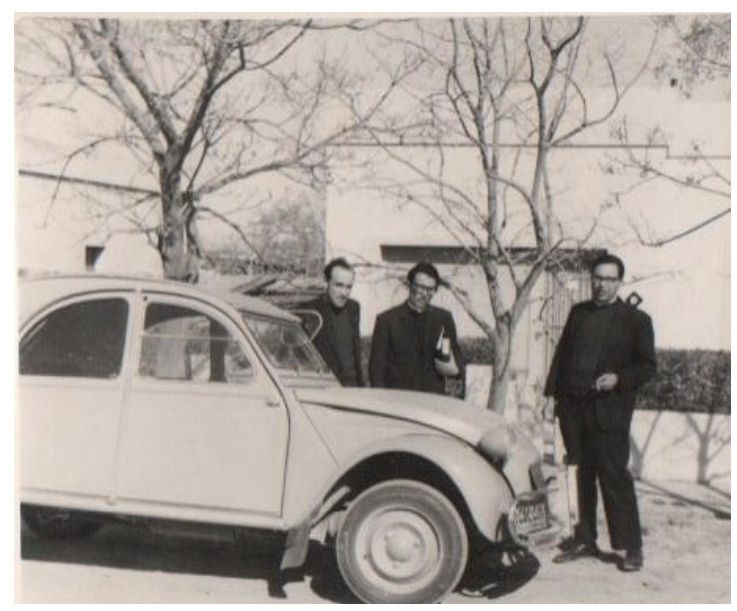

Emilio y "Pepe" en la casa parroquial de Nuestra Señora del Carmen y junto al Citroen en el que se movilizaba el segundo.

Por otra parte, durante el primer año en la ciudad, los sacerdotes dieron clases de religión en cuarto y quinto año del colegio San Vicente de Paul, donde cursaban sus estudios algunas jóvenes que luego se incorporaron a los grupos de reflexión de la

\footnotetext{
${ }^{187}$ En agosto de 1957, se celebró el acto de oficialización de las cuatro ramas de la Acción Católica en la parroquia de Coronel Suárez (Boletín Eclesiástico, Bahía Blanca, septiembre-octubre de 1957).

${ }_{188}$ Entrevista a José Zamorano, Moreno, 19/9/2009.

189 Desde marzo de 1966 hasta el 3 de diciembre de 1981, cuando Monseñor Mayer la erigió canónicamente como parroquia, Nuestra Señora del Carmen funcionó como capilla. Ésta fue bendecida oficialmente en mayo de 1966 (Arzobispado de Bahía Blanca, 1997 y Boletín Eclesiástico, Bahía Blanca, junio-julio-agosto de 1966). Hoy abarca un extenso territorio que consta de varias comunidades, entre ellas la de las Pequeñas Hermanas de la Sagrada Familia en el Pequeño Cottolengo, Cristo Rey (Villa Harding Green), San Lucas (Grümbein), Nuestra Señora de Guadalupe (Villa Cerrito) o Cristo Redentor (Villa Stella Maris).

${ }^{190}$ Bendecido el 2 de abril de 1966 e inaugurado el 29 de abril del año siguiente con la presencia del arzobispo Esorto (Boletín Eclesiástico, Bahía Blanca, enero-marzo de 1966, enero-marzo de 1967).
} 
"loma"191. En ese espacio, conocieron un matrimonio que participaba del Movimiento Familiar Cristiano y se acercaron al mismo. Así, en los años 1967-1968, acompañaron algunos equipos que estaban integrados mayoritariamente por marinos e incluso tuvieron algunas reuniones en Puerto Belgrano. Más tarde, "Pepe" y Emilio se alejaron del MFC mientras iban profundizando su trabajo en otros espacios.

En efecto, una serie de opciones pastorales también fueron definiendo su postura eclesial. En 1966, el arzobispo les pidió a los misioneros que iniciaran en la ciudad el movimiento Cursillos de Cristiandad ${ }^{192}$, que conquistaba el interés de los oficiales de Marina y la jerarquía del Ejército. "Pepe" y Emilio habían conocido de cerca los Cursillos durante los años del Seminario en Madrid, cuando les tocó realizar un análisis crítico de la teología que inspiraba al movimiento. Poco tiempo después, "Pepe" participó de un grupo mientras desarrollaba su práctica pastoral en una parroquia y constató las conclusiones a las que habían arribado en el curso. A partir de esta experiencia previa, plantearon su negativa a Esorto, quedando aquel movimiento en manos de otros sectores, que para los grupos identificados con el catolicismo liberacionista en la ciudad, estaban vinculados estrechamente con "las fuerzas del poder", y concretamente, La Nueva Provincia y la Marina ${ }^{193}$.

Por otro lado, a poco tiempo de llegar a Bahía Blanca, a pedido de las hermanas Misioneras Cruzadas de la Iglesia, con las que ya tenían contacto, Emilio inició el acompañamiento a los grupos Guías "Santa Juana de Arco" y Scouts "San Pío X”, como capellán del centro pastoral La Pequeña Obra ${ }^{194}$.

\footnotetext{
${ }^{191}$ Por su parte, Emilio trabajó como profesor de Ética profesional en la Escuela de Servicio social, donde estudiaban algunos jóvenes a los que invitó a integrar la JUC. Entrevista a Nora, Bahía Blanca, 4/6/2008.

${ }_{192}$ Formaba parte de los sectores eclesiales identificados con el nacionalismo católico que apoyaron, legitimaron e incluso participaron en el gobierno de la "Revolución Argentina" (Moyano, 1992: 382).

${ }^{193}$ Pablo, 3, Bahía Blanca, agosto de 1973. Archivo DIPBA, Mesa Referencia, Legajo 15281, Tomo VIII, "Sacerdotes Tercer Mundo". Según un informe de inteligencia, Pablo era una publicación de laicos bahienses ligados al MSTM, distribuida en el Instituto Juan XXIII. El recuerdo de algunos entrevistados coincide en este punto. María, Fernando y "Coco" Segovia recuerdan que la revista estaba vinculada a Benito Santecchia y otros religiosos de la comunidad del Instituto, así como a profesores e intelectuales de la Comunidad Universitaria Bahiense -de la que hablaremos en el capítulo 3-. Contaba con colaboradores, como el padre de María. Algunos, como el mismo "Coco", aportaban artículos y otros, dinero para financiarla. Se editaron pocos números de un modo "artesanal" utilizando mimeógrafo (Entrevistas a María, Bahía Blanca, 28/2/2013; a Hugo Segovia, Mar del Plata, 27/5/2010; y a Fernando, Bahía Blanca, 30/11/2010). La revista se proponía ser "un testigo profético de Cristo". En su tercer número -el único que he podido revisar- figura un tiraje de 5000 ejemplares y se incluyen notas referidas, fundamentalmente, a la realidad eclesial en los ámbitos local, nacional, latinoamericano y mundial, aunque sin omitir temas de la coyuntura social y política. Así, se cuestionaba a La Nueva Provincia, como opresora de sus trabajadores, vocera de la palabra de Puerto Belgrano, factor de división en la ciudad y en la Iglesia bahiense, y difamadora de los Sacerdotes para el Tercer Mundo.

${ }^{194}$ Véase el capítulo 3.
} 


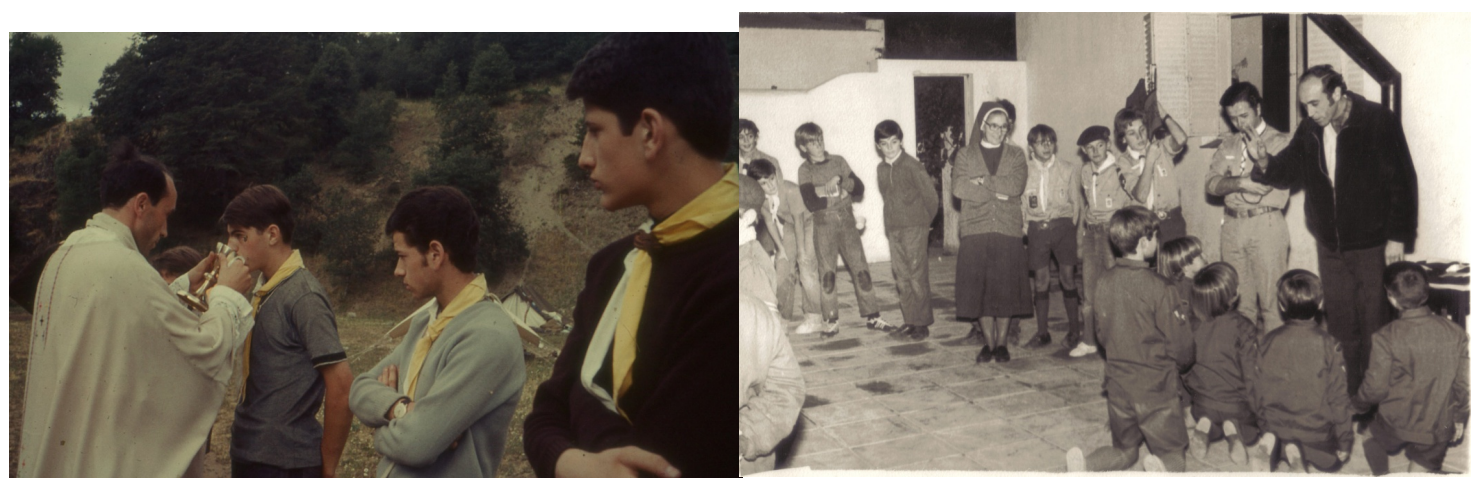

Emilio Flores acompañando al grupo Scout de La Pequeña Obra. Izq.: celebrando misa en un campamento. Der.: en el terreno Scout.

"Pepe", por su parte, estaba más abocado a atender los barrios como Harding Green, Grünbein o Villa Cerrito, ubicados en el sector este de la ciudad y ligados a Nuestra Señora del Carmen. En Harding Green, se hizo cargo de una comunidad preexistente, mientras que en Grünbein y en Villa Cerrito impulsó el desarrollo de las primeras comunidades, iniciando la celebración de la misa y la catequesis con el aporte de jóvenes de Sánchez Elía ${ }^{195}$. Por otro lado, desde 1966, a las tareas pastorales de los sacerdotes se sumó el grupo Scout "San Jorge" de Sánchez Elía, creado desde el La Pequeña Obra. En cuanto a los movimientos especializados de juventud, ambos presbíteros impulsaron la formación de la JUC en 1967, convirtiéndose en sus asesores. "Pepe", además, agrupó y empezó a asesorar -en ocasiones con la ayuda de Emilio- al primer equipo de JOC, en 1968.

A fines de 1970, el arzobispo renovó el contrato de los misioneros para que siguieran trabajando en la arquidiócesis ${ }^{196}$. Pero a mediados de 1971, Emilio abandonó la ciudad para seguir sus estudios en Medellín. A partir de entonces, "Pepe" se hizo cargo de la comunidad de La Pequeña Obra, continuó siendo asesor de los grupos de universitarios y trabajadores, y creó la rama de los estudiantes secundarios. Al finalizar 1974, Emilio regresó a Bahía Blanca, donde permaneció hasta abril de 1975, momento en que partió a Buenos Aires primero, y a España, después, habiendo decidido dejar el ministerio sacerdotal. "Pepe", por su parte, abandonó la ciudad días más tarde, luego de sufrir un atentado con bomba en su casa, perpetrado por la Triple A, el 30 de abril.

\footnotetext{
195 Arzobispado de Bahía Blanca, 1997. Como retomaremos en el capítulo 6, estos laicos, en muchos casos ligados a los grupos de revisión de vida, asumieron un mayor protagonismo en el trabajo pastoral en esas comunidades cuando "Pepe" debió hacerse cargo del acompañamiento del centro pastoral La Pequeña Obra, en 1971, y en 1975, con su partida al exilio.

${ }^{196}$ Boletín Eclesiástico, Bahía Blanca, octubre-noviembre-diciembre de 1970.
} 

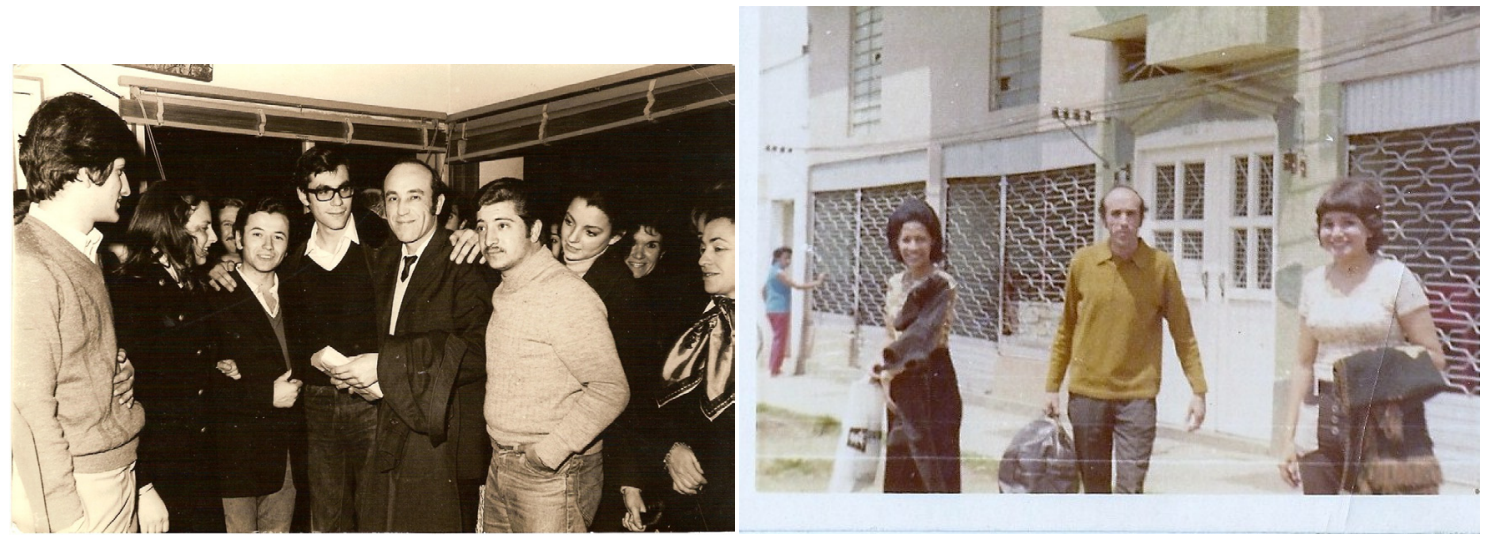

Izq.: Jóvenes de la comunidad Guía-Scout de La Pequeña Obra despiden a Emilio Flores en 1971. Der.: Emilio en Medellín, octubre de 1971. Foto tomada por Eduardo. Archivo de Eduardo.
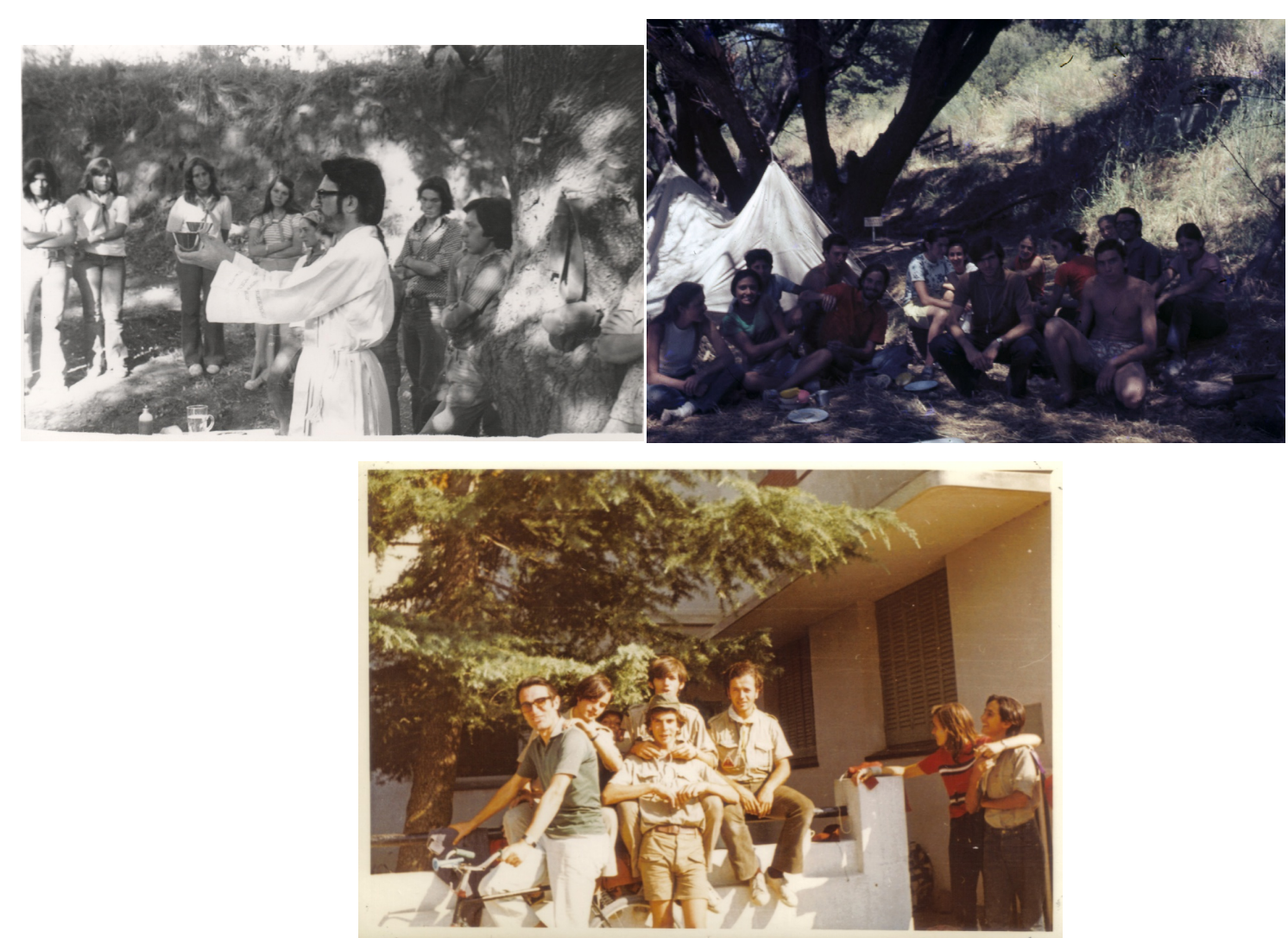

"Pepe" acompañando a la comunidad Guía-Scout de La Pequeña Obra. Arriba y en el centro: en los campamentos. Abajo: junto a un grupo de dirigentes en la puerta de La Pequeña Obra.

Si los cuatro años de Teología en Madrid plantearon las bases de la postura pastoral y teológica de estos sacerdotes, el Concilio Vaticano II y la Conferencia de Medellín la legitimaron. Y la interacción entre el nuevo tipo de reflexión que significó la teología de la liberación y las mismas opciones pastorales en Bahía Blanca, en contacto con los jóvenes trabajadores y estudiantes, y con un grupo de compañeros 
presbíteros y teólogos identificados con la misma línea eclesial ${ }^{197}$, marcaron su profundización. "Pepe", además, tuvo otra experiencia que actuó en este sentido: integró el MSTM, por lo que participó del IV Encuentro Nacional, celebrado en Córdoba en julio de 1971, y de reuniones regionales en Bahía Blanca y Olavarría ${ }^{198}$.

\section{ii) Los grupos de "revisión de vida"}

La JUC comenzó a constituirse en 1967, como un intento de recrear con nuevos integrantes y asesores, la experiencia anterior, que se encontraba desarticulada -como ya mencionamos- a raíz del éxodo de militantes que se incorporaban a agrupaciones de izquierda y del abandono del ministerio sacerdotal por parte del asesor. Por entonces, otro tanto ocurrió, por motivos semejantes, con diversos grupos de JUC afianzados en otras ciudades del país, con lo cual, mientras la nueva JUC bahiense crecía, muchas experiencias similares estaban en crisis o habían desaparecido. La nueva etapa jucista se inauguró cuando algunos integrantes del grupo anterior, entre ellos Ángel y un estudiante de Coronel Suárez que había conocido a "Pepe" y a Emilio en el destino previo de los misioneros, se acercaron a los sacerdotes para proponerles encabezar el resurgimiento del movimiento.

La nueva experiencia llegó a agrupar alrededor de 40 jóvenes divididos en pequeñas comunidades de 6-8 personas. Sus integrantes, nacidos entre 1944 y 1952, eran, en algunos casos, oriundos de Bahía Blanca y, en otros, provenientes de la zona (Darregueira, Saavedra, Punta Alta, Villa Maza), de otras ciudades de la provincia de Buenos Aires (Mar del Plata, La Plata) o de otras provincias (La Pampa, Córdoba, Neuquén). La mayoría de los que no eran bahienses había llegado a la ciudad para realizar sus estudios terciarios o universitarios. Un grupo importante de los varones de este grupo residía en el Pensionado Católico.

Los jucistas eran, en su mayoría, estudiantes de distintas carreras de la UNS (Economía, Contador Público, Ingeniería Civil, Ingeniería Química, Bioquímica, Geología, Filosofía, Historia o Letras), o bien alumnos y egresados de la Escuela de Servicio Social, de la Escuela de Enfermería y del Instituto Juan XXIII. Parte de los jucistas había hecho sus estudios secundarios en colegios religiosos de la ciudad fundamentalmente en el Don Bosco y La Inmaculada- o de sus lugares de origen -

\footnotetext{
${ }^{197}$ Véase el capítulo 3.

${ }^{198}$ Entrevista a José Zamorano, Moreno, 19/9/2009.
} 
dirigidos por religiosos de diversas congregaciones y órdenes (salesianos, maristas, jesuitas o franciscanos capuchinos)-, y contaba con una trayectoria de militancia previa en el MFC, la Legión de María ${ }^{199}$, La Pequeña Hermandad ${ }^{200}$, las ramas juveniles de la ACA o las iniciativas sociales ligadas a las escuelas a las que pertenecían.

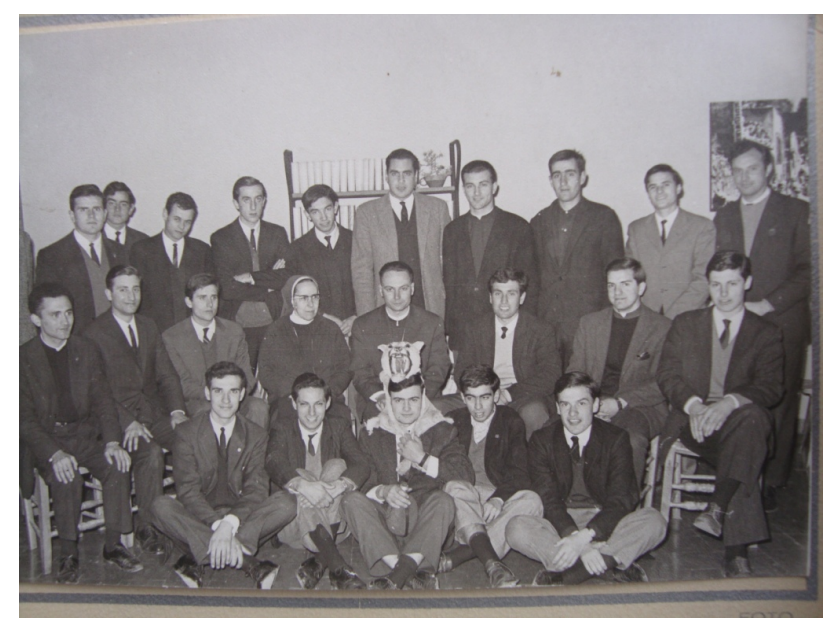

La Pequeña Hermandad, 1967.

En contraste, otros itinerarios educativos habían transitado por instituciones públicas y laicas -ubicadas generalmente en el barrio en que residían sus familias, en el caso de las escuelas primarias, y en el Colegio Nacional o las Escuelas dependientes de la UNS ${ }^{201}$, en el caso de las secundarias. Además de algunas experiencias previas de militancia católica o de trabajo social, una parte de los jóvenes se vio marcada por los Campamentos Universitarios de Trabajo antes o durante su participación en la JUC.

La JOC bahiense también surgió y se desarrolló durante la crisis terminal de la organización a nivel nacional, que, como mencionamos anteriormente, culminó con su disolución por parte del Episcopado en 1971, quedando a criterio de cada obispo el reconocerla en el ámbito diocesano y continuando, aunque sin mayor gravitación, en algunas diócesis (Soneira, 2002 y 2008). En efecto, en Bahía Blanca, la JOC fue (re)

\footnotetext{
${ }^{199}$ Estaba centrada en la oración y orientada exclusivamente a lo religioso, pero significó para los y las adolescentes un primer acercamiento a los barrios periféricos, a partir de la acción apostólica.

${ }^{200}$ Era un grupo integrado exclusivamente por varones caracterizado por una religiosidad individual y una vida espiritual intensa. Fue organizado e impulsado por el Padre Aldo Vara, quien sostenía un discurso anticomunista y contrario a la renovación eclesial. Este sacerdote fue imputado por delitos de lesa humanidad, estuvo prófugo durante 6 meses de la justicia argentina y falleció el 4 de junio de 2014, a los 80 años, en Ciudad del Este, donde cumplía arresto domiciliario a la espera de su extradición.

${ }^{201}$ Eran la Escuela del Ciclo Básico, la Escuela Normal Superior, la Escuela de Comercio y la Escuela de Agricultura y Ganadería. Ésta fue creada en 1951 en el seno del Instituto Tecnológico del Sur, como parte del proyecto tecnológico orientado a la producción, abocada a la formación de especialistas en la labor agropecuaria. Las escuelas Normal Mixta y de Comercio fueron incorporadas a la Casa de Estudios por decreto presidencial del 25/10/1956, mientras que el Ciclo Básico fue fundado en 1962 (Marcilese, 2006).
} 
fundada en 1968 por un pequeño grupo de jóvenes, a propuesta del Padre Zamorano de replicar la experiencia de la JUC pero con trabajadores. Para ello, el sacerdote acercó la historia y la esencia del movimiento a partir de materiales de lectura y del relato de lo vivido en relación con la JOC española.

Aquellos primeros militantes provenían de la capilla del Carmen, donde participaban de la Eucaristía, o bien de los grupos juveniles del MFC. La mayoría de los entrevistados coinciden en que rondaban las 6 personas. Para Paloma, en cambio, fueron 12 los fundadores de la JOC. Si bien no consigue reconstruir la lista completa, recuerda la sorpresa y alegría que entonces les causó constatar, en la primera misa grupal, que sumaban el número de los discípulos de Jesús, y "asumirse" ${ }^{202}$, en esa coincidencia, como sus seguidores: “'Somos 12', fue como simbólico, "vaya, somos los primeros apóstoles de Pepe", era una cosa así. Así pues que estoy segurísima que eran 12 porque todavía me acuerdo de esa emoción ",203.

Como afirma Baczko (1984), "tan fundamental como su proyección hacia el futuro (en forma de utopía) es para un grupo social su peculiar reconstrucción del pasado. Como parte esencial del imaginario dador de sentido, este elemento simbólico explica y justifica su existencia y su misión". Ya para los primeros jocistas, la organización simbolizaba un nuevo nacimiento del Cristo Obrero en la fábrica, el taller, la oficina o el hogar, que traía la misión histórica de instaurar en los trabajadores los valores católicos como únicos principios capaces de devolver la dignidad del trabajo (Bottinelli et al., 2001) $)^{204}$.

A partir de este núcleo jocista bahiense inicial, se fueron incorporando integrantes, llegando a sumar alrededor de 18 personas. Así, para 1972, se habían constituido dos equipos, a los que diferenciaban como "los grandes" y "los chicos", de 8-9 jóvenes cada uno. Se trataba tanto de varones como de mujeres, nacidos entre 1945 y 1955, con diversas trayectorias laborales. En su mayoría, eran empleados de oficinas, comercios, mercados, bancos o empresas, donde atendían al público, desarrollaban tareas administrativas, eran vendedores o viajantes, o cumplían un servicio técnico. También había trabajadores de fábricas de productos alimenticios, textiles y ligados a la

\footnotetext{
202 "Historia de la JOC", apuntes de Paloma enviados por e-mail, 12/2/2013.

${ }^{203}$ Entrevista a Paloma, vía skype Bahía Blanca-Orrefors, 11/2/2013.

204 Por otro lado, en nuestra historia reciente, encontramos otros grupos con trayectorias ligadas a las redes de renovación católica, que han explicado su origen a partir de un núcleo de 12, como es el caso de Montoneros. En una entrevista a Mario Firmenich y Norma Arrostito publicada en la revista La Causa Peronista de septiembre de 1974, los militantes afirmaban que en el momento del secuestro y asesinato de Aramburu, "toda la organización éramos 12 personas, entre las de Buenos Aires y las de Córdoba" (citado en Anguita y Caparrós, 1997: 367), dando inicio al mito de los 12 fundadores (Lanusse, 2007a).
} 
metalurgia; empleadas en hospitales; docentes de escuelas rurales o de las barriadas pobres de la ciudad; y niñeras. Frecuentemente, los mismos jóvenes tuvieron distintos oficios y ocupaciones asalariadas a lo largo del período en que funcionó la JOC. Por ejemplo, entre 1968 y 1975, Dante se desempeñó como periodista en LNP, personal administrativo en "Sancor", y obrero, primero en la misma empresa y luego, en una fábrica de cerveza. La Rusa ${ }^{205}$ fue empleada de una zapatería para luego trabajar en la lanera "San Blas". Clara, por su parte, cuidó niños, trabajó en el hospital Maternidad del Sur y en una fábrica de fideos ${ }^{206}$.

En varios casos, estos itinerarios laborales habían comenzado a temprana edad, como resultado de una situación familiar marcada por las dificultades económicas -en los casos de Dante, José y Clara, relacionadas con la muerte del padre-, e incluso habían implicado el abandono de los estudios secundarios. En otros, los itinerarios laborales eran más recientes, o incluso transitorios. Así, el paso de Lucy por la fábrica de bombones constituyó una breve y única experiencia de trabajo remunerado, antes de casarse y convertirse en ama de casa. Por otra parte, había jocistas que transitaban experiencias de trabajo temporales mientras completaban sus estudios en institutos terciarios o en la universidad. La inclusión de estos militantes en la rama obrera se ligaba a motivos afectivos. Los vínculos personales con sus integrantes y, en particular, con quienes eran sus parejas entonces, los llevó a formar parte de la rama obrera.

La escolarización de buena parte de estos jóvenes tuvo lugar en instituciones públicas, estatales. Las escuelas primarias a las que asistieron funcionaban en sus barrios de origen (escuela ${ }^{\circ} 4$ del centro, escuela $n^{\circ} 9$ de Tiro Federal, escuela $n^{\circ} 34$ del macrocentro, etc.), mientras que entre las secundarias se destaca el Colegio Nacional público, mixto, ubicado a media cuadra de la plaza central de la ciudad-, seguido por las Escuelas Medias dependientes de la UNS, también localizadas en el centro. Otros jocistas, en cambio, cursaron sus estudios en colegios privados, fundamentalmente, religiosos: San Vicente de Paul, María Auxiliadora y María Mazzarello de Fortín Mercedes $^{207}$. El caso de Paloma es singular porque antes de entrar como pupila a este último, estudió en un colegio mixto presbiteriano. Si bien muchos jocistas no completaron el nivel secundario -al menos en esos años-, como adelantamos, algunos

\footnotetext{
${ }^{205}$ Falleció hace algunos años, era la hermana de Liliana y una de las fundadoras de la JOC. Vivía en Sánchez Elía, era catequista de Nuestra Señora del Carmen y militante del Peronismo de Base.

${ }^{206}$ Véase cuadro de trayectorias jocistas en el anexo metodológico.

${ }^{207}$ A cargo de las Hijas de María Auxiliadora, comenzó a funcionar en 1896. Más tarde, se estableció en la casa de las religiosas un orfanatorio para niñas. En 1947, asistían al colegio 59 alumnas oriundas de la zona, de las cuales 32 eran internas (Boletín Eclesiástico, Bahía Blanca, marzo de 1947).
} 
continuaron estudiando en el nivel superior: en la UNS (Jorge, Paloma y Aldo ${ }^{208}$ empezaron a estudiar Contador, Geografía e Ingeniería Industrial respectivamente), en el Instituto Juan XXIII (Ema comenzó a curar Matemática) y en la Escuela Normal (Paloma se recibió de Profesora en enseñanza elemental). En otros casos, la formación fue complementada con cursos de mecanografía, contabilidad, taquigrafía o inglés.

Desde el punto de vista territorial, los militantes de la JOC estaban fuertemente anclados en Sánchez Elía. Al momento de ingresar al grupo de reflexión, la gran mayoría de estos jóvenes eran vecinos de la "loma" mientras el resto, aunque vivía en los barrios aledaños -también ubicados en el este de la ciudad (Tiro Federal, Harding Green)-, estaba ligado a ella a través de la participación en las actividades de la iglesia del Carmen. La celebración de casamientos entre militantes de la JOC, a partir de 1969, modificó en parte la pertenencia barrial de sus miembros, ya que mientras hubo quienes se quedaron la "loma", otros se mudaron a otros barrios, como el Rosendo López, manteniéndose de todos modos, Nuestra Señora del Carmen como centro de referencia.

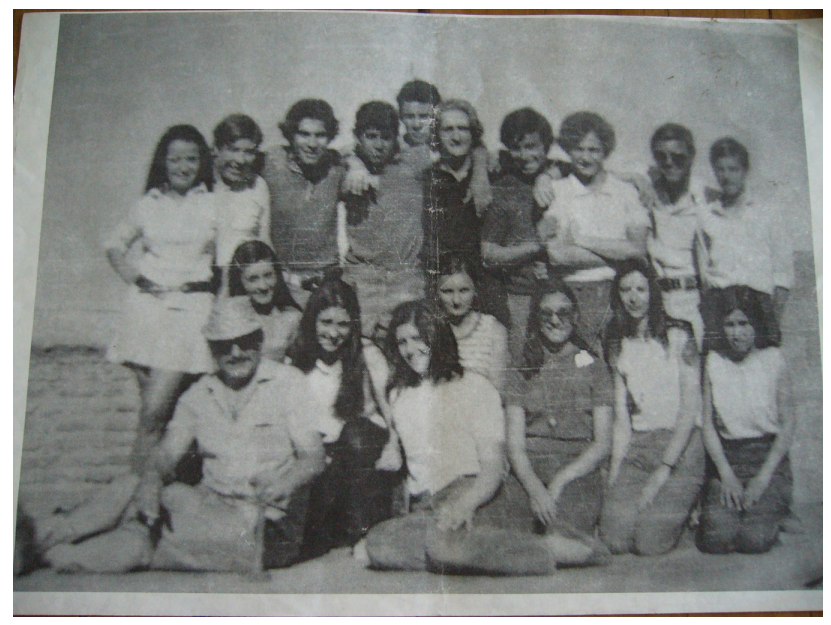

\footnotetext{
${ }^{208}$ Murió en octubre de 2002. Era el compañero de Lucy y hermano de Bruno y Alicia. Vivió en Tiro Federal hasta que se casó, y se mudó al barrio Rosendo López. Fue a la Escuela Normal. Empezó a estudiar Ingeniería industrial en la UNS hasta 1972 que se fue a vivir a Neuquén. Allí siguió estudiando y terminó la carrera en la Universidad Nacional del Comahue en 1976. Mientras estudiaba en la UNS, trabajó en un banco y luego, en un comercio. Participó en la JOC desde su fundación hasta 1972. También integró la JUC. Tuvo militancia de base con los bancarios y luego en Empleados de Comercio.
} 

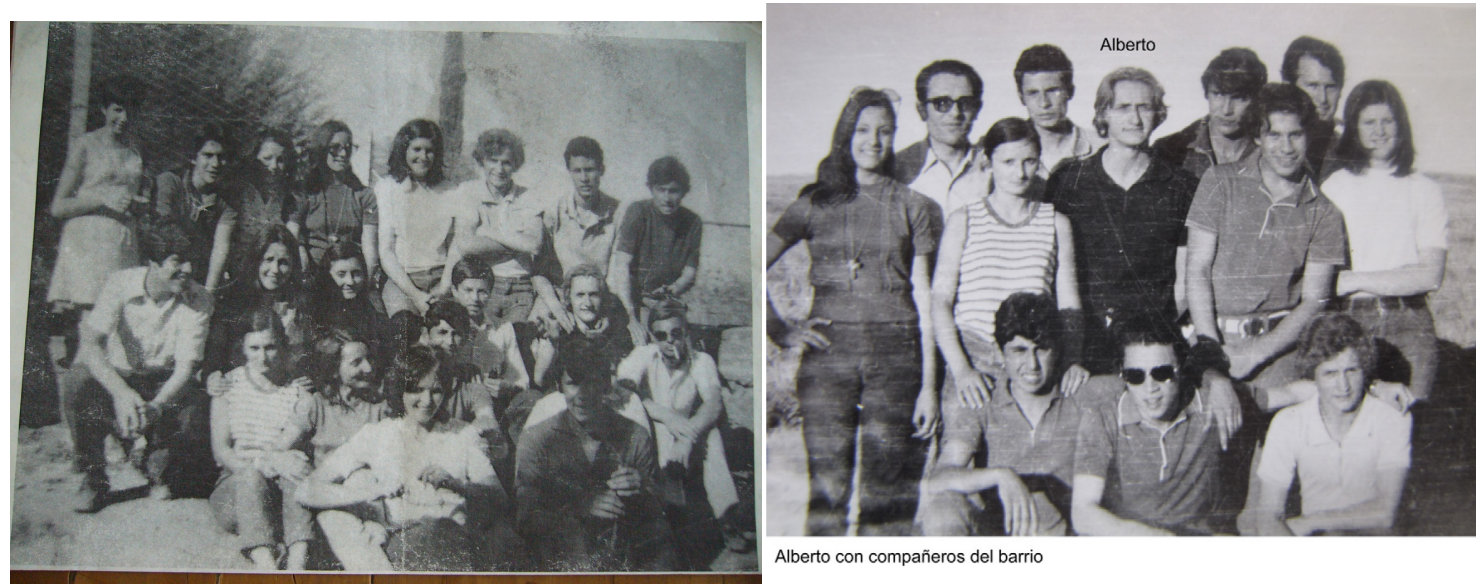

Jóvenes de la JOC y de la JEC de Sánchez Elía.

Por último, la JEC bahiense surgió hacia mediados de 1972 a partir de una propuesta del Padre "Pepe" a los dirigentes más jóvenes del movimiento Guía-Scout de La Pequeña Obra, a algunos Scouts de "San Jorge" y a otros jóvenes que participaban de la parroquia del Carmen. Luego, se incorporaron otros chicos, llegando a sumar alrededor de 30 integrantes, nacidos entre 1954 y 1958, divididos en equipos de 6-7 personas. Además de estar ligados al Scoutismo y Guidismo, algunos de ellos eran también catequistas en esas comunidades. Por otro lado, parte del grupo tenía experiencias de trabajo social en instituciones ligadas al ámbito eclesial o estatal, como voluntarios en Cáritas, en el Pequeño Cottolengo o en el Patronato de la Infancia.

Los grupos de La Pequeña Obra y los de la "loma" funcionaban separados, pero compartían un encuentro anual de formación y revisión. Estas dos comunidades eran diversas en su inserción territorial y composición social. La mayoría de los dirigentes del grupo Guía-Scout de La Pequeña Obra y, luego, también integrantes de la JEC, provenían de sectores medios o profesionales, vivían en el barrio Pedro Pico -ubicado a 15 cuadras de la Plaza Rivadavia-, en el centro o en el universitario, y estudiaban en las Escuelas Medias de la UNS, a excepción de Mario que iba al Colegio Nacional y de Pedro, que cursaba en el Don Bosco. Por otra parte, los miembros de la JEC de Sánchez Elía, en su mayoría, vivían en aquel barrio más popular o venían de los aledaños Tiro Federal o Villa Mitre. Después de haber transitado la escuela primaria en general en el ámbito estatal y en establecimientos ubicados en sus barrios de origen, cursaban el secundario, en algunos casos, en instituciones públicas, como la Escuela de Enseñanza 
Técnica (ENET) N¹ “Ing. César Cipolletti” -sólo para varones- ${ }^{209}$, las Escuelas dependientes de la UNS o el Colegio Nacional; en otros casos, en instituciones privadas religiosas, como La Asunción ${ }^{210}$, o San Vicente de Paul. A pesar de esta diversidad, como plantea Donatello (2010), la sociabilidad católica permitió que personas con posiciones estructurales diferentes tuvieran un imaginario compartido marcado por la renovación católica.

Estos movimientos de Acción Católica especializada tenían un modo común de ingreso al grupo. Los militantes inmersos en un ámbito concreto -en este caso, la escuela, la universidad, el trabajo, el sindicato, el barrio, la capilla- debían invitar a otros, según explicaba "Pepe", "a descubrir este camino de seguimiento de Jesús, con esta perspectiva de compromiso histórico" 211 . Los "contactados" eran frecuentemente compañeros de trabajo, de estudio, de militancia política o de convivencia en el Pensionado Católico, hermanos, amigos, vecinos, participantes de la capilla o de las comunidades ligadas a ésta, o incluso, conocidos de la parada de colectivo. Además de los contactos personales, otra forma de "captación de militantes" era mediante la invitación periódica a participar de actividades más abiertas y masivas, que tenían un carácter recreativo, como campamentos en Sierra de la Ventana, salidas a Pehuen-có, encuentros en el Seminario "La Asunción" o festejos del día del trabajador. Era común en estas jornadas compartir juegos, caminatas, bailes u obras de teatro, y finalizar con la puesta en común de las impresiones e inquietudes de los "acercados".

La "pedagogía de nuevos" tenía una importancia central para el movimiento internacional al que pertenecían la JUC y la JEC - MIEC-JECI ${ }^{212}$-, en cuanto decidía su continuidad en el espacio y en el tiempo, continuidad que se consideraba necesaria en la medida en que se valorara su papel en el ámbito estudiantil. En consecuencia, el movimiento la convirtió en objeto de reflexión, definiendo los criterios y los modos de

\footnotetext{
${ }^{209}$ El colegio estaba ubicado en la calle Chiclana 946, a 9 cuadras del centro. Recién en el año 1977 se trasladó a un nuevo edificio, en el que permanece hasta hoy, ubicado en Azara 1250, en el barrio de Bella Vista. La escuela tenía su sede en una vivienda alquilada que se encontraba, según recuerdan sus alumnos, bastante deteriorada (Seitz, 2010).

210 En 1961, se autorizó el funcionamiento de un colegio dentro del edificio del Seminario Arquidiocesano para estudiantes externos. El nuevo instituto de enseñanza privada fue incorporado a la enseñanza oficial y comenzó a dictar el bachillerato humanista moderno, de 7 años de duración. En 1963, las condiciones de ingreso incluían un examen, una carta de presentación del cura párroco o capellán, el certificado de bautismo y de matrimonio de los padres y el pago de una cuota mensual (Boletín Eclesiástico, Bahía Blanca, enero-marzo de 1961; julio-diciembre de 1963).

${ }^{211}$ Entrevista a José Zamorano, Moreno, 19/9/2009.

${ }^{212}$ Véase el capítulo 3.
} 
llevar adelante la incorporación de militantes ${ }^{213}$. A partir de las diversas experiencias concretas abiertas en el continente, se proponía la "nucleación por integración del movimiento en el medio", esto es, como resultado natural del compromiso de los jóvenes en la realidad universitaria. En ese proceso, los militantes entablaban un diálogo con los otros, cuestionándolos a partir de la acción e induciendo en ellos la actitud de Ver y Juzgar aquellas problemáticas y la comprensión de la necesidad de Actuar en su ámbito. La selección de candidatos se producía de hecho, sin proponérsela deliberadamente entre los compañeros que se encontraban potencialmente motivados para comprender el sentido del movimiento e integrar un equipo de militantes. En consecuencia, las jornadas de iniciación sólo complementaban el proceso anterior, y tenían lugar después de un tiempo de vida de equipo y de trabajo de base, cuya estructura pedagógica se tornaba activa desde el comienzo -asimilándose a la de la revisión de vida-, flexible y diferenciada, adecuándose a la situación y a las necesidades específicas de los ingresantes ${ }^{214}$.

En este marco, en 1969, la JEC planteaba que el movimiento no era proselitista, sino que era descubierto por el medio a través del testimonio de la comunidad y el compromiso personal. Así, la iniciación de nuevos se realizaba por medio de la “concientización" del propio ambiente, la simpatía del joven hacia el movimiento, la manifestación de un deseo de adhesión a Cristo y de servicio a los hombres ${ }^{215}$. Para los actores, se trataba entonces de

hacer consciente a un compañero de tareas de la importancia de encontrar al Señor allí mismo, en sus trabajos y acciones, y ayudar a otros a encontrarlo, de la importancia de un equipo que le posibilitará no caer en un activismo ni a dejarse estar en una apatía, que será una oportunidad constante de conversión ${ }^{216}$.

En efecto, esto logró consolidar los movimientos en pocos años. Pero además, hizo que otros jóvenes en contacto con los jucistas, jocistas o jecistas estuvieran cercanos a ese espacio y, en definitiva, al ámbito de la Iglesia renovadora. Así, hacia 1970 empezaba a darse el fenómeno contrario de los años 1966-1967: mientras en la etapa anterior la JUC se desarticulaba por el éxodo de militantes a partir de sus opciones políticas, ahora se consolidaba con la participación -de diverso tipo y duración- de

\footnotetext{
${ }^{213}$ Véase, por ejemplo, “Cómo se plantea la nucleación en Panamá. Ejemplo de nucleación”, JEC Boletín Secundario, 12-13, febrero-marzo de 1970.

214 "Introducción a una pedagogía de la pastoral universitaria", Servicio de Documentación, 14, mayo de 1968.

215 "Encuentro del Cono Sur. Informe. Líneas pastorales a seguir del movimiento", JEC Boletín Secundario, 9, abril de 1969.

216 "Pedagogía: su finalidad en el movimiento", JEC Boletín Secundario, 11, noviembre de 1969.
} 
militantes con trayectorias religiosas más débiles o provenientes de otras tradiciones. En efecto, según los criterios establecidos por el MIEC-JECI, en principio no era obstáculo la presencia de alguien que no se reconocía cristiano "siempre que él respetara la fe de los demás y su decisión de acrecentarla, comunicarla y celebrarla". En estas condiciones, el ejercicio de la revisión de vida podía ser "un excelente momento apostólico por parte de los creyentes" ${ }^{217}$. Diana, que para esa época había dejado de considerarse católica, se había desvinculado de la Iglesia y cuestionaba fuertemente la religión, describía su relación con los grupos cristianos:

[había] retiros que se hacian en un lugar muy lindo, como encuentros de 2-3 días, o de una semana y se discutía, entonces yo iba ahi pero como no creyente, llevada por estos amigos...Me acuerdo que en esas misas que eran distintas a las habituales, que ya se hacian con guitarra y con canto, pedian por mi [...] también por él [su primer pareja] tenía mucho contacto con todo el grupo y, si querés tenía como una afinidad de vivencias, pero no me lograron volver al rebaño (risas) ${ }^{218}$.

Esta forma de ingreso al grupo a través de la invitación de un integrante del mismo ya estaba presente en los orígenes de la JOC en Argentina y marcó a las diversas experiencias jocistas en el país. Según los Estatutos, para pertenecer a una sección de la JOC, se requería ser presentado por un socio y aceptado por la comisión directiva de la sección. Por otra parte, en coherencia con el espíritu integralista, "un jocista ciento por ciento" era aquel que, entre otras cosas, "conquista[ba] nuevos camaradas para el movimiento" (Bottinelli et al., 2001: 103-104). En este sentido, un militante cordobés de las décadas de 1940 y 1950 contaba que la "captación" era "de persona a persona, o sea, mi compañero de estudio, mi compañero en el colegio, mi compañero en el taller, mis amigos en la barra, en las canchitas de fútbol. Hacerles descubrir la importancia de lo que es ser persona humana,"219.

Una vez que el "acercado" decidía sumarse a la JUC, la JOC o la JEC asumía un compromiso con el grupo, que debía ser total, y que implicaba participar con responsabilidad y disciplina en las actividades comunes, entre las que los encuentros de "revisión de vida" ocupaban un lugar central. De allí que los militantes las vivieran como "obligatorias" 220 , dándole continuidad y estabilidad al grupo. Estas reuniones

\footnotetext{
217 "La revisión de vida", Spes, 27-28, s/f (posiblemente fines de 1975).

${ }^{218}$ Entrevista a Diana, Bahía Blanca, 18/9/2009.

${ }^{219}$ Testimonio de O.M. citado en Blanco, 2008: 20.

${ }^{220}$ Entrevista a Paloma, vía skype, 11/2/2013 y 22/2/2013; a Mirta y Jorge, Bahía Blanca, 14/7/2012. "Historia de la JOC en Bahía Blanca", apuntes elaborados por la JOC de Grünbein a partir de los relatos de Mirta y Jorge, en los primeros años de la década de 1980.
} 
congregaban a cada equipo semanalmente, contaban con la compañía del asesor, tenían lugar en las casas de los militantes -en los casos de la JUC y la JEC- o de "Pepe" -en el de la JOC-, o bien en la Curia -donde "Coco" Segovia era secretario- y se orientaban a reflexionar sobre la vida de los jóvenes al ritmo de Ver, Juzgar y Obrar. A su vez, los equipos contaban con coordinadores, que se reunían periódicamente con los asesores.

Había otras instancias de encuentro significativas para los movimientos, como la misa, que se caracterizaba por la homilía compartida, esto es, construida entre todos los asistentes, sacerdotes y laicos. En el caso de la JUC, la celebración tenía lugar los sábados a la tarde en La Pequeña Obra, reuniendo a los jóvenes de los distintos grupos. Las misas jocistas, en cambio, se celebraban en la casa parroquial de Nuestra Señora del Carmen, alrededor de la mesa de "Pepe". En cuanto a los jecistas, los de Sánchez Elía participaban de las celebraciones de la capilla, mientras los equipos de La Pequeña Obra, lo hacían en el centro pastoral junto al resto de la comunidad.

Por otra parte, en el verano la JUC, la JOC y la JEC respectivamente compartían campamentos o encuentros anuales donde se preparaban temas de formación, reflexión y revisión grupal, se leían y discutían documentos del Concilio, de Medellín y publicaciones del MIEC-JECI, y se constituían en momentos importantes de socialización para los jóvenes. Éstos se realizaron en Pehuen-có o en Villa La Inmaculada $^{221}$. Luis, por ejemplo, evocaba un campamento de la JUC en la playa en el que se discutió sobre la teología de la liberación ${ }^{222}$.

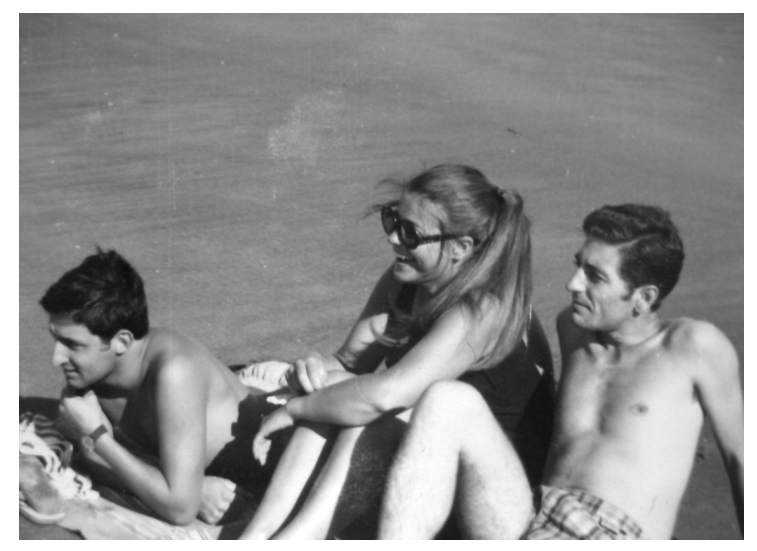

Jucistas en un campamento en la playa.

\footnotetext{
${ }^{221}$ Lugar de recreo y retiros espirituales del Colegio La Inmaculada, ubicado en terrenos cercanos a la Estación ferroviaria de Grünbein y al Seminario Arquidiocesano, sobre la ruta provincial 229, y comprado en 1965 con una superficie de casi 20 hectáreas (Bracamonte, Torre y Vila, 2004).

${ }^{222}$ Entrevista a Luis, Bahía Blanca, 18/12/2008.
} 
En efecto, las vacaciones eran un momento privilegiado para las actividades del MIEC-JECI en todo el continente. Los equipos de secundarios y universitarios solían organizar campamentos para la gente nueva y/o para los militantes y dirigentes, que tenían lugar generalmente fuera de la ciudad, en el campo o en la costa. Esta instancia de convivencia tenía una triple finalidad: revisar y planificar la acción de cara al nuevo año, apuntalar la formación de los militantes y generar un espacio de recreación ${ }^{223}$.

Susana señalaba de los campamentos jucistas: "lo pasábamos re bien...ahí estaba Benito Santecchia contando cuentos y era fantástico „224. Si bien no pertenecía al movimiento, la presencia del salesiano era frecuente en las instancias de encuentro de estos grupos, en las que aportaba su vasta formación teológica. A los lazos tejidos por la JUC, la JOC y la JEC con otros referentes y grupos identificados con la renovación eclesial, así como a sus cruces con otros ámbitos eclesiales, dedico el próximo capítulo.

223 "JEC y vacaciones", JEC Boletín Secundario, 8, noviembre de 1968.

${ }^{224}$ Entrevista a Susana, Bahía Blanca, 1/4/2009. 


\section{CAPÍTULO 3: Espacios de sociabilidad y redes sociales del catolicismo liberacionista en Bahía Blanca}

\section{SUMARIO}

1) Grupos y referentes
a) Los laicos
b) Los sacerdotes "tercermundistas"
c) Las religiosas.

2) Vínculos e interacciones

a) Los lazos tejidos entre los católicos liberacionistas en el espacio local

b) Los grupos de la renovación católica y otros sectores eclesiales en la ciudad

i) Cruces y conflictos

c) La articulación con otros ámbitos del catolicismo liberacionista a nivel nacional e internacional

i) MSTM, CUT, Cristianismo y Revolución

ii) Las redes jocistas

iii) EI MIEC-JECI

iv) Las influencias de los teólogos latinoamericanos

En Bahía Blanca, fue a partir de 1968 que cristalizaron las relaciones entre referentes y grupos católicos, que en algunos casos eran nuevos mientras en otros, experimentaban una renovación aunque estaban enraizados en el desarrollo del movimiento de las décadas previas. Todos ellos compartían una matriz católica “integral” y la identificación con el aggiornamento eclesial, que, como analizamos en el primer capítulo, supuso importantes cambios en la concepción de la Iglesia y de su relación con el mundo. Así, estos cristianos liberacionistas abrazaron la idea de "compromiso" y asumieron diversas formas de intervención pública y de militancia social y política con la intención de participar en la transformación de la realidad, en un contexto histórico -local, nacional y latinoamericano- marcado por la efervescencia social.

Estas experiencias -y los lazos tejidos entre ellas- se prolongaron hasta 1975, año en el que los referentes consagrados y muchos jóvenes de aquella línea eclesial comenzaron a sufrir persecución política, atentados, asesinatos $\mathrm{y}$ amenazas, constituyéndose así en una de las víctimas de las bandas paramilitares. Estas prácticas represivas, sumadas a los asesinatos, las desapariciones y la cárcel, provocaron la 
desestructuración de la militancia católica contestataria y la desarticulación de la red social de la renovación eclesial en Bahía Blanca.

Una vez caracterizadas las ramas especializadas de Acción Católica en Bahía Blanca, en este capítulo me propongo ubicarlas en relación a los espacios de sociabilidad ligados al aggiornamento eclesial, así como las redes sociales que éstos articularon en el espacio local, nacional y latinoamericano. Para ello:

a) describiré a otros integrantes de la red de la renovación católica bahiense: laicos, sacerdotes y religiosas. ¿Cuáles fueron los ámbitos de sociabilidad concretos de los militantes católicos identificados con dicha renovación? ¿Qué formas de funcionamiento, espacios de encuentro y prácticas permiten caracterizarlos?

b) reconstruiré los vínculos e interacciones de estos grupos a nivel local, nacional e internacional. ¿De qué modo esas experiencias articularon una red de relaciones en Bahía Blanca, en Argentina y en América Latina? ¿Qué formas de interacción acercaron a estos actores y a los círculos sociales ${ }^{225}$ que integraban? ¿Qué valores e intereses comunes cimentaron esos vínculos?

c) Por otra parte, en el primer ámbito, me detendré en las relaciones que establecieron con otros sectores eclesiales (la jerarquía, el resto del clero, otros miembros de sus comunidades parroquiales).

\section{1) Grupos y referentes}

\section{a) Los laicos}

El grupo Scout “San Pío X” de La Pequeña Obra había sido fundado en 1961 por la hermana Kotska ${ }^{226}$ y el de las Guías "Santa Juana de Arco" en 1963, siendo ambos de los más consolidados de la ciudad. Un núcleo de dirigentes jóvenes desarrollaba un trabajo sistemático no sólo en relación a la planificación de actividades destinadas a los niños, sino también a la discusión en torno a determinados textos y hechos de la realidad. En cuanto a las primeras, compartían la inquietud de ir más allá de propuestas meramente recreativas y promover momentos de reflexión con los chicos dedicados a temas como la solidaridad, el compañerismo o la necesidad de compartir.

\footnotetext{
${ }^{225}$ Siguiendo a Catoggio (2010), tomamos el concepto de círculo social como sinónimo de espacio concreto de sociabilidad.

${ }^{226}$ Véase el apartado dedicado a las religiosas.
} 

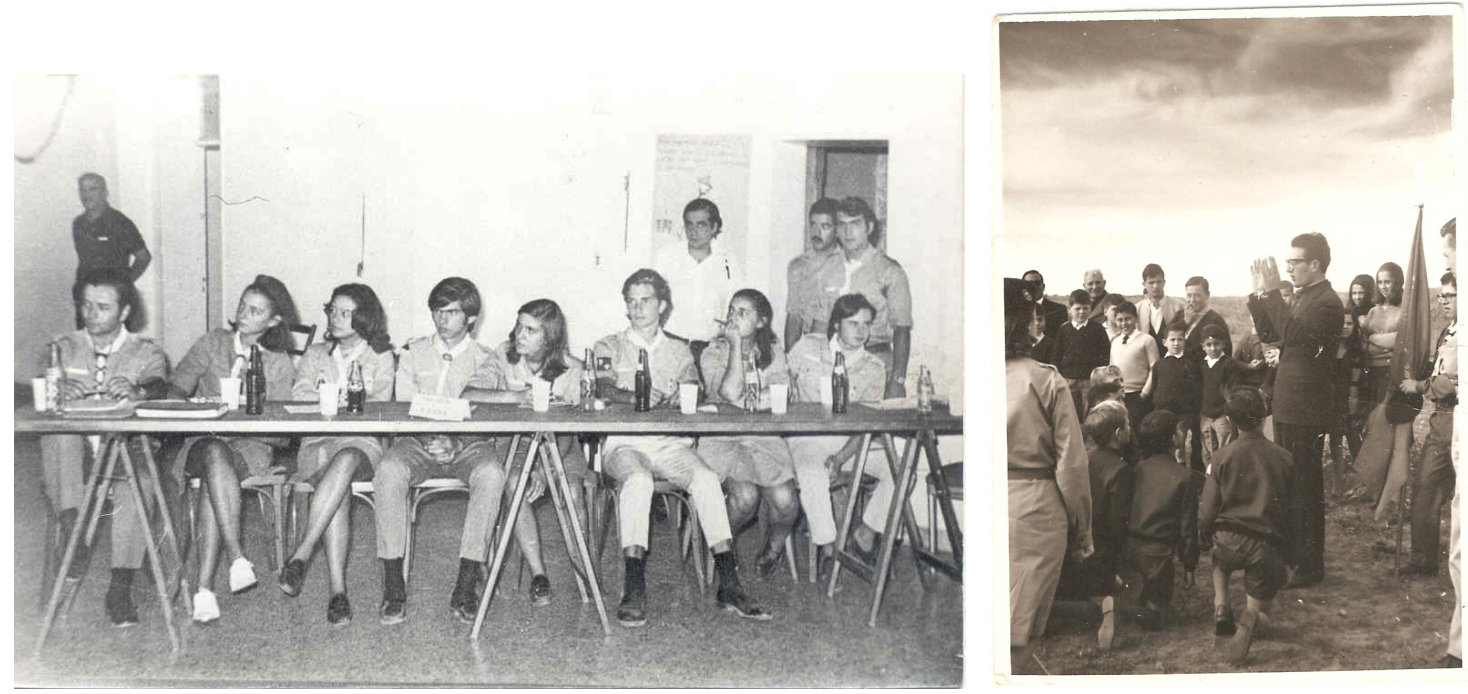

Izq.: Dirigentes de la comunidad Guía-Scout de La Pequeña Obra, en 1972. Der.: "Pepe" y los primeros lobatos de "San Jorge" en Sánchez Elía.

Por otra parte, el grupo Scout "San Jorge” surgió en 1966 en Nuestra Señora del Carmen de Sánchez Elía, una vez que los sacerdotes españoles se habían hecho cargo de la capilla. Como mencionamos, "Pepe" y Emilio ya habían fundado un grupo Scout en Coronel Suárez con ayuda de Kotska. Así, algunos dirigentes de La Pequeña Obra colaboraron en la creación del nuevo grupo y prepararon a los primeros dirigentes de la "loma", reclutados en la comunidad de la parroquia y entre los vecinos del barrio. Se formó entonces la "manada" y se construyó, con la ayuda de los padres de los "lobatos", un pequeño espacio para desarrollar las actividades.

El Grupo Misionero Bahiense (GMB) comenzó a reunirse a fines de los años sesenta. Estaba integrado por una quincena de jóvenes, la mayoría de Bahía Blanca y algunos de Punta Alta, vinculados, de un modo u otro, al ambiente salesiano: eran egresados del colegio Don Bosco o estudiantes del Instituto Juan XXIII. Buena parte de las chicas habían cursado el secundario en La Inmaculada y algunas eran religiosas de la Compañía de María. Otros misioneros habían sido alumnos de Miguel Sarmiento en el Seminario Catequístico ${ }^{227}$. Además, participaban tres seminaristas. El grupo misionaba en enero en San Germán (provincia de Buenos Aires). En esos días, visitaba a los habitantes del lugar, celebraba misas y organizaba charlas sobre temas específicos, como la educación sexual. A veces, en Semana Santa o vacaciones de invierno, volvía al lugar. Durante el año, realizaba reuniones -que en muchos casos tenían lugar en La

${ }^{227}$ Véase el siguiente apartado, dedicado a los sacerdotes. 
Inmaculada y contaban con la presencia de religiosas que tenían gran afinidad con los integrantes- para consolidar el grupo, planificar la misión, discutir documentos eclesiales y organizar actividades para recaudar fondos.

Además de los grupos juveniles, había adultos profesionales identificados con la apertura eclesial que formaban la Comunidad Universitaria Bahiense (CUB). Eran egresados y/o docentes de la UNS y del Instituto Juan XXIII. Ligados por la amistad cimentada en sus trayectorias comunes en la Acción Católica y/o en la Liga de Estudiantes Humanista del Sur, se reunían periódicamente desde mediados de los años sesenta para analizar hechos de la realidad a la luz del pensamiento conciliar, leer documentos eclesiales y revisar las acciones de la Iglesia local. A diferencia de la Acción Católica especializada, la CUB no contaba con un sacerdote asesor, aunque compartía encuentros con el Padre Pipo primero, y con Duilio Biancucci y Benito Santecchia, más tarde. Sus miembros tenían ámbitos de acción fuera del grupo: se comprometían en la política universitaria y colaboraban o participaban en actividades del GMB y de Cáritas.

Por otro lado, Cáritas Arquidiocesana ${ }^{228}$ comenzó a funcionar en 1969, con Néstor Navarro ${ }^{229}$ y un primer grupo de colaboradores recién egresados del secundario y estudiantes de la Escuela de Servicio Social. Inicialmente se reunían en la Curia y en La Inmaculada hasta que, a fines de ese año, se trasladaron al edificio donde también funcionaba el Seminario de Catequesis. Luego, se fueron sumando equipos de voluntarios integrados fundamentalmente por jóvenes. La institución se dedicó a organizar la ayuda inmediata, aunque con una mirada promocional, una fuerte preocupación por no caer en el asistencialismo y la premisa de que los hermanos necesitados eran "otros Cristos",230. Así, tomaron forma distintas iniciativas, como el equipo de trabajadores sociales, los servicios jurídico, de farmacia, y de alimento y ropa, los grupos de voluntarios que trabajaban en centros de salud y un comedor popular. Por otro lado, el vínculo con La Inmaculada dio cauce al proyecto de crear la escuela Nuestra Señora de La Paz, teniendo como representante legal al director de Cáritas. De este modo, se buscaba responder a las necesidades educacionales del barrio y avanzar en la promoción humana. Para obtener recursos económicos, Cáritas compró

\footnotetext{
${ }^{228}$ Tenía como antecedente la Fraterna Ayuda Cristiana, que había sido disuelta en 1967 por el arzobispo Esorto, a raíz de conflictos internos. "Entrevista con Emma Vila, canciller del Arzobispado de Bahía Blanca", Horizontes, 36, agosto/septiembre de 2009.

${ }^{229}$ Véase el apartado dedicado a los sacerdotes.

230 “Testimonio del Padre Néstor Navarro", Horizontes, 36, agosto/ septiembre de 2009.
} 
un mimeógrafo que le permitía vender apuntes a los estudiantes del Instituto Juan XXIII. De ello se encargaba un grupo de alumnos de $5^{\circ}$ año de los colegios Don Bosco, La Inmaculada y María Auxiliadora. Toda la actividad se acompañaba con reuniones de revisión de la tarea y de oración, en las que el grupo compartía la lectura del Evangelio y de documentos eclesiales.

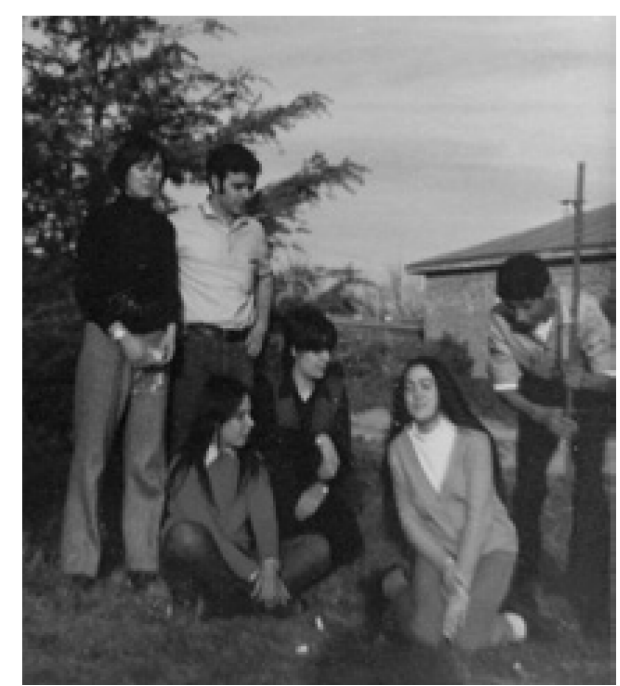

Integrantes de Cáritas, entre ellos Elsa Noemí "Coca" Pablo ${ }^{231}$ (la primera joven sentada a la izquierda). Fuente: Horizontes, 36, agosto-septiembre de 2009.

Por último, en la vecina ciudad de Punta Alta funcionaba la Juventud de Acción Católica (JAC), integrada por jóvenes varones, mayoritariamente estudiantes universitarios, que se reunían semanalmente en la casa del asesor, Hugo Segovia. Por otro lado, en los primeros años setenta, se formaron los Grupos Juveniles Menor y Mayor, nucleados y acompañados en la iglesia Cristo Rey por el Padre Sarmiento. Ésta se constituyó en una experiencia parroquial singular, ya que se eliminaron toda clase de aranceles, se organizó un consejo de administración con representantes de todos los grupos, que gestionaba el aporte voluntarios de socios y coordinaba las tareas de la parroquia. Se crearon, además, un club deportivo infantil, una farmacia popular, una biblioteca barrial y Cáritas ${ }^{232}$. A los grupos iniciales de la parroquia, formados por adolescentes y jóvenes de ambos sexos del barrio suburbano Nueva Bahía Blanca, se

\footnotetext{
${ }^{231}$ Entre marzo de 1973 y agosto de 1975, se desempeñó asistente social de la Escuela Nuestra Señora de la Paz, según consta en el Libro de designaciones de la misma (Archivo del Arzobispado de Bahía Blanca). "Coca" nació en Río Colorado en 1951. Estudió en la Escuela de Servicio Social en Bahía Blanca. Militó en la JP-Montoneros, junto a su compañero Carlos Vicente. Ambos fueron secuestrados en Córdoba, en noviembre de de 1976, y trasladados al CCD "La Perla". "Coca" continúa desaparecida.

232 "Parroquia Cristo Rey", "Capilla Cristo Rey", "Club Defensores de Cristo Rey", Reporte. La revista puntaltense, 10, 18 y 20, febrero, octubre y diciembre de 1974.
} 
sumaron integrantes provenientes del antiguo grupo de Segovia y militantes del peronismo revolucionario (JP, UES y JTP) de Punta Alta. Estos grupos juveniles tenían reuniones semanales de reflexión y llevaban adelante tareas específicas: el Menor estaba a cargo de la farmacia popular "Carlos Mugica" y la biblioteca "Nuevo Hombre" de la parroquia, además de colaborar con el club y proyectar audiovisuales; el Mayor buscaba realizar tareas de inserción y servicio en el barrio -participaba, por ejemplo, en la sociedad de fomento o en campañas para el hospital-, teniendo como objetivo la "liberación nacional",233.

\section{b) Los sacerdotes "tercermundistas"}

Además de los laicos, los espacios sociales identificados con la renovación católica en Bahía Blanca estaban integrados por sacerdotes diocesanos y salesianos. Los presbíteros habían recibido su formación durante los años anteriores al Concilio Vaticano II, cuando ya se respiraban los aires de renovación eclesial, o bien durante el mismo. En el período 1968-1975, trabajaban y desarrollaban tareas pastorales en diversos espacios.

Los misioneros españoles José Zamorano y Emilio Flores estaban abocados, como hemos visto, al trabajo en la capilla del Carmen o en La Pequeña Obra, y al acompañamiento de grupos Scouts, la JUC, la JOC y la JEC, además de algunas horas de docencia a nivel secundario y/o terciario. "Pepe" también integró el MSTM.

Hugo Segovia era secretario canciller de la Curia (1967-1974) y coordinaba la JAC de Punta Alta. En los años anteriores, había sido prosecretario de la Curia, secundando al Padre Norman Pipo (asesor de la JUC hasta 1967). El vínculo con Pipo lo llevó a ser asesor del Pensionado Católico y a estar cercano a la JUC.

Miguel Sarmiento acompañaba el Grupo Misionero Bahiense, era Director Arquidiocesano de Catequesis -teniendo a cargo el Seminario Catequístico Arquidiocesano-, y, desde 1972, párroco de Cristo Rey de Punta Alta. Participó de diversos encuentros del MSTM.

Arriba.: Hugo Segovia (el primero de la izquierda) y Miguel Sarmiento (con anteojos), junto a militantes de los grupos juveniles de Punta Alta. Abajo Izq.: Ordenación de Miguel Sarmiento, a cargo del arzobispo Geminiano Esorto. Tornquist,

233 “Parroquia Cristo Rey", Reporte. La revista puntaltense, 10, febrero de 1974. 
16/12/1967. Abajo Der.: Néstor Navarro y "Pepe" Zamorano concelebrando la misa por el matrimonio de jóvenes jucistas en Nuestra Señora del Carmen.
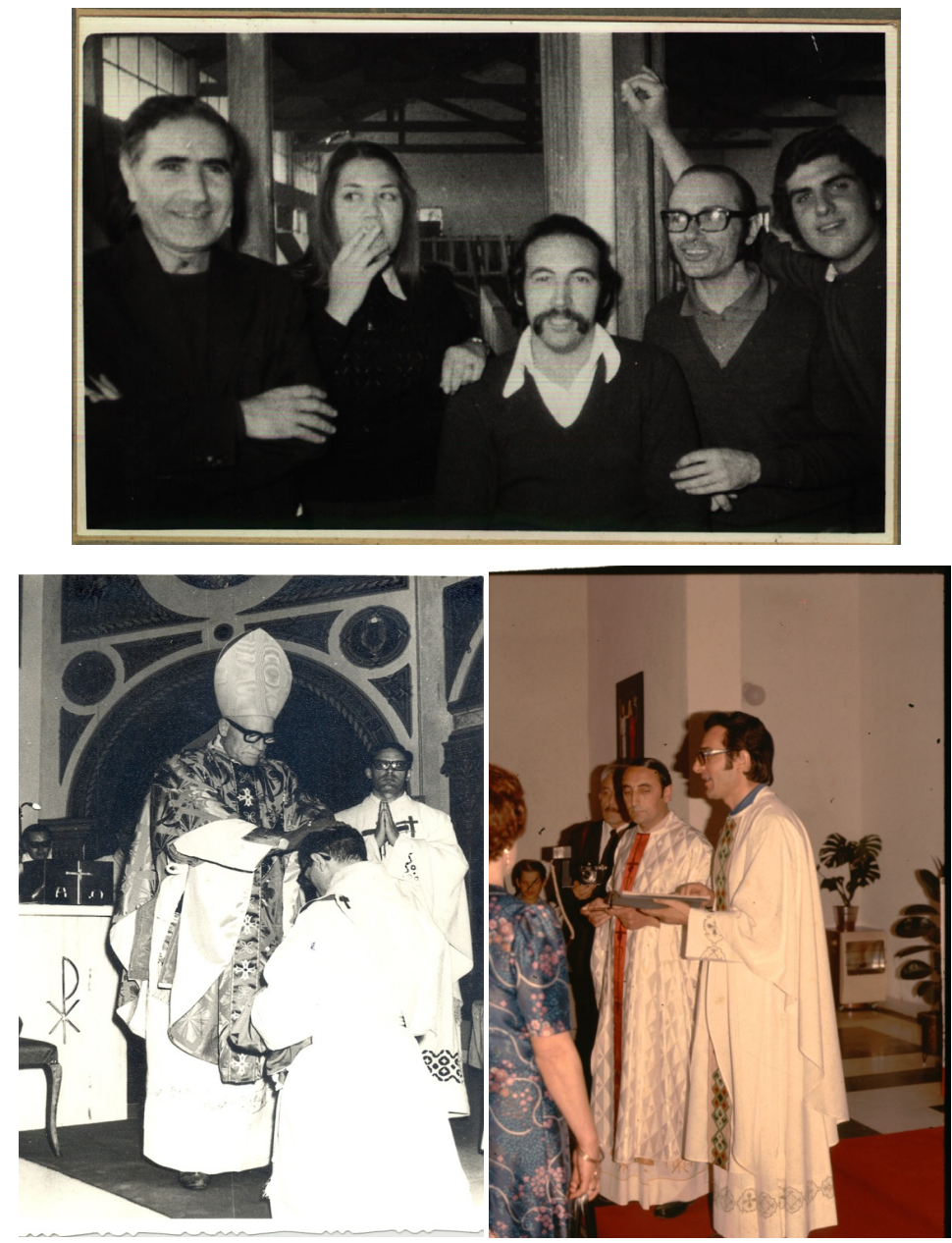

Néstor Navarro era el director de Cáritas Arquidiocesana y, a partir de 1971, representante legal de la escuela Nuestra Señora de la Paz, ubicada en el barrio periférico de Villa Nocito ${ }^{234}$. Por otra parte, fue designado por Monseñor Jorge Mayer

\footnotetext{
${ }^{234}$ La instalación de este núcleo precario comenzó a fines de la década de 1960 y comienzos de la década de 1970 (Formiga y Marenco, 2000). Un informe de inteligencia nos brinda una descripción sucinta del barrio en aquellos años. Ubicado al oeste de la ciudad, a 35 cuadras del centro, ocupaba el triángulo formado por el Canal Maldonado y las vías del ferrocarril en una extensión de $58.700 \mathrm{~m} 2$, con terrenos de propiedad privada. Tenía una población de 376 personas, la mayoría argentinos pero con un alto porcentaje de chilenos. El 57\% de los habitantes eran menores en edad escolar. Había dos instituciones educativas: la Escuela ${ }^{\circ} 24$ y la Escuela Nuestra Señora de la Paz. No existía ningún centro sanitario o asistencial, por lo que su creación era visualizada como una de las necesidades más urgentes. El barrio contaba con una Unidad Básica dirigida por el peronismo de izquierda y se encontraba dentro del radio de acción del Comité de Defensa Barrial Noroeste -ligado al Frente Antiimperialista y por el Socialismo-, del que los servicios subrayaban su "infiltración marxista y trotzkysta". Se destacaba la influencia en el lugar del MSTM a través de Néstor Navarro y de Norma Gorriarán, que era señalada como la persona de mayor arraigo entre la gente del barrio, junto al referente peronista que dirigía la Unidad Básica. Archivo DIPBA, Mesa "Referencia", Legajo 10141, Tomo 2.
} 
encargado de asistir a los refugiados políticos llegados de Chile, a partir del golpe de Estado de 1973.

Benito Santecchia integró la comunidad salesiana del Instituto Juan XXIII entre 1968 y 1975, fue profesor del mismo, y rector en 1973. Su vasta formación como teólogo lo convirtió en un reconocido disertante de encuentros, charlas y jornadas, organizadas no solamente en el ámbito católico -como el Seminario Nacional de Catequesis realizado en Corrientes en 1969, el Primer Encuentro Regional de Cáritas Argentina Zona Sur celebrado en Bahía Blanca en 1972, los espacios de formación de la JUC o los encuentros periódicos de los distintos grupos liberacionistas de la ciudad-, sino también fuera de éste.

Duilio Biancucci, perteneciente a la misma congregación, llegó a Bahía Blanca en 1970, a pedido del inspector salesiano de la Patagonia. En la ciudad, en la que permaneció hasta 1973, fue profesor de Filosofía y Sociología en el Instituto Juan XXIII, y -desde 1971-, de Sociología en el Departamento de Humanidades de la UNS. Celebró misa en la iglesia del Colegio Don Bosco y en la Catedral hasta fines de 1970, en el que fue interrumpido por tres personas mientras desarrollaba el sermón, incidente que ocasionó diversas repercusiones públicas y luego del cual no se le permitió seguir celebrando. No integró el MSTM pero valoraba el trabajo del movimiento ${ }^{235}$.

Benjamín Stocchetti, también salesiano, fue profesor del Instituto Juan XXIII desde principios de los años setenta hasta las semanas posteriores al atentado que le costó la vida a Carlos Dorñak -ocurrido el 21 de marzo de $1975{ }^{236}$. Durante algunos años viajó semanalmente de Viedma a Bahía Blanca para dar Filosofía, Teología o Formación cristiana. Luego fue trasladado a Bahía Blanca, desde donde continuó sus tareas docentes en ambas localidades. En 1974 y 1975 fue rector del Instituto salesiano. Por otra parte, animó un grupo juvenil y se turnó con sus compañeros para dar misa en distintas iglesias. Estando en esta ciudad, se integró al MSTM, comenzó a participar de sus encuentros hasta su disolución y durante un tiempo actuó como referente de la zona

\footnotetext{
${ }^{235}$ Duilio se fue de la congregación salesiana en 1975 para unirse a la diócesis de Morón, donde se desempeñó como profesor de la Universidad Nacional de Luján. En agosto de 1976, dejó el país rumbo a Alemania. Ingresó nuevamente a la congregación en Argentina, en 1991, y la abandonó definitivamente cuatro años más tarde, regresando a la diócesis de Paderborn (Alemania). Comunicación con Duilio Biancucci vía e-mail 19/7/2012; Legajo de Duilio Biancucci, Archivo Histórico Salesiano Patagónico; y "Biancucci, Duilio", en: Diana, 2013: 245-250.

236 Véase el apartado "Cruces y conflictos" en este capítulo.
} 
$\operatorname{sur}^{237}$. Por último, Oscar Barreto integró también la comunidad salesiana del Instituto Juan XXIII, donde se desempeñó como profesor, y participó del MSTM.

Más allá de las distintas actividades que cada uno de estos sacerdotes desarrollaba, se fueron acercando y comenzaron a reconocerse $-\mathrm{y}$ a ser reconocidos por otros- como un grupo, a partir de la común adhesión a las propuestas del Concilio y de Medellín. Además, se identificaban con los principales lineamientos del MSTM, aunque como grupo no expresaron su adhesión de manera explícita ${ }^{238}$. Los sacerdotes eran llamados los "tercermundistas". Sin embargo, algunos de ellos pertenecían al movimiento y otros no ${ }^{239}$.

Como explica Martín (2010), el epíteto “tercermundista” resulta complejo porque connota semánticas opuestas y puede denotar individuos distintos. Si las opiniones corrientes llevarían a incluir en este colectivo a sujetos como Benito Santecchia ${ }^{240}$, un examen detenido muestra que muchos de ellos no han pertenecido al MSTM. En efecto, el movimiento no tuvo formalidades de ingreso ni titularidad de pertenencia. Sus formas sociológicas eran flexibles, aunque no indiferenciadas. No poseía una lista central estable, sino listas regionales ocasionalmente móviles. No obstante, es posible determinar en concreto la identidad de los Sacerdotes Para el Tercer Mundo atendiendo a su participación recurrente en la firma de declaraciones, en las reuniones o en las instancias organizativas del movimiento. Así, este colectivo incluía tanto a militantes como adherentes, mientras dejaba afuera a un conjunto de simpatizantes. La admisión se resolvía en cada diócesis sobre la base de criterios que, sin ser vagos, eran muy generales, como la aceptación de una serie de ideas expresadas en documentos recientes del catolicismo, interpretados en una tónica de "urgencia" y en una perspectiva de extensión a la realidad social); y el "compromiso" de la acción, es decir, de llevar a la práctica en la integridad de la vida aquellos llamados de urgencia.

\footnotetext{
${ }^{237}$ Entrevista a Benjamín Stocchetti, vía e-mail, 25/7/2012.

238 Según Miguel Sarmiento, esta decisión tenía como fin no exponerse y evitar conflictos en la Arquidiócesis. Entrevista a Miguel Sarmiento, Punta Alta, 29/11/10 y 11/2/11.

239 Entrevista a Néstor Navarro, Bahía Blanca, 18/11/10; y a Miguel Sarmiento, Punta Alta, 29/11/10.

${ }^{240}$ En 1990, Benito exponía sus cuestionamientos al MSTM. Para el salesiano, el cristianismo no era una ética solamente; era necesario conservar la riqueza de la tradición católica, que pensaba las cosas desde la encarnación, mediación de extremos y, al mismo tiempo, misterio: “si negás el misterio y la experiencia de la fe, la mediación se rompe y necesariamente te corrés como un tobogán por alguno de los extremos. El catolicismo puede terminar entonces o en un gnosticismo o en un marxismo", quedándose uno "sin la tierra" y el otro, "sin el cielo". Así, la experiencia de la fe no podía trasladarse a una "simple defensa" de la justicia social. Y entendía que el MSTM habría significado una reducción y un alejamiento del lenguaje dialéctico de la fe (Entrevista a Benito Santecchia por J. P. Martín, Buenos Aires, 15/12/1990, en Martín, 2013: 407-422).
} 
Como grupo, los bahienses compartían una reunión semanal, que se llevaba adelante indistintamente en La Pequeña Obra, en la casa de "Pepe" Zamorano o en el Pequeño Cottolengo. Además de los presbíteros mencionados, participó en algunas oportunidades, el diocesano Eliberto Baudry, así como las religiosas que estaban a cargo de La Pequeña Obra. Por otra parte, en sintonía con la propuesta ecuménica del Concilio, recibían la visita de pastores de las Iglesias valdense y metodista (Segovia, 2008). En estos encuentros, que duraban gran parte del día, compartían lo vivido en la semana, reflexionaban sobre las lecturas bíblicas correspondientes a la liturgia del domingo y preparaban en conjunto la homilía en relación a los últimos acontecimientos. Así, en el período en que se replicaron estos encuentros (1969-1975) los sacerdotes difundieron el mismo mensaje en distintas misas de Bahía Blanca y Punta Alta, aunque adaptado a los diversos interlocutores.

\section{c) Las religiosas}

Por otra parte, ciertas órdenes y congregaciones religiosas femeninas se vieron marcadas por el aggioramento de la Iglesia Católica. Entre ellas, la Compañía de María $^{241}$, que tenía a su cargo el colegio La Inmaculada. Esta apertura se reflejó en la creación, en conjunto con Cáritas, de la escuela Nuestra Señora de la Paz en 1971 y, un año después, en la inserción de una comunidad de cinco religiosas -algunas de las cuales trabajaban en esa escuela mientras otras lo seguían haciendo en La Inmaculadaen Villa Nocito. En otras ciudades del país, varias congregaciones femeninas también empezaban a descentralizar la distribución de su personal, atendiendo zonas marginadas, lo que debe entenderse como expresión del proceso de renovación de la vida religiosa (Gera y Rodríguez Melgarejo, 1970).

La escuela surgió a partir de la iniciativa de la hermana Norma Gorriarán-que hacía un tiempo que visitaba el barrio acompañando a otra religiosa que atendía un jardín de infantes-, y del Padre Navarro, que propusieron a Monseñor Esorto convertir el edificio de una iglesia abandonada en escuela. El arzobispo aceptó, pero puso como condición que se celebrara misa los domingos. La escuela, ubicada en Francia 2150,

\footnotetext{
${ }^{241}$ Norma recordaba una anécdota que lo ilustra: "lo que éramos las monjas era como...otro tipo de vida mucho más avanzado que el de ahora, más abierto, tal es así que me acuerdo que la Madre General una vez que vino de Roma me autorizó a salir con los chicos a pintar paredones. Hoy una monja no saldría a pintar paredes (risas), ¿no cierto?”. Entrevista a Norma Gorriarán, Bahía Blanca, 29/10/2008.
} 
abrió sus puertas el 14 de marzo de 1971 con una matrícula de más de 100 alumnos $^{242}$, contando con tres aulas -de $1^{\circ}, 2^{\circ}$ y $3^{\circ}$ grado-, y teniendo como directora a Norma. Con el tiempo, se construyeron más aulas y una sala para la dirección gracias a la ayuda de los padres, vecinos y un grupo "de apoyo"243 que se acercaba a trabajar no sólo en cuestiones materiales sino de reflexión y estudio. Por las noches, funcionaba el Centro de Educación de Adultos $N^{\circ}$ 20. Por otro lado, se ofrecía la merienda, se daba catequesis y se enseñaba corte y confección. Asimismo, la escuela era lugar de reunión para los vecinos. Así, no era fácil de diferenciar lo religioso de lo social en las actividades de este espacio. De este modo, se constituyó en un centro de referencia educativo, eclesial y comunitario.

Para las religiosas, la promoción social era indisociable de la tarea de evangelización. Vivir en el barrio implicaba, por un lado, dejar de lado una vida sin precariedades, propia de gente proveniente de clase media; por otro, una fuerte experiencia comunitaria. Además, permitía un contacto permanente con los vecinos que trascendía los problemas que tenían que ver estrictamente con la escuela. Así, las hermanas se constituyeron en referentes tanto para la gente del barrio, que les demandaban las cosas más variadas, como para los venidos "de afuera" se acercaban a la villa a militar.

Las Misioneras Cruzadas de la Iglesia compartían también la línea de renovación eclesial. Estas religiosas dirigían el centro pastoral La Pequeña Obra, ubicado en el barrio Pedro Pico y dependiente de la parroquia Santa Teresita. El espacio comenzó siendo una institución de beneficencia destinada a niñas pobres, subvencionada por el gobierno y las limosnas de los colaboradores, que contaba con un pequeño oratorio donde se celebraba misa una vez por mes y en Navidad, se realizaban vía crucis, etc. El edificio fue bendecido por el obispo en julio de $1943^{244}$. En septiembre de 1954, las Misioneras, que habían instalado una comunidad en Coronel Dorrego -formalmente reconocida en abril de $1951^{245}$-, fueron autorizadas por Esorto para erigir una casa misión en el local de La Pequeña Obra ${ }^{246}$. Allí, las religiosas comenzaron a dirigir una escuela profesional para alumnas externas ${ }^{247}$.

\footnotetext{
242 "Escuela en Villa Nocito", El Eco, 10/03/71.

${ }^{243}$ Entrevista a Norma Gorriarán, Bahía Blanca, 29/10/2008.

${ }^{244}$ Boletín Eclesiástico, Bahía Blanca, marzo de 1947, julio-agosto de 1951, enero-febrero de 1952.

${ }^{245}$ Boletín Eclesiástico, Bahía Blanca, marzo-abril y mayo-junio de 1951.

${ }^{246}$ Boletín Eclesiástico, Bahía Blanca, septiembre-octubre de 1954.

${ }^{247}$ Boletín Eclesiástico, Bahía Blanca, julio-septiembre de 1968.
} 
Entre las hermanas de dicha comunidad se destacaba Estrella Sastre Campos o "Kotska", que había creado la primera experiencia Scout en la ciudad, el grupo "San Pío X", y ayudado al surgimiento de otros, haciendo del scoutismo un método de formación y herramienta de evangelización para los niños y jóvenes.
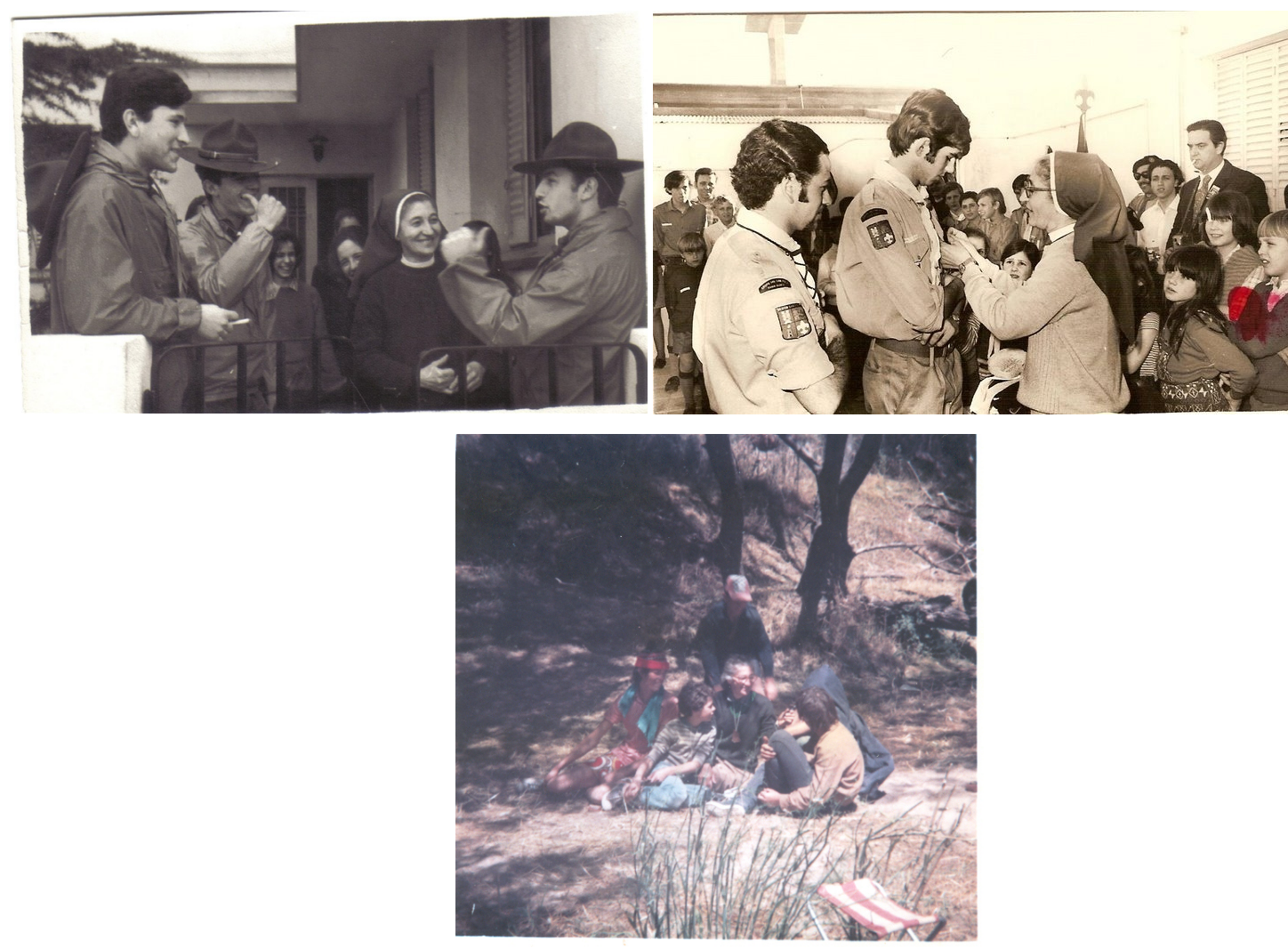

La hermana Kotska (de arriba hacia abajo: en la puerta de La Pequeña Obra; durante las promesas Scouts; y en un campamento rodeada de niños).

A fines de los años sesenta, la renovación litúrgica y la apertura de las religiosas atraían cada vez más fieles al centro de la calle Pedro Pico, acrecentando así la presencia de las hermanas entre la gente del barrio y volviendo cada vez más heterogénea una comunidad donde convivían vecinos, familias del centro, del barrio universitario y del Palihue -uno de los más ostentosos de la ciudad-, profesores universitarios, oficiales de marina, etc. 


\section{2) Vínculos e interacciones}

\section{a) Los lazos tejidos entre los católicos liberacionistas en el espacio local}

Estos grupos compartían la idea de la necesidad y de la posibilidad del cambio social, la crítica al orden establecido y una visión de la Iglesia cercana a los "oprimidos" en su lucha por la "liberación". Sin embargo, en esta pluralidad de actores, también existieron matices que diferenciaron a los grupos en su interior y entre sí, a partir de las formas concretas en que cada uno entendió y se identificó con la renovación eclesial. En otras palabras, los ámbitos de sociabilidad católica liberacionista conformados en Bahía Blanca y Punta Alta entre los últimos años de la década de 1960 y la primera mitad de la siguiente constituyeron una unidad compleja, heterogénea y dinámica. Al tiempo que existían significativos puntos de encuentro entre los espacios laicales -basados en la identificación con la renovación conciliar y los desarrollos de la nueva teología latinoamericana, una misma matriz católica integralista, y el acompañamiento dado por sacerdotes y religiosos que conformaban un grupo marcado por coincidencias teológicas, ideológicas y pastorales-, se manifestaron diferentes imaginarios, corrientes eclesiales y modelos políticos. De allí que los intercambios entre estos círculos sociales y sus integrantes no estuvieran exentos de debates y tensiones. En este sentido, Fernando recordaba un encuentro de grupos católicos entre los que se encontraba la JUC, el GMB y Cáritas, celebrado en el Seminario "La Asunción" hacia 1970, donde sobre la base de la creencia de que la transformación social era posible e inminente, se discutió sobre sus prioridades, características y alcances:

[Juan Carlos] comentó que las medidas de corte asistencialista y qué se yo, podían detener la revolución. Una cosa de la izquierda, viste, muy... [...] le contesté: "mirá, está muy bien todo este tema, el cambio y eso, estamos todos de acuerdo. Pero el tema es que mientras llega la revolución ¿qué se hace con la gente que necesita? ${ }^{248}$

Esta complejidad de los grupos laicales liberacionistas gravitó en un amplio espectro de posibilidades de participación y militancia de los jóvenes, que no se redujeron al activismo político o político-militar, sino que incluyeron intervenciones en los espacios eclesial, social, barrial/villero, gremial, estudiantil o incluso, de la vida

${ }^{248}$ Entrevista a Fernando, Bahía Blanca, 30/11/2010. 
cotidiana, así como diversas opciones político-partidarias. Asimismo, entiendo que dicha complejidad guarda relación con las trayectorias familiares, educativas, laborales, religiosas, ideológico-políticas de sus integrantes y asesores; la diversidad de formas de ligazón que cada uno de los grupos tuvo con las instancias institucionales de la Iglesia; y las particularidades de las dos localidades (las escalas, los entramados políticos, la conformación de las sociedades, los tradicionales vínculos cívico-militares en cuanto sedes de diversas unidades castrenses).

Además de los lineamientos eclesiales en común, los católicos liberacionistas bahienses estaban unidos por la materialidad constitutiva de las relaciones sociales. ¿Qué tipo de vínculos ligaron a los integrantes de los espacios sociales identificados con la renovación católica? ¿Qué rol jugaron las conexiones personales en el contacto entre las distintas experiencias?

Los diversos grupos descriptos estaban unidos por lazos personales. Éstos se basaban en relaciones familiares, afectivas o de trabajo en común. En primer lugar, varios miembros de una familia (hermanos, primos, padres e hijos) participaban a veces del mismo grupo (Guía-Scout, JUC, JOC, JEC, GMB, Cáritas) y otras, en distintos espacios (JUC y JEC; JUC y JOC; JOC y JEC; JEC y CUB; GMB y CUB; GMB y Cáritas; JUC y Cáritas; Guías y Cáritas). En segundo lugar, integrantes de diversos colectivos estaban unidos por lazos afectivos cimentados en sus trayectorias eclesiales previas, su paso por la misma escuela o su pertenencia al mismo barrio. Por citar sólo unos pocos ejemplos, algunos miembros del GMB y de la JUC venían de grupos eclesiales más tradicionales; las hermanas misioneras habían conocido a militantes de la CUB y el GMB cuando cumplían tareas pastorales en Coronel Dorrego, durante los años anteriores a su llegada a Bahía Blanca; Miguel Sarmiento y algunas religiosas de la Compañía de María habían compartido los cine-debates que tenían lugar en el Teatro Don Bosco; Norma Gorriarán había tenido como alumnas en La Inmaculada a integrantes de la JUC; una docente de Nuestra Señora de la Paz trabajaba también en la escuela primaria de Sánchez Elía y había sido maestra de quienes serían luego integrantes del grupo Scout "San Jorge" y de la JEC; algunos docentes de la CUB eran colegas en el Juan XXIII de los sacerdotes salesianos y los jóvenes del GMB que estudiaban en el Instituto tenían a esos presbíteros como profesores; una buena parte de los dirigentes del grupo Scout-Guía de La Pequeña Obra y fundadores de la JEC, eran compañeros de las Escuelas Medias de la UNS, donde habían tenido como celador a un referente de la JUC, además de ser vecinos en el barrio universitario o en el Pedro Pico; 
jóvenes de la JOC y de la JEC venían trabajado juntos en la parroquia de la "loma" y vivían en Sánchez Elía. Así, cada individuo se ubicaba en el cruce de diversos círculos sociales y cuanto más numerosas y diversas eran sus relaciones interpersonales, más grupos se ponían en juego (familia, parroquia, trabajo, estudio, política, etc.) (Agulhon, 2009).

Asimismo, era frecuente que jóvenes que pertenecían a uno de los grupos tuvieran una participación de forma y duración variables en las actividades de los otros. Así, varios miembros de la CUB fueron a misiones en San Germán y otros amigos católicos se sumaron a las iniciativas destinadas a juntar dinero para la misión. Además, jóvenes del movimiento Guía-Scout y de la JUC o de la JEC eran voluntarios en Cáritas, la que funcionaba como espacio de formación en la "línea del servicio al pobre"249 ${ }^{\text {. Por }}$ otra parte, algunos militantes de la JUC y de la JOC acompañaron a los equipos de JEC. En ciertos casos, incluso, los laicos integraban varios grupos al mismo tiempo: la mayor parte de los miembros de la JEC y algunos jóvenes de la JUC eran Guías y Scouts de La Pequeña Obra.

En este sentido, siguiendo a González Bernaldo de Quirós (2008), quien ha abordado la sociabilidad para otros referentes empíricos, la experiencia asociativa abría nuevos espacios de sociabilidad. Y, como ha analizado Agulhon (2009), es frecuente que una asociación comience fácilmente a través de un grupo de amigos, antes de llegar a ser un grupo organizado, esto es, la constitución de una nueva asociación formal se ve favorecida por relaciones amistosas y mundanas entabladas previamente. En el caso bahiense, esto se expresaba en la formación de nuevos grupos a partir de experiencias previas, como ocurrió con el nacimiento de la JEC con dirigentes Scouts y Guías de La Pequeña Obra y de la "loma", unidos por el sacerdote que los acompañaba. Y, al mismo tiempo, en el modo en que las solidaridades tejidas en estos espacios sociales mediaron en el paso de los militantes de un grupo a otro (por ejemplo, desde la JAC a la JUC o del Grupo Misionero a Cáritas).

Por otra parte, algunos militantes, transitaron entre "San Pío X” y "San Jorge". El protagonismo de los dirigentes de La Pequeña Obra en el grupo de la "loma" no sólo se centró en el momento inicial de este último, fundado -como vimos- con la ayuda de los primeros, sino que volvió a aparecer en un período posterior, ligado a las crisis que, por distintas razones, atravesaron tanto uno como otro grupo. Por un lado, "San Jorge"

${ }^{249}$ Entrevista a Fernando, Bahía Blanca, 16/11/2010. 
se vio sacudido por la partida del jefe de grupo a mediados de 1971, después del allanamiento que sufrió "Pepe" ${ }^{250}$. Se trataba de un suboficial de Marina de origen cordobés, que entonces fue detenido por la policía e interrogado sobre las actividades de la parroquia. Después del incidente, el hombre abandonó "San Jorge” y el barrio, y nadie más supo de él. Fue entonces cuando el grupo Scout se disolvió ${ }^{251}$. Algunos dirigentes pasaron a trabajar en La Pequeña Obra, como es el caso de Marta. Más tarde, integrantes de "San Pío" y "Santa Juana" se fueron a Sánchez Elía con la intención de reflotar el grupo Scout. Por otro lado, la salida de estos jóvenes de La Pequeña Obra contribuía a descomprimir la conflictividad en la que estaba sumergida la comunidad ${ }^{252}$.

Más allá de las conexiones personales, algunas de estas experiencias tenían espacios de acción comunes. Por ejemplo, el grupo de Nuestra Señora de la Paz y el de Cáritas mantenían un vínculo alimentado por la actividad en Villa Nocito. Compartían retiros, a la vez que miembros de Cáritas ofrecían un trabajo voluntario en la escuela. Por su parte, la JUC se convirtió en madrina de Nuestra Señora de la Paz ${ }^{253}$. Entre las maestras de la escuela, había integrantes de la JUC, de la JOC, del grupo Guía-Scout de La Pequeña Obra y del GMB. Por último, algunos Scouts realizaban su experiencia de servicio en el barrio, junto a las hermanas de la Compañía de María. Además, muchos militantes jucistas hicieron del barrio su ámbito de militancia y participaron simultáneamente de la escuela, a partir de Cáritas o de la labor docente, y de la Unidad Básica o de la Agrupación Evita.

En este sentido, como profundizaremos en el capítulo 6, el peronismo revolucionario se constituyó en otro canal de encuentro de los militantes católicos pertenecientes a un mismo grupo o a varios colectivos dentro de esta red. Al mismo tiempo, las agrupaciones de la Tendencia Revolucionaria y los círculos católicos liberacionistas compartían los espacios de acción, siendo el barrio un escenario privilegiado. Así, los Scouts y Guías de La Pequeña Obra y la JP confluían en Villa Quilmes en jornadas de trabajo barrial ${ }^{254}$. De forma similar, en Villa Nocito, los militantes de la UES, de la JP, las maestras y las religiosas de Nuestra Señora de la Paz aunaban esfuerzos para pintar la escuela o para conseguir mejoras en el barrio ${ }^{255}$. Es

\footnotetext{
${ }^{250}$ Véase el apartado siguiente.

${ }^{251}$ Entrevistas a José Zamorano, Moreno, 19/9/2009 y 2/9/2011; y a Ema, Bahía Blanca, 27/9/2012.

${ }^{252}$ Volveré sobre este tema en el capítulo 7.

${ }^{253}$ Entrevista a Néstor Navarro, Bahía Blanca, 18/11/10; y a Manuel, Neuquén, 20 y 21/3/2013.

${ }^{254}$ Entrevista a Pedro, Buenos Aires, 15/11/2012.

${ }^{255}$ Entrevista a Norma Gorriarán, Bahía Blanca, 29/10/2008. Entrevista a Juan, Bahía Blanca, 14/8/2012. Entrevista a Gustavo, Bahía Blanca, 12/7/2011. Entrevista a Inés, Bahía Blanca, 18/6/2011.
} 
necesario tener en cuenta que, como parte de su estrategia barrial, la JP-Montoneros contempló el trabajo conjunto con instituciones preexistentes con cierta tradición y arraigo. En La Plata, por ejemplo, la organización articuló con los Centros de Promoción, que, creados en 1968, eran de inspiración cristiana, estaban bajo control municipal y se orientaban a la "ayuda al necesitado" en la periferia de la ciudad (Robles, 2012). Por otra parte, en Moreno, los jóvenes identificados con la Teología de la Liberación se acercaron a la organización de diversas formas o bien, sin incorporarse a ella, participaron desde su militancia social y religiosa en forma conjunta con algunas actividades de la JP (Salcedo, 2011).

Por otro lado, existían instancias de encuentro esporádicas que ponían en relación a los espacios laicales bahienses. La afinidad ideológica y la amistad de los sacerdotes, y el hecho de que las ramas especializadas compartieran el asesor, jugaron un rol central en la confluencia de los grupos. Así, la JUC y la JOC realizaban jornadas conjuntas de reflexión o de formación. Asimismo, de vez en cuando tanto los jóvenes de la JUC y los de Cáritas, como los Scouts-JEC y los jóvenes de Cristo Rey compartían reuniones. Además, la JUC, Cáritas, el GMB y los grupos juveniles puntaltenses se encontraban en jornadas de discusión que tenían lugar en el Seminario "La Asunción". Al mismo tiempo, estos grupos se sentían "aliados" 256 en las reuniones organizadas a nivel de la Arquidiócesis, en las que participaban laicos, religiosas y curas de otras corrientes eclesiales.

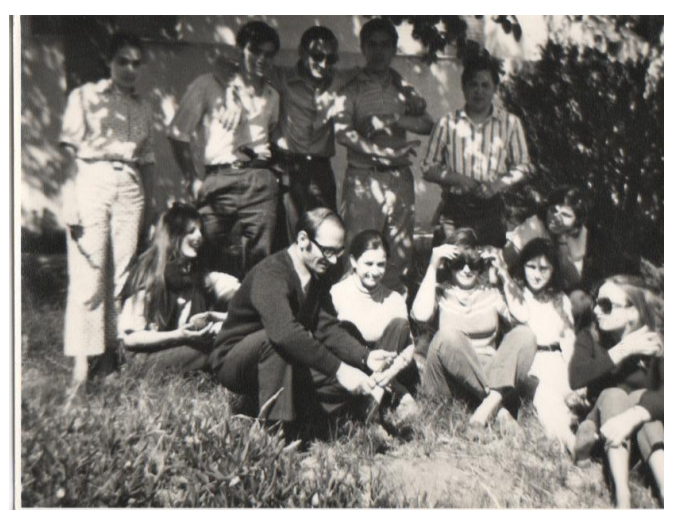

Jóvenes del Seminario Catequístico y de Cáritas, acompañados por Néstor Navarro (de pie, con anteojos negros) y Miguel Sarmiento (agachado), en el Seminario "La Asunción", 1970.

La preparación de la fiesta de la Pascua o de Navidad era ocasión de encuentro, al igual que las misas (con)celebradas por los sacerdotes. Además, si bien los

\footnotetext{
${ }^{256}$ Entrevista a Mónica, Buenos Aires, 9/11/2011.
} 
presbíteros rezaban la misa en diferentes iglesias, según el trabajo pastoral que desarrollaban, si alguno debía ausentarse, lo solía reemplazar un compañero, lo que favoreció el contacto entre los laicos y los otros sacerdotes, más allá de su asesor. Por último, circunstancias más informales, como los cumpleaños y los casamientos, se convertían en oportunidades para compartir entre jóvenes de varios grupos.

Asimismo, los jóvenes de distintas grupos asistían a charlas y disertaciones realizadas por sacerdotes y teólogos reconocidos. Este es el caso del ciclo de conferencias sobre "Capitalismo y Socialismo", ofrecidas por Benito Santecchia en el Juan XXIII, en octubre y noviembre de $1969^{257}$, o de las conferencias brindadas por Carlos Mugica, en la sede de la Asociación Empleados de Comercio y en el Instituto salesiano, en agosto de 1972, cuyo tema era "El compromiso del cristiano hoy en la Argentina" ${ }^{258}$, en ambos casos, dirigidas a un público amplio que incluyó a creyentes y no creyentes.

El entramado de las redes sociales del catolicismo liberacionista en Bahía Blanca se complejiza al contemplar los intercambios con miembros de otras Iglesias cristianas, con los que compartían la perspectiva liberacionista. En la tarea de asistencia a los exiliados chilenos, cubierta en parte a través de Cáritas, Néstor Navarro trabajó junto al pastor metodista Aníbal Sicardi. Además, sacerdotes “tercermundistas" y pastores metodistas y valdenses se encontraban periódicamente en La Pequeña Obra para poner en común la reflexión del Evangelio desde la realidad. Esta vinculación incluía a los laicos que participaron de encuentros y celebraciones en el templo metodista.

Al mismo tiempo, el modo particular de ingreso al grupo, común en estos espacios laicales, así como la movilidad de sus miembros hacían más amplio el tejido de esta red social. Como fue mencionado, la incorporación de nuevos integrantes se concretaba a través de contactos y se admitía la participación ocasional en sus actividades de gente que no pertenecía plenamente al espacio. Así, los límites de los grupos se volvían más difusos con la presencia de un conjunto de jóvenes que podían ser desde católicos "no practicantes" hasta anticlericales declarados, que participaban de las guitarreadas después de las misas de la JUC en La Pequeña Obra -o incluso de algún retiro-, de campamentos organizados por la JOC, o de iniciativas impulsadas por el

\footnotetext{
${ }^{257}$ Archivo DIPBA, Mesa A, Estudiantil, Localidad Bahía Blanca, Legajo $\mathrm{N}^{\circ} 47$.

${ }^{258}$ Archivo DIPBA, Mesa "Referencia", Legajo $\mathrm{N}^{\circ}$ 15281, Tomo II y VII. Los agentes de inteligencia registraron la asistencia de clérigos "simpatizantes de su misma tendencia" [de Mugica], así como de "grupos estudiantiles especialmente de la Juventud Universitaria Católica y de la Juventud Obrera Católica".
} 
GMB con el fin de recaudar dinero para la misión. En el caso de la JUC, jóvenes en contacto con los jucistas por la militancia política tuvieron la experiencia de un paso de duración variable por el movimiento.

En este sentido, a fines de los años sesenta y principios de los setenta, el Pensionado Católico jugó un papel significativo al cimentar vínculos entre los jucistas y los militantes de las agrupaciones estudiantiles, así como entre aquéllos y ciertos espacios y referentes del catolicismo liberacionista a nivel nacional y latinoamericano. Es necesario tener en cuenta que durante el período dictatorial de 1966-1972, la militancia universitaria, reprimida y excluida de los canales de participación democrática, se había visto obligada a explotar otros ámbitos de sociabilidad, donde aprendió a articular estructuras políticas más horizontales y abiertas (Orbe, 2007). En este sentido, había ciertos lugares que funcionaban como espacios de encuentro y discusión política. Uno de ellos era el comedor universitario, punto central de reunión cotidiana de militantes de distintas agrupaciones -sobre todo de los que venían de la zona-, de debate y de distribución de volantes. Otros lugares de reunión frecuente eran las casas de los estudiantes de la zona, donde se combinaban peñas, guitarreadas, bailes y, al decir de Luis, "reuniones revolucionarias"

El Pensionado había comenzado a funcionar en la segunda mitad de la década de 1950, por iniciativa de la JUC, en una casa alquilada ubicada en Zapiola 428, a ocho cuadras de la plaza central de la ciudad y a una distancia equivalente de la UNS y el comedor universitario. Durante los meses previos a su inauguración, la JUC se ocupó de acondicionar la casa, y una vez inaugurada, de gestionarla. A mediados de la década de 1960, la organización compró la propiedad y, a falta de personería jurídica propia, la puso a nombre del Arzobispado de Bahía Blanca.

El Pensionado contaba con un asesor, que era el mismo de la Acción Católica Universitaria. Entre 1956 y 1967, los padres Pipo y Fabris acompañaron a los residentes, los visitaron periódicamente -e incluso, el segundo vivió un tiempo en la casa- y, en los primeros años, se hicieron cargo de reuniones y charlas. Pero no se trataba de una presencia permanente ni una dedicación de tiempo completo. Así, como en la JUC y en la AUDAC, alentaban el protagonismo y la autonomía de los jóvenes. En palabras de Alberto: "en general, nos dejaban un poco...y ya nos habían empezado a inculcar el tema de que el asesor no es imprescindible"260. Por último, había un

\footnotetext{
${ }^{259}$ Entrevista a Luis, Bahía Blanca, 18/12/2008.

${ }^{260}$ Entrevista a Alberto, Bahía Blanca, 29/8/2012.
} 
administrador que rendía cuentas a la JUC, era elegido por asamblea de los residentes, y se encargaba de cobrar las cuotas que los pensionistas aportaban mensualmente para pagar los gastos.

Los residentes sumaban 23 jóvenes, todos varones que, provenientes de distintos lugares de la zona, llegaban a Bahía Blanca para estudiar en la UNS. En su mayoría eran cristianos, aunque no necesariamente integrantes de la Acción Católica. Desde su inauguración, la JUC buscó hacer del Pensionado "un ámbito de fraternidad"261. Y para los actores, se constituyó en una experiencia de vida en comunidad. La existencia de un solo teléfono, una cocina de escasa dimensiones, dos baños, un único equipo de música y cuartos para 2 o 3 personas, hacía indispensable el aprendizaje de la organización grupal. La austeridad del edificio y los pocos recursos económicos de los estudiantes funcionaban en el mismo sentido, esto es, obligaban a pensar en conjunto maneras de hacer la vida más confortable, así como a poner en común los saberes y pertenencias.

Al mismo tiempo, la casa de Zapiola se convirtió en un espacio de socialización para los jóvenes, funcionando como centro de reunión de los estudiantes. Allí se armaban asados y partidos de fútbol en el patio, donde se enfrentaba el grupo de "la Rábida" -como se identificaba a los pensionistas, en alusión al monasterio franciscano andaluz- con otros equipos, y se organizaban fiestas por múltiples motivos que iban desde despedidas de soltero hasta el triunfo de la Liga Humanista en las elecciones.

En el período que nos ocupa -1968-1975-, en la casona, la convivencia seguía regida por un administrador, un reglamento y asambleas, pero éstas tenían un peso cada vez mayor y se hacían periódicamente para discutir cuestiones cotidianas, que para entonces estaban permeadas por la militancia política de los residentes. Al respecto decía Ángel:

había muchos de los que uno en realidad quería que den el ejemplo que dejaban la cocina sucia, el baño sucio, las ollas sin lavar...por el contrario, los que eran más ordenados eran los que no tenían compromiso político. Entonces, era una cosa como que yo siempre recriminaba a la gente, que debíamos ser testimonio en todo, también en la parte tan sencilla de la vida como esa ${ }^{262}$.

El reglamento, elaborado y modificado por los mismos jóvenes, fue cambiando en esos años. Así, el criterio de incorporación de los nuevos pensionistas priorizaba su compromiso. En este sentido, señalaba Ángel: "La mayoría te llevaba para el

\footnotetext{
261 "Dos fundadores", en: Abuelos relatores, 2012: 61.

${ }^{262}$ Entrevista a Ángel, Buenos Aires, 8/10/2009.
} 
compromiso politico y si no te comprometías, era como una discriminación ${ }^{263}$. En realidad, así como no todos los residentes eran católicos ni de la JUC, tampoco todos tenían una acción social o política concreta. Sin embargo, en la residencia estudiantil vivían militantes universitarios de diversas agrupaciones de izquierda. Según los servicios de inteligencia, en 1971, éstas incluían Tendencia Estudiantil Socialista Revolucionaria, la Agrupación Universitaria de Acción Liberadora, los Grupos Socialistas y el Frente Estudiantil Nacional ${ }^{264}$.

Pero además, el lugar es recordado como "núcleo central de la militancia antisistémica de Bahía Blanca" ${ }^{265}$. En este sentido, se consolidó como punto de encuentro de militantes, de discusión de ideas, frecuentemente de modo espontáneo en los ratos que dejaba libre el estudio -favorecido por el ambiente estudiantil y la vida comunitaria- y de organización de movilizaciones masivas en contra de la dictadura de Onganía. Así como en Córdoba, donde las veinte cuadras de pensiones estudiantiles ubicadas en el Barrio Cínicas fueron el centro histórico de la vida política universitaria y un escenario privilegiado de la protesta contra el régimen, tanto en los meses siguientes al golpe como en mayo de 1969 (Brennan, 1996), las repercusiones del Cordobazo en Bahía Blanca se organizaron en el Pensionado, donde mientras se escuchaba la radio de Córdoba se preparaban las bombas molotov, los miguelitos, etc. ${ }^{266}$. También era centro de reunión de las agrupaciones, lo que se veía facilitado por su ubicación, "de paso" a la universidad, y porque al no ser una casa particular daba un mayor margen de libertad para desarrollar las actividades de la militancia ${ }^{267}$. Por otra parte, en ese lugar se distribuían publicaciones como Cristianismo y Revolución y El Combatiente -órgano de propaganda del PRT-. En efecto, era un espacio donde a fines de los años sesenta se desarrollaba una importante actividad de propaganda del PRT El Combatiente, apuntalada por la presencia del militante perretista Hugo Fuentes ${ }^{268}$ (Giménez, 2008: 29). Por último, los referentes latinoamericanos del MIEC-JECI ${ }^{269}$ en sus viajes a Bahía Blanca visitaban el Pensionado ${ }^{270}$.

\footnotetext{
${ }^{263}$ Entrevista a Ángel, Buenos Aires, 8/10/2009.

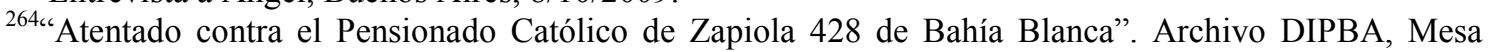
"Referencia", Legajo No 15281, "Sacerdotes del III mundo", Tomo 5. Sobre estas agrupaciones véase el capítulo 6 .

${ }^{265}$ Entrevista a Juan Carlos, Buenos Aires, 29/7/2008.

266 Entrevista a Juan Carlos, Buenos Aires, 29/7/2008.

${ }^{267}$ Entrevista a Eduardo, Bahía Blanca, 16/10/2008; a Graciela, Buenos Aires, 31/7/2008; a Juan Carlos, Buenos Aires, 1/8/2008.

${ }^{268}$ Desaparecido desde el 15 de febrero de 1977.

${ }^{269}$ Véase el último apartado de este capítulo.

${ }^{270}$ Entrevista a Juan Carlos y Mónica, Bahía Blanca, 28/3/2013.
} 


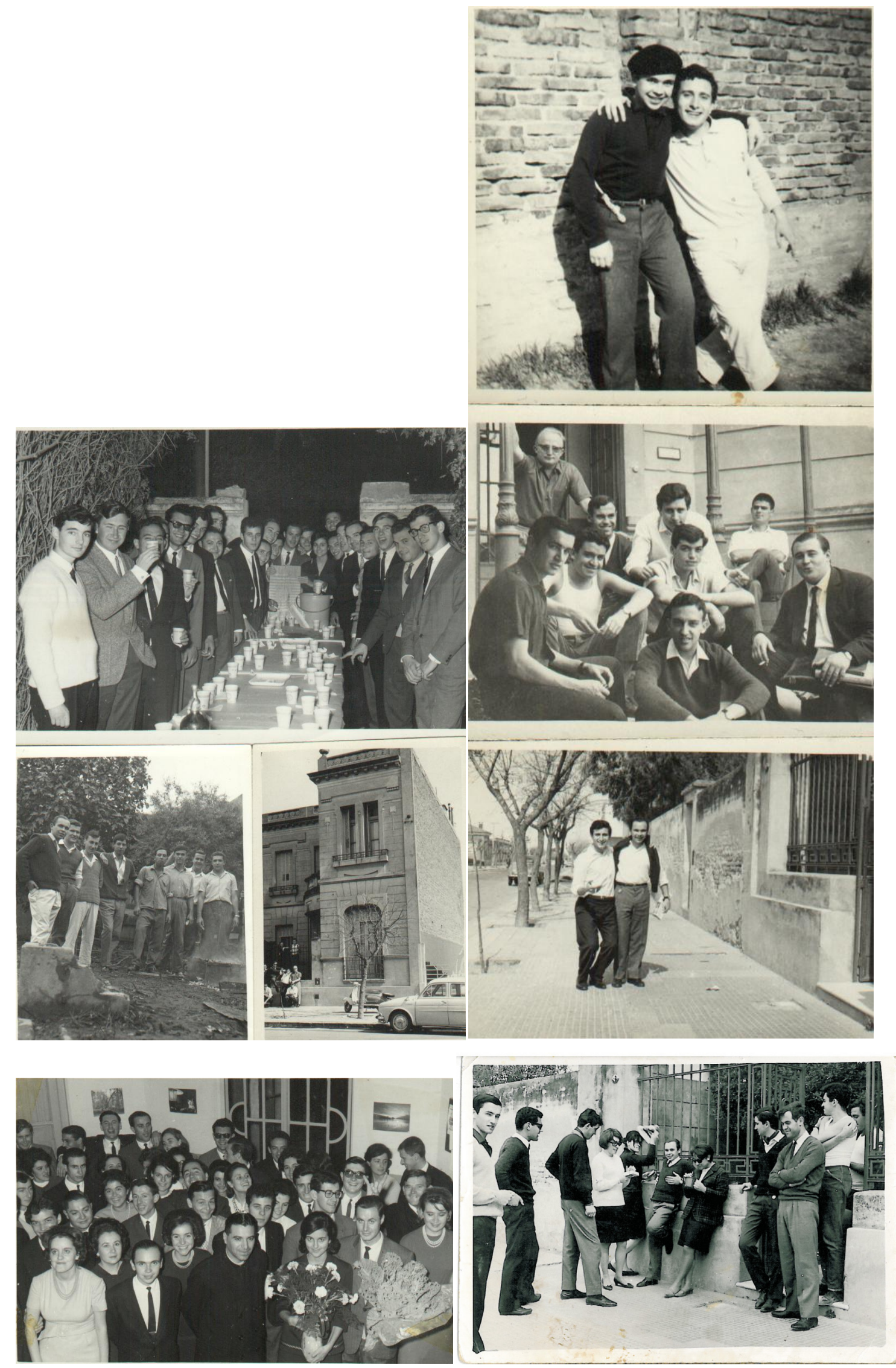

El Pensionado Católico hacia mediados de la década de 1960. En el centro puede verse la fachada del edificio. Abajo, el interior de la casa durante una reunión con la 
presencia de un sacerdote asesor. La primera y segunda foto de la columna de la izquierda y la primera de la derecha están tomadas en el patio. El resto de las imágenes, muestran a los residentes en la vereda.
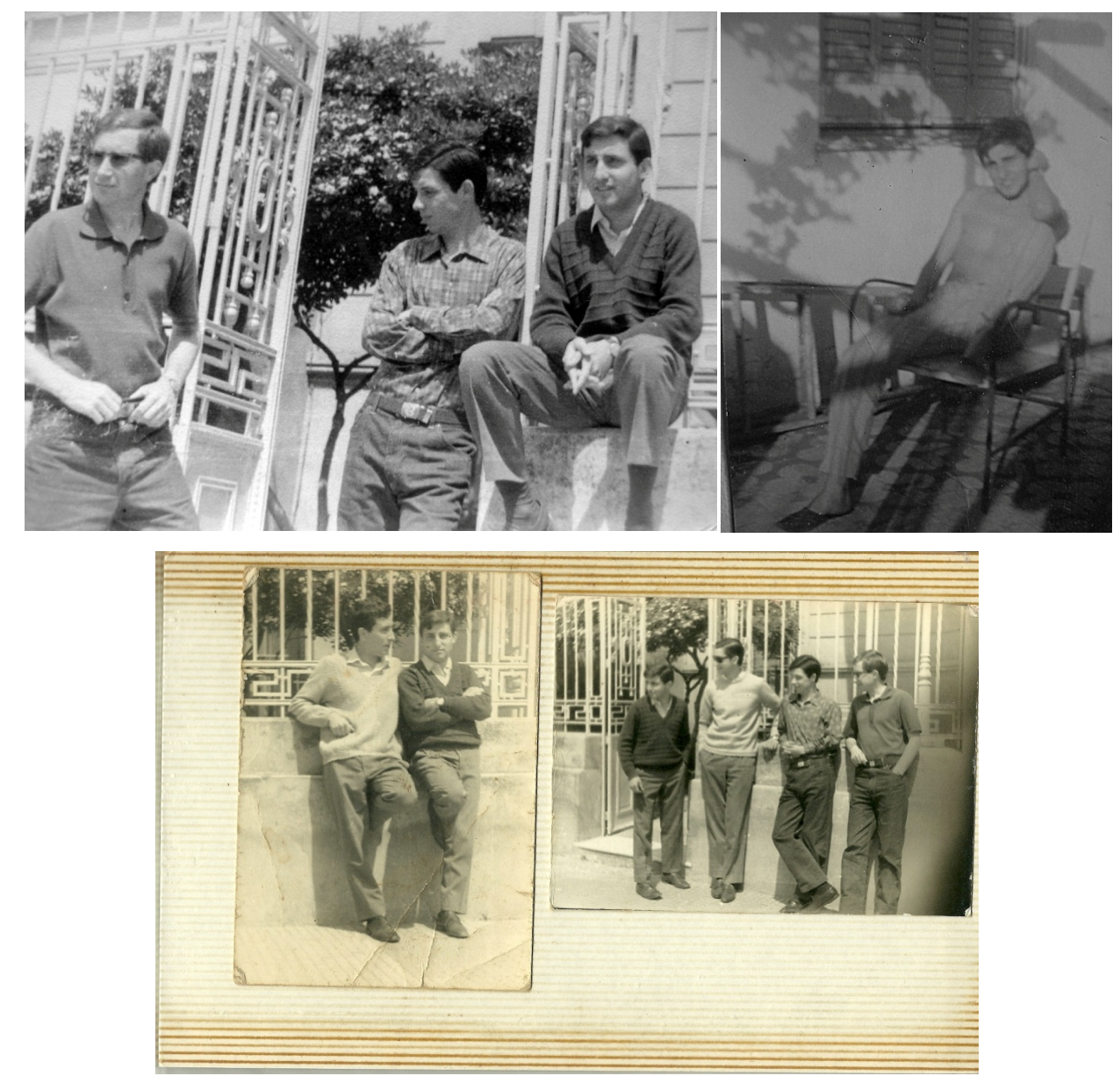

Jóvenes residentes del Pensionado en la puerta del mismo hacia 1968. Y militante jucista en el patio del Pensionado, hacia 1968.

Para entonces, este proceso era común a otras residencias de estudiantes universitarios que habían sido fundadas por la Iglesia Católica en distintos puntos del país tras el derrocamiento de Perón. Como explica Lanusse (2007a), estas casas eran conocidas como Colegios Mayores, estaban a cargo de un sacerdote, y su espacio físico era aprovechado para dictar, por fuera de las carreras de grado, conferencias y cursos sobre temas políticos, económicos y sociales. Por otra parte, desde finales de los años cincuenta, algunos Colegios Mayores no fueron inmunes a los sectores renovadores dentro de la misma Iglesia. Lo dicho anteriormente, sumado a la convivencia de jóvenes de todo el país, favorecía la creación de una atmósfera de debate de ideas, que muchas veces era canalizada hacia la actividad política. Así, por ejemplo, en Resistencia, el Colegio Mayor Universitario -fundado a comienzos de los años sesenta por el sacerdote Rubén Dri- se transformó en un centro de formación cultural y religiosa y, finalmente, 
en un centro político con trabajo en barrios y villas. Más adelante, el grupo refundó la Juventud Peronista y organizó una coordinadora formada además por el Movimiento Integralista, laicos, sacerdotes y la Federación de Comisiones Vecinales. A través de estas comisiones, se organizaban diversas iniciativas, como levantar una escuela, llevar el agua a un determinado lugar, poner un dispensario o marchar por algún reclamo.

Por otra parte, en la Universidad Nacional del Litoral, el nacimiento de los Colegios Mayores trajo como consecuencia la creación de una importante agrupación estudiantil, denominada Ateneo. Ésta experimentó un gradual pasaje hacia el nacionalismo revolucionario identificado con el peronismo y se convirtió en una importante pieza de los debates que atravesaban al catolicismo. Además, el Ateneo comenzó a explorar la actividad barrial, sindical y armada. Asimismo, estrechó vínculos con los gremios santafesinos que formaban parte de la CGT de los Argentinos, con la ASA, con las FAP, con la agrupación Lealtad y Lucha de Córdoba -que los llevó a integrarse a la Tendencia Revolucionaria del Peronismo-, con militantes del norte de Santa Fe organizados alrededor del padre Rafael Yacuzzi, con Cristianismo y Revolución, y con el grupo de Resistencia liderado por Dri (Lanusse, 2007a).

En los Colegios Mayores no sólo residían estudiantes de la universidad estatal sino también de la Universidad Católica de Santa Fe. Allí, los grupos cristianos que adoptaron posturas políticas radicales y el peronismo como identidad, tuvieron protagonismo en los conflictos estudiantiles, encabezados por el Movimiento de Estudiantes de la Universidad Católica (MEUC). En 1968, uno de los Colegios Mayores fue escenario de la huelga de hambre de los alumnos, una vez que éstos fueron desalojados por la policía de la iglesia jesuita Nuestra Señora de los Milagros (Lanusse, 2007a). Asimismo, en la coyuntura conflictiva de aquellos meses, la institución emitió un comunicado donde están presentes una serie de elementos que dan cuenta de la construcción de un imaginario social radical común a las agrupaciones católicas, a saber: la noción de violencia estructural que legitimaba la violencia "desde abajo" y el compromiso con la construcción de una sociedad y de un hombre nuevos, mediante la superación del orden capitalista. Así, los Colegios Mayores facilitaron nexos, recursos organizativos y circulación de discursos habilitantes para la acción colectiva estudiantil. Al mismo tiempo, junto a las asambleas, el comedor universitario o las actividades culturales, estas residencias constituyeron escenarios donde se afirmaron valores ligados a la construcción de una identidad revolucionaria (Diburzi, 2005; 2007). 
En tanto lugar de encuentro de la militancia contestataria, el Pensionado Católico bahiense fue blanco de atentados y allanamientos. Luis recordaba situaciones que ponen de relieve que los estudiantes que vivían allí sabían que eran vigilados por la policía, por lo que se mantenían de algún modo alertas ante posibles allanamientos:

[el Alemán] y me grita “ila cana, la cana!”, ay, la puta que lo parió, estábamos yo y él y digo "no, esta vez me escapo", así que en calzoncillos...salté un tapial que había, yo sabía cómo podía disparar...pasé por una casa que tenía una escalerita y me quedé durmiendo, ¿qué durmiendo? ¡Me recagué de frío! a pesar de que era verano [...] yo ya calculaba: el Alemán solo ¿qué mierda lo iban a llevar si al Alemán no lo llevaban nunca?... y [al otro día] volví, y era el Alemán que estaba obsesionado por la cana ${ }^{271}$.

Los servicios de inteligencia registraron un allanamiento ocurrido el 22 de junio de 1971 en busca de armas robadas por el ERP en el polígono de Punta Alta, durante el cual algunos residentes expresaron que presumían haber sido denunciados por un dirigente local de la Juventud Nacional Peronista, quien ya habría arrojado allí bombas de estruendo y efectuado disparos al aire ${ }^{272}$. En esa oportunidad, la policía se llevó unas cadenas que encontró debajo de una cama y una colección de documentos de la JUC ${ }^{273}$. Dos meses y medio después, el frente del edificio fue tiroteado mientras eran arrojados volantes con "insinuaciones anticomunistas" 274 . Los agentes de inteligencia no descartaban que el atentado hubiera sido perpetrado por los mismos residentes "para reafirmar una presunta persecución al estudiantado y grupo católico" 275 .

\section{b) Los grupos de la renovación católica y otros sectores eclesiales en la ciudad}

¿Cómo era la relación de la JUC, la JOC y la JEC bahienses con la jerarquía? A diferencia de la Acción Católica tradicional, que era una suerte de brazo largo del Episcopado, los movimientos especializados de juventud tuvieron con aquél una relación particular. Estos grupos no tenían un contacto frecuente con la jerarquía eclesiástica, a excepción de los eventos que congregaban a los diversos movimientos de

\footnotetext{
${ }^{271}$ Entrevista a Luis, Bahía Blanca, 18/12/2008.

272 "Atentado contra el Pensionado Católico de Zapiola 428 de Bahía Blanca". Archivo DIPBA, Mesa "Referencia", Legajo No 15281, "Sacerdotes del III mundo".

${ }^{273}$ Entrevista a Ángel, Buenos Aires, 8/10/2009.

274 "Tiros en un pensionado local", El Eco, 01/09/71. Archivo DIPBA, Mesa "Referencia", Legajo No 15281, "Sacerdotes del III mundo", Tomo 5. El Eco fue un diario bahiense fundado en marzo de 1971 y publicado hasta 1974.

275 "Atentado contra el Pensionado Católico de Zapiola 428 de Bahía Blanca". Archivo DIPBA, Mesa "Referencia", Legajo No 15281, "Sacerdotes del III mundo".
} 
Iglesia de la Arquidiócesis, que contaban con la presencia de las autoridades. En el caso de la JOC, la publicación oficial del Arzobispado menciona un único encuentro oficial con Jorge Mayer, concretado el 22 de agosto de 1972, a poco de que el prelado asumiera su cargo ${ }^{276}$. Lucy comentaba "vendría alguna misa o así pero no...más de eso no"277. Y Mirta explicaba: "Nosotros nunca trabajamos así esperando el apoyo de la jerarquía" ${ }^{278}$. De esta manera, estas organizaciones funcionaron durante todo el período con autonomía respecto del arzobispo.

Esta postura de los grupos juveniles universitarios y obreros respecto de la jerarquía contrastaba con la actitud sumisa y dependiente de otros movimientos laicales, que esperaban acatar sin cuestionamientos las resoluciones de aquélla. Hugo Segovia lo ilustraba de la siguiente manera:

Mayer hace una reunión con todos los movimientos de Iglesia, y...-él empieza bien-, dice: "bueno, yo los reúno porque es la primera reunión que tenemos, yo quiero ver qué están haciendo cada uno de ustedes, qué están trabajando, me gustaría que me explicaran”... silencio total. Nadie dice nada ¿no? Y por ahi un señor dice: "¿y usted qué piensa Monseñor?” [...] o sea, esperando que él diera la directiva...El Ver, Juzgar y Actuar no entraba mucho ahi ¿no? Más bien era directamente "acá yo resuelvo tal cosa, vos hacé esto, vos hacé aquello",279.

Aún más, los jucistas, jocistas y jecistas compartían una actitud crítica que los llevaba a cuestionar a la institución a nivel local y a reclamarle su aggiornamento. Jorge y Angélica coinciden en recordar una asamblea celebrada en el Instituto Juan XXIII, en la que participaron diversos grupos eclesiales, donde luego del trabajo en equipos, se planteó a Mayer la necesidad de renovar las líneas eclesiales y un mayor acompañamiento pastoral:

en realidad lo que buscábamos era que tuviera la Iglesia jerarquía-que por ahí nosotros hacíamos esa distinción-, tuviera más compromiso, tuviera más cerca del mundo laboral, de la gente, ¿no?...y eso se cuestionó, se cuestionó públicamente, se PIDIÓ públicamente ${ }^{280}$.

Asimismo, los jóvenes interpelaban a la jerarquía a partir de la acción que ellos asumían en la mejora de las condiciones de vida y de trabajo de los sectores populares. Por ejemplo, en ocasión de la iniciativa del supermercado "Don Diego" de abrir el local los días domingo, los jocistas se movilizaron para detener la decisión patronal, y reclamaron no sólo el compromiso de toda la comunidad cristiana de las distintas

\footnotetext{
${ }^{276}$ Boletín Eclesiástico, Bahía Blanca, octubre-diciembre de 1972.

${ }^{277}$ Entrevista a Lucy, Neuquén, 18/3/2013.

${ }^{278}$ Entrevista a Mirta y Jorge, Bahía Blanca, 11/4/2012.

${ }^{279}$ Entrevista a Hugo Segovia, Mar del Plata, 27/5/2010.

${ }^{280}$ Entrevista a Angélica, Bahía Blanca, 25/4/2012.
} 
parroquias sino también la intervención de las autoridades eclesiásticas. Por un lado, los jóvenes elaboraron volantes explicando la situación y los repartieron a la salida de las misas. Una de las iglesias escogidas fue la de San Francisco, donde el párroco los expulsó llamando a la policía ${ }^{281}$. Al mismo tiempo, se movilizaron a través de sus espacios de militancia gremial -concretamente, en las asambleas de Empleados de Comercio- y política. Y, pidieron entrevista con el arzobispo para solicitar su apoyo ${ }^{282}$.

Como consecuencia de lo anterior, los entrevistados caracterizaban la relación con el arzobispo no sólo como escasa/inexistente o distante sino incluso como "no (muy) buena",283, “tensa",284, “mala",285, “pésima",286 u "horrible"287. Y resaltaban la falta de acompañamiento y de interés que recibieron por parte de la máxima autoridad eclesiástica local ${ }^{288}$. Al respecto, Dante señalaba: “acá la jerarquía no quería saber nada, no quería saber NADA con la JOC y no nos reconoció nunca [...] Pepe a eso no le daba ni cinco de bolilla por supuesto",289.

En ocasiones, ligaban la actitud del arzobispo con la pertenencia de los jóvenes a la comunidad de Sánchez Elía. José y Mirta comentaban: "éramos una piedra en el zapato para él...la comunidad esta ${ }^{290}$; “nos tildaban mal, ya estábamos medios marcados acá, "los de la loma”291. En otros casos, los actores asociaban la hostilidad o indiferencia del arzobispo, especialmente Mayer, con las relaciones tensas que aquel mantenía con el asesor y, en general, con los sacerdotes de la arquidiócesis identificados con la renovación eclesial y el MSTM ${ }^{292}$.

En efecto, los actores establecían la distinción entre Esorto y Mayer. El primero, aunque ligado a una corriente eclesial tradicional, aparecía como un arzobispo accesible para los sectores renovadores, mientras el segundo tomó una postura más dura sin ocultar su oposición a ellos. En palabras de Paloma:

\footnotetext{
${ }^{281}$ Entrevista a Mirta, Bahía Blanca, 18/6/2008; a Mirta y Jorge, Bahía Blanca, 11/4/2012.

${ }^{282}$ Entrevista a Dante, Bahía Blanca, 15/3/2012; a Angélica, Bahía Blanca, 25/4/2012; a Mirta y Jorge, Bahía Blanca, 11/4/2012.

${ }^{283}$ Entrevista a Liliana, Bahía Blanca, 25/6/2008. Entrevista a Bruno, Bahía Blanca, 4/8/2012.

${ }^{284}$ Entrevista a Silvestre, vía e-mail, 29/12/2012.

${ }^{285}$ Palabras de Jorge, Entrevista a Mirta y Jorge, Bahía Blanca, 11/4/2012.

${ }^{286}$ Entrevista a Mirta, Bahía Blanca, 18/6/2008. Palabras de Jorge, en Entrevista a Mirta y Jorge, Bahía Blanca, 11/4/2012.

${ }^{287}$ Entrevista a Mirta, Bahía Blanca, 18/6/2008.

288 Entrevista a Mirta, Bahía Blanca, 18/6/2008. Palabras de Jorge, Entrevista a Mirta y Jorge, Bahía Blanca, 11/4/2012.

${ }^{289}$ Entrevista a Dante, Bahía Blanca, 28/9/2011.

${ }^{290}$ Entrevista a José, Bahía Blanca, 19/6/2008.

${ }^{291}$ Entrevista a Mirta, Bahía Blanca, 18/6/2008.

${ }^{292}$ Entrevista a Liliana, Bahía Blanca, 25/6/2008.
} 
la relación con Esorto era mucho más cercana y después la relación con Mayer fue directamente de corte [...] Esorto era otra persona, Esorto era más...campechano. Además era de compartir cosas, de discutirlas, de negociar, escuchaba más. Mayer no. O sea que fue muy diferente la relación. Mayer nos dejó solos a que nos arregláramos ${ }^{293}$.

Por otra parte, como adelantamos anteriormente, los vínculos de la jerarquía con el grupo de sacerdotes "tercermundistas" fueron complejos. También aquí es posible distinguir dos etapas en función de quién ocupaba el lugar de la máxima autoridad eclesiástica de la arquidiócesis. Como intentaré ilustrar en las próximas páginas a partir de acontecimientos concretos, Esorto protegió a sus sacerdotes y, de alguna manera, avaló sus iniciativas. Por el contrario, las relaciones con Mayer fueron conflictivas desde el momento mismo en que éste asumió su cargo.

En relación al primero, Benjamín Stocchetti sintetizaba el sentir del grupo sacerdotal: "era respetado y querido. Por su misma edad merecía nuestra comprensión. Más aun, tuvo actitudes muy paternas y valientes" 294 . Una anécdota de "Coco" permite describir la personalidad del primer arzobispo de Bahía Blanca, así como el posicionamiento asumido frente a sus sacerdotes, en quienes confiaba a pesar de no siempre comprenderlos y a quienes daba amplia libertad de acción:

un día le dije: "mire Monseñor, yo me voy a tener que ir ahora porque yo tengo que ir a ver a unos chicos que han puesto presos”. “¿Presos por qué? -me dice¿robaron?”. "No, no. Por politica”. "Ah, ¿qué pasa?” Le digo: "mire, son chicos que están con el peronismo, que quieren que Perón vuelva, y yo los conozco". "Ah, ¿vos los conocés a ellos?”. "Sí, además los padres están muy preocupados". "Bueno, haceles todo el bien que puedas",295.

Los sacerdotes liberacionistas no estaban conformes con la designación de Mayer como arzobispo de Bahía Blanca porque entendían que el prelado, al que conocían por su desempeño desde 1957 como obispo de Santa Rosa, no estaba al tanto de la realidad local -de la que se había alejado en la última década y media- ni estaba en condiciones de afrontar su complejidad y conflictividad. Según "Coco", este desconocimiento se puso de manifiesto al momento de nombrar a las personas que debían acompañarlo: se trataba de gente que había trabajado con él, cuya trayectoria Mayer había perdido de vista y -según el ex secretario canciller- ya no tenían

\footnotetext{
${ }^{293}$ Entrevista a Paloma, vía skype, 12/2/2013.

${ }^{294}$ Entrevista a Benjamín Stocchetti, vía e-mail, 25/7/2012.

${ }^{295}$ Entrevista a Hugo Segovia, Mar del Plata, 27/5/2010.
} 
“vigencia" o estaban "superados",296. Por su parte, "Pepe" resumía la postura del grupo sacerdotal y lo ilustraba con una anécdota:

no era un hombre capaz para una diócesis tan dificil con los poderes...reales tan fuertes como el V Cuerpo, la Marina, la Universidad y demás ¿no? [...] me acuerdo que decía Santecchia "esto aquí se maneja como un patrón de estancia: el patrón se va, propone a otro y ese es el que se pone,"297.

Con el correr de los meses, las relaciones con el arzobispo se volvieron más tensas. Unos escritos de Duilio Biancucci y de Benito Santecchia fechados en 1972 y 1973 -respectivamente- dan cuenta de ello. En una carta dirigida a Mayer después de la interrupción de la homilía de Oscar Barreto por parte de miembros de las Fuerzas $\operatorname{Armadas}^{298}$, el primero cuestionaba los lineamientos pastorales de la diócesis, señalando por un lado, la existencia de "ambigüedades difíciles de tolerar", y por el otro, la intervención de La Nueva Provincia marcando las líneas que "por el momento parecieran las únicas bien definidas". Esto, según Biancucci, confirmaba viejos temores planteados en el momento de la toma de posesión de la diócesis:

[entonces] mi preocupación y la de muchos otros fue advertirle que no podía dejarse guiar por "chismes" [...] De seguir así deberemos fundar una nueva archicofradía "la del chisme". Disculpe si insisto en esto; pero hace tres años que vengo sufriendo las consecuencias de estos "devotos" 299 .

Tres años después, en otra carta dirigida al arzobispo, el salesiano volvía sobre este párrafo para señalar las causas de su alejamiento de la arquidiócesis: "tuve que retirarme de Bahía Blanca porque como sacerdote me sentí marginado y sentí la necesidad de cambiar de lugar para ejercer libremente mi ministerio sacerdotal" ${ }^{\prime 300}$.

En 1973, en medio de un retiro espiritual, Santecchia se planteaba como propósito mejorar el vínculo no sólo con Mayer y el resto de la jerarquía local, sino también con sacerdotes, laicos y movimientos de la arquidiócesis que se ubicaban en otras líneas eclesiales:

19/3: Respetar al obispo. Ser leal en la palabra [...] ¿Cómo compaginar mi temperamento rebelde, irónico, "creativo", con el sacerdocio que es docilidad, comprensión, atención a la Palabra? [...] 20/3: Tengo que llegar a ser un factor

\footnotetext{
${ }^{296}$ Entrevista a Hugo Segovia, Mar del Plata, 27/5/2010.

297 Entrevista a José Zamorano, Moreno, 19/9/2009. Miguel también planteaba que la noticia de la designación del nuevo arzobispo fue recibida por el grupo con "temor a lo que se venía". Entrevista a Miguel Sarmiento, Punta Alta, 29/11/2010.

298 Véase el siguiente apartado.

${ }^{299}$ Carta de Duilio Biancucci a Monseñor Jorge Mayer, 27/12/1972, Legajo de Duilio Biancucci, Archivo Histórico Salesiano Patagónico.

${ }^{300}$ Carta de Duilio Biancucci dirigida a Jorge Mayer, 3/5/1975, Legajo de Duilio Biancucci, Archivo Histórico Salesiano Patagónico.
} 
de unidad en la Iglesia [...] 21/3: ¿Cómo hacer para aceptar gente que considero incapaz para los cargos que desarrolla? ¿Combatirlo? No. ¿Asesorarlo? Menos. ¿Ignorarlo? [...] 10/4: Debo revisar mi historia de relaciones desde el punto de vista de la justicia [...] No hablar mal del obispo (reparar): deponer mi actitud de resentimiento. Orar por él. Ya el Señor me indicará sus caminos. Idem con respecto a [algunos sacerdotes]. Con respecto a los profesores del Juan: respetar su dignidad de personas. No denigrar a los movimientos, cursillos, $A C A^{301}$.

Una anécdota evocada por "Coco" y por "Pepe" sirve para ilustrar los antagonismos existentes entre este grupo de curas y el resto del clero local, así como la postura que adoptó Mayer en el marco de aquellas pugnas. A poco de ponerse al frente de la arquidiócesis, el arzobispo convocó a una reunión de presbíteros donde se eligió un equipo encargado de la formación permanente del clero, que incluía a Hugo Segovia, "Pepe" Zamorano y Benito Santecchia. A pesar de que la designación se había hecho por votación, previendo posibles conflictos, el grupo sugirió a Mayer la incorporación de un sacerdote con una postura teológica y pastoral diferente, pero el arzobispo se negó y, en cambio, confirmó a los presbíteros elegidos. Sin embargo, las resistencias se plantearon en la primera reunión que, coordinada por "Coco", se proponía trabajar con un texto de Pablo VI sobre la nueva moral, publicado en el $L^{\prime}$ Osservatore Romano y previamente revisado por el arzobispo. Entonces un sacerdote cuestionó el recorte elegido, sugiriendo que el equipo había manipulado el documento para proponer su propia interpretación del mismo. Se planteó entonces una fuerte discusión que llevó a Mayer a reemplazar a "Coco" por Rómulo García al frente de la reunión. La actitud del referente de la Iglesia bahiense provocó las protestas del equipo y su renuncia. Al respecto, recordaba el ex secretario canciller de la Curia:

al día siguiente nos pusimos de acuerdo los 5 para hablar con el obispo. Entonces el obispo me dice "vos pasaste un mal momento. Pero el Padre Luis también". "Mire, Monseñor, -le digo- acá no se trata de ninguna maratón a ver quién sufrió más. Acá lo importante es la verdad" -me puse muy serio yo-. Acá hay un tema en el fondo muy serio. Nosotros se lo dijimos. Nosotros le pedimos que usted nombrara... Y lo que tenía que haber hecho es haber dicho yo aprobé' -iporque él había aprobado el papel ese!, jel papel lo había leído él!-. Se acababa el tema, pero usted no dijo nada. Usted se cayó la boca",302.

La tensión esbozada por Benito en sus apuntes se le planteaba al resto de los especialistas religiosos identificados con el catolicismo liberacionista. Esto es, ¿cómo

\footnotetext{
${ }^{301}$ Apuntes de Benito Santecchia, Legajo de Benito Santecchia, Archivo Histórico Salesiano Patagónico.

${ }^{302}$ Entrevista a Hugo Segovia, Mar del Plata, 27/5/2010.
} 
conciliar el mandato de la obediencia a la jerarquía, la pertenencia a la Iglesia, y de modo más amplio, del amor al prójimo, incluso al oponente/enemigo, por un lado, y lo que se entendía como fidelidad al Evangelio y a la doctrina cristiana aggiornada en el Concilio y Medellín? ¿Cómo lograr ambos propósitos en un escenario marcado por crecientes conflictos intraeclesiales, así como de efervescencia social y política? "Coco" sintetizaba esta contradicción al evocar las circunstancias de su renuncia como secretario canciller, en la que pesó su difícil relación con Mayer. Al mismo tiempo, le planteó: "Monseñor, no podemos seguir así...yo como sacerdote no puedo estar enfrentado con usted, no puedo...porque es mi padre. Aunque mi padre a mí no me guste, no lo quiera, es mi padre ¿no? "303. Hacer caso omiso de las resoluciones del arzobispo no representaba para los sacerdotes una alternativa. Miguel recordaba haber desobedecido a Mayer en una oportunidad pero lo hizo en el marco de su crisis vocacional y el inminente alejamiento de la vida consagrada. La situación se planteó a raíz de la decisión de los jóvenes de Cristo Rey de nombrar a la farmacia "Carlos Mugica" en homenaje al sacerdote recientemente asesinado. Cuando el arzobispo visitó la iglesia de Punta Alta pidió al párroco que cambiara aquel nombre:

no te iban a decir abiertamente "vinieron a pedirnos de la Base Naval que saques esto porque sino te van a hacer un quilombo". Nunca te hablaban de frente. "Sacá eso". Entonces digo: "no, yo no lo voy a sacar si los chicos no quieren que lo saque. Yo se lo voy a plantear a ellos -le digo-. Acá las cosas se hacen así. Yo no tomo decisiones por sí o por no, por mí mismo”304.

De esta manera, el tipo de relación que las ramas especializadas de Acción Católica establecieron con la máxima autoridad eclesiástica se puede generalizar a todo el espectro del catolicismo renovador bahiense, aunque el carácter de laicos o especialistas religiosos de los actores le imprimió a estos intercambios matices particulares. Así, si Esorto estuvo lejos de identificarse con el catolicismo liberacionista, dejó a sus referentes un amplio margen de libertad, a la vez que respondió por ellos cuando fue necesario. En cambio, Mayer confrontó más directamente con estos sectores y les quitó su respaldo. Estas actitudes y comportamientos disímiles se pusieron de manifiesto en diversos acontecimientos que surcaron la cotidianeidad bahiense a fines de los años sesenta y principios de los setenta, y que involucraron a distintos actores eclesiales -y sociales en general-, poniendo de manifiesto las contradicciones y conflictos que atravesaban a la Iglesia local. Si bien volveremos sobre algunos de ellos

\footnotetext{
${ }^{303}$ Entrevista a Hugo Segovia, Mar del Plata, 27/5/2010.

${ }^{304}$ Entrevista a Miguel Sarmiento, Punta Alta, 29/11/2010.
} 
en el capítulo 3, al abordar las iniciativas de denuncia "profética" emprendidas por la red de renovación católica bahiense, aquí nos detendremos en los cruces entre estos actores y la jerarquía por un lado, y otros sectores eclesiales, por el otro.

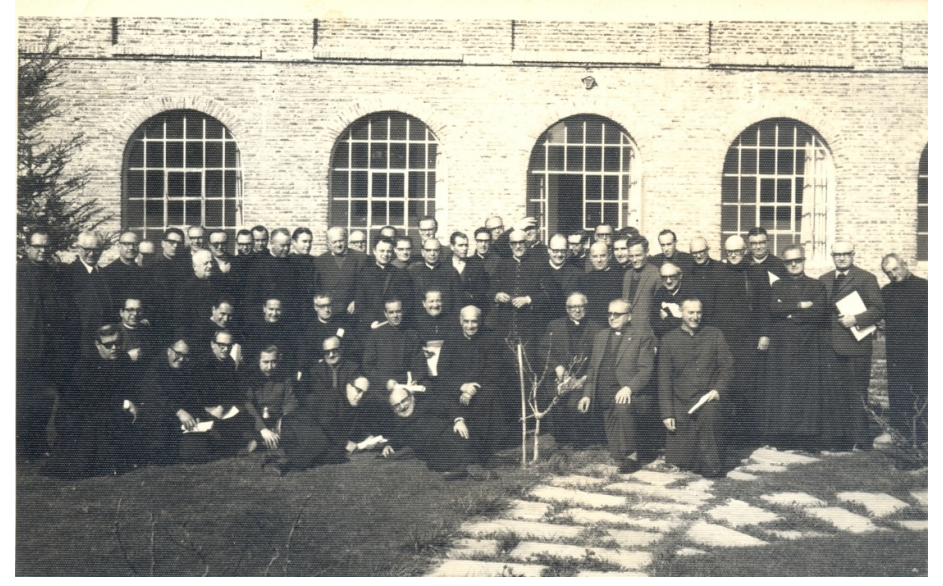

Reunión del clero local en el Seminario La Asunción, 1968.

\section{i) Cruces y conflictos}

El 12 de noviembre de 1969 el presidente de facto, Juan Carlos Onganía, anunció la decisión de consagrar el país al Inmaculado Corazón de María. Así, el mito de la nación católica renacía en el momento de mayor debilidad del régimen (Verbitsky, 2009). Treinta y cinco años antes, el General Agustín Justo, en búsqueda de la legitimidad católica, había consagrado la Argentina al Corazón de Jesús, iniciando de ese modo una práctica que, como mencionamos en el capítulo 1, se volvería común en los gobiernos posteriores (Mallimaci, 1992). En efecto, la iniciativa dividió a la Iglesia en nuestro país. Mientras el cardenal Caggiano y diversos miembros del episcopado argentino concelebraron la misa en la basílica de Nuestra Señora de Luján ${ }^{305}$, el obispo de Neuquén, Jaime de Nevares, emitió un comunicado por el que se reservaba "la autoridad que le corresponde para convocar al pueblo de Dios a un acto religioso de consagración"306. Asimismo, el MSTM lanzó una declaración en la que repudiaba la iniciativa del presidente planteando una serie de críticas: primero, el mensaje parecía sugerir que no quedaba otra alternativa que rezar mientras el pueblo esperaba de los

\footnotetext{
${ }^{305}$ La devoción a la Virgen de Luján comenzó a expandirse a principios del siglo XX, masificándose en los años treinta, como forma de lograr la homogeneización religiosa a partir de una "devoción nacional". Poco a poco, los diversos grupos de inmigrantes y los nativos recién llegados a la gran urbe incorporaron a la "virgen argentina" como signo exterior de su identificación con la patria (Mallimaci, 1992).

306 "En Neuquén”, LNP, 1/12/1969.
} 
gobernantes que resolvieran sus problemas con medios políticos; segundo, la invitación tenía la intención política de mostrar una unión inexistente entre la Iglesia y el gobierno y de instrumentar los sentimientos religiosos del pueblo; tercero, se preguntaba "¿qué es lo que poseemos para consagrar?”, ¿la desocupación, los bajos salarios, la injusticia, la violencia que ejerce el poder? Según los integrantes del movimiento, "todo nuestro culto (si no está precedido por y acompañado por una realización de la justicia y la fraternidad) es aborrecido por Dios, por resultar fingido y apto solamente para tranquilizar conciencias irresponsables o para adormecer justas rebeldías y anhelos de un pueblo". Concluían que si se quería implorar la ayuda de la Virgen era fundamental recoger el intento del pueblo por liberarse y poner en marcha el proyecto emancipador. Lejos de esa intención, en la invitación de Onganía lo religioso amenazaba "ser usado como estupefaciente de las inquietudes del mismo pueblo"307.

La Iglesia y la sociedad bahienses no fueron ajenas a esas tensiones. En la misma línea de posicionamiento crítico de la JUC a nivel nacional, el grupo local se organizó y movilizó, junto a la JOC y a los sacerdotes, para expresar su rechazo, participando en la distribución de volantes, en los que se planteaba que la consagración del país a la Virgen María por parte de un gobierno que cometía injusticias era una contradicción. Cuando estaban repartiendo la declaración en la puerta de la iglesia Sagrado Corazón de Jesús, un religioso salesiano hizo la denuncia, por lo que los detuvieron en averiguación de antecedentes. Fue otro miembro de la misma congregación, Benito Santecchia, quien consiguió que los liberaran ${ }^{308}$.

Este tipo de incidentes se repitió en distintas oportunidades a lo largo de esos años. Los grupos de "revisión de vida" fueron corridos por la policía, a pedido de sectores católicos opuestos a esta línea eclesial, mientras difundían documentos de denuncia en la puerta de las distintas iglesias. Al respecto, Dante contaba:

frente a la iglesia esta que está en Zelarrayán ¿cómo es?...Corazón de María. Bueno, la agarré a mi novia de la mano cuando me di cuenta que era la cana. Y [Nora y Rodolfo], que también estaban -compartíamos actividades, ellos

\footnotetext{
${ }^{307}$ Documento en el que se repudia la iniciativa del General Onganía de consagrar el país a la Virgen, noviembre de 1969, en: Bresci, 1994: 90-94.

${ }^{308}$ Véase por ejemplo, entrevista a Nora, Bahía Blanca, 4/6/2008; o a Paloma, vía skype, 7/2/2013. En verdad, muchos entrevistados mencionaron la consagración del país a la Virgen como oportunidad en la que la estos grupos se movilizaron para expresar su rechazo, y que culminó en la detención de los militantes por unas horas. Sin embargo, no todos los que hablan del incidente participaron en esa acción, y algunos ni siquiera integraban los grupos cristianos en ese momento. Esto tiene que ver con el hecho de que en los testimonios, una serie de fechas y acontecimientos sirven de marco de referencia para el relato de la militancia católica en tanto mantienen un significado particular para el grupo, independientemente de quienes protagonizaron ese momento. Sobre las memorias de la militancia y la violencia política de los integrantes de la JUC véase Dominella, 2012.
} 
estaban en la JUC-, (risas) no, se los chuparon, se los llevaron. Los largaron enseguida, viste, también, el mismo verso, les dijeron “¿pero cómo, siempre la Iglesia y las Fuerzas Armadas se han llevado bien, por qué tenemos que estar discutiendo?" (risas) ${ }^{309}$.

En ocasiones, el hostigamiento de los sectores eclesiales contrarios a los liberacionistas se plasmaba en volantes anónimos. Un ejemplo de este tipo de reacciones tuvo lugar en la vecina ciudad de Punta Alta en octubre de 1970. Un panfleto firmado por un autodenominado "Movimiento Argentino de Conciliación" atacaba a los presbíteros Hugo Segovia y Miguel Sarmiento, acusándolos de ser "marxistas con sotana", "demagogos de la violencia" y "corruptores de la familia", de atraerse las simpatías de los jóvenes para convertirlos en "títeres" de una "maquinaria infernal", de "llevan mujeres a sus domicilios en horas de las noches" y de someter a los ciudadanos, en cada homilía, a un verdadero "masaje cerebral". Frente a tales diatribas no tardó en hacerse pública la respuesta de la comunidad de la parroquia María Auxiliadora de Punta Alta, en apoyo a sus "pastores". En un volante y una declaración, desmentían las acusaciones planteando que "solo mentes desviadas pueden interpretar como marxistas el pensamiento cristiano y conciliar" de los sacerdotes, quienes en sus homilías "transmiten y esclarecen los documentos emanados del Concilio Vaticano II y de Medellín, ambos avalados por la jerarquía de la Iglesia" y enseñan que la unidad comienza en "el amor y el compromiso con Dios y la humanidad para la construcción de un Mundo Nuevo y de un Hombre Nuevo". La feligresía puntaltense calificaba a los "agraviadores" de "seres sin patria ni origen", que demostraban o bien desconocer la doctrina de la Iglesia y su actualización o bien habiéndola analizado, sentirse amenazados en sus "intereses bastardos y materialistas" o en "sus ideologías anticristianas y apátridas" 310 .

Días antes de conocerse el anónimo que atacaba a Miguel y a Hugo, éste último estaba en la mira de las autoridades navales. El 20 de septiembre se le había impedido entrar a la Base de Puerto Belgrano. Y cuatro días después, en la fiesta patronal de la Virgen de la Merced, fueron los propios comandantes quienes le pidieron a Esorto que desvinculara al sacerdote de sus tareas en la arquidiócesis, argumentando su alta "peligrosidad". La respuesta del arzobispo fue entonces defender a su secretario:

les dijo: "bueno, mire, en primer lugar yo tengo buen concepto del Padre. Para mí es un colaborador importante, yo lo necesito. Yo quiero que me traigan las

\footnotetext{
${ }^{309}$ Entrevista a Dante, Bahía Blanca, 15/3/2012.

${ }^{310}$ Archivo DIPBA, Mesa "Referencia”, Legajo No 15281, Tomo V.
} 
pruebas, en segundo lugar. Y en tercer lugar, más importante entre paréntesis, yo soy el que dispongo del destino de los sacerdotes" 311 .

En otras oportunidades, las tensiones se manifestaron en la misma celebración religiosa. El domingo 11 de octubre de 1970 el sacerdote Duilio Biancucci rezó misa en la Catedral. Mientras estaba predicando dos personas se retiraron del templo cuando el celebrante mencionó al MSTM y, al leer unos párrafos de una carta escrita desde la cárcel por el Padre Alberto Carbone ${ }^{312}$, un grupo de marinos avanzó hacia el altar y lo interrumpió diciéndole que "habían venido a escuchar misa y no una apología"313. Según los protagonistas del hecho, el sacerdote estaba utilizando la misa como "tribuna política", por lo que se vieron obligados a "poner las cosas en su lugar"314.

El arzobispo de Bahía Blanca respondió con un comunicado elaborado por un equipo de sacerdotes -entre los que se encontraba Benito Santecchia-, sobre la base de un borrador de Hugo Segovia (Segovia, 2008). Dicha declaración, firmada por Esorto y el clero de la ciudad y de Punta Alta, lamentaba la interrupción violenta del acto litúrgico que "no puede concebirse ni aun cuando los fieles crean que tienen derecho a la protesta", y la desautorizaba en virtud del derecho irrenunciable de la Iglesia a proclamar el Evangelio, de la competencia de los sacerdotes para hacerlo, y de la autoridad exclusiva del obispo para juzgar la aptitud de los últimos. Además, condenaba el clima de difamación contra algunos presbíteros, considerados como "hermanos y amigos", a quienes se atribuían "actitudes y palabras que implican subversión, injerencia política, incitación a la violencia, apología del delito, etc."315. Finalmente, Esorto pedía que el documento fuera leído en todas las misas. Sin embargo, algunos

\footnotetext{
${ }^{311}$ Entrevista a Hugo Segovia, Mar del Plata, 27/5/2010.

${ }^{312}$ Miembro del MSTM y asesor nacional de la JEC argentina. Fue procesado en la causa por el secuestro y asesinato del ex presidente de facto Teniente General Pedro Eugenio Aramburu -ocurridos en mayo de 1970-, al haber sido encontrada en su casa, en julio de ese año, la máquina de escribir con la que habían sido escritos los primeros comunicados de Montoneros. Véase "El P. Carbone y la justicia argentina", Spes, 10, agosto-septiembre de 1970; "Declaración del Padre Alberto Carbone", JEC Boletín Secundario, 15, diciembre de 1970.

313 "Duilio Biancucci. Soy cristiano y como tal...", Graphos, 4, noviembre/diciembre de 1970. Graphos fue una publicación editada entre 1970 y 1973 por estudiantes nucleados en el Club Universitario de Bahía Blanca. A lo largo de sus cuatro años, la revista atravesó importantes cambios en las temáticas, el tono discursivo, la estructura interna y destinatarios. Nació como una revista de estudiantes para estudiantes. Con el tiempo, fue saliendo del ámbito universitario para reubicarse en las calles y en los barrios. Por otra parte, el eje local de los conflictos sociales se desplazó lentamente a los procesos de carácter nacional. En su interior convivieron militantes que expresaban su opinión y la de la agrupación política de pertenencia convirtiéndose en "tribuna" de las distintas tendencias. Hacia fines de 1973 las discusiones entre el grupo de redacción y los dirigentes del Club determinaron su cierre (Giménez, 2009). 314 "Las implicancias de un sermón y un incidente en la Catedral", $L N P, 13 / 10 / 1970$.

${ }^{315}$ Declaración de Monseñor Esorto, transcripta en el informe titulado "Información relacionada con un comunicado del arzobispo de Bahía Blanca". Archivo DIPBA, Mesa "Referencia", Legajo No 15281, Tomo V.
} 
presbíteros plantearon su disconformidad con el texto. Así, según relata Hugo, un capellán de la Base le reprochó que no había sido convocado a participar de la elaboración de la declaración y que se negaba a leerla ${ }^{316}$. En contrapartida con la actitud del referente local, el arzobispo de Paraná, vicario de las Fuerzas Armadas y titular de la Comisión Permanente del Episcopado Argentino, Adolfo Tortolo ${ }^{317}$, juzgó los incidentes planteando que "no debió haberse intentado tal lectura. En la misa sólo tienen cabida la palabra litúrgica y, ocasionalmente, un documento pastoral" 318 .

A pesar de gravedad del escándalo en la Catedral de Bahía Blanca, aquel no fue el único acto litúrgico interrumpido violentamente en ese templo por hombres de la Marina. Un hecho similar ocurrió a mediados de diciembre de 1972, cuando un grupo de personas encabezadas por el teniente de navío Basilio Pertiné impidió al salesiano Oscar Barreto continuar con la homilía. En este caso, tampoco faltaron las repercusiones públicas. Respecto de la actitud del recientemente consagrado Jorge Mayer, sólo hemos hallado referencias indirectas a una declaración firmada por aquél en las opiniones vertidas por otros actores sobre el asunto. Repasemos algunas de ellas.

El vecino Arturo Sahores ${ }^{319}$ disparó el debate mediático justificando la acción del grupo de fieles que interrumpió al celebrante y calificando el hecho como "valiente" reacción del laicado católico en su derecho a reclamar y en su responsabilidad de moderar los excesos de los sacerdotes pertenecientes a un "movimiento semiclandestino" 320 . Según Sahores, la prédica de estos prelados se caracterizaba por la permanente impugnación a la jerarquía, por avivar rencores contra "instituciones que son pilares de la Nación" y utilizar expresiones que "más parecen provenir de discípulos de Lenin o Mao que seguidores de la religión de Cristo". Asimismo, los acusaba de limitarse a exponer hechos de injusticia sin aportar soluciones, quedando éstas peligrosamente libradas a la interpretación de sus oyentes, y de introducir "aberraciones doctrinarias y extravagancias litúrgicas”. Finalmente, aludió a las palabras del arzobispo, quien habría recomendado, ante hechos como aquel, consultar a la autoridad

\footnotetext{
${ }^{316}$ Entrevista a Hugo Segovia, Mar del Plata, 27/5/2010.

${ }^{317}$ Mantenía una posición de franco rechazo al Concilio Vaticano II. Como presidente de la Conferencia Episcopal Argentina -desde abril de 1970-, apoyó al gobierno de Onganía. Luego, jugó un papel clave en el respaldo a la última dictadura militar y en la justificación de su accionar represivo (Mignone, 2006).

318 "Monseñor Tortolo se refirió en Tucumán a los incidentes de la Catedral de B. Blanca", LNP, $17 / 10 / 1970$.

319 En 1968 era el presidente del Consorcio de médicos católicos (Boletín Eclesiástico, julio-agostoseptiembre de 1968).

320 "No hay neutralidad posible entre lo verdadero y lo falso", LNP, 7/1/1973.
} 
eclesiástica, viendo en ellas un reconocimiento implícito al derecho de reclamar $^{321}$. Por el contrario, otros ciudadanos tildaban de grosera y prepotente la iniciativa del grupo de "exaltados" que impidieron que el celebrante siguiera haciendo uso de la palabra ${ }^{322}$, creyéndose "con derechos para transformarse en únicos detentadores de la verdad" 323. Asimismo, subrayaban que Mayer, en su declaración, no justificaba en modo alguno la interrupción del oficio ${ }^{324}$. Y, reivindicaban la labor de los sacerdotes que, en la lucha por la justicia, seguían el ejemplo de Cristo ${ }^{325}$.

Por su parte, Duilio Biancucci dirigió una carta a Mayer en la que le planteaba que lejos de cumplir con el deber de "avisar y hablar con sus sacerdotes", el arzobispo había desaprobado públicamente al salesiano sin antes haber hablado con él, optando por confirmar la "calumnia" echada a rodar por La Nueva Provincia. Así, en lugar de asumir como "pastor" gestos que hubieran significado una "clara defensa del buen nombre de la persona calumniada", Mayer se había dejado guiar por "chismes". En este sentido, le cuestionaba no haber reunido a sus sacerdotes para tratar el tema y, eventualmente, elaborar un documento defendiendo "el derecho de la Iglesia", como había hecho Esorto dos años antes. De esta manera, desde la perspectiva de Biancucci, el arzobispo, planteando como excusa la división del clero, en lugar de resolver el conflicto, lo había agravado y extendido a toda la comunidad cristiana ${ }^{326}$.

Un año antes, un acontecimiento tuvo como protagonista al asesor de la JUC y de la JOC. En el marco de un operativo policial contra una supuesta "célula terrorista", fue detenida Ana María Moreira, quien declaró pertenecer al ERP, y facilitó la aprehensión de otras cinco personas ${ }^{327}$, acusados de presuntas actividades “extremistas", ${ }^{28}$. Los detenidos quedaron a disposición del juez Munilla Lacasa, fueron

\footnotetext{
321 "No hay neutralidad posible entre lo verdadero y lo falso", $L N P, 7 / 1 / 1973$.

322 "Sobre un episodio en la Catedral", $L N P, 20 / 1 / 1973$.

323 "Un cura y sus juzgadores", El Eco, 10/1/1973.

324 "Sobre un episodio en la Catedral", $L N P, 20 / 1 / 1973$.

325 "Un cura y sus juzgadores", El Eco, 10/1/1973.

${ }^{326}$ Carta de Duilio Biancucci a Monseñor Mayer, 27/12/1972, Legajo de Duilio Biancucci, Archivo Histórico Salesiano Patagónico.

327 Eran Pedro Schimpfle (empleado), Francisco Schbib (ferroviario) y los estudiantes Adela Baldi, Guillermo López Chamadoira y Rubén Di Siervo. Luego, fueron detenidos el abogado Everardo Facchini, su esposa, Silvia Morilla, y su hermano, Norberto Facchini, y el estudiante Juan Drisaldi ("Denegaron dos recursos a favor de detenidos", $L N P, 12 / 8 / 1971$; "Otros detenidos", $L N P, 14 / 8 / 1971$; "Informe de la Policía Federal", LNP, 19/8/1971).

328 "En nuestra ciudad se habría descubierto un grupo extremista", $L N P, 9 / 8 / 1971$; "Sin novedad sobre tres presuntas detenciones", $L N P, 10 / 8 / 1971$; "No hay novedades sobre la detención de tres personas", $L N P, 11 / 8 / 1971$. El delito que se les imputaba estaba comprendido entre las competencias de la nueva Cámara Federal en lo Penal de la Nación, que delegó en el juez federal de Bahía Blanca, Carlos Romero del Prado, las tareas de tomar conocimiento de las detenciones hasta el arribo del Dr. Héctor Munilla Lacasa, miembro de la Sala $N^{\circ} 2$ de esa Cámara, con asiento en la Capital Federal. La creación de lo que
} 
alojados en dependencias de la Policía Federal y al cabo de unos días, trasladados a la Capital Federal, sin que fueran informados sus familiares y abogados ${ }^{329}$. En ese contexto, la policía se dirigió a la casa parroquial de Nuestra Señora del Carmen, donde Moreira había participado de algunas reuniones y misas de la JOC. Al no encontrar al Padre Zamorano, detuvo a un vecino y lo trasladó a la Brigada de Investigaciones, para someterlo a un interrogatorio sobre las actividades de la parroquia ${ }^{330}$.

Días después, el juez Munilla Lacasa ordenó el allanamiento de la casa de José Zamorano, que se produjo mientras él se encontraba celebrando misa en el Pequeño Cottolengo. El sacerdote, advertido por los vecinos de lo que ocurría, decidió llevar adelante la celebración normalmente pero les pidió que avisaran al arzobispo. Poco después, el párroco fue a la casa de Haití 1745 en compañía del arzobispo y encontró a varios uniformados revisando una Biblia, algunos libros, ejemplares de La Opinión, folletos - uno de ellos distribuido durante el IV Encuentro Nacional del MSTM ${ }^{331}$. La policía "secuestró" parte de ese material y pidió al sacerdote que los acompañara para entrevistarse con el juez, a lo que accedió acompañado por el abogado Osvaldo Carestía $^{332}$, mientras las cámaras de televisión registraban lo sucedido. Al cabo de pocos días, José Zamorano volvió a ser “invitado a declarar” por Munilla Lacasa, que le hizo una serie de preguntas relativas al trabajo en la parroquia, a los grupos de jóvenes que asesoraba y a algunas personas en particular ${ }^{333}$.

El allanamiento de la casa parroquial y la detención del sacerdote provocaron la reacción de la comunidad de la parroquia, de sus vecinos de Sánchez Elía, de la JUC, del clero local y de Monseñor Esorto, quienes expresaron públicamente su pleno apoyo al Padre Zamorano. Dos días después, se escuchó en la radio y se leyó en el diario un comunicado del arzobispo por el cual elevaba su "enérgica protesta" por los hechos que

se conoció como el "Camarón” se enmarca en una serie de medidas tomadas por el régimen encabezado por Alejandro Lanusse para reencauzar la conflictividad política y reforzar los mecanismos represivos dirigidos contra aquellos que empleaban la vía armada. La ley 19.110 reglamentaba el funcionamiento de la Cámara, con el fin de enjuiciar con mayor celeridad a aquellos "acusados de subversión y terrorismo". El "Camarón” era un tribunal especial con jurisdicción federal, constituido por nueve jueces más un fiscal encargados de juzgar oralmente y en instancia única, una amplia gama de delitos que iban desde rebelión y atentados hasta secuestros y resistencia a la autoridad. El propio gobierno de facto se encargaba de designar a los camaristas que integraban el nuevo fuero anti-subversivo (Chama, 2007).

${ }^{329}$ Esto impulsó las protestas de los abogados, que denunciaron la violación del "debido proceso y las garantías constitucionales" ("Grupo de abogados bahienses", Graphos, 7, septiembre de 1971). Asimismo, motivó el reclamo por la liberación de los presos políticos, que se convertió en una bandera que aunaría la lucha de las distintas agrupaciones estudiantiles, inaugurando un período de gran movilización y organización de los universitarios (Giménez, 2008).

330 "Un procedimiento", LNP, 12/8/1971.

${ }^{331}$ Entrevista a José Zamorano, Moreno, 19/9/2009.

332 "Diversos procedimientos llevó a cabo la policía", LNP, 14/8/1971.

${ }^{333}$ Entrevista a José Zamorano, Moreno, 19/9/2009. 
no hacían más que crear "en el pueblo un estado de tensión e inseguridad para el normal desenvolvimiento de las tareas pastorales" ${ }^{334}$. Por otra parte, aprovechó el acto celebrado en esos días en conmemoración de la muerte del General José de San Martín para advertirle a las autoridades militares que no se entrometieran en cuestiones de la Iglesia. Así lo recordaba Benjamín Stocchetti: “[el arzobispo] se hizo presente ante el jefe del V Cuerpo de Ejército, Gral. Ceretti, y condenando el mal proceder de los militares afirmó: 'General: en este ejército...mando yo'",335. Asimismo, Esorto presidió una misa en la parroquia de la "loma", que fue concelebrada por alrededor de 15 sacerdotes, en solidaridad con el Padre Zamorano.

La actitud del arzobispo resulta significativa en el marco de las tensiones que ya atravesaban a la Iglesia local. En efecto, el apoyo del clero al presbítero agraviado no fue unánime. El repudio al allanamiento concitó el respaldo de los consagrados no necesariamente identificados con el aggiornamento eclesial, como fue el caso del salesiano Francella, que al enterarse del episodio exclamó indignado: “icómo es posible que hayan allanado la casa de un sacerdote?!"336. Sin embargo, también motivó la hostilidad de otros. Esto se puso de manifiesto el 15 de agosto, en una reunión del clero bahiense con motivo de la celebración de la Asunción de la Virgen María. Según recordaba Hugo, ante la pregunta lanzada por Esorto para conocer los pareceres que había sobre lo ocurrido en Sánchez Elía, comenzó una fuerte discusión:

Uno de ellos llegó a decir: "a mí esto no me va a pasar, porque yo no tengo nada que ocultar”...Yo me puse furioso ¿no? Digo: "yo no sé cómo pude escuchar semejante cosa, porque por más que estemos en desacuerdo nosotros interiormente, como familia, tenemos que mostrar la unidad hacia fuera" [...] El arzobispo primero intervino, después se calló la boca. Dejó que gritaran unos contra otros, se sentó ahí. Y cuando vio que no había nada que hacer se retiró [...] Nos fuimos cada uno a su casa, con una angustia muy grande ¿no?, y con una decepción, un estado, "iqué cosa horrible está ocurriendo acá! Estamos divididos. No hay forma de que nos entendamos "337.

Con la irrupción de la violencia de la Triple A, la persecución a los católicos renovadores se hizo cada vez más radical, más sistemática y menos retórica, constituyéndolos en una de las víctimas privilegiadas de las bandas paramilitares. Entre el 21 de marzo y el 30 de abril de 1975, los principales referentes consagrados del

\footnotetext{
334 "Dio un comunicado el arzobispo de Bahía Blanca", LNP, 18/8/1971.

${ }^{335}$ Entrevista a Benjamín Stocchetti, vía e-mail, 10/1/2013. La anécdota también era mencionada por Hugo Segovia (Entrevista a Hugo Segovia, Mar del Plata, 27/5/2010).

336 Entrevista a José Zamorano, Moreno, 19/9/2009. La reacción del entonces director del Instituto Juan XXIII también era evocada por "Coco". Entrevista a Hugo Segovia, Mar del Plata, 27/5/2010.

${ }^{337}$ Entrevista a Hugo Segovia, Mar del Plata, 27/5/2010.
} 
catolicismo liberacionista en Bahía Blanca fueron víctimas de una serie de atentados.

Un grupo de párrocos y directores de colegios religiosos sintetizaba así los hechos:

Fue incendiada la vivienda de la comunidad salesiana del Instituto Juan XXIII y asesinado su vicerrector, el sacerdote Dorñak, el 21 de marzo. La misma noche se atentó contra la obra que Cáritas Diocesana dirige en Villa Nocito, fueron golpeados sus guardianes y buscada por los agresores (con intenciones que es fácil adivinar) la hermana que dirige la escuela; ataque que con mayor violencia, incluso con disparos de armas, se repitió la madrugada del 28 de abril. El mismo 30 de abril fue totalmente incendiada la casa parroquial de Nuestra Señora del Carmen de Villa Sánchez Elía ${ }^{338}$.

En este contexto ${ }^{339}$, las disputas al interior de la Iglesia tomaron un nuevo cariz e intensidad. Las tensiones puestas de manifiesto a lo largo de esos años se expresaron de modo cada vez más violento. La frágil convivencia entre visiones tan variadas e incluso distanciadas de la Iglesia y de sus relaciones con el mundo, y las prácticas eclesiales que de ellas se derivaban, se tornó insostenible. En el nuevo escenario, las diferencias se resolvieron de modo dramático y los posicionamientos se radicalizaron.

Las paredes de la ciudad sintetizaban el terror y la violencia reinantes, y el lugar de los distintos sectores de la Iglesia en ese proceso. En el Instituto Juan XXIII, las leyendas rezaban: "Las A.A.A. son nuestros compañeros/sigan reventando zurdos/ los apoya el pueblo entero"; "Papá no quiero ser guerrillero/ayuda a terminar con los bolches" y "A.A.A. Reg. B. Bca." 340 . En la calle Salta 74: "Los asesinos y torturadores de la Policía Federal mataron al cura Dorñak a media cuadra de su destacamento. A los

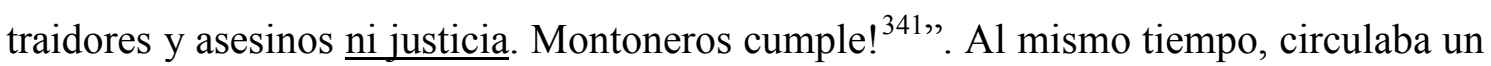
volante que decía: "Al cura Dorñak, a "Nando" Alduvino y a Marisa Mendivil de Ponte,

\footnotetext{
${ }^{338}$ Carta de párrocos y directores de colegios religiosos de Bahía Blanca, dirigida al Presidente de la Conferencia Episcopal Argentina, Adolfo Tortolo. Archivo DIPBA, Mesa DS, Carpeta Varios, Legajo N ${ }^{\circ}$ 3066.

${ }^{339}$ En la misma madrugada del 21 de marzo, habían ocurrido otros hechos como el estallido de la bomba en la casa del padre de Jorge Riganti, militante de la JUP; el secuestro de otro integrante de la JUP y estudiante de la UNS, Fernando Aldubino; el asesinato de Marisa Mendivil, esposa del profesor Roberto Ponte ("Nuevos atentados en Bahía Blanca", $L N P, 22 / 3 / 1975)$. Estos constituían la respuesta al asesinato del subcomisario Héctor Ramos, subjefe del Servicio de Informaciones de la Policía provincial, producido la noche anterior por un grupo de jóvenes armados en la puerta de su casa. En un volante del 20 de marzo, Montoneros se atribuyó el atentado, considerándolo un "acto de justicia popular" ejecutado contra el más "eficiente torturador" y "asesino policial" de la ciudad ("Un combate más, un torturador menos", Archivo DIPBA, Mesa DS, Carpeta Varios, Legajo № 3061. Sobre Ramos, véase Zapata, 2012).

340 "Cinco años de irritación, dos meses de atentados y una comunidad donde domina el miedo a manifestarse", La Opinión, 25/5/1975.

${ }^{341}$ Archivo DIPBA, Mesa DS, Carpeta Varios, Legajo No 3061.
} 
los asesinaron las A.A.A. por peronistas leales. Al subcomisario Héctor Ramos lo ajusticiaron los Montoneros por torturador, asesino y sirviente de la Marina" ${ }^{342}$.

Importantes sectores de la comunidad católica y la opinión pública bahienses culpabilizaban a las víctimas, interpretando los hechos recientes como el resultado de la violencia que ellos mismos habían estimulado con sus prácticas. En este sentido, el interventor de la UNS, Remus Tetu -exiliado rumano de tendencia filofascista-, en su carácter de "integrante laico" de la obra salesiana, dirigió una nota al Inspector Juan Cantini, en la que expresaba que aquella era una oportunidad "no sólo para llorar, sino para reflexionar acerca de nuestras propias culpas"343.

Una semana después del asesinato de Carlos Dorñak, el arzobispo de Bahía Blanca y el Inspector salesiano, recibían una carta anónima de un grupo de católicos que reclamaban una "buena limpieza" del Instituto Juan XXIII y explicaban que los hechos recientes no iban dirigidos "contra la Iglesia Católica ni contra su clero, sino contra un sector del catolicismo ultraizquierdista, castrista, ideológicamente marxista, politizado hasta la médula, instalado en el Instituto Juan XXIII y prohijado por algunos curas ubicados en las corrientes más avanzadas del tercermundismo", acompañados por "algunas monjas bien conocidas por sus ideas disolventes"344.

En palabras de sacerdotes bahienses que al ser entrevistados por La Opinión pidieron que no se los identificara: "La violencia no se justifica pero ellos se la buscaron" o "jugaron con fuego y ahora se queman", argumentando que los perseguidos estaban enrolados en "la línea de hacer una indirecta apología de la violencia, de hablar del 'Che' Guevara, de hacer una interpretación política del cristianismo”, habían "alborotado a la muchachada", habían llevado a los jóvenes a las villas miseria y les habían "lavado el cerebro" con sus sermones y sus clases en los colegios y el Instituto Juan XXIII. Además habían tolerado "reuniones medio raras" y el cambio de nombre del aula magna del Instituto salesiano ${ }^{345}$.

En la misma línea, $L N P$ publicaba una nota de opinión en la que intentaba demostrar en qué medida fueron ciertos núcleos religiosos los que sembraron la semilla de la violencia. El diario recordaba una serie de acciones, omisiones y acontecimientos protagonizados por las actuales víctimas de la violencia que de ningún modo podían

\footnotetext{
${ }^{342}$ Archivo DIPBA, Mesa DS, Carpeta Varios, Legajo No 3116.

343 "Nota de Remus Tetu al Inspector Salesiano", LNP, 23/3/1975.

344 "La jerarquía eclesiástica de Bahía Blanca transmitió a las autoridades la preocupación de su grey por la violencia", La Opinión, 25/5/1975.

345 “Cinco años de irritación...", La Opinión, 25/5/1975. Abordaré los avatares del cambio de nombre del aula magna del Instituto Juan XXIII en el capítulo 5.
} 
justificarse con el argumento de "la libertad en el ejercicio de la misión de la Iglesia" que ahora reclamaban: la celebración de misas donde se hacía "apología de la violencia y del marxismo"; la tolerancia frente al "bautismo ateo" del aula magna del Juan XXIII; la difusión en clase de la sentencia "la Marina es la peor enemiga de la Iglesia"; la utilización en la formación de los alumnos de libros observados por el Vaticano o de autores de la izquierda; el dictado de materias con "abierto tono ideológico"; la prédica, con el pretexto del scoutismo, de una "revolución proletaria a la usanza marxista" y la destrucción de hogares, trastocando así el "respetarás a tu padre y a tu madre". A partir de esta evidencia, $L N P$ instaba a las autoridades eclesiásticas a reflexionar en torno al control que debían ejercer sobre sacerdotes, colegios y scoutismo católicos. Al mismo tiempo, hacía un llamado a los padres para que practicaran una "estricta vigilancia" sobre la educación de sus hijos y no claudicaran en la denuncia de las "desviaciones" 346 .

Por su parte, el arzobispo Mayer levantó su voz de "Padre y pastor" 347 en dos declaraciones por las que repudiaba los atentados "criminales" 348 , los "atropellos injustos" dirigidos contra la Iglesia que atentaban "contra los más elementales derechos humanos de convivencia, de seguridad y de paz"349, condenaba la violencia como "anticristiana y antievangélica" con independencia de quien la ejerciera, y hacía un insistente llamado a la población a "defender los valores evangélicos de la justicia y de la paz" ${ }^{350}$. Al referirse específicamente al atentado del 30 de abril contra el Padre Zamorano, lamentó la destrucción de las pertenencias de la casa parroquial ${ }^{351}$.

Asimismo, Mayer presidió la misa por la muerte de Dorñak. Sin embargo, según algunos testigos, el tono de sus palabras parecía más acorde al caso de alguien que había muerto de gripe o de un paro cardiaco, y no asesinado como víctima de la violencia política $^{352}$. Esto motivó a un grupo de jucistas y jecistas a solicitar una reunión en la Curia para plantear a la jerarquía que "no están acompañando a la comunidad cristiana. A Dorñak lo asesinaron, lo asesinó la derecha, lo asesinó la Triple A,"353.

\footnotetext{
346 "Colegios católicos y autoridades. No se puede sembrar violencia y esperar el fruto de la paz", $L N P$, 25/5/1975.

347 "Declaración de Monseñor Mayer", LNP, 2/5/1975.

348 "Declaración del arzobispado", $L N P, 22 / 3 / 1975$.

349 "Declaración de Monseñor Mayer", $L N P, 2 / 5 / 1975$.

350 "Declaración del arzobispado", $L N P, 22 / 3 / 1975$.

351 "Declaración de Monseñor Mayer", LNP, 2/5/1975.

352 Entrevistas a Mónica, Buenos Aires, 30/7/2008; a Juan Carlos, Buenos Aires, 1/8/2008; a José Zamorano, Moreno, 19/9/2009; a Miguel Sarmiento, Punta Alta, 29/11/2010. Incluso "Coco" recordaba que Mayer había comparado lo sucedido con la muerte del párroco de la iglesia de la Merced ocurrida hacia 1925 en manos de una persona alcoholizada. Entrevista a Hugo Segovia, Mar del Plata, 27/5/2010.

${ }^{353}$ Entrevista a Mónica, Buenos Aires, 30/7/2008.
} 
La actitud del arzobispo se hizo más clara cuando, a raíz de aquel asesinato, los sacerdotes perseguidos se acercaron a hablar con él y le pidieron que como máxima autoridad eclesiástica asumiera un posicionamiento más firme en repudio de lo ocurrido. Al respecto, relataba "Coco": "dijimos ‘ipero usted no dice nada frente a esto? ¿Quién tiene la conducción de la Iglesia?, ¿el rector de la universidad o usted? ${ }^{354}$. Según recuerda "Pepe": "el arzobispo estaba muuuy mal, prácticamente nos dijo que la culpa de la violencia la teníamos nosotros...nosotros habíamos provocado. Saliendo de ahi de la sala, dijimos 'chicos, la Iglesia nos soltó la mano...; Y $Y$ ahora ya nos van a dar!',355. En este contexto, Duilio escribió una carta en la que expresaba su opinión sobre las causas que provocaron la muerte de Dorñak e interpelaba a Mayer como "pastor" de la comunidad cristiana. Según el sacerdote, esta muerte tenía su origen en el ambiente católico bahiense integrado por laicos, sacerdotes y religiosos, y dominado por la “archicofradía del chisme". Estaba implícita para él la responsabilidad del arzobispo que, estando advertido de esta situación desde el momento mismo en que se puso a la cabeza de la arquidiócesis, no tomó una postura decidida para enfrentarla:

la sentencia de muerte, que hoy le tocó a Carlos Dorñak, se fue escribiendo con los chismes, calumnias y rumores que se desparramaban con toda impunidad en la diócesis de Bahía Blanca. Gracias a esta campaña bien orquestada, el Juan XXIII que era considerado como centro cristiano de gran valor, fue pasado a significar "subversión, marxismo, izquierdismo, etc." 356 .

No sólo Mayer sino también sectores de la comunidad católica demostraban a los que calificaban como "curas del Tercer Mundo" que ya no contaban con el apoyo de la institución y que su suerte estaba echada. Habían pasado sólo unos años de las declaraciones del arzobispo anterior, que si bien estaba lejos de identificarse con aquella línea eclesial, les manifestaban su respaldo y protección. En el nuevo contexto, parecía asimismo lejana aquella misa concelebrada por más de diez sacerdotes en repudio por los atropellos vividos por el Padre Zamorano. Después del atentado del 30 de abril, Monseñor Mayer convocó a una reunión de párrocos y rectores de colegios religiosos. Al respecto, "Pepe" relataba: "[uno de los párrocos] comienza diciendo que por qué es que van a buscar a la hermana Norma Gorriarán y por qué van a buscar a los curas del Tercer Mundo, es decir, de pronto sentí que yo era el acusado ahi [...] yo sentí,

\footnotetext{
${ }^{354}$ Entrevista a Hugo Segovia, Mar del Plata, 27/5/2010.

${ }^{355}$ Entrevista a José Zamorano, Moreno, 19/9/2009.

${ }^{356}$ Carta de Duilio Biancucci a Jorge Mayer, 3/5/1975, Legajo de Duilio Biancucci, Archivo Histórico Salesiano Patagónico.
} 
'bueno, esto es lo más duro' ¿no?”357. En este sentido, Benjamín se refería a las diversas posturas del clero local que se pusieron de manifiesto en aquel encuentro:

Algunas francamente muy agresivas, identificadas con la ideología de la Seguridad Nacional. Nos llegaron expresiones irreproducibles, inexplicables para un cristiano y profundamente hirientes para un hermano sacerdote. No se me borra la mañana en la que el presbiterio trató la agresión a Pepe Zamorano; éste permanecía inmóvil, con la cabeza gacha sin decir una palabra como si hubiera merecido el brutal ataque ${ }^{358}$.

Según Hugo, allí, el arzobispo escuchó impasible a un capellán de la Base Naval decir que podía acercarle una lista de los religiosos que estaban "sentenciados por haberse metido en cosas que no tenían que meterse". Y luego Mayer le advirtió a "Coco" que se cuidara, lo que provocó su reacción: “ ¡¿Cómo me dice a mí semejante cosa?! ¿Por qué me tengo que cuidar yo? Usted es el responsable mío. Me tiene que cuidar usted'359.

Como consecuencia de estos hechos, los referentes consagrados del catolicismo liberacionista bahiense dejaron la ciudad, iniciando el camino del exilio, interno o externo. Los siguieron los laicos, muchos jóvenes de la JUC, de la JOC y de la JEC. Se iniciaba así un proceso de desestructuración de la militancia cristiana a nivel local y de toda una experiencia eclesial en la que participaban sacerdotes, religiosas y laicos que compartían concepciones y prácticas inspiradas en el Concilio Vaticano II y en la Conferencia de Medellín. Las diferencias teológicas, ideológicas y políticas que los habían enfrentado con otros grupos al interior de la Iglesia se resolvieron por la fuerza.

Los acontecimientos posteriores al golpe mostraron en la Iglesia local -tal como ocurría a nivel nacional (Ameigeiras, 2008)-, la profundización de la marginación de los sectores renovadores, vigilados de cerca por los servicios de inteligencia ${ }^{360}$, amenazados, perseguidos ${ }^{361}$, asesinados y desaparecidos ${ }^{362}$ por las fuerzas de seguridad,

\footnotetext{
${ }^{357}$ Entrevista a José Zamorano, Moreno, 19/9/2009.

${ }^{358}$ Entrevista a Benjamín Stocchetti, vía e-mail, 25/7/2012.

${ }^{359}$ Entrevista a Hugo Segovia, Mar del Plata, 27/5/2010.

${ }^{360}$ El mismo suboficial Santiago Cruciani, principal interrogador del CCD "La Escuelita", se acercó a Nuestra Señora del Carmen para controlar y amedrentar a la comunidad parroquial y a los ex integrantes de los grupos juveniles asesorados por "Pepe" que quedaban tras la partida del sacerdote y de varios laicos ("Detuvieron al interrogador del Centro Clandestino La Escuelita", Página 12, 15/7/2006).

${ }^{361}$ El 24/3/1976 explotó la segunda bomba en la casa de Hugo Segovia, en Punta Alta ("Dispositivos de prevención", $L N P, 26 / 3 / 1976$ ) -el primer atentado había ocurrido en septiembre de 1975 (“Atentado en un domicilio de Punta Alta", LNP, 4/9/1975). Dos meses más tarde, recibió una amenaza telefónica que lo obligó a abandonar la ciudad. Entrevista a Hugo Segovia, Mar del Plata, 27/5/2010.

362 Entre los militantes católicos bahienses asesinados y desaparecidos por la Triple A y el gobierno militar de 1976-1983 se encuentran: Daniel Bombara (GMB), José Manuel González (Parroquia San Roque), Eduardo Ricci (Scouts de La Pequeña Obra, JEC), María Clara Ciocchini (Guías de La Pequeña Obra, JEC), Horacio Russin (Scouts de la Pequeña Obra, JUC), Elizabeth Frers (Scouts de la Pequeña Obra, JUC), Alberto Paira (JEC, Scouts "San Jorge”), Carlos Rivera (docente), Néstor Gril (Cáritas), Elsa Pablo (Cáritas), Néstor Junquera (JUC) y María Eugenia González (JUC).
} 
y contenidos y apartados por el arzobispo. En este sentido, durante los primeros años de la última dictadura militar, Mayer resolvió cerrar el Pensionado de Zapiola 428 y vender el edificio. Éste había sido objeto de críticas por parte del arzobispo. Al respecto, Ángel decía: "el obispo estaba en contra, decía que era un nido de comunistas" "363. Por otra parte, Mayer resolvió organizar el pase al Estado de la escuela Nuestra Señora de la Paz.

\section{c) La articulación con otros ámbitos del catolicismo liberacionista a nivel nacional e internacional}

¿Cómo se relacionaron estos espacios de la renovación católica en Bahía Blanca y Punta Alta con otros grupos a nivel nacional e internacional? De diversos modos, los contactos de algunos de los círculos sociales mencionados trascendían el ámbito local. Estos vínculos se dieron en diferentes niveles, a saber: la pertenencia de estos grupos a movimientos de carácter nacional, latinoamericano o mundial; las prácticas que los actores llevaron adelante en otros espacios geográficos y las interacciones allí establecidas con militantes provenientes de otras latitudes; la utilización de los mismos canales de comunicación; o las influencias de textos y autores representativos del catolicismo liberacionista en el país y el continente.

\section{i) MSTM, CUT, Cristianismo y Revolución}

Uno de los referentes del catolicismo liberacionista con los que se vincularon los actores locales fue el MSTM. Los presbíteros identificados con la renovación eclesial que desarrollaban sus tareas pastorales en Bahía Blanca participaron de encuentros nacionales y/o zonales del Movimiento: "Pepe" Zamorano fue al IV Encuentro Nacional, que se llevó a cabo en julio de 1971 en San Antonio de Arredondo, Córdoba; Benjamín Stocchetti y Oscar Barreto asistieron al VI Encuentro Nacional, en agosto de 1973, celebrado en la misma ciudad cordobesa; "Pepe" , Miguel Sarmiento y otros curas del grupo participaron de reuniones zonales del movimiento en Olavarría. Al mismo tiempo, no sólo recibían, discutían y difundían los documentos del MSTM, sino también firmaban declaraciones originadas en el movimiento o bien expresando su pertenencia al mismo. Uno de ellos fue una carta a los obispos reunidos en Medellín, de julio de 1968, en la que se manifestaba la esperanza de que la Conferencia no condenara la

\footnotetext{
${ }^{363}$ Entrevista a Ángel, Buenos Aires, 8/10/2009.
} 
violencia derivada, la revolucionaria, sin haber considerado primero la violencia originaria, es decir, la estructuración económico-política del continente ${ }^{364}$. Asimismo, Segovia, como había acompañado al antiguo asesor de la JUC a algunos encuentros nacionales, conocía a otros asesores del movimiento, como Carlos Mugica -a quien recibió más tarde en la Curia cuando visitó al arzobispo antes de dar una conferencia.

En cuanto al GMB, algunos jóvenes estaban en contacto con Monseñor Jaime de Nevares y con el cura obrero Pascual Rodríguez, a partir de una visita a la capital neuquina realizada en julio de 1970, con motivo de organizar un campamento de verano para desarrollar un trabajo solidario. En esa oportunidad, los misioneros aprovecharon para conocer a los dirigentes que habían encabezado la huelga y ocupación obrera de la central hidroeléctrica de El Chocón-Cerros Colorados en febrero y marzo de ese año. En esos meses, los sacerdotes "tercermundistas" de Bahía Blanca habían apoyado la lucha obrera $^{365}$. Don Jaime de Nevares, por su parte, visitó la ciudad en agosto del mismo año, para participar de las Primeras Jornadas Regionales de Pastoral del Comahue, donde confluyeron los grupos bahienses liberacionistas con otros sectores eclesiales ${ }^{366}$.

Por otro lado, como mencionamos anteriormente, en los últimos años de la década de 1960 y primeros años de la década siguiente, una parte de la JUC transitó los

\footnotetext{
${ }^{364}$ Entrevista a José Zamorano, Moreno, 19/9/2009. Y "La justa violencia de los oprimidos para su liberación", Cristianismo y Revolución, 9, septiembre de 1968.

${ }^{365}$ Siguiendo a Healey (2003), en los años sesenta, la Patagonia fue un escenario clave para los intentos estatales de planificación regional, basados en la representación de la gran potencia de aquel territorio. En ese marco, se ubica la obra El Chocón-Cerros Colorados en Neuquén, cuyos primeros pasos fueron aprobados en 1956 como parte de las propuestas de la "Revolución Libertadora" para generar un salto cualitativo en las fuentes de energía y recursos, de modo de apuntalar el desarrollo capitalista del país. El objetivo fundamental de la represa era proveer mayor cantidad de electricidad para los consumidores y la industria del Litoral. El proyecto fue relanzado en 1968, siguiendo las sugerencias del Banco Mundial, bajo la supervisión de un ente mixto con representación del sector privado y del gobierno nacional. Las obras específicas serían llevadas a cabo por una serie de empresas contratistas coordinadas bajo el mando del consorcio ítalo-argentino Impregillo y Sollazo, que ejercía la dirección de la obra. El rápido avance de la misma, símbolo de la "eficacia militar", estuvo fundado en un autoritarismo cotidiano que provocaría un conflicto obrero de grandes resonancias nacionales. Las duras condiciones de trabajo (alta exigencia de los capataces, incumplimiento de las normas de seguridad) y de vida (problemas de vivienda, salubridad y alimentación) llevaron a una serie de reclamos laborales puntuales $\mathrm{y}$, luego, al enfrentamiento generalizado con el gobierno, las empresas contratistas y la burocracia sindical. La organización de los trabajadores se manifestó en diversos paros, que tuvieron lugar en 1969, y contaron con el apoyo del obispo y el cura Pascual Rodríguez. La mediación del gobernador Felipe Sapag llevó a su fin el conflicto. ${ }^{366}$ El evento, que se proponía impulsar una pastoral diocesana de conjunto, contó con la asistencia de religiosas, sacerdotes, laicos y los obispos de Bahía Blanca, Neuquén, Viedma y Santa Rosa, y se llevó a cabo con el aval de Esorto, a pesar de haber recibido amenazas anónimas por ese motivo. Allí participaron como disertantes Remus Tetu y Monseñor De Nevares. Y se eligió a Fortunato Mallimaci, ex militante de la JAC de Punta Alta y miembro de la JUC, como uno de los tres representantes de la Región del Comahue en el Consejo Nacional de Pastoral. Del encuentro se desprendieron una serie de sugerencias que hacían hincapié en la necesidad de una pastoral consciente, comprometida en la realidad, abierta al cambio, con un sentido de unidad de la Iglesia y de conjunto, donde todos, especialmente los jóvenes, tuvieran lugar (Boletín Eclesiástico, Bahía Blanca, julio-agosto-septiembre de 1970).
} 
Campamentos Universitarios de Trabajo, ya sea como participantes o como integrantes de los equipos promotores -como fue el caso de Nora, que viajó a Chaco y a Neuquén en dos veranos consecutivos. Los grupos promotores eran los que organizaban los campamentos en las distintas ciudades y estaban constituidos por estudiantes de la universidad o del nivel terciario que habían hecho previamente la experiencia y trabajaban todo el año para transmitirla, haciendo la convocatoria. A pesar de haber nacido como iniciativa de la Iglesia renovada, los que iban a los Campamentos no eran siempre ni necesariamente cristianos; había estudiantes de otros credos o directamente no creyentes. Si bien podía haber sacerdotes que quisieran participar, era esencialmente un movimiento laico, democrático y abierto en su funcionamiento y organización ${ }^{367}$. En este sentido, los CUT fueron significativos para los actores porque brindaban la posibilidad de conocer e interactuar con gente muy diversa en términos de creencias e ideas políticas, sobre todo para quienes estaban más habituados a vincularse dentro de grupos religiosos.

Otro de los referentes del catolicismo liberacionista a nivel nacional con los que se vincularon los grupos locales fue Cristianismo y Revolución. En cuanto se constituyó en nexo del catolicismo revolucionario argentino (Lenci, 1998), Cristianismo y Revolución fue una lectura obligada para muchos militantes bahienses, en especial para los jucistas, siendo, como ya mencionamos, el Pensionado de Zapiola 428 un punto de distribución. Al mismo tiempo, fue uno de los canales elegidos por los grupos laicales locales para difundir sus declaraciones públicas, tal como veremos en el capítulo 5.

\section{ii) Las redes jocistas}

Por otra parte, durante la primera mitad de la década de 1970, la JOC bahiense mantuvo vínculos con otras experiencias similares que, en medio de la crisis del movimiento a nivel nacional, aún pervivían en Buenos Aires, Tucumán, San Juan o La Plata $^{368}$. Sin embargo, como adelantamos en el capítulo anterior, estas experiencias eran heterogéneas en términos de su composición, su ideología, la relación con la institución

\footnotetext{
${ }^{367}$ Entrevista a Graciela, Bahía Blanca, 31/7/2008.

368 "Pepe" Zamorano y Angélica mencionaron a los grupos platenses, aunque no aludieron a la existencia de contactos entre aquellos y los locales (Entrevista a José Zamorano, Moreno, 19/9/2009 y 2/9/2011; y a Angélica, Bahía Blanca, 25/4/2012). En cambio, los testimonios abundan en referencias a las vinculaciones entre la JOC local y los grupos de Tucumán, Buenos Aires y San Juan (Entrevistas a Mirta, Bahía Blanca, 18/6/2008; a Mirta y Jorge, Bahía Blanca, 11/4/2012 y 14/7/2012; a Bruno, Bahía Blanca, 4/8/2012, a Clara, Bahía Blanca, 10/10/2012, además de las entrevistas a José Zamorano y a Angélica).
} 
eclesial, el rol del asesor, los ámbitos de acción y la síntesis fe-militancia. En primer lugar, las realidades laborales que se discutían en el grupo y sobre las que intervenían los militantes eran diversas. Según recordaba Angélica, en Buenos Aires, se destacaban las luchas de las empleadas domésticas que comenzaban a organizarse desde el punto de vista gremial, y las de los obreros de las fábricas; el grupo de San Juan estaba atravesado por las problemáticas del trabajo en los viñedos y en la cosecha, que involucraba a toda la familia, incluso a los niños que acababan interrumpiendo su escolarización; en Bahía Blanca, sobresalían las experiencias de los empleados de comercio y su pugna por lograr que se respete la jornada de 8 horas ${ }^{369}$. Mirta, por su parte, mencionaba la particularidad de Tucumán, dada por la pobreza y la explotación de los trabajadores de los cañaverales ${ }^{370}$.

En segundo lugar, la relación entre los laicos y el asesor era distinta en los grupos. Mientras los bahienses eran acompañados por "Pepe" Zamorano, en otros lugares los jóvenes trabajaban prácticamente solos o contaban con la presencia nominal de algún sacerdote. En este marco, la experiencia bahiense llamaba su atención y era, incluso, cuestionada. Al respecto, Mirta decía: "nos hacían la crítica como que la relación del cura con nosotros era demasiado paternalista" ${ }^{371}$.

Por otra parte, la orientación ideológica, la vinculación de la JOC con la Iglesia, y con la acción social y política fuera de ésta, marcaba diferencias significativas entre las organizaciones. Los grupos de Tucumán y Buenos Aires mantenían las características señaladas por Soneira (2008) para la década de 1960: mientras el primero estaba más centrado en el ámbito institucional de la Iglesia y compartía una corriente eclesial más conservadora, el segundo -al igual que la JOC bahiense-, se identificaba con la renovación católica y mostraba una apertura tanto a los problemáticas de las condiciones de vida de los trabajadores como a la acción social y política orientada a trasformar la realidad. Al respecto, Mirta y Jorge resaltaban la "afinidad” de los jocistas bahienses con los sanjuaninos y los de Buenos Aires, y la distancia con otros grupos, como el tucumano, que -según su parecer- estando "muy metidos en la Iglesia" y acompañados por sacerdotes "reaccionarios", "no veían la parte política”372. Sin embargo, más allá de las afinidades ideológicas, teológicas y metodológicas de los militantes jocistas de Bahía Blanca y la Capital, la forma de integrar la pertenencia a la

\footnotetext{
${ }^{369}$ Entrevista a Angélica, Bahía Blanca, 25/4/2012.

${ }^{370}$ Entrevista a Mirta y Jorge, Bahía Blanca, 11/4/2012.

${ }^{371}$ Entrevista a Mirta, Bahía Blanca, 18/6/2008.

${ }^{372}$ Entrevista a Mirta y Jorge, Bahía Blanca, 11/4/2012.
} 
JOC y a la Iglesia, por un lado, y a los movimientos políticos contestatarios, por el otro, variaba según los casos. Al respecto Angélica decía:

el trabajo pastoral que se hacía acá, desde la Iglesia, no se daba en otros lugares [...] en esto de darle un sentido cristiano. A veces se quedaba la cosa en la reivindicación, en generar situaciones de justicia, que por supuesto son del Evangelio, pero por ahi no había una explicitación o una referencia a que esto se hace desde el Evangelio, desde el compromiso con un camino que nos marcó Cristo. Era un poco más desde el deseo de una justicia social sin estos matices más espirituales, como completando PARA MÍ un camino de transformación ${ }^{373}$.

Los intercambios entre las experiencias jocistas se daban a través de distintos canales. Por un lado, mediante la correspondencia y las visitas espontáneas e informales de militantes bahienses a la casa de la JOC en Buenos Aires -ubicada en la calle Díaz Vélez-, donde intercambiaban noticias y materiales, además de encontrarse con dirigentes y antiguos referentes nacionales -entre ellos, Enrique Angelelli ${ }^{374}$.

Por otro lado, la vinculación con la JOC de otras diócesis se concretaba mediante encuentros nacionales e internacionales. Los primeros tenían una frecuencia anual y, en el período que nos ocupa, se celebraron en Buenos Aires, San Juan ${ }^{375}$, Bahía Blanca (1974) y Tucumán (1975), y contaron con la participación de jocistas bahienses al primero asistió Bruno; al segundo, Mirta y Angélica; y al último, nuevamente Mirta y otro compañero. El encuentro de 1974 tuvo lugar en el Villa Inmaculada, fue organizado por el grupo local y congregó a militantes jocistas de San Juan y Buenos Aires, entre ellos "Pepe" Palacios. Mirta y Jorge evocaban la misa al aire libre, presidida por el asesor bahiense, en consonancia con la renovación litúrgica del Concilio: "tomamos la comunión con pan común ...una cosa que nos quedó grabada, viste, el atardecer, vos veías allá la loma, el sol se ponía”376. Por su parte, Clara recordaba: "Éramos un montón y cada uno proponía su experiencia"377. En efecto, estos encuentros buscaban poner en común las realidades laborales, y las experiencias de trabajo y de compromiso de cada lugar, al ritmo del Ver, Juzgar y Actuar.

Por otra parte, en diciembre de 1973 tuvo lugar en Bogotá (Colombia) un encuentro latinoamericano de la JOC, que incluyó la presencia de militantes de Brasil,

\footnotetext{
${ }^{373}$ Entrevista a Angélica, Bahía Blanca, 25/4/2012.

${ }^{374}$ Entrevista a Mirta y Jorge, Bahía Blanca, 11/4/2012. Entrevista a Bruno, Bahía Blanca, 4/8/2012.

${ }^{375} \mathrm{Si}$ bien no contamos con el año de realización de estos encuentros, podrían ubicarse en los años 1972 y 1973, en función de la participación de Jorge y de Angélica, quienes ingresaron a la JOC bahiense en marzo de 1972. Además, el documento "Historia de la JOC en Bahía Blanca" dice que fue en el año 1972 cuando se tuvo conocimiento de la existencia de otros grupos de JOC en el país.

${ }^{376}$ Palabras de Jorge, Entrevista a Mirta y Jorge, Bahía Blanca, 11/4/2012.

${ }^{377}$ Entrevista a Clara, Bahía Blanca, 10/10/2012.
} 
Chile, Paraguay, Perú y Argentina. Por la delegación argentina, viajaron "Pepe" Palacios, de Buenos Aires, y Angélica, de Bahía Blanca. Allí cada grupo compartió la historia del movimiento obrero, las experiencias de organización y los derroteros de la JOC en cada uno de los países, que en algunos casos, habían sufrido persecución política $^{378}$. En efecto, como analiza Levenson (2007), este fue el caso de los activistas de la JOC guatemalteca, que fundaron sindicatos en la década de 1960, en una época de terrorismo estatal, convirtiéndose en una de sus víctimas.

Una preocupación común que atravesó estos encuentros fue la necesidad de articular otras instancias de relación más formales que facilitaran la comunicación entre las experiencias jocistas del país; sin embargo, no resultó fácil concretarlas. En ello confluyeron una serie de factores, entre los cuales los actores destacaban la heterogeneidad de las JOC y la falta de continuidad de los militantes en los grupos, que año a año iban cambiando, lo que marcaba una diferencia respecto de la JOC bahiense $^{379}$.

\section{iii) EI MIEC-JECI}

La JUC y de la JEC también establecieron conexiones a nivel nacional e internacional con otras experiencias semejantes que nucleaban a estudiantes católicos del nivel medio y superior. A fines de la década de 1960 y primera mitad de la siguiente, existían en varias ciudades del país -tales como Buenos Aires, Tucumán, Córdoba, Bahía Blanca, Mar del Plata o Santa Rosa. Al mismo tiempo, funcionaban en otros países latinoamericanos, donde adoptaron distintos nombres: por ejemplo, JUC en Argentina, Ecuador, Bolivia o Nicaragua, Unión Nacional de Estudiantes Católicos (UNEC) en Perú, Movimiento Católico Universitario (MCU) en Uruguay, Asociación de Universitarios Católicos en Chile, Movimiento Estudiantil y Profesional (MEP) en México o Equipos Universitarios en Colombia ${ }^{380}$.

\footnotetext{
${ }^{378}$ Entrevista a Angélica, Bahía Blanca, 25/4/2012.

${ }^{379}$ De todos modos, sobre la existencia o no de un equipo coordinador a nivel nacional las opiniones difieren. Por un lado, Mirta, Jorge y Angélica señalaban que si bien había intercambios entre los grupos a través de los canales mencionados, no existía una coordinadora con representantes de cada uno. Por su parte, Bruno afirmaba que tal coordinadora existía, que funcionaba en la casa de la calle Díaz Vélez y que era la encargada de enviar folletería con información sobre las actividades de cada lugar. Y según la "Historia de la JOC en Bahía Blanca" llegó a formarse esa coordinación nacional con militantes que fueron los que luego participaron en el encuentro de Bogotá (Entrevista a Angélica, Bahía Blanca, 25/4/2012; a Mirta y Jorge, Bahía Blanca, 11/4/2012; y a Bruno, Bahía Blanca, 4/8/2012).

380 "Informe de la XXVIII Asamblea Interfederal del MIEC", Spes, 27-28, s/f.
} 
Estos grupos pertenecían al MIEC-JECI, que era la convergencia en América Latina de dos movimientos especializados internacionales que trabajaban con estudiantes. El MIEC Pax Romana, cuyo Secretariado General tenía sede en Friburgo (Suiza), había actuado siempre a nivel universitario, mientras que la JECI, con sede en París (Francia), lo había hecho originalmente a nivel secundario para luego extenderse hacia el medio superior. En 1966 los secretariados latinoamericanos de ambos movimientos decidieron unir esfuerzos y se instalaron en Montevideo (Uruguay). A partir de entonces, la fusión fue creciente: los movimientos universitarios estaban afiliados a ambas internacionales, y desde 1970, el Secretariado Latinoamericano (SLA) era común a ambos equipos, al igual que el asesor eclesiástico ${ }^{381}$. Esta unificación se basaba en una misma línea teológico-pastoral: la asunción del "compromiso con la liberación de América Latina" y el propósito de "ser Iglesia en el proceso social de liberación" 382 . Desde febrero de 1972, el Secretariado comenzó a funcionar en una nueva sede: Lima (Perú), después de una salida de Montevideo signada por "las dificultades del Centro de Documentación, los apuros económicos" una profunda crisis de la JEC local que condujo a la casi desaparición, como consecuencia del alejamiento de los militantes que llegaban a una "etapa de politización", y de una aguda represión ${ }^{384}$. Para entonces, el movimiento abarcaba grupos de estudiantes secundarios y universitarios en casi una veintena de países desde el Río Bravo (México) hasta Tierra del Fuego.

El SLA realizaba un "trabajo pastoral de base", orientado a acompañar y dar apoyo directo a los movimientos. Para ello, los visitaba periódicamente y realizaba seminarios de formación para militantes y asesores ${ }^{385}$. Al respecto, Nancy recordaba: “venía Gilberto Valdéz ${ }^{386}$, nos reuníamos, recuerdo mucho la referencia al movimiento nacional y latinoamericano, o sea, se trabajaba mucho eso, cuántos éramos, dónde estábamos, qué pasaba en el país, encuentros nacionales de reflexión "387. En efecto, una de las formas en las que se canalizaban los contactos entre los grupos bahienses y el

\footnotetext{
381 “Aproximación a la realidad latinoamericana. Iglesia-Movimiento", Spes, 19, octubre 1972.

382 "Aproximación a la realidad latinoamericana. Iglesia-Movimiento", Spes, 19, octubre 1972.

383 “"Editorial”, Spes, 19, octubre 1972.

384 “JEC de Montevideo: una experiencia a tener en cuenta”, Spes, 21, mayo 1973.

385 “Aproximación a la realidad latinoamericana. Iglesia-Movimiento", Spes, 19, octubre 1972.

${ }^{386}$ Militante peruano, fue secretario latinoamericano y miembro del equipo del SLA a principios de los años setenta. Fue elegido presidente del MIEC a nivel internacional, en la Asamblea Interfederal del movimiento, celebrada en Lima en agosto de 1975 ("Informe de la XXVIII Asamblea Interfederal del MIEC”, Spes, 27-28, s/f). En sus viajes a Bahía Blanca conoció a su compañera, integrante de la JUC local.

${ }^{387}$ Entrevista a Manuel y Nancy, Neuquén, 20 y 21/3/2013.
} 
movimiento era a través de las visitas de los integrantes del equipo del SLA y de sus iniciativas. En esos años, Bahía Blanca constituía un centro de referencia de la JUC a nivel nacional, por lo cual, recibía a distintos dirigentes y asesores ${ }^{388}$. El encuentro nacional de la JUC Argentina, llevado a cabo en Bahía Blanca en enero de 1970, se constituyó en una de aquellas oportunidades de intercambio: los participantes contaron con el acompañamiento de Carlos Alberto Payán, por el SLA y Paul Dabezies, asesor nacional del MCU de Uruguay. La reunión convocó a las comunidades de Tucumán, Buenos Aires, Santa Rosa y Bahía Blanca y tuvo como tema de reflexión el movimiento estudiantil en su relación con el pueblo, el rol de la Iglesia dentro del proceso y la experiencia del movimiento ${ }^{389}$.

El número de integrantes del SLA fue variando a lo largo del período en función de las necesidades del movimiento. Desde 1972, se bregó por reducir el equipo a 6 personas (el secretario, representante y responsable del equipo; el director del Centro de Documentación; tres encargados -junto al primero- del trabajo pastoral; y el asistente eclesiástico). Si bien el SLA debía ser único, capaz de asumir el trabajo tanto con secundarios como con universitarios, en la práctica estaba integrado en su mayoría por universitarios $^{390}$. Entre los miembros del SLA figuraron, durante varios años consecutivos, cuatro jucistas y una jecista bahienses: Eduardo, entre febrero $1971 \mathrm{y}$ febrero 1973, Manuel y Nancy, desde diciembre de 1973 hasta abril-mayo de 1976, Juan Carlos y Mónica, entre mayo de 1975 y mediados de 1978.

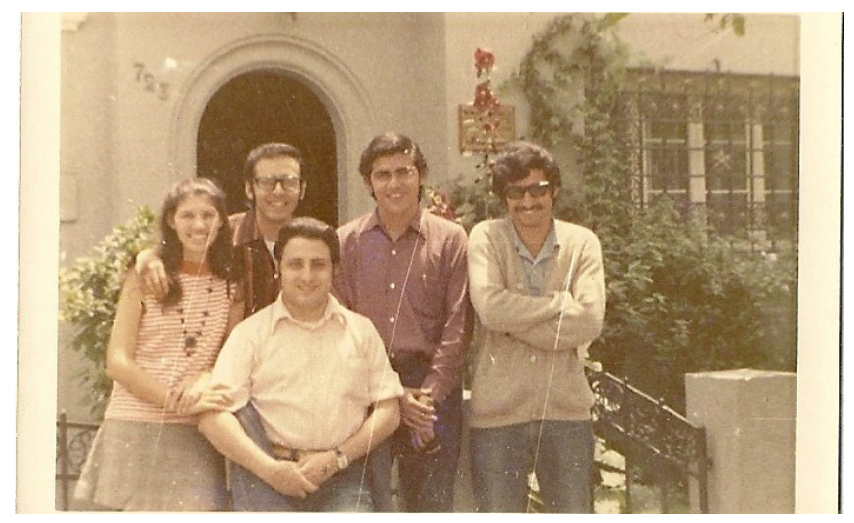

Miembros del SLA en la sede de Lima, 1971-1972.

\footnotetext{
${ }^{388}$ Entrevista a Mónica y Juan Carlos, Bahía Blanca, 28/3/2013.

389 "Noticias", Spes, 12, noviembre 1970.

390 "Aproximación a la realidad latinoamericana. Iglesia-Movimiento", Spes, 19, octubre 1972.
} 
Por otra parte, el movimiento contaba con distintas instancias de encuentro periódico de dirigentes, militantes y asesores a nivel nacional, latinoamericano y mundial, que buscaban reflexionar, partiendo de la realidad socioeconómica y política de los estudiantes, de la Iglesia y del movimiento, sobre el "ser cristianos", para descubrir cómo vivir la fe y "presentar de la manera más eficaz la palabra del Señor en el medio estudiantil". Al mismo tiempo, estas reuniones apuntaban a profundizar la formación teológica de los militantes, de modo de que estuvieran preparados para superar los "desafíos del medio" -entre ellos, el "embate de la politización" "391 . "Pepe" se refería al rol formativo de estos espacios para los militantes y los asesores:

en esos encuentros se procuraba ayudar a todo el tema de una mirada crítica de la realidad, herramientas de interpretación de la realidad, análisis político ¿no? $Y$ por supuesto también todo lo que es la fundamentación teológica de esta mirada de los cristianos ¿no? y esta vivencia de los cristianos en el compromiso histórico [...] Y había a la vez encuentros de asesores latinoamericanos, cuando íbamos entonces era un modo también, desde el movimiento nos creara un espacio donde íbamos también aprendiendo ${ }^{392}$.

Veamos cuáles eran entonces estas oportunidades de interacción de los integrantes del MIEC-JECI: 1) Los encuentros nacionales, de la JEC y de la JUC. 2) El Comité Latinoamericano y Sesión de Estudios, que se realizaba cada dos años, con un representante por cada país. A partir de la realidad del continente y del medio estudiantil en particular, se redefinía la identidad del movimiento y sus orientaciones generales de trabajo, entre ellas, la línea de las publicaciones del Centro de Documentación. Era considerada, así, "una gran revisión de vida"393, donde el sujeto de la misma era el movimiento, visto en proceso a partir de un marco teórico de interpretación. 3) Los encuentros regionales o zonales de militantes de la JUC o de la JEC, que congregaban a los movimientos del Cono Sur, del Caribe, de la Zona Andina y de Centroamérica. 4) Los encuentros de asesores, latinoamericanos o regionales, que buscaban brindar apoyo a los sacerdotes "con una reflexión específica sobre sus problemas tanto en lo personal, cuanto en la línea pastoral, Iglesia y Teología"394. 5) Las reuniones mundiales, esto es, la Asamblea Interfederal del MIEC (cada cuatro años) y la Sesión Mundial de la JECI (cada tres años), que congregaban a miembros del equipo así como de los movimientos

\footnotetext{
391 “Aproximación a la realidad latinoamericana. Iglesia-Movimiento”, Spes, 19, octubre 1972.

392 Entrevista a José Zamorano, Moreno, 19/9/2009.

393 "Noticias del SLA", Spes, 19, octubre 1972. "Aproximación a la realidad latinoamericana. IglesiaMovimiento", Spes, 19, octubre 1972. "Comité Latinoamericano de la JECI", JEC Boletín Secundario, 14 , agosto 1970 .

394 “Aproximación a la realidad latinoamericana. Iglesia-Movimiento”, Spes, 19, octubre 1972.
} 
latinoamericanos. En estas instancias se definían las líneas pastorales a las que también respondía el movimiento en América Latina. Así, la Sesión Mundial era caracterizada como una "gran revisión", donde la JECI de más de 60 países aportaba sus experiencias en el medio estudiantil en el contexto de sus regiones, a la luz de las cuales se buscaba verse a sí misma como movimiento de Iglesia, para juzgar el grado de fidelidad asumido con la realidad "donde se manifiesta el Señor", y poder aproximarse a las acciones que exigían "la construcción del mundo nuevo, del hombre nuevo y de la nueva Iglesia"395.

Además de los encuentros, el MIEC-JECI procuraba enriquecer la formación de sus militantes a través de la convocatoria de expertos que ofrecieran charlas y materiales sobre determinados temas de interés ${ }^{396}$. Así, en agosto de 1973, el SLA convocó al Seminario Latinoamericano sobre "Fe y política", como respuesta a la necesidad de los movimientos de ampliar el marco teórico de la revisión de vida y a la búsqueda que en ellos planteaban las tensiones del "proceso de politización" de los estudiantes cristianos $^{397}$. Parte del material elaborado en el Seminario se ofreció a la reflexión de los equipos de base a través del Servicio de Documentación: por ejemplo, el documento 6 "Praxis de liberación y fe cristiana", de Gustavo Gutiérrez; o el documento 8, "Marco histórico de la Iglesia Latinoamericana", de Alberto Methol Ferré.

Los jucistas y jecistas bahienses, así como su asesor, formaron parte activa de las actividades del movimiento. A nivel nacional, los jucistas se hicieron presentes en al menos tres encuentros, los de 1968 (Buenos Aires), 1969 (Villa Allende) y 1970 (Bahía Blanca): en los dos primeros, a través de algunos representantes y en el último, involucrando a todo el movimiento local, al haber sido Bahía Blanca la sede del mismo. Esta participación se enmarca en el proceso de acercamiento de los primeros grupos jucistas de la ciudad a otras experiencias similares, la búsqueda de integración al movimiento, y la asunción de mayor protagonismo dentro del mismo como sede del secretariado nacional. Al respecto, "Pepe" relataba que en 1969: "como había un enfrentamiento entre dos líneas acá en la Capital Federal que es donde había más grupos de JUC, entonces el Secretariado cayó en nosotros" 398 . Y Nora explicaba que a partir de entonces, "manteníamos correspondencia, teníamos un material hermosísimo, que eran las publicaciones de MIEC-JECI, bueno, trabajábamos ese material [...] al

\footnotetext{
395 “Sesión Mundial 70”, JEC Boletín Secundario, 10, junio 1969.

396 A nivel nacional, algunos movimientos también sostenían instancias periódicas de formación. Por ejemplo, la UNEC de Perú organizaba seminarios, siendo el objeto del noveno, la relación marxismo y cristianismo "Noticias. De los movimientos. Perú: IX Seminario Nacional", Spes, 19, octubre 1972.

397 "Seminario Fe y Política", Spes, 22-23, enero 1974.

${ }^{398}$ Entrevista a José Zamorano, Moreno, 19/9/2009.
} 
estar el Secretariado de la JUC acá, eso nos dio una conexión a nivel nacional, esto empezó a crecer, se empezó a acercar más gente ${ }^{399}$.

A nivel latinoamericano, los delegados provenientes de Bahía Blanca se hicieron presentes en el encuentro de asesores congregado en el Seminario Mayor de Medellín en octubre de 1971: Eduardo lo hizo como integrante del SLA ${ }^{400}$, mientras estaba desarrollando trabajo de base en Centroamérica, y "Pepe" como asesor de la JUC. Allí se encontraron además con Emilio Flores, quien había acompañado a los jucistas hasta julio de ese mismo año y estaba en Colombia desde entonces.

Por otra parte, Julio y "Pepe" asistieron a la Sesión de Estudios y el Comité Latinoamericano de MIEC-JECI, celebrado en Lima en diciembre de 1972, como representantes de la JUC local ${ }^{401}$, y Eduardo lo hizo como miembro del equipo del $\mathrm{SLA}^{402}$. La preocupación de ese encuentro giraba en torno a la "politización" de los militantes y las líneas de trabajo a adoptar para superar los problemas derivados de aquélla. Se proponía, entonces, incrementar la reflexión teórica y científica sobre la realidad como modo de enriquecer y permitir mayor maduración en las opciones; profundizar la reflexión teológica, el conocimiento de la historia de la Iglesia, así como el cultivo de una nueva espiritualidad acorde con la nueva experiencia; trabajar preferentemente con los movimientos que estuvieran llevando una experiencia más "avanzada"; tratar de que el movimiento se insertara lo mejor posible en el conjunto de la Iglesia; extender cuantitativamente la experiencia para ser más "significativos y eficaces" en la Iglesia y en los sectores militantes; estructurar una pedagogía capaz de responder tanto a los sectores más politizados como a los que se incorporaban al movimiento, así como la de impulsar los aspectos comunitarios y organizativos del mismo para que la experiencia contara con la infraestructura de apoyo necesaria ${ }^{403}$.

Al año siguiente, el Seminario "Fe y Política" contó con la participación de otro grupo de bahienses. Al respecto, Juan Carlos recordaba: "se juntó todo, lo más granada que había del momento. Después cada uno siguió su camino. Acá vino Methol Ferré, vino Sena, vino Dussel, vino gente de Chile que justo fue el día del golpe ${ }^{404}$.

\footnotetext{
${ }^{399}$ Entrevista a Nora, Bahía Blanca, 4/6/2008.

${ }^{400}$ Carta de Eduardo dirigida a sus padres desde Medellín, s/f. Archivo personal de Eduardo. Y Eduardo, conversación personal, Bahía Blanca, 14/12/2013.

${ }^{401}$ Boletín eclesiástico. Bahía Blanca, octubre-diciembre de 1972. Entrevista a José Zamorano, Moreno, 2/09/11. Entrevista a Julio, Bahía Blanca, 22/5/2010.

${ }^{402}$ Eduardo, conversación personal, 14/12/2013.

403 "Informe América Latina. Línea de trabajo seguidas desde la última AIF en Friburgo en 1971", Spes, $27-28, \mathrm{~s} / \mathrm{f}$

${ }^{404}$ Entrevista a Mónica y Juan Carlos, Bahía Blanca, 28/3/2013.
} 
Por otra parte, hubo tres encuentros mundiales que contaron con la participación de estudiantes católicos provenientes de Bahía Blanca. A la Sesión de Estudios y Consejo Mundial de JECI que tuvo lugar en Londres a fines de julio de 1970, asistió Ángel como representante de la Argentina. El problema dominante del encuentro fue "la acción de la JECI en relación con el movimiento estudiantil en el contexto de la sociedad actual”. En última instancia, el horizonte del trabajo era la búsqueda de la identidad del movimiento, evitando el riesgo de convertirse en "una fuerza estática conservadora, en un obstáculo tanto para la evolución histórica del mundo estudiantil como para una fe viva", y la definición de la orientación del mismo en el siguiente trienio $^{405}$. De esta experiencia, Ángel recordaba el contraste entre los militantes latinoamericanos, que se identificaban con la corriente eclesial renovadora, marcada por la "visión de los pobres", y las realidades religiosas juveniles de los otros continentes:

Europa que veía las cosas de bien pero de lejos, de afuera, Estados Unidos indiferente, como no viviendo en el mundo...Africa y Asia muy reaccionarios [...] .por ejemplo se discutía si la Virgen era...virgen o no, si había sido un parto, todas estas cosas que nosotros siempre discutimos y vemos que son formalidades y no la esencia de la Iglesia ${ }^{406}$.

El siguiente encuentro mundial de la JECI, realizado en Maastricht (Holanda) en septiembre de 1974, contó con la participación de Eduardo Ricci ${ }^{407}$, por la JEC, de Graciela por la JUC, y de "Pepe" Zamorano como asesor. Al respecto, el sacerdote evocaba las impresiones de dicho encuentro: por un lado, el peso de América Latina en el movimiento, no por la cantidad de equipos o de militantes sino por los aportes de la nueva teología; por el otro, el liderazgo de Eduardo, quien a pesar de ser más joven que la mayoría de los delegados, se destacaba entre ellos: “tendría 18-19 años, jme impactó cuando él se expresaba!...una linda experiencia de Iglesia y militancia, y mucha claridad" 408 .

En tercer lugar, la XXVIII Asamblea Interfederal del MIEC se reunió en Lima en agosto de 1975, cuando cuatro bahienses compartían el trabajo en el Secretariado: Manuel y Nancy, desde fines de 1973, mientras Juan Carlos y Mónica se habían

\footnotetext{
405 “JECI Sesión Mundial. Londres 1970", Spes, 9, julio 1970. Un documento elaborado dos años después, que revisaba los aportes de la Sesión Mundial, corroboraba la impresión de Ángel sobre el mundo no latinoamericano: "La coyuntura del movimiento hoy: visión histórica II", Documento 1, Servicio de Documentación, MIEC-JECI, 23 de febrero de 1972.

${ }^{406}$ Entrevista a Ángel, Buenos Aires, 8/10/2009.

${ }^{407}$ Integrante de los Scouts de La Pequeña Obra y de la JEC bahiense. Estudió en las Escuelas Medias de la UNS y fue militante de la UES y de la JUP. Fue secuestrado en La Plata, donde estudiaba Medicina, el 30 de marzo de 1977 y continúa desaparecido.

${ }^{408}$ Entrevista a José Zamorano, Moreno, 19/9/2009.
} 
incorporado hacía sólo tres meses, luego de haber dejado Bahía Blanca en un clima de persecución y amenazas. "Pepe" también estuvo presente en la Asamblea, a propuesta de Buenaventura Pelegrí ${ }^{409}$, habiendo ya iniciado su exilio y después de haber pasado por Francia para informar sobre la situación del movimiento bahiense. El encuentro de asesores, incluido en la Asamblea, giró en torno a un conjunto de preocupaciones personales, teológicas y pastorales, entre ellas: la dificultad de diálogo con la jerarquía; la falta de preparación frente a problemas que se planteaban agudamente a las nuevas generaciones, como el de la sexualidad y el del compromiso político; o cómo vivir el exilio y la situación de peligro e inseguridad que aquél les planteaba "sobre la base de la seguridad básica en Cristo" 410 .

Por último, los bahienses que integraron el SLA tuvieron la posibilidad de participar en encuentros nacionales o regionales de otros países. De este modo, Eduardo asistió a la Convención nacional del MEP, realizada en Torreón (México), durante 8 días previamente a viajar a Colombia ${ }^{411}$ y a un encuentro de militantes de Centroamérica, México y el Caribe que tuvo lugar en Guatemala en abril de 1971.

Por otra parte, desde sus inicios, el Secretariado intentó participar de los grandes eventos de la Iglesia Latinoamericana y Mundial. Así, en 1967 asistió al encuentro de Buga (Colombia) sobre cristianos en la Universidad, invitada por Departamento de pastoral universitaria del CELAM $^{412}$; un año después, al encuentro del CELAM en Medellín ${ }^{413}$; en 1969-1970, estableció contactos con el Departamento de laicos del $\mathrm{CELAM}^{414}$, y en 1971, concurrió a una reunión conjunta en Montevideo para poner en común líneas pastorales para América Latina; y se relacionó con el Concilio de laicos

\footnotetext{
${ }^{409}$ Responsable internacional del movimiento como asistente eclesiástico del MIEC ("Informe de la XXVIII Asamblea Interfederal del MIEC", Spes, 27-28, s/f). Se preocupó especialmente por la formación y el apoyo a los asesores ("Aproximación a la realidad latinoamericana. Iglesia-Movimiento", Spes, 19, octubre 1972). Viajó por los distintos continentes en los que estaba presente el movimiento, entre ellos, África, durante 1974 ("Informe de la XXVIII Asamblea Interfederal del MIEC", Spes, 27-28, s/f) y América Latina ("Informe", JEC Boletín Secundario, 16, mayo 1971). En sus visitas a Bahía Blanca, trabó amistad con "Pepe" Zamorano (Entrevista a José Zamorano, Moreno, 19/9/2009).

410 "Informe de la XXVIII Asamblea Interfederal del MIEC", Spes, 27-28, s/f.

${ }^{411}$ Postal s/f enviada por Eduardo a su hermano desde Torreón. Archivo personal de Eduardo.

${ }^{412}$ La reunión convocó a un conjunto de expertos y las conclusiones, aprobadas por 30 obispos, se referían a la misión de las universidades católicas latinoamericanas (Armada, 1970).

${ }^{413}$ El encuentro, que tuvo lugar en agosto-septiembre de 1968, produjo para los católicos "postconciliares" importantes documentos "de renovación y compromiso" (Armada, 1970: 325).

${ }^{414}$ En noviembre de 1970, la Comisión Episcopal de dicho Departamento organizó un Encuentro del que participó el asesor latinoamericano con el fin de discutir un proyecto de política pastoral. Los asistentes abordaron la praxis del apostolado laico "en una América Latina en proceso de liberación" para llegar a conclusiones prácticas en orden a una estrategia acorde a la tarea pastoral de la Iglesia latinoamericana ("Noticias. Del CELAM", Spes, 12, noviembre 1970).
} 
del Vaticano, así como con éste último ${ }^{415}$. Por ejemplo, en noviembre de 1970, Carlos Alborno del SLA presentó a Pablo VI un informe sobre la realidad de los estudiantes latinoamericanos, su compromiso, la presencia de los cristianos en las "opciones del presente" $\mathrm{y}$, específicamente, del "aporte de la fe en la praxis política concreta" ${ }^{416}$.

Además de articular el movimiento con la Iglesia global y de trabajar inserto dentro de la estrategia del Departamento de laicos del CELAM y del Concilio de Laicos en América Latina, el MIEC-JECI buscaba vincularse estrechamente con otros movimientos de apostolado seglar, tales como la Juventud Obrera Católica Internacional (JOCI), el Movimiento Obrero Adulto Católico (MOAC), el Movimiento Internacional de Juventud Agraria, Rural y Campesina (MIJARC), el Movimiento de Infancia y Adolescencia Católica (MIYAC), la Juventud Independiente Católica (JIC) ${ }^{417}$, el Movimiento Internacional de Intelectuales Católicos (MIIC). Algunas muestras de la interacción del MIEC-JECI con estas organizaciones fueron la presencia del presidente del movimiento de intelectuales en la Asamblea Interfederal del MIEC de Lima, y del asesor internacional de dicho movimiento en el encuentro de asesores del MIEC que se celebró en paralelo a la Asamblea; la edición en esos meses de uno de los documentos del Servicio de Documentación que recogía la reflexión teológica de la XXII Asamblea Plenaria del MIIC (Roma, abril de 1975), a cargo de Juan Scannone; la confluencia de los militantes en instancias formativas promovidas por el CELAM, como el Seminario sobre la formación social de la juventud (Bogotá, mayo de 1969), en el que participaron distintos movimientos laicos, entre ellos, el MIJARC y el MIEC-JECI ${ }^{418}$; las reuniones organizadas por los secretariados latinoamericanos de la JECI, el MIEC, la JOCI y el MIJARC, con el propósito de confrontar la situación de los medios obrero, campesino y estudiantil, insertos en la realidad del continente, y estudiar posibles formas de colaboración ${ }^{419}$. Para los actores, esta confluencia se hallaba sobradamente justificada:

Los medios en los que se intenta vivir esa vida de testimonio son distintos, pero sometidos a tensiones muchas de ellas iguales. La situación de explotación en que vivimos en cada uno de nuestros países; el problema de la dependencia económica y cultural; la falta de respeto por los valores humanos y por lo tanto la negación de la libertad política y económica, son situaciones que nos alcanzan a todos, que a todos nos incumben, a todos nos interesa solucionar. Asimismo hay un deseo común de vivir auténticamente nuestra $\mathrm{Fe}$, somos conscientes de la

\footnotetext{
415 “Aproximación a la realidad latinoamericana. Iglesia-Movimiento”, Spes, 19, octubre 1972.

416 "MIEC-JECI en el Vaticano", Spes, 11, octubre 1970.

417 “Aproximación a la realidad latinoamericana. Iglesia-Movimiento”, Spes, 19, octubre 1972.

418 "Seminario sobre la formación social de la juventud”, JEC Boletín Secundario, 10, junio de 1969.

419 "Presencia estudiantil en la realidad latinoamericana" y "Noticias", JEC Boletín Secundario, 8, noviembre de 1968 .
} 
importancia de nuestra tarea en lo relativo a construir una imagen de la Iglesia cada día más accesible a los pobres y a los oprimidos ${ }^{420}$.

Otro de los canales de comunicación y formación de los jecistas y jucistas del continente eran las publicaciones del movimiento. El Secretariado Latinoamericano de la JEC Internacional publicaba desde su sede en Uruguay un Boletín Secundario, elaborado por los mismos miembros del equipo y considerado "como un instrumento de trabajo más que permite acompañar la vida del movimiento" mediante un "aporte teórico e informativo" ${ }^{421}$. Según los números que he podido recopilar, los primeros números datan de $1967^{422}$, habiéndose lanzado al menos un ejemplar en 1968, 3 en 1969, 3 en 1970 y 2 en 1971. A partir del número 16, de mayo de 1971, en vistas a constituirse en un servicio más eficaz, se proponía modificar su contenido, abarcando experiencias de los movimientos nacionales; informes sobre el movimiento estudiantil de un país o región; reflexiones del equipo de SLA sobre temas específicos; y estudios sobre pedagogía y teología ${ }^{423}$. Una vez que el Secretariado se trasladó a Lima, dicha revista se habría dejado de elaborar.

Por otra parte, el SLA del MIEC-JECI contaba con un Centro de Documentación que editaba una serie de publicaciones, que en el período que nos ocupa, incluían Spes, Servicio de Documentación y Boletín América Latina. El primero, boletín informativo del Secretariado, fue creado en 1969 y pretendía salir con una frecuencia de $6^{424}$ a 8 números anuales ${ }^{425}$, aunque en la práctica lo hizo de un modo variable: 4 números en 1969, 7 en 1970, 4 en 1971, 1 en 1972, 2 en 1973, 2 en 1974 y 2 en $1975^{426}$. El intervalo entre el número 18, de mayo de 1971, y el 19, de octubre de 1972, está vinculado con la crisis del movimiento en Uruguay y el traslado del SLA a Perú.

El Servicio de Documentación era un "folleto de documentación especializada en educación, Iglesia, política, etc.”, de 8 números al año ${ }^{427}$. A través de distintas "series" identificadas por colores, se proponían documentos que versaban sobre diversos temas. Por ejemplo, la serie amarilla estaba dedicada a "suministrar materiales

\footnotetext{
420 "Relaciones entre los distintos movimientos especializados", JEC Boletín Secundario, 11, noviembre 1969.

421 "Editorial", JEC Boletín Secundario, 16, mayo 1971.

${ }^{422}$ En el número 10 de junio de 1969, se menciona el número 3, de agosto de 1967.

423 "Editorial", JEC Boletín Secundario, 16, mayo 1971.

424 Véase la propaganda de las publicaciones del SLA aparecida en "Algunas ideas sobre el funcionamiento de los grupos", Servicio de Documentación, doc. 12, 1974.

${ }^{425}$ Spes, 20, marzo 1973.

426 "Spes 1/29. Índice temático", Spes, 30, octubre 1976.

${ }^{427}$ Spes, 20, marzo 1973.
} 
que sean de utilidad para los equipos que recién se inician, o que necesitan guías pedagógicas y metodológicas para su funcionamiento" o bien para "cuestionar, enriquecer o refrescar la experiencia pedagógica de los equipos más veteranos" ${ }^{\text {"28 }}$. Entre las cuestiones abordadas figuraban: fe e ideología; Iglesia y política, y las tensiones derivadas de esta relación; Iglesia, Estado y sociedad; Iglesia y pueblo; participación de la Iglesia en el proceso histórico; cristianismo y marxismo; la fe, los cristianos y la realidad de cada región; fe cristiana y praxis de liberación; la teología de la liberación, su método y nociones fundamentales (por ejemplo, el carácter político de la dimensión de Jesús, la historicidad de la salvación, etc.); fe y cultura; el apostolado laico y el rol del laico en el mundo; la juventud y la pastoral juvenil en una sociedad cambiante; la pedagogía de la pastoral universitaria; la universidad en el proceso revolucionario; el movimiento estudiantil en distintos países o en América Latina en general; la “concientización”; la educación liberadora; o la coyuntura del movimiento.

América Latina. Documentación política, económica y educativa, "boletín bimestral conteniendo información sobre acontecimientos latinoamericanos y documentos analíticos" ${ }^{429}$, se empezó a editar desde la sede limeña. Tomando el período que nos ocupa, el primer número estuvo dedicado al peronismo y al análisis de la situación política y económica argentina ${ }^{430}$. El número 2-3, de noviembre de 1973, se refería a la "vía chilena" -la vía democrática al socialismo-, con el objetivo de aportar a la reflexión sobre esta experiencia, abordada tanto en su dimensión económica como política $^{431}$. El número 4, de septiembre de 1974, también versaba sobre la situación de Chile $^{432}$. El boletín 5, de fines de 1974, era un trabajo preparado en el Centro de Documentación y centrado en el análisis de la estructura económica y la situación política brasileñas desde la colonia hasta el período 1964-1974, signado por lo que se consideraba "el engaño económico y la violencia institucionalizada" ${ }^{433}$. El boletín 6-7, de enero-febrero de 1975, abordaba la reforma de la prensa en Perú, considerado uno de los hechos más importantes del proceso político iniciado en $1968^{434}$. Los números $8-9$ y 10 (s/f), divulgaban los resultados de la investigación sobre control natal, llevada adelante por el Centro de Documentación con el auspicio de la UNESCO, donde se

\footnotetext{
428 “Algunas ideas sobre el funcionamiento de los grupos”, Servicio de Documentación, doc. 12, 1974.

${ }^{429}$ Propaganda de las publicaciones del SLA aparecida en "Algunas ideas sobre el funcionamiento de los grupos", Servicio de Documentación, doc. 12, 1974.

430 "Presentación", América Latina, 2-3, noviembre de 1973.

431 "Presentación", América Latina, 2-3, noviembre de 1973.

432 "Presentación", América Latina, 4, septiembre de 1974.

433 "Presentación", América Latina, 5, (mes borroso en el original) de 1974.

434 “Presentación”, América Latina, 6-7, enero-febrero de 1975.
} 
planteaba que el interés que movía a los organismos propulsores del Control Natal y a las naciones desarrolladas que lo auspiciaban era el de evitar el cambio social ${ }^{435}$.

Estos textos se distribuían entre los grupos que funcionaban en los distintos puntos del continente, constituyendo un material fundamental de formación. Con sus publicaciones, el SLA pretendía ser "un apoyo para la reflexión del compromiso cristiano y la maduración de la fe en el proceso de liberación" ${ }^{436}$ y, en particular, "para aquellos que intentan llevar adelante una pastoral estudiantil" "437. Lejos de buscar brindar una formación cerrada, los boletines apuntaban a dar pistas, "aportar elementos"/ "contribuir a la reflexión" 438 , "dejar una serie de interrogantes" sobre cada tema ${ }^{439}$. Se afirmaba que el material era pensado y elaborado para ser "leído y completado en un ambiente de reflexión" 440 por los equipos de base, y se insistía en que sólo tendría validez si era "verificado en la práctica"441 y utilizado "con un sentido/espíritu crítico" 442 . De allí que recurrentemente se solicitara a los jóvenes que luego de leer los artículos le hicieran llegar al SLA sus sugerencias, críticas y aportes ${ }^{443}$. En este sentido, los espacios abiertos en las publicaciones buscaban hacer de ellas "un medio más dialogante" ${ }^{444}$, dando un lugar mayor a las elaboraciones de los militantes $^{445}$.

Sin embargo, la frecuencia o la amplitud con que eran utilizados dependían de cada equipo e, incluso, de cada joven. Así lo expresaba el SLA de la JECI cuando planteaba las limitaciones de su boletín:

En cuanto al contenido, a más de ser demasiado denso en su generalidad, no responde a los diversos momentos de respuesta que viven los movimientos, esto hace que sólo los militantes motivados, con tiempo y método de estudio puedan recibir satisfactoriamente el aporte que con él se pretende dar ${ }^{446}$.

Por su parte, Mónica decía de las publicaciones del MIEC-JECI:

\footnotetext{
435 "Presentación", América Latina 8-9 y 10 (s/f).

${ }^{436}$ Contratapa, Spes, 24, agosto 1974.

437 "Presentación", Spes, 25, mayo 1975.

438 "Presentación”, América Latina, 2-3, noviembre de 1973.

439 “¿Dios está muriendo?”, Servicio de Documentación, sub-serie 2, doc. 1, agosto 1967.

440 “A qué Iglesia nos referimos?”, Spes, 9, julio 1970.

441 “Informe: la Sesión Mundial de la JECI julio-agosto de 1970”, Spes, 15-16, febrero-marzo 1970.

442 "Introducción a una pedagogía de la pastoral universitaria", Servicio de Documentación, serie 1, doc. 14, mayo de 1968. Y "Funciones de la universidad en el proceso revolucionario", Servicio de Documentación, serie 2, doc. 6, noviembre de 1968.

${ }^{443}$ Véase por ejemplo, "Presentación”, Spes, 25, mayo 1975, o "Presentación”, Spes, 26, septiembre 1975.

${ }^{444}$ Es el caso de la "encuesta para el boletín secundario". "Editorial”, JEC Boletín Secundario, 10, junio de 1969.

445 “Editorial”, JEC Boletín Secundario, 16, mayo 1971.

446 "Editorial”, JEC Boletín Secundario, 16, mayo 1971.
} 
me acuerdo mucho de haberlo tenido como material para los en[cuentros] [...] después había movimientos que lo leían más o lo leían menos. Por ejemplo, cuando estuve en Bolivia, que eran hiperdisciplinados, los tipos los ESTUDIABAN...Se reunían, los leían, los comentaban. Depende también de la tradición de cada uno de los movimientos nacionales... Y yo lo que recuerdo, los primeros encuentros de la JEC acá en Bahía, Pepe nos ponía a estudiar ${ }^{447}$.

Julio coincidía en que estos materiales eran consultados por los grupos bahienses y complementaban la formación ofrecida a los militantes en los encuentros del movimiento: "eran hojitas que se doblaban, y, tocando temas del momento, teológicos en su mayoría. Esa información también nos llegaba y la leíamos ",448.

Más allá de estos matices regionales o personales, las publicaciones del SLA constituían el material de preparación de los militantes para las actividades del movimiento. Esto aparece planteado en la Carta Circular del Encuentro del Cono Sur, que se celebraría en Córdoba en febrero de 1971, y cuyo objetivo era tratar la revisión de vida como método central de la mayoría de los grupos, y profundizar en el sentido de otros elementos como la pedagogía de iniciación, las jornadas, los seminarios, la "nucleación", la formación de los militantes o la coordinación. Para ello, los participantes no sólo debían acercar un informe de la problemática de cada sitio y una evaluación de la experiencia metodológica, sino también se les sugería llevar leído el Informe de la Sesión de Estudios y Asamblea Latinoamericana de 1970, publicada en Spes, y una serie de documentos del Servicio de Documentación referidos a la pedagogía de la pastoral universitaria ${ }^{449}$.

\section{iv) Las influencias de los teólogos latinoamericanos}

¿En qué medida y por medio de qué canales la JUC, la JOC y la JEC bahienses se vieron marcados por los nuevos documentos eclesiales y los teólogos liberacionistas? Los mismos jóvenes destacaban el lugar que ocupó la lectura de los primeros, así como los desarrollos de los segundos, tanto en su formación como en sus opciones de militancia. Al tiempo que estos textos influían en la maduración de su forma de vivir la fe, íntimamente ligada al compromiso social, y de su postura político-ideológica ${ }^{450}$,

\footnotetext{
${ }^{447}$ Entrevista a Mónica y Juan Carlos, Bahía Blanca, 28/3/2013.

${ }^{448}$ Entrevista a Julio, Bahía Blanca, 22/5/2010.

449 "Encuentro del Cono Sur, Carta Circular", Spes, 11, octubre 1970.

450 La militancia política y los estudios universitarios les aportaron un conjunto de lecturas complementarias con las anteriores en términos de formación y marcaron tanto la reflexión de estos jóvenes sobre lo popular y las alternativas de cambio real, como sus opciones políticas. Estos materiales
} 
justificaban la acción contestataria de los cristianos. En particular, las constituciones del Concilio, el documento de Medellín, la Teología de la Liberación de Gustavo Gutiérrez y los diversos trabajos de los teólogos latinoamericanos publicados por el Secretariado del MIEC-JECI se constituyeron en materiales de referencia. A ellos se sumaban las encíclicas papales, el documento de San Miguel, las declaraciones del MSTM o los mensajes de los obispos brasileños ${ }^{451}$-entre ellos, Don Helder Camara ${ }^{452}$-, siendo las jornadas y campamentos de verano o invierno, que nucleaban a los distintos equipos de reflexión, las ocasiones privilegiadas para consultar, estudiar, sistematizar y discutir en conjunto estos textos. Al mismo tiempo, los militantes jucistas profundizaron su formación personal en la línea de la renovación eclesial a partir de la lectura de las revistas Tierra Nueva ${ }^{453}$ y Cristianismo y Revolución. Al igual que para los primeros jucistas bahienses, para algunos de sus sucesores también fueron importantes las obras de Emmanuel Mounier, así como las de Pierre Teilhard de Chardin.

Respecto de los documentos de la jerarquía, los actores destacaban su papel como impulso, fundamento y respaldo a la acción social y política. Según Rodolfo, "no te dejaban muchas dudas respecto de la opción por los pobres, la liberación, o sea, nos sentíamos muy legitimados en las opciones políticas de transformación social por la Iglesia" 454 . En esta cuestión coincidía Graciela: "lo que definía era considerar que habia estructuras injustas que había que cambiar y de hecho eso también lo decía la Iglesia, la Populorum Progressio, todos los documentos oficiales de la Iglesia de aquel

incluyeron, entre otros, la teoría de la dependencia, la teoría económica marxista, autores como Franz Fanon, Eduardo Galeano, Paulo Freire, Rodolfo Puiggrós, Juan J. Hernández Arregui y John W. Cooke.

${ }^{451}$ Eran publicados por el SLA del MIEC-JECI. Por ejemplo, La Iglesia que yo quiero, de Don Helder Camara, Spes, 22-23, enero 1974; "He escuchado el clamor de mi pueblo". Documento de los obispos del Nordeste Brasileño, 6 de mayo de 1973, Spes, 21, mayo 1973.

${ }^{452}$ Nacido en el noreste brasileño en 1909, recibió en el seminario una formación tradicionalista. En los años treinta adhirió incluso al movimiento integralista -versión brasileña del fascismo-. Fue nombrado obispo auxiliar de Río de Janeiro en 1952. Tres años después transitó lo que él ha llamado su "conversión a los pobres". Se vio influido entonces por la "teología del desarrollo", marcada por las ideas de la economía humanista del padre Lebret. Fue secretario de la Conferencia de Obispos y asistente general de la Acción Católica. Cuando la JUC sufrió una transformación en 1960, se distinguió por defender a los jóvenes. En 1970 denunció públicamente las torturas del régimen militar. Se acercó a la teología de la liberación e inspiró algunos de los documentos más radicales de los obispos brasileños, convirtiéndose en símbolo del compromiso social de esa Iglesia y su enfrentamiento con la dictadura (Löwy, 1999).

${ }^{453}$ Creada en 1966 y destinada a cristianos y no cristianos, constituyó un intento intelectual de llevar las ideas del Concilio más allá de la esfera religiosa. Se proponía repensar desde la base las expresiones de la fe, crear un espacio de diálogo y abrir canales para un mayor compromiso con la realidad. Se editaron sólo tres números. Su director, Roberto Brito, fue militante de la JEC, de la JUC, y del Humanismo en la UBA. Entre sus fundadores y colaboradores se encontraban los sacerdotes Alejandro Mayol, Rodolfo Ricciardelli o Miguel Mascialino, e intelectuales como Beatriz Sarlo. La revista alcanzó relevancia a través de una polémica con Monseñor Caggiano, en torno a los tópicos del Concilio, en la que se ponía en juego la autoridad del prelado frente a los sacerdotes y laicos con respecto a la interpretación de los lineamientos conciliares y a sus consecuencias políticas (Habegger, 1970; Donatello, 2005).

${ }^{454}$ Entrevista a Rodolfo, Bahía Blanca, 23/6/2008. 
momento" 455 . En consecuencia, como veremos en el capítulo 5, los documentos eclesiales servían de apoyo a la hora de pronunciarse frente a los hechos que sacudían a la opinión pública local o nacional. En sus declaraciones, la JUC, la JOC y la JEC echaron mano a citas de los mensajes de Pablo VI y de los documentos de los obispos latinoamericanos, argentinos y brasileños, para analizar los acontecimientos sociales y políticos del momento, así como para legitimar su posición como cristianos.

En cuanto a los nuevos planteos teológicos en particular, en el caso de la JOC, el influjo provenía de las lecturas de sus obras fundamentales, principalmente, de Teología de la Liberación. Así lo recordaban Jorge, Mirta, Silvestre o Paloma. Sin embargo, esta última también mencionaba materiales de autores no sólo americanos sino también españoles. Entre ellos, Ernesto Cardenal, Helder Camara, Hugo Assmann y Manuel Pérez Martínez ${ }^{456}$.

Para los jucistas y jecistas, los textos de los teólogos latinoamericanos también constituían una fuente ineludible en su formación. Aquí, nuevamente, la influencia de Gutiérrez era predominante. En este sentido, Julio señalaba que constituía el "libro de cabecera" de la JUC: "las directrices estaban ahi" ${ }^{457}$. A su vez, los actores distinguían la corriente representada por el referente peruano -en palabras de Julio, "más latinoamericanista"-, de la línea teológica ligada al argentino Lucio Gera: "éramos primos hermanos pero no éramos eso...para ellos el marxismo no entraba para nada en su análisis. Nosotros sí, rescatábamos el marxismo como método de análisis, dialéctico" ${ }^{458}$. Por su parte, "Pepe", al hablar de las diferencias políticas y teológicas de los sacerdotes del MSTM, mencionaba "la división que fue acentuándose entre los que seguíamos la Teología de la Liberación y los partidarios de la Teología de la Cultura de Rafael Tello y Lucio Gera"459. Así, "Pepe" marcaba una distancia con respecto a esta última y reconocía en la corriente encabezada por Gutiérrez la fuente de la nueva teología en la que más había abrevado ${ }^{460}$.

Los contactos de los jóvenes bahienses con los teólogos de la liberación asumían otros múltiples canales, tanto directos como indirectos. En primer lugar, algunos de estos referentes eran asesores de grupos de estudiantes católicos que pertenecían al

\footnotetext{
${ }^{455}$ Entrevista a Graciela, Buenos Aires, 31/7/2008.

456 Entrevista a Paloma, vía skype, 12/2/2013, 22/2/2013, "El por qué de mi militancia en la JOC", apuntes enviados vía e-mail 1/3/2013.

${ }^{457}$ Entrevista a Julio, Bahía Blanca, 22/5/2010.

${ }^{458}$ Entrevista a Julio, Bahía Blanca, 22/5/2010.

459 "José Zamorano", en: Diana, 2013: 234.

${ }^{460}$ Entrevista a José Zamorano, Moreno, 2/9/2011.
} 
MIEC-JECI y sus elaboraciones teológicas tenían esas experiencias pastorales como punto de partida. El caso más emblemático es el de Gutiérrez, asesor de la UNEC de Perú $^{461}$, lo que guarda relación con su protagonismo en la formación de los militantes. Además, estos especialistas escribían en las publicaciones del movimiento. Al respecto, "Pepe" destacaba la importancia de la "orientación y el acompañamiento teóricopastoral "462 que brindaba SLA a través de sus boletines. Ya el secretariado latinoamericano de la JEC Internacional había incorporado los estudios sobre teología a su Boletín Secundario. Por su parte, el Servicio de Documentación buscó acercar a los lectores "algunos planteamientos que son expresión de cómo un sector de nuestra Iglesia está enfocando el tema de la teología y buscando con ella iluminar diferentes temas de actualidad". Y Spes difundió diversos documentos de los referentes liberacionistas $^{463}$.

\footnotetext{
${ }^{461}$ Entrevista a Mónica, Buenos Aires, 9/11/2011 y a José Zamorano, Moreno, 2/9/2011. Mónica también recordaba a Rolando Muñoz, Jon Sobrino o Ignacio Ellacuría.

${ }^{462}$ Entrevista a José Zamorano, Moreno, 2/9/2011.

${ }^{463}$ Una breve síntesis de los títulos y autores que engrosaban este material puede dar una idea del influjo de las nuevas reflexiones teológicas en los grupos católicos, de los temas abordados y de la diversidad de corrientes representadas en el marco de la teología de la liberación. En el Boletín Secundario, por ejemplo, se retomaron las apreciaciones sobre "Fe y Política" del neomarxista francés y religioso dominico Paul Blanquart durante la Sesión Mundial de Londres (17, junio de 1971), y se incluyeron artículos de otros teólogos, entre ellos de un experto en la Conferencia de Medellín, Pierre Bigó ("Cristianismo e Ideología", 17, junio de 1971).
}

Por otra parte, el Servicio de Documentación ofreció a los jóvenes del movimiento artículos del obispo de Chiapas (México) y presidente del departamento de Misiones del CELAM, Monseñor Samuel Ruiz García ("Los cristianos y la justicia en América Latina", doc. 4, 1973); del profesor de Teología de la Universidad Católica de Chile y asesor del departamento de laicos del CELAM, Rolando Muñoz ("Tensiones en una Iglesia viva", doc. 5, 1973); de Gustavo Gutiérrez ("Praxis de liberación y fe cristiana", doc. 6, 1973); de Raúl Vidales ("Cuestiones en torno al método en la teología de la liberación", doc. 9, 1974); de Lucio Gera ("Teología de la liberación", doc. 10-11, 1974); de Ignacio Ellacuría ("Carácter político de la misión de Jesús", doc. 13-14, 1974; y "Liberación: misión y carisma de la Iglesia Latinoamericana", doc. 15, 1975), presentado como una de las figuras más relevantes del pensamiento teológico en Centroamérica; de Juan Carlos Scannone ("Hacia una pastoral de la cultura", doc. 16, 1975); de Carlos Mesters ("Una Iglesia que nace del pueblo", doc. 17-18, 1975). Asimismo, algunos folletos se centraron en obras de autores europeos, tales como Karl Rahner y J. B. Metz ("Los problemas universales de la Iglesia universal", serie 1, doc. 22, septiembre de 1970), Benoit Dumas ("Iglesia y Política II", serie 1, doc. 27, 1971); o norteamericanos, como Harvey Cox ("El lugar y el objeto de la teología", serie 1, doc. 22, septiembre de 1970).

Por último, el boletín Spes publicó textos de Paul Blanquart ("Fe y Política", 20, marzo 1973), de Segundo Galilea ("Pastoral popular, liberación y política", 21, mayo 1973; "La actitud de Jesús ante la política”, 25, mayo 1975), de Raúl Vidales (“¿Cómo hablar de Cristo hoy?”, 22-23, enero 1974), de Rolando Muñoz ("Educación de la fe hoy", 22-23, enero 1974; "Evangelio y participación política, unidad y pluralismo", 24, agosto 1974); de Monseñor Leónidas Proaño ("Pobreza es garantía", 26, septiembre de 1975), así como síntesis de las palabras de Monseñor Samuel Ruiz ("Papel de la Iglesia es criticar estructuras opresoras, dice obispo", 21, mayo de 1973), de un seminario de Lucio Gera, Rafael Tello, Juan Filipzzi e Ignacio Palacios Videla ("Quince principios generales de Pastoral Popular", 22-23, enero 1974) y de una charla de Gustavo Gutiérrez ("Reflexión teológica. Resumen charla G. Gutiérrez", 27-28, s/f). Asimismo, la revista dedicó tres notas al curso sobre teología que para el IPLA preparó el P. J. Delgado de El Salvador ("La Palabra de Dios, una metodología de la praxis humana", 25, mayo 1975; "Liberación”, 26, septiembre 1975; "El pueblo de Dios", 29, pascua de 1976). 
Al mismo tiempo, el SLA editaba "bibliografías y dossiers sobre temas especializados en problemas universitarios, culturales, políticos y religiosos" ${ }^{\text {,464, que }}$ también incluían textos de los referentes de la teología latinoamericana. Por ejemplo, Apuntes para una interpretación de la Iglesia Argentina, de Gera y Rodríguez Melgarejo o La Pastoral de la Iglesia en América Latina, de Gutiérrez.

En ocasiones, el origen de los materiales publicados por el SLA en sus diversas revistas y folletos residía en otras publicaciones periódicas o libros. Parte de estos textos eran a su vez producto de conferencias o ponencias elaboradas por los autores para otros espacios y destinatarios. Sin embargo, en otros casos, los trabajos fueron preparados especialmente para los jóvenes del movimiento ${ }^{465}$.

En efecto, la influencia de los teólogos liberacionistas llegaba, al mismo tiempo, a través del equipo latinoamericano del MIEC-JECI, en el que, como mencionamos anteriormente, trabajaron durante varios períodos consecutivos cinco bahienses. Este grupo se constituía en interlocutor de obispos y teólogos, planteándoles sus demandas de formación y convocándolos a participar en las actividades del movimiento.

En este marco, los encuentros periódicos de asesores, de dirigentes y de militantes, tanto a nivel nacional como latinoamericano, daban la posibilidad de conocer personalmente a los referentes de la nueva teología. Aquellos militantes que viajaron con el movimiento a distintos lugares del mundo tuvieron la oportunidad de nutrirse de los aportes de quienes influyeron en la teología de la liberación, como Paul Blanquart ${ }^{466}$ -quien intervino en la Sesión Mundial de Londres-, o de íconos del catolicismo liberacionista del Cono Sur, como Dom Helder Camara -quien se hizo presente en Maastricht. En cuanto a los teólogos latinoamericanos, la mayor influencia quizás haya

\footnotetext{
${ }^{464}$ Spes, 20, marzo 1973.

${ }^{465}$ Así, a pedido del SLA, después de una asamblea del CELAM, Rolando Muñoz dictó el tema a los miembros del equipo permanente en la sede del secretariado, siendo esta versión final la que se publicó en el Servicio de Documentación con el título "Tensiones en una Iglesia viva" (doc. 5). El documento 6, "Praxis de liberación y fe cristiana", recogía el aporte de Gustavo Gutiérrez en el Seminario sobre "Fe y Política" -al igual que lo hacía el documento 8, "Marco histórico de la Iglesia Latinoamericana" de Alberto Methol Ferré-. De forma similar, el documento 9, "Cuestiones en torno al método de la Teología de la Liberación" respondió al pedido que el SLA le hizo a Raúl Vidales para que profundizara un tema que sobre el cual había trabajado anteriormente. El documento 27 de la serie 1 retomaba la ponencia del P. Benoit Dumas, asesor del MCU de Uruguay, a la mesa redonda que sobre esta cuestión organizó el SLA en la parroquia universitaria de Montevideo. Asimismo, los textos de Paul Blanquart resultaron de sus intervenciones en la Sesión Mundial de 1970. Y el artículo del número 27-28 de Spes, "Reflexión teológica. Resumen charla G. Gutiérrez" recuperaba los aportes del asesor peruano en la XXVIII Asamblea Interfederal del MIEC.

${ }^{466}$ Michael Lowy (1999) ha estudiado la contribución de la cultura católica francesa a la génesis del cristianismo liberacionista en Brasil. Entre las fuentes francesas en dicho proceso político y religioso, el autor incluye la orden de los dominicos, y, en particular, menciona a Blanquart entre los autores religiosos y teólogos que mostraron gran interés en el marxismo y el socialismo desde la segunda guerra mundial.
} 
sido la de Gustavo Gutiérrez. La interacción de los jucistas y jecistas bahienses con el asesor peruano se dio en 1972 en Lima, durante la Sesión de estudios y Comité Latinoamericano de 1972, en el Seminario "Fe y Política" celebrado al año siguiente y en la XXVIII Asamblea Interfederal del MIEC reunida en agosto de 1975.

La metodología que vertebraba la reflexión de la JUC, la JOC y la JEC constituye, precisamente, uno de los aspectos interesantes desde donde considerar la influencia de los nuevos aportes teológicos. A ella dedicaremos el capítulo 4, que aborda el acercamiento de estos militantes a la acción social y política. 


\section{CAPÍTULO 4: De la revisión de vida al despertar del compromiso cristiano}

\section{SUMARIO}

1) Ver, Juzgar y Actuar

2) Una nueva forma de vivir la fe

3) El descubrimiento de "la realidad" y el impulso al compromiso

La "pedagogía" -como se la llamaba entonces- de la revisión de vida marcó a la JUC bahiense desde 1967, a la JOC desde 1968, años antes que Gustavo Gutiérrez sistematizara en su libro las reflexiones teológicas latinoamericanas de los años sesenta, y a la JEC desde 1972. En este sentido, los movimientos especializados de juventud, anticipaban uno de los ejes de la teología de la liberación. Podría decirse que los grupos de reflexión cristianos, en cuanto pensaban su fe en el contexto de opresión y su historia concreta desde la fe, "hacían teología", aunque en una forma y un lenguaje distinto al de los teólogos profesionales. En este sentido, Julio afirmaba: "nosotros decíamos que la teología se hacía a partir de la experiencia y la reflexión" ${ }^{467}$. Y Rodolfo explicaba:

la revisión de vida no era sólo una pedagogía, sino una manera de hacer teología, es decir, un modo de entender la producción de conocimiento sobre Dios desde la práctica de los creyentes. La teología es una de las principales fuentes de poder al interior de la Iglesia, y eso hacía de la revisión de vida una divisoria de aguas tan profunda ${ }^{468}$.

Asimismo, esa reflexión sobre la realidad a la luz del Evangelio se fue enriqueciendo en esos años, por un lado, con los desarrollos de los teólogos liberacionistas, y por el otro, de los sacerdotes y religiosas que los acompañaban, ya sea en los equipos jucistas, jocistas y jecistas o en los espacios donde llevaban a cabo su compromiso cristiano. Los mismos teólogos latinoamericanos, lejos de definirse como "intelectuales de escritorio", lo hacían como agentes que participaban del "caminar del pueblo" (Boff, 1990). Como vimos en el apartado anterior, muchos de ellos eran asesores de los movimientos especializados de juventud en otros puntos del país o del continente. Por su parte, los religiosos y religiosas que actuaban en Bahía Blanca en aquellos años, inspirados en el Concilio y en Medellín, fueron modelando su postura teológica y eclesial a partir de su acción pastoral y los lazos tejidos entre ellos.

\footnotetext{
${ }^{467}$ Entrevista a Julio, Bahía Blanca, 22/5/2010.

${ }^{468}$ Comunicación vía e-mail, 29/01/2010.
} 
En efecto, desde la óptica liberacionista existían diversos planos de elaboración teológica que, lejos de estar aislados, frecuentemente progresaban de un modo integrado (Boff, 1990). En palabras de Scannone (1987), el discurso de la revisión de vida, el profético y el pastoral constituían un primer paso de discernimiento crítico a la luz de la Palabra. Así, la teología de la liberación era concebida como un fenómeno cultural y eclesial complejo que no se limitaba a los teólogos, sino que recorría todo el cuerpo eclesial, y estaba vivo también en un nivel pastoral (en la reflexión de los obispos, sacerdotes, religiosas y otros agentes pastorales) y en otro popular (en la reflexión teológica en clave liberadora que tenía lugar en las bases de la Iglesia de forma anónima y colectiva, oral y sacramental, crítica y profética), aunque no se llamara "teología". En el primer plano, la teología era producida por teólogos de profesión, de una manera más elaborada y rigurosa; estaba guiada por una lógica de tipo científico (metódica, sistemática y dinámica); utilizaba la mediación socio-analítica, la hermenéutica y la práctica; su producción se materializaba en conferencias, libros y artículos. La teología de la liberación pastoral era más orgánica en relación a la praxis; estaba guiada por una lógica de acción concreta, profética; utilizaba el método del Ver, Juzgar y Obrar; y se expresaba en discusiones y documentos pastorales. En el nivel popular, la teología era más difusa y espontánea; seguía la lógica de la vida (oral, gestual, sacramental); era elaborada a partir de la confrontación del Evangelio y la vida; y se materializaba en comentarios y celebraciones (Boff, 1990). Desde esta perspectiva, entonces, una sabiduría teologal no científica era articulada por "quienes se convierten al pobre, en cuanto ellos son sujeto comunitario de una praxis evangélicamente liberadora y de la inteligencia de la fe que la acompaña" (Scannone, 1987: 45).

Después de haber abordado los ejes vertebradores de la nueva teología latinoamericana, surgida al calor del aggiornamento eclesial (capítulo 1), y de haber descripto los canales concretos por los que aquella influyó en los militantes católicos bahienses (capítulo 3), nos interesa centramos en las formas mediante las cuales estos movimientos especializados de juventud formularon aportes al "esfuerzo de inteligencia del compromiso con Dios y el prójimo a la luz de la fe" (Gutiérrez, 1971), a través del discurso de la revisión de vida y del profético. En este capítulo enfocamos la atención en la reflexión al ritmo de Ver, Juzgar y Actuar, tal y como fue experimentada por los jóvenes bahienses. ¿Qué significación tuvo esta pedagogía en términos de su vivencia religiosa? ¿En qué medida favoreció el discernimiento de los procesos sociales, económicos y políticos del momento, y a partir de aquél los impulsó a una intervención 
transformadora? Así, el capítulo busca aportar nuevas claves para comprender el proceso de acercamiento a la acción social y política protagonizado por los jucistas, jecistas y jocistas, esto es, en qué medida lo hicieron impulsados por su fe, y de modo más amplio, de qué forma su paso por los grupos cristianos marcó sus trayectorias militantes.

\section{1) Ver, Juzgar y Actuar}

El primer paso de la reflexión comunitaria mediante el ritmo de Ver, Juzgar y Obrar consistía en analizar la situación histórica, social, económica y política, identificando sus causas y consecuencias. Le seguía confrontar los datos históricos con el Evangelio, es decir, interpretar su sentido teológico y juzgarlos reflexivamente a la luz de "la positividad cristiana". Por último, se buscaba discernir crítica y prácticamente qué pautas de acción surgían para modificar la realidad social según los criterios evangélicos (Scannone, 1987).

Según recuerdan los protagonistas, el Ver suponía revisar los acontecimientos de la semana vinculados a la realidad en la que estaban inmersos los militantes, describirlos, interpretarlos, relacionarlos con otros. El Juzgar implicaba el ejercicio de pensar qué hubiera hecho Jesús en una situación similar, qué podía decirles el Evangelio "aquí y ahora". En este camino, la Biblia y la vida se vinculaban de dos maneras complementarias. Al decir de "Pepe": "la Palabra ilumina [la realidad] y la realidad va como haciendo actual la Palabra" ${ }^{469}$. Y era el asesor quien acompañaba el intento de descubrir en los hechos que se analizaban los "brotes de la presencia de Dios en la historia" y "tratar de vincular [los] con la Palabra [de Dios]" "470. Así, en general, “Pepe" y Emilio se encargaban de la "iluminación" bíblica, guiando a los jóvenes en el esfuerzo por ligar el Evangelio con su vida cotidiana. Finalmente, la reflexión se orientaba a buscar formas de compromiso concretas que, de manera individual o colectiva y en el marco de los espacios de pertenencia de los militantes, incidieran en la cuestión planteada. En palabras de Patricia, "transformar la realidad desde el lugar donde a vos te tocaba, si era la escuela, si era el trabajo, si era el ámbito estudiantil "471. Al mismo tiempo, el cambio incluía una dimensión personal.

\footnotetext{
${ }^{469}$ Entrevista a José Zamorano, Moreno, 19/9/2009.

${ }^{470}$ Entrevista a José Zamorano, Moreno, 19/9/2009.

${ }^{471}$ Entrevista a Patricia, Bahía Blanca, 19/5/2008.
} 
La revisión de vida tenía implicancias significativas. Por un lado, planteaba una novedad en la articulación de la escritura y el dogma. El punto de partida de la hermenéutica bíblica eran "los hechos y preguntas recibidos del mundo de la historia" (Gutiérrez, 1971: 29), y no la revelación como dato o un conjunto de verdades que debían ser llevadas a la acción. Se partía de la realidad misma, donde los militantes buscaban "cómo llevar adelante su apostolado" (Mallimaci, 1992: 342). Esto significa que la doctrina católica era releída a partir de la militancia en un contexto particular y que la prioridad residía en el análisis de las problemáticas específicas del medio de acción por los militantes, antes que en las directivas de la institución (Mallimaci, 1992).

No había un temario prefijado sino que eran los mismos jóvenes quienes acercaban al encuentro las situaciones a discutir. Eran las propias prácticas de los militantes las que marcaban la agenda de la revisión de vida. En este sentido, Marta decía "empezábamos a largar las cuestiones, los nudos ahi que nos habian resignificado más la semana...y entre todos elegíamos una de esas problemáticas y desde allí después íbamos enredando las otras ${ }^{, 472}$.

En segundo lugar, el Ver, Juzgar y Actuar implicaba una forma particular de relación con Dios. Esta reflexión "de abajo para arriba”, que tenía como punto de partida la vida y no el Evangelio, suponía un encuentro con Dios en una realidad históricamente situada, con lo cual "no hay posibilidad de evasión" 473 . Era en el “actuar" donde el creyente se acercaba a Dios. Era en gestos concretos hacia el prójimo, en el encuentro con otros hombres, en el compromiso con el devenir histórico de la humanidad donde el cristiano amaba/encontraba a Dios (Gutiérrez, 1971). Así lo expresaba la JUC en una declaración de julio de 1971: "en la medida en que como cristianos no nos comprometemos, detenemos la historia y perdemos a Dios, que actúa en ella" ${ }^{474}$. Esto tenía profundas implicancias políticas, desde el momento en que el prójimo era el hombre considerado en la urdimbre de las relaciones sociales, el pueblo explotado, por lo cual, “dar de comer y de beber" como mandaba Jesús, era un acto político, exigía la transformación de esta sociedad (Gutiérrez, 1971). Como sintetizaba una nota del Boletín Spes: amor a Dios es amor al hermano y amor al hermano es decir amor al oprimido y eso significa liberarlo ${ }^{475}$. De allí, que a la afirmación anterior le

\footnotetext{
${ }^{472}$ Entrevista a Marta, Bahía Blanca, 29/5/2008.

${ }^{473}$ Entrevista a José Zamorano, Moreno, 19/9/2009.

474 "Militante cristiano secuestrado y torturado en Punta Alta". Cristianismo y Revolución, 30, septiembre de 1971.

475 “El amor cristiano: ¿imperativo hoy?”, Spes, 12, noviembre de 1970.
} 
siguiera una interpelación: "en consecuencia, exhortamos a todos los cristianos y hombres de buena voluntad [...] a solidarizarse en la búsqueda de una sociedad nueva" ${ }^{\circ 76}$.

Desde esta perspectiva, la lectura de la propia situación, y de modo más general, de los acontecimientos históricos no perseguía un objetivo meramente intelectual ni se agotaba en sí misma; por el contrario, la vida y el ejemplo de Cristo presente en los Evangelios interpelaba a los militantes a traducir las palabras en gestos. Frente a la pobreza, el hambre, las desigualdades sociales, la injusticia o los atropellos de la dictadura no era posible, en palabras de Mirta, "quedarse con el ver nada más",477; los militantes entendían que debían dar un paso más. La dimensión de la acción estaba implícita en toda la reflexión comunitaria aunque se explicitaba en un tercer momento. Como vimos, el actuar daba sentido a la revisión de vida, convirtiéndose a la vez en punto de partida y de llegada de la misma. Eduardo se refería a la dialéctica de la revisión de vida: "era la reflexión sobre nuestra experiencia para volver a proyectarnos, 478 .

De esta manera, la reflexión involucraba un modo distinto no sólo de pensar la fe sino de vivirla. En primer lugar, se trataba de una experiencia comunitaria. Como explicaba Nora, se buscaba que la fe interpelara personalmente y en forma cotidiana, pero que no lo hiciera de modo individual sino con otros ${ }^{479}$. Al mismo tiempo, la fe se recreaba a partir de la praxis concreta. En palabras de Eduardo: "es la forma de vivir la espiritualidad encarnada, no piantada" 480 . La inserción en espacios de acción social y política contestataria requería también una nueva experiencia espiritual, una nueva forma de vivir la oración personal y comunitaria (Gutiérrez, 1971), que se expresaba en misas donde la homilía era compartida -participaba no sólo el sacerdote sino también los jóvenes-, y versaba sobre problemas de la actualidad local y nacional, puestos en relación con la lecturas bíblicas. La música acompañaba las celebraciones e incluía canciones sobre temas religiosos pero también sociales y políticos, de cantautores como Violeta Parra o Daniel Viglietti.

\footnotetext{
476 "Militante cristiano secuestrado y torturado...". Cristianismo y Revolución, 30, septiembre de 1971. En efecto, qué se veía, qué juicios se emitían y qué acciones se tomaban dependían de la sociedad y la época. Así, por ejemplo, como afirma Levenson (2007) para el caso de la JOC guatemalteca en los años sesenta, el resultado fue el sindicalismo, una lucha contra los patrones y después, inevitablemente, contra el Estado, en un contexto de terrorismo estatal y creciente pobreza de la clase trabajadora.

${ }^{477}$ Entrevista a Mirta, Bahía Blanca, 18/6/2008.

${ }^{478}$ Entrevista a Eduardo, Bahía Blanca, 21/3/2008.

${ }^{479}$ Entrevista a Nora, Bahía Blanca, 4/6/2008.

${ }^{480}$ Entrevista a Eduardo, Bahía Blanca, 20/5/2008.
} 
En este sentido, la revisión de vida asumía una concepción integral de la vivencia de la fe que no se limitaba a la esfera de las creencias sino que expandía su influencia a toda la vida del militante, que debía ser guiada por los principios religiosos (Giménez Béliveau, 2005: 221). Como explicaba Rodolfo, se insistía en

que la fe no se viviera como algo al costado o separado o sobreañadido a la vida...la fe y la Palabra de Dios como que eran ...en diálogo permanente con las prácticas...la vida, en todo sentido, no sólo la militancia política sino la vida de pareja, la relación de trabajo... ${ }^{481}$.

El relato de María refuerza este punto: "lo que pretendiamos es no hacer una división de acá soy cristiana y acá soy política, y acá...un laburo y me busco los morlacos "482. Así, Ver, Juzgar y Actuar constituyó una metodología al servicio de un catolicismo integral que vinculaba la creencia religiosa y la vida personal con la vida social y política.

Este catolicismo vivido "integralmente" debía penetrar en cada uno de los "ambientes" donde los militantes desarrollaban su compromiso. En este sentido, la concepción que guiaba su acción era la del "fermento en la masa", que implicaba la inserción en la realidad con un estilo propio, esto es, animados por la fe y compartiendo una intensa vida en comunidad, pero sin segregarse de los demás hombres. En este marco, Graciela decía: "teníamos que evangelizar en el medio en que estábamos",483.

Un encuentro de laicos realizado en Buenos Aires, hacia fines de 1966, justificaba la exigencia de trabajar junto a los no cristianos en el "cambio de estructuras", desde una manera de entender y vivir el catolicismo propiamente "integralista":

Nosotros los cristianos no podemos formar ninguna organización particular. Porque sería sectorizarnos y apartarnos del resto de los hombres que no lo son. El cristianismo no proporciona base ideológica ni cultural. Nos proporciona sí, sentido religioso. $\mathrm{Y}$ en nombre de este sentido religioso es que nos vemos compelidos a definirnos, comprometernos y actuar...Por eso no admitimos partidos ni colegios que sean para cristianos solamente. Queremos que los cristianos se mezclen con todos y actúen entre todos (Habegger, 1970: 169).

Julio también se refería a esta cuestión cuando aludía a la forma en que los jucistas bahienses del período 1967-1975 entendían el compromiso, y en particular, la participación política, distanciándose de sus antecesores, quienes preferían ligarse a agrupaciones cristianas:

\footnotetext{
${ }^{481}$ Entrevista a Nora y Rodolfo, Bahía Blanca, 2/4/2009.

${ }^{482}$ Entrevista a María, Bahía Blanca, 28/2/2013.

${ }^{483}$ Entrevista a Graciela, Buenos Aires, 31/7/2008.
} 
Mucha gente de la Liga terminó en la Democracia Cristiana en Bahía Blanca. Para nosotros la Democracia Cristiana era inaceptable, es decir, no podía haber un partido que se identificara como cristiano. Tenías que integrarte a las estructuras politicas y gremiales, así como tampoco podia haber un gremialismo católico. Vos tenías como cristiano meterte en la masa y ser fermento, pero en las estructuras que en ese momento estaban en la sociedad ${ }^{484}$.

De esta manera, el compromiso por el cambio de la sociedad no podía afrontarse en soledad sino con otros. Así lo entendían también los obispos del Tercer Mundo cuando llamaban a todos los hombres solidarios con su pueblo a adherirse al movimiento por un mundo que reconociera la dignidad humana en toda su plenitud y la igualdad social de todas las clases, y a los cristianos, en particular, a mostrar "que el verdadero socialismo es el cristianismo integralmente vivido, en el justo reparto de los bienes y la igualdad fundamental de todos", asumiéndolo como una forma de vida social más conforme con el espíritu del Evangelio ${ }^{485}$. De esta manera, como buenos católicos integrales, los jucistas, jocistas y jecistas también preferían sumarse a las iniciativas políticas existentes, junto a otros hombres y mujeres.

La revisión de vida, por lo que llevaba de ejercicio reflexivo y analítico, de introversión y -al mismo tiempo- exposición de la propia historia y dificultades, y de modo novedoso de vincular el mensaje cristiano con los hechos de la vida corriente, no resultó sencilla de comprender e incorporar ${ }^{486}$. En general, los jóvenes no estaban habituados a concretar una reflexión en torno a cuestiones específicas - "bajar a tierra ${ }^{, 487}$ en palabras de Paloma-, hacerlo según los pasos del método de la revisión de vida, expresarse en un contexto grupal, poner en común lo vivido, interpretar la realidad estudiantil o laboral, analizar documentos, leer hechos sociales y políticos a la luz de la Palabra de Dios, encontrándole su sentido trascendente, y, a la vez, leer la Biblia desde el compromiso de los militantes en sus propios ámbitos y desde una práctica comunitaria de la fe, sacar conclusiones o llevar la reflexión a la acción.

Sin embargo, en el transcurso de los encuentros y con la ayuda del asesor, los jóvenes adquirieron experiencia en el uso de esta pedagogía. Al respecto, Manuel afirmaba: "el metodólogo nuestro fue Pepe" 488 , lo que da cuenta de que la renovación

\footnotetext{
${ }^{484}$ Entrevista a Julio, Bahía Blanca, 22/5/2010.

${ }^{485}$ Mensaje de los 18 obispos del Tercer Mundo, 1967.

486 Estas dificultades aparecen mencionadas especialmente en "Historia de la JOC en Bahía Blanca" y en las entrevistas a Angélica, Bahía Blanca, 25/4/2012; a Paloma, vía skype, 11/2/2013; a Carlos, Bahía Blanca, 4/5/2011; a Alicia, Bahía Blanca, 9/7/2011; a Julio, Bahía Blanca, 22/5/2010.

${ }^{487}$ Entrevista a Paloma, vía skype, 11/2/2013.

${ }^{488}$ Entrevista a Manuel y Nancy, Neuquén, 21/3/2013.
} 
de los agentes religiosos no sólo fue teológica, doctrinaria y pastoral sino que también se tradujo en su compromiso y testimonio personal -un tipo de relación que era parte de una pedagogía de evangelización de los miembros de la Iglesia que retomaremos más adelante. Al mismo tiempo, los militantes asumieron cada vez mayor protagonismo y autonomía respecto del sacerdote, pudiendo incluso prescindir de su presencia en las reuniones ${ }^{489}$. Por su parte, Manuel se refería a la dinámica de trabajo de su equipo jucista y el tipo de presencia que el asesor terminó teniendo en aquél:

era un grupo muy politizado...y que andaba solo, teníamos una formación, una reflexión ya más armada, entonces Pepe trabajaba con la gente que sentía que estaba un poco más flojita, digamos, que precisaba más acompañamiento de él. $Y$ cuando iba a nuestro grupo decía "yo a este grupo no vengo como cura, vengo a escuchar lo que pasa", porque nuestro debate tenía que ver con la coyuntura ¿no?, y gracias a Pepe, cómo vivir la fe, cómo estar inmerso en eso y no perder nuestra fe ${ }^{490}$.

Aún en el segundo paso de la reflexión, donde el asesor tenía un papel importante en cuanto contribuía a que los jóvenes encontraran la relación entre "la realidad" y el mensaje bíblico, también les proponía que fueran ellos quienes buscaran las lecturas del Evangelio que sirvieran para iluminar los problemas abordados ${ }^{491}$.

Esta pedagogía guiaba la reflexión conjunta de los jucistas, jocistas y jecistas en sus diversas instancias de encuentro, desde las reuniones semanales por equipos hasta los campamentos de verano que congregaban a las ramas en su conjunto o incluso a varias de ellas. Ahora bien, ¿qué particularidades tenía la revisión de vida en grupos de jóvenes trabajadores, universitarios o estudiantes secundarios? ¿Qué implicancias tenía la especificidad del medio en los encuentros? ¿Cuáles eran los temas sobre los que se desarrollaba la reflexión conjunta? ¿Sobre qué cuestiones versaba el Ver? ¿En qué tipo de problemas, espacios, dimensiones de la realidad buscaba Actuar?

En la JOC, los hechos vinculados a la realidad laboral ocupaban un lugar central. Así, se ponía en común lo vivido en la relación con el patrón y los compañeros, las condiciones de trabajo, las luchas y conflictos laborales, o la participación sindical. Mirta sintetizaba:

Suponete, surgía un inconveniente en algún ámbito de trabajo de cualquiera de nosotros, presentábamos el hecho concreto, o sea, el patrón con el empleado, entonces veíamos cuál eran las consecuencias de eso, por qué pasaba eso, lo

\footnotetext{
${ }^{489}$ Entrevista a Inés, Bahía Blanca, 18/6/2011.

${ }^{490}$ Entrevista a Manuel y Nancy, Neuquén, 21/3/2013.

${ }^{491}$ Entrevista a Mirta y Jorge, Bahía Blanca, 14/7/2012.
} 
iluminábamos con el Evangelio y después entre todos decidíamos cómo se actuaba en ese determinado hecho ${ }^{492}$.

Las ramas universitaria y secundaria, en cambio, se centraban en la realidad estudiantil. En sus encuentros, los jucistas abordaban las problemáticas cotidianas que se presentaban en la universidad o los institutos terciarios, mientras que los jecistas se centraban en las escuelas y las cuestiones inherentes al mundo de los estudiantes secundarios $^{493}$.

Pero en las reuniones de la JOC, la JEC y la JUC no se trataba sólo de comentar las situaciones laborales o estudiantiles, sino, fundamentalmente, de revisar la acción/el "aporte" 494 -en palabras de Clara- de los militantes en los espacios donde se desempeñaban, esto es, de qué manera, desde su perspectiva, "llevaban el Evangelio",495 a su medio, convirtiéndose en "testimonio" ${ }^{496}$. De esta manera, el Ver, Juzgar y Actuar se adentraba en la acción "temporal" que asumían los jóvenes de cara a lo que entendían la construcción de un orden social más justo. Así lo expresaba Roberto: "los temas de discusión que nosotros hacíamos en las jornadas religiosas era sobre el compromiso, el compromiso social y el compromiso en la transformación ${ }^{, 497}$.

Respecto de los jocistas, si se trataba de analizar sistemáticamente el modo en que los militantes iban cambiando la realidad del trabajo ${ }^{498}$, la intervención en el propio ambiente variaba en función del tipo de oficio o empleo y de la existencia o no de participación gremial ligada a aquél. Al respecto, Ema comentaba:

¿cuál sería el compromiso que uno podía hacer para traer, para revisar? por ejemplo, el que yo podía tener en mi trabajo...yo estaba en escuelas [rurales] que eran bipersonales, o sea, lo que yo podía hacer ahí. En el gremio, viste, no teníamos participación, por ahi había alguna que otra reunión, por ahí HACÍAMOS alguna reunión, pero no había alguna participación activa [...] No era lo mismo que estar en una fábrica ${ }^{499}$.

Asimismo, los jecistas trataban su participación en las problemáticas del curso y del colegio, y la forma en la que podían acercar a sus compañeros una propuesta de vida

\footnotetext{
492 Entrevista a Mirta, Bahía Blanca, 18/6/2008.

${ }^{493}$ Entrevista a Gustavo, 9/8/2012.

${ }^{494}$ Entrevista a Clara, Bahía Blanca, 10/10/2012.

495 Entrevista a José, Bahía Blanca, 19/6/2008.

${ }^{496}$ Entrevista a José, Bahía Blanca, 19/6/2008, y a Dante Bahía Blanca, 15/3/2012.

${ }^{497}$ Entrevista a Roberto, Bahía Blanca, 18/4/2013.

${ }^{498}$ Entrevista a Dante, Bahía Blanca, 29/8/2011.

${ }^{499}$ Entrevista a Ema, Bahía Blanca, 27/9/2012.
} 
acorde al mensaje cristiano ${ }^{500}$. Aquí, nuevamente, las posibilidades de intervención eran disímiles en función de la idiosincrasia de cada institución educativa. Así lo explicaba Alicia:

A mí me costaba un perú, porque yo estaba en el Colegio Nacional... Era ... ya te digo, duro, que tenías que llevar el guardapolvo hasta acá, las medias azules hasta acá, el pelo con vincha, atado, o sea, ESA escuela, y yo me acuerdo que los otros contaban en las reuniones de que habian podido reunirse, habian hecho una asamblea, habian podido discutir con los compañeros. Y yo, viste, me moría de angustia, porque yo de esas cosas no ${ }^{501}$.

Por otra parte, incluso en el mismo grupo, los compromisos de los militantes eran diversos. De esta manera, se pensaba la participación en el scoutismo, en la comunidad religiosa, en el barrio o la villa, en el gremio y en la política. Entre los jucistas la variedad de carreras y profesiones en las que se estaban formando, así como de medios de inserción de los militantes imprimía a la reflexión una amplia gama de problemas. Así, mientras los jóvenes que desarrollaban un activismo político en la UNS acercaban a las reuniones las situaciones que se les presentaban en las asambleas y tomas de la universidad, los debates ideológicos con compañeros de diversas agrupaciones o sus reflexiones en torno a sus opciones partidarias, quienes hacían de la villa su ámbito de acción -ya sea como docentes, como trabajadores sociales o como activistas políticos- planteaban las realidades que vivían los niños en la escuela, las problemáticas de los vecinos y los interrogantes de cómo profundizar las propias prácticas en dichos escenarios ${ }^{502}$. Al mismo tiempo, quienes se estaban formando en profesiones vinculadas al área de la salud compartían las cuestiones que se presentaban a diario en sus residencias, en relación con las prácticas hospitalarias y el trato a los pacientes $^{503}$.

Al calor de los acontecimientos que se sucedían en el orden local, nacional e internacional, y de las vicisitudes de las trayectorias militantes de los jóvenes, la opción política adquirió cada vez mayor peso en los debates grupales. Las implicancias y dilemas de esa opción en las diversas coyunturas en las que se desplegó atravesaron entonces la revisión de vida en esos años ${ }^{504}$. Entre esas cuestiones figuran la violencia,

\footnotetext{
${ }^{500}$ Entrevista a Elsa, Bahía Blanca, 9/3/2012.

${ }^{501}$ Entrevista a Alicia, Bahía Blanca, 9/7/2011.

${ }^{502}$ Entrevista a Marta, Bahía Blanca, 29/5/2008.

${ }^{503}$ Entrevista a Manuel y Nancy, Neuquén, 21/3/2013.

${ }^{504}$ Entrevista a Elsa, Bahía Blanca, 9/3/2012. Volveremos sobre esta cuestión en el capítulo 7.
} 
la lucha armada o el pase a la clandestinidad de Montoneros ${ }^{505}$. Al respecto, Mónica evocaba una larga discusión sobre la violencia que involucró a la JEC en un encuentro de verano celebrado en Villa Inmaculada en febrero de 1975:

Pepe se puso en una perspectiva muy ontológica, digamos, el valor de la vida, la vida de cual, la vida es un valor en sí mismo o no es un valor en sí mismo, qué se yo, discutió muchísimo, con [Alberto Paira] ${ }^{506}$, conmigo. Después había otro grupo que compartía la preocupación de Pepe digamos ¿no?, la gente que menos compromiso político tenía. Nosotros que estábamos recontra lanzados discutimos MUCHO, MUCHO, MUCHO ${ }^{507}$.

En efecto, más allá de las particularidades de cada ambiente, la reflexión semanal no excluía el abordaje de otros aspectos de la vida de los militantes, como los temas de la coyuntura histórica local, nacional o internacional ${ }^{508}$. Esto implicaba el análisis de un amplio abanico de cuestiones que iban desde los acontecimientos puntuales que sacudían a la opinión pública hasta problemas generales como la pobreza, las desigualdades sociales, la realidad económica o incluso los debates sobre el aborto o la bioética, frente a los cuales se buscaba adoptar una postura crítica ${ }^{509}$.

En este marco, y ligado a lo mencionado en los párrafos anteriores, la política tenía un lugar privilegiado, se constituía en un problema cotidiano y su abordaje se planteaba con naturalidad impregnando diversos temas ${ }^{510}$. De allí que Silvestre sintetizara los temas de discusión de la JOC en "politica y relaciones laborales" 511 , que Eugenia señalara que en la JEC la lectura de la realidad se centraba en "lo político y lo social" políticas, 513 .

Así, algunos acontecimientos clave de esos años tomaron largos debates en los equipos de revisión de vida, ya sea en los encuentros semanales o en los campamentos anuales. Entre ellos, los relatos de los protagonistas destacaban el asesinato del ex

\footnotetext{
${ }^{505}$ Entrevista a Gabriel, Bahía Blanca, 27/10/2012, a Nora y Rodolfo, Bahía Blanca, 2/4/2009, a Aída, Buenos Aires, 17/5/2013.

506 Vivió en Sánchez Elía, fue integrante de los Scouts de "San Jorge", estudió en la Escuela de Enseñanza Técnica ${ }^{\circ} 1$, formó parte de la JEC de la "loma", y fue militante de la UES y Montoneros. Fue asesinado en Berisso, el 26 de abril de 1977.

${ }^{507}$ Entrevista a Mónica, Buenos Aires, 9/11/2011.

508 "Historia de la JOC en Bahía Blanca".

509 Entrevistas a Gustavo, 9/8/2012; a Pedro, Buenos Aires, 16/11/2012; a Ricardo, Bahía Blanca, $8 / 10 / 2011$.

${ }^{510}$ Entrevistas a Carlos, Bahía Blanca, 4/5/2011; a Juan, 24/8/2011; a Pedro, Buenos Aires, 15/11/2012; a María, Bahía Blanca, 21/3/2013; a Manuel y Nancy, Neuquén, 21/3/2013; a María del Carmen, Bahía Blanca, 18/5/2011.

${ }^{511}$ Entrevista a Silvestre, vía e-mail, 29/10/2012.

${ }^{512}$ Entrevista a Eugenia, Bahía Blanca, 30/12/2012.

${ }^{513}$ Entrevista a Elena, Bahía Blanca, 17/6/2010.
} 
presidente de facto Pedro Eugenio Aramburu, perpetrado por la organización Montoneros el $1^{\circ}$ de junio de $1970^{514}$. Y Nora detallaba:

nos llevó días, meses de reflexión porque por un lado, nos alegrábamos de la muerte -digamos entre comillas ¿no?- [...] después, todo lo que significaba la vida, la valoración de la vida, la valoración del enemigo. Digamos, entrábamos en profundos conflictos aún en nuestras propias concepciones ${ }^{515}$.

La vuelta a la democracia y las elecciones de marzo de 1973 también fueron objeto de reflexión. Según relataban Mónica y Juan, estas cuestiones ocuparon el centro de la discusión en un encuentro en Villa Inmaculada en el que participaron tanto los jóvenes de Sánchez Elía como los de La Pequeña Obra, y lo hicieron a pesar de que muchos de los militantes no tenían aún edad para votar"516: "muchos grupos votaban a Allende Allende era el PI, viste- y otros el FREJULI. Entonces ésa fue una división así en los grupos cristianos [...] era bastante debate, digamos, era el tema del momento" ${ }^{517}$. Otros hechos significativos que atravesaron las discusiones grupales fueron la renuncia de Héctor Cámpora o la muerte de Perón.

Por último, en los equipos de reflexión se compartían las experiencias referidas a la vida cotidiana de los militantes, a sus relaciones familiares o de amistad y a sus problemas personales $^{518}$. Al respecto, Angélica ligaba el tratamiento de estos temas a una etapa particular que por entonces transitaban los jóvenes, la "salida" del propio hogar, y lo ubicaba en un primer momento de la JOC, mientras asociaba el siguiente con el abordaje de las cuestiones referidas al mundo laboral. En este punto coincidía la experiencia de Inés en la JEC:

en un comienzo se hablaba mucho de los problemas típicos de la adolescencia en cuanto a la relación con tus padres, con tus hermanos. Yo creo que era, sobre todo, por la etapa evolutiva por la que pasábamos...Después conflictos así puntuales que alguno había tenido en su curso o el grupo de sus amigos ${ }^{519}$.

Para Rodolfo, en cambio, la reflexión sobre la vida más íntima de los militantes, como las vicisitudes de la pareja o de la vinculación con los hijos, correspondió en la JUC a la última etapa, marcada por el recrudecimiento de la represión y la profundización de las

\footnotetext{
${ }^{514}$ Entrevista a Pablo, Neuquén, 19/3/2013.

${ }^{515}$ Entrevista a Nora, Bahía Blanca, 4/6/2008.

${ }^{516}$ Entrevista a Mónica, Buenos Aires, 9/11/2011.

${ }^{517}$ Entrevista a Juan, 31/5/2011.

518 Entrevistas a Nora, Bahía Blanca, 4/6/2008; a Carlos, Bahía Blanca, 4/5/2011; a Francisco, Buenos Aires, 16/11/2012. Historia de la JOC en Bahía Blanca".

${ }^{519}$ Entrevista a Inés, Bahía Blanca, 18/6/2011.
} 
prácticas políticas clandestinas, lo cual, desde su perspectiva, condujo a evitar poner sobre la mesa de discusión las prácticas vinculadas a la militancia ${ }^{520}$.

Unos apuntes tomados por una joven de la JUC, el 16 de enero de 1970 -según Julio, durante un campamento de verano de la rama universitaria celebrado en Pehuencó- nos permiten ilustrar el abanico de cuestiones que eran objeto de reflexión mediante la metodología de la revisión de vida. En primer lugar, el grupo se proponía abordar la "comunidad JUC" y, concretamente, la integración de los equipos entre sí, a la comunidad y a la Iglesia. Luego, la atención se movía a la "realidad global 69", focalizándose en el movimiento estudiantil y su significación, el movimiento obrero y el proceso socioeconómico. En tercer lugar, reflexionaba sobre la vivencia cristiana de la JUC durante 1969, centrándose en la fe a nivel personal y en el equipo, en el medio y en relación a la liturgia. Por último, analizaba el compromiso de la JUC durante el año anterior, distinguiendo los planos personal y comunitario, así como los niveles de la "promoción humana", la "evangelización” y la "estructura". Le seguía la "interpretación profética", en la que se discriminaban el "esclarecimiento humano" y el "evangélico", y la interpretación evangélica del compromiso político. Las anotaciones siguientes aludían a algunos de los aspectos enunciados. Por ejemplo, mencionaban la diversidad de los centros o medios como aspecto negativo de la integración de los equipos, la falta de encuentro humano en un grupo que priorizaba esa dimensión aún antes de la reflexión cristiana, la carencia de conocimiento de "la Palabra actualizada de Cristo hoy en la Iglesia" presente en Medellín y otros documentos, la ausencia de "clarificación evangélica", al tiempo que los jucistas se "manejaban con ideas muy generales todavía", la ubicación de los militantes en un lugar de comodidad y "receptividad" dentro de los equipos y la inexistencia de la necesidad de explicitar el cristianismo ${ }^{521}$.

El abordaje de temas diversos mediante el método Ver, Juzgar y Obrar fue también una marca de experiencias que tuvieron lugar en otros lugares de América Latina. Así, los jocistas de Guatemala se ocupaban de problemas personales, laborales y comunitarios, abarcando múltiples cuestiones que iban desde el abuso sexual hasta el trabajo, la justicia o la educación (Levenson, 2007).

\footnotetext{
${ }^{520}$ Entrevista a Nora y Rodolfo, Bahía Blanca, 2/4/2009. Volveremos sobre esta cuestión en el capítulo 7. ${ }^{521}$ Apuntes de una reunión de la JUC, durante un campamento de verano en Pehuen-có, 16/1/1970. Archivo personal de Julio e Irene.
} 


\section{2) Una nueva forma de vivir la fe}

Desde la perspectiva de los actores, su paso por la JUC, la JOC y la JEC significó el redescubrimiento -y aún el descubrimiento a secas- y la maduración de su fe. Así, para Nora, fue el nacimiento de una "fe adulta" verdadero cristiano ${ }^{, 523}$.

Para quienes participaban ya de la Eucaristía o en los Scouts de Nuestra Señora del Carmen o de La Pequeña Obra, los equipos de revisión de vida marcaron una continuidad o una profundización de las novedades litúrgicas y teológicas que venían incorporando los sacerdotes "Pepe" y Emilio a la vida de la iglesia de la "loma" y ellos junto a las hermanas misioneras, al centro pastoral del barrio Pedro Pico. En efecto, ambos presbíteros y Kotska se constituyeron en referentes de esta nueva experiencia de fe. La misma religiosa española había experimentado cambios en su trayectoria eclesial. Así lo destacaban los entrevistados. Para María del Carmen,

La monja es como que se adosó a la visión innovadora que traía Pepe de la Iglesia, del compromiso cristiano. Ella quizás venía de una forma más tradicional...aparte históricamente ella venía del franquismo, venía de otro palo...Pero como era una monja muy viva, y como era muy adaptable... ${ }^{524}$.

Es posible abordar esta aparente contradicción teniendo en cuenta la existencia de un tipo de catolicismo -analizado en el capítulo 1- que actúa como matriz común de líneas eclesiales tan dispares. Asimismo, no debe perderse de vista que se trataba de especialistas religiosos que ocupaban un lugar particular dentro de la institución y tenían con ella una relación de más largo plazo que posibilitaba/obligaba al mantenimiento de un compromiso exclusivo con la Iglesia. En esta línea reflexionaba Mario:

Kotska ante todo era una gran catequista, porque Kotska podía haber sido franquista en España, acá estar con los curas de Medellín. No era una contradicción. Ella estaba con la Iglesia y con la doctrina de la Iglesia. Si entonces era Medellín esa propuesta, ella estaba con eso. Y si en España estaba con el franquismo era el franquismo ${ }^{525}$.

El grupo de sacerdotes ligados al catolicismo liberacionista en Bahía Blanca y Punta Alta animaron un nuevo pensamiento cristiano en muchos de estos jóvenes. Y lo hicieron a partir de su cercanía a los grupos de revisión de vida desde otros espacios como era el caso de Néstor Navarro, "Coco" Segovia o Miguel Sarmiento- o de su

\footnotetext{
${ }^{522}$ Entrevista a Nora, Bahía Blanca, 4/6/2008.

${ }^{523}$ Entrevista a Lucy, Neuquén, 18/3/2013.

${ }^{524}$ Entrevista a María del Carmen, Bahía Blanca, 18/5/2011.

${ }^{525}$ Entrevista a Mario, Bahía Blanca, 5/1/2013.
} 
trabajo como docentes en el nivel medio o terciario -por ejemplo, Emilio con sus clases en la Escuela de Servicio Social; Benito Santecchia y Benjamín Stocchetti, en el Instituto Juan XXIII, además de que el primero ofrecía conferencias en la UNS-; o "Pepe", en el San Vicente de Paul-. Para Ema, si "Pepe" la había "parido en la fe", Benito había también influido en ella como profesor de teología en el instituto de profesorado, durante su participación en la JUC y en la JOC:

decía que el día del Juicio te iban a preguntar "tuve hambre y me diste de comer, tuve sed y me diste de beber", y nunca iban a preguntar otra cosa...O sea, como que había que preocuparse por la construcción del Reino ¿no?, y todo lo que encerraba la militancia, todo lo que encerraba ese compromiso, que no tanto detalle de si fuiste, si la indulgencia y toda esa historia ${ }^{526}$.

Entre las religiosas que se convirtieron en testimonio de una nueva propuesta religiosa se encontraban, además de Kotska, otras Misioneras Cruzadas, como la hermana Piedad, quien estaba a cargo de las Guías. Desde el recuerdo de su niñez y adolescencia, Nancy comparaba a las misioneras con las hermanas de la Compañía de María que dirigían el colegio La Inmaculada:

para nosotros eran FANTÁSTICAS las monjas esas, modernas, espectaculares, tenían un coso [hábito] más sencillo -las otras tenían una caparazón así-, y corrían y jugaban con nosotras, y nos íbamos de campamento y charlábamos y qué se yo, o sea, eran otra cosa...entonces nosotros mamamos eso ${ }^{527}$.

Sin embargo, las religiosas más jóvenes de la Compañía, especialmente Norma, también actuaron como referentes, al calor de su propio proceso de renovación.

Para los militantes con trayectoria en el Guidismo o en el Scoutismo, estos movimientos habían significado el despertar de una vivencia religiosa orientada por el amor al prójimo, la idea de compromiso y la noción de servicio. Para Nancy, actividades como juntar ropa para los pobres, los campamentos, la organización de las misas, la realización de obras de teatro hacían de las Guías una experiencia evangelizadora fuerte ${ }^{528}$.

Por otra parte, los jóvenes que estaban o habían estado en contacto con otros espacios y referentes del catolicismo renovador en la ciudad, encontraron también en ellos estímulos para asumir una nueva forma de ser cristiano. En este sentido, Dante descubrió ya en el Movimiento Familiar Cristiano, antes de su ingreso a la JOC, una Iglesia que, influida por el Concilio, le resultaba "mucho más cercana, interesada en la

\footnotetext{
${ }^{526}$ Entrevista a Ema, Bahía Blanca, 27/9/2012.

${ }^{527}$ Entrevista a Manuel y Nancy, Neuquén, 21/3/2013.

${ }^{528}$ Entrevista a Nancy y Manuel, Neuquén, 21/3/2013.
} 
cuestión de la ciudad terrena", opuesta a "la Iglesia lejana" que había conocido durante el catecismo ${ }^{529}$. Y para Graciela, este espacio supuso el conocimiento de una

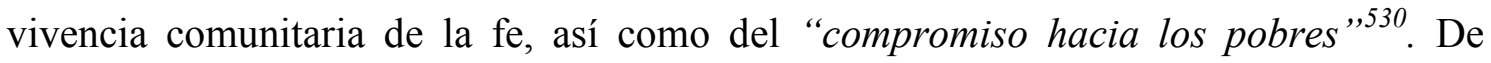
modo similar, Juan Carlos rescataba de su paso por la JAC de Punta Alta, la idea del "compromiso social, religioso" y de "dar testimonio de vida cristiana en el lugar donde uno estaba" ${ }^{531}$. También para los actores fue significativa, aunque en otro sentido, la experiencia del Pensionado Católico. Así lo expresaba Eduardo: “ahí descubrí un poco el valor de la comunidad y de Cristo en la comunidad y ahí es donde yo arranqué mi vida de fe y compromiso ${ }^{, 532}$.

En general, los relatos de los protagonistas oponían la manera de pensar y practicar el catolicismo propia de los colegios religiosos en los que habían cursado sus estudios primarios o secundarios, del catecismo que los había preparado para recibir los sacramentos de la comunión o confirmación, o de los grupos laicales en los que habían iniciado sus trayectorias de militancia católica -tales como la Pequeña Hermandad o la Legión de María-, con una concepción y vivencia radicalmente distinta; en palabras de Silvestre: "un nuevo cristianismo”,533. Ahora bien, ¿cómo describían los entrevistados la experiencia religiosa de su niñez y etapa previa al contacto con la nueva corriente eclesial que la JUC, la JOC y la JEC representaban? ¿Qué características asumió para estos jóvenes la propuesta religiosa de los grupos de revisión de vida -o de un modo más general, de los espacios ligados a la renovación católica-?

Para los protagonistas, la primera resultaba "estructurada",534, "rígida"535, “cerrada 536", “fría"537, “lejana",538, "formal",539, "tradicional”,"540, "ritualista,"541, "estereotipada”, “rutinaria",542, "mecánica",543, "reglamentarista"544, basada en el

\footnotetext{
${ }^{529}$ Entrevista a Dante, Bahía Blanca, 28/9/2011.

${ }^{530}$ Entrevista a Graciela, Buenos Aires, 31/7/2008.

${ }^{531}$ Entrevista a Juan Carlos, Buenos Aires, 29/7/2008.

${ }^{532}$ Entrevista a Eduardo y Patricia, Bahía Blanca, 21/3/2008.

${ }^{533}$ Entrevista a Silvestre, vía e-mail, 29/10/2012.

${ }^{534}$ Entrevista a Patricia, Bahía Blanca, 19/5/2008, y a Susana, Bahía Blanca, 1/4/2009.

${ }^{535}$ Expresión de Nancy, entrevista a Manuel y Nancy, Neuquén, 21/3/2013. Entrevista a Elena, Bahía Blanca, 17/6/2010.

${ }_{536}^{536}$ Entrevista a Elena, Bahía Blanca, 17/6/2010; a Héctor, Bahía Blanca, 1/5/2010.

${ }^{537}$ Entrevista a Lucy, Neuquén, 18/3/2013.

${ }^{538}$ Entrevista a Dante, Bahía Blanca, 28/9/2011.

${ }^{539}$ Entrevista a Juan, 24/8/2011. "Por qué de mi militancia en la JOC", apuntes de Paloma, enviados vía e-mail, febrero de 2013.

${ }^{540}$ Entrevista a Eugenia, Bahía Blanca, 30/12/2012; a Mario, Bahía Blanca, 5/1/2013; a Julio, Bahía Blanca, 22/5/2010; a Elena, Bahía Blanca, 17/6/2010; a Héctor, Bahía Blanca, 1/5/2010.

541 "Por qué de mi militancia en la JOC", apuntes de Paloma, enviados vía e-mail, febrero de 2013. Entrevista a Nora, Bahía Blanca, 4/6/2008.

${ }^{542}$ Entrevista a María del Carmen, Bahía Blanca, 18/5/2011.
} 
cumplimiento de preceptos y obligaciones -tales como "ir a misa", "no cometer pecados", "no tener relaciones sexuales" $" 545$-, el miedo a ser castigado, la culpa, la participación en ritos que les parecían incluso incomprensibles -como la misa con el sacerdote de espaldas y hablando en latín-, la memorización del catecismo. Todo ello ubicaba a los fieles en un lugar pasivo y despojaba al mensaje cristiano de sentido para sus vidas concretas ${ }^{546}$. En este sentido, Aída recordaba: “mi vieja nos llevaba a la famosa misa de gallo y nos quedábamos dormidas" "547. Al mismo tiempo, esta Iglesia parecía poner el énfasis en la oración y la relación personal/individual con Dios ${ }^{548}$, al tiempo que carecía de una preocupación por este mundo -en palabras de Marta, no tenía "los pies en la tierra",549-, de allí que se la definiera como "espiritualista" 550 , "mística" "551/"salve tu alma",552 y a sus seguidores como "chupasirios",553. Y en relación con lo anterior, esta propuesta religiosa resultaba "atemporal",554 y “anticuada" ${ }^{, 555}$. En este sentido, Clara recordaba las misas de su infancia:

era arrodillarme y "padrenuestro que estás en los cielos", y ni sabías que MIÉRCOLES estabas rezando ni qué significaba ni por qué lo hacías...en la época que tenía que entrar a la Iglesia con una mantilla porque era "una falta de respeto" y bueno, todos los atuendos que tenías que llevar ${ }^{556}$.

En este marco, muchos de los jóvenes habían sufrido una suerte de crisis respecto de la religión asumida por tradición familiar y habían decidido, aún considerándose creyentes en algunos casos, alejarse de la Iglesia en los años previos a su ingreso a la JOC, la JUC y la JEC. Esta distancia incluía desde el abandono de la concurrencia a misa hasta incluso declararse agnósticos, como en el caso de Jorge. En otros casos, sin dejar de participar de la vida de la Iglesia, los jóvenes habían planteado su resistencia a ciertos modos establecidos de llevarla adelante. Ema mantenía viva la fe que le había dado su madre, iba semanalmente a misa y participaba de concursos de

\footnotetext{
${ }^{543}$ Entrevista a Juan, 24/8/2011.

${ }^{544}$ Entrevistas a Juan Carlos, Buenos Aires, 29/7/2008 y a Nora, Bahía Blanca, 4/6/2008.

${ }^{545}$ Entrevista a Juan Carlos, Buenos Aires, 29/7/2008.

${ }^{546}$ Entrevista a Eugenia, Bahía Blanca, 30/12/2012; a Nora, Bahía Blanca, 4/6/2008; a Manuel y Nancy, Neuquén, 21/3/2013; a Paloma, vía skype, 22/2/2013.

${ }^{547}$ Entrevista a Aída, Buenos Aires, 17/5/2013.

${ }_{548}$ Entrevista a Ángel, Buenos Aires, 8/10/2009. Entrevista a Julio, Bahía Blanca, 22/5/2010.

${ }^{549}$ Entrevista a Marta, Bahía Blanca, 29/5/2008.

${ }^{550}$ Entrevista a Marta, Bahía Blanca, 29/5/2008. Entrevista a Julio, Bahía Blanca, 22/5/2010.

${ }^{551}$ Entrevista a Elena, Bahía Blanca, 17/6/2010.

${ }_{552}$ Entrevista a Marta, Bahía Blanca, 29/5/2008.

${ }^{553}$ Entrevista a Héctor, Bahía Blanca, 1/5/2010.

${ }_{554}^{554}$ Entrevista a Julio, Bahía Blanca, 22/5/2010.

555 Entrevista a Héctor, Bahía Blanca, 1/5/2010. Expresión también utilizada por Nancy, entrevista a Nancy y Manuel, Neuquén, 21/3/2013.

${ }^{556}$ Entrevista a Clara, Bahía Blanca, 10/10/2012.
} 
preguntas del catecismo, pero al mismo tiempo, no le encontraba sentido a determinadas imposiciones de las Hermanas Vicentinas que estaban a cargo del colegio donde cursaba sus estudios. Por ejemplo, se negaba a llevar a la iglesia una especie de carnet para hacerlo sellar y, así, dejar constancia de la asistencia a la celebración dominical, que era un aspecto relevante en el boletín de calificaciones ${ }^{557}$. Nancy y Patricia, junto al resto de su curso, también se rebelaron contra normas similares de las religiosas de la Compañía de María; en particular, contra la obligación de usar mantilla en la misa ${ }^{558}$.

Desde la perspectiva de los protagonistas, la JUC, la JOC y la JEC, en cambio, invitaban a vivir una fe muy distinta. En primer lugar, en contraste con los deberes que rodeaban la experiencia religiosa en el pasado, el grupo de reflexión se presentaba como un espacio abierto, que no requería una declaración previa de la identidad católica, y la integración a él como una opción personal, libre, voluntaria ${ }^{559}$. En este marco, algunos se reencontraron con la vida espiritual a partir de la resignificación de la Eucaristía. Es el caso de Eduardo y de Marta, después de transcurrido un tiempo de participación en la JUC o en los Scouts -respectivamente- y se manifestó de modo espontáneo en un contexto de comunión grupal. Así relataba Marta su experiencia:

una vez se le muere la madre a uno de los dirigentes y después el velorio, como se había quedado solito, se viene al campamento. Y entonces Pepe hace adentro de la carpa una misa con los ocho dirigentes que éramos y eso fue terrible porque ahí sí comulgaron y yo no... me encontré con la gran contradicción...fue fuertísimo, yo no comulgué y me moría de ganas porque ahi sí tenía sentido pero yo no estaba viste...Así que ahi se me dividió de nuevo toda la cuestión y le pedí a Pepe hablar con él. Yo nunca había hablado así con un cura ...y ahí entonces empecé a revisar todo esto ${ }^{560}$.

En efecto, para los actores, se trataba de una fe que hacía sentido en la vida de cada uno. La lectura del Evangelio por primera vez interpelaba a cada cual en su cotidianeidad y parecía tener algo que decirles. Al mismo tiempo, las celebraciones, compartidas en comunidad y donde todos construían la homilía, se cargaban de contenido $^{561}$.

En este proceso, los jóvenes tomaron un lugar activo en las prácticas religiosas. Lejos de aceptar verdades incuestionables, repetir las lecciones de los catequistas y de sentirse espectadores de celebraciones vacías, los laicos adquirían una real participación

\footnotetext{
${ }^{557}$ Entrevista a Ema, Bahía Blanca, 27/9/2012.

${ }^{558}$ Entrevista a Nancy y Jorge, Neuquén, 21/3/2013.

${ }^{559}$ Palabras de Jorge, Entrevista a Mirta y Jorge, Bahía Blanca, 14/7/2012.

${ }^{560}$ Entrevista a Marta, Bahía Blanca, 29/5/2008.

${ }^{561}$ Entrevista a Paloma, vía skype, 11/2/2013.
} 
en la vida de la comunidad cristiana. Al respecto, Eugenia explicaba que desde que se acercó a las Guías y empezó a asistir a las misas donde colaboraba con las lecturas y las ofrendas, comenzó a sentirse "partícipe", "tenida en cuenta" que ubicaba al laico en un lugar central, imprimía a la vivencia de la fe un carácter nuevo $^{563}$.

Al tiempo en que el mensaje cristiano se volvía comprensible, cercano, vivencial y anclado en este mundo, la relación con Dios cambiaba sustancialmente. Mientras antes prevalecía la imagen de un Dios que castigaba, que inspiraba temor, ahora aparecía ligado al amor, la misericordia, el perdón, a la alegría. En este sentido, para los actores, su ingreso a estas organizaciones cristianas juveniles les permitió "sanar" las marcas de su paso por el colegio religioso, ligadas al miedo a Dios y a la preocupación por el "pecado" 564 . En esta nueva imagen de Dios también prevalecía la cercanía. Desde la nueva perspectiva, los jóvenes podían encontrarlo en los momentos y situaciones ordinarias, en la vida de todos los días y en las cosas sencillas. En este sentido, decía Pedro de "Pepe" y Emilio:

los tipos tiraban un poncho en el suelo y teníamos la misa ahí. Entonces no podías más que rendirte (risas), porque era tan natural y tan humano, y tan empático... Estar en el campo, estar en contacto con la naturaleza, y el tipo te hablaba de Dios a través de las plantas, de las $\operatorname{cosas}^{565}$.

En esta nueva experiencia de fe, los jóvenes comenzaron a renegar de las formalidades, a cuestionar a la institución, a distinguir la propuesta evangélica de las dinámicas eclesiales, o el mensaje de Jesús de la historia de la Iglesia ${ }^{566}$. El centro de la misión cristiana era ahora el hombre, lo que acercaba a los militantes cristianos a los activistas no creyentes movidos por las mismas premisas. Juan destacaba este punto con una anécdota: "Pepe también nos formó buscando la esencia y no la forma, viste. Cuando fue la muerte del Che, por ejemplo, no dudaba de que iba a estar en el paraíso, $Y$ nos decía eso y lo fundamentaba por qué: por el compromiso con los pobres ${ }^{, 567 .}$

\footnotetext{
${ }^{562}$ Entrevista a Eugenia, Bahía Blanca, 30/12/2012.

${ }^{563}$ Entrevista a Inés, Bahía Blanca, 18/6/2011; a Julio, Bahía Blanca, 22/5/2010; a María, Bahía Blanca, 21/2/2013; a Elena, Bahía Blanca, 17/6/2010.

${ }^{564}$ Entrevista a Marta, Bahía Blanca, 29/5/2008.

${ }^{565}$ Entrevista a Pedro, Buenos Aires, 15/11/2012.

${ }^{566}$ Entrevista a Clara, Bahía Blanca, 10/10/2012.

${ }^{567}$ Entrevista a Juan, 31/5/2011.
} 
Desde entonces, para los jóvenes el sentido de la fe católica era el amor al prójimo y el mandamiento de dar la vida por los hermanos ${ }^{568}$. De allí emergía una religiosidad diferente estrechamente ligada a las nociones de solidaridad y de servicio $^{569}$. El amor a Dios ya no se manifestaba en la repetición de oraciones o el cumplimiento de ayunos y de la obligación de ir a la iglesia, sino en salir al encuentro de los hermanos. En palabras de Paloma: "no era solamente ponerme a rezar" ${ }^{\text {570; }}$ y de Marta: "no podía haber una fe descomprometida de la carne, de la realidad, de la historia...desentendida y escindida la oración de la práctica"

Por otra parte, como también mencionamos en el apartado anterior, la nueva propuesta contemplaba al grupo como instancia fundamental para la vivencia de la fe. La relación con Dios estaba mediada por los otros, se volvía necesariamente "social" $" 572$. El componente comunitario, y ligado a él, afectivo no era un dato menor de la nueva forma de concebir el catolicismo. En palabras de María: "habíamos llegado a la conclusión que la forma madura de vivir la fe y reflexionarla era a través de la comunidad $^{, 573}$. En efecto, el testimonio de los compañeros y el acompañamiento del asesor apuntalaban la propia reflexión cristiana y las celebraciones religiosas.

\section{3) EI descubrimiento de "la realidad" y el impulso al compromiso}

Esta nueva forma de vivir la fe, encarnada y comunitaria, de la mano de la revisión de vida, significó para los actores la oportunidad para acercarse intelectualmente al escenario económico, político y social de su tiempo. En efecto, el ejercicio de los dos primeros momentos de la reflexión representó la posibilidad de abordar los problemas sociales y el desarrollo de una mirada crítica de la situación del país y del papel de cada uno en ella. En este sentido, Alicia comentaba que las reuniones de la JEC le ofrecieron "luces para ver" y "armar estos pedazos de historia, de sociedad $y$ de política" ${ }^{\text {574 }}$. Y Gustavo decía que aquel fue un ámbito donde los

\footnotetext{
568 Entrevista a José, Bahía Blanca, 19/6/2008; a Ana, Bahía Blanca, 17/10/2012; a Elsa, Bahía Blanca, 9/3/2012; a Norma, Bahía Blanca, 8/4/2011.

${ }^{569}$ Entrevista a Ana, Bahía Blanca, 17/10/2012; a Clara, Bahía Blanca, 10/10/2012; a José, Bahía Blanca, 19/6/2008; a Patricia, Bahía Blanca, 19/5/2008.

${ }^{570}$ Entrevista a Paloma, Bahía Blanca, 22/2/2013.

${ }^{571}$ Entrevista a Marta, Bahía Blanca, 29/5/2008.

${ }^{572}$ Entrevista a Ángel, Buenos Aires, 8/10/2009.

${ }^{573}$ Entrevista a María, Bahía Blanca, 21/2/2013.

${ }^{574}$ Entrevista a Alicia, Bahía Blanca, 9/7/2011.
} 
militantes "incorporaron" la realidad a través de un "proceso racional de toma de conciencia, 575 .

En el caso de la JOC, el grupo se constituyó en un espacio de discernimiento de su ser trabajador y de las problemáticas, dinámicas y dificultades inherentes al mundo de los obreros y los empleados. Se conformó en una primera instancia para pensar, objetivar y desnaturalizar las situaciones cotidianas del trabajo, de lo que se derivaba la asunción de una posición frente a éstas, así como nuevas actitudes y comportamientos. Sobre esta cuestión, Liliana ejemplificaba:

los patrones siempre tienden a dividir al empleado, nunca les conviene que estén juntos. Había un momento que estábamos pasando entre todos los compañeros de trabajo, yo ahí lo planteaba, entonces él ["Pepe”] me decía "¿y vos cómo estás con tus compañeros?”, "y con mis compañeros asi”, él nos hacía ver esas cosas, siempre le conviene al patrón que vos no te unas...si vos estás dividido no pueden hacer nada pero si vos te unís podés hacer algo... ¿no?, por ejemplo, más [menos] horas de trabajo ${ }^{576}$.

Una de las implicancias de esta reflexión fue, entonces, el reconocimiento de las potencialidades del trabajo como actividad humana creadora, del valor del oficio de cada uno y de la dignidad de su condición de "laburantes". En este sentido, Silvestre afirmaba: "nosotros en la JOC, sentíamos que éramos de la clase trabajadora" 577. Angélica explicaba: "el punto fuerte, por lo menos para mí, fue eso de valorar el trabajo en todo lo que hace no solamente al ingreso económico, a tener una independencia, sino también, al desarrollo de las capacidades de cada uno, el estímulo para la formación " 578 .

A partir de este "descubrimiento de la realidad", la fe se volvió indisociable de la acción orientada a su transformación ${ }^{579}$. Según recuerdan los jucistas, el grupo compartía la convicción de que "la fe hay que vivirla" 580 y, más aún, "hay que explicitarla" ${ }^{581}$. La idea de que la fe y el compromiso se implicaban e incluían mutuamente en la persona creyente era una convicción compartida por los grupos de

\footnotetext{
${ }^{575}$ Entrevista a Gustavo, Bahía Blanca, 12/7/2011 y 9/8/2012.

${ }^{576}$ Entrevista a Liliana, Bahía Blanca, 25/6/2008.

577 Entrevista a Silvestre, vía e-mail, 29/10/2012.

${ }^{578}$ Entrevista a Angélica, Bahía Blanca, 25/4/2012.

579 Entrevista a Roberto, Bahía Blanca, 18/4/2013; a María, Bahía Blanca, 21/2/2013; a Héctor, Bahía Blanca, 1/5/2010; a Elena, Bahía Blanca, 17/6/2010; a Julio, Bahía Blanca, 22/5/2010; a Ángel, Buenos Aires, 8/10/2009; a Nora, Bahía Blanca, 4/6/2008; a Juan Carlos, Buenos Aires, 1/8/2008; Mónica, Buenos Aires, 30/7/2008; a Mario, Bahía Blanca, 5/1/2013; a Francisco, Buenos Aires, 16/11/2012; a Juan, Bahía Blanca, 31/5/2011; a Noma, Bahía Blanca, 8/4/2011; a Inés, Bahía Blanca, 18/6/2011; a Alicia, Bahía Blanca, 9/7/2011.

${ }_{580}$ Entrevista a María, Bahía Blanca, 21/2/2013.

${ }^{581}$ Entrevista a Elena, Bahía Blanca, 17/6/2010.
} 
estudiantes católicos del continente. Para el MIEC-JECI, si todo hombre estaba comprometido, la fe no podía ser la de un hombre sin compromiso: "no existe una fe pura". Este "catolicismo integral" asumía diversas opciones según el sentido en el que se orientara el compromiso: unos expresaban su adhesión a Cristo en un compromiso conservador mientras otros lo hacían en un compromiso transformador revolucionario. Con toda la gama de variaciones posibles, estos eran identificados como los dos polos de la vida cristiana en América Latina. Desde esta perspectiva, los criterios de autenticidad de la fe no había que buscarlos solamente en la referencia a "Cristo Dios Salvador" y a la comunidad creyente/Iglesia sino también, simultáneamente, en la relación con el mundo y los hombres "de hoy y aquí" por medio de un "compromiso verdadero y eficaz". Éste no se descubría en el Evangelio sino en la lucha misma, mediante las ciencias sociales y políticas, etc. Esto suponía, como lo expresaban los movimientos, que "Dios habla en los acontecimientos, en la historia humana en su totalidad" ${ }^{582}$. En este sentido, para los liberacionistas, era impensable la tesis de la "Iglesia de sacristía" que cuidaba solamente el culto o entendía la evangelización volcada hacia "la eternidad". En palabras de Dom Helder Camara:

¿Cómo limitarnos a la sacristía cuando debemos ser presencia de Cristo en medio de los hombres, nuestros hermanos? ¿Cómo cuidar sólo del culto cuando el primer mandamiento de amar a Dios necesita ser complementado por el segundo, igual al primero, de amar al prójimo? ¿Cómo hacer evangelización queriendo que el pueblo sufra con paciencia en esta vida, aguardando la recompensa del cielo, cuando esto sería transformar la religión en opio del pueblo, como afirma de ella el marxismo? ${ }^{583}$.

Desde esta perspectiva, entonces, "el hombre no puede optar entre el culto y el compromiso. El culto solamente tiene sentido cuando va inserto dentro del compromiso del hombre con el hombre" 584 .

De esta manera, en cuanto la revisión de vida proponía un nuevo modo de vivir la fe que establecía un necesario "puente" con la realidad", los actores encontraron en estos grupos un impulso para la acción. Desde la óptica de los protagonistas, el compromiso cristiano "salía" 585 de los intercambios y lecturas colectivas, esto es, era abrazado desde la reflexión comunitaria. Este hacer debía trascender los muros de la iglesia para proyectarse en la sociedad y la política. Al mismo tiempo, ya no bastaba

\footnotetext{
582 "Notas sobre fe y compromiso", JEC Boletín Secundario, 9, abril de 1969.

583 "Iglesia que yo quiero. Dom Helder Camara", Spes, 22-23, enero de 1974.

584 "Culto y compromiso. Ficha bíblica 8", Spes, 26, septiembre de 1975.

${ }^{585}$ Entrevista a Alicia, Bahía Blanca, 9/7/2011.
} 
con ayudar; era necesario dar un paso más. La caridad cristiana debía ser dejada atrás para asumir cambios de fondo. Al respecto, decía Norma: "la JEC te llevaba cada vez más, obviamente por decisión propia, a tomar un compromiso, cada vez más

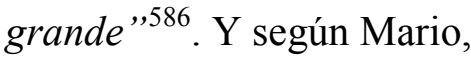

Había mucho machacar el que habia que estar, que habia que dar fruto, que habia que germinar...que había que hacer algo, viste. La inacción no era bien vista [...] se hablaba mucho de la explotación del carisma...los talentos. Todo apuntaba a la acción, qué tenemos que hacer, y qué hay que hacer ${ }^{587}$.

Para los jóvenes trabajadores, la JOC también se constituyó en un estímulo para acercarse a los sindicatos. Si el trabajo era una actividad dignificante, la defensa de los derechos laborales se volvía una exigencia. Había que involucrarse en los reclamos de los obreros y empleados, unirse a los compañeros de la empresa para plantear demandas al patrón. Se trataba de procurar la valoración del trabajo y el respeto por la condición del trabajador ${ }^{588}$. Pero esta actitud iba incluso más allá del espacio laboral. También aquí, había que convertirse en militantes; en palabras de los actores, "incorporarse a la sociedad",589 " "trabajar para la comunidad" permanentemente, ${ }^{, 592}$.

Como explica Levenson (2007), la JOC hacía énfasis en que la gente tenía el poder de transformar la vida. Al declarar a las masas como entes capaces de percibir la realidad, al proclamar su capacidad de ser jueces y actores, y al llevarlos junto con sus problemas concretos al seno de la Iglesia, la JOC creó una dinámica que a menudo llevó al activismo político, incluso mucho antes del advenimiento de la teología de la liberación ${ }^{593}$.

Y era precisamente la construcción social y política que llevaban adelante los militantes en los diversos ámbitos de la sociedad y de la política lo que daba sentido a estos grupos cristianos. Lejos de agotarse en sí mismas, estas comunidades se

\footnotetext{
${ }^{586}$ Entrevista a Norma, Bahía Blanca, 8/4/2011.

${ }^{587}$ Entrevista a Mario, Bahía Blanca, 5/1/2013.

${ }^{588}$ Palabras de Mirta y de Jorge respectivamente. Entrevista a Mirta y Jorge, Bahía Blanca, 14/7/2012.

${ }^{589}$ Entrevista a Angélica, Bahía Blanca, 25/4/2012.

${ }^{590}$ Entrevista a Clara, Bahía Blanca, 10/10/2012.

${ }^{591}$ Entrevista a Paloma, Bahía Blanca, 1/3/2013.

${ }^{592}$ Entrevista a Bruno, Bahía Blanca, 4/8/2012.

${ }^{593}$ Así, la JOC jugó un papel importante en la vida de la clase obrera en muchas ciudades, donde su efecto político variaba. De la rama de Buenos Aires, por ejemplo, creció la Confederación Sindical Continental Demócrata Cristiana, de tendencia centrista, la Confederación Latinoamericana de Trabajadores (CLAT) y en Brasil, los militares abolieron las JOC en 1964 porque sus miembros eran militantes sindicales (Levenson, 2007).
} 
proyectaban hacia afuera; la pertenencia a las mismas suponía, necesariamente, la acción de sus integrantes más allá de ellas. Sobre este punto se explayaba Eduardo:

la JUC como tal no ejercía ninguna presión a sus miembros en cuanto a las actitudes que debian asumir fuera de la JUC en lo que le llamábamos "el compromiso" en general, pero si entendíamos que había que tener un compromiso y que ese compromiso era el que se tenía que ver reflejado en las reuniones subsiguientes como espacio donde se compartía una actividad transformadora con otros, desde una actitud plural, pero habia que tener un compromiso. Si vos estabas boludeando ¿de qué estábamos hablando? ¿ ¿qué estabas haciendo alli? ${ }^{594}$.

Ahora bien, ¿qué rasgos asumía el compromiso cristiano tal y como lo entendían los actores? En primer lugar, se orientaba hacia la transformación de la sociedad. "Hombre Nuevo", "mundo nuevo", “liberación"595 constituían el horizonte del compromiso cristiano. El "cambio de estructuras" y, concretamente, del ambiente donde el militante se desenvolvía, aparecía como una exigencia, desde el momento en que se consideraba, con la nueva teología latinoamericana, que la salvación cristiana se daba en la lucha por la liberación que emprendía el pueblo. El sentido de esa transformación era, desde la perspectiva liberacionista, "hacer el Reino de Dios presente". Ser cristiano implicaba participar activamente de la venida del Reino en este mundo. En palabras de Ángel: "este paraíso que veíamos tan lejano -y acá era el lugar de sufrimientoempieza acá, entonces había que tener una igualdad de relación entre los hombres, había que ocuparse del resto de la gente, que son nuestros hermanos" ${ }^{, 596}$. De esta manera, los creyentes estaban llamados a ser hacedores de aquella construcción, agentes del cambio ${ }^{597}$.

Esa empresa, por otra parte, aparecía como posible e inminente. Desde la óptica de los actores, la historia conducía irremediablemente hacia un cambio radical, el "socialismo", una sociedad de iguales, sin exclusiones ni explotación. Al respecto, decían Dante y Paloma: "la revolución estaba a la vuelta de la esquina",598.

Este proyecto implicaba, al mismo tiempo, la crítica al orden vigente y el anuncio de otro mundo posible; esto es, por un lado, la denuncia valiente y explícita de

\footnotetext{
${ }^{594}$ Entrevista a Eduardo, Bahía Blanca, 20/5/2008.

595 Entrevista a Ángel, Buenos Aires, 8/10/2009; a Marisa, Neuquén, 19/3/2013; a Lucy, Neuquén, 18/3/2013; a Paloma, vía skype, 1/3/2013 y "Por qué de mi militancia en la JOC", apuntes de Paloma, enviados vía e-mail, febrero de 2013.

${ }^{596}$ Entrevista a Ángel, Buenos Aires, 8/10/2009.

${ }^{597}$ Entrevista a Eugenia, Bahía Blanca, 30/12/2012.

598 Entrevista a Dante, Bahía Blanca, 15/3/2012. Y "Por qué de mi militancia en la JOC", apuntes de Paloma, enviados vía e-mail, febrero de 2013.
} 
las injusticias y de sus causas, y, por el otro, una acción concreta y eficaz para erradicarlas $^{599}$.

Ese compromiso se traducía en lo que más tarde se consagraría como la "opción por los pobres", lo que suponía una toma de conciencia de la existencia de diversas clases sociales, del conflicto entre ellas, y la asunción de un posicionamiento frente al mismo. Al respecto, Nora decía:

la opción por la gente más sencilla de nuestro pueblo, digamos, que vivía y vive en la injusticia, en una situación que no accede a cubrir las necesidades básicas, en la falta de trabajo o en la inestabilidad laboral, en la precariedad de la vivienda, digamos, todo eso era, viste [...] desde qué lugar nos ubicábamos para mirar la sociedad y su transformación ${ }^{600}$.

Desde esta perspectiva, era prioritario ayudar y transformar la situación de las personas desvalidas/desposeídas/negadas en su dignidad, de "los que menos tienen"601. En este sentido, la categoría de "oprimido" incluía no sólo a las personas carenciadas en sus condiciones materiales de existencia sino fundamentalmente, a quien no conocía sus derechos o no sabía cómo pelear por ellos. Si bien no se descartaba la asistencia directa, era fundamental priorizar las acciones orientadas a su promoción o, en palabras de José, procurar que "se sepan defender" 602 por sí mismos.

Por otra parte, la profundización del compromiso suponía traducir las enseñanzas bíblicas a las actitudes y comportamientos ordinarios. Esto significaba asumir un estilo de vida marcado por la búsqueda de coherencia personal. En primer lugar, se hacía hincapié en la austeridad, así como en el rechazo al individualismo, a la superficialidad, a la ostentación y al consumismo. La opción por los humildes contenía la asunción de su condición, hacerse pobre como lo hizo Jesús, esto es, tener lo necesario para vivir y no lo que es posible comprar. Así, para los actores, se trataba de "no estar a la última moda", "no tentarse con los placeres mundanos",603, "andar con lo puesto "604. María del Carmen ilustraba con una anécdota personal el modo en que el mensaje de compromiso unido al del ascetismo impregnaba la vida cotidiana de los militantes:

\footnotetext{
${ }^{599}$ Entrevista a José, Bahía Blanca, 19/6/2011. "Por qué de mi militancia en la JOC", apuntes de Paloma, enviados vía e-mail, febrero de 2013.

${ }^{600}$ Entrevista a Nora, Bahía Blanca, 4/6/2008.

${ }^{601}$ Entrevista a José, Bahía Blanca, 19/6/2008.

${ }^{602}$ Entrevista a José, Bahía Blanca, 19/6/2008.

${ }^{603}$ Entrevista a Juan, 31/5/2011 y Bahía Blanca, 14/8/2012.

${ }^{604}$ Entrevista a Pedro, Buenos Aires, 15/11/2012.
} 
A mis 15 años mis padres me habian regalado el gamutón. Yo ahí ya estaba en La Pequeña Obra, estaría con las Guías y empezaría la JEC. Y me acuerdo que [...] la reflexión era "bueno, si tenemos el gamutón y está el chico de Quilmes que no tiene zapatillas, que no tiene para comer", como quieras, era una ostentación, un sacrilegio, ¿¿cómo ibas a ir con un gamutón?! Yo no iba a ir a Villa Quilmes ${ }^{605}$ con gamutón, pero no iba ni siquiera al CINE con el gamutón. El gamutón lo dejé guardado arriba del placard y se lo comieron las polillas. No lo usé $N U N C A^{606}$.

La sencillez de los militantes no sólo se manifestaba en la vestimenta sino que también condicionaba sus hábitos y los distintos momentos vitales. En este sentido, Paloma evocaba las discusiones con sus padres a la hora de preparar su casamiento. Desde su perspectiva, el modo de celebrar el sacramento debía responder, no a las pautas culturales o a la tradición familiar, sino a los principios y valores asumidos:

mi padre quería poner mozos con guantes. Y yo le decía “ino, por favor, qué vergüenza!" [...] mi madre trae un vestido de bodas español, con bolados, de esos sevillanos de organza hecho plato los volados porque estaban hechos sin costuras. A mí me daba vergüenza, así que cuando llegó mi madre casi se muere cuando vio que lo corté y lo dejé con dos volados (risas)...en una minifalda que encima cuando yo veo lo que pasa es que los volados eran así plato, así que tenía que venir ajustándolo porque se levantaba de un lado (risas), se levantaba del otro. Mi padre quería una fiesta a todo... "No, no, la fiesta será en el jardín en la casa de mi abuela, yo fiesta en salón no". La coherencia total, viste, era imposible otra cosa ${ }^{607}$.

Algunas prácticas grupales daban cuenta, a la vez que alimentaban, el "despojo de lo material". Por ejemplo, la costumbre de compartir las pertenencias durante los campamentos de "San Pío” y "Santa Juana”. Norma comentaba que se ponían en común las bolsas de dormir y "al que le tocaba le tocaba" 608 . Y Mario recordaba: "en la

\footnotetext{
${ }^{605}$ El origen de este asentamiento data de la década de 1960 (Formiga y Marenco, 2000). Según un informe de inteligencia de noviembre de 1973, la villa estaba ubicada al sudeste de la ciudad, a 15 cuadras de la plaza Rivadavia, entre las calles Berutti, Saavedra y las vías del FFCC General Roca aunque algunas viviendas avanzaban sobre la calle Neuquén sin respetar el trazado urbano-, y ocupaba una extensión aproximada de $12.700 \mathrm{~m} 2$. Su población se estimaba en unos 138 residentes, de los cuales el $64.29 \%$ eran argentinos y el $35.54 \%$ eran chilenos; el $68 \%$ estaban en edad escolar, mientras el ausentismo escolar se calculaba en $50 \%$. La única escuela del barrio era la $n^{\circ} 8$. No existían centros sanitarios o asistenciales, por lo que estas demandas eran atendidas en la sala médica de Villa Rosario. Entre las necesidades más imperiosas figuraban el servicio de aguas corrientes, el alumbrado, además de las habitacionales que eran abordadas a través de la ayuda estatal. Los pedidos de mejoras habían sido efectuados por dirigentes de la JTP. Archivo DIPBA, Mesa "Referencia", Legajo 10141, Tomo 2. Volveré a mencionar este asentamiento en el capítulo 6.

${ }^{606}$ Entrevista a María del Carmen, Bahía Blanca, 18/5/2011.

${ }^{607}$ Entrevista a Paloma, vía skype, 11/2/2013.

${ }^{608}$ Entrevista a Norma, Bahía Blanca, 8/4/2011.
} 
carpa, por ejemplo, se socializaban los cigarrillos. Había una chica que fumaba Benson y le tocaba unos Particulares -viste, esos negros feos fuertes-" 609.

Al mismo tiempo, el énfasis en la responsabilidad y el trabajo acompañaba la formación de los jóvenes en estos espacios. La exigencia, la disciplina personal, el estar "siempre listos" -según rezaba el lema Scout- atravesaban sus prácticas. Estas actitudes eran internalizadas por los actores; esto es, eran ellos, en el marco de una dinámica grupal que implicaba un compromiso con los otros, quienes se auto-imponían las obligaciones y no se permitían llegar tarde, faltar, involucrarse a medias, distraerse o, en palabras de Paloma, "aflojar",610. En este sentido, Carlos afirmaba: "no se descansaba. Y habia que participar en todas las actividades que se puedan...Era muy hermoso y exigente al mismo tiempo" 611 . Norma ilustraba este punto con una anécdota también mencionada por Cecilia y por Mario:

la otra vez lo cargábamos a Pepe cuando estuvimos con él, porque le decíamos en un campamento de dirigentes, me acuerdo en Pehuen-có, fuimos 4 días: "¡Pepe, nos hiciste tener el culo en la arena 8 horas todos los días reflexionando! ¡No nos dejabas ni ir a bañar! No, era terrible, era una cosa que ahora...Éramos chicos, teníamos 18 años y capaz que estábamos desde las 9 de la mañana hasta las 12 y media, comíamos [...] viste, el cura nos tenía reflexionando todo el día (risas). Pero nosotros éramos felices con eso, re chochos, porque era algo tan natural ${ }^{612}$.

Como consecuencia de lo anterior, los espacios de diversión y recreación quedaban relegados a un lugar marginal en la cotidianeidad de los militantes o bien se distanciaban de aquellos generalmente transitados por la juventud de la época. Juan Carlos hacía referencia a la misa de la JUC, lo que nos permite ilustrar esta cuestión: "el el sábado a la noche es para la joda, no para...ah, todos los de Bahía iban ahí a la Pequeña, yo decía 'es de secta'...el sábado a la noche, si no iba a bailar un sábado a la noche me moría, decían 'nosotros no',"613. Desde la lógica de los actores, hábitos como salir a bailar o ir al cine eran pensados como actitudes superficiales/ individualistas o bien como una suerte de lujo innecesario.

El estilo de vida cristiano también tenía que explicitarse en otros ámbitos. El militante debía ser, al mismo tiempo, buen hijo, buen hermano, buen amigo, buen esposo, buen vecino, buen compañero, buen alumno, buen Scout, etc. Los vínculos con

\footnotetext{
${ }^{609}$ Entrevista a Mario, Bahía Blanca, 5/1/2013.

${ }^{610}$ Entrevista a Paloma, vía skype, 11/2/2013.

${ }^{611}$ Entrevista a Carlos, Bahía Blanca, 4/5/2011.

${ }^{612}$ Entrevista a Norma, Bahía Blanca, 8/4/2011.

${ }^{613}$ Entrevista a Juan Carlos, Buenos Aires, 1/8/2008.
} 
los otros debían estar regidos por el respeto, la honestidad y la valorización de la persona. Eduardo lo ejemplificaba con una anécdota:

había un compañero del pensionado que se quería voltear a una piba y me decía "yo me la voy a clavar"...Le digo: "sí, lindo ejemplo el tuyo...haciendo uso de una mujer...por placer nada más, no porque la quieras”, “ ¿y qué problema hay?" decía él. "¿Y cuál es el tipo de revolucionario que vos estás proponiendo?, ¿cuál es la capacidad de entrega del revolucionario que vos proponés? ¿Es un revolucionario que va a ser capaz de utilizar a otros en beneficio propio? ¿O va a ser capaz de dignificar a otros dándole espacio y respetándolos?",614.

La búsqueda de coherencia también llevaba a cuestionar las actitudes que los militantes católicos tomaban en otras esferas de su vida privada. Al respecto, Eduardo contaba una situación planteada durante su viaje por Centroamérica como miembro del SLA:

cuando fui a México me llamó la atención, la gente más importante del movimiento le daban importancia a la droga bárbara...entonces hubo una discusión con ellos porque yo les planteaba básicamente “¿qué proceso de liberación se está alimentando cuando todo depende de la droga? "615.

Se trataba de dar forma, a partir de la propia vida, al Hombre Nuevo; de asumir sus valores éticos y morales durante la construcción misma de un orden social más justo, orden que acabaría por consagrarlo, bajo la forma de mujeres y hombres comprometidos, generosos, sencillos, al servicio de los demás, sinceros, auténticos, leales, disciplinados. Como afirma Carnovale, el Hombre Nuevo era mucho más que un portador de la ideología revolucionaria: era la encarnación de la nueva era, de nuevos valores, de nuevas sensibilidades, de una nueva moral. Y esa nueva moral se construía, se templaba y se evidenciaba en el día a día, en cada acto, en cada decisión; de ahí la necesidad de la prescripción y de la vigilancia permanente de la conducta cotidiana (2012: 84). Este ideal se constituía, de este modo, en el modelo a seguir no sólo en las organizaciones político-militares sino también al interior de las redes católicas liberacionistas. Por otra parte, las virtudes del Hombre Nuevo, encarnado -como hemos mencionado- en la figura del Che Guevara, tenían claras resonancias cristianas. Al decir de un militante del PRT-ERP entrevistado por Carnovale:

Yo digo: bueno, yo voy a luchar por un mundo mejor y el futuro está en mis hijos. Ahí estoy diciendo de alguna manera que a mí me pueden matar. Es jugarse al todo o nada, al Cristo. Te imaginás que yo vengo ideológicamente con una educación cristiana. ¿Y cuál es la imagen cristiana del combatiente? Cristo, que muere crucificado. Después tengo la otra imagen, la del Che Guevara [...]

\footnotetext{
${ }^{614}$ Entrevista a Eduardo, Bahía Blanca, 20/5/2008.

${ }^{615}$ Entrevista a Eduardo, Bahía Blanca, 20/5/2008.
} 
Es una cara que se superpone a la otra (Miguel, 12/1/2000, en Carnovale, 2005: 12).

En este sentido, Dante afirmaba que para los militantes cristianos revolucionarios el referente a seguir era el mismo Jesucristo, lo que imprimía a la formación moral recibida rasgos peculiares:

los cuadros que salen de la Iglesia son, en esas condiciones, en esa época, debieran ser, tipos incorruptibles...porque vos tomás un ejemplo muy lejano, muy difícil, digamos, pero que es Cristo, viste. Entonces nosotros tratábamos de que todo nuestro accionar estuviera inspirado en lo que hubiera hecho Cristo en determinado momento ${ }^{616}$.

En efecto, esta matriz de valores y actitudes personales aprendidas en los grupos cristianos, encontró más tarde afinidades con las que regían la vida del militante en las agrupaciones políticas. Cuando los jucistas, jocistas y jecistas se incorporaron al activismo contestatario, contaban con una formación ética y moral que aportaron al nuevo espacio, o bien que les permitió trabajar sobre una misma base con los compañeros que tenían otras trayectorias previas. En este sentido, Dante explicaba que en el PB existía una suerte de "ética de la política" en la que confluían los activistas cristianos con militantes provenientes de otras tradiciones ideológicas:

había una ética y una cosa de no utilización de los demás, en eso el Peronismo de Base era medio purista...Y de esa matriz no salís más. De la matriz cristiana $y$ de la matriz del purismo político, de cuidado, "no usar a éste", "el que esté con nosotros tiene que estar porque está convencido, no porque alguien le dio algo" [...] nosotros ahí coincidimos con eso también...con esa idea de la política como testimonio. En ese sentido, a pesar de que nosotros éramos los cristianuchis y los otros eran los peronistas, nosotros en general, los laburantes...habia una coincidencia de base, digamos [...] habia una coincidencia en la concepción cristiana de la vida. No afanar... ser solidario ${ }^{617}$.

Por su parte, Francisco destacaba los rasgos comunes del modo de ejercer la militancia presente tanto en la JEC como en la UES, ligado a la formación cristiana de los actores:

¡habia una moralina en la UES! Muy fuerte. Yo no sé también si no vendría porque los [responsables] eran también gente de parroquia, de Iglesia. Pero por ejemplo, en un encuentro de la UES...no sé dónde, afuera, qué se yo, se castigó a una pareja porque él se había cambiado de cama, se había ido a acostar con la novia, parece que hicieron ruido en medio de la noche. Y hubo toda una discusión al respecto...Que esto está en el marco de lo que hablamos antes...era un comportamiento liberal, un comportamiento individualista ${ }^{618}$.

\footnotetext{
${ }^{616}$ Entrevista a Dante, Bahía Blanca, 28/9/2011.

${ }^{617}$ Entrevista a Dante, Bahía Blanca, 15/3/2012.

${ }^{618}$ Entrevista a Francisco, Buenos Aires, 16/11/2012.
} 
Al mismo tiempo, los principios que guiaban a los jóvenes cristianos inspiraron sus cuestionamientos a determinadas prácticas de sus compañeros de militancia, marcando una particularidad de los militantes provenientes del ámbito eclesial. Dante recordaba discusiones con los activistas del PB respecto de las condiciones morales en que debía desarrollarse la revolución, discusiones que tenían raíz en las contradicciones que las acciones de los otros planteaban respecto de su formación originaria:

A veces nos pasábamos de rosca, pero éramos medio monjes [...] Yo me acuerdo que yo expulsé a un compañero -cuando quedé como responsable del PB acá- que tenía dos compañeras, viste, entonces un día lo agarré y le digo "¿cómo es? Primero que es un problema de seguridad. Un día tenés un quilombo, te denuncian por despecho. $Y$ después porque moralmente no es aceptable. O una u otra" (risas)... Vos fijate hasta dónde nos metíamos ${ }^{619}$.

En efecto, la experiencia de la revisión de la vida y de las iniciativas comunes ${ }^{620}$ daba cuenta de que el compromiso era un asunto colectivo. El mismo proceso de lectura crítica de la realidad y de toma de postura a favor de la liberación no era transitado en soledad sino junto a los compañeros y amigos. La militancia aparecía a la vez como elección personal y como fruto de una formación y de, en palabras de Juan, un “crecimiento” grupal. Así lo vivió Gustavo:

la transformación no se da en forma individual, se da en forma grupal. Si hubo posibilidades de transformación fue justamente por procesos comunitarios, no por procesos individuales. No porque yo 'ah, me di cuenta, hice esto'. No. Fue por un proceso que vivimos muchos. Es decir, el compromiso tomado como una cuestión comunitaria, como una cuestión de muchos ${ }^{621}$.

Además, el equipo de reflexión era el sostén para la acción social y política de los militantes. Los intercambios con los pares eran centrales para repensar continuamente la propia práctica y potenciarla. Los compañeros se convertían en referentes para clarificar los objetivos y fundamentos de la militancia, y buscar su "coherencia" con los valores cristianos. Esto, desde la perspectiva de Paloma, generaba una suerte de dependencia de los otros:

todos sabíamos que teníamos que cumplir un compromiso y en la medida en que nos apoyábamos en los demás podía ir funcionando ese compromiso. En ningún momento, ninguno de los militantes de los grupos sintió que el compromiso se podía hacer de manera individual. O sea esto lo hacemos todos o no lo hace ninguno ${ }^{622}$.

\footnotetext{
${ }^{619}$ Entrevista a Dante, Bahía Blanca, 28/9/2011.

${ }^{620}$ Véase el capítulo 5.

${ }^{621}$ Entrevista a Gustavo, 9/8/2012.

${ }^{622}$ Entrevista a Angélica, vía skype, 1/3/2013.
} 
Asimismo, para los creyentes, la fe que se compartía en sus comunidades, además de iluminar la reflexión, alimentaba y consolidaba sus opciones de militancia. Al decir de Paloma al evocar las homilías compartidas: "esa experiencia hacía que ese compromiso creciera, se hiciera más explícito, tuviese más sentido" ${ }^{23}$. En otras palabras, la convicción de que la relación con Dios se daba en el encuentro con los otros y la vivencia de comunidad fueron claves en la gestación de una concepción de lo colectivo como condición fundamental de la construcción social y política. La propia experiencia mostraba que la generación de proyectos alternativos requería el trabajo en común, el compartir con el otro e integrarse a un grupo ${ }^{624}$.

En este sentido, los grupos de revisión de vida también actuaron como puntapié para el compromiso social y político de los militantes cristianos a partir de las relaciones afectivas tejidas en ellos. La JUC, la JOC y la JEC, vinculados de modo más amplio a la parroquia, al centro pastoral, eran el lugar de pertenencia y de trabajo en común con los amigos y los referentes -como Kotska, "Pepe" o los dirigentes del Scoutismo- y de diversión y celebración. Para los jóvenes, estos espacios constituían su “casa”"625, un punto privilegiado de encuentro. Así, la participación en un conjunto de actividades ligadas al ámbito eclesial encontraba en los vínculos de amistad y compañerismo uno de sus impulsos centrales. Como explica Agulhon (2009) para otros referentes empíricos, más allá de los espacios y las actividades pautadas, aquí la sociabilidad era mucho más frecuentemente informal. Ana decía: "todo el grupo de chicos era muy lindo por eso te atrapaba y te gustaba ir a participar porque la pasabas bien y con buena gente "626. En aquel conglomerado de grupos y acciones ligadas a la Iglesia, a la oportunidad para estar con los amigos se sumaba la de interactuar con jóvenes del otro sexo. Así lo señalaba Francisco:

lo que más me enganchaba de todo eso eran esas dos cosas: un protagonismo entre mis pares, como cualquier chico...los campamentos que tenían una magia...los fogones...querer ser como mis referentes DENTRO de los Scouts [...] y estar en un lugar donde habia chicas ${ }^{627}$.

En ocasiones, estos estímulos se imponían al interés que despertaban las propias iniciativas. Por ejemplo, para Mario, la JEC era el menos "motivador" de los espacios

\footnotetext{
${ }^{623}$ Entrevista a Paloma, vía skype, 22/2/2013.

${ }^{624}$ Entrevista a Paloma, vía skype, 1/3/2013.

625 "A corazón abierto", por Susana Garbiero, Esapi de Oro. Publicación de la Comunidad Guía-Scout de la Pequeña Obra de Bahía Blanca, 7, octubre de 2011. Entrevista a Mónica, Buenos Aires, 30/7/2011; a Liliana, Bahía Blanca, 25/6/2008.

${ }^{626}$ Entrevista a Ana, Bahía Blanca, 17/10/2012.

${ }^{627}$ Entrevista a Francisco, Buenos Aires, 16/11/2012.
} 
eclesiales en los que se involucró y, sin embargo, eligió participar allí porque estaban sus amigos, con los que quería pasar el mayor tiempo posible ${ }^{628}$. Por su parte, Pedro evocaba un encuentro de la JEC en Mar del Plata, al que fue porque lo invitó quien había sido su dirigente Scout, convirtiéndose así en una oportunidad para compartir con él unos días:

yo entendería la mitad de las cosas, y otras sí. Yo iba con Eduardo [Ricci], viste...iba fascinado de poder (se emociona)...viste que vos vas de campamento como un chico y después el flaco que te lleva que es tu idolo, tu referente, te dice, "no, vamos solos a Mar del Plata", y yo, no me importaba ni para qué, estaba absolutamente extasiado con la relación personal ${ }^{629}$.

El afecto y la confianza mutua eran la condición y, al mismo tiempo, la consecuencia de compartir sus vidas en las reuniones semanales, donde, como hemos visto, también se abordaban problemáticas personales. En este sentido, Jorge destacaba "el compañerismo extraordinario que había”"630. Y María sintetizaba el tipo de vínculo que construyó en la JUC con sus pares: "eran mis hermanos",631.

Así, para jóvenes que transitaban los 15 a 18 años en el caso de los jecistas, o alrededor de los 20 años, en el de los trabajadores y universitarios, los grupos ligados al catolicismo liberacionista constituyeron un espacio de contención y de afirmación de la personalidad, de crecimiento y maduración, de expresión de ideas y sentimientos. La posibilidad de compartir las propias dificultades y dolores hacía que los equipos de revisión de vida tuvieran, en palabras de Paloma, un efecto "terapéutico" para los militantes. Para Clara, la experiencia jocista y, especialmente, el acompañamiento de "Pepe", le sirvió para trabajar su autoestima ${ }^{632}$. Este proceso fue común a los movimientos especializados de juventud en otros países. Por ejemplo, en Guatemala, la JOC contribuyó al desarrollo individual de las personas como responsables de sus destinos, al "auto empoderamiento moral", al fortalecimiento de una identidad de protagonistas históricos y a la afirmación de la confianza personal. Dentro de la JOC, los jóvenes se percibían a sí mismos como "sujetos" en lugar de "objetos" y fue esa perspectiva la que llevaron a las fábricas, como sindicalistas (Levenson, 2007).

En relación a lo anterior, la JUC, la JOC o la JEC representaron un ámbito de sociabilidad que excedía y ampliaba el que ofrecía la familia. Si otros jóvenes

\footnotetext{
${ }^{628}$ Entrevista a Mario, Bahía Blanca, 5/1/2013.

${ }^{629}$ Entrevista a Pedro, Buenos Aires, 15/11/2012.

${ }^{630}$ Entrevista a Mirta y Jorge, Bahía Blanca, 11/4/2012.

${ }^{631}$ Entrevista a María, Bahía Blanca, 21/2/2013.

${ }^{632}$ Entrevista a Clara, Bahía Blanca, 10/10/2012.
} 
encontraron este espacio en el deporte, en el club del barrio o en los bailes, estos militantes lo hallaron en la Iglesia. El grupo religioso, en el que se recreaba la vida social cotidiana, incluida la distracción y el ocio, era un tipo de asociación voluntaria que se ubicaba a una escala mayor que el ámbito doméstico, el grupo original de amigos o el vecindario, y comenzaba a ocupar un lugar central en las costumbres de los protagonistas (Agulhon, 2009). En muchos casos, el ingreso a la vida parroquial fue un hito que marcó un antes y un después en la adolescencia, el paso de una etapa de relativa soledad o aislamiento a otra de apertura en la que los protagonistas aprendieron a relacionarse y a confiar en sus pares ${ }^{633}$. Por ejemplo, Angélica contaba:

yo hasta los 12 años era como vivir en el campo. Estábamos allá [en Harding Green] con un teléfono en un almacén [...] las salidas eran las salidas familiares y después alguna vez que nos juntábamos para ir a bailar con unas amigas, pero ahí, al club de la villa, y no teníamos demasiada vida social [...] Así que empezar a integrar los grupos por eso para mí fue muy significativo, porque fue una manera de insertarme ${ }^{634}$.

Por otra parte, para los universitarios venidos de los pueblos y ciudades de la zona, la contención afectiva que ofrecía la JUC o el Pensionado católico también adquiría otra dimensión por la lejanía del hogar y de los círculos de socialización primaria.

Las experiencias compartidas no sólo sellaron lazos de amistad, sino también dieron origen a relaciones de noviazgo que más tarde terminarían en el matrimonio. La vivencia de una fe encarnada y comunitaria, la idea de compromiso, y las actitudes y los valores comunes marcaron la elección del compañero ${ }^{635}$. Para Paloma, la vida en pareja y la participación en la JOC estaban estrechamente ligadas: "yo lo vivía como un proyecto de pareja. Y...eso un poco consolidaba la relación de pareja, con lo cual también era muy importante ¿no? Porque luego cuando empezamos a tener hijos ya era un proyecto de familia ",636.

Otras opciones vitales también se vieron marcadas por la participación en estos espacios y el peso de los lazos afectivos que los atravesaban. La elección de una profesión u oficio estuvo influida por la idea de compromiso cristiano y la búsqueda de coherencia personal, así como por el ejemplo de los referentes y la necesidad de mantener los vínculos con los compañeros. Así, al terminar el secundario, Elsa empezó a estudiar Letras porque era una carrera disponible en la UNS, lo que implicaba no tener

\footnotetext{
${ }^{633}$ Entrevista a Liliana, Bahía Blanca, 25/6/2008; a Clara, Bahía Blanca, 10/10/2012.

${ }^{634}$ Entrevista a Angélica, Bahía Blanca, 25/4/2012.

${ }^{635}$ Entrevista a Mirta, Bahía Blanca, 18/6/2008.

${ }^{636}$ Entrevista a Paloma, vía skype, 1/3/2013.
} 
que irse de la ciudad y mantener el contacto con el grupo, en el que se sentía muy arraigada $^{637}$. Pedro, por su parte, eligió estudiar Geología después de compartir una caminata por el cauce de un río durante un campamento con su dirigente, Horacio Russin, que era estudiante de esa carrera ${ }^{638}$. Y Aída abandonó el estudio de Inglés en el Instituto Juan XXIII para empezar Trabajo Social, después de ingresar a la JUC, hacerse de nuevos amigos -muchos de los cuales estudiaban en la Escuela de Servicio Social- y abrazar la convicción de la necesidad de "cambiar el mundo",639.

De esta manera, los grupos cristianos se constituyeron en una suerte de "espacio total" para los militantes. La fe, el servicio, el compromiso, la formación, la amistad, la pareja, eran parte de una misma experiencia, se entrelazaban. De allí que Mario definiera al grupo Scout como "una pequeña comunidad donde están cubiertas todas las necesidades" ${ }^{640}$. Por otro lado, Mónica decía respecto de las motivaciones que la llevaron a integrar el movimiento Scout, la JEC y más tarde, la UES:

Era un lugar donde tenías amigos, donde la pasabas bien, donde, viste, te sentías que formabas parte de una experiencia que valía la pena también...lo sacrificial vino después, digamos, la verdad que fue muy festivo todo ese tiempo ¿no?, muy con la sensación de que "vamos, vamos", viste...era un lugar de placer, era un lugar de realización...y además donde la gente se hacía amiga, se hacia novia, se todo...donde te juntabas, tenías un asado y te cagabas de risa, donde guitarreabas y la pasabas bárbaro ${ }^{641}$.

Por su parte, Mirta planteaba en términos similares su pertenencia a la JOC:

estaban todas tus relaciones, tus amistades, todo estaba ahi, viste...no, fueron años muy intensos, muy lindos...nos casamos todos ahí, la mayoría, muchas parejas se formaron ahí...ya que vos discutían tantas cosas que bueno, te enamorabas (se ríe). Sí, yo una vez que empecé acá... a militar en la JOC y eso, ya fue todo para mí, fue todo ${ }^{642}$.

Como consecuencia de lo anterior, la participación en el movimiento eclesial ocupó un lugar central en la cotidianeidad de los jóvenes. Los militantes compartían gran parte de su tiempo. La intensidad de estos vínculos multiplicaba las oportunidades

\footnotetext{
${ }^{637}$ Entrevista a Elsa, Bahía Blanca, 9/3/2012.

${ }^{638}$ Entrevista a Pedro, Buenos Aires, 15/11/2012. Horacio nació en Bahía Blanca en 1951. Cursó la secundaria en el Colegio Nacional y luego en la Escuela de Agricultura y Ganadería, dependiente de la UNS. Comenzó a estudiar Geología en la universidad hasta que le tocó hacer el servicio militar, luego del cual abandonó la carrera para iniciar Trabajo Social en la Escuela de Servicio Social. Participó desde chico en el grupo Scout de La Pequeña Obra, donde más tarde se convirtió en dirigente. Fue militante de la JUC y de la JUP. Fue secuestrado el 2/10/1976 junto a su compañera en su domicilio del centro de Bahía Blanca, trasladado al CCD de Baterías, del que fue retirado el 22/11/1976 y continúa desaparecido.

${ }^{639}$ Entrevista a Aída, Buenos Aires, 17/5/2013.

${ }^{640}$ Entrevista a Mario, Bahía Blanca, 5/1/2013.

${ }^{641}$ Entrevista a Mónica, Buenos Aires, 30/7/2008.

${ }^{642}$ Entrevista a Mirta, Bahía Blanca, 18/6/2008.
} 
de encuentro: reuniones de reflexión, misas, campamentos, encuentros, cumpleaños, comidas, guitarreadas, etc. Al respecto, Bruno contaba de la JOC: "siempre estábamos juntos...jEra una cosa de todos los fines de semana!...Aparte de las reuniones que teníamos, nos juntábamos, no sé, a tomar mate" ${ }^{643}$. Y Aída decía de los jucistas: "sólo nos faltaba dormir juntos" ${ }^{644}$. Como explica Gabriel, este tipo de actividades recreativas completaban y consolidaban el trabajo en común: "en la reunión del scoutismo se armaba un asado para esa noche, o una comida, o unas empanadas en la casa de algún compañero, y era guitarreada y...este mundo se continuaba "645.
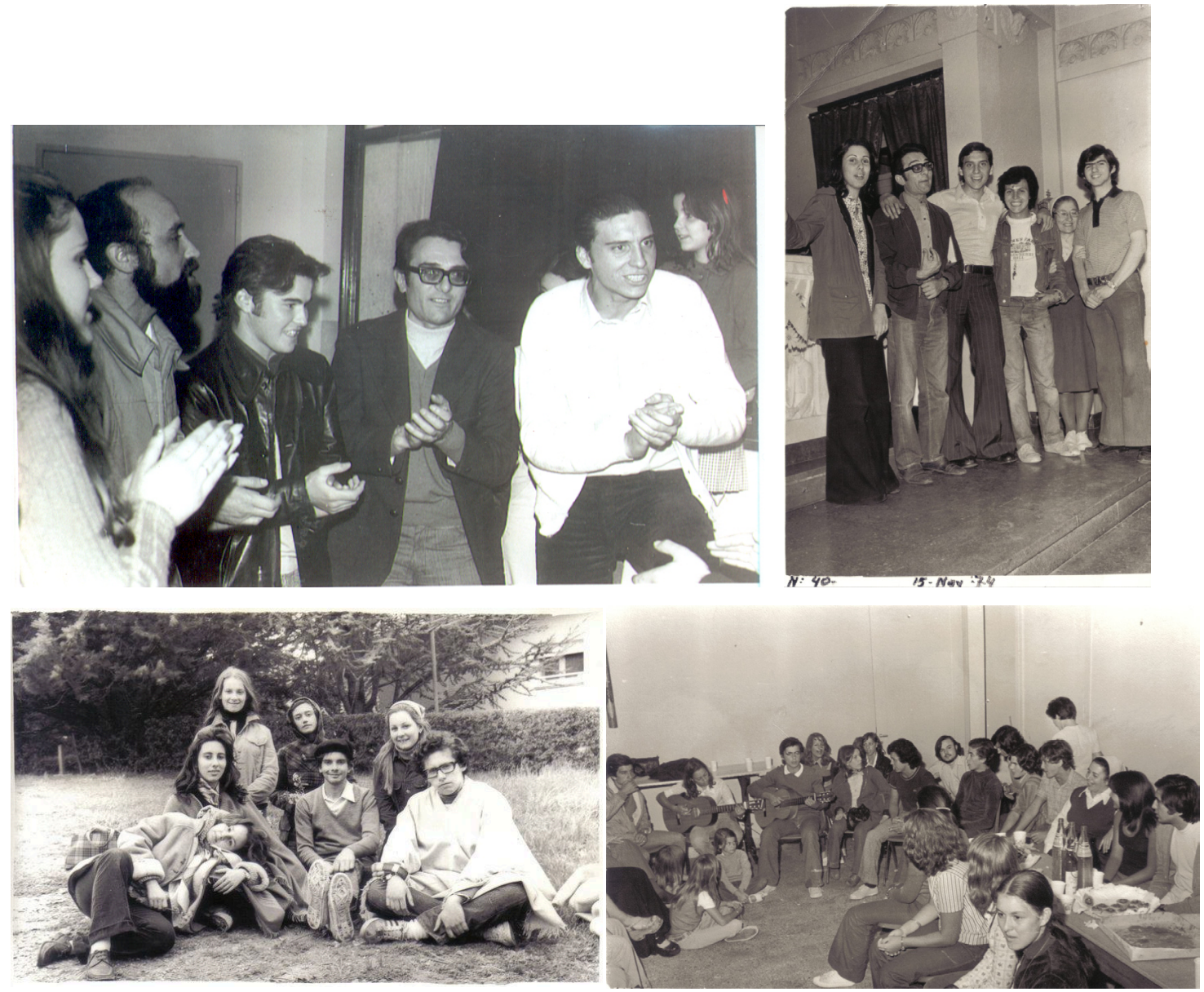

\footnotetext{
${ }^{643}$ Entrevista a Bruno, Bahía Blanca, 4/8/2012.

${ }^{644}$ Entrevista a Aída, Buenos Aires, 17/5/2013.

${ }^{645}$ Entrevista a Gabriel, Bahía Blanca, 7/11/2012.
} 

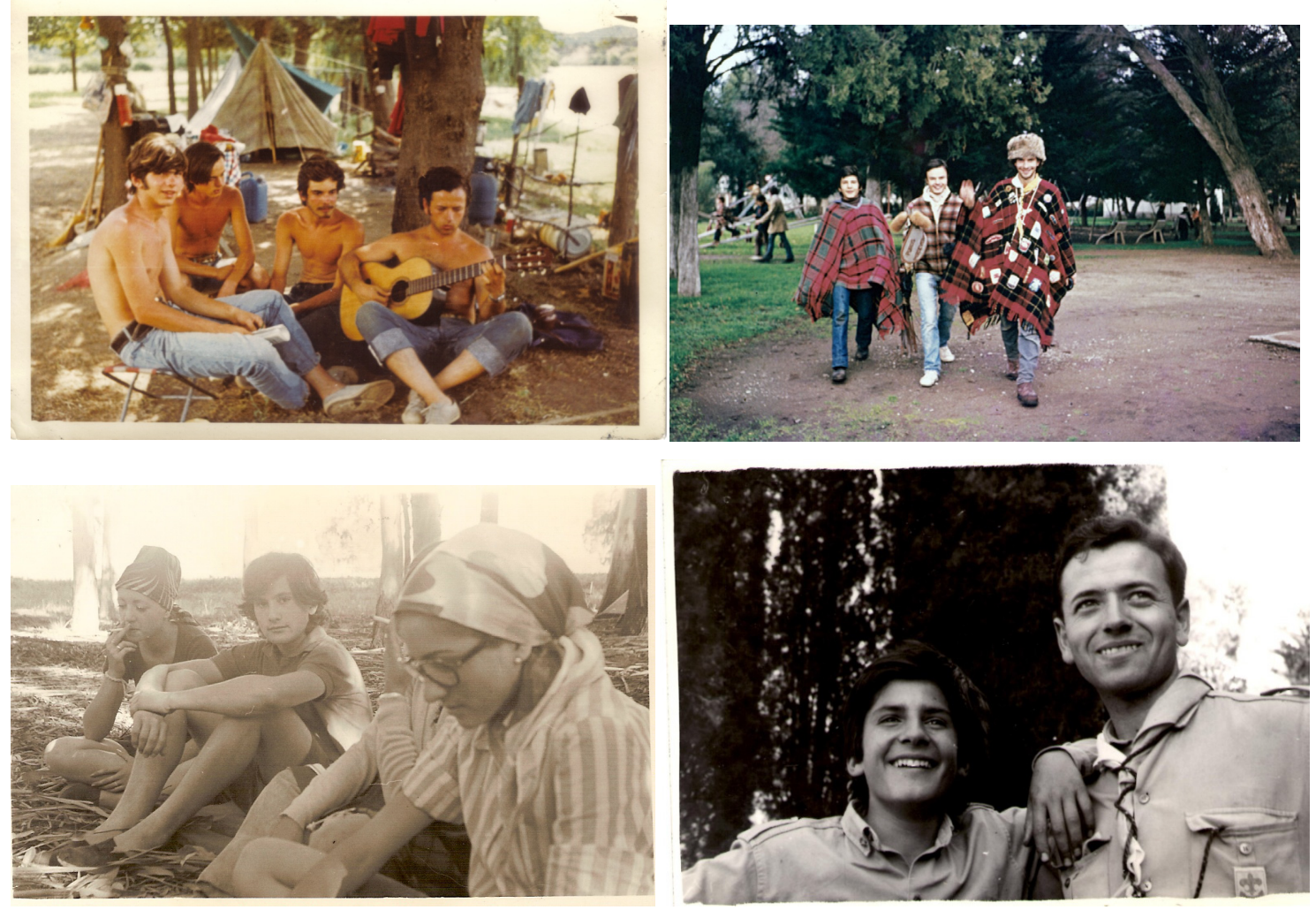

Jucistas y jecistas dirigentes Scouts y Guías de La Pequeña Obra en diversos cumpleaños, salidas grupales, comidas, guitarreadas y campamentos.
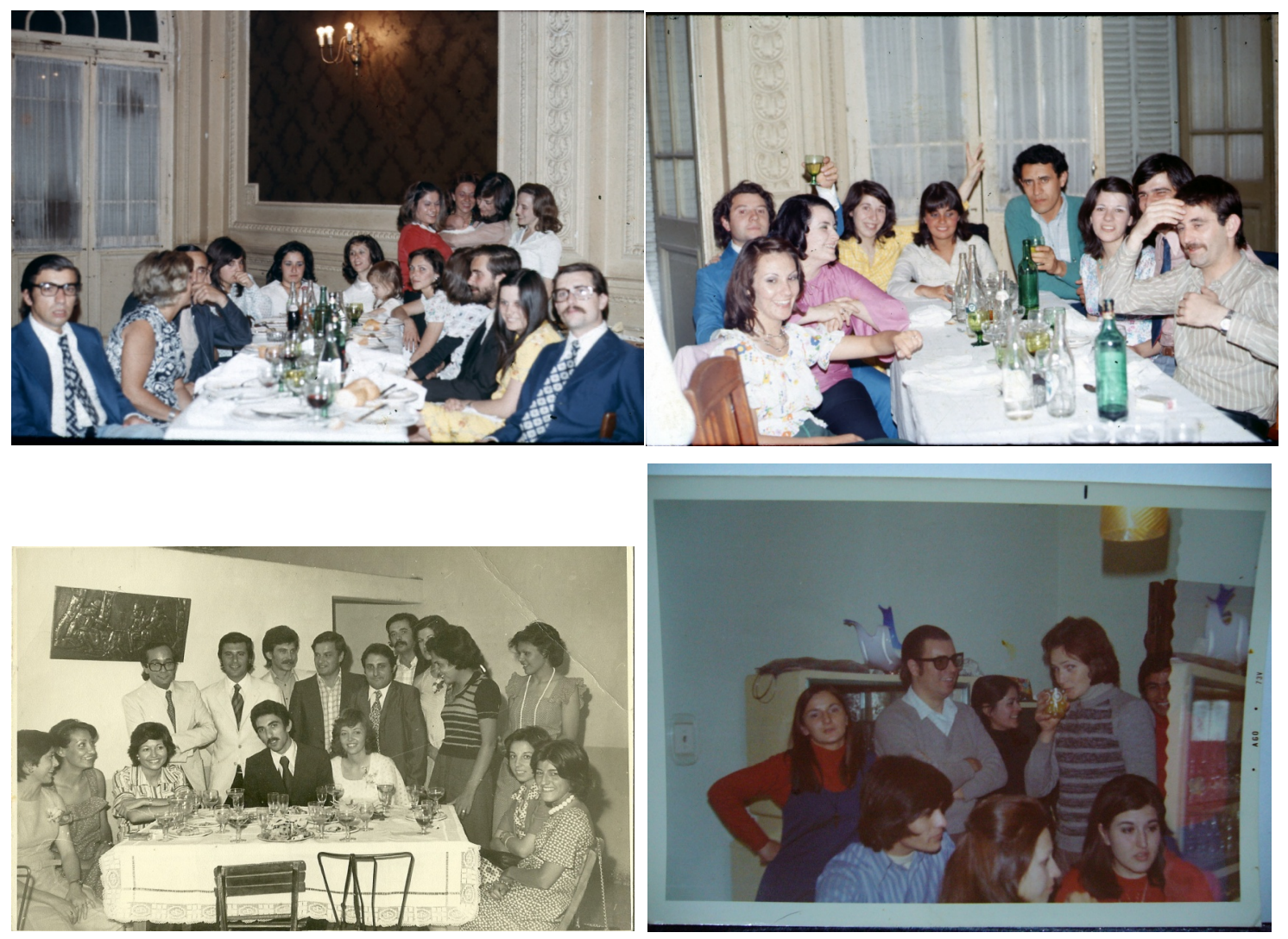
(Las primeras tres imágenes) Militantes jucistas celebrando el matrimonio de dos parejas del grupo. Arriba der.: están María Eugenia González (la primera joven de la derecha) y Néstor Junquera ${ }^{646}$ (a su lado, con corbata azul, tapado por el joven que se lleva la mano a la frente). Abajo der.: militantes de la JOC festejando el cumpleaños de una compañera.

En suma, al interior de estos círculos sociales, la dimensión emocional se constituyó en un componente fundamental de los vínculos (González Bernaldo de Quirós, 2008), en tanto éstos se alimentaban de visiones del mundo y valores compartidos, de una interacción cotidiana, regular e intensa y de actividades comunes que en sí mismas implicaban, en muchos casos, un involucramiento personal y afectivo. Al mismo tiempo, el contexto grupal actuó como estructura de contención y las relaciones interpersonales allí tejidas sirvieron como marco para la construcción y el mantenimiento de una identidad colectiva (Deaux y Martin, 2003). Así, la pertenencia al movimiento Scout, a la JUC, a la JEC y a la JOC, se erigió en un elemento constitutivo fundamental de la identidad de este conjunto de militantes. El hecho de compartir una determinada forma de vivir la fe, un estilo de vida marcado por el compromiso y la austeridad, un conjunto de ideas vinculadas a la transformación de la sociedad, diversas prácticas sociales y políticas concretas, un ámbito de reflexión sobre esa inserción en la realidad, y espacios celebratorios, sellaron relaciones afectivas profundas y duraderas. Tal como plantea Guglielmucci para las organizaciones revolucionarias: "constituía un colectivo surcado por relaciones no sólo políticas, sino también de parentesco, amistad y pareja", "la organización conformaba para sus miembros un referente político y afectivo primordial" (2006: 76-77).

En consecuencia, la afectividad fue un elemento esencial en las prácticas colectivas, dentro del espacio eclesial y más allá de éste, y en las decisiones personales de los militantes en lo referente a su participación en el grupo Scout, la conformación de la JEC, y como profundizaremos más adelante, la asunción de alguna forma de compromiso e incluso, la colaboración que brindaban quienes no tenían militancia política, a sus compañeros. Así, el paso por los diversos espacios de la Iglesia y desde éstos a la acción política fueron vividos como un proceso colectivo/grupal. Como

\footnotetext{
646 María Eugenia y Néstor fueron secuestrados el 9/11/1976, cuando tenían 22 y 25 años respectivamente. Ella era ama de casa y él trabajaba en la construcción de la Petroquímica. Militaban en la JP. Luego de la irrupción de "fuerzas de inteligencia vestidos de civil" en la casa familiar, sus dos hijos fueron llevados por los vecinos a casa de sus abuelos paternos. La pareja fue vista en el centro clandestino de detención "La Escuelita" y continúa desaparecida. Véase https://juiciobahiablanca.wordpress.com/2011/09/28/construyendo-un-mundo-mejor/, consultado el $27 / 10 / 2014$.
} 
plantea Carnovale (2012) para el caso del PRT-ERP, en el mundo de los vínculos personales, las fronteras entre el compromiso, la ideología, la moral, la afectividad se tornan lábiles, difusas, permeables. Esto da cuenta de un encadenamiento de prácticas y sentidos que contribuyó a modelar una identidad y una sensibilidad que, al igual que en el caso de los militantes perretistas, en los integrantes de la JUC, la JEC y la JOC incluso persiste hasta hoy como una impronta definitiva ${ }^{647}$.

El impulso al compromiso que los actores experimentaron en la JUC, la JOC y la JEC también se alimentaba de experiencias previas o contemporáneas, en la capilla de la "loma" o en el centro pastoral La Pequeña Obra. Por ejemplo, para José, fue en "San Jorge" donde mamó el ideal de servicio y el lema de "dejar el mundo un poco mejor de lo que lo encontramos "648. De modo similar, Juan señalaba que en este grupo comenzó a "mirar las cosas sin indiferencia" "49. También el paso por "San Pío X” y "Santa Juana" marcó especialmente a sus protagonistas, no sólo en el respeto a la naturaleza, sino también en la formación orientada a la solidaridad. En este sentido, Elsa destacaba que su etapa de dirigente significó "empezar a unir todo lo que decía la religión en cuanto al amor al prójimo, el darse, y demás, pero también la idea de que era el compromiso y el comprometerse, digamos, comprometerse con los pobres, comprometerse con un proyecto" ${ }^{\circ 50}$.

En particular, el servicio que las Guías y Scouts brindaban en Cáritas o en diversos barrios periféricos de la ciudad fueron importantes en este proceso de construir, en palabras de Norma, "sensibilidad social" un gran impacto en su vida por el conocimiento de la realidad que implicaban las visitas semanales a las familias carenciadas y las campañas solidarias que se organizaban en La Pequeña Obra, como la que tuvo lugar en ocasión de una inundación ${ }^{652}$.

De esta manera, el paso por los grupos de revisión de vida resulta, en muchos casos, inescindible de la pertenencia previa y simultánea a los Scouts, las Guías, o de modo más amplio, a la parroquia o al centro pastoral. Así, las actividades que se llevaban a cabo desde los distintos ámbitos, si bien objetivamente distinguibles, en la

\footnotetext{
${ }^{647}$ Entrevista a Ricardo, Bahía Blanca, 8/10/2011; a María del Carmen, Bahía Blanca, 18/5/2011; y a Norma, Bahía Blanca, 8/4/2011.

${ }^{648}$ Entrevista a José, Bahía Blanca, 19/6/2008.

${ }^{649}$ Entrevista a Juan, 24/8/2011.

${ }^{650}$ Entrevista a Elsa, Bahía Blanca, 9/3/2012.

${ }^{651}$ Entrevista a Norma, Bahía Blanca, 8/4/2011.

${ }^{652}$ Entrevista a Manuel y Nancy, Neuquén, 21/3/2013.
} 
práctica cotidiana eran vividas como "muy entrelazadas"653, "todo lo mismo",654, "una sola cosa" ${ }^{655}$. Preparar actividades para los Scouts, reflexionar, jugar al fútbol, guitarrear formaban parte de una sola experiencia común. Así, en el recuerdo aparecen difíciles de separar. De acuerdo al testimonio de Carlos: “aunque las dinámicas eran diferentes, las personas éramos las mismas" ${ }^{256}$. De esta manera, la formación del equipo de reflexión se sumaba a otros espacios y prácticas que, desde la vivencia personal de estos militantes, constituían una única experiencia colectiva, al tiempo que contribuía a consolidarla. Al respecto, Juan sostenía:

Nosotros éramos una familia. Como grupo ¿Por qué? Porque terminabas la escuela, íbamos a jugar. Más allá de los deberes, eso es lo que tiene el barrio como entidad multiorgánica ¿no? Porque no te escapás. Y, dentro de eso, la actividad social, central nuestra era los Boy Scouts [...] éramos como una entidad social, colectiva [...] Empezar el grupo de reflexión de la JEC fue algo también natural. No era una cosa extemporánea o una propuesta novedosa. De alguna manera, era como ir completando la formación que íbamos recibiendo o ir creciendo como grupo ${ }^{657}$.

En esta constelación de grupos y actividades, en el caso de los secundarios, la JEC se constituyó en un espacio de pertenencia valorado como central para algunos jóvenes, mientras para otros, ocupó un lugar marginal; en palabras de los actores, "un relleno", "un grupo más dentro de lo que estábamos haciendo"658. De cualquier manera, aportaba una novedad para quienes no tenían una trayectoria eclesial previa y significaba la profundización de un proceso para los dirigentes Scouts. Si el scoutismo los había formado en el servicio, la solidaridad, en el trabajo conjunto, y por ello, en el compartir, escuchar, reflexionar ${ }^{659}$, la revisión de vida venía a profundizar el trabajo de los dirigentes; al decir de Juan, a "sistematizar una visión misional de la vida" ${ }^{\text {"660 }}$. En palabras de Pedro, "era una prolongación del grupo Scout inserto en la sociedad"; "la proyección del grupo Scout en un nivel más maduro de acción "661.

Para los jucistas, los Campamentos Universitarios de Trabajo también se convirtieron en una oportunidad privilegiada para conocer la realidad -concretamente, las condiciones de vida de los trabajadores del campo-, posicionarse frente a ella y,

\footnotetext{
${ }^{653}$ Entrevista a María del Carmen, Bahía Blanca, 18/5/2011.

${ }^{654}$ Entrevista a Ricardo, Bahía Blanca, 8/10/2011.

${ }^{655}$ Entrevista a Cecilia, Bahía Blanca, 2/6/2011.

${ }^{656}$ Entrevista a Carlos, Bahía Blanca, 4/5/2011.

${ }^{657}$ Entrevista a Juan, 31/5/2011.

${ }^{658}$ Entrevista a Cecilia, Bahía Blanca, 2/6/2011.

${ }^{659}$ Entrevista a Gustavo, Bahía Blanca, 12/7/2011.

${ }^{660}$ Entrevista a Juan, 31/5/2011.

${ }^{661}$ Entrevista a Pedro, Buenos Aires, 16/11/2012.
} 
como consecuencia de aquello, lanzarse a la acción para cambiarla. En general, los jóvenes vivieron la experiencia en forma contemporánea a su participación en los equipos de reflexión, durante los veranos del período 1968-1971, teniendo como destino una variedad de zonas del interior del país -Chaco, Corrientes, Santiago del Estero, Neuquén-, ligadas a múltiples actividades rurales -cosecha del tabaco, del algodón, de la fruta, trabajo de los hacheros, etc.- . Más allá de esta diversidad, todos coincidían en destacar la relevancia de los Campamentos en su trayectoria de fe y de militancia. En este sentido, Nora planteaba su opción política en parte como consecuencia de haber compartido con los wichis de Chaco la jornada de "sol a sol" de la cosecha del algodón, la sequía o la mala calidad del agua, y un año después, el trabajo en los secaderos de fruta de Neuquén. Respecto del primer viaje, decía:

La gente hacía como pequeños pozos en la tierra y recogían el agua de lluvia pero era agua marrón porque ni siquiera era un piletón hecho con material porque no podían, no tenían para material, y tomábamos esa agua barrosa. Al principio decís "bueno, eso yo no lo tomo" pero después si querías [...] era vos, qué te pasa a vos cuando tenés que tomar eso, cuando no te podés bañar. Me acuerdo una vez que se largó un chaparrón con todo y nosotras, que el tema del pelo, jay qué alegría!, salimos para bañarnos con malla y yo me acuerdo que quedé con toda la cabeza con jabón, con champú (risas), era un chaparrón de verano, no te alcanzaba ${ }^{662}$.

Para los protagonistas, conocer de cerca, o mejor, experimentar en carne propia la vida diaria de las personas humildes, las dificultades del trabajo en condiciones de intenso calor, la explotación, la precariedad de la vivienda y la alimentación, tenía un fuerte impacto en términos religiosos y políticos. Suponía un mayor conocimiento de las realidades regionales, una nueva mirada del contexto social y económico, así como el inicio de una búsqueda de formas de acción contestataria por fuera del ámbito eclesial $^{663}$. Al respecto, Elena planteaba que los estudiantes volvían

fortalecidos en que a la gente no se la podía dejar vivir así, que había que buscar una manera de sacarlos de esa situación. Nosotros por pensar que estábamos con otra posibilidad, con comida todos los días, casa calentita, con estudio, teníamos que poder hacer algo porque eso mejore ${ }^{664}$.

En efecto, la propuesta de los CUT se volvía especialmente sensibilizadora/ movilizadora o, al decir de "Pepe", implicaba "un shock muy fuerte con la realidad

\footnotetext{
${ }^{662}$ Entrevista a Nora, Bahía Blanca, 4/6/2008.

${ }^{663}$ Entrevista a Graciela, Buenos Aires, 31/7/2008; a José Zamorano, Moreno, 19/9/2009.

${ }^{664}$ Entrevista a Elena, Bahía Blanca, 17/6/2010.
} 
marginal" "665, dada la extracción social de los participantes, esto es, jóvenes provenientes de los centros urbanos del país, de clase media, que en general no tenían trayectorias previas marcadas por la carencia material o las dificultades en el acceso a la comida, el agua potable, la vivienda, la vestimenta, la educación, la salud o el trabajo.

Además de la "dureza" del medio de inserción, la intensidad del Campamento estaba dada por el intercambio con jóvenes de todo el país, con múltiples recorridos religiosos -ligados a diversas corrientes eclesiales y a distintos credos- e itinerarios políticos. Este aspecto era destacado por Héctor, Susana y Julio, quien contaba:

fue una experiencia así...interesante ¿no?, de descubrir gente que tenía los mismos valores, los mismos objetivos de cambio, de justicia, pero que provenía, digamos, de una experiencia totalmente distinta ¿no?: laica, atea, incluso marxista. Y bueno, está todo el descubrimiento de la unión entre marxistas y cristianos. Para nosotros que veníamos de una experiencia tradicional, el marxismo era el cuco. Y ahi nos encontramos con gente como uno, que se expresaba como uno, y realmente se da una interesante unión en ese sentido ${ }^{666}$.

Asimismo, los jucistas destacaban la impronta del iniciador de los CUT, "Macuca" Llorens, a quien habían conocido en sus recorridos por el país donde visitaba a los grupos promotores. Para los actores, era un referente en la "opción por los pobres" y el compromiso cristiano ${ }^{667}$. Del sacerdote, Manuel recordaba una anécdota que lo marcó especialmente:

Él dice, cuando estaban construyendo la villa esta, o las viviendas en Mendoza...una pareja, ella quedó embarazada, se embarazaron mejor dicho y...cuando estaba por nacer, decidieron irse del trabajo ese del barrio para no criar el hijo en condiciones de intranquilidad, de zozobra, de limitaciones. Y en la reflexión que hizo la comunidad, él dice se llegó a la conclusión de que vivir en la clase media era más peligroso que vivir en el barrio, porque los valores de la clase media eran destructivos, en el barrio había riesgos pero el conjunto de valores que se vivía era mejor que el de la clase media. Y recuerdo la expresión final: “¿tengo derecho a tener mi hijo en el barrio, en la villa, en un lugar precario? a ¿tengo derecho a mi hijo entre la burguesía, los burgueses? "668.

A estas experiencias y referentes, se sumaba la impronta de las ideas e iniciativas de los Sacerdotes para el Tercer Mundo. Los actores recordaban la conferencia que Carlos Mugica ofreció en Bahía Blanca sobre el compromiso cristiano en la Argentina de entonces. En particular, Paloma evocaba que el referente nacional del MSTM

\footnotetext{
${ }^{665}$ Entrevista a José Zamorano, Moreno, 19/9/2009.

${ }^{666}$ Entrevista a Julio, Bahía Blanca, 22/5/2010.

${ }^{667}$ Entrevista a Graciela, Buenos Aires, 31/7/2008.

${ }^{668}$ Entrevista a Manuel y Nancy, Neuquén, 21/3/2013.
} 
"proponía una transformación de las personas, un encarar con compromiso el tiempo histórico que se vivía" 669 . También Manuel decía de esa charla: "recuerdo una idea fuerte, que es 'no hagamos otro mundo, hagamos de este mundo otro mundo, hagamos de este mundo un mundo otro'" 670.

A nivel local, en este proceso los jóvenes se vieron marcados, además, por la cercanía de Benito Santecchia, a través de su acompañamiento en algunos campamentos de verano de la JUC, de sus homilías y de sus conferencias. Según los protagonistas, la influencia del salesiano respondía a la combinación de su sólida formación intelectual con su capacidad para comunicar sus ideas y una personalidad que resultaba muy atractiva. En este sentido, Manuel destacaba: "era un teólogo de fuste. Además de inteligente era ágil, era DIVERTIDO, se reía con facilidad, te empujaba"671. Por su parte, María decía que con el teólogo:

nos sacamos el cuco que siempre tenía la vieja Acción Católica que era el comunismo (risas)...Y entonces empezamos a analizar los diálogos entre católicos y marxistas ¿no cierto? Y que era importante porque vos tomás categorías que no tenés ningún problema de nada ${ }^{672}$.

En el ámbito bahiense, otros espacios ligados a la renovación católica ejercieron su influjo en las trayectorias de los jóvenes. Uno de ellos fue Cáritas, lugar donde los estudiantes de la Escuela de Servicio Social -entre ellos, varios jucistas- desarrollaban sus prácticas profesionales y donde un grupo de jecistas, tanto de la "loma" como de La Pequeña Obra llevaban adelante un trabajo voluntario. Al respecto, Aída afirmaba:

En esa época Cáritas era un bastión del trabajo social...con Néstor Navarro a la cabeza...Había un equipo de abogados, había médicos, asistentes sociales, las viejas que acomodaban las ropas... pero no era Cáritas que entregabas un paquete de fideos y chau, y un saquito de lana. Era otra cosa, era atender a la gente, prestarle atención, involucrarse con su problemática y a ver adónde lo derivabas, si con los abogados, todo el mundo laburando ad honorem ${ }^{673}$.

En el caso de Aída, su trabajo en Villa Rosario desde la asociación "Comisión católica Argentina de la Campaña Mundial contra el hambre" fue significativa en su camino de compromiso. La organización, constituida a fines de 1962 en la Capital Federal, se proponía desarrollar una acción conjunta en la lucha contra el hambre, "despertando la conciencia" de los católicos e informando a la opinión pública sobre

\footnotetext{
${ }^{669}$ Entrevista a Paloma, vía skype, 7/2/2013.

${ }^{670}$ Entrevista a Manuel y Nancy, Neuquén, 21/3/2013.

${ }^{671}$ Entrevista a Manuel y Nancy, Neuquén, 20/3/2013.

${ }^{672}$ Entrevista a María, Bahía Blanca, 21/2/2013.

${ }^{673}$ Entrevista a Aída, Buenos Aires, 17/5/2013.
} 
este flagelo, así como en el logro de una "verdadera promoción humana"674. Entre las iniciativas lanzadas en el país en este sentido, figuraban el "plato del convidado ausente" -en venta desde 1965, su importe se destinaba a promociones piloto de la India, Vietnam, Biafra y Pakistán-; una colecta anual que culminaba con la "jornada mundial del sacrificio voluntario" y un oficio religioso a cargo del arzobispo; el programa nutricional y desarrollo de comunidades, con huertos escolares y familiares, y comedores escolares.

Así, desde 1965, la comisión regional local trabajaba en Villa Rosario, una de las barriadas más extensas y carenciadas de la ciudad ${ }^{675}$. Después de un período de reconocimiento y estudio del barrio a través de visitas domiciliarias y de encuentros periódicos de alfabetización, la organización estableció un centro comunitario levantado por los mismos vecinos y algunos colaboradores -incluida la JUC- a partir de 1966, con materiales donados -entre los aportes más importantes figuraba el del Ejército- o adquiridos a través de diversas actividades de financiamiento llevadas a cabo por la comisión regional. En el salón funcionaba un jardín de infantes, que al ampliar su matrícula se organizó en dos turnos; un comedor escolar, que en 1973 recibía diariamente a unas 120 personas; una "post-escuela", para lo que se nombraron dos maestras -una para la mañana y otra para la tarde-; una escuela de adultos; talleres de cerámica, carpintería, alpargatería, peluquería, corte y confección, tejido, bordado, trabajos en cuero, cocina, orquesta, danzas y títeres, dramatización; venta de ropa usada y acolchados; charlas de asistentes sociales, médicos, dentistas, etc., y desde 1973, una salita médica con un consultorio y un centro de primeros auxilios; y una huerta. El espacio se convirtió en centro de reunión de los vecinos donde se comentaban las necesidades del barrio -como la falta de luz eléctrica, de teléfono público, de canillas y

\footnotetext{
${ }^{674}$ Estatuto aprobado en Buenos Aires el 23 de agosto de 1966, Carpeta "Comisión Mundial de Lucha Contra el Hambre", Archivo Cáritas Bahía Blanca.

${ }^{675}$ Situada al suroeste de la ciudad, a orillas del arroyo Napostá y a 18 cuadras de la Plaza Rivadavia, su origen se remonta a la década de 1960 (Formiga y Marenco, 2000). Según un informe de los servicios de inteligencia locales elaborado en septiembre de 1973, la villa ocupaba una extensión de $16.400 \mathrm{~m} 2$, teniendo una longitud de $1200 \mathrm{~m}$ comprendidos entre las calles Brown y 1810, sobre terrenos del Ferrocarril General Roca. El 67 \% de sus 768 residentes eran argentinos, mientras el 33 restante eran chilenos. El $47 \%$ de la población eran niños en edad escolar, aunque el porcentaje aproximado de deserción escolar era del $30 \%$. El número restante asistía a los establecimientos educativos próximos $\left(n^{\circ}\right.$ 54, 8 y 12). En el lugar, se había establecido una Unidad Básica ligada a la JTP y dirigida por Rubén Bustos. Por otra parte, funcionaba una sala médica municipal ubicada en la calle Saavedra al 2400. En efecto, entre las necesidades más imperiosas de la villa, figuraba los sistemas sanitarios, además de la construcción de viviendas y el mejoramiento del alumbrado público. Archivo DIPBA, R. 10141, Tomo 2. Según la Regional Bahía Blanca de la "Comisión católica Argentina de la Campaña Mundial contra el hambre", uno de los problemas más acuciantes del barrio arrojado por el propio censo de febrero de 1966, era el analfabetismo. Carta al jefe Batallón 181 de Comunicaciones y al intendente municipal, del 8 de marzo de 1966. Carpeta “Comisión Mundial de Lucha Contra el Hambre”, Archivo Cáritas Bahía Blanca.
} 
de líneas de ómnibus-, y, en ocasión de las inundaciones del arroyo, en centro de evacuados $^{676}$.

Durante dos años, Aída participó de la "post-escuela", donde daba apoyo escolar a los chicos, a contra turno de la escuela. Allí enseñaba con el método de Paulo Freire, a través de palabras que describía como 'bien detonantes, como 'huelga', 'cooperativa', 'trabajo en equipo ${ }^{\prime, 677}$. A partir de las siguientes fotos ${ }^{678}$, ella evocaba esa experiencia: ahi está el arroyo donde dos por tres algún pibe se caía y venía todo mojado, lo poníamos cerca de una estufa y salía el vapor y el olor del agua estancada. Las fotos donde están las maestras con los pibes creo que son de un jardín de infantes, donde me dieron "alojamiento" para los pibes mios un tiempito. Ellas tenian leche, pan y dulce de leche, y lo compartían conmigo. Le echaban agua a la leche para "agrandarla" y para que alcanzara para todos. Habia una nena que tenía la cabeza llena de piojos, venía corriendo, me abrazaba y me decía: "cheñorita, lo chicos me enchuchan con lulcheleche". No me olvidaré nunca más de esos días. Después fuimos a una casa que una familia prestaba, y la casa era como las que aparecen en las fotos. Y los pibitos más chicos andaban con los pies en el agua, como en la foto...Dios!, qué épocas ${ }^{679}$.
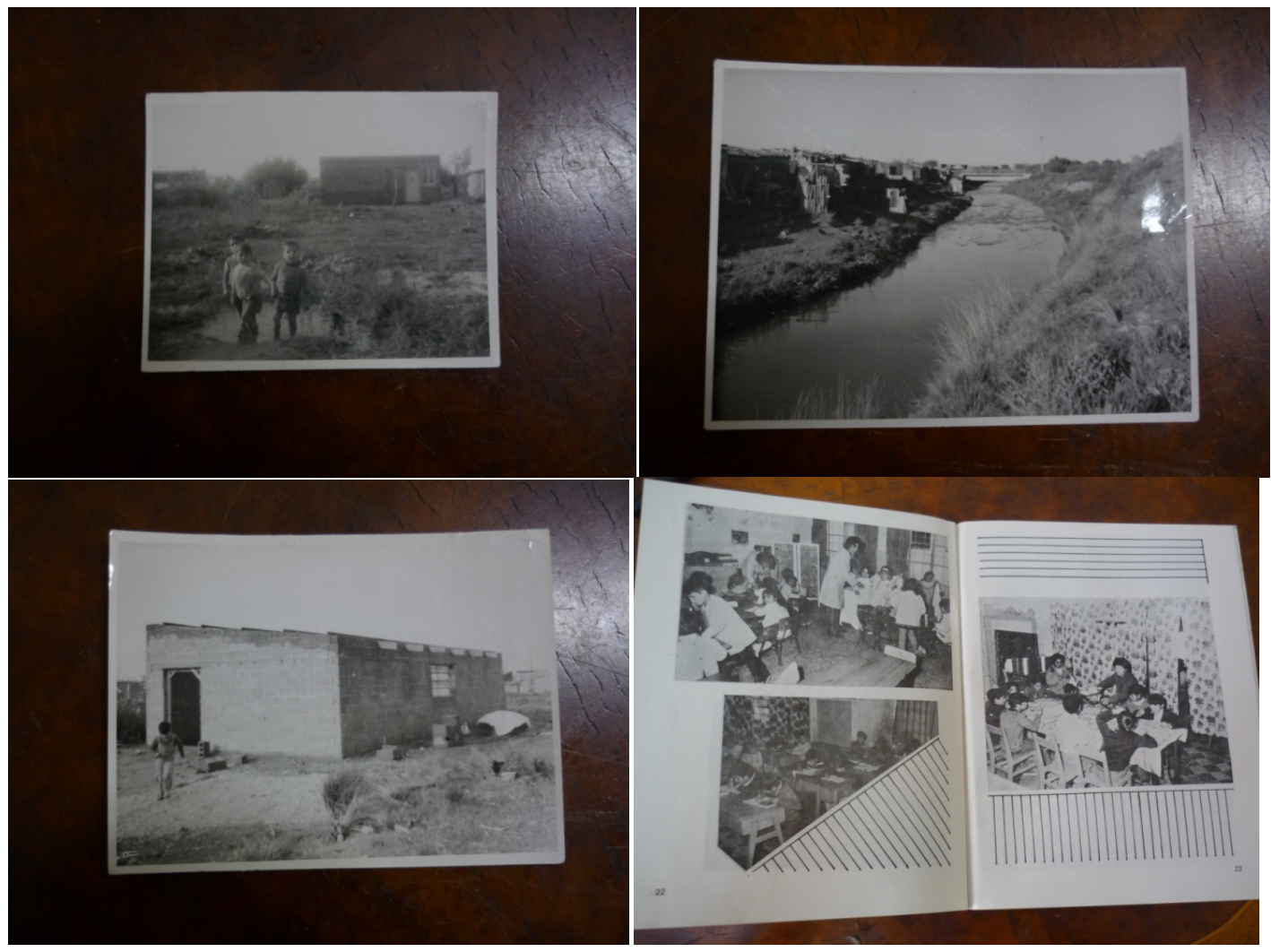

676 "Una obra piloto una magnífica lección. Villa Rosario. Bahía Blanca”, Cultura Popular, 25, marzo abril, mayo junio 1974; Carta a la dirección de promoción y desarrollo de la comunidad del 19 de febrero de 1973; Memorias de los ejercicios 1970-1972 y 1973-1974; Carta al comandante del V Cuerpo de Ejército, 23 de mayo de 1974. Carpeta “Comisión Mundial de Lucha Contra el Hambre”, Archivo Cáritas Bahía Blanca.

${ }^{677}$ Entrevista a Aída, Buenos Aires, 17/5/2013.

${ }^{678}$ Carpeta "Comisión Mundial de Lucha Contra el Hambre", Archivo Cáritas Bahía Blanca.

${ }^{679}$ Aída, comunicación vía e-mail, 5/7/2013. 
Por otro lado, una serie de experiencias previas transitadas en espacios ajenos a los eclesiales tuvieron una fuerte huella en muchos de estos jóvenes. Por ejemplo, algunos jecistas y acercados de la JUC, alumnos de las Escuelas Medias de la UNS, habían sido voluntarios en el Patronato de la Infancia ${ }^{680}$. En este marco, los fines de semana visitaban a los niños y jóvenes, les brindaban apoyo escolar, les daban de comer o les cambiaban los pañales en el caso de los más pequeños, organizaban juegos y paseos con ellos, e incluso, los llevaban a pasar el domingo a sus casas. Para María del Carmen, aquel fue un espacio donde canalizaba su "espíritu solidario" 681 . El contacto frecuente con la realidad de los chicos internados, llevó a los voluntarios a cuestionar a la comisión que administraba la institución y a enfrentarse a sus integrantes, lo que ocasionó tensiones que obligaron a algunos jóvenes a abandonar la actividad.

En particular, las experiencias que tuvieron lugar en el seno familiar ocuparon un lugar fundamental. Como afirma Levenson (2007), diversos estudios han sugerido que las comunidades preexistentes, como la parentela, son el combustible de las movilizaciones de clase y la conciencia política. Ése fue el caso en la ciudad de Guatemala, donde la vida en los barrios y la familia dieron a los futuros sindicalistas valores y experiencias en la solidaridad. En relación a los bahienses, la fe, las inquietudes/el compromiso social o la actitud crítica de sus padres y abuelos, y el ejercicio de discusión política en la mesa, fueron preparando el camino para su propio acercamiento a la sociedad y a la política. En este sentido, Nora decía: "no nací de un repollo tampoco ¿no? (sonrie), digamos, esta sensibilidad por lo social y eso la recibí de mi papá" ${ }^{682}$, quien había participado de las luchas de los maquinistas en el gremio "La Fraternidad" y de la organización de su pueblo, entonces un pequeño paraje a la vera de las vías del tren, ubicado al sureste de la provincia de Buenos Aires. Por su parte, Marta traía el ejemplo de su abuelo y su infancia en la quinta -localizada en un pueblo del sudoeste de la provincia de Buenos Aires-, donde vivían con los peones y sus familias, compartiendo la mesa y las tareas por igual:

Mi abuelo decía -era extremista mi abuelo- "si tenés dos tapados en el ropero, Chita, uno no te pertenece, es del que va caminando por la calle desnudo". Esa era su manera y la vivía, porque mi abuelo tenía un par de zapatos para ir a

${ }^{680}$ Entrevistas a Beatriz, Bahía Blanca, 23/4/2009; a Julia, Buenos Aires, 17/9/2009; a Diana, Buenos Aires, 18/9/2009; a María del Carmen, Bahía Blanca, 18/5/2011; a Cecilia, Bahía Blanca, 2/6/2011.

${ }^{681}$ Entrevista a María del Carmen, Bahía Blanca, 18/5/2011.

${ }^{682}$ Entrevista a Nora, Bahía Blanca, 4/6/2008. 
misa y unos así grandotes para todos los días, un traje para ir a misa o grandes ocasiones y pilchas tal cual los obreros...si había que quedarse extra se quedaba él...revisando el frigorífico que en ese entonces era peligroso porque era amoníaco, él hacía la mortadela calentita y se las llevaba para el mate de la mitad de mañana ${ }^{683}$.

De forma similar, Eduardo afirmaba que en su hogar le brindaron una "base de vida" ligada a una concepción comunitaria y horizontal, de debate, independencia, protagonismo, y valoración del trabajo con otros para un objetivo común. En particular, resaltaba: "mi papá tuvo una idea de servicio muy clara en toda su vida, fue un tipo que estuvo toda su vida al servicio de todas las instituciones del pueblo" ${ }^{684}$. Asimismo, para Manuel fue clave la figura paterna -español, médico, ateo militante, anarquista hasta que terminada la guerra civil renunció a esa pertenencia luego de haber presenciado matanzas entre comunistas y anarquistas-, en cuanto le enseñó a pensar y le mostró que "hay que respetar a la naturaleza, hay que respetar a la gente, hay que respetar a todo el mundo" 685 .

A partir de lo analizado, podemos decir que, en gran medida, estos jóvenes descubrieron la acción social y política desde la JUC, la JEC y la JOC, o de modo más amplio, desde las redes del catolicismo liberacionista, y que las prácticas que asumieron como consecuencia encontraron impulso y justificación en una determinada visión de la fe, encarnada/comprometida con la realidad. En otras palabras, los jucistas, jocistas y jecistas fueron recorriendo un camino que marcó un trayecto militante que desde el compromiso cristiano los habría de llevar a asumir diversas formas de intervención en una serie de espacios sociales y políticos. Más allá de los antecedentes familiares o escolares, el comienzo de dicho recorrido se encuentra precisamente en esta instancia de "descubrimiento" y "reflexión" de la vida personal desde una perspectiva del cristianismo, que representaron los movimientos especializados de juventud. Esta instancia estaba en diálogo y marcaba una continuidad con otras experiencias ligadas al catolicismo liberacionista en la ciudad y en el país -como Cáritas, el movimiento GuíaScout, los CUT o el MSTM-.

En este sentido, Gustavo, al resaltar el influjo que tuvo Medellín en la convicción de la transformación social, afirmaba:

El que viene de una formación marxista histórica lo saca de Marx, el que estudió sociología, tiene elementos en las ciencias sociales donde puede llegar a

\footnotetext{
${ }^{683}$ Entrevista a Marta, Bahía Blanca, 29/5/2008.

${ }^{684}$ Entrevista a Eduardo, Bahía Blanca, 20/5/2008.

${ }^{685}$ Entrevista a Manuel y Nancy, Neuquén, 20/3/2013.
} 
la misma conclusión. O, el trabajador, que sufre una situación de injusticia, o persona que sufre, que por su misma experiencia dice "bueno, esta estructura no me responde", y llega por su práctica a dirigente sindical, llega por su historia. Nosotros, que venimos de los grupos cristianos, ¿de dónde entendimos de que había que cambiar la estructura? ¡De ahi! No hay otro lugar ${ }^{686}$.

También Pablo hacía referencia a su propio trayecto militante iniciado en la JUC a partir de la idea del compromiso y la influencia de los documentos eclesiales, aunque reconocía el peso de otros factores contextuales:

mi apertura mental política empieza ahí...aparte yo empiezo en la universidad, a partir de las manifestaciones del Cordobazo, a participar en alguna medida, empiezo a ir a asambleas, reuniones. Pero realmente creo que ahí...me permitió, incluso desde el punto de vista cristiano, del compromiso...los documentos de la Iglesia, Camilo Torres...Entonces ahí va por ese lado ¿no? Yo no sé si hubiera militado, si no hubiera hecho mi paso por la JUC...la verdad no sé, capaz que sí, viste, pero...yo empiezo a participar a partir de ahí y a participar más activamente a partir de mi paso por la JUC. Capaz que hubiera llegado a lo mismo por otro lado, pero no sé, hasta tengo mis dudas ${ }^{687}$.

Como sintetizaba Mónica, los jucistas, jocistas y jecistas se sumaron a la "ola" de la acción social y política contestataria “entrando por ese costado" "688, mientras sus compañeros de militancia lo hicieron a partir de trayectorias religiosas, ideológicas y políticas divergentes. Asimismo, estos jóvenes eran "hijos de su tiempo", por lo que compartían las características de su generación. De allí, que la renovación eclesial y su catolicismo integral no sean suficientes para explicar su pensamiento y práctica antisistémica. Ellos mismos se reconocían formando parte de un colectivo mucho más amplio y diverso de jóvenes que optaban por un proyecto social alternativo, a partir del rechazo a la dictadura de Onganía-Levingston-Lanusse y sus arbitrariedades -siendo la "Masacre de Trelew" ${ }^{689}$ uno de los acontecimientos de mayor impacto-; del clima de movilización que generó su oposición -cristalizada en el Cordobazo-, las manifestaciones callejeras, las asambleas y las tomas de la UNS; del modelo de la Revolución Cubana y los movimientos de liberación del Tercer Mundo; el ejemplo de

\footnotetext{
${ }^{686}$ Entrevista a Gustavo, 9/8/2012.

${ }^{687}$ Entrevista a Pablo, Neuquén, 19/3/2013.

${ }^{688}$ Entrevista a Mónica, Buenos Aires, 30/7/2008.

${ }^{689}$ En la madrugada del 22 de agosto de 1972 en la Base Aeronaval "Almirante Zar" de Trelew, fueron asesinados 16 presos políticos y militantes de Montoneros, FAR y PRT-ERP que siete días antes habían protagonizado el copamiento e intento de fuga del penal de Rawson. Las víctimas fueron Rubén Pedro Bonet, Jorge Ulla, Humberto Suárez, José Mena, Humberto Toschi, Miguel Angel Polti, Mario Delfino, Alberto Del Rey, Eduardo Campello, Clarisa Lea Place, Ana María Villarreal de Santucho, Carlos Astudillo, Alfredo Kohon, María Angélica Sabelli, Mariano Pujadas y Susana Lesgart. Al mismo tiempo, fueron heridos de gravedad Alberto Camps, María Antonia Berger y Ricardo René Haidar. Sobre las repercusiones de la "Masacre de Trelew" en Bahía Blanca véase Dominella, 2014b.
} 
los "mártires" latinoamericanos "Che" Guevara o Camilo Torres; la referencia a Evita y Perón en nuestro país; la lectura y discusión de los textos de Marx, Harnecker, Hernández Arregui, Cooke, Galeano, Fanon o las teorías de la dependencia; la identificación con prácticas culturales que alimentaban el clima de época, como la música de Viglietti o la canción española que rezaba: "que la tortilla se vuelva, que los pobres coman pan y los ricos mierda mierda",690.

${ }^{690}$ Entrevista a Mirta, Bahía Blanca, 18/6/2008. 


\section{CAPÍTULO 5: La denuncia profética}

\section{SUMARIO}

1) Los sectores liberacionistas se defienden

2) La oposición a la dictadura de Onganía

3) Iniciativas frente a los atropellos policiales

4) El repudio a la Masacre de Trelew

5) Acciones de Navidad

6) La lucha contra el Camino de Cintura

En el capítulo anterior, hemos analizado la "pedagogía” de la revisión de vida y su significación en el nacimiento de una nueva vivencia religiosa estrechamente unida a la toma de conciencia de los problemas de su tiempo y a una acción, asumida en consecuencia, que pretendía ser transformadora del orden vigente. Por otra parte, tanto los consagrados como los laicos profundizaron el discernimiento crítico de los sucesos sociales de acuerdo a los principios cristianos a través del discurso profético. Como vimos en el primer capítulo, en Medellín, los obispos latinoamericanos habían planteado que le correspondía a la Iglesia denunciar con firmeza las realidades que constituían una afrenta al espíritu del Evangelio. Por su parte, el MSTM planteó en el terreno político el modelo del profeta como crítico de la sociedad (Martín, 2010). Según el movimiento, de cara al proceso de liberación, la Iglesia debía denunciar las injusticias y juzgar los programas políticos o económicos a la luz de la Palabra de Dios ${ }^{691}$. Al mismo tiempo, el MSTM entendía que había que pasar de la denuncia a los hechos de significación política.

Antes de analizar las formas y los espacios en los que los militantes católicos bahienses buscaron anunciar el Reino de Dios a través de su compromiso individual en diversos espacios, nos interesa explorar la dimensión profética de su acción colectiva. Para eso, ampliaremos la mirada para abarcar las iniciativas de la JUC, la JOC y la JEC en el marco de aquellas emprendidas conjuntamente por los movimientos y referentes del catolicismo liberacionista en la ciudad. ¿Qué acontecimientos motivaron la intervención crítica de la las ramas especializadas de Acción Católica, así como la de otros grupos y representantes locales de la renovación eclesial?, ¿qué situaciones se

\footnotetext{
${ }^{691}$ Nuestra Reflexión, 11/10/1970.
} 
propusieron denunciar?, ¿qué estrategias construyeron para ello?, ¿a quiénes se enfrentaron en ese proceso?, ¿cómo articularon esos cuestionamientos con el Ver, Juzgar y Actuar?

\section{1) Los sectores liberacionistas se defienden}

En el período que nos ocupa, estos grupos hicieron oír su voz frente a los cuestionamientos que por entonces sufrían los sectores renovadores del catolicismo local. Así, como mencionamos en el capítulo 3, en octubre de 1970, a pedido de Monseñor Esorto, los sacerdotes Segovia, Santecchia, Zamorano, Navarro y Baudry elaboraron el documento definitivo que, firmado por el arzobispo y el clero de Bahía Blanca y Punta Alta, se publicó en repudio de la interrupción de la homilía de Duilio Biancucci en la Catedral.

Por otra parte, días antes del conflicto en la Catedral habían sido cuestionadas las homilías de Miguel Sarmiento y Hugo Segovia, lo que provocó la reacción de la comunidad perteneciente a la parroquia María Auxiliadora. Tal como vimos anteriormente, los fieles puntaltenses difundieron un volante apoyando a los sacerdotes $\operatorname{agraviados}^{692}$.

En esos meses, una serie de declaraciones públicas de los sectores bahienses identificados con el catolicismo liberacionista también enfrentaron los ataques vertidos a dicha corriente eclesial por el diario local. En diciembre de 1970, LNP dedicó nueve artículos a impugnar al MSTM ${ }^{693}$, acusándolo de destruir impunemente con sus simplismos "nuestra Patria y nuestra fe"; de presentar concepciones del cristianismo que no eran coherentes con la doctrina de la Iglesia o que iban directamente contra ella como cuando afirmaban la necesidad de erradicar la propiedad privada de los medios de producción-, y al no aceptar la doctrina; de estar "poniendo los prolegómenos de un movimiento centrífugo de consecuencias imprevisibles"; de restar importancia al elemento institucional de la Iglesia y a su jerarquía; de tender al "horizontalismo" y propender a una desacralización casi total que atentaba contra el núcleo mismo de la

\footnotetext{
${ }^{692}$ Declaración (volante) de la comunidad de la parroquia María Auxiliadora de Punta Alta, de octubre de 1970, Archivo DIPPBA, Mesa "Referencia”, Legajo No 15281, Tomo V..

693 El objetivo de los artículos -publicados entre el 9 y el 15 de diciembre de 1970- era refutar las concepciones vertidas por el MSTM en el documento Nuestra reflexión, enviado a los obispos en respuesta a la declaración de la Comisión Permanente del Episcopado, de agosto de 1970, referida al movimiento. Según Verbitsky (2009), uno de los firmantes de esa declaración, que cuestionaba fuertemente al MSTM, fue Monseñor Germiniano Esorto.
} 
religión; de estar atados al "carro del marxismo" y servir con sus declaraciones sólo al "segundo mundo marxista"; de no hablar en nombre de Dios ni de la Iglesia, pareciendo más bien profetas de Marx o el Che; de propiciar la violencia, en la medida que "la estructura marxista domina las mentes de estos extraños sacerdotes"; de olvidar la misión específica de la Iglesia que era de orden religioso y no político, económico o social, con el peligro de que "se acabe por creer que el fin de la Iglesia sea edificar el paraíso en esta tierra"; de alentar expectativas vanas en los desvalidos, con su prédica a favor de la liberación en este mundo; de proponer liberaciones esclavizadoras como el socialismo, callando al mismo tiempo, otras liberaciones del pecado como la estructura laicista que "excluye a Cristo de las escuelas", o "la injusta estructura jurídica que inhibe al gobierno para intervenir más radicalmente en favor de la moralidad en los espectáculos públicos"; de incubar el resentimiento e incitar a la rebelión a los pobres, en lugar de evangelizarlos; de deleitarse en las supuestas o reales injusticias de la historia de la Iglesia como si no se sintieran hijos de ella.

En efecto, en su construcción discursiva, $L N P$ fue ubicando a lo que llamaba "tercermundismo" en el lugar del enemigo, y como tal, de un "otro peligroso". Las mismas fuerzas de seguridad reconocieron en 1976 la importancia fundamental del matutino en tanto único medio real de difusión y acérrimo enemigo del tercermundismo del marxismo y del peronismo ${ }^{694}$ (Zapata, 2008). Como plantea Lull, "el discurso político de un medio de comunicación parece inseparable de la construcción de la imagen del antagonista político, sea éste asumido como enemigo o adversario. En efecto, al desplegar su estrategia destinada a producir, reproducir e imponer a la sociedad las representaciones de la realidad que conforman su propio universo político, dicho medio compone la imagen de un oponente a quien dota de todos los rasgos negativos" (Llull, 2005: 119) ${ }^{695}$. En una concepción como la sostenida por la dirección

\footnotetext{
${ }^{694}$ Así, más allá de estos sectores eclesiales, la empresa se constituyó en hito simbólico de todo lo ideológicamente repudiable para la militancia revolucionaria de la ciudad. En este sentido, los actores evocaban que dentro del itinerario de las manifestaciones callejeras bahienses de los años sesenta y setenta, el paso por la puerta de la sede del multimedios dirigido por los Massot, constituía una parada obligada. Entonces, los sectores movilizados dedicaban unos minutos a arrojar piedras, verduras, frutas, etc., al edificio, al tiempo que le propinaban insultos a los referentes del diario (Entrevista a Norma Gorriarán, Bahía Blanca, 29/10/2008; a Rodolfo, Bahía Blanca, 23/6/2008; a Juan Carlos, Buenos Aires, 1/8/2008). En ese sentido, Luis decía: "siempre cuando había que putear y romper algo era las cosas de LNP porque era el enemigo, digamos, el representante ideológico del enemigo de turno" (Entrevista a Luis, Bahía Blanca, 18/12/2008).

${ }^{695}$ A diferencia de la autora, aquí sostenemos una concepción más amplia de lo político que excede lo partidario. Consideramos político el discurso de la prensa en tanto se constituye en un actor clave que interviene en las disputas por la distribución del poder en la sociedad, de las que los conflictos eclesiales reseñados son un ejemplo.
} 
del diario bahiense, en la que el catolicismo era el fundamento de la Patria y de la argentinidad, el "tercermundismo" no sólo representaba al enemigo de la Iglesia, de la doctrina y de la religión católica sino, de modo indisociable, al enemigo de la Nación. Aún más, en su discurso anti-tercermundista, el matutino intentó constituirse en una suerte de "tribuna doctrinaria"696, formulando una narración con ambiciones normativas. En otras palabras, en sus ataques a los referentes locales del catolicismo liberacionista, $L N P$ asumió una autoridad "religiosa". Al marcar lo que ellos "debían" y "no debían" hacer o ser, se arrogaron una función que excedía la propia como medio de comunicación.

A pesar de la injerencia de $L N P$ en incumbencias de las autoridades eclesiásticas, la empresa se hizo menos merecedora de las quejas que del reconocimiento del episcopado argentino, el cual, le otorgó el premio San Gabriel por su "testimonio cristiano y su defensa de la ortodoxia" $" 697$. En este sentido, Benito Santecchia reflexionaba en 1975 sobre el impacto de las notas que LNP dedicó al catolicismo renovador:

la opinión pública indefensa absorbía esta división "entre buenos y malos" ("buenos y malos obispos; buenos y malos sacerdotes; buenos y malos católicos") y digería como palabra de la Iglesia las más disparatadas versiones. En tanto, los responsables [eclesiales] guardaban silencio (no pocas veces aparecieron apoyando). De hecho el magisterio profético de la Iglesia había sido arrebatado por la prensa local, que aparecía como el paladín de la ortodoxia, especialmente por sus páginas marianas ${ }^{698}$.

De modo similar actuaron los integrantes de la Marina que interrumpieron las homilías de Biancucci y Barreto. En general, y como se puso de manifiesto unos años después de modo dramático, las Fuerzas Armadas avanzaron sobre el enfrentamiento interno del catolicismo, llevando a cabo lo que consideraban una "purificación" de los sectores renovadores -a los que identificaban como "marxistas" y "subversivos"-. Esa intervención, desde su punto de vista, se hallaba justificada por la omisión de la propia conducción eclesiástica (Ameigeiras, 2014). Como explica Zanatta (2008: 85):

$\mathrm{Si}$, en efecto el deber profesional del ejército era el de defender la nación, cuya unidad e identidad definía en términos confesionales, entonces la defensa de la nación católica se transformaba por las FFAA en cuestión vital

\footnotetext{
${ }^{696}$ Expresión de Sidicaro (1993), citado en Llull, 2005: 25-26.

697 “Carta abierta a la Señora Ernestina Herrera de Noble, directora del diario Clarín”, Pablo, 3, agosto de 1973.

698 Santecchia, Benito, Notas sobre una "Publicación” aparecida en Bahía Blanca (1972-1973), 15 de junio de 1975, f1. (Citado en Vanzini, 2008: 62).
} 
de seguridad nacional. Esto tuvo también como consecuencias que los militares tendieran a erigirse en teólogos de la nacionalidad.

Así, el personal de inteligencia y los torturadores de los centros clandestinos de detención se consideraban a sí mismos como "vigiladores" de una supuesta "pureza doctrinal católica" o "restauradores del orden natural participando de una guerra santa". Desde la perspectiva de los grupos de tareas, la "infiltración" de la "subversión" dentro del catolicismo, que venía así a profanar lo más sagrado de la Nación, o bien la "debilidad" de las autoridades eclesiásticas que no resolvían el problema, los obligaba a auto-atribuirse la misión de defensa de la "verdadera" fe (Morello, 2011: 5-7). Para Dri (2011: 166), en la ayuda del brazo secular para librar a la Iglesia del "marxismo" -obra del "demonio" que amenazaba con desnaturalizarla- es posible hallar una de las claves para comprender la relación entre la jerarquía y el poder militar.

Volviendo a las nueve notas de la $L N P$, en respuesta, la JUC, la JOC, la Comunidad Universitaria Bahiense y el Grupo Misionero Bahiense elaboraron conjuntamente una declaración que, según los servicios de inteligencia, se distribuyó a la finalización de la misa en la Catedral, en el Instituto Superior del Profesorado Juan XXIII y en la UNS. El volante, titulado "Medios de comunicación social en Bahía Blanca. ¿Qué persigue La Nueva Provincia?”, denunciaba la actitud de la empresa como opuesta al papel que, acorde a la declaración de Medellín, debían cumplir los medios de comunicación. Así, el primer apartado, “qué dice nuestra realidad?”, estaba dedicado a describir los recursos utilizados por el multimedios local para oponerse "sistemáticamente a toda manifestación en pro de la justicia social", al movimiento obrero y estudiantil, a la Iglesia y últimamente de modo particular, al MSTM. Allí se afirmaba que las estrategias del diario, que no excluían aquellas "inmorales", comprendían, entre otros: la cita de frases fuera de contexto, la tergiversación de textos, la selección "tendenciosa" de la información y el uso "inteligente" de los espacios de su publicación para destacar y hacer pasar desapercibidas determinadas noticias. En la segunda parte “¿qué dice la Iglesia?”-, se lo confrontaba con lo que planteaba el documento del episcopado latinoamericano sobre la función de los medios -estar al servicio de "la liberación del hombre"-, y la vinculación de ciertas empresas con los grupos económicos y políticos “interesados en mantener el statu quo social”. Según los movimientos laicales, $L N P$ actuaba “en pro de intereses materialistas y de minorías". De allí que los jóvenes se sintieran en la obligación de denunciar esta situación y de ofrecer 
como elemento de juicio el último documento del MSTM atacado por el diario local. Y lo hacían identificándose como miembros de una "Iglesia peregrina", "en comunión con nuestros obispos y todo el Pueblo de Dios", al que no podían permitir que se intentara dividir "deshonestamente creando confusión y sembrando odios"699, con el cuestionamiento a un sector eclesial, que estaba, justamente, comprometido con la búsqueda de la justicia. Podría afirmarse, siguiendo a Gutiérrez (1971), que para estos colectivos identificados con el catolicismo liberacionista, la unidad de la Iglesia en un mundo enfrentado por la lucha de clases pasaba por atacar las causas de la división entre los hombres, esto es, por la opción por los "oprimidos".

Por su parte, Cristianismo y Revolución dio a conocer una carta de un grupo de laicos bahienses dirigida a Diana Julio de Massot, en la que planteaba una serie de cuestionamientos en relación a los nueve artículos, en gran parte coincidentes con la declaración anterior. En la carta se denunciaba el doble discurso del matutino que decía asumir la conciliación mientras atacaba a un sector eclesial, buscando así "dividir a la Iglesia misma, y frenar el compromiso que ella ha asumido en esta hora límite para América Latina". Asimismo, se decía que LNP pretendía estar exenta de sensacionalismo al tiempo que recurría a la calumnia y parcializaba la información. Además, se afirmaba que la empresa declaraba su obediencia y respeto al magisterio de la Iglesia pero infravaloraba los pronunciamientos en la que la misma se expresaba (Concilio Vaticano II, Conclusiones de Medellín y Declaración de San Miguel). Y finalmente, ventilaba los problemas de la institución "con la soberbia propia de quien ha dejado de buscar la verdad porque ya se considera en posesión absoluta de ella"700.

Además de las iniciativas mencionadas y más allá de esta coyuntura en particular, diversas homilías de los sacerdotes identificados con el catolicismo liberacionista estuvieron dedicadas a responder a los ataques del diario. Al respecto, José Zamorano recordaba: "una vez fuimos con LNP a la misa y empezamos a hablar contra LNP, para responderle (risas)...Un poco ingenuos pero bueno" ${ }^{\text {,701 }}$. Mónica, por su parte, evocaba su primera misa en el centro pastoral La Pequeña Obra, celebraba por Emilio Flores: "no me voy a olvidar jamás Emilio entró a la capilla con un diario de LNP abajo del brazo...debe haber sido año '70 calculo yo - y yo tenía, sí, 13 años-, y se

\footnotetext{
${ }^{699}$ Declaración (volante) de la JUC, la JOC, la Comunidad Universitaria Bahiense y el Grupo Misionero Bahiense, titulada "Medios de comunicación social en Bahía Blanca. ¿Qué persigue La Nueva Provincia?", sin fecha (hacia diciembre de 1970). Archivo DIPPBA, Mesa "Referencia", Legajo No 15281, Tomo V.

700 "Nuestro dolor y nuestra protesta", Cristianismo y Revolución, 28, abril 1971.

701 Entrevista a José Zamorano, Moreno, 19/9/2009.
} 
dedicó a contestar en la homilía una editorial de LNP" ${ }^{\text {702 }}$. Por otra parte, Cecilia y Norma ${ }^{703}$ mencionaban las predicaciones de "Pepe" en aquel centro pastoral y las reacciones que causaban en algunos integrantes de la comunidad ligados a las Fuerzas Armadas:

terminaba la homilía y se armaba un lio bárbaro porque habia dos grupos, había un grupo que estaban muy caliente porque él hablaba, claro, comentaba, por ejemplo, lo que salía en La Nueva Provincia. Y, entonces los militares -había muchos marinos militares- furiosos contra Pepe, discutían. Y después estaban los universitarios, que estaban totalmente de acuerdo con lo que decía Pepe ${ }^{704}$.

Por otra parte, en 1973, la revista Pablo dedicaba varias notas a criticar a $L N P$ con similares argumentos a los utilizados por los grupos laicales liberacionistas en los años anteriores. En primer lugar, se planteaba que el matutino era factor de división, tanto de la sociedad bahiense como de la Iglesia: "comprometida con la Marina y sus intereses, profundiza cada vez más el foso de separación con el pueblo"; y en cuanto a la Iglesia, mientras marginó "alguna valiente declaración” de Monseñor Esorto, "manosea y juega con el actual arzobispo". Asimismo, se decía que la empresa "se erigió en justa calificadora de obispos, sacerdotes y movimientos”. En relación a esta cuestión, se destacaba el compromiso de $L N P$ y la Marina con los Cursillos de Cristiandad, ligados a las "fuerzas de poder" y pretendidos depositarios de la "verdad absoluta". En consecuencia, para la publicación, no era de extrañar "el adoctrinamiento diario" recibido a través del periódico, así como los ataques lanzados desde sus páginas “con absoluta falta de caridad a algún sacerdote que osa interpretar el Evangelio con criterio distinto a esta Junta Consultora", resultando ilustrativos los "duros" artículos contra el MSTM ${ }^{705}$.

Un conflicto en el Juan XXIII que tuvo lugar en esos meses también puede resultar ilustrativo del posicionamiento de los sectores estudiantiles y católicos renovadores frente al medio periodístico hegemónico de la ciudad. A mediados de 1973, un grupo de estudiantes de la JUP decidió sustituir el nombre del aula magna del Instituto, llamándola "Mariano Pujadas" - una de las víctimas de la Masacre de Trelew-. Desde el $1^{\circ}$ de agosto de 1970, llevaba el nombre de "La Nueva Provincia", en

\footnotetext{
702 Entrevista a Mónica, Buenos Aires, 30/7/2008.

${ }^{703}$ Entrevista a Norma, Bahía Blanca, 6/8/2011.

${ }^{704}$ Entrevista a Cecilia, Bahía Blanca, 2/6/2011.

705 Pablo, 3, agosto de 1973. Archivo DIPBA, Mesa "Referencia", Legajo No 15281, Tomo VIII. "Sacerdotes Tercer Mundo".
} 
reconocimiento al apoyo prestado por la empresa en la campaña de recaudación de fondos para la concreción del nuevo edificio.

La imposición de dicho nombre había sido cuestionada en aquel momento por los alumnos, quienes organizaron una manifestación y repartieron volantes rechazando la iniciativa de los directivos. Según los servicios de inteligencia, las motivaciones del grupo estudiantil estaban íntimamente ligadas con la acción de sacerdotes ubicados en la línea del MSTM y, en particular, eran inspiradas por uno de ellos, quien en aquel momento era profesor del Instituto salesiano y mantenía una estrecha relación con sectores de la JUC y de distintas tendencias, "algunas izquierdistas" de la UNS ${ }^{706}$. La manifestación habría "pretendido poner en evidencia el repudio de este grupo hacia el diario 'La Nueva Provincia', que en diversas notas de fondo y editoriales ha fustigado severamente la actividad y gestión de los sacerdotes tercermundistas" ${ }^{, 707}$.

Casi tres años después ${ }^{708}$, una asamblea de alumnos del Instituto Juan XXIII, en la que participaron también obreros provenientes de los barrios de la ciudad, decidió rebautizar el aula magna, "dándole a este hecho un carácter de desagravio en virtud del nombre que poseía". Para los estudiantes, $L N P$ era el "fiel vocero de los intereses oligárquicos y reaccionarios", "el representante de los sectores dominantes contrarios al proceso de Reconstrucción Nacional que ha iniciado nuestro pueblo". Asimismo, consideraban a la empresa "distanciada sustancialmente del significado cristiano de los medios de comunicación" ${ }^{, 709}$. Según lo expresaron algunos oradores, resultaba "deshonroso" que el aula magna llevara el nombre del diario por considerarlo “ignominioso y anticristiano" $" 710$. En consecuencia, en medio de cánticos que, según el mismo matutino en cuestión, constituían un "ataque personal" contra el diario y su dirección, los estudiantes colocaron en el acceso a la sala una placa de madera con la inscripción "Mariano Pujadas". Para LNP, con estos hechos, “el extremismo" daba "una

\footnotetext{
${ }^{706} \mathrm{Si}$ bien el nombre del sacerdote se encuentra tachado en el material facilitado por la Comisión Provincial por la Memoria, conforme al reglamento del Archivo, la información incluida en el informe de inteligencia permite deducir que se trataba de Benito Santecchia. El salesiano parecía inquietar en gran medida a los servicios de inteligencia que informaron detalladamente sobre sus iniciativas, como por ejemplo, sus cuatro conferencias sobre "Capitalismo y Socialismo", dictadas en octubre y noviembre de 1969. Archivo DIPBA, Mesa A, Estudiantil, Localidad Bahía Blanca, Legajo No 47.

${ }^{707}$ Archivo DIPBA, Mesa A, Estudiantil, Localidad Bahía Blanca, Legajo $\mathrm{N}^{\circ} 47$.

${ }^{708}$ Recordemos que en 1973 Benito Santecchia suplió al primer rector del Instituto Juan XXIII, el Padre Osvaldo Francella. Durante el período en que actuó como rector interino, se intentó aplicar un proyecto educativo fiel a las líneas de renovación de la Iglesia, con un espíritu crítico y una mirada comprometida frente a la realidad de los más pobres (Vanzini, 2008).

${ }^{709}$ Solicitada firmada por la Juventud Universitaria Peronista, sector Juan XXIII, El Eco, 17/7/1973.

710 “Juan XXIII: simbólico cambio de nombre el aula magna”, LNP, 11/7/1973.
} 
nueva muestra de su entronización en el ámbito universitario", de la mano de "un grupo de estudiantes que proclamó a viva voz su identificación con la violencia"711.

Sin embargo, la iniciativa de la JUP en el Instituto salesiano no prosperó. En una asamblea general del alumnado celebrada pocos días después se rechazó la nueva designación y se decidió la sustitución del nombre "La Nueva Provincia" por el de "Argentina" 712 .

\section{2) La oposición a la dictadura de Onganía}

Una de las primeras iniciativas públicas de la JUC consistió en una volanteada contra el uso del NAPALM por parte de las fuerzas estadounidenses en la guerra de Vietnam. Tanto "Pepe" como Ángel lo recordaban entre risas por lo alejado del reclamo respecto de la realidad propia, y el segundo lo atribuía a la influencia de la izquierda, por definición "internacionalizada", en los militantes jucistas ${ }^{713}$. Sin embargo, las actividades que impulsaron los sectores católicos identificados con el Concilio Vaticano II y la Conferencia de Medellín en los años siguientes estuvieron enraizadas en problemáticas y contextos más cercanos.

En el período comprendido entre 1967 y 1972, los sacerdotes "tercermundistas", la JUC, la JOC y otros grupos laicales se movilizaron conjuntamente en coyunturas específicas, para manifestar su oposición a la autodenominada "Revolución Argentina". Por ejemplo, en 1969, los padres Zamorano, Flores, Santecchia y Sarmiento, junto a otros ciudadanos bahienses, elaboraron una solicitada -que fue publicada en La Nueva Provincia- contra las medidas arbitrarias del gobierno de Juan Carlos Onganía y reclamaron por la libertad de los presos políticos que continuaban detenidos sin haber sido interrogados ni sometidos a proceso o acusación alguna ${ }^{714}$.

Pocos días después, los católicos renovadores bahienses manifestaron su rechazo a la decisión del presidente de facto de consagrar el país a la Virgen María. Como mencionamos en el capítulo 3, los sacerdotes, la JUC y la JOC bahienses difundieron la

\footnotetext{
711 "Juan XXIII: simbólico cambio de nombre el aula magna”, LNP, 11/7/1973.

712 Archivo DIPBA, Mesa A, Estudiantil, Localidad Bahía Blanca, Legajo N 47. Según Vanzini, dicha asamblea habría sido convocada por el rectorado del Instituto al enterarse de la medida de la JUP, lo que sugiere que la forma en que $L N P$ difundió los hechos no contempló lo realizado por los salesianos en su exacta veracidad (Vanzini, 2008: 61).

${ }^{713}$ Entrevistas a José Zamorano, Moreno, 19/9/2009 y a Ángel, Buenos Aires, 8/10/2009.

714 “Solicitada. La situación de los presos políticos”, LNP, 29/11/1969.
} 
declaración elaborada por el MSTM a la salida de las misas. Esta actividad fue registrada por los servicios de inteligencia locales ${ }^{715}$, e interrumpida por la policía.

Por su parte, los jóvenes de la JUC habían tomado postura frente al gobierno militar mediante otra declaración. El texto comenzaba rezando uno de los pasajes del Antiguo Testamento más recurrentes en la lectura bíblica realizada en clave liberacionista: "Y ahora, al oír el gemido de mis hijos, sometidos a cadenas, he decidido liberarlos en virtud de mi alianza" (Éxodo 5, 5). A continuación, realizaban una serie de críticas a la "Revolución Argentina". En primer lugar, la detención de centenares de ciudadanos bajo el pretexto de "conservar el orden", incluidos varios estudiantes de Bahía Blanca, confirmaba las palabras de la Conferencia Episcopal de Medellín, a saber: los sectores dominantes "califican de acción subversiva todo intento de cambiar el sistema social que favorece la permanencia de sus privilegios" y "recurren al uso de

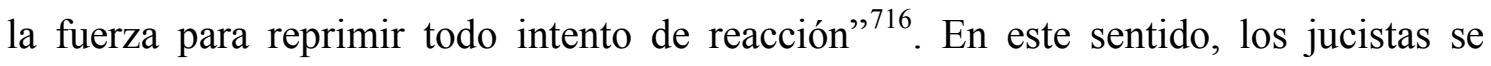
preguntaban qué derecho tenía el poder ejecutivo a disponer de personas sin justificación, por el sólo "delito" de ejercer la libertad de pensamiento. Por otro lado, el cierre de fábricas, talleres e ingenios, la suba de precios de los artículos de primera necesidad y los salarios congelados con aumentos no adecuados al costo de la vida daban cuenta del tipo de "orden" que se deseaba imponer y demostraban que los objetivos del gobierno, lejos de orientarse a la realización de la persona, como postulaba Jesús, apuntaban a determinados intereses económicos. Por último, los jóvenes se definían como cristianos que no querían convertirse en cómplices de la injusticia y que compartían una "opción clara y decidida a favor de los cambios audaces, profundos y urgentes" a los que comprometía el Evangelio. En ello se sentían urgidos por la misma Palabra de Dios, y en particular, por las "Bienaventuranzas" -texto también muy utilizado por los cristianos liberacionistas para expresar su posicionamiento como discípulos de Jesús-: "Felices los que tienen hambre y sed de justicia porque serán saciados"; "Felices los que son perseguidos por practicar la justicia, porque de ellos es EL REINO DE LOS CIELOS” (Mateo 5, 6-10). De allí que se vieran obligados a

\footnotetext{
${ }^{715}$ Archivo DIPBA, Mesa "Referencia", Legajo No 15281, Tomo I.

716 "Paz", en: Segunda Conferencia General del Episcopado Latinoamericano, Medellín, septiembre de 1968, Documentos finales. Citado en Declaración (volante) de la JUC Bahía Blanca, sobre la "Revolución Argentina", sin fecha. Archivo DIPBA, Mesa A, Estudiantil, Juventud Universitaria Católica, Localidad Bahía Blanca, Legajo No 111.
} 
denunciar las arbitrariedades que suponía el estado de sitio vigente, así como las consecuencias del "tiempo económico"717.

\section{3) Iniciativas frente a los atropellos policiales}

En el marco de la oposición a la dictadura, los grupos liberacionistas también emprendieron una serie de iniciativas públicas contra los abusos policiales y el autoritarismo del régimen militar que se manifestaban en la ciudad y la región, y tenían entre sus víctimas a los militantes católicos. Como describimos en el capítulo 3, en agosto de 1971, fue allanada la casa parroquial de Sánchez Elía y llamado a declarar "Pepe" Zamorano, debiendo dar cuenta de sus actividades pastorales. Esos hechos provocaron la reacción de la comunidad de Nuestra Señora del Carmen, de la JUC, del clero local y de Monseñor Esorto, quienes expresaron públicamente su pleno apoyo al Padre Zamorano de diversas maneras: la primera, a través de una conferencia de prensa; los jóvenes universitarios, mediante una declaración leída en esa oportunidad, en la que repudiaban los atropellos sufridos por su asesor en el marco de aquellos perpetrados por la policía tanto en la ciudad como en el resto del país; el arzobispo, mediante un comunicado en el que expresaba su protesta frente a ese tipo de situaciones que obstaculizaban el "normal desenvolvimiento de las tareas pastorales", y el gesto de presidir la misa concelebrada por más de una docena de presbíteros en la iglesia de la "loma"718.

Por otra parte, la JUC, la JOC, el GMB, la CUB y la JAC de Punta Alta elaboraron una denuncia -firmada en julio y dada a conocer por Cristianismo $y$ Revolución en septiembre de 1971- por el secuestro de un militante cristiano en Punta Alta y su sometimiento, mediante torturas, a un interrogatorio referido a las actividades de los grupos de Iglesia. En la declaración, ubicaban tal arbitrariedad dentro de la escalada represiva del gobierno y la asociaban con "la campaña de persecución y difamación contra algunos sacerdotes". Desde su perspectiva, estos hechos no hacían más que confirmar, nuevamente, la advertencia de los obispos reunidos en Medellín

\footnotetext{
${ }^{717}$ Declaración (volante) de la JUC Bahía Blanca, sobre la "Revolución Argentina", sin fecha. Archivo DIPBA, Mesa A, Estudiantil, Juventud Universitaria Católica, Localidad Bahía Blanca, Legajo No 111. Luego del golpe de Estado de 1966, el gobierno anunció que la "Revolución Argentina" tendría "tres tiempos", a saber: uno en el que el énfasis recaería sobre lo "económico" y el "ordenamiento"; otro posterior, en el que el tema principal sería lo "social" y apuntaría a la justicia redistributiva; y otro final, en el que el énfasis recaería sobre lo "político" (O' Donnell, 1982).

718 "Dio un comunicado el arzobispo de Bahía Blanca", LNP, 18/8/1971. "Conferencia de prensa Villa Sánchez Elía”, $L N P, 16 / 8 / 1971$.
} 
acerca de la tendencia de los sectores más favorecidos a considerar "subversiva" toda iniciativa orientada a transformar el orden vigente. Como cristianos, los firmantes expresaban su repudio contra estos atropellos porque en ellos se negaba la dignidad humana y las exigencias evangélicas, exigencias que, como señalaban los obispos argentinos en San Miguel y el mismo Pablo VI, urgían a los cristianos a defender los derechos de los pobres y marginados, a cooperar con su opinión y acción en la eliminación de toda forma de opresión, y a participar en la transformación justa y necesaria de la sociedad. En consecuencia, exhortaban a todos los creyentes y hombres de buena voluntad a tomar conciencia de la gravedad de los hechos y a solidarizarse en la búsqueda de una sociedad nueva ${ }^{719}$.

\section{4) El repudio a la Masacre de Trelew}

Entre las manifestaciones de la violencia represiva de la dictadura que concitaron la organización y la protesta tanto de los sacerdotes "tercermundistas" como de los laicos identificados con esta línea eclesial, se ubican los hechos conocidos como la "Masacre de Trelew". Sin embargo, ésta fue más que un episodio emblemático del autoritarismo del régimen de Onganía-Levingston-Lanusse; se constituyó en el anticipo del terrorismo estatal, poniendo de manifiesto que los crímenes de Estado comenzaron mucho antes del 24 de marzo de $1976^{720}$. Una cierta naturaleza del crimen se expresaba ya en las contradicciones de las versiones militares: "la palabra oficial sobre los hechos enuncia (y se enuncia desde) una ambigua zona en donde convive lo oculto y lo inocultable, lo que se sabe y lo que se silencia o censura, lo reprobable y lo que se reivindica" (Pittaluga, 2006: 83). El escenario de la masacre, lejos de ser una región apartada, era una instalación del Estado, donde era de público conocimiento que allí estaban alojados los 19 militantes. Además, el gobierno militar no negó su existencia, aunque no habló claramente. Así, se trataba de instalar la masacre en una región de penumbras, ambivalente, a medias visible e invisible, dejando que lo no dicho actuara a su manera. Lo que se decía oficialmente mostraba el ocultamiento, para señalar que ese crimen estaba situado más allá de lo que podía decirse. Se buscaba exponer ante la

\footnotetext{
719 "Militante cristiano secuestrado y torturado en Punta Alta", Cristianismo y Revolución, 30, septiembre de 1971.

${ }^{720}$ El 15 de octubre de 2012, el Tribunal Oral Federal de Comodoro Rivadavia condenó a prisión perpetua a Luis Sosa, Emilio Del Real y Carlos Marandino por los delitos perpetrados en Trelew en agosto de 1972, y declaró a estos últimos como crímenes de lesa humanidad. "La masacre tuvo su día de justicia 40 años después", Página 12, 16/10/2012.
} 
sociedad ese sitio y ese poder más allá de la ley. De esta manera, el crimen de Trelew prefiguraba la doble dimensión del exterminio planificado tal como se produjo en Argentina: por un lado, la superposición de las funciones públicas formalmente admitidas para ciertos espacios y sus destinos cuasi-secretos en la producción y gestión del exterminio; por otro, la imposibilidad de nombrar lo que se sabe que sucede, o decirlo de modo distorsionado. Así, el acontecimiento planteaba el armado incipiente de una nueva disposición en relación a las formas de represión de la disidencia política y de disciplinamiento social (Pittaluga, 2006).

Si bien los fusilamientos de Trelew sacudieron a todo el país, Bahía Blanca y Punta Alta se vieron movilizadas en forma particular por la cercanía de los sobrevivientes durante los días siguientes. Alberto Camps y Ricardo Haidar fueron trasladados a Puerto Belgrano en un avión naval durante la tarde ${ }^{721}$ del 22 de agosto, e internados en el hospital naval, mientras la llegada de María Antonia Berger se produjo al día siguiente ${ }^{722}$. Al mismo tiempo, comenzaron a arribar no sólo los padres, hermanos y compañeros de los heridos sino también de los asesinados, como fue el caso de Alicia Leichuk $^{723}$.

Asimismo, se iniciaron las gestiones de los abogados defensores de presos políticos destinadas a preservar la integridad física de los militantes hospitalizados, obtener información sobre su situación y quebrar la incomunicación en la que se encontraban, de modo que pudieran visitarlos tanto los letrados como los familiares ${ }^{724}$. Finalmente, estos últimos pudieron entrevistarse con los jóvenes. Luego de aquella visita, la hermana y la esposa de Haidar, y el padre de Camps hicieron pública una

\footnotetext{
${ }^{721}$ Telegrama del comisario Trujillo, Mesa "D(s)", Carpeta Varios, Legajo 383, Tomo 1. FONDO DIPPBA División Central de Documentación, Registro y Archivo. "Dos heridos fueron trasladados a la Base Pto. Belgrano", LNP, 23/8/1972.

722 "Informe sobre extremistas heridos internados hospital Base Naval Puerto Belgrano" del 25/8/1972, Mesa "D(s)", Carpeta Varios, Legajo 383, Tomo 1. FONDO DIPPBA División Central de Documentación, Registro y Archivo. "Los sobrevivientes están internados en la Base de Puerto Belgrano", LNP, 24/8/1972.

723 "Pasó por Bahía Blanca en viaje a Trelew un grupo de abogados", LNP, 23/8/1972. Alicia Leichuk viajó a esta ciudad porque los primeros rumores inclúán a su esposo entre los heridos. Fue en el camino entre el aeropuerto y Puerto Belgrano donde escuchó la noticia que confirmaba a Rubén Bonet entre las víctimas. Entrevista a Alicia Leichuk, Radio Futura, 16/5/2011. Disponible en: http://radiofuturalaplata.blogspot.com.br/2011/05/nuevo-impulso-para-el-enjuiciamiento-de.html. Acceso: 11/3/2014.

724 "Pasó por Bahía Blanca en viaje a Trelew un grupo de abogados", LNP, 23/8/1972. "Recurso de amparo", LNP, 24/8/1972; "Recurso desestimado", LNP, 25/8/1972. "Telegrama", LNP, 25/8/1972. Telegrama s/f elevado a la DIPPBA, "Informe sobre extremistas heridos internados hospital Base Naval Puerto Belgrano" del 25/8/1972, "Informe relacionado conferencia de prensa abogados defensores elementos extremistas internados hospital naval Puerto Belgrano" del 27/8/1972, "Ampliando Memorando Dpto. D 104" del 29/8/1972, Mesa “D(s)", Carpeta Varios, Legajo 383, Tomo 1. FONDO DIPPBA División Central de Documentación, Registro y Archivo.
} 
declaración firmada en Bahía Blanca el 28 de agosto de 1972, en la que difundieron el relato de los sobrevivientes, tal y como aquellos lo habían expuesto frente al instructor militar que los había indagado, contradiciendo la versión oficial:

instantes antes de la muerte de dieciséis detenidos, éstos junto con los tres sobrevivientes fueron sacados por personal militar de sus celdas y alineados en el pasillo cerrado que corre entre las mismas. Suponían que se trataría de uno de los habituales interrogatorios que a diario practicaba personal de policía federal, llamándoles no obstante la atención el hecho de sacarlos en forma conjunta puesto que los anteriores interrogatorios se habían efectuado en forma individual. Una vez alineados en ese lugar, el mismo personal militar sin previo aviso, ni incidente de ninguna naturaleza, comenzó a hacer fuego sobre los detenidos. En esa circunstancia varios de estos lograron refugiarse en las celdas abiertas a sus espaldas, siendo en esos lugares, en los que oficiales de marina penetraron disparando a quemarropa, pudiendo notar que la misma operación se repetía en las celdas cercanas a las que ocupaban en ese momento. Tanto Camps como Haidar manifestaron que en momentos de refugiarse en dichas celdas se hallaban ilesos $^{725}$.

En efecto, la dictadura construyó un relato sobre lo ocurrido según el cual los 16 detenidos habían resultado muertos después de un intenso tiroteo con las fuerzas de seguridad, al intentar fugarse de la Base Aeronaval, habiendo tomado algunos rehenes. Ante la incapacidad de sostenerlo con argumentos lógicos, echó mano a la coacción para impedir toda averiguación que diera lugar a otra narración. Así, el 22 de agosto, el gobierno militar emitió una serie de "decretos-leyes" que imponían una férrea censura en cuanto a la información periodística ${ }^{726}$. En este marco, los medios reprodujeron las versiones oficiales sobre lo sucedido. Sin embargo, no todo fue obra de la intimidación gubernamental; varios diarios se hicieron eco de los rumores militares (Pittaluga, 2006). En Bahía Blanca, LNP asumió un compromiso con el discurso de las fuerzas armadas y de seguridad, como lo hizo en otros momentos clave de la historia argentina (Montero, 2006). Las informaciones ofrecidas por el matutino en los días siguientes se inscribían en la misma narrativa oficial ${ }^{727}$. Al mismo tiempo, el diario respaldó esta explicación

\footnotetext{
725 Mesa "D(s)", Carpeta Varios, Legajo 383, Tomo 1. FONDO DIPPBA División Central de Documentación, Registro y Archivo.

${ }^{726}$ El día de la masacre, el presidente de facto sancionó y promulgó la ley 19.797 que incorporaba un nuevo artículo (el 212) al Código Penal, por el que cual "el que por cualquier medio difundiere, divulgare o propagare comunicaciones o imágenes provenientes de o atribuidas o atribuibles a asociaciones ilícitas o a personas o a grupos notoriamente dedicados a actividades subversivas o de terrorismo, será reprimido con prisión de seis meses a tres años". "Artículo 212 del C. Penal", $L N P$, 23/8/1972.

727 "Fueron muertos 15 guerrilleros que intentaban huir de Trelew", "Dos heridos fueron trasladados a la Base Pto. Belgrano", "Posición de distintos sectores de opinión", "Escenario de los sucesos. Base Aeronaval Almirante Zar", "Considérase que no habría existido un apoyo exterior", LNP, 23/8/1972; "Cerrado hermetismo en la Base Aeronaval de Trelew", "Asciende a 16 el número de extremistas fallecidos" y subnota "Llegaron a Rosario los restos de Carlos Del Rey", LNP, 24/8/1972; "Rechazan un
} 
resaltando el carácter de "terroristas"/ "extremistas" de las víctimas de Trelew y su peligrosidad. Así, el 23 de agosto publicó un informe sobre los antecedentes judiciales de los 19 "elementos" que protagonizaron los sucesos del 22 de agosto. En el mismo, se detallaba, además de sus datos personales, las “organizaciones guerrilleras clandestinas" a las que pertenecían, las circunstancias de detención, los delitos por los que habían sido procesados, el tribunal interviniente, la fecha y el decreto por el cual fueron puestos a disposición del Poder Ejecutivo Nacional ${ }^{728}$. Al día siguiente, reiteró la pertenencia a FAR y Montoneros, así como las causas por las que estaban acusados los heridos ${ }^{729}$.

En este marco, la intervención de los sectores católicos liberacionistas locales estuvo motivada por la urgencia de preservar la vida de los heridos, por la necesidad de dar a conocer y a la vez denunciar lo sucedido, y una vez conocido el relato de los sobrevivientes, por desmentir la explicación del "intento de fuga". Sobre la primera cuestión, Miguel Sarmiento planteaba: “acá en Punta Alta enseguida se conoció el tema y el primero que larga la alarma es 'Coco' [Hugo Segovia], porque el tema era instalar enseguida que acá estaban los tres sobrevivientes antes que los mataran,"730.

En este sentido, resultaba vital "interesar" al arzobispo ${ }^{731}$ en el asunto y comprometerlo en las gestiones destinadas a lograr que los familiares y los abogados defensores pudieran visitar a los heridos en Puerto Belgrano. Así, el 26 de agosto se concretó una audiencia ${ }^{732}$ entre aquellos y el recientemente consagrado Jorge Mayer, gracias a la mediación del secretario canciller, Hugo Segovia, quien había trabajo amistad con el letrado Everardo Facchini, al ser ambos oriundos de Punta Alta. En este sentido, en ciudades de dimensiones medias -en comparación con Buenos Aires, Rosario o Córdoba-, el entretejido de redes sociales resultaba relativamente estrecho. Así, los vínculos personales facilitaron los contactos entre familiares, abogados, sacerdotes y laicos, así como la elaboración inmediata de iniciativas comunes. "Coco" explicaba que entonces no había restricciones para hablar con la máxima autoridad

recurso de amparo en favor de los heridos en Trelew" y subnotas "Desmentido en la Base", "Informe oficial", "En General Roca", $L N P, 25 / 8 / 1972$.

728 "Vinculación de los terroristas con organizaciones clandestinas", LNP, 23/8/1972. Semanas más tarde, el matutino bahiense publicó un informe del Comandante del V Cuerpo de Ejército, general Ceretti, dirigido a la opinión pública, sobre los hechos del 15 de agosto en el penal de Rawson. "Informó el General Ceretti sobre los sucesos de Rawson", LNP, 14/9/1972.

729 "Los sobrevivientes están internados en la Base P. Belgrano", LNP, 24/8/1972.

${ }^{730}$ Entrevista a Miguel Sarmiento, Punta Alta, 11/2/2011.

731 "Informe relacionado conferencia prensa abogados defensores elementos extremistas internados hospital naval Puerto Belgrano" del 27/8/1972, Mesa "D(s)", Carpeta Varios, Legajo 383, Tomo 1. FONDO DIPPBA División Central de Documentación, Registro y Archivo.

${ }^{732}$ Boletín Eclesiástico, Bahía Blanca, octubre-diciembre 1972. 
eclesiástica. Sin embargo, cuando los abogados locales, encabezados por Facchini, se acercaron por primera vez al Arzobispado, se toparon con un capellán de la Marina que intentó obstaculizar la audiencia:

[Facchini] le dice: "mire, yo soy abogado, necesito hablar...". "No, el arzobispo no está. Está en Buenos Aires. Va a estar por lo menos una semana en Buenos Aires. ¿Qué lástima!'. Este hombre no sé si sospechó que no era cierto. El arzobispo estaba. A la mañana siguiente él va a la Curia, yo estaba en la Curia en mi oficina: "Estoy con el asunto de Trelew. Che, oíme una cosa, el arzobispo no está ¿no?”. "Sí, ¿cómo no va a estar?”. "Porque yo quería hablar con él". Teléfono de abajo. Arriba, llamo: "Monseñor acá hay un señor que quiere...". "Bueno, - a Mayer ¿eh?- que suba",733.

La reunión contó además con la participación de otros presbíteros, entre ellos, el canciller de la Curia, quien se ocupó de avisar a los medios de comunicación locales para que registraran el ingreso de las personas al edificio. Durante la misma, los padres de los heridos informaron a Monseñor Mayer sobre la situación de aislamiento en la que permanecían los tres militantes, contradiciendo la información que el jefe de la Base le había dado a aquél por teléfono previamente, causándole con ello gran sorpresa e inquietud. "Coco" contaba los detalles del encuentro en el que los familiares, si bien no consiguieron que el arzobispo aceptara acompañarlos al hospital naval, lograron su palabra de que intercedería por ellos en Puerto Belgrano:

Estuvimos nosotros también adentro. El obispo pidió que fuéramos con él. Bueno, ahi yo me acuerdo perfectamente que el papá de este chico Haidar dijo: "mire, yo soy radical, Monseñor, soy católico dominical, practico. Mi hijo no. Yo no comparto algunas posturas de mi hijo aunque yo lo respeto porque él está convencido de un ideal y yo estoy tratando de defenderlo, de verlo, porque no lo he podido ver. Entonces yo dudo de lo que está pasando. No sé si mi hijo vive o no vive". "Pero usted...". "No, Monseñor, yo como una persona -estaban los otros dos padres, él estaba con la mujer. Los otros dos padres estaban solos- le puedo asegurar que no los hemos visto nosotros". "Pero i¿cómo?! Bueno, yo me voy a ocupar entonces de esto" ${ }^{, 734}$.

Por otra parte, algunos sacerdotes se reunieron con los padres de los sobrevivientes para interiorizarse sobre lo ocurrido. Así lo evocaba José Zamorano:

nos enteramos por lo siguiente: familiares de...no sé si fue un sobreviviente, acudieron al arzobispado y tuvieron una entrevista, Segovia, algunos de nosotros y habrá sido Santecchia y yo y algunos más, en el hotel Plaza ${ }^{735}$ que

\footnotetext{
${ }^{733}$ Entrevista a Hugo Segovia, Mar del Plata, 27/5/2010.

${ }^{734}$ Entrevista a Hugo Segovia, Mar del Plata, 27/5/2010.

735 Era el "Hotel Austral". Allí se alojaron el 29 de agosto los abogados defensistas provenientes de Buenos Aires y de Córdoba que tomaron contacto con los colegas locales. "Ampliar Memorando Dpto. “D” 104", del 29/8/72, Mesa "D(s)", Carpeta Varios, Legajo 383, Tomo 1. FONDO DIPPBA División Central de Documentación, Registro y Archivo.
} 
estaba enfrente al arzobispado, en la esquina. Ahí estuvo una compa...los papás de uno de los muertos o...Y ahí supimos lo que había pasado, porque no se sabia $^{736}$.

Como resultado de esos encuentros, los presbíteros identificados con la renovación eclesial organizaron una misa concelebrada por las víctimas y los heridos, para repudiar los fusilamientos. "Pepe" Zamorano daba relevancia a la denuncia de la masacre como un hito en la consolidación de este grupo sacerdotal:

nosotros tomamos una postura muy clara respecto de la masacre de Trelew. Los curas, el grupo nuestro, tuvimos una misa en la parroquia de Lourdes, que entonces estaba de párroco Baudry. Como 18 curas estuvimos ahí en señal de PROTESTA por la masacre. Entonces como que ahi ya nos fuimos definiendo mucho $^{737}$.

Hugo Segovia, por su parte, resaltaba el sentido de la iniciativa a la luz de la situación de los militantes heridos y de sus familiares, que aún no habían podido visitarlos: "ahí se hizo después una misa, un día creo que un sábado a la noche, una misa que participó mucha gente, pidiendo por la libertad de esos chicos ${ }^{, 738}$.

El oficio religioso tuvo lugar el mismo 26 de agosto a las 21 horas en Nuestra Señora de Lourdes y estuvo a cargo de una docena ${ }^{739}$ de sacerdotes y religiosos, entre ellos "Pepe" Zamorano, "Coco" Segovia, Miguel Sarmiento, un grupo de salesianos, el párroco Eliberto Baudry y el Vicario General de la Arquidiócesis, Rómulo García, quien la presidió ${ }^{740}$. Según María, quien participó de la misa, “ahí intervinieron todos los curas" pero "el que tuvo la voz cantante fue Baudry",741. En efecto, en su organización, los impulsores tuvieron especial cuidado en la elección de los clérigos que estarían a cargo de la homilía, evitando que lo hicieran aquellos que estaban más expuestos públicamente. Así lo explicaba "Coco":

No hablé nada por un montón de motivos. Primero, porque estaba sumamente cuestionado y segundo porque me pareció...que no encontraba sentido hablar yo en ese momento ahi [...] Yo no quise tal vez por precaución, sabiendo cómo venía la mano ¿no? Sabiendo que la Base Naval era...Para colmo mi papá era militar...se había jubilado, habia fallecido ya ¿no?, o sea que era casi una

\footnotetext{
${ }^{736}$ Entrevista a José Zamorano, Moreno, 19/9/2009.

${ }^{737}$ Entrevista a José Zamorano, Moreno, 19/9/2009 y 2/9/2011.

${ }^{738}$ Entrevista a Hugo Segovia, Mar del Plata, 27/5/2010.

739 Según Miguel Sarmiento, fueron "más de 10" (Punta Alta, 11/2/2011), mientras "Pepe" Zamorano estimó primero un número de 12-14 sacerdotes (Moreno, 19/9/2009) y luego, de 18 (Moreno, 2/9/2011).

${ }^{740}$ Entrevistas a José Zamorano, Moreno, 19/9/2009 y 2/9/2011; Hugo Segovia, Mar del Plata, 27/5/2010; Miguel Sarmiento, Punta Alta, 29/11/2010 y 11/2/2011.

${ }^{741}$ Entrevista a María, Bahía Blanca, 28/2/2013.
} 
traición para ellos, que un hijo de un militar fuera un "guerrillero" como aparecía yo, "altamente peligroso" $" 742$.

Resulta pertinente pensar estos comportamientos en ciudades donde las esferas civil y militar estaban fuertemente imbricadas, de modo que la presencia militar condicionaba las respuestas y actitudes de los actores. Miguel Sarmiento coincidía en que si bien la homilía fue preparada entre todos los curas identificados con la renovación eclesial, ellos procuraron que hablaran los más "moderados" o "tranquilos" en lugar de aquellos que eran conocidos por sus predicaciones "punzantes" y actitudes "drásticas", de modo de evitar que la iniciativa fuera cuestionada por las autoridades eclesiásticas, empezando por el mismo García: "para no armar quilombo, nos repartimos las predicaciones entre los que éramos menos agresivos del grupo. Entonces ni Pepe, ni Coco ni Benito decidieron hablar. Hablamos Stocchetti, Baudry, García y yo. Fuimos los 4 que bajamos alguna reflexión" ${ }^{\text {,43 }}$. Según Miguel, en esta decisión pesaban los reparos que había puesto la jerarquía a la realización de la misa, frente a los cuales se quiso garantizar que la misma se llevara adelante como un signo significativo de la Iglesia a nivel local:

García en ese momento era el Vicario General y fue el que autorizó y que se propuso encabezar una misa concelebrada siempre y cuando fuésemos moderados en las homilias e involucráramos a todos: no solamente a los que llamaban los guerrilleros muertos sino también a los soldaditos que habían matado en la cárcel, que fuera una misa contra la violencia en general, sin tomar partido por ninguna de las partes. Se lo aceptamos. Lo importante era que había que salir al frente -estaban los tres chicos acá en la Base internados-, y había que hacer algún gesto, algo había que hacer ${ }^{744}$.

Probablemente, esta cuestión haya estado presente al momento de hacer la convocatoria. En el volante de invitación a la celebración, la JUC planteaba la obligación de alzar la voz frente a los sucesos de Trelew y Rawson "que han costado la vida de 17 personas (un guardiacárcel y 16 presos políticos), hechos que son una manifestación más de la violencia que impera en todos los órdenes de la realidad argentina, hechos que sacuden nuestra conciencia”. Pero a continuación, se ponía el acento en la impugnación del accionar represivo:

como cristianos, sentimos la necesidad de expresar un signo asumiendo la parte de culpa que nos cabe; de esperanza por la vida de los heridos, y que el amor sea

\footnotetext{
${ }^{742}$ Entrevista a Hugo Segovia, Mar del Plata, 27/5/2010.

${ }^{743}$ Entrevista a Miguel Sarmiento, Punta Alta, 29/11/2010 y 11/2/2011.

${ }^{744}$ Entrevista a Miguel Sarmiento, Punta Alta, 11/2/2011.
} 
el signo de nuestras vidas; como así también de denuncia por la total ausencia de respeto a la dignidad de la persona humana por parte de quienes detentan el poder. Entendemos que nuestro signo debe ser asumido por todo aquel que se siente interpelado, por tal invitamos a unirnos en oración-reflexión ${ }^{745}$.

De este modo, la JUC interpretaba el acontecimiento del 22 de agosto como hecho episódico de una violencia sistémica, y a la vez como expresión de la violencia represiva de la dictadura militar. Sobre el abordaje de este suceso en las reuniones jucistas, Manuel recordaba: "Nosotros de lo de Trelew teníamos una reflexión cristiana. Politicamente también, pero una reflexión cristiana" ${ }^{746}$.

La iglesia recibió entonces a decenas de personas que incluían a los integrantes de los grupos laicales que aquellos sacerdotes acompañaban en Bahía Blanca y Punta Alta. Sobre este punto, Miguel Sarmiento decía: “Estaba repleta la iglesia! Casi todos jóvenes. Me acuerdo que uno de ellos fue Daniel Bombara ${ }^{747}$ porque yo después le pregunté qué le había parecido, y sí, estaba conforme con lo que había dicho"748. Según los servicios de inteligencia, entre los 50 asistentes -de los cuales 30 eran jóvenes-, había "activistas estudiantiles que pretendían iniciar en el lugar una huelga de hambre, en señal de protesta por aquellos hechos, pero la misma no se concretó" ${ }^{749}$.

Por otra parte, desde el mismo 22 de agosto los estudiantes y docentes del Instituto Juan XXIII, así como los salesianos de esa comunidad, alzaron su voz para repudiar los asesinatos. Esa tarde los alumnos levantaron cursos y llevaron a cabo una asamblea que trató los sucesos de la Base "Almirante Zar" y resolvió realizar una misa en la capilla del establecimiento. La misma, oficiada por Oscar Barreto "por los argentinos muertos en Trelew", contó con la participación de más de un centenar de estudiantes. Alrededor de las 21 horas, los jóvenes salieron a la calle portando velas encendidas y se concentraron en las escalinatas del edificio para expresar su homenaje a los 16 militantes, iniciativa que congregó a unas 50 personas, según los cálculos de los agentes de inteligencia. Poco después, la manifestación fue dispersada por fuerzas policiales. Si bien la policía provincial no intervino a pedido del rector del Instituto, se

\footnotetext{
745 Declaración (volante) de la JUC, titulado "A los compañeros estudiantes", Mesa "D(s)", Carpeta Varios, Legajo 383, Tomo 1. FONDO DIPPBA División Central de Documentación, Registro y Archivo.

${ }^{746}$ Entrevista a Manuel y Nancy, Neuquén, 20/3/2013.

${ }^{747}$ Alumno del Instituto Juan XXIII, integrante del Grupo Misionero Bahiense y militante de la JUP. Fue secuestrado el 29/12/1975 y torturado hasta la muerte, ocurrida el 2/1/1976, constituyéndose en el primer desaparecido bahiense. Sus restos fueron identificados en 2011 por el Equipo Argentino de Antropología Forense. Véase http://bahiagris.blogspot.com.ar/ y http://juiciobahiablanca.wordpress.com.

${ }^{748}$ Entrevista a Miguel Sarmiento, Punta Alta, 29/11/2010.

749 "Misa por los caídos en Trelew" del 27/8/1972, Mesa "D(s)", Carpeta Varios, Legajo 383, Tomo 1. FONDO DIPPBA División Central de Documentación, Registro y Archivo.
} 
hizo presente personal de la policía federal, que detuvo a tres jóvenes, para ponerlos en libertad horas más tarde, una vez identificados ${ }^{750}$. Esta movilización era evocada por Patricia, que entonces era alumna del Instituto:

el Juan no tenía demasiado movimiento. El único hecho que recuerdo con mucha fuerza fue el 22 de agosto del 72, con la masacre de Trelew, que cuando nos enteramos de la masacre nos fuimos del Juan y hubo un acto en la esquina, ahi en la bocacalle...nosotros participamos y llevamos otra gente ${ }^{751}$.

Durante la concentración, los estudiantes distribuyeron una declaración firmada por la "Asamblea de estudiantes del Juan XXIII" que, según los servicios de inteligencia, había sido elaborada en el colegio Don Bosco con la participación de "sacerdotes terceristas" "752. Bajo la frase inicial "Han sido muertos en Trelew, casi una veintena de jóvenes argentinos", profesores y estudiantes de las carreras de Inglés, Letras, Psicología, Filosofía y Psicopedagogía, se definían frente a lo ocurrido. Para los actores, las muertes de los jóvenes -y aquí, al igual que otros espacios del catolicismo renovador en la ciudad, incluían las de "esos agentes y esos soldados que son mandados a pelear contra nosotros, sin dejarles pensar que son parte del pueblo igualmente que nosotros"- llamaban a la reflexión, a "tomar conciencia", a "no quedarse callados" y manifestar su "repugnancia frente a este estado de cosas":

Queremos atacar las causas de esta situación insoportable, insostenible, que ha llevado a este estado de guerra civil. Aquí no podemos atacar métodos y medios. Aquí debemos adherirnos a esas motivaciones, las mismas que tenemos nosotros, producto de lo mismo que sentimos y que es HAMBRE, LA DESOCUPACIÓN, LA INJUSTICIA, Y LA CADA VEZ MAYOR FALTA DE LIBERTAD. Esas son las causas, esas causas que son nada más ni nada menos que violencia legalizada y que debe repugnarnos a todos (énfasis en el original).

Al mismo tiempo, desde la perspectiva de los firmantes del documento, los últimos sucesos invitaban a "reaccionar", a "desterrar el 'no te metas'", esto es, a involucrarse, a "comunicarse e integrarse" para acabar con "toda esta miseria humana que nos rodea": “Acaso meterse es alterar el orden o el orden lo altera el hambre, la injusticia, la falta de libertad?"753.

\footnotetext{
750 "Repercusión de los sucesos de Trelew en Bahía Blanca" del 22/8/1972, Mesa "D(s)", Carpeta Varios, Legajo 383, Tomo 1. FONDO DIPPBA División Central de Documentación, Registro y Archivo. Y "Concentración en el Instituto Juan XXIII", $L N P, 23 / 8 / 1972$.

${ }^{751}$ Entrevista a Patricia, Bahía Blanca, 19/5/2008.

752 "Repercusión de los sucesos de Trelew en Bahía Blanca" del 22/8/1972, Mesa "D(s)", Carpeta Varios, Legajo 383, Tomo 1. FONDO DIPPBA División Central de Documentación, Registro y Archivo.

${ }_{753}$ Volante firmado por la "Asamblea estudiantes el Juan XXIII", Mesa "D(s)", Carpeta Varios, Legajo 383, Tomo 1. FONDO DIPPBA División Central de Documentación, Registro y Archivo.
} 
En la tarde del 25 de agosto, los estudiantes del Juan XXIII celebraron otra asamblea con el objeto de informar sobre la detención de los compañeros durante el acto del 22 frente al Instituto y, a la vez, analizar la situación del propio movimiento estudiantil durante los últimos meses ${ }^{754}$. Según los agentes de inteligencia, en la reunión tomaron la palabra dos jóvenes que explicaron la forma y circunstancias en que habían sido apresados, así como los detalles del interrogatorio al que habían sido sometidos. Más tarde, una estudiante se refirió a los sucesos de Trelew como "brutales asesinatos y fusilamientos", destacando que el hecho "había sido preparado y que incluso el oficial de marina llevaba el arma con balas de fogueo". Luego, se distribuyó el volante de la “Asamblea estudiantil Guillermo López" de la UNS que convocaba a un acto común en las escalinatas del edificio de la universidad ${ }^{755}$, entendiendo que la lucha conjunta de todos los sectores estudiantiles y populares era el único camino "para impedir estos asesinatos y lograr la libertad de todos los presos políticos"756.

En esos días, los católicos renovadores bahienses cuestionaron las explicaciones oficiales de los hechos de la Base "Almirante Zar". En particular, una vez hecho público el comunicado de los familiares de Berger, Haidar y Camps, estos sectores -al igual que otros actores, como los estudiantes universitarios ${ }^{757}$ - se ocuparon de difundir la verdad de lo ocurrido aquella madrugada, así como de denunciar su ocultamiento por parte de las autoridades militares y la prensa. Se intentaba construir un relato que expusiera la verdad, aferrándose al decir de los protagonistas. Al igual que las publicaciones analizadas por Pittaluga (2006), los actores bahienses asumieron la tarea de disputar la coacción dictatorial a la palabra rompiendo el silencio y construyendo otra narración que desarticulara la ficción de la fuga y que denunciara las características del crimen. Estos relatos buscaban exponer lo silenciado, mostrar el horror del fusilamiento. Así, el personal de la DIPPBA secuestró un volante distribuido en el Instituto salesiano que, bajo el título de "La mentira de patas cortas", transcribía el documento de los padres de los sobrevivientes y postulaba que estos testimonios venían a confirmar que en la base militar de Trelew se había consumado un asesinato, que había sido ocultado por un

\footnotetext{
${ }^{754}$ Volante titulado "Asamblea estudiantil”, Mesa A, Estudiantil, Localidad Bahía Blanca, Legajo No 47. FONDO DIPPBA División Central de Documentación, Registro y Archivo.

${ }^{755}$ Informe titulado "Asamblea de estudiantes del Instituto del Profesorado Juan XXIII" del 25/8/1972, Mesa A, Estudiantil, Localidad Bahía Blanca, Legajo $\mathrm{N}^{\circ} 47$. Archivo DIPPBA.

${ }^{756}$ Volante firmado por la "Asamblea estudiantil Guillermo López" del 7/9/1972, Mesa "D(s)", Carpeta Varios, Legajo 383, Tomo 1. FONDO DIPPBA División Central de Documentación, Registro y Archivo. ${ }^{757}$ Volante firmado por la "Asamblea estudiantil Guillermo López" del 7/9/1972, Mesa "D(s)", Carpeta Varios, Legajo 383, Tomo 1. FONDO DIPPBA División Central de Documentación, Registro y Archivo.
} 
régimen en descomposición y carente de legitimidad, a través de la difusión de una versión falsa y de la imposición de la censura:

Las autoridades elaboraron una mentira enorme con respecto a los hechos ocurridos en Trelew. Es una mentira más, fiel reflejo del inexorable derrumbe de la dictadura militar. Pretendieron hacerla "correr" y como refuerzo, emitieron un decreto-ley prohibiendo por cualquier medio la divulgación de hechos o imágenes "subversivas". Pero (como siempre) la mentira tiene patas cortas. La verdad se supo de labios de los propios protagonistas que vinieron a corroborar lo que el PUEBLO ya sabía: a los detenidos en Trelew los asesinaron a mansalva. AL PUEBLO ya no se lo puede engañar [...] BASTA DE TORTURAS! BASTA DE MUERTES! BASTA DE MISERIA! NO SEAMOS CÓMPLICES CON NUESTRO SILENCIO (énfasis en el original) ${ }^{758}$.

Por otro lado, un informe de los agentes de inteligencia mencionaba que el mismo sacerdote que había oficiado una misa por "los argentinos muertos en Trelew" distribuyó volantes "con supuestas declaraciones de los familiares de los extremistas heridos". El parte también aludía a la homilía de "Pepe" Zamorano del 10 de septiembre, referida a la "prostitución de la verdad" de los medios informativos, que distorsionaban los hechos a su "gusto", por lo que los católicos debían estar atentos "para establecer el verdadero significado de las informaciones" "759. Si bien aquí no hay referencias explícitas a $L N P$ o al acontecimiento del 22 de agosto, debe considerarse que el contexto en el que fueron emitidas las palabras del sacerdote estaba atravesado por las repercusiones de aquellos sucesos.

A un año de la masacre, el tercer número de Pablo cuestionaba a $L N P$ en relación a la versión que la empresa periodística había construido sobre los hechos ocurridos en la Base "Almirante Zar". En la misma línea de las declaraciones que los grupos católicos liberacionistas habían elaborado a propósito de los ataques del diario al MSTM en 1970, la revista se dirigía a Diana Julio expresando que si bien respetaba y defendía la libertad de prensa como un derecho inalienable, LNP no podía "seguir siendo libre para mentir, atropellar, manosear y destruir dividiendo". En una carta abierta a la directora de Clarín referida a la libertad de prensa, se insistía en que $L N P$ "a través de una abusiva concepción de la misma, ha quitado todo derecho a la persona

\footnotetext{
${ }^{758}$ Volante titulado "La mentira de patas cortas" del 25/8/1972, Mesa A, Estudiantil, Localidad Bahía Blanca, Legajo $\mathrm{N}^{\circ}$ 47. FONDO DIPPBA División Central de Documentación, Registro y Archivo.

759 "Memorando Depto. ' $C$ ' $\mathrm{N}^{\circ}$ 430. Cumplimiento despacho ' $\mathrm{C}$ ' $\mathrm{N}^{\circ} 2230$ " del 13/9/1972, Mesa "Referencia", Legajo N ${ }^{\circ}$ 15281, Tomo V. Archivo DIPPBA.
} 
para estar adecuadamente informada, abusando del avasallador privilegio de ser el principal diario local ${ }^{\prime 760}$.

\section{5) Acciones de Navidad}

Con la nueva coyuntura abierta en el país con la elección de Héctor Cámpora, los grupos cristianos continuaron expresándose públicamente contra la violencia política que se acrecentaba tanto en el orden nacional, de la mano de la represión paraestatal, como en el regional, como resultado de la instauración de regímenes dictatoriales en el Cono Sur. En diciembre de 1973, la JEC, la JUC, la JOC, la CUB y Cáritas, elaboraron una declaración que presentaba una lectura del contexto político nacional y latinoamericano. En el encabezado, una cita del Evangelio de Lucas rezaba: "María dio a luz a su hijo y lo envolvió en pañales y lo recostó en un pesebre, porque no había lugar para ellos en el albergue". Así, la Navidad era el marco elegido por estos grupos para interrogarse sobre su "compromiso evangélico" ante una realidad en la que los pueblos de América Latina se empeñaban en "no hacerle lugar" a Cristo que "vuelve a nacer" entre los hombres. En este marco, constataban las diversas formas en que "se atenta contra los derechos humanos" ${ }^{761}$ : en Chile, con miles de personas muertas, torturadas, sometidas a prisión y desarraigadas; en Bolivia, Uruguay y Brasil, con el incremento de las torturas y la construcción en este último de "un 'milagro económico' sobre el sacrificio de trabajadores y campesinos, con una Iglesia perseguida y amordazada"; en Argentina, con la escalada de violencia que amenazaba el desarrollo, por parte del gobierno, de un "programa popular" que representaba "la concreción de un proyecto liberador", violencia que se ponía de manifiesto en "la matanza de Ezeiza, la proliferación del asesinato sindical y político, los secuestros, los atentados y amenazas a legisladores y publicaciones periodísticas, la persecución ideológica”, así como en la omisión de investigación de "sucesos graves" ocurridos en el país. En este escenario,

\footnotetext{
760 Pablo, 3, agosto de 1973. Archivo DIPBA, Mesa "Referencia", Legajo № 15281, Tomo VIII. "Sacerdotes Tercer Mundo".

${ }^{761}$ Las referencias en el documento a la "vigencia o no" de los derechos humanos, así como a situaciones que "atentan" contra los mismos, parecerían contradecir la tesis de Carassai (2010) sobre la inexistencia de una conciencia social sobre los derechos humanos durante la primera mitad de la década de 1970, o bien podrían estar hablando de excepciones a esta generalización en ciertos círculos sociales. En este sentido, Juan decía: "Vos fijate en el momento histórico que estamos hablando si ves alguna otra denuncia sobre derechos humanos. Y no ves. Es contado. O sea, este es un material de avanzada para la época, porque de alguna manera profetiza lo que va a pasar después" (Entrevista a Juan, Bahía Blanca, $14 / 8 / 2012$ ).
} 
según los firmantes, la Navidad debía recordar a los cristianos que "como Iglesia, somos búsqueda y esperanza de vida, libre de ataduras temporales, pero profundamente comprometida con la realidad del hombre y de la historia”. Y en ese sentido, se sentían identificados con las palabras de los obispos del nordeste brasileño, quienes habían planteado que "la liberación, conforme a los designios del Padre, se va dando a través y dentro del Pueblo donde se verifica la dimensión socio-política del hombre. Dios salva a cada uno dentro de un Pueblo, el Pueblo de Dios, objeto de su amor"762.

La Navidad también había sido la ocasión elegida por otros referentes del catolicismo liberacionista en nuestro país para expresarse sobre la realidad de su tiempo. Así, en 1968, el MSTM lanzó una declaración, titulada "Compromiso de Navidad", al tiempo que promovió hechos concretos de denuncia y compromiso en ocasión de la celebración de dicha fiesta religiosa. Mediante el documento, buscaba responder al llamado de los obispos latinoamericanos reunidos en Medellín que impulsaban a "denunciar enérgicamente los abusos y las injustas consecuencias de las desigualdades excesivas entre ricos y pobres". En consecuencia, atacaban el hambre, el analfabetismo, las enfermedades endémicas, el problema habitacional, el armamentismo, la discriminación, el "imperialismo internacional del dinero", el capitalismo nacional, la injusta distribución de tierras, la desocupación, la política social, no sólo en el mundo, sino también en Latinoamérica y en Argentina, en particular. Desde la perspectiva de los sacerdotes, se trataban de males que constituían un impedimento para que surgiera el Hombre Nuevo y para festejar "con despreocupada alegría al Señor recién nacido". Con el propósito de añadir a estas palabras la fuerza de un gesto de protesta, diversos grupos de sacerdotes acompañados de laicos en múltiples puntos del país realizaron ayunos de 50 horas o suprimieron la celebración de la Eucaristía, a la vez que organizaron jornadas de debate público, oración, lectura bíblica y estudio de los documentos de Medellín. Según el MSTM, en Bahía Blanca, dos sacerdotes, un grupo de universitarios y otras personas concretaron el ayuno a partir de la misa vespertina del 22 hasta una celebración penitencial el 23 a la noche, y lo acompañaron con un temario de reflexión. Además, se leyó el compromiso de Navidad en varios lugares periféricos ${ }^{763}$.

En 1969, los Sacerdotes para el Tercer Mundo volvieron a considerar propicia la Navidad para que en todo el país se promovieran hechos que denunciaran

\footnotetext{
$\overline{762}$ Declaración (volante) de la CUB, la JUC, la JOC, la JEC y Cáritas, sin título, del 23/12/1973. Archivo personal de Mirta y Jorge.

${ }^{763}$ Declaración Compromiso de Navidad, diciembre de 1968, y Crónica sobre los hechos de Navidad.
} 
proféticamente las situaciones de injusticia y actualizaran "la venida de la Liberación que esa festividad recuerda y anuncia”. Para ello proponían marchas y petitorios, ayunos acompañados de reflexión y oración, y la lectura de declaraciones con denuncias concretas que, más allá de los planteos locales, podían incluir en común las torturas, los bajos salarios, la intromisión cada vez mayor de los militares en los cargos directivos de las grandes empresas extranjeras y nacionales, así como exigencias referidas al levantamiento del estado de sitio, la devolución de los sindicatos a los trabajadores sin trampas ni proscripciones y el cese de las torturas a los detenidos ${ }^{764}$.

\section{6) La lucha contra el Camino de Cintura}

En esos años, la toma de postura a favor de las personas pobres, compartida por los referentes de la renovación católica en Bahía Blanca, llevó a estos grupos a intervenir en otro tipo de situaciones que se plantearon en el ámbito local. Así ocurrió en 1972 a propósito del conflicto suscitado por la planificación del Camino de Cintura.

Las vicisitudes de este proyecto deben comprenderse en un marco más general. Siguiendo a Healey (2003), el desarrollismo trazó las líneas maestras para las políticas económicas y sociales de los años sesenta y setenta. Entre sus frutos más obvios figuran las grandes obras de infraestructura -muchas de las cuales tuvieron sus orígenes en propuestas de estos años o fueron iniciadas entonces-, la estrategia de "polos de desarrollo" -que conllevaba la concentración de las inversiones en lugares considerados estratégicos confiando que redundaría en beneficio de toda la nación-, y el debate cada vez más amplio sobre el desarrollo regional. En este marco, la "Revolución Argentina" privilegió a las grandes industrias y a las fuertes inversiones extranjeras y estatales. En materia de desarrollo regional, se destacó una abierta vocación planificadora. Después del Cordobazo, se profundizaron las inversiones públicas de envergadura y la planificación a largo plazo tomó una marcada orientación regional. La presentación del Plan de Desarrollo y Seguridad de Levingston apostaba al desarrollo regional como parte central de una estrategia de desarrollo global. En eso representaba un giro

\footnotetext{
${ }^{764}$ Carta del Secretariado proponiendo realización de 'hechos significativos' en ocasión de la Navidad, 3/12/1969. Es significativo que parte de estas sugerencias sobre el contenido de las declaraciones coincide con los temas que son objeto de denuncia en el documento de la JUC sin fecha que analizamos en el segundo apartado de este capítulo, aunque no hemos podido determinar que aquél haya sido elaborado en este marco (Declaración (volante) de la JUC de Bahía Blanca, sobre la "Revolución Argentina", sin fecha. Archivo DIPBA, Mesa A, Estudiantil, Juventud Universitaria Católica, Localidad Bahía Blanca, Legajo $\left.\mathrm{N}^{\circ} 111\right)$.
} 
fundamental en las posturas desarrollistas anteriores, pues proponía un franco abordaje de las desigualdades regionales y un esfuerzo directo de desarrollo regional como un fin esencial en sí mismo. Luego, muchos elementos del programa económico de Levingston perduraron en el gobierno de Lanusse (Healey, 2003).

En este escenario, a comienzos de 1971, se concretaron las primeras reuniones entre los directivos de Vialidad Nacional y el intendente de Bahía Blanca, Gustavo Perramón Pearson, para tratar la elaboración de un antiguo proyecto de construcción del Camino de Cintura ${ }^{765}$. El nuevo trazado vial, propuesto en el "Plan de Desarrollo de la ciudad y partido de Bahía Blanca" aprobado ese año, buscaba concretar la interconexión entre las rutas, la vinculación entre los puertos y la facilitación del acceso a los mismos, así como la contención de la red urbana interna ${ }^{766}$. La obra contemplaba la construcción de dos caminos a manera de doble anillo interdependiente: uno de circuito mayor, ejecutado por la Unidad de Vialidad Nacional, que unía las rutas 3, 33, 35 y 229; y otro más pequeño, a cargo de la Dirección Provincial de Vialidad, que es el que afectaba a algunas barriadas pobres de la ciudad ${ }^{767}$. Éste cubriría aproximadamente 30 kilómetros, su licitación estaba pensada para principios de 1973, y contaría con la financiación del Banco Interamericano de Desarrollo (BID).

\footnotetext{
765 "Camino de cintura", El Eco, 27/3/1971. Los primeros planos de Vialidad Nacional databan de 1937. En 1955, la Municipalidad de Bahía Blanca aceptó la traza, pero en 1959, el organismo nacional le solicitó la suspensión de los permisos de construcción y subdivisión de los lugares de paso. Luego, no se formularon proyectos definitivos ni se encararon obras pero se mantuvo la idea sobre la necesidad de la traza tanto a nivel local como provincial (Plan de Desarrollo de Bahía Blanca, 1971).

${ }^{766}$ Plan de Desarrollo de Bahía Blanca, 1971. Este informe, elaborado en el período 1968-1970, se proponía guiar el desarrollo de la ciudad en los siguientes 15 años, a partir del estudio de los acontecimientos que tendrían mayor relevancia en las décadas venideras. Desde la perspectiva estatal, se preveía un dramático crecimiento urbano, ligado a las obras básicas de infraestructura, la radicación de industrias y la reactivación portuaria, que exigían su promoción, al tiempo que su orientación y control. Estos cambios se veían como el resultado de que Bahía Blanca se hubiera convertido en el centro urbano de mayor gravitación en el territorio austral -por razones históricas, geográficas y económicas-, y que hubiera sido designada como polo provincial de crecimiento.

767 "Bahía Blanca ¿polo de crecimiento?”, Graphos, 11, noviembre de 1972.
} 


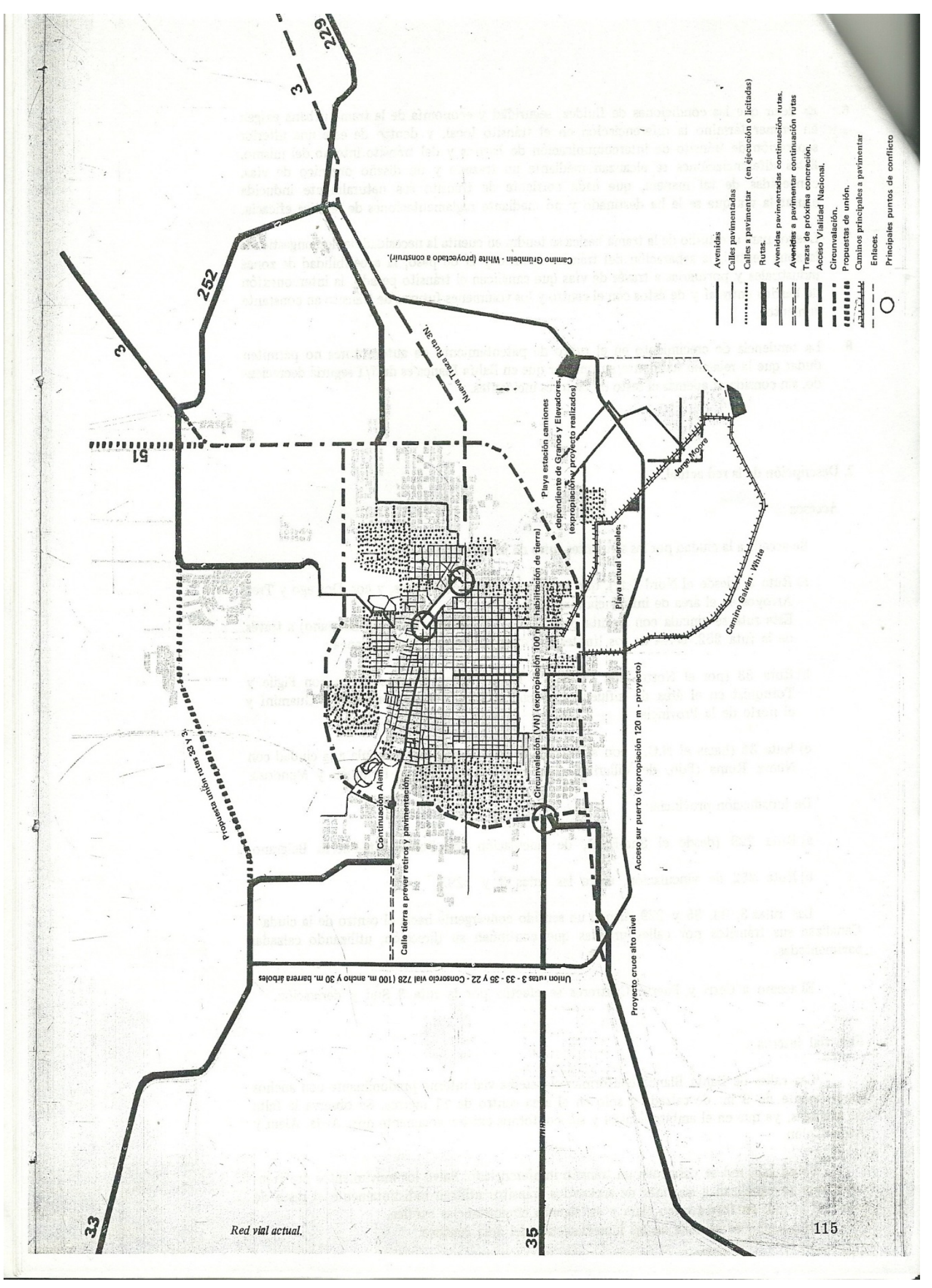


La Municipalidad de Bahía Blanca propuso corregir el trazado de la Avenida de Circunvalación interior en el tramo que iba desde el cruce con la Av. Jorge Moore hasta el enlace con la ruta 3 sur, desplazándose hasta el borde de la vía férrea. De este modo, se pretendía evitar que un sector residencial de los barrios Catamarca, San Blas, Pampa Central y Villa Nocito quedara marginado entre la vía del ferrocarril y una ruta primaria de circulación rápida. Sin embargo, no escapaban a las autoridades las dificultades que suponía alterar el régimen de expropiaciones ya iniciado por Vialidad Nacional en este sector $^{768}$. En el período 1970-1973 se proyectaba el comienzo del programa de adquisición anticipada de tierras, que incluía la continuación de las expropiaciones para la apertura de la Avenida de Circunvalación, y la realización de las primeras obras ${ }^{769}$.

La concreción del proyecto implicaba el desalojo de una parte de las familias de Villa Nocito - previo pago de una indemnización que algunas de ellas ya denunciaban como inferior al valor de sus viviendas-, y la destrucción de la escuela Nuestra Señora de la $\mathrm{Paz}^{770}$. De allí que los vecinos rechazaran la iniciativa estatal por los perjuicios que les traería en materia de vivienda y educación. En primer lugar, se negaban a perder sus casas. Además, a diferencia de la opinión del Municipio y de los directivos de Vialidad Nacional a favor de la viabilidad de las soluciones encaminadas a través de la Secretaría de Vivienda de la Nación ${ }^{771}$, descreían de la promesa de la construcción de 208 casas en el Barrio Matadero porque no quedaba claro a quiénes se las adjudicarían. Si bien estaban de acuerdo en que no querían que se las regalaran y que, por el contrario, estaban dispuestos a pagarlas, no podrían hacer frente al adelanto que se les exigía. En segundo lugar, la gente se resistía a que la escuela, que había sido en parte construida gracias al "esfuerzo del barrio", fuera demolida, dejando "sin educación" a sus hijos al no encontrar fácilmente lugar en las instituciones educativas más cercanas de los barrios Maldonado o Noroeste, que tenían su matrícula completa ${ }^{772}$.

Desde la perspectiva de los residentes de Villa Nocito, la toma de conciencia del problema, la falta de respuestas concretas a sus reclamos y las promesas de ayuda incumplidas por parte de los sucesivos intendentes, así como del arzobispo, impulsaron la organización y movilización de los vecinos para enfrentar colectivamente el desalojo, así como las presiones y los intentos de dividirlos a partir del argumento de que la

\footnotetext{
${ }_{768}$ Plan de Desarrollo de Bahía Blanca, 1971.

${ }^{769}$ Plan de Desarrollo de Bahía Blanca, 1971.

770 “Bahía Blanca ¿polo de crecimiento?”, Graphos, 11, noviembre de 1972.

771 "Camino de cintura", El Eco, 27/3/1971.

772 "Los barrios se organizan. Villa Nocito (BB), un barrio que desaparece", Nuevo Hombre, 5/2/1973.
} 
mayoría eran chilenos, con el cual el gobierno municipal intentaba desentenderse del problema. Al respecto, los actores expresaban:

se creen que la gente son animales o ganado, que los pueden echar de cualquier parte. Pero acá no va a suceder eso, porque acá la gente está unida. Este barrio está unido y no piensa salir hasta que no tengamos soluciones. Es una vergüenza que las autoridades contemplen más la construcción de un camino de cintura y no contemplen el problema social que eso está acarreando.

entre chilenos y argentinos no hay ninguna diferencia, son de carne y hueso como todos. Tanto chilenos como argentinos, los habitantes de Villa Nocito estamos todos unidos que no nos van a venir a barrer como si fuéramos mosquitos. Somos chilenos, pero tenemos hijos argentinos, y no por ser chilenos no nos vamos a merecer una casa digna ${ }^{773}$.

En esa lucha contra el trazado del Camino de Cintura $^{774}$ se involucraron diversas agrupaciones e instituciones vinculadas al barrio, entre ellas, la escuela Nuestra Señora de la Paz y Cáritas. La primera fue el centro de las reuniones de los vecinos. La segunda puso a disposición su mimeógrafo, en el que las maestras, las trabajadoras sociales y las religiosas imprimieron volantes donde planteaban su resistencia a la obra, para luego repartirlos en Villa Nocito, así como en el centro de la ciudad. Al mismo tiempo, Cáritas elaboró un informe sobre los perjuicios que implicaba la construcción del Camino de Cintura para los habitantes de los barrios afectados por el proyecto, que fue presentado al gobierno municipal en una entrevista personal con el intendente en agosto de 1972. En dicho documento, se argumentaba que familias enteras quedarían irremediablemente en la calle ya que, en primer lugar, en el momento del desalojo, no estarían concluidas aún las viviendas proyectadas en el Barrio Matadero; en segundo lugar, el número de personas desalojadas sería superior a la cantidad de casas que se proyectaba construir; en tercer lugar, la mayoría de estos vecinos no estarían en condiciones socioeconómicas de abonar la cuota mensual para la adquisición de las viviendas. Por otra parte, no existía un relevamiento social que hiciera posible conocer el número de los perjudicados ni había sido aclarado oficialmente quiénes serían los beneficiarios de las nuevas construcciones. Ante la falta de respuestas del municipio, Cáritas se sentía en la

\footnotetext{
773 "Los barrios se organizan. Villa Nocito (BB), un barrio que desaparece", Nuevo Hombre, 5/2/1973.

${ }^{774}$ Finalmente, el proyecto original de la Avenida de Circunvalación no se concretó. En la Reformulación del Plan de Desarrollo Urbano de Bahía Blanca (1983) se planteaba la necesidad de ajustar el proyecto para adecuarlo a la evolución de la ciudad y su estructura circulatoria vial. En el sector de Villa Nocito, dada la existencia de un acceso a 600 metros, el camino de circunvalación interno había perdido vigencia en su función de enlazar las rutas $3 \mathrm{~N}$ y S. Además, con el crecimiento de la ciudad, este camino que era periférico, resultaba entonces incorporado a la trama urbana y por su ancho (aproximadamente 100 metros) se había transformado en un vacío urbano que separaba dos sectores residenciales y se constituía en una zona baldía, que resultaba apta para ser ocupada por otros usos urbanos, como áreas de recreación.
} 
obligación de informar a las diversas instituciones locales "sobre tan serio problema humano que afecta a un núcleo vivo de nuestra comunidad, a fin de que -oportunamente sensibilizados- concreten su compromiso" 775 .

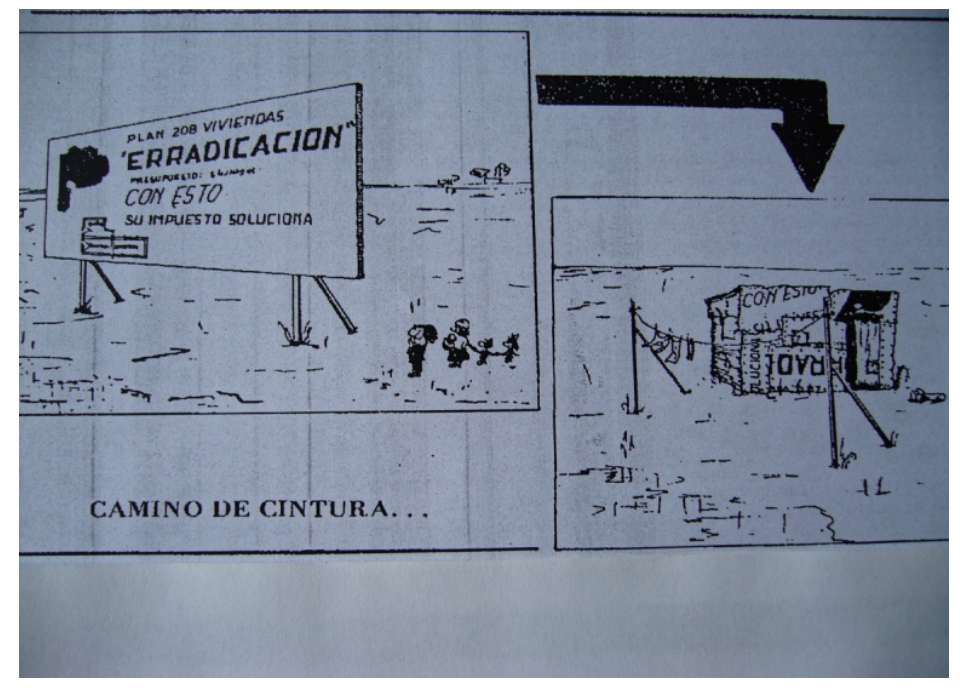

Por su parte, se conocieron las definiciones públicas de la JUC sobre el conflicto. En un informe abocado al "análisis e interpretación" del problema, la organización laical planteaba que el Camino de Cintura había sido planificado suponiendo un crecimiento de la población y un desarrollo industrial que estaba muy lejos de la realidad presente y futura, teniendo en cuenta el contexto económico y político nacional. En consecuencia, y tomando en consideración los costos monetarios y sociales implicados, no era una inversión prioritaria para la ciudad. Luego, los jóvenes agregaban que en un país dependiente como Argentina, el desarrollo de infraestructura beneficiaba a los monopolios extranjeros directamente relacionados con estos organismos crediticios - esto es, la Alianza para el Progreso y el BID-, al tiempo que hacía crecer la deuda externa y agudizaba la situación de dependencia. Por otra parte, la JUC criticaba la decisión de las autoridades de llevar adelante la obra sin tener en cuenta al grupo social afectado por la misma, y lo consideraba un exponente más de la habitual política discriminatoria en detrimento de estos sectores sociales. Según Graphos, los jucistas terminaban su documento con una interpretación evangélica del problema y proponían una opción como cristianos ${ }^{776}$.

\footnotetext{
775 "Bahía Blanca ¿polo de crecimiento?”, Graphos, 11, noviembre de 1972.

776 "Bahía Blanca ¿polo de crecimiento?", Graphos, 11, noviembre de 1972. La imagen corresponde al mismo artículo de Graphos.
} 
En suma, el análisis anterior nos permite afirmar que la denuncia de los escenarios considerados de injusticia, entendidos como situaciones de "pecado", que llevaron adelante los sectores católicos liberacionistas bahienses se materializó en documentos públicos. Así, la JUC, la JOC y la JEC articularon el discurso de la revisión de vida y el profético. Por medio de comunicados, en general repartidos bajo la forma de volantes a la salida de las misas dominicales en distintas iglesias de la ciudad, o en ocasiones publicados en la prensa local o nacional, estos grupos expresaron sus críticas contra acciones y medidas del gobierno militar de Onganía-Levingston-Lanusse, de las fuerzas armadas y de seguridad, de las autoridades municipales o de La Nueva Provincia. Cuando optaron por hacer públicas sus opiniones en los medios de comunicación, encontraron un espacio privilegiado en las revistas que actuaban como nexo del catolicismo liberacionista a nivel nacional -Cristianismo y Revolución- o local -Pablo-, o en aquellas que, fuera del ámbito religioso, actuaban como tribuna del movimiento estudiantil -Graphos-.

Las iniciativas descriptas anteriormente muestran una estrategia común a las distintas expresiones de la renovación católica, consistente en la emisión de documentos de denuncia en los que a partir de la condena de situaciones concretas, se impugnaba el orden social y político existente (Donatello, 2010). Los estudiantes católicos de otros lugares del mundo, pertenecientes al MIEC-JECI, también echaron mano a las declaraciones para expresar sus posicionamientos ante determinados acontecimientos sociales y políticos. Por ejemplo, a fines de 1968, la JEC y la Acción Católica Universitaria francesas elaboraron un documento que distribuyeron en las puertas de las iglesias, a la salida de la misa dominical, cuando el Sindicato Cristiano de enseñanza particular se mostraba hostil a la participación de estudiantes secundarios en el movimiento estudiantil de mayo ${ }^{777}$. En el orden nacional, los comunicados sobre diversos hechos políticos fueron una forma típica que marcó las intervenciones públicas del MSTM, aunque su participación se extendió, además, a distintos actos de protesta, ayunos, ollas populares, ocupaciones de fábricas e ingenios y notas en los medios de comunicación (Touris, 2012b).

Estos textos, sobre todo aquellos firmados por las ramas especializadas de Acción Católica y otros grupos laicales, se desarrollaban al ritmo del Ver, Juzgar y Obrar, de modo que incluían la descripción y análisis de un problema del entorno, su

\footnotetext{
777 "Declaración común de la JEC y la acción católica universitaria francesas", JEC Boletín Secundario, 8 , noviembre de 1968 .
} 
interpretación a la luz de la Biblia y los documentos de la Iglesia o sus referentes, y una propuesta de acción o toma de postura "como cristianos" que se desprendía de lo anterior. De este modo, los documentos citados permiten ilustrar el tipo de reflexión que los jóvenes llevaban adelante, esto es, qué cuestiones "veían" en la realidad de su tiempo, qué lugar ocupaban las citas del Evangelio y la palabra de la jerarquía eclesiástica, tanto para "iluminar" desde la fe el estudio de los datos históricos como para respaldar sus posturas, y en qué medida ese análisis llevaba a acciones concretas.

En la lectura de los hechos sociales, económicos o políticos, en ocasiones echaban mano a herramientas teóricas, como las que brindaba la economía y concretamente, la teoría de la dependencia. Este es el caso del informe que elaboró la JUC sobre el Camino de Cintura, centrado en los aspectos técnicos y financieros, así como en los actores afectados por la iniciativa.

Entre los textos bíblicos y eclesiales utilizados para "juzgar" esas situaciones figuran citas del Antiguo Testamento, del Evangelio, de las declaraciones de los obispos reunidos en Medellín, en San Miguel, o provenientes del nordeste brasileño, y de las encíclicas de Pablo VI. Por ejemplo, la JUC encabezó su declaración contra las "medidas arbitrarias" del gobierno de Onganía con un pasaje del Éxodo. Es interesante la inclusión de esta imagen, en tanto la liberación de Egipto era, para los cristianos liberacionistas, el paradigma de las luchas por la liberación. De acuerdo a lo que sostiene Gutiérrez (1971), es ante todo un acto político, que consiste en la ruptura con una situación de despojo y de miseria, y el inicio de la construcción de una sociedad justa y fraterna; pero, al mismo tiempo, un hecho salvífico, que estructura la fe de Israel y en el que se expresa el amor de Dios por su pueblo. Asimismo, en ese documento, los jucistas recurrían a las "Bienaventuranzas" para demostrar que su opción por los “cambios audaces, profundos y urgentes", reclamada por el Papa, era antes urgida por la Palabra de Dios. Con ello, quedaban asociados la lucha por la justicia y la venida del Reino de Dios, el compromiso con la transformación social y el seguimiento de Jesús. La aceptación del Reino pasaba necesariamente por la construcción de un mundo más justo (Gutiérrez, 1971). Desde esta perspectiva, si la justicia era el atributo central de Dios, el elemento constitutivo de la salvación y del proyecto de Dios, y la llave de acceso al Reino de los Cielos, la fe no podía ser ajena a la exigencia de justicia, lo que implicaba intervenir en favor de las personas pobres y oprimidas. Esto suponía atacar las causas históricas y sociales de la pobreza. De allí que la persecución, la cruz y el martirio se vieran como un desenlace lógico de esta lucha (Aguirre y Vitoria, 1990). 
Por otra parte, la necesidad de "actuar" se traducía en la denuncia conjunta de situaciones consideradas injustas. En este sentido, las declaraciones que hemos analizado dan cuenta de que la palabra podía ser también un importante gesto comprometido. Las situaciones sobre las que versaban los documentos abarcaban un amplio abanico de temas, a saber:

- la represión, las torturas, los secuestros, los asesinatos, las detenciones y las persecuciones que tenían lugar no sólo en Argentina, e incluso en Bahía Blanca, sino también en otros países del continente, y que eran perpetrados por fuerzas armadas y policiales bajo regímenes dictatoriales, o bien por grupos parapoliciales en períodos de democracia.

- el hostigamiento que sufrían los sectores identificados con la renovación católica, que se traducía en situaciones diversas que iban desde el arresto sin justificación, el sometimiento a interrogatorios sobre las actividades pastorales, el allanamiento del domicilio hasta las acciones de desprestigio del MSTM o de sus referentes -ya sea mediante volantes anónimos o ataques sistemáticos y fundamentados teológicamente desde la prensa-, pasando por la violación de su derecho a proclamar el Evangelio en la misa.

- la tergiversación y ocultamiento de información o, incluso, la construcción de noticias falsas por parte del principal medio de comunicación local, así como de su injerencia en cuestiones eclesiales que eran de incumbencia de las autoridades eclesiásticas.

- las medidas de gobierno que, desde la perspectiva de los liberacionistas, eran ajenas a las necesidades y demandas de los sectores populares: en primer lugar, las orientadas a utilizar lo religioso para legitimarse, así como para acallar las demandas del pueblo; luego, la política económica que afectaba los intereses de los trabajadores; por último, los proyectos de infraestructura urbana que implicaban la erradicación de un sector de las barriadas humildes de la ciudad.

Las declaraciones de otros referentes del catolicismo liberacionista versaban sobre temáticas similares. Así, los comunicados del MSTM exhibían su oposición al modo de producción capitalista, a la "Revolución Argentina", a la jerarquía -por su complicidad con los gobiernos militares y su silencio frente a la situación socioeconómica, la persecución y la represión política-, a los medios periodísticos y a "los ricos" -anunciando, por un lado, que la revolución latinoamericana pondría fin a su reinado y por otro, su condena a la hora del Juicio Final- (Touris, 2012b). 
Como hemos visto anteriormente, las intervenciones de los integrantes de la red de la renovación católica en Bahía Blanca estaban ligadas tanto a problemáticas del orden local como nacional e internacional. En este último plano, a excepción de la primera volanteada de la JUC que versaba sobre la guerra de Vietnam, los actores priorizaron las cuestiones enraizadas en la realidad regional o continental.

Si bien los documentos públicos fueron la estrategia más frecuentemente utilizada por sacerdotes y laicos identificados con la renovación eclesial para manifestar su posicionamiento frente a acontecimientos resonantes, estos actores también echaron mano a otros repertorios de acción para desempeñar la función profética. Uno de ellos fueron las misas, especialmente aquellas concelebradas por varios presbíteros y presididas por algún representante de la jerarquía eclesiástica local a pedido de los primeros. Así ocurrió para repudiar tanto el allanamiento a la casa parroquial de "la loma" y las detenciones de "Pepe" en agosto de 1971, como el asesinato de los 16 presos políticos en la Base "Almirante Zar" un año después. Más allá de estos gestos puntuales, el púlpito fue un lugar cotidiano desde el cual vincular la Palabra de Dios con la vida y asumir posicionamientos claros en relación a los hechos políticos y sociales del momento. De esta manera, los sacerdotes contestaron a diversos editoriales de LNP y los ataques que recibían los Sacerdotes para el Tercer Mundo.

Estas iniciativas nos permiten dimensionar el papel que jugaron las relaciones sociales establecidas entre las diversas experiencias católicas liberacionistas en la acción social y política de los militantes católicos, esto es, la función política que podían ofrecer los vínculos de sociabilidad. Así, los lazos entre los grupos fortalecieron su capacidad de movilización frente a objetivos comunes y facilitaron la práctica contestataria de sus miembros de diversas maneras. Entre ellas, la articulación de denuncias públicas, como las analizadas en este capítulo, y otras alternativas que abordaremos en el próximo apartado.

Los documentos explicitaban el posicionamiento político de los actores, al tiempo que esbozaban una reflexión teológica sobre aquél. Inspirados en las fuentes arriba mencionadas, los actores se definían como cristianos. Así, expresaban su identificación con los que, interpretando el sentir de los marginados, defendían sus derechos y se unían a ellos en la transformación "justa y necesaria” del orden vigente y 
lo interpretaban como una exigencia evangélica. Entendían, con Pablo VI, que "las organizaciones cristianas tienen una responsabilidad de acción colectiva"778.

De este modo, en estas acciones se ponía de manifiesto una determinada visión de la Iglesia y su relación con el mundo, y una forma de vivir la fe que asumía la necesidad de intervenir en la realidad de su tiempo y de su lugar en un sentido liberador. Nuevamente, la praxis social era pensada como el lugar mismo donde el cristiano jugaba con otros su destino de hombre y su fe en un Dios de la historia. La participación en el proceso de liberación se constituía en un lugar obligado y privilegiado de la reflexión -lugar teológico- y vida cristianas. La utopía, el proyecto de una sociedad donde "todo el mundo tenga vida",779, impulsaba la acción en el presente a través de la denuncia y el anuncio, ambas de insoslayable dimensión política en el contexto latinoamericano (Gutiérrez, 1971). En palabras de Touris (2011, 2012b), las acciones proféticas fueron el método y el imaginario liberacionista fue la utopía que iluminó el horizonte de estos actores.

Desde la perspectiva liberacionista, los cristianos debían ser críticos de la sociedad como servicio a la liberación del hombre. Aquí, la denuncia profética de la injusticia emergía como exigencia de la Iglesia en el contexto de la lucha contra la opresión en América Latina, e implicaba el rechazo al uso del cristianismo para legitimar el orden establecido. En palabras de la JUC en ocasión de su documento sobre la "Revolución Argentina": "como cristianos no podemos hacer menos que denunciar esta situación de injusticia, porque callando seríamos cómplices de la misma"780.

Como ha analizado Touris $(2011,2012 \mathrm{~b})$ para el caso del MSTM, los gestos proféticos marcaron el tono de una presencia cada vez más visible de los integrantes de la "constelación tercermundista" en la escena pública. En este camino, pretendían seguir la tradición del Antiguo Testamento, donde los líderes espirituales, más que entregarse a la liturgia, denunciaban las contradicciones de la situación política reinante; esto es, se proponían invertir la subordinación de la palabra al rito y devolverle su fuerza profética. El profeta, que desempeñaba a la vez un rol espiritual y político, y que lejos de aparecer como un teórico hacía denuncias concretas, se tornaba una figura capaz de aparecer como la voz de los sin voz -convirtiendo las palabras en instrumentos de

\footnotetext{
778 "Militante secuestrado y torturado en Punta Alta", Cristianismo y Revolución, 30, septiembre de 1971.

${ }^{779}$ Entrevista a José Zamorano, Moreno, 19/9/2009.

${ }^{780}$ Declaración (volante) de la Juventud Universitaria Católica de Bahía Blanca, sobre la "Revolución Argentina”, sin fecha. Archivo DIPPBA, Mesa A, Estudiantil, Juventud Universitaria Católica, Localidad Bahía Blanca, Legajo No 111.
} 
concientización del pueblo oprimido-, de enfrentarse a los poderes establecidos, así como de traducir el imperativo divino sobre la historia y de traer un mensaje de esperanza.

Pero no bastaba con denunciar este orden injusto, había que anunciar un nuevo tipo de sociedad y un nuevo hombre. El anuncio de otro mundo posible, como crecimiento del Reino de Dios, era la contracara y la consecuencia inevitable de la actitud profética. Se trataba de concretar históricamente la utopía cristiana -que estaba en relación con el Reino de Dios- a través de la creación de un orden social, político, económico y cultural radicalmente distinto al actual (Ellacuría, 1990c). Siguiendo a Touris $(2011,2012 b)$, la política era pensada como el medio exclusivo a través del cual podían impulsarse los proyectos transformadores. Desde esta óptica, sólo el desplazamiento al campo político permitiría la realización plena de la función profética. Si hay un momento histórico donde la profecía adquiere poderosa significación, es en las épocas de crisis, entendida ésta como la tensión entre un universo en extinción y otro a punto de nacer. Por lo tanto, lo que subyace en esta idea es que la irrupción del profeta en el campo político exige una identificación con el orden nuevo, revolucionario y cuya inminente emergencia se está anunciando. Si el profetismo bíblico era un profetismo político anclado en la función religiosa, el profetismo cristiano de corte tercermundista se desplazaría hacia la órbita secular ante el reconocimiento de que la política era el único medio propio del mundo moderno a través del cual podía trazarse un proyecto colectivo con el objeto de transformar la sociedad. En la convicción de que la participación católica debía estar presente en todos los espacios sociales, en el rechazo a la autonomización de la religión y la política, subyacía, nuevamente, la matriz católica integral.

Más allá de las actividades descriptas en este apartado, los militantes católicos no tenían un apostolado común como JUC, JOC o JEC. Como mencionamos en el capítulo 4, el grupo cristiano no era un espacio de acción, aunque interpelaba a sus miembros a asumir un compromiso. Sólo así cobraba sentido la revisión de las propias prácticas en sus comunidades. Ahora bien, si la JUC, la JOC o la JEC eran la comunidad de reflexión mientras, en palabras de Mónica, "el lugar de acción era afuera, era con otros ${ }^{\text {,781 }}$. ¿Cuáles eran los ámbitos de militancia católica de estos jóvenes? ¿En qué espacios encarnaban su compromiso cristiano? El próximo capítulo

\footnotetext{
${ }^{781}$ Entrevista a Mónica, Buenos Aires, 30/7/2008.
} 
está dedicado a abordar las diversas prácticas que asumieron los militantes de la JUC, la JOC y la JEC en vistas a participar del cambio social. 


\section{CAPÍTULO 6: El anuncio del Reino de Dios. Espacios y prácticas de la militancia católica}

\section{SUMARIO}

1) La acción pastoral

a) EI MIEC-JECI y la JOC

b) Scouts y Guías

c) La liturgia y la catequesis

2) El trabajo social

a) El voluntariado de Cáritas

b) La presencia en los barrios periféricos. El caso de Villa Nocito

3) La militancia en el lugar de trabajo

4) La militancia estudiantil: la escuela secundaria y la universidad

5) La militancia política y las opciones político-partidarias

a) EI "encanto y desencanto" con agrupaciones marxistas

b) La opción por el peronismo revolucionario

i) ¿Por qué el peronismo?

ii) Las redes católicas y la militancia política

iii) Las afinidades entre catolicismo liberacionista y peronismo

c) La lucha armada como forma de hacer política

En el intento de comprender el compromiso social y político de los jucistas, jocistas y jecistas bahienses analicé, en primer lugar, las influencias de viejas y nuevas formas de entender y vivir el catolicismo marcadas por la vocación de intervención social en un contexto histórico, latinoamericano y nacional, de efervescencia colectiva; luego, me adentré en las propias experiencias de los militantes en el descubrimiento de un modo "encarnado" de vivir la fe; por último, abordé las formas mediante las cuales estos jóvenes se involucraron colectivamente en la denuncia de las situaciones de injusticia, que entendían como primer paso de la transformación del orden vigente. En el presente capítulo intento dar cuenta de los espacios y las prácticas de la militancia católica bahiense. En este sentido, quiero avanzar en la reflexión en torno a las siguientes cuestiones: ¿qué afinidades podemos reconocer entre el catolicismo liberacionista y diversas opciones de compromiso ligadas a la idea de "cambio de estructuras"?, ¿cuáles fueron los ámbitos de construcción social y política de estos jóvenes?, ¿qué influencia tuvo la materialidad constitutiva de las relaciones sociales en la habilitación de estas alternativas de militancia?, ¿por qué algunos jucistas, jocistas y 
jecistas canalizaron su compromiso cristiano a través del activismo político-partidario e incluso armado?, ¿por qué una buena parte de ellos eligió el peronismo revolucionario?, ¿qué particularidades asumió este proceso en cada una de las tres ramas?

\section{1) La acción pastoral}

Los jóvenes de la JUC que optaron por la acción dentro del espacio eclesial, la desarrollaron como dirigentes del movimiento Guía-Scout de La Pequeña Obra, como catequistas o como militantes del MIEC-JECI. Algunos de ellos se ocupaban también de la música durante las misas. Si bien este tipo de intervención era alimentada por la reflexión con los compañeros, para Nancy, Patricia u Horacio Russin, por ejemplo, era anterior -e incluso, facilitó- la integración a los equipos de revisión de vida.

En cuanto a los jocistas, el trabajo pastoral fue uno de los espacios privilegiados en los que los militantes encarnaron su compromiso cristiano, constituyendo una de las particularidades de esta rama y marcando una diferencia respecto a los estudiantes. Esta acción se desarrolló en Nuestra Señora del Carmen o en las comunidades ligadas a aquélla, y daba cuenta del arraigo de estos jóvenes en la capilla de la "loma". En muchos casos, dicha participación era preexistente a la pertenencia a la JOC. Recordemos que parte de su núcleo fundacional fue contactado a partir de los vínculos tejidos en torno a la iglesia. Allí, entonces, los jocistas fueron catequistas, dirigentes de "San Jorge", animadores de celebraciones religiosas, así como "co-responsables" las comunidades de Grünbein y Harding Green.

En el caso de los jecistas, el ámbito de trabajo pastoral primordial para el grupo de La Pequeña Obra eran los Scouts "San Pío X” y las Guías "Santa Juana de Arco". La participación en estos espacios era de más larga data que la del ámbito de reflexión y constituía, incluso, el lugar fundamental de referencia. Cuando surgió la JEC, los protagonistas continuaron con la actividad Scout. En cuanto al grupo de Sánchez Elía, algunos jóvenes tenían como espacio de trabajo pastoral los Scouts "San Jorge", mientras otros canalizaban su compromiso en la liturgia y en la catequesis de la capilla. Asimismo, algunos jóvenes -en la "loma" y en La Pequeña Obra-, se comprometieron dentro del movimiento acompañando a nuevos equipos de reflexión, participando en encuentros nacionales, latinoamericanos o mundiales o trabajando en el Secretariado.

\footnotetext{
${ }^{782}$ Entrevista a José Zamorano, Moreno, 2/9/2011.
} 


\section{a) EI MIEC-JECI y la JOC}

La actuación intra-movimiento de los militantes de la JUC y la JEC, por un lado, y de la JOC, por el otro, se desarrolló de diversas maneras. En primer lugar, a través de la asistencia a los equipos que se iniciaban. En efecto, jucistas como Nora o Graciela acompañaron durante un tiempo a comunidades de secundarios en formación, y la última, durante su exilio en Buenos Aires en 1975, brindó su ayuda a un grupo de universitarios. Por su parte, Manuel hizo lo propio con un equipo jucista bahiense integrado por militantes de la Federación Juvenil Comunista (FJC) ${ }^{783}$. Asimismo, los miembros de la JEC con más experiencia, como Eduardo Ricci o Mónica, actuaron como coordinadores de los nuevos grupos. Por otra parte, algunos jocistas colaboraron con "Pepe" en el acompañamiento de los equipos de la "loma". Así, Mirta coordinó las primeras reuniones del grupo juvenil que terminó por conformar la $\mathrm{JEC}^{784}$.

Además, en esos años, Mirta y Jorge apoyaron en Grünbein la formación de un equipo de JOC con adolescentes de la comunidad, estudiantes y trabajadores. La iniciativa, si bien breve, alcanzó a elaborar un boletín llamado El Mensajero de la Juventud Obrera Católica de Grünbein, cuyo primer número data de abril de 1975, y a articular diversas acciones en el barrio. Entre ellas figuraban, en primer lugar, la ayuda dada a la escuela desde mediados de 1973, que incluyó el arreglo de los juegos, la pintura del comedor, la organización de rifas, kermeses y fiestas para recaudar fondos destinados a la instalación del gas y la compra de los calefactores ${ }^{785}$. En segundo lugar, los jocistas colaboraron con la comisión de fomento en los trámites de la instalación del agua corriente, cobrando casa por casa las cuotas correspondientes al zanjeo y a las piezas que faltaban ${ }^{786}$. En tercer lugar, el grupo promovió la animación de la liturgia, procurando que se celebrara misa al menos una vez por mes y organizando actividades para las fiestas -como el pesebre viviente de la Navidad de 1974-. Éste, que se proponía recibir a Jesús "que vuelve a nacer en cada año y se presenta entre nosotros en cada hombre que sufre desocupación, hambre, enfermedad", culminó con la entrega de las

\footnotetext{
${ }^{783}$ Entrevista a Manuel y Nancy, Neuquén, 21/3/2013.

${ }^{784}$ Entrevista a Mirta, Bahía Blanca, 18/6/2008.

785 "Nuestra ayuda a la escuela", El Mensajero de la Juventud Obrera Católica de Grünbein, 1, abril 1975.

786 "Nuestra ayuda en la instalación del agua", El Mensajero de la Juventud Obrera Católica de Grünbein, 1, abril 1975.
} 
ofrendas a "las familias más necesitadas del barrio"787. Por otro lado, al igual que el grupo de Sánchez Elía, los jocistas de Grünbein organizaron actividades recreativas destinadas a acercar nuevos integrantes al grupo. Una de ellas fue un viaje a Pehuen-có, realizado en enero de 1975, que congregó a unas 40 personas de Grünbein y Harding Green, donde se compartieron partidos de fútbol, el baño en el mar, caminatas, guitarreadas y una reflexión final donde cada uno expresó cómo había pasado el día ${ }^{788}$.

Los jóvenes afirmaban, con el fundador del movimiento, que la Iglesia había sido creada por Dios "para los pobres" y que para el cumplimiento de su misión "necesita muy de veras a la clase obrera". En este marco, la JOC venía a continuar la obra de Cristo en medio de los jóvenes trabajadores y trabajadoras, proclamando su dignidad, "sea cual sea su cultura y su actitud religiosa inicial". El movimiento se proponía entonces ayudarlos a descubrir "su propia personalidad, el sentido humano, religioso y apostólico de toda su vida" y a encontrar "a Cristo en las personas, en la amistad, en el trabajo, en el compañerismo". Asimismo, procuraba la "toma de conciencia" de los trabajadores de sus "condiciones inhumanas de vida", al tiempo que los invitaba "a actuar en pro de un mundo más justo, más humano, más fraterno",789.

Otra de las formas en que los jóvenes se comprometieron con la JOC o el MIECJECI -según los casos- fue como representantes de Bahía Blanca o de Argentina en los encuentros nacionales, del Cono Sur, latinoamericanos o mundiales. Como vimos en el capítulo 3, los bahienses estuvieron presentes en todas las instancias de intercambio del MIEC-JECI en el período. Algo similar puede decirse en el caso de los obreros, a pesar de que el nivel de articulación del movimiento era significativamente menor. Ángel, Graciela, Eduardo Ricci y Manuel representaron a los estudiantes católicos del país en los encuentros mundiales que tuvieron lugar en Inglaterra, Holanda y Perú, Julio lo hizo en el encuentro del Cono Sur en este último país, y "Pepe" participó como asesor “argentino" en Perú y en Colombia. Angélica hizo lo propio con los obreros católicos de Argentina en el encuentro mundial de Colombia. Por otra parte, Bahía Blanca, fue sede de encuentros nacionales tanto de la JUC como de la JOC, al tiempo que envió delegados -por ejemplo, Nora en el caso de los universitarios, o Mirta, Angélica y Bruno, en el de los trabajadores- a otros encuentros del país.

\footnotetext{
787 "El Pesebre Viviente”, El Mensajero de la Juventud Obrera Católica de Grunbein, 1, abril 1975. 788 "Salida a Pehuen-có”, El Mensajero de la Juventud Obrera Católica de Grunbein, 1, abril 1975. 789 “QQué es la JOC?”, El Mensajero de la Juventud Obrera Católica de Grunbein, 1, abril 1975.
} 
Estas instancias de intercambio trataban de reunir a líderes representativos del pensar y sentir de las bases del movimiento ${ }^{790}$. De allí que la asistencia a los mismos fuera rigurosamente seleccionada entre aquellas personas consideradas capaces de comunicar la experiencia de su lugar, de hacer un trabajo de síntesis e interpretación, y de la posterior difusión de lo hablado en su comunidad ${ }^{791}$. Así, los requisitos para los participantes de la Sesión de Estudios y el Comité Latinoamericano del MIEC-JECI correspondiente al período 1970-1972, eran ser miembro de la coordinación nacional si existía, o, en su defecto, de la coordinación regional de ciudad; tener experiencia en el movimiento de por lo menos año y medio, y amplia experiencia pedagógica y "praxis de compromiso liberador", y, por último, garantizar la permanencia en el movimiento ${ }^{792}$.

Algunos bahienses, incluso, se dedicaron al movimiento a tiempo completo. Eduardo, Manuel, Nancy, Mónica y Juan Carlos trabajaron temporalmente para el MIEC-JECI desde el Secretariado Latinoamericano, y el último lo hizo también durante su exilio en la sede mundial de la JECI. Los miembros del SLA viajaban a los diferentes lugares para participar en las reuniones de equipo, trabajar con las coordinaciones nacionales, hacer extensión de la JUC o la JEC donde fuera débil y aportar elementos de pedagogía, pastoral y teología, así como instrumentos teóricos de "análisis de la realidad"793. El SLA estaba integrado por un secretario y un equipo permanente compuesto por militantes de base de distintos países del subcontinente que se renovaban periódicamente, siendo elegidos entre los referentes destacados de las diversas comunidades, por su inserción en ellas ${ }^{794}$, su formación, y su compromiso social y político. En este sentido, a principios de 1972 se planteaba la necesidad de contar con líderes "capaces de una respuesta global a la problemática del Movimiento en América Latina, pero al mismo tiempo, capaces de movilizar a cristianos que ya están pensando de manera más sistemática y especializada el problema de la sociedad, de la Iglesia"795.

La experiencia de Eduardo en el Secretariado puede servir para ilustrar la militancia intra-movimiento de los referentes locales. El joven integró el equipo latinoamericano entre febrero de 1971 y febrero de 1973, junto a militantes de Brasil -

\footnotetext{
790 “Sesión Mundial 70”, JEC Boletín Secundario, 10, junio 1969.

791 "Informe 10. Cali: Comité Latinoamericano", Spes, 10, agosto-septiembre 1970.

792 "Noticias del SLA", Spes, 19, octubre 1972.

793 "Aproximación a la realidad latinoamericana. Iglesia-Movimiento", Spes, 19, octubre 1972.

${ }^{794}$ Entrevista a Juan Carlos, Buenos Aires, 1/8/2008.

795 “Aproximación a la realidad latinoamericana. Iglesia-Movimiento”, Spes, 19, octubre 1972.
} 
Teresa-, El Salvador -Andrés Campos ${ }^{796}$-, México -Francisco Merino-, Colombia -Iván Jaramillo $^{797}$ - y Perú -Gilberto Valdéz-. Su trabajo se focalizó en Centroamérica y México. Así, tomando como base El Salvador, recorrió al menos dos veces los países de la región: Colombia, México, Honduras, Guatemala, Nicaragua y Costa Rica, además de visitar las sedes del Secretariado en Montevideo y en Lima ${ }^{798}$.
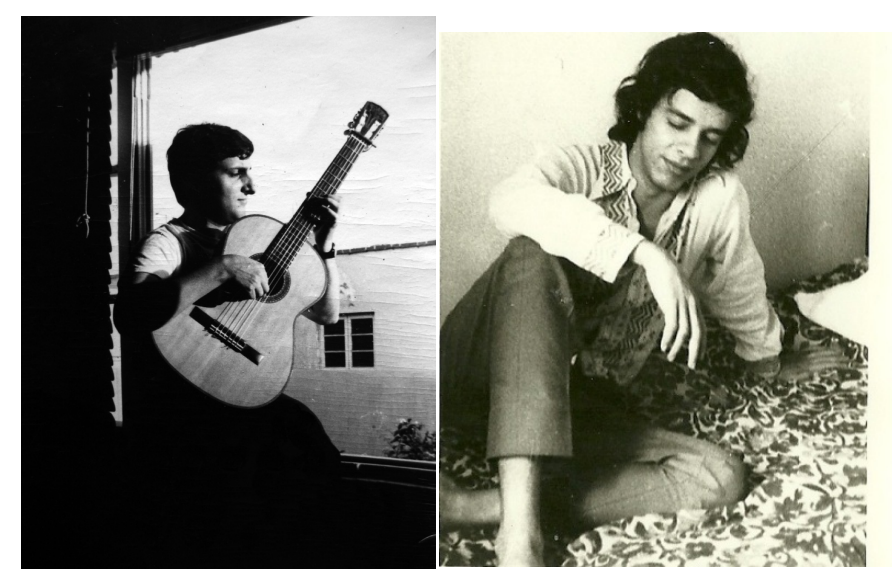

Izq.: Eduardo en la sede del SLA en Lima (1971-1972). Der.: Iván Jaramillo. Foto tomada por Eduardo en el Comité Latinoamericano del MIEC-JECI. Lima, diciembre de 1972.

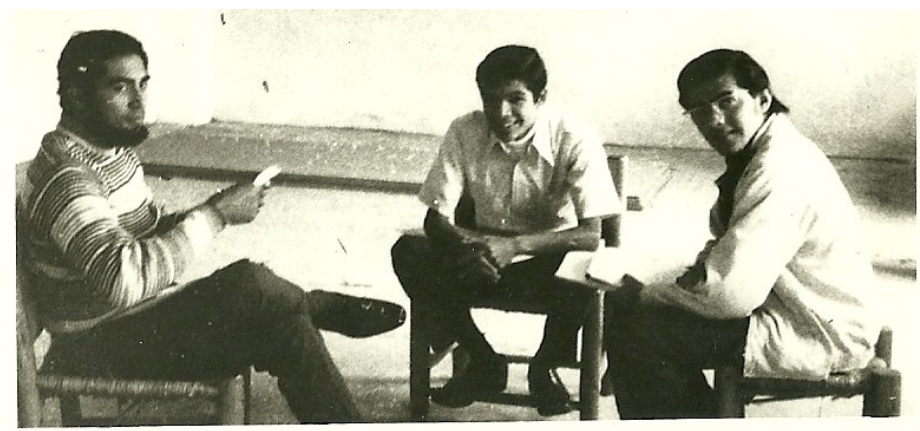

De izq. a der.: un asesor del movimiento, un militante de Honduras y Andrés Campos.

Foto tomada por Eduardo, 1971-1972.

En ese itinerario, participó del encuentro de Centroamérica, México y Caribe celebrado en Guatemala, en marzo de 1971; de la convención nacional del MEP en México en septiembre-octubre de 1971; del encuentro latinoamericano de asesores,

\footnotetext{
${ }^{796}$ Estudiante jecista. En 1971, llevó a cabo trabajo de base con la JEC de Paraguay, Bolivia ("Noticias", JEC Boletín Secundario, 17, junio de 1971) y Chile.

${ }^{797}$ Militante de la JEC. Entre otras tareas, estuvo a cargo de la publicación del documento "La coyuntura del movimiento hoy: visión histórica I y II", que versaba sobre la relación fe-política, con el objetivo de clarificarla y colaborar en la tarea del cristiano comprometido (Servicio de Documentación, doc. 1 y 2 , s/f). En 1971, realizó trabajo de base en Argentina ("Noticias", JEC Boletín Secundario, 17, junio 1971).

${ }^{798}$ Pasaporte de Eduardo. Archivo personal de Eduardo.
} 
realizado en Medellín a fines de octubre y principios de noviembre de 1971; y del encuentro del Cono Sur, que tuvo lugar en Lima en diciembre de 1972. Además, trabajó con diversos equipos. Así, tiempo después, una militante guatemalteca, le escribía agradeciendo "lo que nos diste, gracias por tu amistad, por tus cuestionamientos, por tu ejemplo, gracias a ti, mucho aprendimos"799.
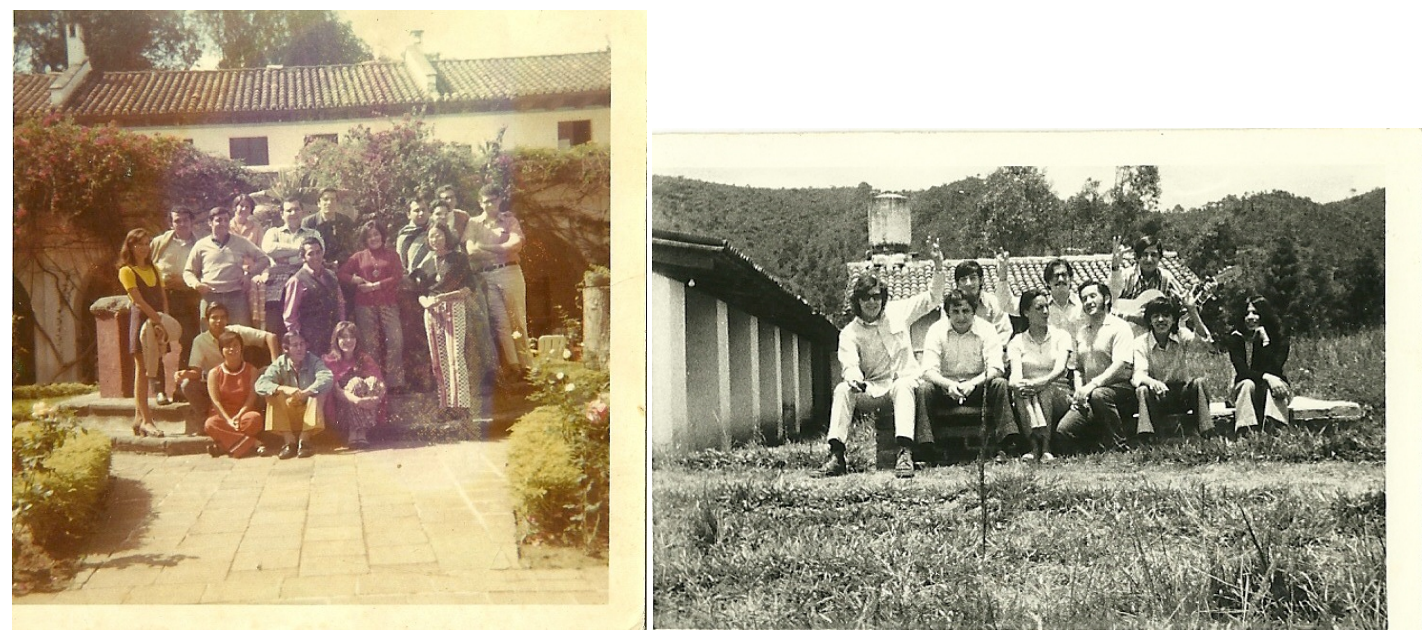

Izq.: encuentro de jóvenes del movimiento provenientes de Honduras, Costa Rica, República Dominicana, Nicaragua, Guatemala, El Salvador y México, en Guatemala, marzo de 1971. Der.: miembros del movimiento en Guatemala durante la segunda visita de Eduardo en 1972.

En esos dos años, la dedicación al movimiento fue exclusiva. En este sentido, a poco de dejar el país, Eduardo escribía desde Montevideo: "Estoy trabajando con la gente del SLA muy fuerte y a la vez estudio" ${ }^{" 000}$. Y desde el Centro Universitario Católico de El Salvador contaba: "yo, tratando de hacer todo lo que pueda y recogiendo la mayor experiencia posible ya que la oportunidad me lo permite" ${ }^{801}$. El trabajo obligaba a estar continuamente viajando. En ese itinerario, en orden a acompañar a los movimientos y en un escenario latinoamericano marcado por la efervescencia social y, a la vez, por la represión, la mirada estaba puesta en la realidad social y política. Así, en una postal dirigida a su hermano desde Honduras, Eduardo le mostraba una choza para que se imaginara "cómo viven los campesinos":

\footnotetext{
${ }^{799}$ Postal de Patricia Urrutia, enviada a Eduardo desde Guatemala, s/f. Archivo personal de Eduardo.

${ }^{800}$ Postal de Eduardo desde Montevideo dirigida a sus padres, s/f. Archivo personal de Eduardo.

${ }^{801}$ Postal de Eduardo desde El Salvador a sus compañeros del Pensionado Católico, s/f. Archivo personal de Eduardo. La intensidad del trabajo en el movimiento es corroborada por la experiencia de Olga María, integrante del secretariado nacional de Guatemala. En una postal del 13/12/1972, la militante contaba: "el trabajo está bien duro, sigo con desvelos y sin tiempo para nada". Archivo personal de Eduardo.
} 


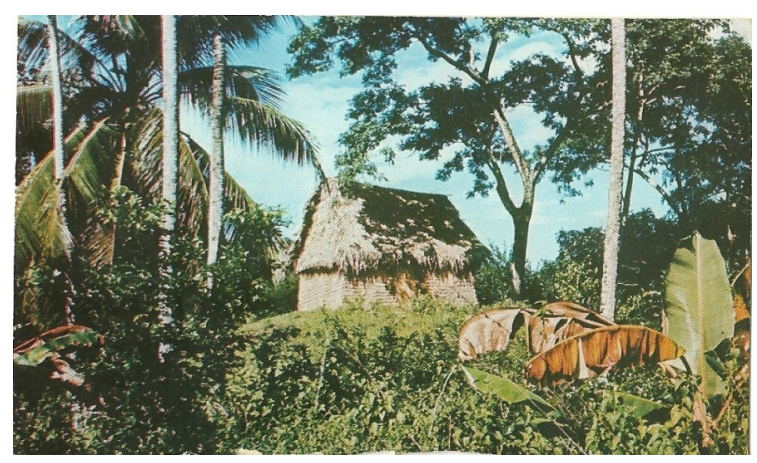

En otra postal enviada a sus padres, con la imagen del Hotel Intercontinental de Managua, Eduardo decía: "miren cómo se castigan los gamboas, mientras el pueblo de Nicaragua se está muriendo de hambre. 40 a 50\% de mortalidad infantil, 60 a $65 \%$ de desocupación, 60 a 65\% de analfabetismo. ¡QQué me cuentan!!’. También desde la capital nicaragüense, despachaba otra tarjeta, "para que se den una idea de la pobreza que hay por aquí, las casitas que pueden apreciar son de las mejorcitas que se pueden ver en Managua y ¡eso que es la parte central!’. Y desde México, mandaba una foto de la plaza de Tlatelolco y explicaba que allí "los estudiantes fueron encerrados prácticamente y luego masacrados" ${ }^{802}$.

La tarea asumida desde el SLA no estuvo exenta de peligros. Así, a fines de 1971, Eduardo y Francisco Merino fueron detenidos en Montevideo e interrogados por la policía, que creía ver en el equipo un nexo entre los revolucionarios latinoamericanos ${ }^{803}$. Al mismo tiempo, cuando Andrés Campos retornaba de trabajar con compañeros católicos de Concepción, el jecista fue impedido de bajar en el aeropuerto de Montevideo y obligado a tomar un avión para Brasil, donde fue arrestado y torturado durante 11 días. Según el militante, sus captores pretendían que confesara ser un agente de enlace de los tupamaros, un espía cubano y un comunista infiltrado en la Iglesia ${ }^{804}$.

Otros bahienses se dedicaron a hacer un trabajo de extensión del movimiento en el ámbito nacional. En el marco de la crisis en la que estaba inmersa la JUC y del protagonismo que adquiría en esos años el grupo bahiense, hubo varios intentos de reanimar el movimiento de la mano de los militantes locales con ayuda del SLA. En efecto, la extensión era una preocupación del MIEC-JECI, de allí que apuntara a la formación de movimientos fuertes y estructurados a nivel nacional, con coordinaciones

\footnotetext{
${ }^{802}$ Postales de Eduardo, s/f. Archivo personal de Eduardo.

${ }^{803}$ Conversación con Eduardo, 5/1/2014.

804 “Mi fe creció en prisión”, Spes, 19, octubre 1972.
} 
representativas y militantes formados, y al mismo tiempo, al crecimiento del número de integrantes: "no nos interesa ser pocos. Nos interesa ser numerosos y por lo tanto cuantitativamente significativos en el medio estudiantil y en la Iglesia misma". Se planteaba el trabajo prioritariamente en países con importancia geopolítica -entre ellos, Argentina-, insistiendo en las coordinaciones nacionales ${ }^{805}$. Así, en 1971, se encomendó a Manuel que viajara por el interior en busca de las experiencias jucistas que aún sobrevivían con el propósito de contribuir a su relanzamiento. Entonces, el militante visitó Mar del Plata, donde se formó un grupo de una docena de jóvenes a partir de un núcleo preexistente, y Santa Rosa, donde se constituyó una comunidad incipiente. También fue a Buenos Aires, Santa Fe y Córdoba, donde, sin embargo, encontró ex jucistas dispersos, lanzados al compromiso político-militar, y sacerdotes que lejos de estar interesados en asesorar estudiantes, se abocaban al trabajo villero o con obreros ${ }^{806}$. De este modo, si bien el acompañamiento bahiense fue significativo para ciertas experiencias nacientes, mostró una vez más, que la JUC local se afianzaba a contramano del panorama general. Por otra parte, hacia 1974, Julio viajó a Río Cuarto y a Mendoza, junto a una militante peruana, para contactar estudiantes dispuestos a retomar la $\mathrm{JUC}^{807}$.

\section{b) Scouts y Guías}

En el centro pastoral del barrio Pedro Pico, militantes jucistas y jecistas integraban un núcleo de dirigentes, el "consejo de grupo", que desarrollaba un trabajo sistemático no sólo en relación a la planificación de actividades destinadas a los niños y adolescentes, sino también al estudio y la discusión en torno a los documentos de la Iglesia, temas de educación ${ }^{808} \mathrm{y}$ hechos de la realidad, acompañados por Kotska y “Pepe". En cuanto a las primeras, como mencionamos en el capítulo 3, se inspiraban en la inquietud de ir más allá de propuestas meramente recreativas y promover momentos de reflexión dedicados a cuestiones como la solidaridad, el compañerismo o la necesidad de compartir. En este sentido, para algunos, el scoutismo y la militancia laica en la Iglesia estaban orientados a la "promoción integral de las personas" 809 . Según Susana, la vivencia de comunidad de los dirigentes de "San Pío" y "Santa Juana" de la

\footnotetext{
805 “Aproximación a la realidad latinoamericana. Iglesia-Movimiento", Spes, 19, octubre 1972.

${ }^{806}$ Entrevista a Manuel y Nancy, Neuquén, 20 y 21/3/2013.

${ }^{807}$ Entrevista a Julio, Bahía Blanca, 22/5/2010.

808 “1970”, Esapi de Oro, 7, octubre de 2011.

809 "Diáspora", por Susana Garbiero y Alejandro Cantaro, Esapi de Oro, 7, octubre de 2011.
} 
"generación del '70" estaba basada en la lucha por el "Hombre Nuevo", "nuevo para transformar la realidad, nuevo para luchar contra el pecado (injusticias)", en la idea de "dar la vida por los hermanos más pobres"; "Ser Scout (o guía) era ser comprometido, coherente" $" 810$. De forma similar, para Nancy, las Guías significaron "poner en práctica el Evangelio" "11. Y para Patricia, la espiritualidad que animaba a las Guías era la "preparación para la vida de servicio",812.
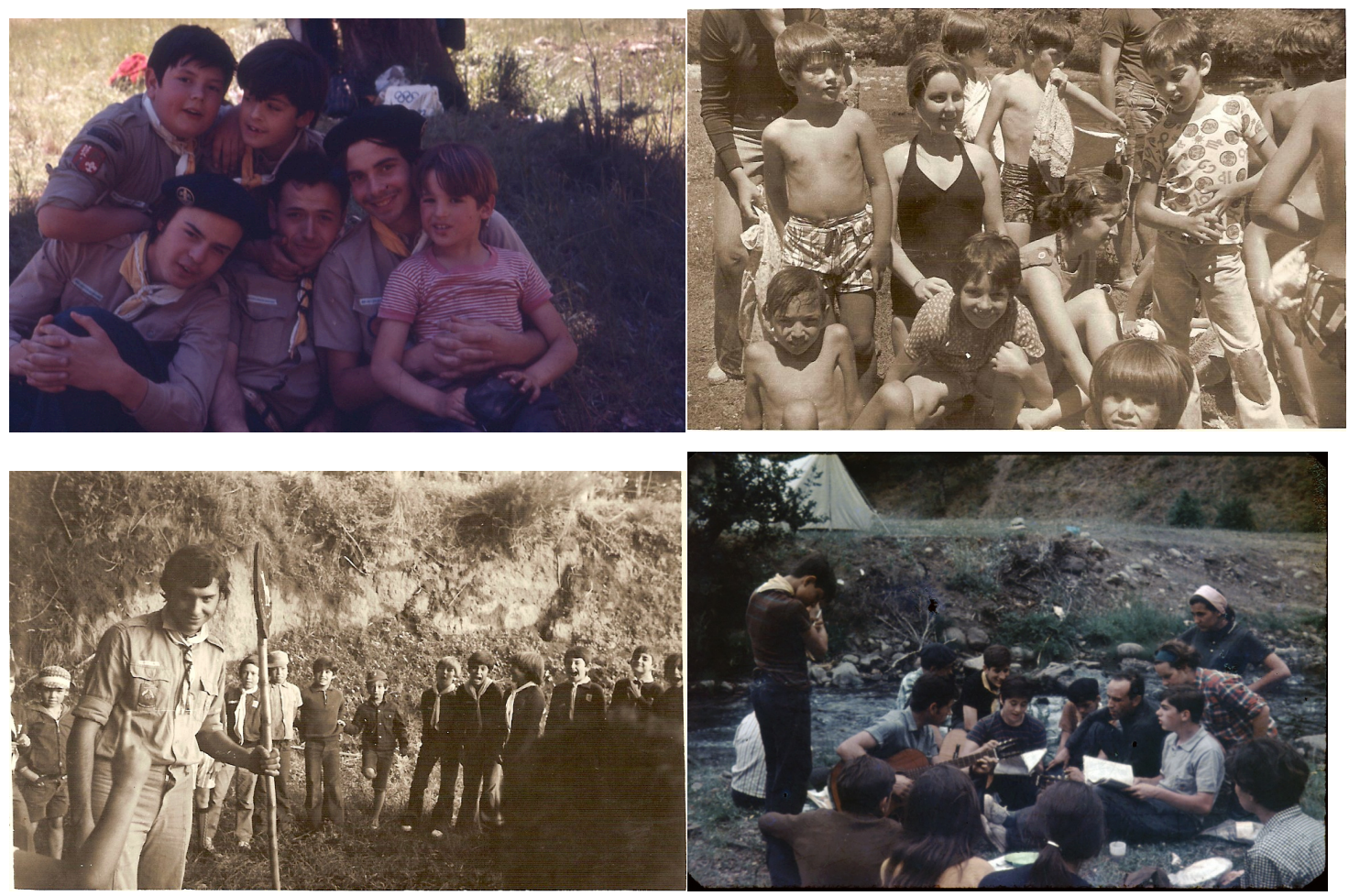

Dirigentes Scouts y Guías con niños y jóvenes del movimiento durante los campamentos. En el centro de la primera foto, Horacio Russin, y a su derecha Eduardo Ricci.
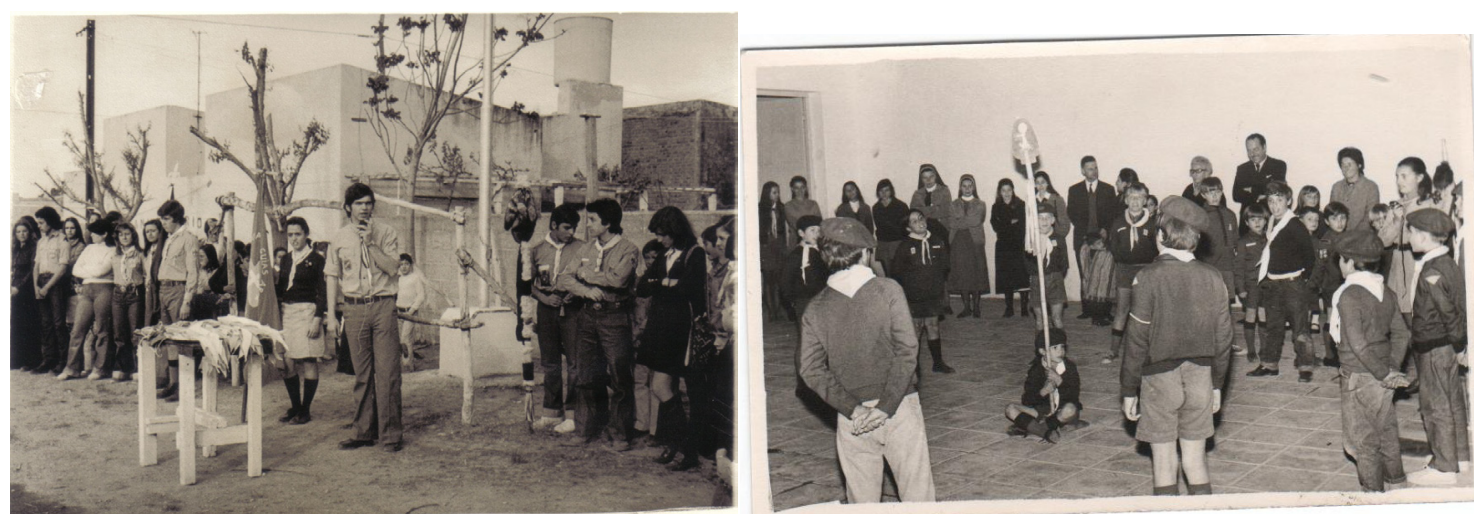

\footnotetext{
810 “A corazón abierto”, por Susana Garbiero, Esapi de Oro, 7, octubre de 2011.

${ }^{811}$ Entrevista a Nancy y Manuel, Neuquén, 21/3/2013.

${ }^{812}$ Entrevista a Patricia, Bahía Blanca, 19/5/2008.
} 
Izq.: actividad en el terreno Scout. Der.: Elizabeth Frers ${ }^{813}$ (derecha) con sus lobatos.

Otros integrantes de la JOC, de la JEC e incluso de la JUC llevaron adelante su compromiso cristiano en los Scouts "San Jorge" de Sánchez Elía. El trabajo apuntaba a la formación de los niños y jóvenes en los valores cristianos, sintetizados en el propósito de "dejar el mundo un poco mejor de cómo lo encontramos" $" 14$. Como explicaba Ema, una de las primeras akelas, el acento no estaba puesto en el método y las técnicas del Scoutismo sino en el aprendizaje y el ejercicio de valores, como la solidaridad, a través de la vida al aire libre, el juego, la convivencia y los momentos de reflexión: "yo no entendía mucho de Baden Powell y toda la historia, porque lo que acá armábamos era la educación por el compromiso, o sea, en el Scoutismo veíamos otros detalles. Era más

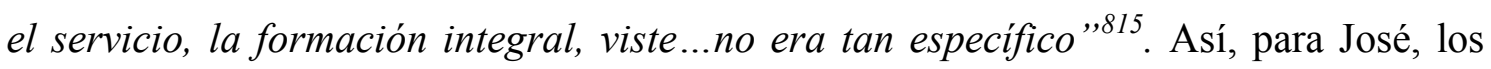
Scouts fueron el lugar donde mamó y, al mismo tiempo, canalizó el ideal de servicio y el mandamiento del amor al prójimo ${ }^{816}$.

\section{c) La liturgia y la catequesis}

Entre los jucistas, jocistas y jecistas hubo animadores de la liturgia y catequistas. En primer lugar, participaban de la Eucaristía a través de la música. En Sánchez Elía, habían organizado un coro que dirigía una religiosa del Pequeño Cottolengo - espacio donde se juntaban a ensayar-, en el que José y la Rusa tocaban la guitarra mientras otros jóvenes, como Clara, cantaban ${ }^{817}$. En La Pequeña Obra, tampoco faltaban los músicos, entre ellos, Horacio Russin, Ana o Francisco.

\footnotetext{
813 Dirigente Scout de La Pequeña Obra hasta 1973, integrante de la JUC y militante de la JUP. Fue secuestrada en enero de 1977 y vista en el CCD La Escuelita. El 13/4/1977 fue trasladada a La Plata y días después, fusilada en un falso enfrentamiento (Véase Partnoy (2006); "Caen otros 8 extremistas", LNP, 22/4/1977; y Poder Judicial de la Nación, Veredicto dictado en la causa $N^{\circ} 982$ caratulada "Bayón Juan Manuel y otros...", 12/9/2012, disponible en el Centro de Información Judicial: http://www.cij.gov.ar/nota-9833-Condenaron-a-prision-perpetua-a-14-acusados-por-crimenes-de-lesahumanidad-cometidos-en-Bahia-Blanca.html).

${ }^{814}$ Entrevista a José, Bahía Blanca, 19/6/2008.

${ }^{815}$ Entrevista a Ema, Bahía Blanca, 27/9/2012.

${ }^{816}$ Entrevista a José, Bahía Blanca, 19/6/2008.

${ }^{817}$ Entrevista a Clara, Bahía Blanca, 10/10/2012.
} 


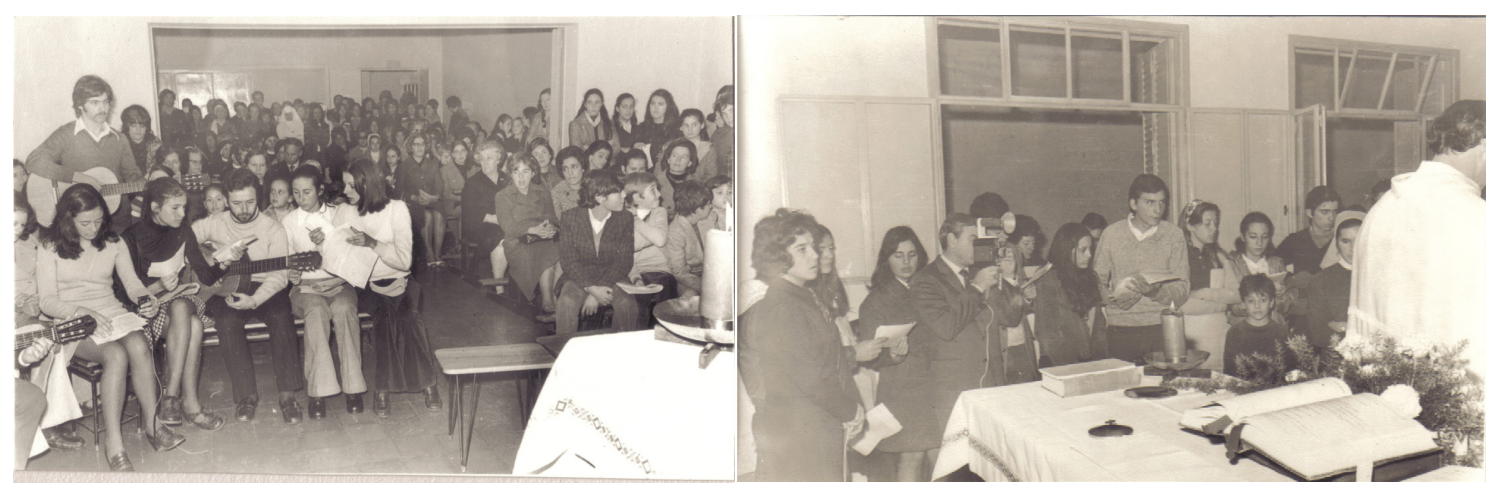

El coro en La Pequeña Obra. En la primera foto, Horacio Russin sentado tocando la guitarra. En la segunda, a la izquierda, detrás del fotógrafo, Ely Frers.

Asimismo, en la "loma", los jocistas intervenían en la organización de jornadas de reflexión, encuentros y celebraciones con motivo de la Pascua o la Navidad. En diciembre de 1973, por ejemplo, hicieron un pesebre viviente que recorrió el barrio e involucró a toda la comunidad de la capilla ${ }^{818}$. Por otra parte, algunos jóvenes protagonizaron los comienzos de nuevos grupos de Nuestra Señora del Carmen. Así, Clara y Liliana, en vistas a "hacer un trabajo para la comunidad", impulsaron los primeros pasos de la Cáritas de la capilla ${ }^{819}$.

En cuanto a la catequesis, algunos integrantes de la JOC y de la JEC estaban a cargo de esta tarea en Nuestra Señora del Carmen, con la ayuda de las hermanas del Pequeño Cottolengo, con quienes se reunían para formarse y planificar las actividades. Por otra parte, los jocistas se desempeñaron como catequistas en Grünbein y Harding Green. Esta labor, que se orientaba a preparar a los niños para recibir los sacramentos de la comunión y confirmación, estaba ya impregnada por la renovación católica, que rompía con la forma tradicional del estudio de la religión que habían conocido los militantes en su niñez. En este sentido, para enseñar catecismo no hacía falta contar con una formación religiosa sólida, sino poder transmitir lo que entendían como la esencia del mensaje de Jesús. Así, Clara decía de su trabajo en Grünbein: “hacíamos no el catecismo que me tocó a mí sino el de hablarle a los chicos, de enseñarles a ser solidarios, a ser compañeros, a ayudar al otro, desde ese punto de vista ${ }^{, 820}$.

El trabajo pastoral de los jocistas en los barrios fue impulsada por "Pepe" Zamorano, en parte a raíz de la partida de Emilio Flores, que lo obligó a asumir mayores responsabilidades en otros espacios hasta entonces a cargo de aquél. Esos jóvenes, en

\footnotetext{
818 “El pesebre viviente", El Mensajero de la Juventud Obrera Católica de Grunbein, 1, abril 1975.

${ }^{819}$ Entrevista a Clara, Bahía Blanca, 10/10/2012.

${ }^{820}$ Entrevista a Clara, Bahía Blanca, 10/10/2012.
} 
algunos casos -como el de la Rusa o el de Mirta en los primeros años- provenían de Sánchez Elía, y en otros, vivían en el mismo lugar -por ejemplo, Angélica en Harding Green, o Mirta y Jorge desde 1974 en Grünbein-. Se trataba de comunidades incipientes que se afianzaron como resultado del trabajo del misionero español, acompañado y luego continuado con mayor protagonismo por los laicos. Así, la comunidad de San Lucas en Grünbein se inició en 1968 con la celebración de la misa y los encuentros de catequesis. Mirta recordaba: “cuando fuimos nosotros no se hacía misa, nada y se empezó a hacer misa en la escuela" ${ }^{\prime 21}$. En cambio, la comunidad de Cristo Rey en Harding Green databa de 1949 cuando se comenzaron a rezar misas, aunque fue posteriormente cuando algunos sacerdotes -franciscanos, primero, y salesianos, después- atendieron el barrio con mayor regularidad y organizaron la catequesis, constituyéndose entre 1960 y 1962 en un lugar de misión ${ }^{822}$. Bruno recordaba su inserción en esa comunidad, donde trabajaba junto Angélica: "formamos grupos ahí, porque ya lo teníamos medio incorporado. Una experiencia muy linda tuvimos en el barrio, con chicos de ahí, con gente, eran todos laburantes, un barrio medianamente humilde $^{, 823}$. De ese trabajo pastoral surgió la catequesis para niños que no habían tomado la comunión o que, incluso, no estaban bautizados, en un asentamiento cercano integrado por trabajadores de los hornos de ladrillos.

El compromiso de los catequistas no se limitaba a los encuentros de preparación para la Eucaristía sino que incluía, además, un trabajo con los niños y sus familias o, en palabras de Angélica, "algún ingrediente de compromiso, de comunicación en el barrio ${ }^{824}$. Los mismos catequistas, junto a otros compañeros de la JOC, organizaban actividades recreativas semanales y otras más esporádicas, que, al igual que la catequesis, si bien estaban centradas en los jóvenes también buscaban integrar a los adultos, a través de la preparación de las jornadas. Al respecto, Angélica contaba de Harding Green: "los sábados a la tarde convocábamos a los jóvenes para jugar al vóley [...] festejábamos el día del niño, con lo cual había una convocatoria re linda, hacíamos chocolate, entonces le dábamos lugar a las mamás que se acerquen y participen" 825 . Y Clara relataba una anécdota de una fiesta del día del niño en Grünbein: "yo cero haciendo tortas en esa época. Bueno, hice una torta y la

\footnotetext{
${ }^{821}$ Entrevista a Mirta, Bahía Blanca, 18/6/2008.

${ }^{822}$ Arzobispado de Bahía Blanca, Guía Arquidiocesana. 1997.

${ }^{823}$ Entrevista a Bruno, Bahía Blanca, 4/8/2012.

${ }^{824}$ Entrevista a Angélica, Bahía Blanca, 25/4/2012.

${ }^{825}$ Entrevista a Angélica, Bahía Blanca, 25/4/2012.
} 
emborraché, pero la emborraché tanto que la torta andaba nadando en el vino. Y los chicos me dicen 'señorita, iqué olor a vino tiene esta torta!',826. En este sentido, la preparación para los sacramentos o la animación de grupos juveniles no era un fin en sí mismo sino que era más bien, el instrumento para trabajar en el barrio. Para los actores, no se trataba de procurar que más gente se incorporase a la Iglesia, sino de comprometerse con las personas, en la lucha por su dignidad. De esta manera, la tarea tenía como horizonte la transformación social, y era su manera de canalizar su compromiso cristiano.

De forma similar, durante la primera mitad de la década de 1970, para los Scouts y las Guías de La Pequeña Obra, la catequesis en los barrios estaba estrechamente unida al apoyo escolar de los niños, la asistencia a los enfermos y la ayuda a las familias, al descubrir que la "opción por los pobres de la Iglesia necesariamente debía incluir un compromiso concreto y que el cambio de la sociedad debía comenzar por uno mismo" ${ }^{827}$. En Villa Serra ${ }^{828}$, por ejemplo, se había iniciado un trabajo pastoral del que Pedro y Mario participaban intentando formar un grupo Scout ${ }^{829}$. Y en Villa Quilmes, los dirigentes coordinaban encuentros semanales de preparación para la comunión ${ }^{830}$.

\section{2) El trabajo social}

\section{a) El voluntariado de Cáritas}

Había jóvenes de la comunidad Guía-Scout y de la JEC, tanto de Sánchez Elía como de La Pequeña Obra, y de la JUC, como voluntarios en Cáritas Arquidiocesana. Algunos habían dejado atrás esa experiencia cuando se incorporaron al grupo Scout, de modo que para ellos fue anterior a la participación en la JEC, aunque considerada parte del mismo proceso de descubrimiento, en palabras de María del Carmen, “del propio camino desde donde trabajar por los demás" ${ }^{831}$. Para otros, llegó a ser una de las formas en las que eligieron encarnar el compromiso cristiano.

\footnotetext{
${ }^{826}$ Entrevista a Clara, Bahía Blanca, 10/10/2012.

827 "1970", Esapi de Oro, 7, octubre de 2011. Entrevista a Cecilia, Bahía Blanca, 2/6/2011.

${ }^{828}$ Ubicado al sur de la ciudad, entonces era una zona de chacras de tamariscos.

${ }^{829}$ Entrevista a Mario, Bahía Blanca, 5/1/2013. Entrevista a Pedro, Buenos Aires, 15/11/2012.

${ }^{830}$ Entrevista a María del Carmen, Bahía Blanca, 18/5/2011.

${ }^{831}$ Entrevista a María del Carmen, Bahía Blanca, 18/5/2011.
} 
Una de las secciones en las que los militantes llevaban adelante su voluntariado era el mimeógrafo. Aquí se turnaban Néstor Grill ${ }^{832}$ o Juan. Por su parte, Inés colaboraba armando los apuntes ${ }^{833}$. El trabajo implicaba tipiar textos, imprimirlos y multiplicarlos para venderlos a los alumnos del Instituto Juan XXIII. De esta manera, Cáritas obtenía dinero para solventar los servicios de farmacia, alimentos, etc. En este sentido, el criterio que la institución sostenía era que las ayudas recibidas debían provenir del trabajo y no de fuentes que resultaran contradictorias con el Evangelio ${ }^{834}$. Zulma sintetizaba: "Caritas tenía que manejarse con recursos genuinos. No podíamos

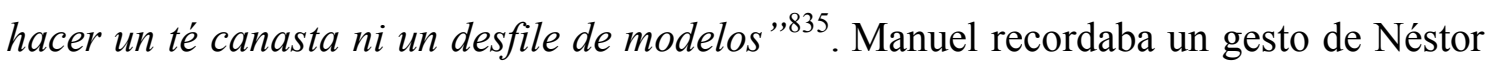
Navarro que puede servir para ilustrar este punto: "rechaza la donación del Ejército de mantas...porque es el Ejército, y Cáritas no puede aceptar mantas de los soldados para los pobres, de un Ejército que nosotros decíamos 'está contra los pobres" ",836.

También en orden a conseguir los recursos económicos necesarios para sus actividades, Cáritas inauguró una librería debajo de las escalinatas del Instituto salesiano, donde vendía a un precio accesible para los alumnos los textos de lectura obligatoria solicitados por los docentes. Durante un año, ésta fue atendida por Manuel, quien además se encargaba de comprar los libros en Buenos Aires ${ }^{837}$.

Otros voluntarios trabajaban en la sección Farmacia. Cáritas tenía un convenio con la farmacia de Empleados de Comercio por el cual ésta le vendía medicamentos contra receta con descuento, y luego la institución se encargaba de entregarlos en forma gratuita a las personas que los necesitaban. Por otra parte, había conseguido que una lista de médicos le diera las muestras gratis y que diversos laboratorios le donaran remedios. En este marco, los jóvenes, entre ellos, Ana o Eduardo Ricci, cubrían turnos

\footnotetext{
${ }^{832}$ Nacido en Jacinto Arauz, tenía 23 años y cursaba tercer año de la Escuela Técnica. Fue secuestrado por un grupo de tareas de la Marina, de su domicilio de Darregueira 441 de Bahía Blanca el 4/11/1976. Fue llevado al CCD "Baterías", de donde habría sido retirado la noche del 22 de noviembre. Aún permanece desaparecido. Disponible en: http://juiciobahiablanca.wordpress.com/el-juicio/, consultado el 19/9/2014.

${ }^{833}$ Entrevista a Inés, Bahía Blanca, 18/6/2011.

${ }^{834}$ Entrevista a Néstor Navarro, Bahía Blanca, 18/11/2010.

${ }^{835}$ Entrevista a Zulma, Bahía Blanca, 25/8/2010.

${ }^{836}$ Entrevista a Manuel y Nancy, Neuquén, 20/3/2013.

837 Entrevista a Manuel y Nancy, Neuquén, 20/3/2013. Según Zulma (entrevista, Bahía Blanca, 25/8/2010), durante otro período, la librería fue atendida por Diana Diez, quien trabajaba en ENTEL. El 18/11/1976, mientras Diana transitaba por Darregueira y Donado, fue secuestrada por varias personas armadas. Fue interrogada y permaneció en cautiverio en el CCD "Baterías" hasta su liberación el 4/2/1977. Disponible en: http://juiciobahiablanca.wordpress.com/el-juicio/, consultado el 19/9/2014.
} 
para ordenar los medicamentos que llegaban, atender los pedidos y comunicarse con los laboratorios o con la farmacia para conseguirlos ${ }^{838}$.

Asimismo, Cáritas contaba con la ayuda de los voluntarios en la sección alimentos -entre ellos, María Clara Ciocchini ${ }^{839}$ - y en la de ropería. Aquí, las asistentes sociales indicaban qué tipo de ropa se necesitaba, un grupo de mujeres -entre las que se encontraba Elda Ciocchini o la madre de Patricia- remendaba las prendas de las donaciones, y luego, las jóvenes, como María del Carmen o Cecilia, se ocupaban de separarlas por talles, doblarlas, armar las bolsas de los pedidos $\mathrm{y}$, en ocasiones, entregarlas a las familias destinatarias ${ }^{840}$.

Por último, Cáritas era el lugar de las prácticas de los estudiantes de la Escuela de Servicio Social, por lo cual, un grupo importante de jucistas trabajó también en la institución, entre ellos, Aída, Nora u Horacio Russin. En estos casos, la misma elección de la carrera estaba motivada por el intento de asumir un mayor compromiso cristiano del lado de los marginados en espacios que, superando el asistencialismo, se ocuparan de su promoción. En este sentido, decía Aída: "no era Cáritas que entregabas un paquete de fideos y chau, y un saquito de lana. Era atender a la gente, prestarle atención, involucrarse con su problemática" ${ }^{841}$.

\section{b) La presencia en los barrios periféricos. El caso de Villa Nocito}

Por otra parte, los Scouts, Guías y jecistas vinculados a La Pequeña Obra descubrieron el compromiso social a través de diversas experiencias de "servicio" ligadas a la pertenencia al grupo y, fundamentalmente, a las ramas mayores. Esto podía tomar distintas formas, desde colectas de alimentos o campañas de ayuda a los damnificados de una inundación, hasta acciones puntales de asistencia a personas humildes, que apuntaban a resolver necesidades concretas y a compartir tiempo con ellas. Así, Carlos, Eduardo Ricci, Pedro y Gabriel visitaban un conventillo ubicado en Villa Mitre donde vivía una señora que se encontraba postrada y su hija, y le llevaban alimentos, le hacían las compras, le brindaban compañía con la guitarra y le arreglaban

${ }^{838}$ Entrevista a Néstor Navarro, Bahía Blanca, 18/11/2010; a Zulma Bahía Blanca, 25/8/2010; a Ana, Bahía Blanca, 17/10/2012.

${ }^{839}$ Entrevista a Zulma Bahía Blanca, 25/8/2010. María Clara fue guía de La Pequeña Obra, estudiante de las Escuelas Medias de la UNS, militante de la JEC y de la UES. Se fue a vivir a La Plata en diciembre de 1975, luego de que la Triple A fuera a buscarla a su casa. Fue secuestrada el 16/9/1976, en el operativo militar conocido como "La Noche de los Lápices" (http://bahiagris.blogspot.com/, capturado el 14/12/10). ${ }^{840}$ Entrevista a Cecilia, Bahía Blanca, 2/6/2011. Entrevista a María del Carmen, Bahía Blanca, 18/5/2011.

${ }^{841}$ Entrevista a Aída, Buenos Aires, 17/5/2013. 
la casa, que así se convirtió en un punto de encuentro ${ }^{842}$. Otros jóvenes iban al Instituto de Rehabilitación del Lisiado y ayudaban a sumergir a los discapacitados en la pileta de agua caliente, como parte de su tratamiento ${ }^{843}$.

Otra forma en la que se concretaba el servicio era mediante el trabajo en los barrios periféricos. Se trataba de áreas marginales dentro del espacio urbano, afectados por procesos de exclusión y segregación. Siguiendo a Formiga y Marenco (2000), el primero está dado por la imposibilidad de participar formalmente en la construcción de la ciudad, mientras que el segundo está marcado por la localización en las áreas más inadecuadas respecto a las condiciones de habitabilidad. Así, la villa "constituye el último reducto de la escala habitacional por las deterioradas condiciones materiales y simbólicas de existencia" ligadas a ella (Kowarick, 1991: 89, citado en Formiga y Marenco, 2000: 71). Pero esta "otra" ciudad, la "de los otros", "es sobre todo oportunidad de sobrevivencia para los que viven en y de ella" (Borja, 1998: 2, citado en Formiga y Marenco, 2000: 71). Aquí se plantea el problema de vivienda que afecta a la población de escasos recursos y que se resuelve al margen de la ley, en sitios con deficitarios servicios públicos e infraestructura urbana, en terrenos de propiedad de terceros, y con construcciones de material precario (Formiga y Marenco, 2000).

La acción en las áreas periféricas de las ciudades, a través de la participación en educación popular, cursos de alfabetización o formación de grupos parroquiales con trabajo promocional, fue un canal de evangelización elegido por los estudiantes del MIEC-JECI a nivel latinoamericano ${ }^{844}$. En el caso bahiense, como mencionamos en el apartado anterior, los miembros de "San Pío X" y "Santa Juana" realizaban su experiencia de servicio en Villa Nocito, Villa Quilmes y Villa Serra. La labor semanal destinada a los niños se canalizaba a través de la preparación de partidos de fútbol y otras actividades, además de la merienda. En este sentido, Mario decía: "la herramienta del juego siempre fue práctica, fue efectiva para juntar gente. Después se iba viendo en qué se podía profundizar" 845 . Asimismo, los Scouts y las Guías daban apoyo escolar, visitaban a las familias, ayudaban a construir sus casas o a pintar la escuela, y en el caso

\footnotetext{
${ }^{842}$ Entrevista a Carlos, Bahía Blanca, 4/5/2011; a Gabriel, Bahía Blanca, 7/11/2012; a Pedro, Buenos Aires, 15/11/2012.

${ }^{843}$ Entrevista a Pedro, Buenos Aires, 15/11/2012

844 "Una experiencia de evangelización en el medio estudiantil", Spes, 29, pascua de 1976.

${ }^{845}$ Entrevista a Mario, Bahía Blanca, 5/1/2013.
} 
de Villa Nocito, colaboraban también en la animación de iniciativas de las religiosas a cargo de Nuestra Señora de la Paz, como las celebraciones del día del niño ${ }^{846}$.

En esta acción barrial, los jóvenes compartían la preocupación por trabajar junto a la gente ${ }^{847}$ y por acompañarla en sus propias luchas, evitando el asistencialismo. Al respecto, María del Carmen afirmaba que era su modo de encarnar el compromiso cristiano y que si bien no era una práctica "muy transformadora de la realidad porque los pibitos seguían en Villa Quilmes, no le conseguíamos agua potable ni que le hicieran las cloacas", tampoco la vivían como una acción de "beneficencia" porque "siempre la intención era abrirle la cabeza al otro" ${ }^{848}$. Por su parte, Mario planteaba que a pesar de las limitaciones que tenían este tipo de iniciativas, tenían objetivos genuinos: "eran trabajos difíciles de ver frutos. Tampoco eran tan continuados, ni el tipo que trabajaba en la villa se quedaba a vivir en la villa. Ibas el sábado y de lunes a viernes podias hacer tu vida particular, pero era un compromiso honesto y sincero" ${ }^{849}$.

Más allá del servicio de los Scouts y las Guías, Villa Nocito fue uno de los espacios fundamentales de construcción social y política de muchos de los jóvenes católicos bahienses. Su acción también se desarrolló a partir del trabajo en Cáritas y Nuestra Señora de la Paz, la Unidad Básica y la Agrupación Evita. La escuela contaba con una asistente social, una psicopedagoga, un grado diferenciado para los alumnos que tenían alguna discapacidad, y otro para aquellos con problemas de aprendizaje que, una vez superados, se integraban al grado que les correspondía. Norma definía el trabajo realizado desde la institución como una tarea de "evangelización" entendida en términos de promoción humana y la recordaba como una experiencia de gran entrega personal inspirada en la esperanza y la certeza del cambio de la sociedad. El compromiso se tornaba, incluso, identificación con la gente, en cuanto se buscaba compartir sus problemas y formas de vida, lo que aparece ilustrado en la siguiente anécdota:

se enfermó una señora, tenían que hospitalizarla muy grave, el marido con ella en el hospital. No tuvimos mejor idea que no nos llevamos los muchachitos sino nos fuimos a vivir nosotros al rancho. La forma única que teníamos de abrigarnos era con los perros...era lo único que nos daba calor a todos ahí, todos en una cama grande, todo como vivían ellos ${ }^{850}$.

\footnotetext{
${ }^{846}$ Entrevista a Carlos, Bahía Blanca, 4/5/2011.

${ }^{847}$ Entrevista a Ricardo, Bahía Blanca, 8/10/2011.

${ }^{848}$ Entrevista a María del Carmen, Bahía Blanca, 18/5/2011.

${ }^{849}$ Entrevista a Mario, Bahía Blanca, 5/1/2013.

${ }^{850}$ Entrevista a Norma Gorriarán, Bahía Blanca, 29/10/2008.
} 
Para las maestras, su profesión era su modo de encarnar su compromiso cristiano. En este sentido, Paloma decía que su función consistía en la formación de los alumnos en el espíritu crítico "hacer reflexionar a los chicos sobre la historia, las circunstancias, el pasado, el presente y la actitud hacia el futuro, en enseñarles si te están diciendo esto por qué, siempre preguntar por qué"851. Por su parte, Patricia entendía su labor como la posibilidad de realizar la utopía de "transformar la realidad" “metido" en el barrio, entre la gente ${ }^{852}$. Por otra parte, desde la dirección de la escuela se buscaba que las docentes compartieran un cierto perfil de compromiso social. De allí, que muchas de ellas hubieran sido contactadas a partir de la red de la renovación católica local. Ahora bien, la educación de los niños en los valores cristianos y una perspectiva liberadora no se daba a través de la enseñanza de la religión sino del ejemplo y de la vivencia concreta, cotidiana. Así, Paloma describía la cooperativa que armó con los alumnos de $5^{\circ}$ grado en 1975, en la que aprendieron a organizarse y a trabajar en conjunto, asumiendo protagonismo en la resolución de sus problemas:

hacíamos cosas vendibles y el dinero, íbamos a Amorosi y yo le lloraba que veníamos de una escuelita de Villa Nocito, entonces me hacían los precios de regalo y llevaba los lápices de colores, los bolígrafos, los cuadernos, los papeles para forrar y todo eso. Además los chicos hacían las cuentas de cuántos cuadernos se podian comprar, si tal era el precio... ${ }^{853}$.

Por su parte, Rosita, como ex alumna, destacaba que al delegarle responsabilidades, los chicos se sentían valorados, se les transmitía que ellos "podían", además de las virtudes de compartir, ayudar, pensar en el otro:

En la escuela había agua y en los otros lugares no, tenían canillas públicas, y cuando estábamos en los recreos nosotros que éramos los más grandes, le llevábamos agua a los vecinos [...] Entonces, si bien jugábamos, siempre algún servicio hacíamos [...] Y después siempre uno era el responsable de hacer algo: una semana por ejemplo, a uno de los chicos le tocaba no sé...cerrar la puerta del aula, a otro le tocaba regar las plantas, a otro le tocaba llevar el registro, cosas así que vos decías bueno, era sentirte también importante ${ }^{854}$.

En este marco, la actividad de las maestras se extendía más allá del trabajo en el aula e implicaba volver a la tarde al barrio para visitar a las familias, hablar con los padres e interiorizarse de la realidad de cada niño -que se veía reflejada en la clase: chicos que tenían problemas de aprendizaje o que se dormían en los bancos porque

\footnotetext{
${ }^{851}$ Entrevista a Paloma, vía skype, 7/2/2013.

${ }^{852}$ Entrevista a Patricia, Bahía Blanca, 19/5/2008.

${ }^{853}$ Entrevista a Paloma, vía skype, 12/2/2013.

${ }^{854}$ Entrevista a Rosita Rodríguez, Bahía Blanca, 29/4/2009.
} 
venían de trabajar-, de modo de poder llevar a cabo intervenciones adecuadas a las situaciones particulares. Para Paloma o Marta, aquello era parte inherente a su función como maestras ${ }^{855}$.

La Unidad Básica "Mártires de la Liberación” fue otro lugar de construcción política por el cual los jucistas canalizaban su compromiso cristiano. El espacio se orientaba a la mejora de la calidad de vida de la gente, a resolver sus necesidades de vivienda e infraestructura. Desde allí se iniciaron entonces las gestiones para la instalación de las canillas públicas, los servicios del agua potable y la luz, la apertura de calles, la demarcación de manzanas o el reconocimiento de los terrenos para los vecinos que estaban asentados. Para Rodolfo, se trataba de "acompañar a la gente en reclamos que tenían que ver con sus condiciones de vida y ayudar a la organización, promover la solidaridad entre ellos, acompañar esos procesos" ${ }^{\text {} 856}$. En ese espacio se encontraban los habitantes del barrio, los universitarios que militaban en la JP-Montoneros y algunas maestras de la escuela, como Patricia y Marta, que sintieron la necesidad de incorporar la acción política para comenzar a cambiar la realidad social, "ir a las causas" superando la impotencia que generaba el contacto con aquélla.

Por último, la Agrupación Evita se constituyó en otro ámbito de encuentro y de trabajo común en Villa Nocito que nucleaba, en este caso, a las mujeres:

todo lo que fuera participación de las mujeres u organizar cosas para los chicos, el chocolate, el día del niño, esas cosas que podían integrar [...] hacíamos algunas reuniones y...se trataba de eso, de cómo íbamos con los chicos y con las familias, integrando...y cosas muy cotidianas que tenían que ver con la dignidad, con ese tratamiento que recibian en los hospitales, con aprender a reclamar ${ }^{858}$.

Esto se comprende en el contexto de 1973, cuando tanto el PRT-ERP como Montoneros decidieron crear sendos frentes de masas de mujeres -el Frente de Mujeres y la AE respectivamente. Estas iniciativas no fueron el resultado de una reflexión genérica por parte de las conducciones ni de influencias feministas. En el caso de Montoneros, en el marco del abandono de la lucha armada, buscaba reorientar su estrategia hacia la profundización del trabajo político con los sectores populares. Ello era fundamental para desbancar a la ortodoxia peronista y, de ese modo, obtener el control del movimiento (Grammático, 2005, citado en Freytes, 2008).

\footnotetext{
${ }^{855}$ Entrevista a Paloma, vía skype, 12/2/2013; a Marta, Bahía Blanca, 29/5/2008.

${ }^{856}$ Entrevista a Rodolfo, Bahía Blanca, 23/6/2008.

${ }^{857}$ Entrevista a Marta, Bahía Blanca, 29/5/2008.

${ }^{858}$ Entrevista a Marta, Bahía Blanca, 29/5/2008.
} 
No resulta sencillo distinguir las prácticas de los militantes católicos en cada uno de los espacios de Villa Nocito cuando buena parte de estos jóvenes participaba simultáneamente de la escuela, ya sea a partir de Cáritas o de la labor docente, de la Unidad Básica y de la Agrupación Evita. Además, había una especie de "conjunción de ideales" entre las distintas prácticas que hacía que confluyeran en actividades comunes. Para Rodolfo, "en lo que eran grupos cristianos, grupos sensibles socialmente y JP de Montoneros, había una simbiosis muy importante” ${ }^{859}$. Al respecto, Nora decía: “todos estábamos como en todo, eran como procesos de poca diferenciación...había una cosa ahí de que todos éramos lo mismo...empezamos sí como grupos de Iglesia y después ya...digamos, la politización...se fue irradiando" ${ }^{860}$.

\section{3) La militancia en el lugar de trabajo}

El lugar de trabajo fue el espacio primordial de militancia de los jocistas. Si la JOC les había mostrado el carácter dignificante del trabajo, el valor de la propia ocupación y, al mismo tiempo, las injusticias del mundo laboral y la necesidad de comprometerse para cambiarlo; si en ese espacio habían reflexionado sobre el "sentido humano, religioso y apostólico" 861 de sus vidas y habían aprendido a ver y a potenciar sus dones, los jóvenes buscaban transmitir esa experiencia a sus compañeros. Los jocistas guatemaltecos compartían la preocupación por la realización de la persona “integral", por la afirmación de la identidad, dignidad y derechos como trabajadores y seres humanos, preocupación que trasladaron a la lucha a nivel de fábricas (Levenson, 2007). En Bahía Blanca, los militantes de la JOC, procuraban acercarse a otros "laburantes" en la empresa o la oficina, en el sindicato, en el barrio o incluso durante el viaje diario en colectivo, para conversar sobre sus empleos, sus problemas y necesidades ${ }^{862}$. Así, intentaban fomentar relaciones de solidaridad con los pares y humanizar los vínculos ${ }^{863}$, y a la vez, mostrar la necesidad de tener un "espíritu crítico" frente a la realidad social. Jorge contaba su experiencia en este sentido:

cada hecho que pasaba "ah, pero fijate lo que dice La Nueva Provincia”, "pará un cachito, analizá un poco lo que dice La Nueva Provincia, ¿por qué no lo miran desde este punto de vista?". Ahi teníamos nuestras grandes discusiones

\footnotetext{
${ }^{859}$ Entrevista a Nora y Rodolfo, Bahía Blanca, 2/4/2009.

${ }^{860}$ Entrevista a Nora y Rodolfo, Bahía Blanca, 2/4/2009.

861 “QQué es la JOC?”, El Mensajero de la Juventud Obrera Católica de Grünbein, 1, abril 1975.

862 "Historia de la JOC en Bahía Blanca".

${ }^{863}$ Entrevista a Mirta y Jorge, Bahía Blanca, 14/7/2012. Entrevista a Angélica, Bahía Blanca, 25/4/2012.
} 
en el trabajo. O compañeros, cuyo objetivo era ir a levantarse minas. Entonces uno trataba, "escuchame, ¿tu objetivo de la vida cuál es?"864.

Pero, fundamentalmente, en las charlas con otros obreros y empleados se intentaba contribuir a la "toma de conciencia" de su condición de trabajadores, que los ubicaba en un lugar estructuralmente diferente al del jefe y que le confería una serie de posibilidades, capacidades y derechos que debían conocer y ejercer. En este sentido, Mirta evocaba una conversación con una compañera en el colectivo: “¿por qué te tenés que ir pintada y vestida como quiere tu patrón? Andá como vos quieras. Tenés que estar 12 horas parada y tenés que ir de taco y pintada. ¿Por qué no podés ir de zapatillas? ¿Por qué no pedís...?”. ${ }^{865}$ La tarea no era sencilla con los empleados de comercio, que eran pocos en sus lugares de trabajo y tenían un vínculo cercano con los patrones, además de contar con un sueldo alto en comparación con otros trabajadores. La asunción de su ser trabajador conllevaba entonces la participación con otros para mejorar su situación. En ese sentido, los jocistas se proponían "tratar de organizar el reclamo grupal”; "que cada empleado se sintiera digno de su trabajo, y responsable de luchar por su sueldo, por su aguinaldo, por respeto" ${ }^{866}$.

Este compromiso condujo a muchos militantes a optar por la participación en el gremio. Así ocurría con otras experiencias como la de Guatemala, donde los jocistas, haciendo énfasis sobre el cambio personal, la identidad y el propio empoderamiento, fundaron sindicatos durante los años sesenta. Según Levenson (2007), este proceso estaba ligado a los términos religiosos con que ellos entendían la vida, el poder y los elementos de clase. Ser activistas significaba para ellos la forma de cumplir genuinamente con las exigencias de ser cristianos. Como expresaba Dante, cambiar la realidad del trabajo "también implicaba un compromiso gremial",867. Dicha intervención, no obstante, asumió diversas formas y grados de intensidad, abarcando un amplio arco de prácticas que iba desde la asistencia a algunas reuniones hasta la ocupación de cargos directivos, pasando por la formación de listas para disputar la dirección del sindicato ${ }^{868}$.

Mirta y Jorge, por ejemplo, participaron de la formación de la agrupación "26 de julio" -nombre elegido en homenaje a Eva Perón-, en vistas a presentarse a las

\footnotetext{
${ }^{864}$ Entrevista a Mirta y Jorge, Bahía Blanca, 14/7/2012.

${ }^{865}$ Entrevista a Mirta y Jorge, Bahía Blanca, 11/4/2012.

${ }^{866}$ Entrevista a Mirta y Jorge, Bahía Blanca, 14/7/2012.

${ }^{867}$ Entrevista a Dante, Bahía Blanca, 28/9/2011.

868 "Historia de la JOC en Bahía Blanca".
} 
elecciones gremiales. La idea partió de un grupo de trabajadores en disidencia con la conducción de la Asociación Empleados de Comercio, que estaba en manos de un líder histórico al que se veía estrechamente ligado con la patronal. La estructura gremial resultante aparecía como "cerrada" y anquilosada. De allí que se buscara su renovación planteando una alternativa distinta. Sin embargo, la iniciativa no perduró, sucumbiendo ante la inercia del poder establecido y en el marco del recrudecimiento de la represión ${ }^{869}$.

La idea de que la cúpula de Empleados de Comercio estaba "acomodada" con los empresarios desestimaba la participación gremial de otros militantes. Así lo vivió Liliana, quien se acercó a una asamblea del gremio para plantear que el supermercado donde trabajaba estaba haciendo un vaciamiento previo a presentar la quiebra que dejaría a los empleados en la calle, pero no obtuvo ninguna respuesta: “ $U y$, sabés cómo me miraron! Parece que me querían matar los delegados y todo" $\$ 70$.

Sin embargo, los militantes se imponían el compromiso individual de participar en las asambleas; en palabras de Angélica, "de estar, de apoyar, de dar nuestra opinión "871. Por ello, mantenían la presencia en las reuniones del sindicato, aunque les resultaba difícil intervenir. Al respecto, Bruno explicaba: "no teníamos la palabra...Nos borraban [...] nos costaba muchísimo. No nos dejaban entrar [...] pero bueno, donde podíamos meter un dedito lo metíamos" ${ }^{\prime 872}$. En este marco, algunos buscaban otras puertas de acceso al espacio gremial. Por ejemplo, Bruno logró integrarse a través del equipo de fútbol: "me mandaba ahí. Inclusive fui a Buenos Aires a jugar con Empleados de Comercio. Íbamos a jugar, qué se yo, a Tigre, entonces nos juntábamos Tigre, San Fernando, San Isidro, a una recreación deportiva. Y yo le metía ficha" ${ }^{\text {,873. }}$

Los jocistas también tuvieron distintos grados de participación en otros gremios. Ema, que era maestra, se acercó al Centro de Educadores aunque la militancia en ese espacio era limitada en contexto de dictadura, reduciéndose a la convocatoria o la asistencia a algunas asambleas. Al respecto, Ema recordaba:

Me acuerdo que una vuelta hicimos una reunión y que yo estaba con otra compañera y que hablaban de hacer un paro, no sé qué, entonces yo le dije "si hay un paro, hay que hacer un paro activo, no hay que quedarse en la casa". Y

\footnotetext{
${ }^{869}$ Entrevista a Mirta, Bahía Blanca, 18/6/2008.

${ }^{870}$ Entrevista a Liliana, Bahía Blanca, 25/6/2008.

${ }^{871}$ Entrevista a Angélica, Bahía Blanca, 25/4/2012.

${ }^{872}$ Entrevista a Bruno, Bahía Blanca, 4/8/2012.

${ }^{873}$ Entrevista a Bruno, Bahía Blanca, 4/8/2012.
} 
la otra, como era militante de izquierda, me dice "si querés deci que podemos manifestarnos, algún escrito, pero no digas paro activo",874.

Por su parte, Dante tuvo una intensa y diversificada actividad gremial en esos años, en función de sus distintos empleos y de los cambiantes contextos políticos. En primer lugar, mientras trabajaba en La Nueva Provincia, intentó iniciar el sindicato de televisión, pero al poco tiempo lo despidieron por "peronista, tercermundista y sindicalista ${ }^{\text {875 }}$. Más tarde, mientras trabajaba en Sancor, se afilió a la Asociación de Trabajadores de la Industria Lechera y, junto a otros compañeros, presentó una propuesta que logró afianzarse al interior de la empresa y ganar las elecciones gremiales. Dante se convirtió entonces en el secretario de organización. Luego se abocaron a la campaña de afiliación, recorriendo las plantas de productos lácteos de Bahía Blanca -donde además de Sancor, estaba Magnasco, el frigorífico Viñuela, y empresas pequeñas como Balkan o la lechería Carlitos-, y de las localidades cercanas, con desigual suerte entre los trabajadores.

Según explicaba Dante, el nuevo espacio gremial alcanzó una fuerte organización -con mayoría de trabajadores de Sancor aunque también de Viñuelas- y la comisión directiva se caracterizó por su combatividad. El enfrentamiento con la patronal tenía en Sancor un punto privilegiado debido a las dimensiones e importancia de la empresa, y las condiciones de trabajo y de trato de los empleados que justificaban los reclamos. Al calor de esas luchas, los mismos obreros fueron afianzando su posición frente a la jefatura y comprometiéndose en la disputa por nuevas conquistas laborales $^{876}$.

Por otra parte, los enfrentamientos con los patrones se replicaron en las empresas pequeñas. Dante contaba la situación que se planteó con el dueño de Balkan -suboficial del Ejército, peronista, retirado de la fuerza con la "Revolución Libertadora"-, una fábrica familiar que contaba, además, con personal asalariado y que introdujo la producción de yogurt en la ciudad a mediados de la década de 1960:

voy un día como sindicalista, con una asamblea. Y dice "pero esto no es así porque cuando estaban los otros, nosotros..." -porque la gente se empezó a quejar que no tenían ropa, que no tenían...-. Le digo "bueno, a partir de ahora es de otra manera entonces usted tiene que hacer esto, esto...". Después no tuvimos más problema pero de entrada ;tuve una pelea pero...grande! ${ }^{877}$.

\footnotetext{
${ }^{874}$ Entrevista a Ema, Bahía Blanca, 27/9/2012.

${ }^{875}$ Entrevista a Dante, Bahía Blanca, 28/9/2011.

${ }^{876}$ Entrevista a Dante, Bahía Blanca, 28/9/2011.

${ }^{877}$ Entrevista a Dante, Bahía Blanca, 28/9/2011.
} 
Por otra parte, Dante participó del intento de formar en Bahía Blanca una seccional de la CGT de los Argentinos. Para ello, en 1971 viajó con un compañero a Los Polvorines para encontrarse con el referente de la central obrera. Si bien pudieron entrevistarse con Ongaro, no consiguieron definir las directivas necesarias para la organización local. Al respecto, Dante recordaba el impacto que le causó la personalidad del sindicalista y las dificultades, pese a los intereses que compartían, que tuvieron para comunicarse con él en el plano de las acciones concretas que pretendían llevar adelante: "no te escuchaba Raimundo [...] Estuvimos como tres horas y el tipo nos dijo 'y cuando estuvimos en Argelia y plin plin plan'. ;Nosotros lo que queríamos era ver cómo organizábamos una cosa en Bahía!"878.

Cuando Dante entró a trabajar en la cervecería Santa Fe, se encontró con que las condiciones de trabajo y la relación con los compañeros eran particulares. Por un lado, los turnos eran de 8 horas y rotativos, alternándose semanalmente el trabajo de mañana, de tarde y de noche. En cuanto a los empleados, se trataba de trabajadores nuevos, que no se conocían entre ellos. Se repartían entre la producción, los "de todo servicio" y los de mantenimiento y caldera. Esta sección estaba a cargo de suboficiales de marina retirados. La presencia militar se extendía al superintendente -que era una suerte de gerente-, también vinculado con las Fuerzas Armadas. En efecto, según recuerda Dante, el régimen de trabajo que éste impartía dentro de la fábrica era "casi militar" 879 . Por otra parte, el médico de la fábrica era el capitán Streich, quien poco después trabajó en el CCD "La Escuelita". Dante recordaba el día en que le hizo la revisación previa a comenzar a trabajar: "Dice 'Usted ¡es casado con hijos?'. 'Sí, soy casado, con dos hijos'. Y, dice 'bueno, está bien, porque nosotros acá en la fábrica queremos gente responsable, seria, que no ande en politica, esa cosa de los guerrilleros ",880. En ese marco, no resultaba sencillo articular las demandas de los trabajadores, si bien hubo algunos intentos: “empezamos ahí a organizar la cosa adentro pero muucho cuidado, ni siquiera había sindicato. Es decir, no había delegado, yo hacía de delegado "881.

La actividad gremial de los jocistas también se articuló en los lugares de trabajo con la militancia política desde el Peronismo de Base. Al respecto, Dante explicaba que, en una primera etapa, el trabajo gremial del PB iba de la mano con otros dos frentes, el

\footnotetext{
${ }^{878}$ Entrevista a Dante, Bahía Blanca, 28/9/2011.

${ }^{879}$ Entrevista a Dante, Bahía Blanca, 28/9/2011.

${ }^{880}$ Entrevista a Dante, Bahía Blanca, 28/9/2011.

${ }^{881}$ Entrevista a Dante, Bahía Blanca, 28/9/2011.
} 
barrial y el universitario -representado por el Frente Estudiantil Nacional (FEN) ${ }^{882}$-, aunque era el primero el que tenía la prioridad:

teníamos trabajo en varios gremios: en metalúrgicos, en lechero, en textil, en ferroviario, en la carne, teníamos -en empleados de comercio también había una agrupación-, nuestros pequeños núcleos y agrupacioncitas de base, -en municipales ganamos una huelga en el '70 que duró como 40 días-. Ahi había que actuar y estábamos presentes y volanteábamos ${ }^{883}$.

En este sentido, la acción política entre los trabajadores incluía la participación en las medidas de fuerza que acompañaban los reclamos. Sobre este punto, Dante recordaba: "eran paros activos que se decía 'a las 10 de la mañana salimos del trabajo' y a las 10 de la mañana salías. Y después bueno, si pasabas por los comercios, en el centro, que no cerraban [...] se cerraban medio de prepo" 884 .

Para los peronistas de base locales, la labor en los gremios debía partir de un trabajo reivindicativo de mejoramiento laboral y, al mismo tiempo, articularse con una política "verdaderamente revolucionaria". Esta tarea resultaba lenta y dificultosa, teniendo en cuenta "la composición heterogénea de los obreros", la falta de "politización" de las bases y de intervención de los trabajadores en los sindicatos, que, por otra parte, eran caracterizados como "paternalistas y verticalistas", ya que no practicaban "medidas democráticas" ni hacían asambleas permanentes, además de negar "al trabajador la aparición directa dentro del mismo". Se debía lograr entonces tanto la activa participación gremial como la formación de activistas "que esclare[cieran] la conciencia de los trabajadores" y lucharan por la conquista de las direcciones de los sindicatos, que debían "ir siempre un paso más delante de sus bases pero sin despegarse de las mismas". En este sentido, la militancia en este frente implicaba el enfrentamiento con las cúpulas sindicales. Este trabajo se enmarcaba en la lucha antiburocrática, desde el momento en que el sindicato era considerado el aparato montado por la burocracia y las fuerzas contrarrevolucionarias para sustentar su poder ${ }^{885}$.

\footnotetext{
${ }^{882}$ Nacido de la alianza entre estudiantes de Buenos Aires y Rosario en 1966. Fue la agrupación peronista que mayor trascendencia adquirió en la universidad antes de los años setenta (Orbe, 2007). Se definía como independiente, militante del peronismo revolucionario, nacionalista y antiimperialista, en lucha por la "liberación nacional" y el "socialismo". En ese marco, entendía el movimiento estudiantil como uno de los frentes de batalla contra la dictadura y el "sistema", y abogaba por vincular las luchas universitarias con las que libraba la clase obrera ("El movimiento estudiantil responde", Graphos, 5, abril de 1971).

${ }^{883}$ Entrevista a Dante, Bahía Blanca, 15/3/2012.

${ }^{884}$ Entrevista a Dante, Bahía Blanca, 28/9/2011.

885 "Peronismo de Base. Acerca de la militancia revolucionaria", Graphos, 16, agosto de 1973. La nota transcribía un reportaje a Joaquín Gutiérrez, obrero y militante del PB de Bahía Blanca, que se refería a las políticas llevadas a cabo por los distintos frentes. Sin embargo, se aclaraba que sus opiniones no necesariamente reflejaban las posiciones políticas del PB bahiense.
} 
En efecto, las FAP-PB eran fuertemente antiburocráticas; consideraban a la burocracia como enemigo, aunque secundario, detrás de la patronal (Raimundo, 2004). Así lo expresaba el PB bahiense: "la burocracia no es Rucci, ni Coria, ni Miguel, sino que es toda una forma de expresión sindical que tiene su explicación en la esencia misma del sistema [...] Nosotros -como obreros- sabemos bien quiénes y cómo nos joden cotidianamente los patrones, los milicos y los burócratas" ${ }^{886}$. En Bahía Blanca, las tensiones se manifestaban con el líder de la CGT, Roberto Ponce ${ }^{887}$, o con los referentes de los distintos sindicatos, y se explicitaban con amenazas y golpizas. Sobre este punto, Dante recordaba un acto donde "la gente de la CGT fue preparada para CONTENER sobre todo a los estudiantes. iY se armó un desparramo TERRIBLE! antes de empezar. Ahi empezaron ya algunas cuestiones internas dentro del movimiento popular" ${ }^{\prime 88}$.

En esta segunda etapa, hacia 1974-1975, la militancia de los peronistas de base se abocó al trabajo obrero, en detrimento de los barrios y, fundamentalmente, de la universidad, donde se abandonó totalmente el frente político. Así lo explicaba Dante: "ya en esa época habíamos pasado a desarrollar una actividad plenamente gremial...revolucionaria, digamos, no vinculada a los gremios sino a armar comisiones obreras dentro de las fábricas ${ }^{\prime 889}$. Esto guarda relación con el modo particular en el que el PB concebía la relación entre lucha sindical y política. El sindicato era considerado el organismo natural de la clase obrera, que posibilitaba la unión, la toma de conciencia y las mejoras de su condición, así como la identificación del enemigo, pero no era el instrumento adecuado para la lucha revolucionaria, en cuanto limitaba su acción a la mera reivindicación. Hacía falta entonces la organización político-militar de los obreros y la construcción del ejército del pueblo. Para ello, el instrumento impulsado fueron las agrupaciones de base, tanto a nivel del ámbito laboral de inserción, como barrial, aunque estas últimas, como mencionamos, fueron perdiendo peso. Estas agrupaciones se orientaban a la organización política de los obreros partiendo de los lugares de trabajo, organizados por sección y fábrica, en las distintas ramas de actividad.

\footnotetext{
886 “Juventud Peronista y Peronismo de Base", Graphos, 12, abril de 1973. La nota recogía las respuestas que ambas organizaciones habían dado a un mismo cuestionario, con el objetivo de clarificar el panorama de las distintas corrientes políticas que tenían cabida dentro del peronismo.

887 Dirigente sindical proveniente de la Unión de Recibidores de Granos y Afines (URGA). Se desempeñaba como Secretario General de la CGT local e integrante de la mesa nacional de las 62 organizaciones. En 1973, ingresó al Congreso como diputado por el FREJULI. Peronista ortodoxo, hacía oír su repudio hacia los "extremistas" o "izquierdistas" que "se disfrazan de peronistas" -haciendo alusión a los militantes del PRT-ERP, Montoneros y distintas ramas de la izquierda peronista (Zapata, 2012).

${ }^{888}$ Entrevista a Dante, Bahía Blanca, 28/9/2011.

${ }^{889}$ Entrevista a Dante, Bahía Blanca, 28/9/2011.
} 
El PB funcionaba como la coordinación de las distintas agrupaciones que tenían un carácter fuertemente autónomo. El horizonte primordial era la construcción de poder obrero dentro de la fábrica, cuyos ejes fundamentales eran: el control de la producción, la democracia -representada en la asamblea con participación de todos los trabajadores por sección, turnos y fábrica- y la organización de comisiones obreras (Raimundo, 2004).

\section{4) La militancia estudiantil: la escuela secundaria y la universidad}

Un espacio central de la militancia de los integrantes de la JUC fue la UNS. Como afirman Mallimaci, Cucchetti y Donatello (2006), la acción en el campo político partidario a través de la universidad constituyó una de las opciones de los católicos de sectores medios que habían experimentado la renovación conciliar dentro de las ramas especializadas de Acción Católica. Así lo reconocían los propios actores entonces: la universidad era vista como "caja de resonancia de nuevas formas de compromiso de los cristianos, condicionados por su extracción social y el medio en que actúan y dinamizados por la corriente posconciliar" (Habegger, 1970: 141).

Como hemos visto, para estos jóvenes, la opción por la militancia universitaria se hallaba justificada por la idea de que cada cual debía comprometerse en su propio ámbito, idea compartida en los grupos cristianos, y discutida entre los estudiantes. En palabras de Luis: "el militante estudiantil debe militar en la universidad"890. En este sentido, Juan Carlos recordaba los debates sobre este tema entre los activistas de la JUP: "unos decían que se vayan de la universidad a laburar a los barrios. No, yo en esa no estuve nunca porque es así: o te quedás en la universidad y cambiás la universidad o dejabas la universidad y te ibas a laburar a un barrio" 891 .

"La militancia universitaria era una militancia de todos los días", decía Luis ${ }^{892}$, una práctica que atravesaba los vínculos personales, las actividades aparentemente desvinculadas de ella, incluso los momentos de recreación. En este sentido, para los actores, la carrera estaba estrechamente unida a la actividad política. Muchas veces los militantes buscaban alternativas que aportaran una formación teórica que iluminara su activismo -como es el caso de los que eligieron Economía-. Y, de modo más amplio, los

\footnotetext{
${ }^{890}$ Entrevista a Luis, Bahía Blanca, 18/12/2008.

${ }^{891}$ Entrevista a Juan Carlos, Buenos Aires, 1/8/2008.

${ }^{892}$ Entrevista a Luis, Bahía Blanca, 18/12/2008.
} 
jóvenes compartían una preocupación por poner al servicio del cambio social las herramientas que ofrecía el estudio. Sobre esta cuestión, Rodolfo comentaba:

La carrera de Economía en aquel momento no era lo que es ahora...tenía Teoría Económica Clásica I, en Clásicos I leías el tomo 1 de El Capital...y nosotros nos juntábamos a estudiar y era casi una formación para la militancia leer a Marx...entonces era todo lo mismo, todo era en función de una militancia ${ }^{893}$.

Esto se comprende en un escenario particular. Hacia fines de la década de 1960, los estudiantes de Economía mostraban cierta disconformidad con su formación, planteando, por un lado, la falta de actualización de los contenidos, y por el otro, la necesidad de mayor pluralidad de enfoques. Como respuesta a estos reclamos, en 1971, una comisión de alumnos y docentes elaboró un nuevo plan de estudios, para ser puesto en práctica a partir de 1972. La propuesta era crear una nueva escuela (no limitarse a repetir las teorías dominantes), formar economistas creativos que pudieran, no sólo insertarse en el mercado laboral o en programas de posgrado, sino, fundamentalmente, hacer aportes a la transformación de la realidad social, orientados especialmente al abordaje de los problemas del subdesarrollo. Una aspiración central era resaltar el carácter político de la ciencia económica. Para garantizar una enseñanza no dogmática, el plan intentaba analizar las teorías desde sus propios autores, ubicados en su contexto histórico. Esto reconocía la existencia de distintas perspectivas para abordar un mismo problema económico, a la vez que vinculaba cada desarrollo teórico al clima de época en el cual fue gestado, admitiendo así que no existen leyes universales. Asimismo, con el fin de asegurar la libertad en la transmisión del conocimiento, se buscaba confrontar fuentes originales con las interpretaciones de los docentes. Este plan resultó una excepción para la UNS. Una vez derogado, con la designación de Remus Tetu como interventor de la UNS en 1975, los nuevos planes $(1976,1989,2002)$ tendrían como propósito clave el ingreso al mercado de trabajo de los graduados. Por otra parte, la pluralidad de enfoques daría paso a la estructuración de la formación en base a un paradigma único, el de la economía neoclásica (Colectivo Viceversa, 2009).

Pero volviendo al tema que nos ocupa, ¿qué acciones implicaba la militancia en la universidad? Debemos tener en cuenta que en el marco de la dictadura inaugurada en 1966, las prácticas del movimiento estudiantil se transformaron profundamente. Uno de estos cambios consistió en el reemplazo de los centros de estudiantes por las asambleas

${ }^{893}$ Entrevista a Rodolfo, Bahía Blanca, 23/6/2008. 
como nueva forma organizativa, constructora de nuevas legitimidades y jerarquías. Aquellas se concebían como un modelo alternativo para ejercer el poder en las casas de altos estudios, rigiéndose por el principio de la democracia directa, en contraposición a la democracia representativa burguesa que el reformismo había consagrado desde 1918 (Orbe, 2007). De allí que la discusión constante, en las reuniones de las agrupaciones y en las asambleas, fuera uno de los aspectos prioritarios de la militancia universitaria.

El activismo en la universidad cambiaba no sólo al calor de la mayor movilización estudiantil ${ }^{894}$ sino también de la escalada represiva que el gobierno lanzaba como respuesta, en la forma de allanamientos, persecuciones y detenciones de militantes de distintas agrupaciones políticas, y de acción policial en las manifestaciones callejeras (Orbe, 2007). Así, en la UNS, en 1969 se inició un renacimiento de la actividad política estudiantil, con actos relámpago en el comedor universitario, en los que se informaba sobre los hechos de violencia ocurridos en distintos lugares del país y se decidían planes de acción a nivel local que contemplaban paros, manifestaciones y peticiones al rectorado. A pesar de no contar con autorización de las autoridades, los primeros actos no fueron reprimidos, pero cuando las iniciativas de oposición al gobierno nacional se expresaron en la vía pública, la intervención policial provocó incidentes, con una importante cantidad de detenidos y heridos. Fueron precisamente las persecuciones de militantes políticos -como las que hemos mencionado al hablar del allanamiento de la casa de "Pepe" Zamorano- y la intensificación de los enfrentamientos con la policía desde 1971, las que conmocionaron al movimiento estudiantil y acercaron a las agrupaciones en una lucha abierta contra el gobierno y por la libertad de los presos políticos. Así, aquél superaba la apatía, la fragmentación y las disidencias extremas que habían dificultado hasta entonces la formación de un frente estudiantil único ${ }^{895}$. En consecuencia, la agitación estudiantil tuvo una escalada inédita (Orbe, 2006, 2007).

En este marco, los actores participaron del levantamiento de los cursos, los actos relámpago y las movilizaciones en el centro de la ciudad, en las que, según Rodolfo, el enfrentamiento con la policía funcionaba como "gimnasia habitual" del militante ${ }^{896}$, que aprendía así a ubicarse dentro de la manifestación, a defenderse, a tirar bombas

\footnotetext{
${ }^{894}$ Desde una perspectiva general, la relación entre los estudiantes y la dirigencia universitaria se complicó a lo largo de la década de 1960. Los estudiantes se movilizaron contra los exámenes de ingreso, considerados limitacionistas, contra el aumento de los aranceles de los comedores universitarios y contra las restricciones presupuestarias. También cuestionaron con fuerza a recepción de subsidios externos considerados formas de penetración imperialista (Buchbinder, 2005).

895 “Del movimiento estudiantil bahiense", Graphos, septiembre de 1971. Y Giménez, 2008: 53.

${ }^{896}$ Entrevista a Rodolfo, Bahía Blanca, 23/6/2008.
} 
molotov o bolitas de rulemanes a los caballos. Por otra parte, los jóvenes hacían pintadas que rezaban "abajo la dictadura" o "por un gobierno nacional y popular" 897.

Durante los actos o las asambleas en el comedor universitario, los militantes repartían volantes. Según Juan Carlos, parte de ellos era confeccionado con un mimeógrafo que la JUC consiguió hacia 1969 y usó a partir de entonces con un criterio "democrático" 898 .

Asimismo, los estudiantes protagonizaron tomas de la universidad. El trabajo de Orbe (2007), nos permite reconstruir una crónica de estas iniciativas durante esos años: en abril de 1970, se ocuparon las dependencias de la avenida Alem para reclamar por la liberación de los estudiantes detenidos en la ciudad bajo el imperio de la ley 17.401/67 de represión de actividades comunistas; en septiembre de 1970, se produjo la toma del edificio del rectorado (Colón 80) en demanda de cambios en el régimen de estudios, la expulsión y la conformación de un tribunal académico para algunos profesores, que culminó con el desalojo por parte de la policía y la detención de algunos alumnos; a mediados de mayo de 1971, se ocuparon nuevamente algunas dependencias de la UNS para exigir la destitución de una profesora del Departamento de Química.

Los riesgos de la militancia en tiempos de dictadura hacía necesario cuidar ciertas normas de seguridad, trabajar "tabicado", evitar conocer información personal de los compañeros o conservar libros, volantes o fotos que comprometieran a otros y dieran una excusa a la policía para detenerlos ${ }^{899}$. A la vez, el activismo estudiantil involucraba tareas de menor exposición pero que resultaban centrales y ocupaban buena parte del tiempo, tales como la formación teórica, basada en la lectura de bibliografía y documentos partidarios, y en el análisis de la coyuntura nacional e internacional.

Para los jucistas que eligieron la universidad como ámbito de compromiso, el año 1973 marcó un punto de inflexión. En efecto, con la vuelta del peronismo al poder, el espacio universitario bahiense comenzó un proceso que Orbe llama "revolución peronista”. El ministro de educación Jorge Taiana designó como interventor al abogado Víctor Benamo, cercano a la $\mathrm{JP}^{900}$. Con él se abría una etapa de gran protagonismo del

\footnotetext{
${ }^{897}$ Entrevista a Eduardo, Bahía Blanca, 16/10/2008.

${ }^{898}$ Entrevista a Juan Carlos, Buenos Aires, 29/7/2008.

${ }^{899}$ Entrevista a Luis, Bahía Blanca, 18/12/2008.

900 Esto se comprende en un proceso más amplio. Cámpora decretó la intervención transitoria de las universidades nacionales, con el objetivo de que recuperaran su autonomía y gobierno tripartito. La misma se llevó adelante con miembros afines a la JP-Montoneros. Entonces, la universidad fue visualizada como uno de los "baluartes del proceso revolucionario que se avecinaba". En esta concepción confluían los debates que se daban a nivel latinoamericano y la trayectoria político-ideológica particular que signó al país en la segunda mitad del siglo XX. En este contexto, fueron reformadas las estructuras administrativas y curriculares para que se adecuaran a este modelo de universidad "militante". Partiendo de la convicción de que "la hegemonía de las clases dominantes se ejercía a través de los contenidos de la
} 
peronismo revolucionario en la UNS y de reformas administrativas, académicas y curriculares que apuntaban a hacer posible la participación de la universidad en la construcción del "socialismo nacional"901 (Orbe, 2007).

Entre las medidas implementadas por Benamo, podemos mencionar las siguientes: se nombró "Universidad Nacional del Sur. Dr. Miguel López Francés" diputado nacional que durante el primer gobierno peronista participó en la creación del Instituto Tecnológico del Sur- a la institución, y "Mártires de Trelew", al salón de actos del edificio del rectorado; se designaron nuevas autoridades; se estableció el ingreso libre e irrestricto; se crearon comités de gestión por departamento, integrados por docentes, no docentes y alumnos que participarían en la toma de decisiones; se creó el Instituto de Estudios para el Tercer Mundo "Eva Perón” para promover el estudio de los "pueblos oprimidos"; y se aprobó el Ciclo Básico Universitario a implementarse en 1974, con el objetivo de promover el análisis de la realidad latinoamericana y nacional (Visotsky y Gattari, 2004). Por otra parte, se resolvió que toda persona que deseara seguir cursos libres en la UNS podría hacerlo cualquiera fuera su formación escolar. Se exigía a los departamentos programar cursos de extensión y capacitación en función de las necesidades del medio (Orbe, 2006, 2007).

Asimismo, se impulsó un plan de reconstrucción orientado a transformar la institución en una universidad "práctica y militante, comprometida con el destino del pueblo", ligada "con el desarrollo económico regional”, profundizando, de este modo, su vinculación con el "medio" "902. En palabras de los actores, la universidad debía salir de la "campana de cristal", formar "servidores públicos" y contribuir a la

enseñanza y de las formas de transmisión", se impugnaron los planes de estudio, los programas de las materias y las formas de evaluación, se sustituyeron las clases teóricas y prácticas por "reuniones y encuentros", se crearon materias dedicadas al estudio de la realidad social argentina e institutos abocados a la investigación de problemáticas del Tercer Mundo, se llevó adelante una intensa política de extensión, se suprimieron las restricciones al ingreso y fueron expulsados los docentes identificados con la dictadura y los que desempeñaban cargos en empresas multinacionales (Buchbinder; 2005). Durante el gobierno de Perón y bajo la gestión de Taiana, se introdujeron nuevos cambios en el ámbito universitario a través de la promulgación de la ley 20.654, del 26/3/1974. Ésta garantizaba la autonomía académica y docente, la libertad de cátedra, la responsabilidad científica y legal de las enseñanzas y doctrinas expuestas en clase, la autarquía económica y financiera, la facultad de la universidad de sancionar sus estatutos, organizar su sistema académico y administrativo, y designar y remover a su personal. Se prohibía el proselitismo político partidario o las ideas contrarias al sistema democrático, y los docentes no podían defender intereses que estuvieran en pugna con los de la Nación. Asimismo, se reincorporaron los docentes cesanteados entre 1955 y 1973 por razones políticas o gremiales. Según Mignone, esta normativa traducía el espíritu de la época ya que enunciaba los paradigmas de liberación nacional, justicia social, proyección comunitaria, solidaridad, servicio público y tradición patriótica y popular (1998: 50).

${ }^{901}$ Las breves gestiones de Antonio Tridenti y Héctor Arango implicaron una continuación de la política implementada por Benamo (permaneció en su cargo desde 2/6/1973 hasta mediados de1974).

902 "UNS y Pueblo", El Eco, 22/12/1973. 
transformación social ${ }^{903}$. Para ello, se creó una serie de programas de intervención comunitaria: las "mesas de trabajo" y la "brigada universitaria de trabajo"904 junto a la JUP ${ }^{905}$; la "Universidad al campo", que contemplaba la puesta en producción de los establecimientos rurales de la UNS; "la Universidad al pueblo", orientado a resolver necesidades populares, redefinir la situación de barrios de emergencia, realizar encuestas sobre medicamentos y salud, utilizar los laboratorios para hacer análisis gratuitos; "Universidad e industria", que buscaba contribuir al proceso tecnológico del país, por medio de la construcción de cohetes antigranizo e investigaciones sobre hidrocarburos; "Universidad y desarrollo", cuyo fin era promover la integración regional; "Ciencia y autonomía nacional", que se encargaba de desarrollar líneas de investigación de base para superar la dependencia científica (Orbe, 2006, 2007).

Los actores mencionaban algunas de estas iniciativas, como la formación de bancos de sangre para donarlos al policlínico o la fabricación con soja ${ }^{906}$, la reparación y pintura de una escuela en un barrio ${ }^{907}$ y los campamentos de trabajo, como el que tuvo lugar en 1974, en el dique Paso Piedras, donde se armó una huerta comunitaria ${ }^{908}$. Estas acciones colectivas, en cuanto eran oportunidades de encuentro, buscaban intensificar los lazos entre los compañeros. A los militantes cristianos les recordaban sus propias actividades. En palabras de Juan Carlos: “ese repertorio que uno lleva a la política partidaria es el mismo repertorio que tiene en su grupo religioso "909.

Los jucistas que militaron en la JUP desde 1973 también evocaban la participación en las movilizaciones masivas y los actos de la agrupación; la

\footnotetext{
${ }^{903}$ Entrevista a Juan Carlos, Buenos Aires, 1/8/2008, y a Eduardo, Bahía Blanca, 20/5 y 16/10/2008.

${ }^{904}$ Se proponían eliminar las diferencias entre trabajo intelectual y manual para que sus integrantes se incorporaran en forma activa al trabajo social y se comprometieran con la realidad nacional (Orbe, 2006).

${ }^{905}$ Destinada a nuclear a "los sectores justicialistas que han venido actuando en al ámbito estudiantil", fue proclamada en una conferencia de prensa realizada en el salón de actos de la UNS en mayo de 1973 (“JUP”, El Eco, 16/5/1973). Esto ocurría en el marco de la profundización de la peronización de la universidad y la transformación de las agrupaciones peronistas a nivel nacional: si hasta allí rechazaban la política universitaria y se ocupaban más bien de "hacer política nacional en la universidad", esto es, de que el peronismo tuviera en la universidad un canal que le permitiera incorporar a los estudiantes como uno de los sectores sociales más activos, ahora se trataba de elaborar una política universitaria peronista y combativa para hacer frente a la situación especial de la institución y sus actores (Barletta y Tortti, 2002).

${ }^{906}$ Entrevista a Juan Carlos, Buenos Aires, 1/8/2008. En efecto, las mesas de trabajo de Bioquímica y Biología, en colaboración con la JUP de la Escuela de Enfermería, confeccionaron registros de dadores de sangre, mientras que las Brigadas de Agronomía se proponía fijar médanos en el sur de la provincia con asesoramiento del INTA, realizar ensayos de fertilización en campos aledaños a la ciudad y asesorar a horticultores de Aldea Romana (Orbe, 2006).

${ }^{907}$ Entrevista a Eduardo, Bahía Blanca, 20/5/2008.

${ }^{908} \mathrm{La}$ actividad fue registrada por los servicios de inteligencia, que identificaron a 17 militantes de la JUP, entre ellos, Juan Carlos, Eduardo y Elsa (Archivo DIPPBA en Archivo personal de Juan). Años después Eduardo (entrevista, Bahía Blanca, 20/5/2008) se enteraría por un militar que para los servicios de inteligencia, en aquel campamento se había hecho práctica militar.

${ }^{909}$ Entrevista a Juan Carlos, Buenos Aires, 1/8/2008.
} 
participación en el cambio de autoridades; los juicios académicos y la expulsión de profesores; los viajes a Buenos Aires para la asunción de Cámpora, el regreso definitivo de Perón al país y el $1^{\circ}$ de mayo de 1974 , o con motivo de la realización de reuniones con referentes nacionales del movimiento. Rodolfo rememoraba el viaje a la Capital de militantes de la JUP, JP y JTP, entre los que se encontraba José Luis Peralta ${ }^{910}$, para entrevistarse con las autoridades y solicitarles la confirmación de Benamo en el cargo. Otros resaltaban el contacto con el mundo sindical de la UNS y la preparación de las elecciones, que según Juan Carlos, fueron ganadas por la JUP pero que por un acuerdo nacional "hubo que dárselas a la Federación Juvenil Comunista" 911.

Para algunos militantes, su activismo político en la UNS -e incluso sus estudiosconcluyó en 1975 con la llegada de Remus Tetu como interventor designado por el ministro de educación Oscar Ivanissevich" ${ }^{912}$, lo que marcó el inicio de la "dictadura adelantada"913 en la institución. Se iniciaba entonces una etapa que "tenía que ver más con las políticas universitarias del siglo XIX, una universidad que prepara profesiones del tipo especializado ya que la misma brindará a la sociedad una variante de servicios utilitarios y 'estratégicos'" (Alcira Trincheri; 2003: 68). En sus primeras declaraciones, Tetu afirmó que debían revisarse los programas y sus bibliografías para "depurar la estructura curricular de la UNS de todo lo tendencioso, unilateral y partidista, de todo lo reñido con las exigencias elementales del acto de enseñar y de aprender, así como de todo lo que pueda atentar contra la seguridad del país" (Orbe, 2006: 165).

Durante su gestión ${ }^{914}$, se restringió el ingreso; se cerraron y fusionaron departamentos -por ejemplo, Humanidades, Economía y Geografía-; se suspendió la inscripción y el dictado de algunas carreras; se despidió a 225 docentes sin elevar sumario; se restringió la designación de alumnos como ayudantes; se atacaron

\footnotetext{
${ }^{910}$ Estudiante de Economía y militante de la JP-Montoneros. Fue secuestrado en Mar del Plata en agosto de 1976, trasladado a Bahía Blanca, torturado en "La Escuelita" y fusilado en un enfrentamiento fraguado el 18/9/1976 en la esquina de Dorrego y Gral. Paz (Véase https://juiciobahiablanca.wordpress.com).

${ }^{911}$ Entrevista a Juan Carlos, Buenos Aires, 1/8/2008.

912 En el marco del giro conservador y autoritario del gobierno, desde julio de 1974, Ivanissevich reemplazó a Taiana y dispuso la intervención de las universidades, designando para ello a personajes reaccionarios que asumieron sus cargos acompañados de grupos paramilitares. Así, quedaba inaugurado un escenario marcado por la violencia política y la instalación de un aparato represivo en el seno de las universidades. Los centros de estudiantes fueron clausurados, muchos alumnos fueron obligados a renunciar a sus carreras, se produjeron cesantías masivas de docentes, secuestros de profesores y alumnos en los mismos recintos de la casa de estudios que luego aparecían asesinados.

${ }^{913}$ Concepto utilizado por Alcira Trincheri (2003) al abordar la intervención de Tetu en la Universidad del Comahue y es retomado por Visotsky y Gattari (2004) para analizar el caso de la UNS.

914 Tetu fue reemplazado por Julio Reynoso, en agosto de 1975, con la llegada de Pedro Arrighi al ministerio de educación. Su gestión, que concluyó en marzo de 1976, constituyó una continuidad con respecto a la de Tetu y marcó la transición hacia el terrorismo de estado (Orbe, 2006).
} 
directamente las conquistas estudiantiles mediante la proscripción de los centros de estudiantes, el cierre de los Comités de Gestión, la prohibición de las asambleas de curso, las cátedras paralelas y los juicios académicos a los docentes; se cerró temporalmente el comedor universitario; se reformaron los planes de estudio y se terminaron las experiencias de extensión. Por otra parte, se nombró un cuerpo armado de seguridad y vigilancia que se instaló en los pasillos impidiendo la actividad política. En este escenario, el 3 de abril de 1975 en el ala de Ingeniería fue asesinado el estudiante David "Watu" Cilleruelo -secretario de la FUS y militante de la FJC-por Jorge Argibay, suboficial de la Armada e integrante de la custodia de Tetu. A lo largo del año, se multiplicaron las detenciones y asesinatos de estudiantes (Orbe, 2006).

En cuanto a los secundarios, los jecistas se convencieron de que, como cristianos, debían tener presencia en las aulas y en las luchas de los estudiantes del nivel medio. En palabras de Carlos: "como cristianos, teníamos que estar ahi",915. Y algunos, entendieron que, para ello, debían encuadrarse en una organización política. En este sentido, el compromiso de los actores en la escuela abarcaba un amplio abanico de acciones que, en un marco más general, caracterizaban a los jóvenes católicos latinoamericanos. Un estudio de 1970 puede ayudarnos a identificarlas y distinguirlas. Entre los tipos de intervención intraescolar se mencionaban los compromisos “interpersonal”, “en la promoción del medio", "gremial” y "de concientización”. El primero consistía en ayudar a los compañeros en las cuestiones personales, familiares o de estudio, dialogar con los profesores y estrechar la relación con ellos, así como fomentar el diálogo a nivel de curso para solucionar problemas de enemistad, discriminación, etc. ${ }^{916}$. Una anécdota de Inés puede servir para ilustrar la preocupación de los jecistas por acompañar a sus pares en sus dificultades:

una compañera había quedado embarazada y confió en mí como para charlarlo y para que la acompañe a hacer un aborto. Yo me hacía cruces, cómo yo como cristiana, como amiga, podía ayudar a esa compañera. Y bueno, la acompañé mucho, la respeté mucho, le dije todo lo que yo pensaba, que la decisión de última era de ella, ese fue algo concreto que llevé a las reuniones de la JEC ${ }^{917}$.

\footnotetext{
915 Entrevista a Carlos, Bahía Blanca, 4/5/2011.

916 Estudio de la JEC latinoamericana..., JEC Boletín Secundario, 14, agosto de 1970. En "Una experiencia de evangelización en el medio estudiantil", Spes, 29, pascua de 1976, se menciona el contacto interpersonal, el trabajo en la escuela -desde el centro de estudiantes- y en la clase -uniendo a los compañeros en torno a reclamos básicos-, como espacios de la militancia de los estudiantes católicos.

${ }^{917}$ Entrevista a Inés, Bahía Blanca, 18/6/2011.
} 
El segundo tipo de acción apuntaba a crear las condiciones para la participación en las clases, para el desarrollo de las capacidades artísticas, culturales y deportivas de los estudiantes, para la amistad, la solidaridad, el servicio, y a la vez, para el cuestionamiento a los valores "burgueses" de los estudiantes ${ }^{918}$. En este nivel, Inés aludía a diversas iniciativas que emprendió en su escuela. En primer lugar, sus intervenciones en las clases de religión buscaban promover otras miradas sobre la fe y el ser cristiano que, acordes con la renovación conciliar, se encarnaran en la realidad concreta, "la vida cotidiana, la convivencia, el compañerismo”. Luego, su participación en la organización de eventos deportivos desde el centro de estudiantes procuraba proponer una forma de practicar la actividad física más inclusiva y pluralista: “decíamos 'tenemos que participar todos', tengas condiciones o no tengas condiciones, ayudar desde la planilla, o sea, otro concepto de ver el deporte, la competencia"919.

La tercera forma de compromiso asumida por los jecistas en la escuela se orientaba a la participación en las luchas masivas del estudiantado que suponían un cierto grado de organización, con objetivos reivindicativos (por el cambio de profesores, programas, medidas disciplinarias, por la organización de los estudiantes en centros, por presupuesto, por la participación en la dirección de los colegios, por la enseñanza gratuita) o bien reformistas (por cambios de fondo en el sistema educativo, por una educación liberadora) ${ }^{920}$. Para los bahienses, era menester involucrarse en las discusiones del curso y en las asambleas del colegio. Así, los jecistas tuvieron protagonismo en las movilizaciones e iniciativas emprendidas en las propias escuelas.

Por ejemplo, en 1973, los alumnos de la Escuela Normal se enfrentaron a las autoridades cuestionando el sistema de calificaciones, en el que se promediaba la nota de desempeño cognitivo con una nota de evaluación de los aspectos actitudinales. Según los estudiantes, la posibilidad de subir o bajar la nota final de cada materia a partir de esta segunda instancia era utilizada por algunos profesores para castigar a los alumnos que tenían mayor participación en el centro de estudiantes. En consecuencia, solicitaron que se suprimiera la nota de concepto y, para ello, convocaron a una reunión con padres, profesores, directivos y el interventor de la universidad ${ }^{921}$. Para Gabriel, este hecho fue "muy disparador en el compromiso político",922.

\footnotetext{
918 Estudio de la JEC latinoamericana..., JEC Boletín Secundario, 14, agosto de 1970.

${ }^{919}$ Entrevista a Inés, Bahía Blanca, 18/6/2011.

${ }^{920}$ Estudio de la JEC latinoamericana..., JEC Boletín Secundario, 14, agosto de 1970.

${ }^{921}$ Entrevistas a Gabriel, Bahía Blanca, 27/10/2012, y a Francisco, Buenos Aires, 16/11/2012.

${ }^{922}$ Entrevista a Gabriel, Bahía Blanca, 27/10/2012.
} 
A fines de octubre y en noviembre de 1973, los alumnos de las Escuelas Medias de la UNS ocuparon el edificio para apoyar la intervención de Benamo y sumarse a la toma que por entonces se producía en la universidad (Seitz, 2010). Francisco recordaba la medida protagonizada por el centro de estudiantes, en el que confluían militantes de diversas agrupaciones políticas, entre las que la UES adquiría un lugar central:

éramos como el brazo ejecutor de las políticas de lo que se llamaba la Tendencia Revolucionaria dentro del ámbito estudiantil. Cuando tomamos el colegio es porque habia que tomar el colegio. Obviamente nos convencimos, analizamos, pero detrás de eso estaba una necesidad de ganar ese espacio ${ }^{923}$.

Entre las iniciativas más significativas del período se encuentra la toma de la ENET $n^{\circ} 1$, ocurrida previamente ${ }^{924}$. Debe tenerse en cuenta que para entonces, ésta junto al Colegio Nacional y las Escuelas Medias de la UNS, eran las más importantes de la ciudad, y por tanto, uno de los espacios educativos de mayor visibilidad (Seitz, 2010). La toma de la ENET comenzó el 12 de junio de 1973, cuando un grupo de alumnos se reunió con la rectora Fenil Echarren, y el director, Enrique Faggi, y le manifestó su malestar por el estado en que se encontraba el establecimiento -deterioro del edificio y falta de equipamiento de los talleres- y los invitó a retirarse, acusando a la primera de no ocuparse suficientemente de sus tareas. Los protagonistas de la toma fueron los alumnos de $4^{\circ}, 5^{\circ}$ y $6^{\circ}$ año -entre ellos, Alberto Paira y Gustavo-. Al principio, eran 200 estudiantes que, divididos grupos, rotaban durante las 24 horas. A ellos se sumaban otros que acompañaban llevando alimentos o cigarrillos. Pero la cantidad de estudiantes fue disminuyendo, hasta reducirse a una "guardia" de 20 alumnos (Seitz, 2010).

La toma tuvo un carácter pacífico, implicó la suspensión de las clases y estuvo marcada por la preocupación constante de los estudiantes por el cuidado de la escuela. Incluso organizaron un grupo de vigilancia nocturna y pintaron los muros exteriores. Por otro lado, la medida no tuvo motivaciones político-partidarias. Si bien algunos de

\footnotetext{
${ }^{923}$ Entrevista a Francisco, Buenos Aires, 16/11/2012.

${ }^{924}$ El proceso de tomas de escuelas, así como de otras instituciones (medios de comunicación, sindicatos, fábricas, organismos oficiales, universidades) que tuvo lugar durante los 49 días del gobierno de Cámpora, tenía un carácter anticontinuista. Así, en las escuelas y universidades, los estudiantes se manifestaron por el desplazamiento de directores o profesores identificados con la dictadura precedente. En la mayoría de los casos, los alumnos expresaron también otros reclamos, como la reforma del plan de estudios (Nievas, 1999: 362). En Bahía Blanca, los ámbitos ocupados fueron muy diversos, a saber: la emisora LU7 Radio General San Martín, el Departamento y el Instituto de Ingeniería de la UNS, el Policlínico Ferroviario, la delegación local de la Subsecretaría de Trabajo y del Ministerio de Trabajo, el Distrito $19^{\circ}$ de la Dirección Nacional de Vialidad, la Escuela de Servicio Social, el Departamento de Química e Ingeniería Química de la UNS y la Escuela de Graduados, el Hospital Dr. José Penna, la Dirección de Construcciones Portuarias y Vías Navegables, la sede de la Zona Sanitaria Primera, la empresa CREDILOM S.A., el edificio de Tribunales y la administración de la Aduana (Seitz, 2010).
} 
sus protagonistas eran militantes de la UES u otras agrupaciones, la mayoría no tenía adscripciones políticas. Además, los alumnos, incluidos quienes eran militantes, acordaron defender el carácter no partidario de la medida. Así, cuando un grupo de la JP pintó consignas políticas en las paredes, e incluso amenazó a los estudiantes que intentaron oponerse, Alberto Paira -por entonces ya un referente de la UES-, salió al cruce de los activistas pidiéndoles que se retiraran. Detrás de esta actitud estaba la idea de que si se "politizaba" la toma, la reivindicación, que contaba con el consenso de todo el estudiantado, perdería fuerza ${ }^{925}$. Finalmente, la medida se levantó el 19 de junio de 1973. Los alumnos entregaron el colegio al inspector que procuró normalizar el funcionamiento de la escuela y nombró un interventor (Seitz, 2010).

Este tipo de iniciativas daba cuenta de un clima de creciente organización de los estudiantes secundarios, que resultaba novedoso. Si a fines de los años sesenta, las agrupaciones estudiantiles de la UNS señalaban sus dificultades para encontrar apoyo a sus propuestas entre los secundarios, y los informes de inteligencia ratificaban la apatía de estos sectores ${ }^{926}$, a mediados de 1972, estos últimos comenzaron a agruparse, acercándose a los centros de estudiantes, que se multiplicaron un año después, y haciéndose frecuentes las movilizaciones de la UES en el espacio público (Seitz, 2010). A nivel nacional, fue durante los años 1966-1969 ${ }^{927}$ que se dio un proceso de constitución de una porción del alumnado como movimiento social, siguiendo los andariveles de los universitarios, y de la conformación de un frente opositor a la dictadura. La movilización de los secundarios comenzó a partir de la intervención a las universidades, que afectaba también a las escuelas dependientes de aquéllas. En este período, las acciones de los actores se caracterizaron por acompañar las luchas de sus pares de la educación superior y por una creciente politización, lo que alentó a varios partidos políticos a procurar organizarlos -en este proceso, se destacó el PC y luego, la Tendencia Estudiantil Socialista Revolucionaria (TERS) ${ }^{928}$ - (Bonavena, 2012). En este

\footnotetext{
${ }^{925}$ Entrevista a Gustavo, Bahía Blanca, 12/7/2011 y testimonio de Alfredo Ayude durante el homenaje a Alberto Paira, celebrado en Bahía Blanca el 8/7/2011.

926 "En Bahía Blanca y su jurisdicción, los sectores estudiantiles secundarios, en motivo de la innovación en los programas de estudio y exámenes, no han exteriorizado reacción alguna y menos aún los grupos de izquierda que no existen" (Archivo DIPPBA, Mesa A. Factor Estudiantil, Legajo No1, Bahía Blanca, Tomo 11, 18/6/1968, citado en Seitz, 2010: 29).

${ }^{927}$ Hay pocos trabajos sobre el movimiento estudiantil secundario en la Argentina o bien evidencian un acotado sustento empírico. Según Bonavena (2012), ello se debe a la discontinuidad de su acción en el tiempo, comparada con el protagonismo de los universitarios, y la dificultad para encontrar fuentes.

928 Entendía el movimiento estudiantil como parte importante de la oposición a la dictadura militar. Levantaba la consigna de gobierno obrero-estudiantil de la universidad, que se correspondía a la de gobierno obrero-popular del país. Con ello proponía que el estudiantado uniera sus reivindicaciones a las
} 
contexto, muchos jóvenes comenzaron su acción política a temprana edad, en los centros de estudiantes. A principios de los años setenta, existían diversas agrupaciones de secundarios, que respondían a diferentes tendencias políticas dentro de la izquierda; entre ellas, la UES; la Juventud Guevarista, vinculada al PRT; la FJC; la Juventud Socialista, del Partido Socialista; el Grupo de Estudiantes Socialistas Antiimperialistas (GESA); la Juventud Radical Revolucionaria, ligada al partido Radical (Seitz, 2010).

Los jecistas bahienses participaron activamente en este proceso de organización del estudiantado secundario, contribuyendo a la formación de los centros de estudiantes. Así lo hicieron María Clara Ciocchini, Gabriel o Francisco en la Escuela Normal, donde convivían militantes de la UES con los del PB y la FJC, así como alumnos que no estaban adscriptos a las agrupaciones. En este sentido, Gabriel recordaba que la idea era que el centro debía ser un espacio “apolítico”, no comprometido con ningún grupo en particular, de modo de facilitar la llegada a los compañeros ${ }^{929}$.

Por su parte, Inés fue testigo y protagonista de la organización de las alumnas en el colegio San Vicente de Paul, a través de la constitución del centro y la designación de delegadas por curso. Entre las problemáticas que buscaban cambiar, se encontraban las reglas disciplinarias: "se intentaba lograr un contrato de convivencia más que una NORMA rígida que viniera 'no a esto, no a lo otro, no a pintarse las uñas, no a... ",930.

En la ENET, la toma fue el momento más álgido de movilización de los alumnos pero éstos venían llevando a cabo diversas iniciativas, entre ellas, unas jornadas pedagógicas que buscaban difundir los lineamientos de Paulo Freire ${ }^{931}$, y asambleas, en las que participaban los delegados de curso. Fue precisamente en ese espacio donde se decidió la medida. En los años siguientes, esa coordinadora de estudiantes siguió existiendo, pero parte del estudiantado dejó de participar ante lo que percibían como el avance de los alumnos que tenían una pertenencia político-partidaria (Seitz, 2010). En ese período, Gustavo, quien se incorporó a la UES, profundizó su compromiso gremial e integró una lista para las elecciones del centro de estudiantes ${ }^{932}$.

de los trabajadores y a sus objetivos socialistas y revolucionarios, escapando al "academicismo burgués" ("El movimiento estudiantil responde", Graphos, 5, abril de 1971).

${ }^{929}$ Entrevista a Gabriel, Bahía Blanca, 7/12/2012.

${ }_{930}$ Entrevista a Inés, Bahía Blanca, 18/6/2011.

${ }^{931}$ Entrevista a Gustavo, Bahía Blanca, 12/7/2011. A principios de los sesenta vieron la luz las teorías pedagógicas crítico-reproductivistas que cuestionaban la escuela por ser un instrumento de reproducción de un orden social injusto. Surgieron entonces propuestas que planteaban reformas en el sistema educativo, o bien ubicarse por fuera y en oposición a éste. Entre ellas, la Pedagogía de la Liberación, inspirada en la obra de Freire. Estas experiencias de renovación didáctica comenzaron a filtrarse en el sistema educativo luego del "Cordobazo" y tuvieron auge en el tercer gobierno peronista (Seitz, 2010).

${ }^{932}$ Entrevista a Gustavo, Bahía Blanca, 12/7/2011. 
Estrechamente unido al compromiso gremial, el último tipo de intervención de los jóvenes católicos se concretó en el cuestionamiento y la denuncia a nivel de la realidad educativa o, de un modo más amplio, de la realidad nacional (la explotación, el sistema capitalista, el imperialismo, etc.). En este sentido, Alicia y Elsa coincidían en que les cabía contribuir a la "toma de conciencia" de sus compañeros respecto de las situaciones que se planteaban en la escuela así como de las problemáticas sociales y políticas más generales ${ }^{933}$. En cuanto a los medios elegidos, éstos incluían el diálogo cara a cara, las organizaciones gremiales, políticas o culturales, mesas redondas, debates, charlas, conferencias, jornadas de estudio, manifestaciones masivas, denuncias públicas, periódicos, carteleras, murales, volantes ${ }^{934}$.

En este marco, una parte de los jecistas se unió a la UES. Como exponía antes Francisco, en estos casos, la participación en los centros de estudiantes estaba vinculada con esta adscripción partidaria. En efecto, según explicaban Inés y Gustavo, una de las prioridades de la UES era refundar los centros y que éstos funcionaran en cada uno de los colegios como espacios de discusión y de acción que atendieran a sus realidades específicas $^{935}$. La idea era "hacer una politica de transformación en los colegios secundarios",936, desarrollar en ellos una "labor de concientización política"937. En este sentido, la UES Bahía Blanca resumía su trabajo de base, resaltando la acción de "cada militante en su curso creando una conciencia de lucha nacional y popular"; la participación en las tomas de colegios y en las jornadas pedagógicas, “dando la línea de la Tendencia en cuanto a problemas de la educación y la participación en la tarea de la reconstrucción nacional"; la formación de mesas y brigadas de trabajo para colaborar en los frentes barriales; y la presencia en las movilizaciones ${ }^{938}$.

En efecto, los militantes de la JEC que integraron la UES participaron de una serie de actividades que excedían el ámbito escolar, como los actos y marchas que tuvieron lugar en Bahía Blanca -ligados a la campaña electoral del FREJULI ${ }^{939}$, el aniversario de la Masace de Trelew ${ }^{940}$ o la muerte de Perón-, y en la Capital -el $1^{\circ}$ de

\footnotetext{
${ }^{933}$ Entrevista a Alicia, Bahía Blanca, 9/7/2011; a Elsa, Bahía Blanca, 9/3/2012.

${ }^{934}$ Estudio de la JEC latinoamericana..., JEC Boletín Secundario, 14, agosto de 1970.

${ }^{935}$ Entrevista a Inés, Bahía Blanca, 18/6/2011; a Gustavo, Bahía Blanca, 12/7/2011.

${ }^{936}$ Entrevista a Gustavo, 9/8/2012.

937 "Ponen el hombro en Salta 500 secundarios", El Eco, 8/1/1974.

938 "Los secundarios en lucha", Graphos, 16, agosto de 1973.

${ }^{939}$ Entrevista a Gabriel, Bahía Blanca, 27/10/2012. "Un gran acto del Frente”, El Eco, 3/2/1973.

${ }^{940}$ Entrevista a Marisa, Neuquén, 19/3/2013, y a Inés, Bahía Blanca, 18/6/2011. "Información relacionada acto aniversario sucesos de Trelew", 23/8/1974, Archivo DIPPBA, Mesa "D(s)", Carpeta Varios, Legajo 383. Tomo 5.
} 
mayo de 1974 en la Plaza de Mayo-, la distribución de volantes y publicaciones como El Descamisado ${ }^{941}$, la realización de pintadas, las reuniones de discusión de documentos partidarios, la confección de la revista de la agrupación -"Notas de interés del estudiante secundario"-, los operativos de solidaridad en los barrios periféricos o los campamentos.

El boletín de la UES, que estaba a cargo de un grupo de militantes entre los que se encontraba Juan, contaba con diversas secciones dedicadas a las cuestiones políticas y estudiantiles, así como a problemáticas puntuales de interés general -por ejemplo, la vivienda-, a la música -la columna era elaborada por Francisco-, o al humor, y tenía una tirada de alrededor de 300 ejemplares que se distribuían en 12 colegios. La impresión, según Juan, se llevaba adelante utilizando muchas veces el mimeógrafo de Cáritas, dado que algunos de los militantes eran voluntarios en dicha institución ${ }^{942}$.

Con respecto a la acción en las villas, bajo el lema de "devolver al pueblo lo que el pueblo nos da", los militantes compartían jornadas para refaccionar escuelas primarias, como Nuestra Señora de la $\mathrm{Paz}^{943}$. Al respecto, Inés recordaba: "la escuela estaba bastante deteriorada, y formamos un grupo, los chicos del Industrial, que sabian de construcción y demás, y un grupo de San Vicente, y pintamos"

En cuanto a los campamentos de la UES, Juan participó en uno que tuvo lugar en Saliqueló en enero de 1974, y que reunió a unos 50 militantes de distintas ciudades y colegios, con el doble objetivo de trabajar en una escuela y formarse, a través de la lectura y discusión de material de estudio ${ }^{945}$. Por su parte, Gustavo fue uno de los 9 bahienses que viajó a Salta en enero de 1974, para participar del "operativo de reconstrucción General Martín de Güemes”, donde 500 militantes provenientes de múltiples puntos del país realizaron tareas de limpieza de calles, refacción de escuelas y viviendas, campañas de salud pública, organización de dispensarios, y construcción de canales de riego y defensa para la contención de ríos, en ocho municipalidades salteñas. Este trabajo, que tenía lugar entre las 6 de la mañana y las 12 del mediodía, era complementado con la formación y discusión política, que se desarrollaba por la tarde. Asimismo, los jóvenes compartían actividades artísticas y fiestas populares. Así, el

\footnotetext{
${ }^{941}$ Entrevista a Alicia, Bahía Blanca, 9/7/2011; a Pedro, Buenos Aires, 15/11/2012; a Inés, Bahía Blanca, 18/6/2011.

${ }^{942}$ Entrevista a Juan, Bahía Blanca, 14/8/2012.

${ }^{943}$ Entrevista a Juan, Bahía Blanca, 14/8/2012, y a Gustavo, Bahía Blanca, 12/7/2011.

944 Entrevista a Inés, Bahía Blanca, 18/6/2011.

${ }^{945}$ Entrevista a Juan, Bahía Blanca, 14/8/2012.
} 
campamento se proponía que los militantes se consustanciaran con la realidad del pueblo y brindaran apoyo efectivo a la "reconstrucción del gobierno popular"946.

\section{5) La militancia política y las opciones político-partidarias}

Como adelantamos anteriormente, los jocistas, jucistas y jecistas bahienses desarrollaron una militancia política en aquellos años. ¿Por qué la acción política se constituyó en una alternativa -y en ocasiones la privilegiada- para estos actores? ¿Qué motivos los impulsaron a tomar esa opción? ¿Qué itinerarios concretos adoptó? Los jóvenes eligieron el activismo político en organizaciones revolucionarias a partir de la convicción de que éste formaba parte o, aún más, era “el máximo nivel” y el modo más "generoso" de compromiso de un cristiano ${ }^{947}$, una opción "coherente" $" 948$ con su fe, una manera de vivirla "históricamente" 949 , de "cumplir el Evangelio" "950. Al respecto, Gustavo decía: "nosotros creíamos que el Espíritu [Santo] soplaba para ahi",951.

El compromiso político fue vivido por los actores como la consecuencia de la asunción de la exigencia de transformar la realidad, como aporte a la construcción del Reino de Dios en este mundo. Así lo explicaba Jorge: "si no intentás modificar las estructuras te quedás en el limbo. Todo muy lindo, el amor de Jesús, Dios te va a favorecer cuando te mueras pero la cosa tiene que ser acá" ${ }^{952}$. En efecto, como hemos visto, para los cristianos liberacionistas, salvación histórica y salvación cristiana podían diferenciarse aunque no separarse. Desde esta perspectiva, sólo un paso alejaba la toma de postura a favor de un orden social más justo y la acción política como vía para lograrlo. El cambio social encontraba en la política una herramienta privilegiada, se ponía en juego en dicha arena. La pobreza, el hambre, la desigualdad requerían soluciones radicales, en tiempos donde la revolución parecía posible, necesaria e inminente. La apuesta era por un proyecto político que alumbrara una nueva sociedad donde no fuera ya necesaria la ayuda a los pobres, desde el momento en que todos tendrían las mismas posibilidades de acceso a la vivienda, a la educación o al trabajo.

\footnotetext{
946 Entrevista a Gustavo, Bahía Blanca, 12/7/2011. "La UES en Salta”, "Ponen el hombro en Salta 500 secundarios”, El Eco, 8/1/1974; “Operativo Güemes”, El Eco, 11/1/1974.

${ }_{947}$ Entrevista a Mónica, Buenos Aires, 30/7/2008 y 9/11/2011.

${ }^{948}$ Entrevista a Gustavo, Bahía Blanca, 12/7/2011; a Ricardo, Bahía Blanca, 8/10/2011.

${ }^{949}$ Entrevista a Alicia, Bahía Blanca, 9/7/2011.

${ }^{950}$ Entrevista a Juan, 31/5/2011.

951 Entrevista a Gustavo, Bahía Blanca, 12/7/2011.

${ }^{952}$ Palabras de Jorge, entrevista a Mirta y Jorge, Bahía Blanca, 11/4/2012.
} 
Si, como contaba Paloma, los militantes revisaban permanentemente la "eficacia" de su accionar en el entorno, la política emergía como el arma más eficaz para lograr la utopía. Y más allá de los jóvenes bahienses, esta cuestión constituía una preocupación primordial para los cristianos liberacionistas. La idea de que "el amor ha de realizarse en la acción consciente de búsqueda de eficacia al servicio de los demás" era compartida en la reflexión del MIEC-JECI sobre el sentido de la vida militante ${ }^{953}$. Ya Camilo Torres había destacado esta idea en sus esfuerzos por vincular a los cristianos con la teoría y la práctica revolucionarias. Para el sacerdote, la esencia del cristianismo era el amor a los demás y éste, para ser verdadero, debía buscar la eficacia. No podía hallarla en la beneficencia, la limosna, las pocas escuelas gratuitas o los escasos planes de vivienda. En la situación que vivía su pueblo, la revolución era la única manera para hacer efectivo el amor al prójimo. De este modo, la lucha revolucionaria aparecía como un imperativo cristiano (Levine, 2011).

Así, la participación en agrupaciones políticas significaba la profundización de las intervenciones que los actores asumían en su medio. En este sentido, la acción pastoral, barrial o gremial no eran suficientes, incluso para quienes las desarrollaban en paralelo al activismo político. Mirta, que era catequista, decía: "hasta acá puedo llegar en la Iglesia pero si quiero cambiar un poco más la sociedad, me tengo que meter más en política, tengo que estudiar un poco más por dónde viene la cosa",954.

Y así como las maestras de Villa Nocito encontraron en la Unidad Básica o la Agrupación Evita otros canales de acción simultáneos de compromiso barrial, los militantes que trabajaban en otras zonas periféricas de la ciudad desde instituciones diversas vivieron un proceso similar. Aída, explicaba su militancia política como consecuencia de su labor en la post-escuela de Villa Rosario: "no te alcanzaba con esto solamente, vos necesitabas otro marco, otra estructura, otra explicación "955 . En efecto, el compromiso con los pobres, que partía de un deber moral como cristianos, enfrentó a los militantes bahienses con aquella realidad, modificándose así su percepción social e impulsándolos a asumir prácticas políticas, aunque sin abandonar la militancia social ni el grupo católico. Sobre esta cuestión, Donatello, al analizar las redes del catolicismo liberacionista y las trayectorias de los militantes católicos que optaron por la acción política insurreccional, señalaba:

\footnotetext{
953 "Pascua y evangelización”, Spes, 6-7, abril-mayo de 1970.

${ }^{954}$ Entrevista a Mirta, Bahía Blanca, 18/6/2008.

${ }^{955}$ Entrevista a Aída, Buenos Aires, 17/5/2013.
} 
Aquí la transformación más profunda en el nivel de las trayectorias se daba por la visualización de la pobreza, la exclusión, y la marginalidad como fenómenos que iban más allá de los planteos morales inmediatos. Lo cual generaba una reflexión -que llevaba a los integrantes al campo de la ética y la política- y que fundamentalmente implicaba un llamado a la acción que excede las posibilidades de las redes de las cuales forman parte (2003: 108).

Como plantea Levine (2011) para Camilo Torres, estos militantes habían llegado a la conclusión de que ser fiel al Evangelio requería obligaciones que los llevarían más allá de los límites de la Iglesia institucional. Siguiendo a Donatello (2010), las posibilidades de acción dentro de la esfera estrictamente religiosa eran limitadas. Ni la jerarquía ni los movimientos laicales estaban en condiciones de dar cauce a las aspiraciones revolucionarias. En consecuencia, lo religioso debía penetrar y constituirse en político.

De los testimonios se desprende, entonces, que aquella opción era vivida como un paso natural/normal, el fruto de la revisión de vida. En este sentido, Jorge decía: "entrar a militar a la JOC prácticamente te llevaba como por un tubo a la militancia política" 956 . Y para Ricardo: "había una COINCIDENCIA entre lo que era nuestra militancia política, nuestra militancia de Iglesia, nuestra militancia con la sociedad" ${ }^{957 .}$.

Ahora bien, una vez que los militantes católicos abrazaron la militancia política, ¿qué afinidades encontraron entre su pertenencia eclesial y su participación en los nuevos espacios? ¿Qué prácticas y saberes facilitaron su integración al mundo de la política? Cuando estos jóvenes se incorporaron a las agrupaciones que se asumían como revolucionarias contaban con un conjunto de experiencias adquiridas en el ámbito del catolicismo que estaban en condiciones de aportar al grupo político. En particular, la capacidad/ el ejercicio de trabajar en grupo, de organizar/ planificar/ coordinar actividades, de reflexionar, y en particular, de observar la propia práctica, de analizar críticamente/interpretar hechos sociales y políticos, de leer y estudiar, y de debatir/ dialogar, lo que, a su vez, suponía formar una opinión personal/ tomar una postura, poner en palabras/ exponer argumentos en público, escuchar, moderar, procurar que todos se expresen, sacar conclusiones, integrar pareceres, buscar acuerdos. Este aspecto cobraba especial relevancia en el contexto dictatorial previo a 1973, en el que la militancia estudiantil y la posibilidad de discusión política estaban limitadas.

En este sentido, como ha analizado Agulhon (2009) para otros referentes empíricos, cuando la política no podía expresarse en otra parte, penetraba en la vida de

\footnotetext{
${ }_{956}$ Palabras de Jorge, entrevista a Mirta y Jorge, Bahía Blanca, 11/4/2012.

${ }^{957}$ Entrevista a Ricardo, Bahía Blanca, 8/10/2011.
} 
asociaciones que encontraban su razón de ser en otros objetivos. Así ocurrió en los círculos burgueses, entre los hombres con afinidades de vecindario, entorno o amistad, que se reunían para leer el periódico y conversar. Pero esta sociabilidad pueblerina les brindaba ocasión para discutir y opinar sobre política, hábitos que, así, transformaron mentalidades, politizándolas. También la JUC, la JEC o la JOC multiplicaron los espacios de lectura y debate político. Al calor de las reuniones semanales y en el marco de efervescencia social de aquellos años, la comunidad y el grupo de amigos contenido en ella, descubrió en conjunto la política. Como en los casos analizados por el historiador francés, vemos a "la política utilizar estructuras tomadas de la sociabilidad y la sociabilidad siempre proclive a colorearse de política" (Agulhon, 2009: 123).

Los saberes se ponían en juego mediante una práctica sistemática llevada a cabo de manera comunitaria. La reunión de revisión de vida era el ámbito privilegiado de aprendizaje, aunque éste también tenía lugar durante otras actividades periódicas del movimiento, tales como los campamentos de verano, las asambleas y los encuentros. En consecuencia, eran internalizados de modo espontáneo. Paloma decía del hábito de planificar, proyectar y fijar objetivos: "lo adquiríamos al estar trabajando así en grupo. Era como algo que se nos introducía sin darnos cuenta" 958 .

Asimismo, el protagonismo de los jóvenes en estos espacios, su "corresponsabilidad" al decir del asesor, el criterio de pertenecer a un "movimiento de jóvenes dirigido por jóvenes" -que inspiraba particularmente al Scoutismo pero también marcaba a los grupos de reflexión-, fue la condición de posibilidad para que esa construcción de saberes tuviera lugar. En este sentido, como explicaba Mirta, la figura de un coordinador, que guiaba la reflexión en cada encuentro, era significativa: "tenías que dejar hablar a todos, tenías que tomar nota, tenías que hacer una síntesis de lo que se decía y tenías que ir al Evangelio y buscar la iluminación. O sea que vos te hacías o te hacías " ${ }^{959}$. El ejercicio rotativo de este rol hizo que con el tiempo todos estuvieran en condiciones de desempeñarlo. Al respecto, Bruno decía: "lo hacíamos con tal naturalidad, que ni nos entorpecíamos"960. Por su parte, Manuel aludía a los saberes recreados conjuntamente en los encuentros jucistas, ligados a la práctica de la discusión grupal, que suponían un papel activo de todos los integrantes: "nos escuchábamos mucho...realmente entre nosotros habia 4-5 que eran buenos oradores [...] y nuestra

\footnotetext{
${ }_{958}$ Entrevista a Paloma, vía skype, 22/2/2013.

${ }^{959}$ Entrevista a Paloma, vía skype, 22/2/13.

${ }^{960}$ Entrevista a Bruno, Bahía Blanca, 4/8/2012.
} 
manera de trabajar facilitaba que los que hablaban menos hablaran [...] si no hablabas te reclamaban que hablaras, sobre todo Pepe",961.

En ocasiones, el aporte que los grupos de revisión de vida hacían en términos de formación planteaba una continuidad con lo aprendido en otros espacios del catolicismo liberacionista local, especialmente, en el movimiento Guía-Scout. Pedro rescataba el aprendizaje organizativo que había significado su participación en "San Pío X":

decíamos "vamos a escalar el Tres Picos". Le mandábamos una carta a los padres: "traer tal cosa, tal otra", cuando estaba el colectivo nos íbamos [...] salir solo es una cosa y salir de a 30 o de a 100 como son los campamentos es otra, entonces necesitas una organización, una comunicación que te entrena ${ }^{962}$.

En suma, la JUC, la JOC y la JEC se constituyeron en un ámbito de formación integral, no sólo en relación a una serie de concepciones, valores y actitudes que impulsaron a los jóvenes a la acción, sino también a un conjunto de herramientas organizativas y relacionales asociadas al trabajo colectivo que resultaron claves en el mundo de la militancia social y política. Mónica explicitaba esta vinculación en el caso de la UES: "veníamos como cuadros semiformados"963. También apuntaba Carlos: "los chicos de la JEC llevaban las inquietudes y las habilidades de reflexionar, de armar, de agrupar gente" 964 . Y Gustavo repasaba las ventajas que estas aptitudes previas les significaron en términos de adaptación a las tareas propias del activismo político:

coordinar una reflexión, un encuentro, organizar el encuentro, son elementos que la persona que no tiene una práctica, o no tenía una vivencia de grupo, de organización, de participación, no la tiene. Y en ese sentido, nosotros estábamos MUY favorecidos, con muchos más elementos que otros compañeros ${ }^{965}$.

Por su parte, Manuel hacía referencia a la preparación que había adquirido en la JUC en el hábito de lectura de documentos y bibliografía, como un capital que luego facilitó su participación en las agrupaciones de la izquierda peronista: "habíamos incorporado una pedagogía...yo le era útil al Peronismo de Base porque había que estudiar un material, yo estudiaba el material, lo discutíamos y yo ponía cosas que los demás no ponían" "966.

El protagonismo de la Iglesia en la formación de militantes no era nuevo, sino que estaba estrechamente unido al pasaje de un catolicismo de concentración de fuerzas

\footnotetext{
${ }^{961}$ Entrevista a Manuel y Nancy, Neuquén, 21/3/2013.

962 Entrevista a Pedro, Buenos Aires, 15/11/2012.

${ }^{963}$ Entrevista a Mónica, Buenos Aires, 9/11/2011.

${ }^{964}$ Entrevista a Carlos, Bahía Blanca, 4/5/2011.

965 Entrevista a Gustavo, 9/8/2012.

${ }^{966}$ Entrevista a Manuel y Nancy, Neuquén, 21/3/2013.
} 
-con partidos políticos, sindicatos y obras católicas-, a otro de penetración en la sociedad y el Estado -que buscaba católicos que dirigieran los sindicatos, los partidos y la educación. Para esa tarea, como hemos visto, fueron claves dispositivos como la Acción Católica. Así, miles de jóvenes tuvieron su primera actividad social, cultural, de análisis, de conocimiento de la realidad nacional, de participación política a través de su incorporación a esta organización, y rápidamente surgió en ellos la necesidad de llevar esos principios a la acción (Mallimaci, 1992). Como plantean Bidegain (2009) y Catoggio (2010b) para el caso de las mujeres, la Acción Católica se constituyó en un nuevo espacio de socialización que aportó una plataforma que fomentaba el aprendizaje organizativo y establecía las condiciones para un movimiento social. En otras palabras, en ese ámbito, "las mujeres católicas realizaron aprendizajes y articularon una trama asociativa que [...] sentaron las bases para la articulación de demandas llevadas más tarde a la arena social y política" (Catoggio, 2010b: 33). Dentro de esta misma matriz, uno de los objetivos pastorales de la renovación católica en la Argentina pasaba por la formación del mayor número de militantes, y ello implicaba una estrategia de inserción en la política. "Una actitud intramundana que implica, sin embargo, una visión supramundana y ecuménica de la acción política" (Mallimaci, Cucchetti y Donatello, 2006: 17).

\section{a) EI "encanto y desencanto" con agrupaciones marxistas}

Los jucistas militaron en diversas agrupaciones universitarias. Debe tenerse en cuenta que durante el Onganiato, tuvo lugar una "partidización" de la vida universitaria, que se tradujo en el desplazamiento de las antiguas agrupaciones gremiales de los estudiantes por tendencias políticas (Barletta y Tortti, 2002; Orbe, 2007). En la UNS confluían agrupaciones que actuaban como frentes estudiantiles partidarios y eran la expresión del proceso de cambio, movilización y "politización" del movimiento estudiantil. En general, estos espacios compartían un posicionamiento antidictatorial y un discurso revolucionario/combativo: los Grupos Socialistas ${ }^{967}$-que seguían la línea

\footnotetext{
${ }^{967}$ Surgieron en Bahía Blanca en 1970. Su objetivo era "terminar con el sistema capitalista y construir el socialismo" y entendían que para ello el uso de la violencia era inevitable. Abogaban por la organización y toma de conciencia de los estudiantes respecto de la necesidad de intervenir en la lucha por una sociedad y un hombre nuevos ("El movimiento estudiantil responde", Graphos, 5, abril de 1971).
} 
del PRT-ERP ${ }^{968}$-, el Frente de Acción Estudiantil (FAE) ${ }^{969}$-ligado a los sectores más combativos de la clase obrera nucleados en torno a la CGT de los Argentinos-, la TERS -que continuaba el programa y posicionamiento de Política Obrera ${ }^{970}$-, el FEN -que militaba en el peronismo revolucionario-, la Agrupación Universitaria de Acción Liberadora (AUDAL) ${ }^{971}$-adherida al Frente de Agrupaciones Universitarias de Izquierda (FAUDI) vinculada al PCR - y la Agrupación Estudiantil Reformista (AER) ${ }^{972}$ -que formaba parte del Movimiento de Acción Reformista (MOR), vinculado al PC-.

AUDAL tuvo un fuerte componente de militantes cristianos -y en particular, jucistas- que protagonizaron su formación. Según Juan Carlos, sus principios estaban "sacados de los documentos de Medellín"973. La agrupación nucleaba a gente identificada con la crítica al orden vigente que luego siguió diversas trayectorias en grupos trotskistas y peronistas. Por otra parte, en los primeros años de la década de 1970, algunos jucistas participaron en los Grupos Socialistas y en la TERS.

En muchos casos, desde fines de los años sesenta hasta el advenimiento de la oleada represiva de las Tres A, los mismos jóvenes pasaron por diferentes agrupaciones: el PRT antes o después del V Congreso, AUDAL, y en 1973, se incorporaron a la JUP.

\footnotetext{
${ }^{968}$ El PRT en Bahía Blanca tuvo dos etapas: la primera, de formación, entre 1965 y 1969, y la segunda, desde 1970. Entonces el pequeño grupo que conformaba el PRT El Combatiente se debilitaba mientras surgían nuevos grupos que protagonizaron la segunda etapa del partido. Esto confluía a nivel nacional con la celebración del V Congreso y la constitución del ERP. Nacía el PRT-ERP en la ciudad con un nuevo programa, nuevos militantes y nuevas prácticas (Giménez, 2008).

969 Agrupación que incluía a peronistas y no peronistas, se definía como revolucionaria y abogaba por la liberación nacional y el socialismo, esto es, por la lucha contra los monopolios y la oligarquía, por una universidad para el pueblo, por la socialización de los medios de producción, en suma, "por todo el poder para el pueblo" ("El movimiento estudiantil responde", Graphos, 5, abril de 1971).

970 Organización trotskista surgida en 1964 a partir de un grupo de militantes que se separaron de Reagrupar (desprendimiento del Movimiento de Izquierda Revolucionario Argentino), para formar un partido revolucionario de la clase obrera, bajo las banderas del marxismo-leninismo. El PO se propuso una actividad sistemática en torno a los obreros, asistiendo a las fábricas para vender sus materiales, analizando los conflictos fabriles en su prensa e interviniendo en los procesos de lucha de los trabajadores. Así, el PO participó en las huelgas contra el Onganiato. Hacia 1968, ya existían varias agrupaciones sindicales de PO: Vanguardia Metalúrgica, Trinchera Textil, Vanguardia Obrera Mecánica, y sus militantes integraban comisiones internas de fábricas en Buenos Aires, Rosario y Córdoba. Hacia 1971, la agrupación creó una juventud socialista con el objetivo de ser de masas: la Unión de Juventudes por el Socialismo (UJS), y en 1972 llegó a reunir a 1.200 militantes en su primer congreso. A partir de 1983, Política Obrera tomó el nombre de Partido Obrero (Kohn, 1999).

${ }^{971}$ Postulaba una "universidad del pueblo liberado" y a los estudiantes, como columna importante del proceso revolucionario, que debía romper con el rumbo capitalista de desarrollo, a partir de un gobierno de liberación social y nacional encabezado por la clase obrera aliada a las masas explotadas de la población. Aquí la violencia aparecía como ingrediente implícito y garantía del triunfo del programa popular ("El movimiento estudiantil responde", Graphos, 5, abril de 1971).

${ }_{972}$ Defendía la solidaridad latinoamericana y la unidad obrero estudiantil -contra el imperialismo, la oligarquía, el fascismo, el militarismo y el "clericalismo oscurantista"-, enfrentaba a la dictadura y abogaba por un nuevo tipo de poder democrático y popular. Proponía la lucha organizada de los estudiantes y procuraba ubicarla en el contenido político e ideológico del movimiento reformista de 1918 ("El movimiento estudiantil responde", Graphos, 5, abril de 1971).

${ }^{973}$ Entrevista a Juan Carlos, Buenos Aires, 29/7/2008.
} 
Otros militantes católicos desarrollaron su actividad política en AUDAL pero se alejaron durante un tiempo de esta agrupación para formar la Tendencia Antiimperialista Revolucionaria (TAR) -integrada en parte por militantes próximos al PRT-ERP- y retornaron más tarde a la primera. Hubo también quienes comenzaron militando en Nueva Línea de Acción ${ }^{974}$ y luego dejaron la militancia en la universidad y pasaron a trabajar en la JTP. Pero más allá de las trayectorias individuales cambiantes, en un proceso que Juan Carlos definía como de "encanto y desencanto", esta diversidad muestra que en la JUC llegaron a convivir militantes de agrupaciones que seguían distintas líneas políticas dentro de la izquierda peronista y no peronista.

En el nuevo marco de la llegada del peronismo al gobierno, la mayoría de los jucistas que militaban políticamente -incluso en espacios ligados al PRT o al PCR- se enrolaron en agrupaciones que conformaban la Tendencia Revolucionaria del Peronismo, tanto dentro como fuera de la universidad. A ellos se sumaron jóvenes que no habían tenido activismo político previo. Al mismo tiempo, otros militantes jucistas de agrupaciones universitarias de izquierda se mantuvieron al margen del peronismo y profundizaron su acción en el PRT-ERP y el PCR.

Las trayectorias de Pablo y de Luis dan cuenta de ello. Al respecto, Pablo decía que de los integrantes de la JUC que participaron en el PRT fueron "uno o dos que quedamos, el resto se fueron todos para el lado del peronismo" "975. Entre las razones que lo llevaron a elegir este espacio figuraban la búsqueda de compromiso en la lucha antidictatorial, así como la esperanza revolucionaria, en un clima de creciente movilización estudiantil. El antiperonismo de su familia influyó para descartar las alternativas de la izquierda peronista, mientras que la presencia de algunos compañeros del Pensionado Católico en el partido-ejército liderado por Santucho lo decidió a sumarse a sus filas. Pablo destacaba este aspecto a la hora de explicar "por qué el PRTERP": "vos ya armaste tu círculo de amistades" "976. Luego, la identificación con la agrupación fue gradual y se fue afianzando al calor de su participación en los Grupos Socialistas y de la formación partidaria.

Como otros "perros" bahienses, después dejó su militancia en el espacio universitario y se "proletarizó". Por entonces, la composición social del PRT-ERP -con

\footnotetext{
$\overline{974}$ Agrupación de corta duración que intentaba plantear una alternativa de acción política estudiantil a las organizaciones trotskistas, consideradas dogmáticas. Sin embargo, los servicios de inteligencia la identificaban con los Grupos Socialistas (Archivo DIPPBA, Mesa A, Estudiantil, Legajo $\mathrm{N}^{\circ} 119$, Localidad Bahía Blanca).

${ }_{975}$ Entrevista a Pablo, Neuquén, 19/3/2013.

${ }^{976}$ Entrevista a Pablo, Neuquén, 19/3/2013.
} 
una mayoría de estudiantes de clase media- los enfrentó al problema de cómo llevar adelante la misión de conducir al proletariado en un proceso revolucionario. Fue tomando forma la convicción de que era imposible trabajar junto a los obreros por la revolución si no vivenciaban sus necesidades y problemáticas. Se imponía la urgencia de vivir como obreros para sentir como ellos y formar una moral proletaria que acompañara la revolución socialista desde dentro. La "proletarización" implicaba el alejamiento de la vida estudiantil, el ingreso al mundo laboral, el distanciamiento del hogar de los padres y la formación de nuevas unidades familiares compuestas por militantes. En este marco, se formaron una serie de frentes partidarios en vistas a profundizar la "inserción de masas": el militar, el estudiantil, el sindical, el barrial y el de propaganda (Giménez, 2008). Pablo se fue entonces a vivir al barrio Noroeste con su compañera y comenzó a trabajar en una fábrica de fideos, para luego hacerlo en una casa de repuestos y en un banco. Se abocó a la acción en los barrios, en vistas a favorecer la organización de los vecinos en reclamos concretos así como en vistas a encuadrar sus luchas en una práctica revolucionaria. Su militancia involucraba en gran parte contactar referentes barriales y charlar con la gente, entre la que había un sector de ferroviarios y obreros de la construcción, así como distribuir el periódico partidario. Como plantea Giménez (2008), el trabajo del PRT dentro del movimiento obrero no era una acción meramente militante, desligada del "hacer cotidiano" y la creación de vínculos personales; las conversaciones con la gente, las lecturas y búsqueda de discusión complementaban el reparto del material impreso en los talleres, las fábricas o las casas de los obreros. Por otra parte, el barrio -en particular, Villa Nocito, Noroeste, Villa Delfina, Ingeniero White, Villa Rosario, Gris y Loma Paraguaya- se constituyó al mismo tiempo en espacio de "proletarización", de vinculación con organizaciones obreras, de propaganda y de acciones armadas -como la expropiación y reparto de alimentos-.

Las salidas de Pablo para repartir volantes o hacer pintadas, completaban la tarea, además de la presencia en las movilizaciones durante el gobierno de Cámpora ${ }^{977}$. En efecto, entre mayo y agosto de 1973, el PRT-ERP gozó de un período de legalidad durante el cual aumentó el número de militantes obreros, estudiantiles y la inserción entre los trabajadores bahienses y creció la tirada de sus órganos de prensa, que además de ser distribuidos por los militantes, podían adquirirse en los kioscos (Giménez, 2008).

\footnotetext{
${ }^{977}$ Entrevista a Pablo, Neuquén, 19/3/2013.
} 
Para Luis, la izquierda peronista tampoco representó un camino posible. La tradición política familiar tuvo su peso en ello. Al mismo tiempo, la opción marxista estaba unida a su trayectoria personal; en particular, a las lecturas de su adolescencia sobre la Revolución Rusa y sus líderes, y la teoría marxista en general. La urgencia de acabar con lo que consideraba un régimen de explotación para alumbrar una sociedad diferente lo movió a acercarse a las asambleas y movilizaciones universitarias. El PCR se constituyó en una alternativa a partir de la invitación de algunos compañeros ${ }^{978}$. Desde entonces y hasta 1975, su militancia se desarrolló en la UNS.

Este escenario heterogéneo desde el punto de vista de los recorridos políticoideológicos de los jóvenes católicos complejiza la mirada respecto de la relación entre catolicismo renovador y peronismo revolucionario, que fuera objeto de reflexión por parte de diferentes protagonistas de la época y de análisis por varios cientistas sociales. Los itinerarios personales atravesados por el "encanto y desencanto" con distintas agrupaciones políticas y la existencia de militantes católicos comprometidos con la transformación social desde agrupaciones vinculadas a la izquierda no peronista, como el PCR o el PRT-ERP, enriquece el panorama.

\section{b) La opción por el peronismo revolucionario}

\section{i) ¿Por qué el peronismo?}

Si no todos los jocistas, jucistas y jecistas bahienses asumieron la militancia política, la mayor parte de los que tomaron ese camino lo hicieron dentro del peronismo. Este proceso también fue vivido como un resultado lógico para quienes se identificaban con el pueblo o la clase obrera. José lo sintetizaba de esta manera: "el peronismo era la línea que no sé si representaba pero sí que tenía como opción preferencial por los pobres...de alguna manera eso es lo que uno entendía como compromiso" ${ }^{979}$. Por su parte, Mónica explicaba el razonamiento: “¿los pobres qué son? Peronistas. ¿Vos qué tenés que ser? Como los pobres " 980 . Algunos militantes constataron la identificación de las masas con este movimiento político a partir de sus propias experiencias. Por ejemplo, Marta y Patricia optaron por el peronismo después de que empezaron a trabajar

\footnotetext{
${ }^{978}$ Entrevista a Luis, Bahía Blanca, 18/12/2008.

${ }^{979}$ Entrevista a José, Bahía Blanca, 19/6/2008.

${ }^{980}$ Entrevista a Mónica, Buenos Aires, 30/7/2008.
} 
como maestras en Villa Nocito ${ }^{981}$. Y Manuel se hizo peronista durante su viaje por el país como representante del MIEC-JECI, el día que presenció en Córdoba un debate entre los chicos de un barrio sobre si aceptar o no la construcción de una escuela por parte del Ejército y la imposición del nombre de "Ejército Argentino" a la misma. Ellos concluyeron que el Ejército era el enemigo del pueblo pero que necesitaban la escuela, por lo tanto, que le pusieran el nombre que quisieran y después se lo cambiarían: "yo dije acá hay algo que yo no entiendo, yo tengo que escuchar mejor al pueblo. Y estos son todos peronistas. Yo tengo que acercarme a esta experiencia popular" ${ }^{982}$.

Desde el punto de vista de los actores, los gobiernos del período 1946-1955 habían significado importantes conquistas sociales. Al respecto, decía Liliana: “cuando yo empiezo a ver parte de la historia, de Perón y Evita, que las 8 horas de trabajo, las vacaciones, el voto a la mujer, es lo que más me identificó, que hizo para todos, no para un grupo de los poderosos "983. Y aún más, para algunos, la emergencia del peronismo había implicado un vuelco en la propia historia familiar. Así lo vivió Clara: "nosotros éramos pobres recontra pobres, no llegar a ser indigentes pero...y de repente hubo alguien como Eva Perón, que se acordara de los pobres",984. En efecto, era particularmente la figura de "Evita" la que condesaba la identificación con las demandas del pueblo. En palabras de José, ella "entendía a los pobres",985.

Desde esta perspectiva, el golpe militar de 1955 había interrumpido un proceso político y social que tenía como protagonista a los sectores subalternos, marcando un retroceso con respecto a los logros planteados. Así, algunos militantes asumieron el peronismo después de haber conocido el antiperonismo. Por ejemplo, Silvestre explicaba su opción: "por la persecución y proscripción. Algo tenía que tener para ser odiado por una parte de la sociedad argentina" "986. En esta línea, Dante decía: “empecé a hacerme peronista a los 7 años, porque me quedó grabado el bombardeo a la Plaza de Mayo" 987 . Por otra parte, los actores reconocían que en los años de proscripción, el peronismo había experimentado una actualización ideológica y doctrinaria ${ }^{988}$.

En suma, para estos jóvenes así como para muchos de su generación, el peronismo era un movimiento popular, solidario con/ favorable al obrero, y por lo tanto,

\footnotetext{
${ }^{981}$ Entrevista a Patricia, Bahía Blanca, 19/5/2008; a Marta, Bahía Blanca, 29/5/2008.

982 Entrevista a Manuel y Nancy, Neuquén, 20/3/2013.

${ }^{983}$ Entrevista a Liliana, Bahía Blanca, 25/6/2008.

${ }^{984}$ Entrevista a Clara, Bahía Blanca, 10/10/2012.

${ }^{985}$ Entrevista a José, Bahía Blanca, 19/6/2008.

${ }^{986}$ Entrevista a Silvestre, vía e-mail, 29/10/2012.

${ }^{987}$ Entrevista a Dante, Bahía Blanca, 28/9/2011.

${ }^{988}$ Entrevista a Gustavo, Bahía Blanca, 12/7/2011; a Eduardo, Bahía Blanca, 20/5/2008.
} 
constituía el camino al socialismo en Argentina; en palabras de Paloma, era un "movimiento de liberación nacional" 989 . Si la transformación debía hacerse desde y con el pueblo, respetando su identidad, este movimiento político que contenía a las mayorías, representaba y concretaba un proyecto revolucionario. Desde esta óptica, el cambio social en el país pasaba por el movimiento liderado por Perón. Lucy sintetizaba la cuestión de la siguiente manera: "la construcción del Hombre Nuevo cerraba perfectamente con el peronismo de Cámpora. Ese me parece que fue el eje de todos los grupos [...] mi compromiso cristiano hoy es comprometerme con el peronismo "990.

Las trayectorias familiares jugaron un papel significativo en la opción partidaria de algunos jóvenes. La presencia de madres, padres, tíos militantes o simpatizantes de aquel movimiento, o de personas cercanas beneficiados por las políticas sociales impulsadas por Perón, fue señalado como un factor importante a la hora de explicar su identificación con el movimiento. Ésta aparecía entonces como una opción que en alguna medida habían asumido en la casa. Al respecto, Clara contaba: "ya vengo con el peronismo de cuna. Me metieron tanto en la cabeza que después, yo mirando y leyendo y escuchando, dije 'bueno, vamos', y me meti en el peronismo" "991.

Otras experiencias familiares estuvieron marcadas por la convivencia de una heterogeneidad de posicionamientos ideológicos. La propia opción por el movimiento peronista reconocía como antecedentes los argumentos de ciertos familiares, así como el ejercicio de discusión política que como resultado de aquella diversidad de opiniones, había tenido lugar en el hogar. Por ejemplo, el padre de Jorge simpatizaba con Perón mientras su madre, empleada de un hospital público, protestaba porque el gobierno la obligaba a ir a los actos: "yo tenía las dos visiones",992. En otros casos, la identificación con el peronismo aparecía en clara ruptura con la tradición familiar. Ni José, ni Liliana, ni Nora, ni Marta, ni Manuel venían de hogares peronistas, y Aída, Elsa, Mónica, Francisco, Gabriel o Paloma habían crecido en un ambiente francamente antiperonista.

En estas trayectorias políticas, el origen socioeconómico de las familias no constituye un dato menor. En efecto, la oposición entre peronistas y antiperonistas que marcó las luchas políticas en nuestro país desde los años cuarenta estaba cargada de contenidos de clase (Torre, 2002). En este marco, el distanciamiento y la crítica al peronismo aparecía fuertemente en las casas de los jóvenes de clase media y, en

\footnotetext{
989 “Por qué y cómo milité en el PB”, apuntes de Paloma, enviados vía e-mail, febrero de 2013.

${ }^{990}$ Entrevista a Lucy, Neuquén, 18/3/2013.

${ }^{991}$ Entrevista a Clara, Bahía Blanca, 10/10/2012.

992 Palabras de Jorge, entrevista a Mirta y Jorge, Bahía Blanca, 11/4/2012.
} 
particular, con padres intelectuales -como los jucistas y jecistas ligados a La Pequeña Obra-, mientras que la simpatía o la adhesión a dicho movimiento fue frecuente, aunque no exclusiva, en los hogares de trabajadores -como los de los jóvenes de la "loma"-. De esta manera, el activismo dentro de la izquierda peronista de los segundos representaba una continuidad o incluso, una profundización respecto del posicionamiento político de sus padres, mientras que el de los primeros planteaba una novedad. Sobre la cuestión, Nora señalaba el descubrimiento que este grupo hizo del peronismo "a pesar que nosotros como juventud veníamos muy marcados por una mirada de horror al peronismo porque eran las masas populares -los negros, los cabecitas negras, como decía la oligarquía y la clase media-, lavándose las patas en la Plaza de Mayo"993.

Este proceso debe entenderse en el marco de la "radicalización" acompañada de "peronización" de los sectores medios y universitarios de los años sesenta, a la que aludíamos en el capítulo 1. Los intelectuales experimentaban entonces una suerte de "autoculpabilización" en virtud de que habrían vivido su condición como "privilegio" y "separación” con respecto del pueblo, no sólo por su situación social sino especialmente por su ubicación política, que les habría impedido comprender el fenómeno peronista. Ahora, en cambio, atravesaban una especie de "rescate" y una valorización de aquello que no había sido entendido. Por otra parte, el peronismo encontraría un terreno fértil para operar una fuerte ruptura con las tradiciones universitarias al ir incrementando sus adhesiones en un movimiento estudiantil que no sólo le había sido sumamente adverso sino que desde los años cuarenta había construido su propia identidad contra él y había contribuido a proscribirlo también de la universidad (Barletta y Tortti, 2002).

Ahora bien, el horizonte socialista definió a los militantes católicos bahienses por la izquierda peronista. Así, frente a la existencia de otras agrupaciones dentro del movimiento en Bahía Blanca, algunos actores explicaban su opción por la Agrupación Peronista de Frente, que más tarde pasó a llamarse PB, porque ésta reivindicaba a Cooke y a Ongaro, y levantaba la bandera de la revolución. En este sentido, en abril de 1973, el PB expresaba: "si los elementos reformistas y burgueses enquistados todavía en el movimiento esperan la bendición de los militares y de la oligarquía para tomar ese camino, la movilización y la lucha popular seguirán construyendo esa Patria Justa, Libre y Soberana, la Patria Socialista" 994 . En efecto, si en la primera etapa FAP-PB se proponía el regreso de Perón y la vigencia de la "Patria Justa, Libre y Soberana",

\footnotetext{
${ }_{993}$ Entrevista a Nora, Bahía Blanca, 4/6/2008.

994 “Juventud Peronista y Peronismo de Base", Graphos, 12, abril de 1973.
} 
entendiendo al peronismo como un movimiento de liberación nacional, hacia 1970 se proclamaba el socialismo, planteándolo como condición necesaria de la liberación social e indisociable de la liberación nacional, y asociando la tradicional consigna antes citada con la de "Patria socialista" (Raimundo, 2004).

Por otra parte, entre las razones que motivaron a los jecistas y jucistas bahienses a optar por la UES, la JP o Montoneros estaban las ideas de independencia económica, soberanía política, antiimperialismo, liberación -en oposición a dependencia-, justicia social, socialismo. En efecto, en sus comunicados de 1970 y 1971, Montoneros declaraba casi siempre tres objetivos que se identificaban entre sí: "Patria Justa, Libre y Soberana", retorno de Perón e instauración del socialismo nacional. En el recuerdo de los actores estas metas también aparecían estrechamente unidas. Así, Ricardo hablaba de la lucha por la vuelta de Perón y la construcción del Hombre Nuevo como aspectos indisociables $^{995}$. En 1972, un documento interno de Montoneros especificaba que los objetivos eran la liberación nacional del dominio imperialista y la construcción del socialismo, entendiendo éste como la supresión de la propiedad privada y la socialización de los medios de producción, y la planificación de la economía de acuerdo con las particularidades de la estructura productiva del país (Lanusse, 2007a).

Sin embargo, como mencionamos en el capítulo 1, Montoneros carecía de una ideología y un programa claramente definidos. Su construcción discursiva se encontraba enmarcada en un campo semántico común a la izquierda del peronismo, a la experiencia de la proscripción y a una serie de ideas-fuerza (Donatello, 2010). Según Gillespie (1987), los militantes se mostraron más dispuestos a escuchar la retórica de Perón que a estudiar historia política o a buscar teóricos de relieve, y ese pragmatismo constituyó la fuerza, a la vez que la debilidad de la organización en los primeros años. Más aún, para Calveiro (2008), fue uno de los mecanismos políticos que más tarde asfixiaron la práctica de Montoneros y la condujeron a la derrota política y militar. Este pragmatismo, favorecido por una construcción teórica cada vez más deficiente e incluso por cierto menosprecio por la elaboración intelectual -que se reemplazó por algunas "verdades" nunca cuestionadas-, y puesto de manifiesto en una dudosa apelación a la "realidad" -como si esta no fuera multifacética y susceptible de innumerables lecturas- y en el énfasis en la acción, dio lugar a severas contradicciones en la línea política, así como a una incomprensión insuficiente y esquemática tanto de Perón como del

${ }^{995}$ Entrevista a Ricardo, Bahía Blanca, 8/10/2011. 
movimiento peronista. Gustavo señalaba la falta de formación de la UES y Montoneros: "era meterse en la pileta y nadar"; lo importante era "la práctica",996. Y Rodolfo decía: "teníamos armado un collage de cosas que nos cerraban a nosotros sobre la historia y sobre cada cosa teníamos algún planteo pero súper simplificado",997. En cuanto a los objetivos, en particular, convivían diversas ideas bajo el paraguas del “socialismo nacional” (Gillespie, 1987). Eduardo reconocía que "patria socialista" "era una formulación hipotética de algo que ni siquiera tenías idea de lo que ibas a construir" "998. Por su parte, Gustavo evocaba un diálogo entre militantes en el que ante la pregunta de qué hacer cuando tomaran el poder, contestaban “iqué sé yo!, después vemos $" 999$.

En este universo aun amplio y diverso del peronismo revolucionario, los jóvenes de la JOC se unieron al PB, los de la JEC a la UES -pasando más tarde, en algunos casos, a integrar la JUP o Montoneros-, y los de la JUC, tanto al PB como a la JPMontoneros. Si bien entre los universitarios convivieron militantes de los dos espacios, también aquí es posible identificar itinerarios cambiantes y reconocer una periodización en la cual el paso por el PB fue previo a la militancia en la JUP, JP o JTP.

En efecto, en esos años, el PB atravesó distintas crisis a partir del surgimiento de líneas internas contrapuestas: "movimientistas" y "alternativistas"; "oscuros" e "iluminados" -considerados los más "ideologistas", querían profundizar el Proceso de Homogeneización Política Compulsiva ${ }^{1000}$. Estas crisis desembocaron en rupturas y en el pasaje de militantes a la JP-Montoneros. Como resultado de este proceso, en 1973, FAP-PB terminó de definir la línea política que la caracterizó hasta su disolución en 1979, plasmada en la "alternativa independiente". Ésta sostenía la necesidad de construir la patria socialista, una política que no fuera capitalizada por la burocracia y la

\footnotetext{
${ }^{996}$ Entrevista a Gustavo, 9/8/2012.

${ }^{997}$ Entrevista a Rodolfo, Bahía Blanca, 23/6/2008.

${ }^{998}$ Entrevista a Eduardo, Bahía Blanca, 20/5/2008.

${ }^{999}$ Entrevista a Gustavo, 9/8/2012.

${ }^{1000}$ Iniciado en septiembre de 1971 en búsqueda de nuevas prácticas y formas organizativas. Supuso el abandono de los frentes y sumió a la organización en la formación teórica, basada en el estudio de la experiencia acumulada de los trabajadores -en la que la historia del peronismo ocupaba un lugar central(Raimundo, 2004). Paloma, que se unió al PB en esta etapa, recordaba la conformación de grupos de lectura y discusión política, donde se leía desde Marx hasta Cooke, Hernández Arregui o Althusser (entrevista, vía skype, 1/3/2013). Sobre este proceso, Dante decía: "había que meter a todo el mundo adentro de ese PHPC. ¡Una locura total! Un año duró, mientras todo lo demás seguía, nosotros un internismo absoluto" (entrevista, Bahía Blanca, 28/9/2011). Mientras tanto, una creciente movilización de masas era capitalizada por la JP-Montoneros. En este marco, los militantes fueron abandonando el PHPC y, luego, la conducción lo dio por terminado (Raimundo, 2004).
} 
burguesía, una organización político-militar de la clase obrera y el pueblo peronista, una metodología que fuera desde las bases hacia la dirección (Raimundo, 2004).

Para los jucistas, el paso del PB a la JP tuvo que ver con diferencias ideológicas o bien con los lazos personales tejidos en esos años. Roberto, por ejemplo, cuando se fue a vivir a Choele Choel conoció a un dirigente montonero con el que entabló una relación de amistad que lo acercó a la Tendencia ${ }^{1001}$. En este proceso, las elecciones fueron un punto de inflexión. Rodolfo recordaba: "votamos a Cámpora, creímos que había que apoyar esa etapa y otros decían que no, que había que votar en blanco porque no habia poder suficiente para cambiar nada por vía electoral y que había que seguir haciendo trabajo de base" ${ }^{\prime 1002}$.

En efecto, para la JP, las elecciones constituían un paso hacia la toma del poder y la profundización de la etapa ofensiva del movimiento. Le seguía continuar con la construcción del Ejército Peronista que era visualizado como la única garantía para lograr un "real poder popular". Le tocaba al gobierno iniciar la "reconstrucción nacional", que iría "socavando las bases del poder del régimen, satisfaciendo las necesidades populares" mientras se aceleraría y profundizaría la organización del pueblo con su movilización ${ }^{1003}$. Gustavo subrayaba la relevancia de esta herramienta en la estrategia de la JP-Montoneros: "era el eje fundamental de toda la política. El que se moviliza es el que tiene poder político, el que es capaz de transformar la cosa. Entonces, había que movilizarse" ${ }^{1004}$. De allí que, como decía Rodolfo, las manifestaciones masivas de 1973 y el protagonismo de la JP en los nuevos cargos de gobierno, fueran leídos por la organización como crecimiento de su poder ${ }^{1005}$.

En cambio, para el PB local, las elecciones habían sido una propuesta del "sistema" para "recomponer la partidocracia, 'canalizar' las aspiraciones populares de cambios revolucionarios en el Parlamento y, fundamentalmente, integrar al peronismo a la mayor parte del movimiento". Sin embargo, la masividad del voto mostraba la unidad de la respuesta popular que, si bien dejaba al "sistema" prácticamente intacto, abría "la posibilidad de una participación creciente del pueblo en la construcción de sus propias organizaciones". La contundencia electoral no bastaba para desarmar a los gorilas y disolver a los monopolios; había que transformar la expresión electoral en una fuerza

\footnotetext{
${ }^{1001}$ Entrevista a Roberto, Bahía Blanca, 18/4/2013.

1002 Entrevista a Rodolfo, Bahía Blanca, 23/6/2008.

1003 "Juventud Peronista y Peronismo de Base", Graphos, 12, abril de 1973.

${ }^{1004}$ Entrevista a Gustavo, 9/8/2012.

1005 Entrevista a Rodolfo, Bahía Blanca, 23/6/2008.
} 
organizada que impidiera los retrocesos que intentarían los enemigos ${ }^{1006}$. En otras palabras, frente a la postura montonera, se afirmaba que la "lucha estructural" no respondía a los intereses de los obreros sino a los de la burguesía y la burocracia, y que un gobierno elegido por el pueblo podía utilizarse como una herramienta, aunque no la principal, para lograr el fortalecimiento de la organización y la lucha obrera en las fábricas o en los barrios (Raimundo, 2004). Sobre las elecciones Dante recordaba: "habia discusiones feroces sobre ese tema. Y que la salida no era esta salida condicionada, que era una alternativa a la revolución, jun quilombo, mal!",1007.

Sigamos repasando brevemente los lineamientos ideológicos y organizativos de estas agrupaciones de modo de enmarcar la militancia de los jucistas, jocistas y jecistas bahienses y de comprender su acercamiento a aquellos espacios. En el surgimiento de Montoneros, las sociabilidades y redes católicas renovadoras tuvieron una influencia directa. Luego, en la medida en que se desarrolló como organización político-militar y se incorporó al peronismo como una estructura clandestina, una "formación especial", la marca genética católica se fue borrando o permaneció pero en clave secular. La opción por el peronismo expresaba una búsqueda que conciliaba los contenidos católicos contestatarios con experiencias seculares (Donatello, 2010).

Las premisas en las que debían coincidir los militantes al momento de ser encuadrados en Montoneros eran, además del socialismo como objetivo, el peronismo como identidad política y la lucha armada como metodología (Lanusse, 2007a; Salcedo, 2011). Como todos los grupos guerrilleros de fines de los años sesenta que adoptaron la identidad peronista buscaron asociarse simbólicamente con las luchas de la Resistencia, considerándola un período culminante de la militancia, digno de quedar como ejemplo de combatividad de la clase trabajadora. El término mismo, "Resistencia", llegó a incluir el extremismo, a significar un movimiento de izquierda, un concepto en cierto modo revolucionario (James, 1990). Al constituirse en organización nacional y ser legitimada políticamente por Perón, Montoneros pasó a formar parte del movimiento y, en consecuencia, se planteó los debates en torno al peronismo. Según Lanusse (2007a), en 1970 y 1971 Montoneros sostuvo una posición cercana a los postulados movimientistas (que creían en un Perón y en un peronismo revolucionario en su conjunto, relegando a un segundo plano las diferencias dentro del movimiento y apostando a que la propia lucha obligaría a sumarse a los "traidores", mientras ayudaría

1006 “Juventud Peronista y Peronismo de Base", Graphos, 12, abril de 1973.
${ }^{1007}$ Entrevista a Dante, Bahía Blanca, 28/9/2011. 
al pueblo a tomar conciencia revolucionaria y a radicalizar sus objetivos), mientras que en 1972 se inclinaba a formar una tendencia revolucionaria dentro del movimiento para hegemonizarlo (sostenían que dentro del mismo existían diferencias irreconciliables en cuanto a los objetivos estratégicos pero le reconocían potencialidad revolucionaria y llamaban a dar combate en su interior, mientras que Perón si no era genuinamente revolucionario estaba dispuesto a volcarse en ese sentido).

De todas maneras, como afirma Gillespie (1987), los militantes crearon un Perón a su propia imagen y semejanza. En esta relación, la organización aspiraba a ser reconocida como vanguardia del pueblo mientras le reservaba a Perón el rol de conductor estratégico. En palabras de Rodolfo: “a Perón se lo veía como referente del movimiento y como una figura que era capaz de aglutinar un montón de sectores [...] pero el liderazgo lo tenía que tener Montoneros ${ }^{\prime 1008}$. De esta manera, ésta capitalizó el reconocimiento del líder entre 1971 y 1973, al tiempo que protagonizó su regreso al país y la asunción de Cámpora. Así, contra sus intenciones originales, se sumó a la estrategia electoral, adaptándose a la voluntad de Perón. Después de las elecciones, su fe en Perón la llevó a confiar en que él optaría por una trayectoria inequívoca, siempre que la izquierda peronista siguiera siendo una base de poder multitudinaria. Según Gustavo, se sostenía que Perón era "pragmático" y que se "volcaba" hacia adonde había "más fuerza" ${ }^{1009}$. En este sentido, el líder del movimiento era ubicado "del lado del sector popular ${ }^{\prime 1010}$. En esta lectura, los indicios que respaldaban su inclinación por la derecha peronista eran minimizados. En palabras de Rodolfo: "siempre lo justificábamos todo a Perón, como diciendo 'bueno, lo hace por esto, lo hace por lo otro'”1011. En particular, se recurría a la teoría del "cerco" para explicar su comportamiento.

Sin embargo, con Perón en el poder, las diferencias ideológicas y la disputa por la dirección del proceso saldrían definitivamente a la superficie, encontrando en el acto del $1^{\circ}$ de mayo de 1974 un punto de inflexión. Al respecto, Rodolfo recordaba: "salimos de Bahía Blanca, y supongo que todos del interior de Montoneros, con la idea de irnos de la Plaza [...] para mostrarle a Perón que estaba perdiendo enfrentándose con Montoneros" ${ }^{\prime 012}$. Este acontecimiento tuvo una repercusión inmediata en el trabajo de superficie de los militantes en los diversos frentes políticos. En Villa Nocito, esta

\footnotetext{
${ }^{1008}$ Entrevista a Rodolfo, Bahía Blanca, 23/6/2008.

${ }^{1009}$ Entrevista a Gustavo, Bahía Blanca, 12/7/2011.

${ }^{1010}$ Entrevista a Nora, Bahía Blanca, 4/6/2008.

1011 Entrevista a Rodolfo, Bahía Blanca, 23/6/2008.

1012 Entrevista a Rodolfo, Bahía Blanca, 23/6/2008. La Tendencia se hizo presente en Plaza de Mayo con 60 mil personas. Perón los llamó “imberbes”, “estúpidos”, “infiltrados”, “mercenarios” (Gillespie, 1987).
} 
ruptura significó el fin de la acción territorial. Si la JP había sido valorada por la gente por su identidad peronista, el episodio del día del trabajador y la negativa de la organización a conseguir colectivos para viajar a la Capital para el velorio de Perón llevaron a que los vecinos echaran a los jóvenes de la Unidad Básica. Marta contaba:

Iba, por ejemplo, a golpear una casa y recibirme la señora -porque yo iba por un problema por la nena- y sacarme el tema: "vio, señorita, cómo nos engañaron, eran todos Montoneros y decían que eran peronistas y gente buena, vio, gente buena como fulanito y fulanito, quién iba a pensar con todo lo que me ayudaron, quién iba a pensar que eran Montoneros, enemigos de Perón" "1013.

En cuanto a "Evita", la organización compartía con el pueblo la adoración de su figura, admitiendo todos sus aspectos míticos. Se trataba del símbolo de la combatividad, la mujer que había intentado crear una "milicia de trabajadores" a principios de los años cincuenta (Gillespie, 1987). En otras palabras, quien había asumido una opción "radical" por la clase trabajadora ${ }^{1014}$. En este sentido, Rodolfo aludía a la reivindicación que de ella hacía la JP: “de Evita conocíamos una frase o dos frases y nos arreglábamos con eso...con la imagen que nosotros inventábamos del mito" ${ }^{\prime 1015}$.

Para Montoneros, la lucha armada era el único medio eficaz que tenían a su disposición. Su composición social hizo inviable una orientación clasista y la participación en las luchas obreras. Siguiendo a Gillespie (1987), para Montoneros los conflictos entre las clases eran de importancia secundaria en comparación con las luchas nacionalistas contra la dominación extranjera. Asimismo, la organización rechazó la guerrilla rural del modelo cubano. En cambio, optó por la guerrilla urbana, a partir del ejercicio de la violencia sobre agentes del Estado -particularmente, personal militar y de la policía- y enemigos políticos claramente definidos. Se inclinaba por una guerra popular, esto es, que fuera apoyada e incorporara al pueblo. En los primeros años, se cultivaba su simpatía mediante un uso mínimo de la violencia ofensiva y la selectividad de los objetivos: los blancos favoritos eran el símbolo del privilegio y de la opulencia (compañías y empresarios extranjeros). Y las acciones armadas buscaban hacerse con recursos y demostrar la vulnerabilidad del régimen militar.

A partir de este posicionamiento como vanguardia armada del pueblo, la relación con los frentes de masas se constituyó en un desafío. En 1971 se crearon las

\footnotetext{
${ }^{1013}$ Entrevista a Marta, Bahía Blanca, 29/5/2008.

1014 Entrevista a Marta, Bahía Blanca, 29/5/2008.

1015 Entrevista a Rodolfo, Bahía Blanca, 23/6/2008.
} 
Unidades Básicas Revolucionarias (UBR), que venían a sumarse a las ya existentes Unidades Básicas de Combate (UBC), para crear un puente entre las organizaciones armadas y las de base, entendidas como las dos "patas" de la lucha popular, y constituirse en dirigencia táctica del movimiento de masas -mientras a las UBC les correspondía la conducción estratégica-. Las UBR eran un nivel dentro de Montoneros ${ }^{1016}$, sometidas a su funcionamiento celular, clandestino, compartimentado y dividido en zonas geográficas (Lanusse, 2007a), y estaban integradas por militantes del frente de masas.

Éste estaba constituido por las mencionadas JP, JTP, JUP, UES, AE, MVP y MIP, que eran en principio autónomas, pero en función de la campaña electoral de 1973 -en la que fueron protagonistas claves-, se unieron a la Tendencia Revolucionaria, subordinándose progresivamente a Montoneros. Según Gillespie (1987), la actividad política de masas constituyó un giro estratégico decisivo de la organización. En los años 1972 y 1973, estas agrupaciones experimentaron un fuerte crecimiento, lo que supuso una gran afluencia de militantes a la organización y un fortalecimiento de su capacidad de movilización. Por otra parte, se produjo un encuadre masivo, en parte debido a la presión de los integrantes de los frentes de masas por encuadrarse y recibir instrucción militar, lo que se concretó a través de cursos en las regiones alejadas de los centros urbanos donde se impartían clases de tiro -como lo corrobora el testimonio de algunos jecistas-. Asimismo, en esta etapa se desarrolló la lógica de la especialización y la complementariedad, tanto en las funciones específicamente militares como en las políticas. A medida que se consolidó el encuadramiento de los dirigentes de las agrupaciones dentro de la organización, la autonomía que habían tenido antes se fue disipando. Y el incremento de la represión profundizó la necesidad de integración entre la organización y su frente, perdiendo éste su fuerza política y volumen numérico, con las disidencias internas y el abandono de la militancia (Donatello, 2010).

\footnotetext{
${ }^{1016}$ Siguiendo a Donatello (2010), entre 1971 y 1977 la estructura de Montoneros era de carácter federal. En vistas a la creación de un poder autónomo desde el barrio hasta el plano nacional, al criterio geográfico se sumaba el asentamiento en las estructuras de producción y en la política estudiantil. Por ende, la organización se sostenía sobre un frente político territorial y a él estaban subordinados los frentes sindical, campesino y estudiantil, con distintos niveles de encuadre: 1. los oficiales, agrupados según distintos órdenes de conducción (a. la conducción nacional; b. el consejo nacional, integrado por los jefes regionales; c. las jefaturas regionales, integradas por las columnas; d. las columnas, constituidas por UBC; e. las UBC, integrada por quienes tenían a su cargo las UBR); 2. los aspirantes, que integraban las UBR y militaban en el frente de masas; 3. el frente de masas. En Bahía Blanca, que pertenecía a la Regional 1 entre las 7 del país, la organización realizaba tareas en los barrios y en la UNS ("Juventud Peronista y Peronismo de Base", Graphos, 12, abril 1973). El carácter verticalista, burocrático, no democrático de esta estructura, ligado a las necesidades de la organización militar, obstaculizó la resolución de los conflictos internos (Gillespie, 1987).
} 
Por otra parte, una serie de coincidencias en las concepciones ideológicas, los repertorios de acción, las formas de sociabilidad y las redes personales empujaron a miembros de la JOC y de la JUC, a identificarse con el PB. En primer lugar, su carácter obrerista y la asunción de la tradición de la Resistencia, así como de las luchas históricas y actuales de los trabajadores en las fábricas, era en un factor de identificación política clave para los actores ${ }^{1017}$. En este sentido, el PB local recomendaba a los estudiantes que se documentaran sobre las luchas del proletariado peronista libradas desde 1955 y que acompañaran las de entonces:

los compañeros de Somisa, del Chocón, los docentes de la CUTE, los azucareros tucumanos, los campesinos chacareros, entre tantos otros, dicen con sus luchas, que el proceso sigue y que más que explicarlo doctoralmente, cabe sumarse con todas nuestras fuerzas para que el camino se acorte ${ }^{1018}$.

La inscripción en esa línea histórica llevaba a concebir la lucha en la confluencia de distintas generaciones. De allí el rechazo de la división por juventudes que planteaba la Tendencia Revolucionaria ${ }^{1019}$.

En este sentido, el PB compartía el rol central de la clase obrera como sujeto revolucionario. En palabras de Jorge: "tiene que ser la clase obrera la que tiene que llegar al poder. No los estudiantes y la clase obrera atrás -que era lo que pensábamos que favorecía en general la cúpula de Montoneros-" ${ }^{2020}$. Como explicaba otro militante:

La clase que puede y debe asumir la misión de emancipar al pueblo y efectuar la transformación del actual régimen social debe ser la clase trabajadora, porque es la clase en cuyas condiciones de existencia se encarna todo el mal de la sociedad burguesa y no hay otra clase que esté situada más abajo de la escala social. Y sobre la que pesa mayormente todo el resto de la sociedad ${ }^{1021}$.

Así, la "alternativa independiente de la clase obrera y el pueblo peronista", que significaba la adopción de una definida posición clasista, proponía la organización política autónoma de los obreros peronistas por fuera de las estructuras formales del movimiento. Esta concepción, que contenía la crítica a la forma de organización leninista, a la construcción desde "arriba", desde un partido de cuadros que articula y dirige -desde "afuera"- al movimiento de masas, quitándole protagonismo, impactó en

\footnotetext{
${ }^{1017}$ Entrevista a Dante, Bahía Blanca, 15/3/2012 y “Por qué y cómo milité en el PB”, apuntes de Paloma enviados vía skype, $1 / 3 / 2013$.

1018 “Juventud Peronista y Peronismo de Base", Graphos, 12, abril de 1973.

1019 Entrevista a Dante, Bahía Blanca, 15/3/2012.

${ }^{1020}$ Palabras de Jorge, entrevista a Mirta y Jorge, Bahía Blanca, 11/4/2012.

1021 "Peronismo de Base. Acerca de la militancia revolucionaria", Graphos, 16, agosto de 1973.
} 
el modelo organizativo y en las prácticas políticas del $\mathrm{PB}$, marcadas por una preocupación constante por verificar el impacto de sus acciones entre los obreros (Raimundo, 2004). Al respecto, Dante recordaba: “me decía un compañero 'vos referénciate en lo que piensan los laburantes más antiguos, que esos tienen toda la historia y toda la experiencia',"1022. El interés por captar los posicionamientos y demandas de los trabajadores y evitar los riesgos de convertirse en una vanguardia lejana se manifestaba en la metodología utilizada en los lugares de trabajo, que por otra parte tenía la ventaja de preservar a los militantes de la exposición pública que se volvía cada vez más problemática en tiempos de represión:

se parecía un poco a lo del Ver Juzgar y Actuar...identificar los problemas que habia en nuestro lugar de laburo y en el volante mismo hacias la propuesta. Y lo dejábamos en el baño. Y entonces se producía...una charla, un debate, y si la propuesta la tomaba el conjunto, quiere decir que era buena, y si no le daban pelota quería decir que estábamos corridos de la realidad ${ }^{1023}$.

En segundo lugar, estaba presente la idea de la revolución como un proceso gradual ligado a la toma de conciencia, la organización y la participación activa de la clase trabajadora. El acento estaba puesto en el protagonismo del pueblo antes que en la urgencia de la transformación ${ }^{1024}$. En este punto, José decía: “los cambios para nosotros eran más lentos, o sea, había que concientizar la gente, que la gente sea consciente de lo que hace, que la gente se dé cuenta...no llevarlos de las narices",1025.

Así, al referirse al trabajo en el ámbito barrial, un militante planteaba que "debe ser el constante adoctrinamiento de la gente, la profundización, el hablar del socialismo, explicar su significado" y fundamentalmente, "tratar de que la gente intervenga directamente"1026. Mirta describía el tipo de acción con el que el PB se había hecho presente en la localidad cercana de General Cerri en ocasión de un conflicto obrero: "hicimos una reunión, tratábamos de hablar con la gente que habian despedido, de cómo hacer tomar conciencia al resto de la ciudadanía de lo que había pasado. Más de denuncias de los despidos, acompañar a las familias que se habian quedado sin laburo" 1027 . Por su parte, Paloma y Dante evocaban su acción barrial en el sector este de la ciudad a partir de visitas periódicas a los vecinos, con las que fueron ganando

\footnotetext{
1022 Entrevista a Dante, Bahía Blanca, 15/3/2012.

${ }^{1023}$ Entrevista a Dante, Bahía Blanca, 28/9/2011.

1024 Entrevista a Jorge y Mirta, Bahía Blanca, $11 / 4$ y 14/7/2012, y a María, Bahía Blanca, 21/2/2013.

${ }^{1025}$ Entrevista a José, Bahía Blanca, 19/6/2008.

1026 "Peronismo de Base. Acerca de la militancia revolucionaria", Graphos, 16, agosto de 1973.

${ }^{1027}$ Entrevista a Mirta y Jorge, Bahía Blanca, 14/7/2012.
} 
arraigo en el lugar ${ }^{1028}$. Y por último, la intervención de Mirta y Jorge en Villa Nocito, donde iban "a colaborar con trabajo social" y acompañar a un grupo que funcionaba en la villa, visitando familias, ayudando a unos compañeros a construir una casa y participando de algunas reuniones ${ }^{1029}$, ilustra la militancia de base en el ámbito barrial.

Para los actores, esta metodología de trabajo -considerada auténticamente "revolucionaria"- marcaba una distancia respecto a la utilizada por la JP -calificada de "paternalista”- en Villa Miramar, Loma Paraguaya o San Martín. A propósito de un acto llevado adelante en Cerri, en el que la JP reclutaba a la gente tocando el bombo y "subiéndolas en un colectivo", se planteaba:

su metodología es incorrecta ya que la revolución no la hace un reducido grupo de determinadas personas por más claras y revolucionarias que sean si no hay una participación activa y constante del pueblo. Hay que saber diferenciar bien el trabajo para las bases y el trabajo de trabajarse a las bases. Esta última medida no busca un esclarecimiento a nivel popular sino que generalmente busca lo que en la jerga política se denomina "espacio" político ${ }^{1030}$.

En ocasiones, los activistas del PB percibían que la estrategia de la JP resultaba más efectiva a la hora de ocupar aquellos espacios, llegando a "coparlos". Pero desde su perspectiva, la prioridad era la construcción de poder obrero y no el crecimiento cuantitativo de los militantes o la ocupación de espacios de gobierno: "defender los derechos obreros en una sección de fábrica no es espectacular ni trascendente en el plano de la opinión pública, pero son los pasos valientes que los más claros compañeros de la clase obrera dan en el camino hacia una conciencia colectiva" ${ }^{2031}$.

En tercer lugar, los jocistas y jucistas que militaron en el PB se identificaron con una mirada crítica con respecto a Perón, que estaba vinculada a la visión del peronismo como un movimiento heterogéneo, atravesado por contradicciones de clase. Al respecto, Paloma contaba: "a Perón no lo veían ni como líder ni con un rol revolucionario ni que iba a hacer que la clase obrera tomara el poder"1032. En efecto, la "alternativa independiente" cuestionaba el liderazgo estratégico de Perón como conductor del proceso revolucionario, por considerarlo un burgués. Este posicionamiento resultó un dilema para la organización, que se reflejó en las distintas estrategias discursivas empleadas para articular las posiciones de Perón con la política de la organización, y en las contradicciones que sufrían los militantes. Si bien lo reconocían como líder del

\footnotetext{
${ }^{1028}$ Entrevista a Paloma, vía skype, 12/2/2013.

${ }^{1029}$ Entrevista a Mirta y Jorge, Bahía Blanca, 14/7/2012.

1030 "Peronismo de Base. Acerca de la militancia revolucionaria", Graphos, 16, agosto de 1973.

1031 "Juventud Peronista y Peronismo de Base", Graphos, 12, abril de 1973.

1032 Entrevista a Paloma, vía skype, 22/2/2013.
} 
pueblo, no hablaban de él como "nuestro líder" -algo común en el discurso de Montoneros-. Además, frecuentemente no se lo trataba como "general" sino como "compañero". La consigna era "los trabajadores al poder con Perón presidente", siendo éste, en definitiva, una herramienta más para lograr la liberación nacional y social (Raimundo, 2004). Así lo explicaba Jorge: “para nosotros Perón era el elemento que podía llegar a aglutinar las fuerzas para lograr la patria socialista" ${ }^{1033}$. Hubo entonces una constante lucha por resignificar sus actitudes para canalizarlas hacia los objetivos propuestos y por marcar los límites de su gobierno -que desde su perspectiva, estaba lejos de concretar la toma del poder por los obreros-, a través de una crítica, en general, indirecta para evitar mermar la legitimidad provista por su figura -en palabras de Paloma: "no se decía abiertamente pero lo decíamos entre casa"1034-, aunque el ataque directo también se hizo presente, acentuándose después de su muerte (Raimundo, 2004).

En contraste, la figura de Eva era reivindicada como referente de los obreros en sus luchas cotidianas $\mathrm{y}$, en general, de los sectores populares en su marcha al socialismo. Para el PB local, "Evita” seguía viva "en la bronca diaria contra el patrón y el burócrata sindical que negocia las luchas de la clase trabajadora", y su presencia se afirmaba "en la lucha permanente y en la organización que creciendo desde las bases logrará la definitiva Patria sin explotadores ni explotados"1035.

En cuarto lugar, el PB tenía una postura frente a la opción armada que la diferenciaba de otras organizaciones político-militares. Paloma explicaba: "no era de foco, sino que se planteaba de la clase obrera y para la clase obrera. Entonces no era una lucha contra destacamentos militares, ni bombas a militares" ${ }^{\prime 1036}$. En este punto, Dante coincidía en que el acento estaba puesto en "organizar independientemente a la clase obrera y al pueblo peronista, con apoyo armado pero sin una guerra de aparatos $" 1037$. Esto permitió esquivar la tendencia hacia una preponderancia militarista. En consecuencia, desde 1973 predominaron las pequeñas acciones y los objetivos comprendían principalmente a sujetos ligados al ámbito laboral -empresarios, burócratas, supervisores-. La acción armada fue tomando cada vez más la forma de autodefensa de la clase obrera y consistió en el uso de bombas contra propiedades o vehículos, secuestros, amedrentamientos y palizas, llevadas adelante por comandos

\footnotetext{
${ }^{1033}$ Palabras de Jorge, entrevista a Mirta y Jorge, Bahía Blanca, 11/4/2012.

${ }^{1034}$ Entrevista a Paloma, vía skype, 22/2/2013.

1035 "Peronismo de Base. Acerca de la militancia revolucionaria", Graphos, 16, agosto de 1973.

${ }^{1036}$ Entrevista a Paloma, vía skype, 22/2/2013.

${ }^{1037}$ Entrevista a Dante, Bahía Blanca, 28/9/2011.
} 
formados por integrantes de los frentes (Raimundo, 2004). Al respecto, Dante planteaba que se trataba de una presencia débil "que intervenía por ahí en situaciones de conflicto obrero, donde había que poner un poco de 'acción directa',"1038. Paloma ejemplificaba el tipo de iniciativas emprendidas para acompañar luchas puntuales:

en la textil donde trabajaba [la Rusa] una vez hubo un conflicto serio. No me acuerdo en qué consistió el conflicto y quién era el que estaba en ese momento, pero sí sé que por ejemplo se puso una bomba de estruendo y de poner negro la puerta de la persona esta responsable de esa fábrica ${ }^{1039}$.

Por otra parte, la estructura "federativa" de PB-FAP derivó en una escasa conflictividad entre la dinámica del frente de masas y la lucha armada, como ocurrió en Montoneros, donde sus militantes sufrían las tensiones que provocaban las operaciones armadas en relación al desarrollo de la política de base. Si bien la propuesta era dar más peso a la acción política que a la armada y ésta era constantemente debatida, existieron importantes diferencias regionales en el peso relativo de las FAP y el PB (Raimundo, 2004). En el caso bahiense, según Dante y Mirta, no hubo desarrollo de las FAP ${ }^{1040}$.

Más allá de las coincidencias políticas, las afinidades de los jóvenes católicos con el PB se daban en el nivel de las prácticas concretas. La "concientización de los trabajadores" respecto de sus condiciones de vida y de trabajo, a la que apuntaba el PB como paso fundamental para el cambio, suponía un trabajo cara a cara, de militante a militante. El contacto personal, respetando tiempos y posibilidades de cada uno, lo hacía, para los actores, "más acercado al Evangelio"1041. En este sentido, Mirta recordaba: "trabajábamos tan abajo que nos decían los 'topos', los 'zócalos",1042. En efecto, el planteo basista era cercano a la práctica que venían desarrollando desde la JOC con los compañeros en los lugares de trabajo.

Por otra parte, la opción por el PB también resultaba atractiva por su carácter “democrático" y "federalista" 1043 . Lejos de ser una organización verticalista que contaba con una conducción única, las diversas células contaban con un margen de autonomía. En palabras de Dante: "en cada lado cada uno tenía su política, no había así una bajada de línea" ${ }^{1044}$. Esta característica le otorgaba a los diversos grupos participación

\footnotetext{
${ }^{1038}$ Entrevista a Dante, Bahía Blanca, 15/3/2012.

${ }^{1039}$ Entrevista a Paloma, vía skype, 22/2/2013.

${ }^{1040}$ Entrevista a Dante, Bahía Blanca, 15/3/2012, y a Mirta, Bahía Blanca, 18/6/2008.

1041 Palabras de Mirta, entrevista a Mirta y Jorge, Bahía Blanca, 11/4/2012. Entrevista a María, Bahía Blanca, 21/2/2013.

${ }^{1042}$ Entrevista a Mirta, Bahía Blanca, 18/6/2008

${ }^{1043}$ Entrevista a Paloma, vía skype, 22/2/2013.

${ }^{1044}$ Entrevista a Dante, Bahía Blanca, 28/9/2011 y 15/3/2012.
} 
activa en la discusión de las políticas comunes. Paloma recordaba reuniones de las diversas regionales donde se discutían las realidades de cada localidad y se construía acuerdos respecto de las líneas de acción de la organización ${ }^{1045}$. La conformación de los espacios de dirección se guiaba por los mismos principios, respetando la opinión de los militantes. En este sentido, Dante evocaba su paso por la coordinadora local en 1974:

hicimos una pequeña dirección colegiada en ese momento en la dirigencia y yo fui el responsable. Pero era una responsabilidad muy laxa. Perón decía, y en esto tenía razón el viejo, "se conduce lo que se deja conducir". Si los otros no quieren que vos los conduzcan, no...entonces es parte de te ganás el respeto, la confianza de los compañeros, no es una orden que vino "este va a ser el jefe $" 1046$.

Según Jorge, en dicho espacio se compartía información sobre el trabajo de los distintos grupos locales, se decidían las acciones comunes, y se distribuían las tareas. Luego, algunos compañeros articulaban el trabajo con los militantes de otras ciudades ${ }^{1047}$. Así, PB-FAP fue evolucionando desde una dirección más tradicional y vertical, a otra que adoptó un lugar de intermediación y coordinación (Raimundo, 2004).

En suma, esta metodología "de abajo hacia arriba" que apuntaba a "concientizar" a los trabajadores sobre su situación y a impulsarlos a involucrarse en el cambio, postulada por la "alternativa independiente", era compatible con la inserción en el propio ambiente, en base al fortalecimiento de los vínculos con los compañeros, que desarrollaban los jocistas en la fábrica o la oficina. Al mismo tiempo, el funcionamiento participativo y horizontal de las células del PB, así como de su estructura a nivel nacional, se integraba sin tensiones con el trabajo en pequeñas comunidades o en asamblea de los grupos cristianos. Asimismo, las tareas de militancia que incluían la confección de volantes donde planteaban sus posturas ante determinados hechos, el énfasis en la formación política a través de la lectura de documentos partidarios, o las reuniones de discusión, donde se analizaban los acontecimientos políticos del momento, eran afines con el ejercicio de debate, análisis, articulación de acuerdos y lectura crítica que traían los militantes de la comunidad cristiana.

\footnotetext{
1045 “Por qué y cómo milité en el PB”, apuntes de Paloma enviados vía e-mail, 1/3/2013.

${ }^{1046}$ Entrevista a Dante, Bahía Blanca, 15/3/2012.

1047 Entrevista a Mirta y Jorge, Bahía Blanca, 14/7/2012.
} 


\section{ii) Las redes católicas y la militancia política}

Un tercer factor no menor que impulsó el ingreso al PB de los jocistas fue el activismo previo de otros militantes en la agrupación. Los lazos de afecto y confianza entre estos jóvenes jugaron un papel esencial en el paso de la militancia eclesial a la acción político-partidaria. Así, a mi pregunta de por qué el $\mathrm{PB}$, los actores referían, entre otros factores, a la presencia de sus parejas y amigos. Por ejemplo, Mirta y Jorge contaban que se acercaron a la organización porque "empezó [Dante] a charlar así qué era el Peronismo de Base y empezó también a traer bibliografía, y empezamos a leer y dijimos, bueno, que había una cierta similitud con lo de la JOC "1048.

El comienzo de la militancia política de los estudiantes también se vio marcada por las relaciones personales tejidas dentro y fuera de los grupos cristianos. Ya hemos mencionado que el acercamiento de Pablo al PRT se dio en el marco de los vínculos creados en el Pensionado Católico. La agrupación universitaria Nueva Línea de Acción se formó a partir de algunos contactos establecidos por los estudiantes en los CUT. Pero también los jóvenes que optaron por el peronismo revolucionario vivieron procesos similares. María contaba que se unió al PB porque su compañero estaba comprometido en ese espacio ${ }^{1049}$. En cuanto a la JP, Aída, por ejemplo, explicaba su incorporación como un proceso natural ligado a su amistad con militantes de esa organización ${ }^{1050}$. Por otra parte, la participación en la Unidad Básica o en la AE de Villa Nocito, resultó en buena medida de un trabajo previo en Cáritas o en la escuela, poniendo de relieve el peso de los vínculos cara a cara surgidos en los círculos sociales liberacionistas en el paso de una militancia social a otra política. Juan Carlos subrayaba el rol que jugaron las amistades en la decisión de unirse a las agrupaciones de la Tendencia:

esta importante presencia de grupos cristianos en Bahía y su fuerte presencia en la JP logra una cierta unidad ideológica basada quizá más en afecto, vínculos personales que en la discusión que se daba aquí, por ejemplo, sobre Perón, Montoneros, porque era discutir con tus mismos amigos ${ }^{1051}$.

Y Marta resaltaba el papel de este tipo de lazos en una fase posterior de la militancia: "las opciones del pase a la clandestinidad no fueron solamente desde un discernimiento o estrategia política, se jugó todo el ser joven, lo emocional, lo afectivo" $" 1052$.

\footnotetext{
${ }^{1048}$ Entrevista a Mirta, Bahía Blanca, 18/6/2008.

${ }^{1049}$ Entrevista a Roberto, Bahía Blanca, 18/4/2013.

${ }^{1050}$ Entrevista a Aída, Buenos Aires, 17/5/2013.

1051 Entrevista a Juan Carlos, Buenos Aires, 1/8/2008.

1052 Entrevista a Marta, Bahía Blanca, 29/5/2008.
} 
Por su parte, los jecistas no sólo se sumaron a la rama secundaria de la Tendencia Revolucionaria cuando vieron la necesidad de un compromiso político, sino que incluso protagonizaron su formación. En efecto, la UES en Bahía Blanca surgió a partir de un importante componente de jóvenes católicos - tanto de Sánchez Elía como de La Pequeña Obra-, a propuesta de referentes de la JUP, entre los que se encontraban jucistas como Juan Carlos o Manuel. Así, en el primer grupo de la UES estaban Alberto Paira, Gustavo o Mónica. Luego, se incorporaron otros compañeros de los equipos de revisión de vida, siguiendo a sus amigos o referentes. Así lo sintetizaba Francisco: "nosotros íbamos detrás de los grandes [...] La JEC eran los hermanos menores de la $J U C^{״ 1053}$. Gabriel también daba cuenta de la importancia de los vínculos personales en la conformación de la nueva agrupación y en la integración de los militantes a la misma: "me acerco porque mis compañeros de la JEC, del grupo, estaban en el centro de estudiantes, y aparecen algunos compañeros más grandes, que eran de la JP y dicen 'hay que formar la UES ",1054. Mónica y Marisa recordaban incluso una reunión en La Pequeña Obra, organizada por los jucistas militantes de la JUP para interiorizar a los más chicos sobre la izquierda peronista, a partir de la cual algunos iniciaron su activismo político en la agrupación correspondiente a los estudiantes del nivel medio $^{1055}$.

Las trayectorias de estos jóvenes bahienses muestran que, como plantea Donatello (2003), los espacios de conformación y reproducción de la identidad religiosa gestaron lazos que dieron origen a grupos y actitudes que posibilitaron la generación de proyectos alternativos, y el ingreso y la adaptación de los sujetos a los mismos. La función de estas redes fue la de servir de espacios sociales de creación de solidaridades que fueron retomadas posteriormente en otros ámbitos. Así, en esa relación religiónpolítica, la influencia de la primera no sólo remite a una modalidad discursiva, ideológica o simbólica, sino que se afinca en la materialidad constitutiva de las relaciones sociales. Esto es, la existencia de redes sociales creadas por el catolicismo liberacionista, donde nacieron vínculos que propiciaron la participación política. Por su parte, González Bernaldo de Quirós (2008) señala que los vínculos de sociabilidad, que en algunos casos podrían contribuir a constituir lazos fuertes, más globalmente

\footnotetext{
${ }^{1053}$ Entrevista a Francisco, Buenos Aires, 16/11/2012.

${ }^{1054}$ Entrevista a Gabriel, Bahía Blanca, 27/10/2012.

${ }^{1055}$ Entrevista a Marisa, Neuquén, 19/3/2013, y a Mónica, Buenos Aires, 30/7/2008.
} 
multiplican los contactos personales que generan relaciones de confianza entre los actores. Y en este sentido, la sociabilidad liga el juego político a la dinámica relacional.

La acción conjunta de los cristianos en el espacio político -incluso las tareas cotidianas de la militancia- se vio facilitada por las relaciones afectivas que estaban cimentadas en la vivencia compartida de la fe y el trabajo del espacio eclesial. Según Juan, esto les daba a los militantes una suerte de "hándicap"1056 especial. El nuevo ámbito de acción, a su vez, consolidó ese vínculo, que algunos definían como de “hermanos" "1057. Así, para los actores, el paso por las agrupaciones políticas estuvo surcado por la continuidad de la militancia católica con los mismos compañeros, a pesar de que en aquéllas el trabajo también era compartido con otras personas.

Más allá de la propia comunidad de reflexión, las actividades comunes de los tres movimientos especializados también iniciaron contactos que se profundizaron al calor del trabajo en los grupos políticos. Por ejemplo, durante el PHPC del PB, Dante y Paloma confluyeron en un grupo de lectura y discusión con militantes de la JUC, incluida una maestra con la que poco después Paloma compartió el trabajo en la escuela Nuestra Señora de la $\mathrm{Paz}^{1058}$. Por otra parte, algunos militantes de la JOC y del PB, por un lado, y de la JEC y de la UES, por el otro, así como vecinos que no tenían una adscripción partidaria, impulsaron una corta iniciativa política. Se trató del intento de conformar una suerte de unidad básica, la "Sabino Navarro", que buscaba nuclear a la gente de la "loma" y hacer actividades para el barrio. Llegaron a alquilar un local a la vuelta de la casa parroquial y a repartir algunos volantes ${ }^{1059}$.

El peso de los afectos y de los vínculos personales tanto en las prácticas colectivas como en las decisiones individuales de los militantes católicos, se vuelven a poner de relevancia en otro aspecto, ligado a las actitudes y comportamientos de los simpatizantes del peronismo revolucionario. Veamos brevemente esta cuestión. "Pepe" recordaba que si bien había un grupo de jóvenes que tenía un compromiso político más definido, los otros apoyaban "todo el proceso que se iba dando" 1060 . Por su parte, Ema explicaba su adhesión a dicho proyecto político a partir de los lazos que la unían con

\footnotetext{
${ }^{1056}$ Entrevista a Juan, Bahía Blanca, 14/8/2012.

${ }^{1057}$ Entrevista a Juan, Bahía Blanca, 14/8/2012.

1058 Entrevista a Paloma, vía skype, 7/2/2012.

1059 Entrevista a Mirta, Bahía Blanca, 18/6/2008; a Inés, Bahía Blanca, 18/6/2011.

${ }^{1060}$ Entrevista a José Zamorano, Moreno, 2/9/2011.
} 
militantes católicos: "estaba compartiendo todo lo que esa gente hacía, no sé si será porque uno conocía a la gente y sabía con el espiritu que lo hacía" ${ }^{1061}$.

Una parte de los jocistas si bien no se involucró en el campo político, estaba acercada al PB a partir de los vínculos con sus compañeros, y de la identificación ideológica con el peronismo, que hizo que acompañara el activismo de sus pares, repartiendo volantes, participando de las marchas, prestando el auto, etc. ${ }^{1062}$. También entre los estudiantes hubo quienes, sin formar parte de la JUP o de la UES y considerándose simpatizantes, pero también incluso, sin estar identificados con la izquierda peronista, compartían publicaciones de la JP-Montoneros y realizaban algunas tareas puntuales como participar de charlas, reuniones o movilizaciones ${ }^{1063}$, distribuir volantes o la revista El Descamisado en sus colegios ${ }^{1064}$, "relevar paredones" que pudieran servir para que los militantes plasmaran sus consignas políticas ${ }^{1065}$, o directamente salir con ellos a hacer pintadas durante la noche ${ }^{1066}$.

Más aún, en tiempos de recrudecimiento de la represión paraestatal y estatal, los jóvenes que no tenían militancia política ofrecieron a los compañeros lugar en sus casas para esconder sus publicaciones o pasar la noche, o les facilitaron la salida de la ciudad. Este tipo de actividades eran consideradas un "servicio" o una forma de ayudar a sus $\operatorname{amigos}^{1067}$, aún sin necesariamente coincidir con las iniciativas o líneas políticas de las agrupaciones político-militares -como la lucha armada o la continuidad de la militancia en clandestinidad-. Para estos cristianos, importaba más "dar una mano" al compañero que la tarea en sí misma. Así lo vivieron María del Carmen y Carlos: "participaba de pequeños accionares que pudieran colaborar para que el otro, mi amigo, tuviera ese compromiso"” 1068 ; “mi compromiso cristiano era un compromiso social, y acompañar a mis amigos, hermanos, que estaban en un compromiso politico" ${ }^{\prime 1069}$.

Además del rol que jugaron las relaciones afectivas surgidas en los ámbitos del catolicismo liberacionista bahiense en la acción de los militantes que no tenían activismo político, este aspecto muestra, por un lado, que si a partir de la crítica al

\footnotetext{
${ }^{1061}$ Entrevista a Ema, Bahía Blanca, 27/9/2012.

1062 Entrevista a Mirta y Jorge, Bahía Blanca, 11/4/2012; a Angélica, Bahía Blanca, 25/4/2012; a Bruno, Bahía Blanca, 4/8/2012.

1063 Entrevista a Ana, Bahía Blanca, 17/10/2012; y a María del Carmen, Bahía Blanca, 18/5/2011.

${ }^{1064}$ Entrevista a Pedro, Buenos Aires, 15/11/2012; y a María del Carmen, Bahía Blanca, 18/5/2011.

1065 Entrevista a María del Carmen, Bahía Blanca, 18/5/2011; a Norma, Bahía Blanca, 8/4/2011; a Cecilia, Bahía Blanca, 2/6/2011.

${ }^{1066}$ Entrevista a Ana, Bahía Blanca, 17/10/2012.

1067 Entrevistas a Angélica, Bahía Blanca, 25/4/2012; y a Bruno, Bahía Blanca, 4/8/2012.

1068 Entrevista a María del Carmen, Bahía Blanca, 18/5/2011.

${ }^{1069}$ Entrevista a Carlos, Bahía Blanca, 4/5/2011.
} 
"sistema" muchos jóvenes asumieron una actitud militante, buscando inscribirse en alguna tradición, otros no se incorporaron a agrupaciones políticas pero, a partir de un conjunto heterogéneo de autores, textos y referencias ocasionales, compartían una actitud contestataria que aunque imprecisa, e incluso débil, operaba efectivamente en la conciencia de aquella juventud (Cattaruzza, 1997: 106). Por otro lado, estas reacciones dan cuenta de la presencia de una lógica evangélica, de una voluntad de seguimiento del Jesús histórico, comprometido con los que sufren, que es la misma que llevó a otros compañeros a asumir algún tipo de activismo contestatario ${ }^{1070}$. Gabriel explicaba el criterio que guiaba a quienes ofrecían su ayuda a los militantes: "estás mal, te están persiguiendo... Y es lo que hacía Cristo con los perseguidos. No voy a decir que lo que hacés está bien pero no tengas ninguna duda que yo te cobijo" ${ }^{1071}$.

\section{iii) Las afinidades entre catolicismo liberacionista $y$ peronismo}

Para comprender por qué la acción política de buena parte de los cristianos liberacionistas bahienses se canalizó mayoritariamente a través del peronismo conviene explorar las razones que algunos de sus referentes encontraron para optar por aquel movimiento. En efecto, mientras en otros países latinoamericanos "ir al pueblo" y "estar con los pobres" significaba encontrarse con el socialismo y el comunismo, en Argentina se trataba de relacionarse con el movimiento peronista (Mallimaci, Cucchetti y Donatello, 2006). 'Si la opción por los pobres suponía considerar al 'pueblo' como sujeto histórico, y si éste era peronista, el 'hacerse peronista' significaba compenetrarse con el sentido de la historia" (Donatello, 2005b: 246).

El repaso de las afinidades previas entre peronismo y catolicismo -véanse los capítulos 1 y 2- nos permite entender que la elección de los actores por aquel movimiento suponía una "actitud natural", esto es, no representaba grandes rupturas con una visión del mundo y un universo de significados ligados a sus pautas de socialización (Donatello, 2005b). Por otra parte, el imaginario de Hernán Benítez y Eva Perón -en el que se destacaba la diferenciación entre clericalismo y religión, la consideración de las

\footnotetext{
${ }^{1070}$ Desde la perspectiva liberacionista, Jesús no aparece como aquel del que se espera la salvación sino como alguien que envía a proseguir su misión. Ser su discípulo en América Latina encuentra en el Reino de Dios su motivación y contenido; abrazar la cruz implica expresar la acogida del Reino en la solidaridad con los pobres reales y el compromiso por la transformación liberadora (Sobrino, 1990; Lois, 1990).

${ }^{1071}$ Entrevista a Gabriel, Bahía Blanca, 27/10/2012.
} 
realizaciones del peronismo como concreción histórica del mensaje evangélico o la continuidad espiritual entre peronismo e Iglesia en la opción por los humildesantecedió en el tiempo la obra teológica liberacionista. El peronismo se proclamó continuador de la obra liberadora de Jesús y del cristianismo primitivo, al tiempo que consideraba al cristianismo como el "primer peronismo" que conoció la humanidad. Según Perón, si la prédica de Jesús fue eminentemente popular, al justicialismo debía reconocérselo como un cristianismo adaptado a nuevas condiciones históricas (citado en Cucchetti, 2005: 44). La afinidad "religión/pueblo", tan marcada en el catolicismo de los años sesenta y setenta, se estableció cuando comenzaron a interactuar lo religioso y lo político con el fin de derribar la tradición liberal. El peronismo se concentró en el contenido mismo de la esperanza cristiana -el reino de los trabajadores-, priorizando el objetivo terrenal del cristianismo. La distinción que hacía entre cristianismo de forma y de fondo operó muy fuertemente en las producciones teológicas de los años sesenta y setenta. Así, la lectura peronista del catolicismo integral inauguró afinidades entre lucha peronista y catolicismo liberacionista que aparecieron años después (Cucchetti, 2005).

Abordemos ahora las relaciones entre peronismo y catolicismo liberacionista, en los casos del MSTM y de Cristianismo y Revolución, en cuanto se constituyeron en puntos de referencia para los actores bahienses. Siguiendo a Martín (2010), fue en el marco de la reflexión en torno a las alternativas del cambio político real donde los STM descubrieron al peronismo. Para el MSTM, el proceso revolucionario y el camino al socialismo tenían en cada país antecedentes válidos, considerando que en Argentina, la experiencia peronista y la larga fidelidad de las masas al movimiento constituían un elemento clave en la incorporación del pueblo al proceso revolucionario ${ }^{1072}$. Desde esta perspectiva, entonces, el peronismo, a pesar de no representar una auténtica vanguardia revolucionaria, era el único movimiento de raigambre popular; y lo popular debía ser, la nota esencial y distintiva de todo movimiento revolucionario auténtico ${ }^{1073}$.

Vemos cómo, en el ideario político del MSTM, el concepto de "pueblo" constituía un marco de referencia fundamental. Esto tenía antecedentes históricos y teológicos que habían preparado el acercamiento a los sectores más desprotegidos mediante el trabajo en las villas y poblaciones empobrecidas de las zonas agrarias o como curas obreros (Martín, 2010). En este sentido, al adjudicarse el deber de "hacerse pueblo", asumiendo sus expectativas y elecciones, el MSTM descubría que éste, en su

\footnotetext{
1072 Comunicado del Tercer Encuentro Nacional, 2/5/1970.

1073 Síntesis de las Conclusiones de los equipos regionales, 3/5/1969.
} 
gran mayoría, se veía y expresaba en el peronismo, porque era el movimiento que le había permitido adquirir el mayor grado de conciencia política y de combatividad histórica $^{1074}$. En otros términos, si los STM compartían el ideal y el diagnóstico de la marcha del pueblo hacia su liberación (Martín, 2010), entendían que el anhelo de justicia del pueblo argentino se expresaba mayoritariamente a través del peronismo ${ }^{1075} \mathrm{y}$ que era esta fuerza masiva la que lo convertía en revolucionario ${ }^{1076}$. Así, en este camino, dicho movimiento ayudaba a lograr la unión de las masas, a cuestionar las bases del sistema opresor y a construir la patria socialista ${ }^{1077}$.

Por lo tanto, el MSTM, si bien como tal no podía optar por el movimiento peronista ya que no debía comprometerse partidariamente, se obligaba a estar abierto a sus realizaciones y buscar en él las líneas de interpretación para la liberación ${ }^{1078}$. Ahora bien, el acercamiento al peronismo se convertía en opción por parte de un sector mayoritario del $\mathrm{MSTM}^{1079}$. Para Mugica, por ejemplo, aquél era el movimiento histórico al que debía acceder naturalmente un cristiano para mirar las cosas del lado de los pobres, porque servía al pueblo y le obedecía, ponía el acento en el proyecto humano e interpretaba tanto la dimensión inmediata de la evangelización (Perón había comenzado a atender las necesidades del pueblo), como la estructural (con él la clase trabajadora había empezado a sentirse protagonista y, unida a los estudiantes y a otros sectores, había producido una evolución que llevó a la profundización del peronismo $)^{1080}$.

El texto elaborado por la regional Mendoza y redactado por Rolando Concatti para ser discutido en el Tercer Encuentro Nacional, sintetizaba el pensamiento mayoritario del movimiento en relación a esta cuestión. Entre las razones decisivas de la opción por el peronismo figuraba, en primer lugar, la idea de que no se trataba de una opción por un partido político sino entre fuerzas sociales -pueblo y antipueblo, mayoría

\footnotetext{
1074 Síntesis de la encuesta enviada a los miembros del movimiento sobre "Peronismo-socialismo" en preparación del Cuarto Encuentro Nacional, 7/8/1971; Documento final del Quinto Encuentro Nacional, 19/10/1972.

1075 Comunicado de los 60 sacerdotes que se entrevistaron con Perón, 9/12/1972.

1076 Documento del Cuarto Encuentro Nacional, 9/7/1971.

1077 Declaración de Coordinadores, Secretario y Secretariado sobre el retorno de Perón al país, 4/12/1972.

1078 Síntesis de la encuesta enviada a los miembros del movimiento sobre "Peronismo-socialismo" en preparación del Cuarto Encuentro Nacional, 7/8/1971.

${ }^{1079}$ Las diferentes posturas de los STM frente a esta cuestión, a partir del regreso de Perón al país y al poder, consumaron una fractura cada vez mayor en el MSTM. En él convivían un sector ajeno a toda simpatía con el peronismo con una mayoría favorable al mismo, y aquí a su vez, se distinguían quienes brindaban un apoyo crítico y quienes ofrecían un acompañamiento incondicional a Perón (Martín, 2010). ${ }^{1080}$ Mugica, 1973.
} 
desposeída y minoría privilegiada-, siendo el peronismo el nombre concreto para designar la fuerza social revolucionaria, es decir, el proletariado. En segundo lugar, se planteaba que el peronismo era un movimiento real que había asumido en términos contemporáneos las tres vertientes de las que se nutría un verdadero movimiento histórico, esto es: el movimiento nacional -había retomado la lucha antiimperialista y tratado de imponer la soberanía política y la independencia económica-, el movimiento democrático -había sido una democracia al servicio del pueblo- y el movimiento proletario -había dado fuerza, identidad, organización y triunfo al proletariado. En tercer lugar, se aducía que con Perón, el pueblo había cobrado conciencia experimental de su poder, de sus derechos y del modo de conquistarlos; había logrado unidad real; había participado, decidido y defendido a un gobierno que supo para él; había adquirido una identidad; y había revelado una combatividad que jamás había tenido antes ${ }^{1081}$.

De lo anterior los STM deducían que el peronismo había inaugurado el proceso revolucionario en la Argentina, por lo cual, se dirigía necesariamente hacia definiciones radicales que el golpe de 1955 había postergado. Sin embargo, para que el peronismo pudiera cumplir su responsabilidad como eje del esfuerzo liberador hacía falta superar una serie de deficiencias profundas, a saber: la ausencia de una ideología -de una teoría y proyecto revolucionario-, una organización equívoca y el espontaneísmo como método. Con todo, para los actores, no se podía ser revolucionario y antiperonista. El peronismo "es la memoria viva de una Revolución que fue. Y a nivel de pueblo es la honda esperanza de la Revolución que debe venir, la Revolución que hay que hacer" 1082 .

En esta misma línea, Cristianismo y Revolución afirmaba que si cada pueblo tenía su propia vía para llegar al Hombre Nuevo ${ }^{1083}$, el camino argentino al socialismo se hacía a través del movimiento obrero peronista ${ }^{1084}$. En este sentido, el peronismo era la concreción argentina del proletariado en la lucha de clases y una etapa de la construcción del socialismo (Morello, 2003). La incorporación del pueblo a la lucha por la liberación había empezado el 17 de octubre de $1945^{1085}$. Y en los últimos años, los caminos recorridos por el peronismo llevaban a la revolución popular como única salida. La consolidación de la tendencia del peronismo revolucionario sería fundamental

\footnotetext{
${ }^{1081}$ Concatti, 1972.

1082 Concatti, 1972: 55.

1083 Cristianismo y Revolución, 9, septiembre 1968.

${ }^{1084}$ Cristianismo y Revolución, 4, marzo 1967.

${ }^{1085}$ Cristianismo y Revolución, 21, noviembre 1969.
} 
en la integración de la vanguardia que expresaría las necesidades y aspiraciones del pueblo $^{1086}$. En esta lucha, para la revista, si Perón conducía al pueblo, FAR, FAP y Montoneros, eran la vanguardia de la guerra contra el sistema (Morello, 2003).

Los argumentos que respaldaban la opción del grupo por el peronismo se repetían: cuando la Iglesia se acercaba al pueblo se encontraba con que éste era peronista, entonces "ser peronista es ser pueblo"1087. El peronismo era históricamente la representación del proletariado nacional, asumiendo conscientemente su capacidad combativa, el movimiento que había encarnado las aspiraciones populares y producido su triunfo. Y Perón era la única representación real y auténtica de estos sectores. La función de aquel movimiento era incorporar a las masas al proceso de liberación. Su tendencia revolucionaria buscaba, justamente, recuperar ese papel histórico. Y era el pueblo trabajador peronista quien conduciría el proceso (Morello, 2003).

No obstante, la revista también mantenía una visión crítica del peronismo, destacando errores, debilidades y tareas pendientes. El peronismo había sido una doctrina de cohesión nacional, pero no revolucionaria. En este sentido, debía explicitar su proyecto socialista, superar su cortedad ideológica, actualizar su doctrina, así como desarrollar una estructura revolucionaria que hiciera de nexo entre Perón y el pueblo. Así, para Cristianismo y Revolución, era necesario darle al movimiento elementos tanto teóricos como prácticos que condujeran a la toma del poder (Morello, 2003).

En suma, frente al llamado de las autoridades de la Iglesia a modificar las estructuras sociales injustas, los fieles debían optar en concreto y aquella elección estaba cargada de historicidad. Es aquí donde los católicos liberacionistas argentinos descubrieron el peronismo. Muchos de ellos entendieron, con Mugica, que éste era "un movimiento que asume los valores cristianos en determinada época" ${ }^{1088}$. Y se apoyaron en la visión del "pueblo": el decirse peronista, más que una opción política, aparecía como un aspecto de su identificación con los marginados (Martín, 2010). La convicción de que no había liberación posible si no se partía del pueblo, sus valores y su praxis, los llevaba a ver el peronismo como revolucionario por esencia. Se constituía, así, en la vía argentina al socialismo, aunque restara aún actualizar su doctrina y su proyecto.

\footnotetext{
${ }^{1086}$ Cristianismo y Revolución, 10, octubre 1968.

1087 "Carta de las FAP a los MSTM", Cristianismo y Revolución, 26, citado en Morello, 2003: 223.

${ }^{1088}$ Mugica, 1973: 35.
} 


\section{c) La lucha armada como forma de hacer política}

En esos años, el debate en torno a la opción por la lucha armada se convirtió en la discusión política por excelencia (Calveiro, 2005), que no dejó indiferentes a los militantes cristianos. Existía un amplio consenso sobre la legitimidad de la violencia insurgente $^{1089}$ entre ellos, tal como ocurría a nivel general. La violencia como alternativa necesaria para la toma del poder y la realización de la esperanza revolucionaria era aceptada y comprendida. Pero esta convicción llevó sólo a algunos de estos jóvenes a hacer una opción personal por la lucha armada y asumió diversos matices en función del contexto histórico y de las concepciones ideológicas y enfoques estratégicos de las organizaciones de pertenencia. Ahora bien, ¿qué representaciones sobre la violencia contestataria circulaban $-y$ qué prácticas concitaban esas representaciones- entre estos jóvenes? ¿Cómo vivieron estos actores la posibilidad de involucrarse personalmente en la lucha armada? ¿Qué razones los llevaron a aceptarla y/o ejercerla? ¿En qué medida las posturas frente a la violencia se justificaban desde la fe y la doctrina católica?

En toda aproximación a la cuestión de la violencia revolucionaria en los años setenta, surge la imposibilidad de reducirlo a una libre opción adoptada desde un punto de partida exento de las "tensiones de la historia" (Kaufman, 2010). Para comprender las distintas formas de ejercicio de la violencia y los diversos posicionamientos en torno a la lucha armada se vuelve imprescindible ubicarse en el contexto histórico en el que se desplegaron, problema sobre el que los entrevistados insistían recurrentemente. Excluir a sus simpatizantes y protagonistas de ese marco supondría "dejarlos al desnudo como un monstruo" (Bayer, 1993). Si todo acto de memoria comporta la doble dificultad de reinsertarlo en su sentido original y releerlo a la luz del presente, abordar esta cuestión se torna aún más complejo, ya que nuestra realidad y los sucesos ocurridos cuatro décadas atrás se inscriben en constelaciones de valores, imaginarios y mundos de sentido absolutamente diferentes (Calveiro, 2008).

\footnotetext{
${ }^{1089}$ Siguiendo a Kaufman (2010), utilizo esta expresión como sinónimo de violencia contestataria o revolucionaria, para referir a las acciones de fuerza que se vuelcan en contra del orden establecido, y la entiendo como una forma de violencia política. Este último término es genérico y engloba fenómenos variados. En sus acepciones más comunes, aparece muy cercano al de represión. Pero es necesario evitar confundir los diversos tipos de violencia política visibles en determinados contextos históricos. Así, la violencia insurgente debe ser diferenciada de la represión, es decir, de la implementación de mecanismos coactivos por parte del Estado, sus aparatos o agentes vinculados a él -incluso los paraestatales- para eliminar la acción disruptiva de diversos actores sociales y políticos (Levín, 2010a; Águila, 2013).
} 


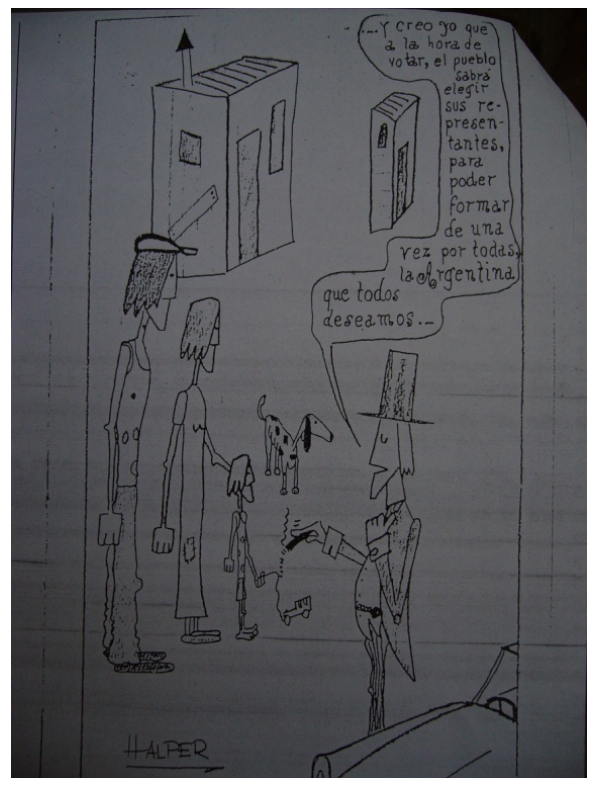

En este sentido, aquellos procesos se explicaban a partir de una serie de factores impersonales, tanto estructurales como coyunturales, a la vez que subjetivos. Entre los primeros cabe destacar, por un lado, la constatación de un sistema económico injusto, causante de marginalidad, desigualdad, pobreza, explotación, en beneficio de una minoría detentadora del poder. Esos rasgos constituían, para los actores, violencia. Por el otro, una larga historia de golpes militares y de violencia política. Nadie creía en la democracia como camino posible para la transformación social. Así lo expresaba un dibujo de publicado en Graphos. En palabras de Rodolfo: “¿qué democracia? Si cuando pierden te matan o te bombardean la Plaza de Mayo, te fusilan"1090. En este sentido, decía Paloma de la lucha armada: "la encontraba justificada por el fracaso de los métodos utilizados con anterioridad"1091. En efecto, la historia argentina del siglo XX estuvo atravesada por "la trunca transición del régimen oligárquico al democrático (1912-1930) durante el cual se alternaron dictaduras militares y cívico-militares con ejercicio restringido de la democracia. Seis golpes de Estado signaron fuertemente el rumbo político argentino (Ansaldi, 2010).

Ligado a lo anterior, Rodolfo decía: "la política tenía mucho de cosa violenta" ${ }^{1092}$. La violencia política en Argentina se hundía en una larga historia pero había asumido gran protagonismo en las últimas décadas, lo que llevaba a su naturalización. Durante los años setenta, se produjo una suerte de autonomización de la violencia (Levín, 2010). Se asistió entonces al vuelco de la política hacia un escenario que despreciaba las formas institucionales de la democracia, acompañada de la exaltación de las formas bélicas que empalmaban, a su vez, con una concepción de la política como una cuestión de fuerza y de confrontación entre dos campos (Carnovale, 2007; Calveiro, 2005, 2008; Terán, 2006; Pozzi, 2006). Los enemigos eran los que tenían el poder y las armas, a los que no iban a renunciar fácilmente. Y si explotaban y

\footnotetext{
${ }^{1090}$ Entrevista a Rodolfo, Bahía Blanca, 23/6/2008.

1091 "Por qué y cómo milité en el PB", apuntes de Paloma enviados vía e-mail, 1/3/2013.

1092 Entrevista a Rodolfo, Bahía Blanca, 23/6/2008.
} 
reprimían a la clase obrera, la violencia del pueblo resultaba legítima. En este sentido, se expresaba Gabriel:

la militancia sin lucha armada era exponerse a la muerte. Los grupos de tareas y los paramilitares se estaban matando de un modo que había que tomar armas para defenderse. Y la revolución, había muestras de que era muy difícil hacerlo sólo con la opción política, tomar el poder implicaba la lucha armada ${ }^{1093}$.

En las últimas décadas, se sumaba al cuadro político la proscripción del peronismo y los movimientos de liberación que afloraban en América Latina y el mundo, especialmente en Cuba, que constituía la prueba de que la revolución era posible (Morello, 2003). Éstos mostraban, en palabras de Juan Carlos, "que no había posibilidades de salir del capitalismo sino se salía por la vía violenta" ${ }^{1094}$.

Por otro lado, los documentos eclesiales parecían reforzar el diagnóstico de la realidad y la necesidad de transformarla. Como mencionamos anteriormente, Pablo VI admitía la legitimidad de la insurrección revolucionaria "en caso de tiranía evidente y prolongada" ${ }^{1095}$. Y los obispos reunidos en Medellín afirmaban que el cristiano creía en la paz y en la justicia como condición para la alcanzarla, y veía que América Latina se encontraba ante una situación de injusticia o "violencia institucionalizada" ${ }^{1096}$. Incluso las palabras de Jesús no parecían condenar la violencia en la búsqueda de la justicia: echó a latigazos a los mercaderes del templo y sentenció "no hay mayor amor que dar la vida por los amigos", “a los tibios los vomitaré” y "deja todo y sígueme" 1097.

Pero si hubo elementos económicos, sociales y políticos que conformaron las condiciones de la acción, ésta se explicaba por la identificación con determinados valores, principios, descripciones de sí y del mundo, y personas: la generosidad sin límites, la capacidad de entrega, la disposición a morir por los demás, como lo había hecho Jesús. En este sentido, Norma decía: “vos estabas convencido que por los más pobres había que dar la vida" ${ }^{1098}$. Esta idea tenía raíz en la fe, aunque no era exclusiva de los militantes católicos. Los vínculos entre la imaginería revolucionaria y ciertos componentes de la tradición cristiana caracterizaron a las organizaciones radicalizadas de los años setenta y reconocían varios antecedentes en la historia de las izquierdas. El Hombre Nuevo que debían imitar, al tiempo que construir los militantes, se identificaba

\footnotetext{
${ }^{1093}$ Entrevista a Gabriel, Bahía Blanca, 7/11/2012.

${ }^{1094}$ Entrevista a Juan Carlos, Buenos Aires, 1/8/2008.

1095 Populorum Progressio, 1967.

1096 Documentos Finales, 1968.

${ }^{1097}$ Entrevista a Mónica, Buenos Aires, 30/7/2008.

1098 Entrevista a Nora, Bahía Blanca, 4/6/2008.
} 
por ser humilde, solidario, estar siempre dispuesto, ser sacrificado, dar la vida. En la concepción revolucionaria se entrecruzaba la figura del héroe y la del mártir, dándole a la militancia un contenido sacrificial. La muerte legitimaba y redimía la revolución en marcha, al tiempo que habilitaba lo heroico (Carnovale, 2005). En otras palabras, los muertos en combate contribuían a allanar el camino a la construcción de un orden social regido por la utopía del Hombre Nuevo (Touris, 2011). En este sentido, siguiendo a Catoggio (2010a, 2011), los agentes del catolicismo que más tarde sufrirían la represión, construían un horizonte utópico donde el martirio se contemplaba como una posibilidad cierta, como consecuencia no buscada pero previsible y no resistida de la acción. Aún más, la muerte se convertía en privilegio porque acercaba a los militantes a Jesús, quien al dar su vida por la justicia, había marcado el camino del calvario, la cruz y la resurrección (Morello, 2003).

De allí, como mencionamos en el capítulo 4, la identificación con figuras como "el Che" Guevara y Camilo Torres. Siguiendo a Morello, desde la óptica del catolicismo liberacionista, ambos eran signos de la aspiración a construir el Hombre Nuevo, ejemplos de revolucionario auténtico y mártires que inmolaron su vida por la redención humana. A pesar de que "el Che" no era creyente, reconocían en su sed de justicia, su entrega y su amor al prójimo, un "heroísmo cristiano". Al mismo tiempo, el legado del sacerdote colombiano radicaba en haber señalado que la revolución era una lucha cristiana, "la única manera eficaz y amplia de realizar el amor para todos" (2003: 156). Así, como plantea Catoggio, una vez muerto en combate, fue reivindicado como un "mártir religioso por razones políticas". De este modo, la figura del mártir permitía, por un lado, “'secularizar' figuras ejemplares de origen religioso a partir del énfasis puesto en la dimensión política de su acción”, y por el otro, integrar "en un imaginario religioso a individuos que provienen de otros campos de actividad" (2011: 103). Al decir de Touris $(2011,2012 b)$, en la corriente liberacionista, la noción del martirio fue resignificada con un acento fuertemente político. La defensa de la verdad y la justicia llevó a incluir en ella no sólo a aquellos que dieran su vida por causa de Dios sino a los que sin poseer una adscripción religiosa se hubieran comprometido con la misma lucha.

El sentido sacrificial de las acciones religiosas se tradujo en los cristianos revolucionarios en la legitimación de la acción armada (Touris, 2011, 2012b). No sorprende entonces, que algunos militantes católicos bahienses hayan elegido transitar este camino, sin experimentar con ello tensiones evidentes con sus creencias religiosas. En este sentido, Rodolfo le escuchó decir a un compañero: "la forma superior de ser 
católico es ser Montonero" "1099. Al mismo tiempo, explicaba su experiencia: "la opción por medios violentos yo no la veía como una licencia de mi fe religiosa [...] al contrario, yo estaba convencido de que esto era fundado en la opción de fe" ${ }^{\text {"100 }}$. Tampoco Gabriel se planteaba una disyuntiva entre las prácticas religiosas y las políticas, aunque éstas incluyeran la participación o el apoyo de operativos armados: "seguíamos yendo a misa y no es que íbamos, viste, a pedirle perdón a Dios por haber estado en la semana vivando que Montoneros se había cargado a tal""1101. De modo similar, lo vivió Juan, quien señalaba que la acción militar, en el marco del compromiso político: "era nuestra concepción de vida. Vos tenías que cumplir el Evangelio ¿qué era? Y era asumir el compromiso. Sacudirle para adelante" ${ }^{1102}$; así, para el militante, el sentido por el que ejercía la violencia lo liberaba de cualquier tipo de tensión.

También otros jóvenes adherían al planteo de la violencia contestataria pero no podían asumirla por motivos personales, vinculados al carácter - “yo soy un tipo más reflexivo que impulsivo... Yo la aceptaba pero no la veía como para mí"1103 - , al miedo - "no me atrevía""1104 - o a la situación familiar - "entendía que la lucha armada era un camino, entendía de acá (señalándose la cabeza), después yo no la podía asumir...pero, además [...] yo quería criar a mi hijo" "1105 -. Para quienes estaban convencidos de que vivían en un orden generador de una "violencia estructural", que debía abolirse, el hecho de no estar convencidos de la vía guerrillera o hacer una opción por abstenerse de desarrollar tareas militares no se traducía forzosamente en el repudio hacia los métodos violentos, y mucho menos hacia los compañeros que los defendieron. Entre sus amigos, hubo quienes los sospechaban equivocados pero también quienes los admiraban por animarse a "jugarse" enteramente por la causa. En este sentido, Lucy comentaba que el comentario sobre el compañero que hacía la opción armada era "mirá este tipo se decidió” o "da todo, yo no" ${ }^{1106}$. María del Carmen señalaba que en la JEC había "un respeto absoluto para dejar hacer al que tomara un camino [armado] si consideraba que dar la vida por el hermano iba por aquel camino" ${ }^{1107}$. Alicia e Inés iban más allá al afirmar que la decisión de entrar a la clandestinidad y la opción armada eran vistas

\footnotetext{
${ }^{1099}$ Entrevista a Rodolfo, Bahía Blanca, 23/6/2008.

${ }^{1100}$ Entrevista a Rodolfo, Bahía Blanca, 23/6/2008.

${ }^{1101}$ Entrevista a Gabriel, Bahía Blanca, 7/11/2012.

1102 Entrevista a Juan, 31/5/2011.

${ }^{1103}$ Entrevista a Ángel, Buenos Aires, 8/10/2009.

${ }^{1104}$ Entrevista a Elena, Bahía Blanca, 17/6/2010.

1105 Entrevista a Nora, Bahía Blanca, 4/6/2008.

${ }^{1106}$ Entrevista a Lucy, Neuquén, 18/3/2013.

${ }^{1107}$ Entrevista a María del Carmen, Bahía Blanca, 18/5/2011.
} 
entonces como la consecuencia y, a la vez, la evidencia de que esos compañeros eran los militantes "más maduros"1108 o "mejor dotados": "era hasta un honor"1109. Al mismo tiempo, si las prácticas de las organizaciones político-militares despertaban simpatías, éstas no estaban exentas de una mirada crítica: "nos parecía bien cuando iba el ERP, robaba un camión de carga y lo repartía. Nos parecía que estaba fuera de lugar también, porque era una propaganda, la gente recibía la carne y ¿qué hacía después? ¿Qué tipo de reivindicación era?" 1110.

El hecho de que el valor político de la violencia estuviera en el consenso general aunque no lo practicaran todos los militantes, y que muchos de ellos hicieran una opción explícita por no ejercerla pero sin rechazarla de plano, y que lejos de repudiar a las organizaciones armadas, les reservaran un importante reconocimiento por los objetivos que perseguían, vuelve más complejo el problema de la violencia insurgente y señala los matices en las posturas asumidas. En el próximo capítulo volveré sobre esta cuestión, y específicamente, analizaré los debates y dilemas planteados al interior de los grupos cristianos en torno a la vía armada.

\footnotetext{
${ }^{1108}$ Entrevista a Inés, Bahía Blanca, 18/6/2011.

${ }^{1109}$ Entrevista a Alicia, Bahía Blanca, 9/7/2011.

${ }^{1110}$ Palabras de Jorge, entrevista a Mirta y Jorge, Bahía Blanca, 11/4/2012.
} 


\section{CAPÍTULO 7: Las tensiones entre catolicismo liberacionista y militancias contestatarias}

\section{SUMARIO}

1) La preponderancia de la militancia política

2) La convivencia entre diversas opciones ideológico-políticas

3) Los dilemas de la "doble pertenencia"

a) Militantes políticos en los grupos cristianos

b) "Cristianuchis" en las agrupaciones políticas

c) Militantes católicos y/o activistas políticos

4) Debates y conflictos en torno a la vía armada

La JUC se definía como "movimiento de frontera", que intentaba llevar la fe al medio cotidiano en el que se desenvolvían sus integrantes y traer a la Iglesia lo político ${ }^{1111}$. En palabras de Julio: "si bien nos sentíamos Iglesia nos sentíamos siempre en una zona límite. A veces estábamos un poquito afuera, a veces un poquito adentro, tanto por decisión de la jerarquía como por opciones, siempre estábamos jugando en el limite $" 1112$.

Por su parte, el Secretariado Latinoamericano, al describir la identidad del MIEC-JECI, decía: "Queremos ser una presencia de Iglesia en el medio estudiantil y de éste en el seno de la Iglesia. Esto nos permite tener una presencia original dentro de la Iglesia y por otra parte afirmar la autonomía del mundo estudiantil"1113. De modo similar, un año y medio antes, señalaba que este posicionamiento "en un límite fronterizo en donde la Fe, la Pastoral, la Iglesia y la Política encuentran su punto dialéctico, uniéndose pero distinguiéndose”, había planteado conflictos y tensiones que no eran fáciles de superar ${ }^{114}$.

En relación a esta cuestión, Donatello afirma que, después de una primera instancia de acercamiento a la sociedad y a la política, las ramas especializadas de Acción Católica atravesaron un segundo momento "donde la política partidaria penetró en estas instituciones. Es en esta última instancia donde los militantes tuvieron que optar entre las estructuras institucionales de la Iglesia y el mundo extramuros" (2010: 40).

\footnotetext{
${ }^{1111}$ Entrevista a Nora, Bahía Blanca, 4/6/2008.

1112 Entrevista a Julio, Bahía Blanca, 22/5/2010.

1113 "Informe de la XXVIII Asamblea Interfederal del MIEC", Spes, 27-28, s/f.

1114 “Presentación”, Spes, 22-23, enero 1974.
} 
Ahora bien ¿qué tipo de contradicciones llevaba implícito este doble movimiento entre la Iglesia y el medio en los caminos concretos en los que discurrió, tanto en la JUC, como en la JEC y la JOC? El presente capítulo se adentra en las consecuencias que tuvo en los grupos de reflexión el "contacto con el mundo" del que intenté dar cuenta en el capítulo anterior. Es decir, analiza los conflictos surgidos de la heterogeneidad de formas de compromiso elegidas, los desencuentros entre identidad católica y opciones políticas, así como las tensiones suscitadas en torno a la pertenencia simultánea a la JUC, la JEC o la JOC y a las organizaciones políticas revolucionarias. En torno a esta cuestión, me interesa pensar: ¿cómo repercutió en las ramas estudiantiles y obrera la opción política de algunos de sus integrantes?, ¿cómo convivían el interior de las agrupaciones políticas los militantes cristianos con aquellos no creyentes?, ¿en qué medida se planteó la necesidad de optar entre la estructura eclesial y la militancia política?, y en ese caso, ¿qué razones motivaron a los militantes a tener que elegir entre una y otra?, ¿qué debates y dilemas concitó al interior de los grupos de reflexión la vía armada? En suma, ¿hubo distintas formas de integrar la fe y la política?, ¿qué cambios y continuidades pueden reconocerse en esa relación a lo largo del período?

\section{1) La preponderancia de la militancia política}

Si bien los grupos de revisión de vida proponían una fe encarnada en la realidad a través de la acción con otros en vistas al cambio social -acción que no era emprendida por el movimiento sino por cada uno de los jóvenes de diversas maneras-, no todas las formas de militancia eran valoradas por igual a la hora de evaluar su aporte a la construcción del Reino de Dios. Esta cuestión emergía como una de las "tentaciones" en las que también caía el movimiento en otros puntos del continente. Así, un informe elaborado por el asesor paraguayo a partir del material provisto por el Centro de Documentación del SLA señalaba la tendencia de los equipos a excluir a los que no tenían una "opción radical" constituyéndose grupos "de elite de cristianos radicalizados irrespetuosos de la libertad de opción temporal de sus integrantes, cerrados al pluralismo" $" 1115$. Asimismo, un estudio de la JEC latinoamericana incluía una serie de interrogantes que resumían las tensiones que se manifestaban al interior del movimiento y que condicionaban el compromiso de los militantes. Entre ellas, se encontraban los

1115 "Introducción a una pedagogía de la pastoral universitaria”, Doc. 14, Servicio de Documentación, mayo de 1968. 
siguientes: ¿la fe exige un compromiso político?, ¿el cristiano podrá comprometerse partidariamente?, ¿el movimiento debe exigir una opción política?, ¿qué hacer entonces con los "no comprometidos"?, ¿será posible mantener una comunidad de fe con militantes que tienen diversas opciones de compromiso? ¿O llegará un momento en que se dará el rompimiento de los "no comprometidos"? ${ }^{1116}$. Veamos cómo fue vivida esta cuestión en cada una de las ramas especializadas bahienses.

En la JUC se constituyó una especie de jerarquía que colocaba la acción política por encima de las demás opciones, consideradas una suerte de "aspirina",1117 que apuntaba a los síntomas, una tarea asistencial que intentaba solucionar cuestiones inmediatas de los necesitados y no a resolver de raíz el problema de la opresión. Así, Aída recordaba que los universitarios llamaban a sus compañeras “'las amorfas de Servicio Social'. ¿Por qué? Porque nosotras dábamos un paquete de fideos y una curita, y ellos hacían la revolución, jla puta que los parió!",1118.

Desde esta perspectiva, el trabajo barrial, así como la acción social en cualquier otro espacio, debía ligarse a la participación en agrupaciones políticas que incluían, en palabras de los actores, "un horizonte de transformación de la sociedad"1119 o un "proyecto de toma del poder" $" 1120$. No obstante, resulta difícil separar lo social y lo político a la hora de analizar las formas que asumió la militancia cristiana, en cuanto estas diversas prácticas, al estar motorizadas por la esperanza de la concreción de la construcción social antisistémica, tenían un carácter político.

Más allá del respeto que los jucistas procuraban tener frente a la multiplicidad de experiencias de compromiso cristiano, el hecho de que la opción política se valorara como una forma superior de militancia -o, al decir de los protagonistas, "el único compromiso que valía"1121, la "meca" a la que había que llegar"1122 o "la opción predilecta y por excelencia" 1123 -, y la pretensión por parte de quienes estaban ya integrados a las agrupaciones de sumar a sus compañeros de comunidad, producía tensiones y hacía que quienes no estaban convencidos de esa opción, no podían asumirla o elegían otras formas de compromiso, se sintieran cuestionados, presionados o de algún modo marginados dentro del grupo. Susana comentaba: "fue medio...no sé si

\footnotetext{
${ }^{1116}$ Estudio de la JEC latinoamericana..., JEC Boletín Secundario, 14, agosto de 1970.

${ }^{1117}$ Entrevista a Eduardo, Bahía Blanca, 16/10/2008.

${ }^{1118}$ Entrevista a Aída, Buenos Aires, 17/5/2013.

1119 Entrevista a Rodolfo, Bahía Blanca, 23/6/2008.

${ }^{1120}$ Entrevista a Nora, Bahía Blanca, 4/6/2008.

${ }^{1121}$ Entrevista a Rodolfo, Bahía Blanca, 23/6/2008.

${ }^{1122}$ Entrevista a Graciela, Buenos Aires, 31/7/2008.

${ }^{1123}$ Entrevista a Eduardo, Bahía Blanca, 16/10/2008.
} 
desgastante pero como excluyente por ahi [...] desde lo personal yo lo vivía como eso, o te comprometés políticamente o no existís" ${ }^{1124}$.

Este tipo de tensiones también se puso de manifiesto en la JOC, donde se insistía cada vez más en la idea de que el compromiso cristiano fuera vivido a través de la inserción en movimientos políticos que propugnaban el cambio social. Al respecto, los actores referían que había terminado por instalarse en el grupo la idea de que "el compromiso debía pasar por lo partidario" ${ }^{1125}$; el que se comprometía políticamente "se lo veía mejor",1126, incluso despertaba una cierta "admiración",1127. Pero, como analizamos anteriormente, buena parte de los jocistas, sin limitarse al espacio laboral, desarrollaban su acción en otros ámbitos, y entendían que se trataba de formas no menos legítimas de asumir la participación en la transformación de la realidad. Para ellos, el compromiso cristiano trascendía la política, de modo que no veían la necesidad de acercarse a una agrupación específica ${ }^{1128}$. En este marco, no fue tan simple la convivencia entre diversos itinerarios militantes. En este sentido, apuntaba Dante:

los que teníamos más compromiso por ahí sentíamos que teníamos que tratar de que nuestros compañeros entraran más concretamente en la política, más comprometidamente, y los otros como que decían "no, pero tenemos que construir la Iglesia también ",1129.

Entre estos últimos, algunos se vieron interpelados a realizar el paso hacia la militancia política, como es el caso de Angélica: "yo me sentí presionada, pero lo RESOLVÍ, o sea, yo hice mi elección" ${ }^{1130}$. Incluso Ema recordaba una situación planteada en una reunión en la que una compañera instaba a otra a definirse políticamente: "te ponía el dedo ahí como diciendo 'tenés que encontrar un compromiso'. Y eso uno lo tiene que descubrir, tiene que engancharse" ${ }^{\prime 1131}$. Por su parte, los jocistas que tuvieron militancia política reconocían que su convicción de que esta opción era una condición necesaria para producir el cambio de estructuras los llevaba a cuestionar a los que no tenían una práctica semejante. Según Jorge, el

\footnotetext{
${ }^{1124}$ Entrevista a Susana, Bahía Blanca, 1/4/2009.

${ }^{1125}$ Entrevista a Angélica, Bahía Blanca, 25/4/2012.

${ }^{1126}$ Palabras de Mirta, entrevista a Mirta y Jorge, Bahía Blanca, 11/4/2012.

${ }^{1127}$ Palabras de Jorge, entrevista a Mirta y Jorge, Bahía Blanca, 11/4/2012. Entrevista a Bruno, Bahía Blanca, 4/8/2012; y a Ema, Bahía Blanca, 27/9/2012.

${ }^{1128}$ Entrevista a Angélica, Bahía Blanca, 25/4/2012; y a Bruno, Bahía Blanca, 4/8/2012.

${ }^{1129}$ Entrevista a Dante, Bahía Blanca, 28/9/2011.

${ }^{1130}$ Entrevista a Angélica, Bahía Blanca, 25/4/2012.

${ }^{1131}$ Entrevista a Ema, Bahía Blanca, 27/9/2012.
} 
interrogante era “¿dónde vas a hacer tu actuación si no participás en politica?”"1132. En palabras de Mirta, "en ese momento el que no estaba en política era un gil de aquellos. Si vos no estabas militando en algo eras, no sé, un despistado total" "1133. Así, la pertenencia a agrupaciones revolucionarias de una parte del grupo había introducido nuevas divergencias en la JOC, atravesando la dinámica grupal. Sobre este punto se explayaba Angélica: "al principio es como que éramos un bloque pero después, la vida como que te va ofreciendo otras posibilidades, y cada uno va insertándose donde quiere, donde puede, donde elige, en definitiva",1134.

También al interior de la JEC surgieron diferencias a partir de las distintas trayectorias militantes de sus integrantes, aunque no siempre implicaron conflictos explícitos. A propósito de esta cuestión, Mónica evocaba uno de los últimos encuentros anuales en el que se planteó un debate entre jóvenes que militaban en la UES y otros que trabajaban en las villas. Para estos últimos, la tarea barrial no sólo era una forma válida de compromiso cristiano sino que resultaba más útil que la acción política. Para los primeros, en cambio, el compromiso social cobraba sentido si no se reducía a la asistencia material y, en cambio, servía para que la gente del barrio tomara conciencia de la realidad ${ }^{1135}$. Al respecto, Gabriel señalaba que frente a aquellos jóvenes que asumían niveles crecientes de responsabilidad en las agrupaciones políticas, otros jecistas entendían no sólo que no era necesario abrazar ese activismo sino también que era errado, en cuanto "encuadraba, iba haciendo perder otras opciones e impedía que ese tronco común pudiera seguir siendo así, porque claro, algunos militantes de la JEC podían tener otra formación política, y entonces se comenzaban a apartar ",1136.

En la disyuntiva, nuevamente, la acción política era valorada como el nivel más alto de compromiso cristiano. En palabras de Pedro: "en la cadena, la militancia política era como aumentar el compromiso" ${ }^{1137}$. Y Gabriel señalaba que el activismo político era asociado a la entrega absoluta del cristiano en la construcción del Reino: “al compañero que militaba lo veías como el que había apostado más"1138. Esto suponía relegar a un segundo plano otro tipo de prácticas, como las que los jecistas llevaban a cabo en el movimiento Guía-Scout o en los barrios periféricos de la ciudad. Desde esa

\footnotetext{
${ }^{1132}$ Palabras de Jorge, entrevista a Mirta y Jorge, Bahía Blanca, 11/4/2012.

${ }^{1133}$ Entrevista a Mirta, Bahía Blanca, 18/6/2008.

${ }^{1134}$ Entrevista a Angélica, Bahía Blanca, 25/4/2012.

${ }^{1135}$ Entrevista a Mónica, Buenos Aires, 9/11/2011.

${ }^{1136}$ Entrevista a Gabriel, Bahía Blanca, 27/10/2012.

${ }^{1137}$ Entrevista a Pedro, Buenos Aires, 16/11/2012.

${ }^{1138}$ Entrevista a Gabriel, Bahía Blanca, 7/11/2012.
} 
perspectiva, la labor social paliaba ciertas necesidades pero no atacaba el problema general $^{1139}$. Al decir de Mario: "si vos decías `yo este sábado hice una chocolatada con los pibes del barrio' no cotizaba lo mismo que si habias hecho una reunión en la universidad para proponer que tal cosa se cambie" ${ }^{1140}$.

De allí que los jóvenes que habían hecho la opción política vieran como "tibios" a aquellos que no la compartían ${ }^{1141}$. Por su parte, los jóvenes que no tenían esa militancia se sentían subestimados, postergados y demandados por sus compañeros para tomar una definición político-partidaria: "el que tenía compromiso político te miraba como 'bueno, a vos te falta un poquito más pero tenés que llegar',"1142. En esa línea, Ana decía:

muchas veces a mí me han dejado de lado por no participar, por no ser un militante político, no pertenecer a la JUP [...] en algunos momentos por ahí nos sentimos medio presionados, porque te decían 'bueno, tenés que decir de qué lado estás'o 'bueno, si pensás así tenés que buscar cómo canalizás eso ${ }^{1143}$.

Para estos jecistas, como para los obreros, el espectro de alternativas de búsqueda de coherencia con el Evangelio superaba a la política. Si este camino inspiraba consideración y adhesión, constituía una opción personal que no podía ser naturalizada como la única posible sin atender a las posibilidades, limitaciones y deseos de cada uno.

Asimismo, el hecho de que las trayectorias políticas de los jóvenes pasaran por el peronismo, planteó resistencias adicionales entre los compañeros - del grupo Scout y de la JEC de La Pequeña Obra- que no se identificaban con aquel movimiento. Así, la discusión sobre la forma y el espacio en que debían comprometerse como cristianos se mezclaba con las reacciones contra el itinerario concreto que había asumido la militancia política de los jecistas. Sobre la cuestión, Cecilia recordaba:

tenías que comprometerte-tenías que comprometerte. Yo no entendía por qué el compromiso tenía que pasar por un compromiso político. Digo, si yo estaba trabajando en Villa Quilmes, o sea, el compromiso lo tenía pero ¿por qué tenía que ser político? Y no sólo tenía que ser político sino que tenía que pasar por el partido peronista. Entonces yo no estaba de acuerdo ${ }^{1144}$.

\footnotetext{
${ }^{1139}$ Entrevista a Carlos, Bahía Blanca, 4/5/2011.

${ }^{1140}$ Entrevista a Mario, Bahía Blanca, 5/1/2013.

1141 Entrevista a Ricardo, Bahía Blanca, 8/10/2011; a Juan, 31/5/2011.

${ }_{1142}$ Entrevista a Norma, Bahía Blanca, 8/4/2011.

${ }^{1143}$ Entrevista a Ana, Bahía Blanca, 17/10/2012.

${ }^{1144}$ Entrevista a Cecilia, Bahía Blanca, 2/6/2011.
} 


\section{2) La convivencia entre diversas opciones ideológico-políticas}

El encuentro de militantes que, desde distintas concepciones políticas dentro de "una opción global por los pobres", participaban en "el proceso social de liberación" constituía una de las líneas de trabajo del MIEC-JECI en América Latina. Éste entendía que los múltiples aportes de "una conciencia de unidad, pluralismo y de crítica desde dentro" enriquecían al movimiento ${ }^{1145}$. Sin embargo, procesar la unidad en la diversidad al interior de los equipos no era tarea sencilla. Por ejemplo, el informe preparado por la JUC de Buenos Aires para el encuentro nacional de Ramos Mejía, en febrero de 1967, mencionaba los enfrentamientos entre jucistas ubicados en distintas posturas ideológicas que provocaron "una inhibición al diálogo necesario para una revisión evangélica en común", poniendo de manifiesto "la falta de un profundo sentido de Iglesia" (Armada, 1970: 312). En consecuencia, esta cuestión se convirtió en objeto de reflexión constante. Así, Ronaldo Muñoz planteaba en el boletín Spes que la evidencia de este pluralismo en la Iglesia y en las propias comunidades podía llevar a los cristianos a buscar un corte claro entre lo que los unía (la fe en el Evangelio y en ciertos valores humanos generales que de él se derivaban) y lo que los diferenciaba (los criterios y opciones ideológicopolíticos), a fin de reforzar lo primero y dejar lo segundo al margen de la vida común. No obstante, la experiencia revelaba que este intento resultaba cada vez más difícil y también inauténtico. De esta manera, al decir del teólogo, los militantes cristianos debían buscar una unidad dinámica. Esto implicaba mucho más que el simple respeto a las posiciones diferentes, sobre la base de una unidad en la fe mantenida en el plano de las generalidades abstractas; suponía "un permanente cuestionar y dejarse cuestionar, dentro y fuera de la comunidad, sobre la base de una opción común por el Dios de los pobres que nos desafía hoy en la historia de nuestro pueblo" ${ }^{\text {1146. }}$

En Bahía Blanca, a diferencia de la JOC o de la JEC, en la JUC convivieron militantes de diversas agrupaciones políticas. Ni en la rama obrera ni en la secundaria la política fue la única opción ni necesariamente la mayoritaria, pero todos los jecistas que asumieron la militancia política lo hicieron en las filas de la UES-Montoneros, mientras los jocistas que eligieron unirse a organizaciones revolucionarias lo concretaron en el PB. En cambio, como hemos visto, los recorridos jucistas estuvieron marcados por el

1145 "Documentos: aproximación a la realidad latinoamericana. Iglesia-Movimiento", Spes, 19, octubre de 1972. "Informe América Latina", Spes, 27-28, s/f.

1146 “Evangelio y participación política. Unidad y Pluralismo. Rolando Muñoz “, Spes, 24, agosto de 1974. 
"encanto y desencanto" con un abanico amplio de espacios partidarios, así como por la coexistencia de activistas del PB, de la JP-Montoneros, del PCR, del PRT-ERP o incluso del $\mathrm{PC}^{1147}$. Esto ocurrió a pesar de que, por un lado, la adscripción a la línea de la Tendencia Revolucionaria del Peronismo se convirtió, en 1973, en el posicionamiento político mayoritario; y, por el otro, que algunas de las otras trayectorias políticas hayan coincidido en el tiempo con una mayor desvinculación de los ámbitos eclesiales.

En efecto, no resultó sencillo integrar en la JUC a jóvenes con los que los jucistas compartían la militancia pero no la fe, ni conciliar determinadas concepciones políticas con la propuesta de vivencia religiosa de la JUC. Es decir, si nos preguntamos por el peso de la identidad católica en los diversos itinerarios político-ideológicos y si aquélla resultó más fácilmente compatible con ciertas adscripciones políticas, pareciera que dicha identidad era más fuerte u ocupaba un lugar central en las definiciones personales de los integrantes de la JUC que o bien no asumieron una acción concreta, o bien desarrollaron una militancia social o bien llevaron a cabo su activismo político en las filas de las agrupaciones de la izquierda peronista. En cambio, esta relación fue más problemática en el caso de Luis, identificado con el PCR, que además parece haber tenido una trayectoria de mayor movilidad en relación a la JUC: se acercó al encontrar un espacio abierto e interesante de reflexión en el que compartía los valores y la militancia, pero no terminaba de abrazar la creencia religiosa, por las controversias que generaba la confrontación con la teoría marxista. Finalmente, terminó abandonando la JUC y, al no tener una práctica religiosa o eclesial más allá de ese espacio, eso significó su alejamiento de la Iglesia. En este sentido, Luis explicaba:

eran cuestionamientos más bien personales, muchas veces lo charlaba con marxistas y me convencían, lo charlaba con tipos católicos y me convencían ellos pero, de todas maneras, nunca me cerró totalmente, digamos, a partir de 17-18 años. Yo leí Hegel, Engels, Marx. Por ahí Marx decía que religión es el opio de los pueblos ¿entendés?, aunque yo eso no lo aceptaba, consciente o inconscientemente eso te marca también las dudas ${ }^{1148}$.

Según Manuel, los militantes del PC tampoco integraron cómodamente su fe cristiana con su identidad comunista: "seguían siendo creyentes y tenían que ocultarlo en su

\footnotetext{
${ }^{1147}$ Manuel y Nancy mencionaban la presencia en la JUC de cuatro militantes del PC que compartían un mismo equipo de revisión de vida al que Manuel asesoraba a pedido de "Pepe". La participación de estos jóvenes es recordada por otros jucistas -por ejemplo, Pablo, María o Roberto-, aunque no así su adscripción partidaria (Entrevistas a Manuel y Nancy, Neuquén, 20 y 21/3/2013; a Pablo, Neuquén, 19/3/2013; a Roberto, Bahía Blanca, 18/4/2013).

1148 Entrevista a Luis, Bahía Blanca, 18/12/2008.
} 
organización [...] Iban a veces a las misas, sí, pero los [compañeros] no sabían que iban a misa...por eso, vivían en una tensión de mierda" ${ }^{1149}$.

En cambio, militantes jucistas con otros itinerarios de izquierda encontraron más puntos de conexión entre su fe católica y su pertenencia eclesial, por un lado, y su activismo político, por el otro. Este es el caso de Pablo, quien en el PRT-ERP no vivió contradicciones por su identidad católica. Al respecto, él decía: "nadie te cuestionaba ni te decía nada. Al contrario, te decían 'seguí participando'”. Y explicaba que esto era así, en primer lugar, porque varios compañeros y dirigentes también provenían de los grupos religiosos; y en segundo lugar, porque la formación partidaria tenía una significativa impronta cristiana:

no era el marxista esquemático, más propio de los grupos más trotskistas, si bien alguno pudo haber tenido en su inicio algún antecedente, algún desprendimiento, pero los trostkos eran más estrictos en eso del ateísmo. No, ahí ni pelota...es decir, no se planteaba. Yo no sé si vos habrás leido algún documento de aquella época pero...yo creo que había una influencia...Incluso había algún documento [interno], no sé, "los cristianos y la revolución”... ${ }^{1150}$.

En relación a esta cuestión, Carnovale (2005) ha estudiado la relación entre la construcción identitaria del PRT-ERP y la tradición cristiana. Según la autora, dicho proceso devino no sólo de un conjunto de formulaciones teórico-ideológicas sino además de un entrecruzamiento de imaginario político, prácticas y postulados morales, que estaba fuertemente teñido de elementos propios de una cultura religiosa de innegable tradición cristiana, pero reconocible básicamente a partir de las formas de religiosidad propias de la modernidad. Estos vínculos se ponían de manifiesto en una de las figuras clave del universo simbólico perretista: la del héroe. Los militantes venían a abonar el largo camino hacia el socialismo y a construir, día a día, a partir de su praxis, el Hombre Nuevo. Si bien éste habilitaría el futuro, ya resultaba claro para todos que podía identificarse básicamente por los valores éticos y morales que portaba, valores de resonancia cristiana. En particular, existía un fuerte componente cristiano en la constitución del héroe perretista: el martirio. Como mencionamos en el capítulo anterior, las figuras del héroe y del mártir se entrelazaban, se fundían y confundían en el imaginario colectivo de la organización. La muerte venía a otorgar el sentido de verdad a una revolución en marcha que para triunfar exigía el sacrificio de sus mejores hijos.

\footnotetext{
${ }^{1149}$ Entrevista a Nancy y Manuel, Neuquén, 20/3/2013.

${ }^{1150}$ Entrevista a Pablo, Neuquén, 19/3/2013.
} 
Como esta muerte legitimante abonaba necesariamente el camino hacia la revolución que inauguraría una nueva era, constituía, a su vez, una muerte redentora.

Por otra parte, Seoane (1993) ha analizado los escritos de Santucho, donde es posible rastrear su postura sobre la religión y el cristianismo, en particular, que influiría en los posicionamientos partidarios. Desde su perspectiva, la religión no sólo debía salir de la vida pública sino también de la privada y el sentimiento religioso no debía ser discriminante para la política. El cristianismo era un movimiento con una doctrina interesante que podía desempeñar un papel favorable, incluso participar del liderato, en la etapa revolucionaria. Si el cristiano era consecuente con la actitud de Jesús, tenía la obligación irrenunciable de denunciar a los fariseos y luchar por las reivindicaciones de los pueblos oprimidos. En este sentido, Santucho distinguía entre la jerarquía y la grey católica, la esencia social del cristianismo de Jesús y de las catacumbas, y la institución eclesial. Si Jesús destruía falsas verdades, llamaba la atención sobre la supremacía del hombre sobre lo material, señalaba la injusticia de las desigualdades, y su actitud no reconocía dioses ni dogmas sino que era crítica, creadora, reivindicativa e histórica; la Iglesia argumentaba sobre el origen divino de la desigualdad, servía de máscara a las injusticias más grandes, estaba aliada al privilegio y a los explotadores, era conservadora, estática, deformaba las mentes, se oponía a las reivindicaciones de los pobres, condenaba la revolución y era enemiga de la liberación de los pueblos. Así, el dirigente planteaba que los verdaderos imitadores de Cristo eran los que entregaban la vida por una sociedad justa. De allí que alentara a su hermano Julio para que se ordenara sacerdote y ejerciera, desde ese lugar, el servicio de los pobres.

Ahora bien, más allá de las formas y los grados en que cada joven pudo integrar su identidad cristiana y su práctica política a partir de la formación teórica recibida en su organización, la pervivencia en la JUC de una cierta diversidad político-ideológica daba lugar a intensas polémicas en torno a las ideas y las acciones políticas de los militantes. En este sentido María y Roberto recordaban:

$R$ : eran discusiones, viste, "yo tengo la verdad", "no, la verdad la tenemos nosotros”, una cosa así. "¿Cómo van a hacer eso?, ustedes son foquistas", "ustedes no son nada" (risas) [...] qué era lo mejor, qué era lo correcto y lo que había que hacer M: horas, foquismo-insurrección ${ }^{1151}$.

${ }^{1151}$ Entrevista a Roberto, Bahía Blanca, 18/4/2013. En efecto, más allá de la noción general compartida de que estaba en curso una guerra revolucionaria que requería algún tipo de estrategia armada, la concepción que cada organización política tenía sobre la "lucha armada" difería en casi todo (Kaufman en foro de clase Kaufman, 2010). 
Por su parte, Pablo evocaba los debates informales que se generaban después de las reuniones: "cuando íbamos a comer algo por ahí alguna chicanita, viste, pero yo no me sentí marginado por eso, no no no ${ }^{1152}$. Asimismo, las disputas ideológicas atravesaban, incluso, el espectro del peronismo revolucionario y afectaban las relaciones, no sólo de los militantes que compartían una misma rama especializada sino también las de aquellos que integraban grupos distintos. Por ejemplo, Eugenia evocaba conflictos por divergencias políticas entre integrantes de la JOC y de la $\mathrm{JEC}^{1153}$. Esos intercambios eran posibilitados por una base común dada, en primer lugar, por una serie de nociones generales sobre la necesidad del cambio social, además de concepciones teológicas compartidas; en segundo lugar y en relación a lo anterior, por la identificación de un conjunto de enemigos ligados al mantenimiento del statu quo; en tercer lugar, por vínculos afectivos que surcaban los intercambios grupales; y en último término, por la metodología de reflexión que obligaba a escuchar al otro y a dialogar.

Sin embargo, esta complejidad grupal no estaba exenta de tensiones. La línea política con la que simpatizaba la mayoría, la JP-Montoneros, se fue imponiendo sobre las otras. Y esto hizo que los que no se identificaban con el peronismo, ya sea porque no habían definido una postura política partidaria o porque adherían a los lineamientos de otras corrientes de izquierda, como mínimo, no se sintieran cómodos. Así lo vivió Aída:

en una reunión de la JUC, un conspicuo de la JUC me hizo mierda -así te lo digo con esta grosería-, porque yo no me afiliaba al Partido Peronista, porque yo no adoptaba concretamente una militancia política. $Y$ digo "¿por qué tengo que hacerlo? Yo adhiero pero no tengo por qué ser incondicional, porque yo tengo dudas, porque a mí me genera dudas esto" ${ }^{1154}$.

En el mismo sentido, Manuel recordaba que cuando fue elegido para recorrer el país para dar nuevo impulso a las experiencias jucistas, fue cuestionado por un grupo de militantes bahienses que entendían que sus reservas para abrazar la identidad política peronista lo convertían en un mal representante: "una reunión así con 7-8 compañeros, ¿y vos podrás viajar sin ser peronista por el interior?’. Porque no había alternativa, eras cristiano, querías el cambio, eras peronista... iPero no sabés cómo me enjuiciaban porque yo no era peronista! Pero feo, feo" ${ }^{\prime 155}$.

\footnotetext{
1152 Entrevista a Pablo, Neuquén, 19/3/2013.

${ }^{1153}$ Entrevista a Eugenia, Bahía Blanca, 30/12/2012.

${ }^{1154}$ Entrevista a Aída, Buenos Aires, 17/5/2013.

${ }^{1155}$ Entrevista a Manuel y Nancy, Neuquén, 20/3/2013.
} 
En relación a los militantes del PC, si bien los actores los recordaban unidos a la JUC y respetados en el grupo, Manuel señalaba que ocupaban un lugar marginal porque se habían incorporado más tarde, no tenían trayectoria en espacios eclesiales y no abrazaban el peronismo, por lo cual no cualquier jucista estaba en condiciones de acompañarlos en su reflexión cristiana: "yo era el único que tenía disposición natural para ir a un grupo de chicos cristianos comunistas" ${ }^{1156}$, por las afinidades que los acercaban: "venían de afuera, entonces vivieron experiencias parecidas a las mías entonces yo simpatizaba con eso, y pensaban distinto" "1157.

Para Luis, la integración a la JUC de activistas políticos no peronistas resultaba más compleja incluso que la de aquellos militantes que no ejercían una acción concreta en su medio, a pesar del énfasis de la reflexión grupal en la exigencia del compromiso cristiano. En este marco, desde su perspectiva, su alejamiento de aquel espacio tuvo que ver con diferencias político-partidarias, más que con sus cuestionamientos religiosos, y con la persistencia en el grupo de problemas para tolerar y aceptar las divergencias, por lo que se consolidaba al costo de perder los matices internos:

en la época de AUDAL, cuestionaba muchas cosas, pero no desde el punto de vista católico, sino que era un problema de cuestionamiento político hacia la lucha armada [...] un poco que pensaban como que nosotros íbamos a JUC para ganar militantes [...] me plantearon eso...bueno, y no me quedó otra que irme [...] lo tomé como que ellos me echaban por algo que no era lo que me decían. Una cosa era lo que me decian: que yo era marxista, que yo no era católico, que me había metido ahí pero que no terminaba de definirme qué hacía y que no podía seguir en JUC. Y bueno, ta bien, sino puedo seguir en JUC, listo, yo tengo mis dudas con respecto a Dios y aún las sigo teniendo...Pero yo creo que la duda sobre un ser superior si la desligás de toda tu trayectoria por el bien común...es como que Dios te está aislando, en vez de acercarte. A mí me duró 10 días-15 que me sentí muy herido, yo dije "no, es una cuestión política, lo tengo que analizar así" ${ }^{\prime 158}$.

En este sentido, la adscripción a diferentes perspectivas políticas no ocasionó siempre ni necesariamente conflictos explícitos sino, más bien una suerte de "decantación natural" que hacía que la gente que pensaba diferente no ingresara al grupo o bien que optara por abandonarlo al no sentirse del todo representada. Y esto ocurría con independencia de las asimetrías en cuanto a las vivencias personales que hacían que mientras algunos reconocían a los otros como pares, como uno más, "de los nuestros" o “compañeros" y no hacían diferencias en el plano afectivo, muchos de

\footnotetext{
${ }^{1156}$ Entrevista a Nancy y Manuel, Neuquén, 20/3/2013.

${ }^{1157}$ Entrevista a Nancy y Manuel, Neuquén, 21/3/2013.

${ }^{1158}$ Entrevista a Luis, Bahía Blanca, 18/12/2008.
} 
ellos se sentían discriminados ${ }^{1159}$. Con todo, la diversidad presente en la JUC no era fácil de resolver o de digerir. Pareciera que el grupo tendía a homogeneizarse alrededor de las posturas mayoritarias y a marginar, en alguna medida, a los que no encajaban en ese cuadro. Al respecto, Juan Carlos decía:

hay una dificultad en los grupos cristianos después de tolerar aquellas experiencias que tienen expresiones politicas partidarias...Se discute pero los expulsa. Se expulsa como después se va a expulsar, qué se yo, los que no estén en nada, o se va a expulsar a aquellos que oohh, no son peronistas o no quieren ser peronistas, vos vas viendo un poco eso ¿no? hay 100, se quedan 50, 40, 30, 20, aunque el grupo mantiene una importancia bastante grande ino?, aun dentro de eso, hay una mayor gente que decide aceptar cierta pluralidad pero no es fácil la pluralidad porque la pluralidad después se hace teológica, se hace política, se hace institucional, se hace cómo se entiende la Iglesia, los curas, todo lo demás ${ }^{1160}$.

\section{3) Los dilemas de la "doble pertenencia"}

Mientras algunos conflictos tuvieron lugar al interior de la JUC, la JOC o la JEC, en relación a las heterogeneidades de las trayectorias militantes de los jóvenes, otros se plantearon en la vinculación del mundo católico con el que lo rodeaba. Fe y militancia fueron de la mano, se alimentaron, impulsaron y justificaron mutuamente pero a partir de cierto momento la simbiosis empezó a resquebrajarse. Si muchos cristianos descubrieron el compromiso a partir de la reflexión de la realidad iluminada desde la fe y de la necesidad de Actuar en la transformación de la realidad que seguía al Ver y al Juzgar; y si la militancia política era valorada en los grupos católicos como una forma "superior" de compromiso, en ocasiones, la pertenencia a espacios dentro y fuera de la Iglesia dejó de ser compatible, complementaria o fácilmente armonizable y pasó a ser incluso contradictoria. Tal vez no internamente para quienes habían hecho sus elecciones políticas desde su identidad cristiana, pero sí para algunos de los que compartían con ellos o bien el activismo contestatario sin pertenecer al ámbito eclesial, o bien la comunidad religiosa sin acompañar el paso a la política. De uno y otro lado, comenzó a presentarse la tensión entre pertenencia eclesial y militancia política, y la idea de que la participación en los dos espacios amenazaba de alguna manera al propio.

\footnotetext{
${ }^{1159}$ Entrevista a Nora y Rodolfo, Bahía Blanca, 2/4/2009.

${ }^{1160}$ Entrevista a Juan Carlos, Buenos Aires, 29/7/2008.
} 


\section{a) Militantes políticos en los grupos cristianos}

¿Cómo vivió la comunidad cristiana la doble pertenencia de sus integrantes? En La Pequeña Obra, emergieron conflictos que acabaron por dividirla. Si bien el compromiso de los jóvenes en el scoutismo y en el barrio era aceptado y alentado, las rispideces comenzaron cuando una parte de los dirigentes Scouts y Guías se incorporaron a la acción política. Aquí, como adelantamos anteriormente, las controversias en torno a dicha opción se confundían con las reacciones que suscitaba el itinerario concreto que aquélla había asumido, las agrupaciones del peronismo revolucionario. Al respecto, Ricardo decía: “pareció ser que esta cuestión de buscar un sponsor político era mala palabra" 1161 . El activismo de los jóvenes marcó los límites de la amalgama que la renovación eclesial había logrado en una comunidad tan heterogénea como aquélla ${ }^{1162}$. Y el recrudecimiento de la violencia política acentuó el miedo de las hermanas misioneras y el rechazo de quienes se identificaban con el antiperonismo. Sobre esta cuestión, Gabriel contaba:

habia gente muy conservadora, y entonces se empiezan a producir como algunas fracturas. Yo no me voy a olvidar nunca de gente que estaba conmigo en el grupo, gente interesante, pero cuando en la homilía de Pepe después de la muerte de Perón, él hace una reflexión sobre qué había significado Perón para la comunidad y hubo gente que era muy antiperonista, se levantó... ${ }^{1163}$.

En consecuencia, al tiempo que algunas familias se alejaron de la comunidad, los jóvenes comprometidos en la acción partidaria se vieron obligados a optar entre su pertenencia a la misma y su activismo. Al respecto, Mónica recordaba:

Kotska nos planteaba muy claramente que el compromiso cristiano era incompatible con el compromiso político, como que de alguna manera el compromiso político comprometía la comunidad cristiana [...] y ahi Kotska realmente en un momento nos dijo 'hay que elegir ${ }^{\text {'164. }}$.

Para quienes habían hecho su opción política desde la fe e incluso la entendían como una forma privilegiada de compromiso cristiano, esta disyuntiva fue vivida con gran contradicción. La comunidad no era sólo el espacio de participación cristiana, sino también de los afectos más cercanos y el lugar donde se habían formado en una serie de

\footnotetext{
${ }^{1161}$ Entrevista a Ricardo, Bahía Blanca, 8/10/2011.

1162 Entrevista a Carlos, Bahía Blanca, 4/5/2011; a María del Carmen, Bahía Blanca, 18/5/2011; a Norma, Bahía Blanca, 6/8/2011; a Eugenia, Bahía Blanca, 30/12/2012.

${ }_{1163}$ Entrevista a Gabriel, Bahía Blanca, 7/11/2012.

${ }^{1164}$ Entrevista a Mónica, Buenos Aires, 30/7/2008.
} 
valores que estuvieron en la base de su militancia social y política ${ }^{1165}$. Las mismas religiosas habían tenido una influencia significativa en la identificación de los jóvenes con la línea eclesial que los había acercado a la acción contestataria.

En el marco de discusión y crispación crecientes dentro de La Pequeña Obra, una reunión, que tuvo lugar a principios de 1975, precipitó la resolución de la crisis. Un grupo de padres de profesión militar acusó a los dirigentes de "subversivos" "1166 y de estar llevando a cabo una "infiltración ideológica sutil" sobre los chicos ${ }^{1167}$. En consecuencia, Kotska planteó la necesidad de cerrar las ramas mayores del grupo GuíaScout -el Raisol y el Raisolito ${ }^{1168}$-, recurriendo a una reflexión evangélica: "un poco ella dice 'para que el árbol crezca hay que podarlo',"1169. Y sentenció: "si esto es obra de Dios va a permanecer. Si es sólo obra de los hombres, aquí se termina"1170. La decisión de la religiosa podía ser interpretada de distintas maneras: como una reacción inspirada por el miedo porque "se le habian ido las cosas de las manos" "1171, como un intento de "suavizar las aguas""1172, de "frenar las cosas", de ponerle "límite" a los dirigentes ${ }^{1173}$, o de proteger a la comunidad evitando que se rompiera ${ }^{1174}$. De cualquier modo, la medida suponía dejar sin tareas a un grupo de dirigentes. A partir de este incidente y del clima de tensión que se vivía en la comunidad, algunos jóvenes se alejaron de "San Pío X" y "Santa Juana” y pasaron a otros grupos -María Clara Ciocchini, María del Carmen y Gabriel se dedicaron a "reflotar" "San Jorge" en Sánchez Elía-, profundizaron el trabajo social en Villa Quilmes o en Villa Serra, o se abocaron plenamente a su compromiso político. Sin embargo, ya antes de estos conflictos, dirigentes como Elizabeth Frers se habían distanciado del grupo para dedicarse plenamente a la militancia en la JUP.

Este tipo de planteos acerca de la incompatibilidad de la acción de los cristianos en el campo político y su vida de fe no tuvieron lugar en las ramas especializadas de Acción Católica. Pero el proceso mediante el cual parte de sus miembros se convirtieron

\footnotetext{
1165 “Por qué recordarlos?” por María Laura Barral, Esapi de Oro. 7, octubre de 2011.

${ }^{1166}$ Palabras de Nancy. Entrevista a Nancy y Manuel, Neuquén, 21/3/2013.

${ }^{1167}$ Entrevistas a Norma, Bahía Blanca, 8/4/2011 y 6/8/2011.

${ }^{1168}$ Fue una experiencia novedosa, surgida en 1973, que consistió en la fusión de los Scouts mayores, que habían pasado a ser "Raiders", con las guías del "Solar". "1970”, Esapi de Oro. 7, octubre de 2011.

${ }^{1169}$ Entrevista a Norma, Bahía Blanca, 8/4/2011; y a Mario, Bahía Blanca, 5/1/2013.

1170 "1970", Esapi de Oro, 7, octubre de 2011.

1171 Entrevista a Norma, Bahía Blanca, 8/4/2011; y a Mario, Bahía Blanca, 5/1/2013.

1172 Entrevista a Carlos, Bahía Blanca, 4/5/2011.

${ }^{1173}$ Entrevista a Cecilia, Bahía Blanca, 2/6/2011.

${ }^{1174}$ Entrevista a Mónica, Buenos Aires, 30/7/2008; a Gabriel, Bahía Blanca, 7/11/2012; a Mario, Bahía Blanca, 5/1/2013.
} 
en activistas políticos tuvo su impacto al interior de los equipos. En primer lugar, el carácter antisistémico de las organizaciones políticas en las que se involucraron y el contexto represivo en el que llevaron adelante sus prácticas -ligado primero a la dictadura militar de 1966-1973, luego a los enfrentamientos de la izquierda y la derecha peronista y, por último, al desarrollo de organizaciones paramilitares-, condicionaron la revisión de vida que tenía lugar en las reuniones semanales. Esto es, en dicho marco, había dilemas y situaciones diarias vinculadas a la militancia en el PB, en la JP, en la UES o en Montoneros, que resultaban vedadas a la reflexión comunitaria. El Ver versaba sobre un abanico de temas cada vez más acotado y marginal en la vida de los jóvenes, y excluía los problemas que ocupaban un lugar central en su cotidianeidad. Al respecto, Jorge decía: “había una protección de información”, "había cosas que no se podian decir" 1175 . Y Dante explicaba: "en la politica, hay cuestiones que son secretas, entonces vos no las podías trasladar absolutamente al grupo cristiano o viceversa" ${ }^{\prime 176}$. En este punto coincidía Paloma:

La JOC quedaba fuera de ciertas acciones y situaciones que estábamos viviendo en el grupo político, no se podían compartir, eran compartimentos estancos. Esas tensiones sí se vivieron, claro...no sé si eran motivo de discusiones, pero sí eran motivo de silencios. Esos silencios estaban más cargados que nada ${ }^{177}$.

La JUC tampoco fue ajena a la censura gradual que algunos militantes fueron imponiendo a lo que compartían en las reuniones respecto de sus prácticas, por lo que, desde la mirada de Rodolfo, en los últimos tiempos, el Ver, Juzgar y Actuar comenzó a girar en torno a aspectos intimistas, de la vida personal o bien a la política general:

cuando la reflexión vos no la hacés alrededor de una práctica es como que se seca un poco. Como las prácticas no se podían compartir mucho, no se podía comentar todo, entonces ahi había un límite de lo que vos podías reflexionar, porque tenías que hablar de cosas muy generales ${ }^{178}$.

Por otra parte, el ejercicio de la actitud crítica y el aprendizaje de ciertos valores que representaban los grupos de reflexión, si en un primer momento impulsaron a los jóvenes a unirse a las agrupaciones peronistas, más tarde, los llevaron a criticar determinadas prácticas políticas que desde la perspectiva cristiana resultaban contradictorias. En este sentido, Paloma decía: "he reaccionado bastante violentamente

\footnotetext{
${ }^{1175}$ Entrevista a Mirta y Jorge, Bahía Blanca, 14/7/2012.

1176 Entrevista a Dante, Bahía Blanca, 28/9/2011.

1177 Entrevista a Paloma, vía skype, 22/2/2013.

${ }^{1178}$ Entrevista a Rodolfo, Bahía Blanca, 2/4/2009.
} 
ante ciertas incoherencias. Yo no sé si era porque era de la JOC o porque yo VEÍA las incoherencias" ${ }^{\prime 179}$. Desde el momento en que buena parte de los jocistas habían asumido un compromiso político, las reuniones de reflexión versaban en gran parte sobre la revisión del accionar político de los militantes, constituyéndose en espacios para cuestionarlo. Así lo recordaba Angélica:

[Pepe] y [Dante] han tenido encuentros donde no compartian. Abiertamente cada uno expresaba su opinión, pero sí me acuerdo que eran -para mí que estaba ahi tratando de entender qué pasaba-dos caminos. De un lado era el cambio desde lo que Cristo nos propone. Y el otro cambio como más violento, como más rápido, como más desde lo que yo quiero hacer ${ }^{1180}$.

En estos cuestionamientos se ponían en conflicto las dinámicas de funcionamiento de ambos espacios: si por un lado, la reflexión de la JOC asumía un carácter comunitario, crítico y dialéctico, donde la acción era continuamente revisada en conjunto, evaluada a la luz de la coherencia cristiana y así potenciada, la militancia política estaba signada por la urgencia de actuar, y de responder a las políticas definidas en otros espacios, que si bien podían ser más o menos "democráticos", no necesariamente contaban con la participación de todos los militantes. Otros movimientos especializados latinoamericanos también constataban que "el actuar supera a veces la dinámica de la reflexión"1181 . Así, el militante tendía a caer en el "activismo", lo que le impedía una reflexión seria y el cuestionarse profundamente, limitando su compromiso a una acción automática de respuesta al medio que luego se podía “quemar" al no lograr fundamentarla y darle sentido ${ }^{1182}$. Al respecto, Paloma decía:

["Pepe"] por ejemplo planteaba “"pero eso lo están considerando realmente como transformador, eso es un compromiso hacia la transformación?". Y [Dante] saltaba como si le hubieran puesto un cuete, porque le estaba cuestionando algo que él ya estaba redactando en la próxima revista ¿no? O sea...Pepe hacía sólo un señalamiento así para que reflexionáramos. Pero no se podía a veces reflexionar sobre una postura que ya en la inmediatez de la situación tenías que tomar ${ }^{1183}$.

El señalamiento de la incoherencia de determinadas acciones políticas con los principios cristianos también tuvo lugar en el caso de la JP-Montoneros. Nuevamente, el asesor se ocupó de explicitar sus críticas frente a los operativos de la organización que ponían en jaque los valores evangélicos y que, desde su perspectiva, aparecían como

\footnotetext{
${ }^{1179}$ Entrevista a Paloma, vía skype, 22/2/2013.

${ }^{1180}$ Entrevista a Angélica, Bahía Blanca, 25/4/2012.

1181 "Informe: la pedagogía en la JEC uruguaya", Spes, 21, mayo de 1973.

${ }_{1182}$ Estudio de la JEC latinoamericana..., JEC Boletín Secundario, 14, agosto de 1970.

${ }^{1183}$ Entrevista a Paloma, vía skype, 22/2/2013.
} 
injustificables incluso desde la óptica de los fines que con ellos se perseguían. En este sentido, Mónica afirmaba: "discutíamos todos con todos en realidad, pero Pepe era un tipo que no te dejaba pasar una" ${ }^{1184}$. Entre estos operativos, quizás el más emblemático haya sido el asesinato del secretario general de la CGT, José Ignacio Rucci ${ }^{1185}$, perpetrado el 25 de septiembre de 1973, en plena etapa "en la superficie" de Montoneros. La represalia buscaba atraerse el apoyo masivo de la clase obrera pero fracasó en este objetivo, dado que aquélla no compartía en su totalidad la caracterización de "traidor" que daba la organización al jefe sindical, mientras que la estrategia militarista la aislaba de algunos de los sectores obreros más radicales (Gillespie, 1987). Aún más, tanto los hechos de Ezeiza como el asesinato de Rucci pueden tomarse como hitos públicos muy notorios en el deterioro de la relación política de Montoneros tanto con Perón como con el pueblo peronista en general (Salcedo, 2011).

Asimismo, "Pepe" cuestionaba las directivas de la dirección que suponían mayores riesgos para los militantes políticos. Entre ellas, la decisión de retornar a la clandestinidad, anunciada en septiembre de $1974^{1186}$. Para Montoneros, se trataba de una medida defensiva, una "retirada estratégica" en respuesta a una "ofensiva" enemiga que incluía a la Triple A y a las fuerzas de policía regulares, con la que buscaban proteger sus propias fuerzas y tomar iniciativas militares con el fin de acosar, desmoralizar y desorientar al enemigo. La organización aspiraba todavía al liderazgo de un movimiento de liberación nacional, basado en el peronismo, en vanguardia de un frente de liberación nacional más amplio, que incluiría la mediana empresa nacional y sus expresiones políticas, bajo el liderazgo de la clase obrera. La única novedad era que muerto Perón, Montoneros se veía a sí misma como principal arquitecta y constructora de tales estructuras (Gillespie, 1987).

En general, el asesor manifestaba su preocupación por la exposición a la que se sometían los jóvenes en las tareas cotidianas de la militancia. Así lo recordaba Mirta: "él siempre metía su bocadito por ejemplo cuando alguno se zarpaba demasiado con alguna manifestación, o se jugaba demasiado"1187. En particular, "Pepe" alertó a los más chicos, de los que se sentía responsable, de los peligros que suponía la

\footnotetext{
${ }^{1184}$ Entrevista a Mónica, Buenos Aires, 9/11/2011.

${ }^{1185}$ Entrevista a Gustavo, 9/8/2012.

${ }^{1186}$ Entrevista a José Zamorano, Moreno, 19/9/2009.

${ }^{1187}$ Entrevista a Mirta y Jorge, Bahía Blanca, 14/7/2012.
} 
profundización de su activismo político ${ }^{188}$. Así lo hizo, por ejemplo, durante el encuentro de la JEC en el verano de 1975, en oportunidad de un largo debate en torno a la vía armada ${ }^{1189}$. En este sentido, afirmaba Francisco: "era muy crítico con respecto a la incorporación de adolescentes en las agrupaciones políticas, sobre todo cuando se puso más densa la cosa. Él decía, básicamente: un adolescente no está en condiciones de asumir un compromiso que implica riesgo de muerte" ${ }^{1190}$. Por último, una anécdota del propio "Pepe" daba cuenta de su postura frente a la decisión de los jecistas de continuar militando en un escenario de represión creciente y de sus intentos por disuadirlos:

en el año '76 yo estaba en otra parroquia en Villa Tesei y vino a verme Eduardo Ricci, que había participado de un encuentro de la JEC a nivel de América Latina, del Cono Sur, en Buenos Aires...Yo le dije: "por favor, Eduardo, salí. Sali de la UES. Sali, por favor, que NO HAY salida, que esto no va. No es este el camino"...El dijo que estaba convencido...Yo dije que era una barbaridad seguir pensando en una participación dentro de una estructura que era militar, que era la de los Montos. Y ya ni siquiera dentro de la estructura militar, hacer política en ese esquema ${ }^{1191}$.

Otro de los aspectos más controvertidos fue el carácter integral que fue adquiriendo el compromiso político. Mientras éste iba llenando la vida de los jóvenes, se resentía su presencia en otros espacios, como el eclesial o, incluso, el familiar. Esta cuestión era advertida, a nivel general, por los equipos de estudiantes católicos que funcionaban en distintos puntos del continente. Así, en 1970 se señalaba el "desequilibrio personal" como una de las consecuencias del compromiso asumido: la vida del militante se iba complicando, surgían nuevas tareas y diversos campos de responsabilidad, al tiempo que aparecían "incomprensiones" y choques generacionales e ideológicos a nivel familiar, de la pareja, etc., cuando ese compromiso no se producía "al unísono con los que nos rodean" "192. En los grupos bahienses en particular, este problema era destacado tanto por los compañeros, especialmente por quienes no compartían la pertenencia a las agrupaciones políticas, como por el asesor. Según recuerdan los protagonistas, "Pepe" acompañaba a los jóvenes en sus opciones de compromiso -en palabras de Silvestre, mostraba "modestia y respeto hacia el proceso

\footnotetext{
${ }^{1188}$ Entrevista a Mónica, Buenos Aires, 9/11/2011; a Gabriel, Bahía Blanca, 27/10/2012.

${ }^{1189}$ Entrevista a Mónica, Buenos Aires, 9/11/2011.

${ }^{1190}$ Entrevista a Francisco, Buenos Aires, 16/11/2012.

${ }^{1191}$ Entrevista a José Zamorano, Moreno, 19/9/2009.

1192 "Pascua y evangelización", Spes, 6-7, abril-mayo de 1970.
} 
de cada uno" ${ }^{1193}$ - pero se ocupaba de subrayar la necesidad de no desatender la participación religiosa ni los lazos afectivos. Al respecto, Gabriel evocaba las reuniones de los dirigentes Scouts y Guías, donde acompañados por "Pepe" y Kotska, reflexionaban sobre cómo "mantener nuestra fe y que no se resquebrajara por este compromiso político que asumíamos" ${ }^{\text {1194 }}$. Respecto de la JOC, Mirta y Jorge contaban:

M: el más cuestionado internamente era [Dante], porque hacíamos un encuentro de la JOC, [Dante] no está. Haciamos un trabajo barrial y [Dante] no está. Es cierto, el tiempo no te daba para las dos cosas. Pero [Dante] como que se iba borrando de los compromisos de la JOC para asumir sus compromisos políticos $[\ldots]$

J: Claro, y el cuestionamiento tenía que ver más bien con él, qué le pasaba A ÉL [...] "¿y qué pasa con tu vida de fe, si no vas nunca a un encuentro, -nunca no, pero- si no participás como participan los demás, de la Eucaristía, de las reuniones con los otros grupos de JOC?" ${ }^{1195}$.

Por su parte, Dante percibió este tipo de cuestionamientos como "celos" de su comunidad de reflexión respecto de su participación política, en cuanto ambas esferas se superponían en sus objetivos, destinatarios e iniciativas. A pesar de que "se convivía" sin llegar a una ruptura, recordaba

recelo en el sentido de que bueno, uno estaba ahi para llevarse militantes a la política, viste, porque después se planteaba la cosa de la construcción de la Iglesia. Y ahí es donde se te armaba algún despelote [...] En realidad, son espacios de la política, tanto uno como el otro. Hay un momento que vos tenés que optar, ¿cuál es lo que debo construir? [...] porque empezamos a competir, viste...en los mismos espacios. En lugar de ser la JOC un grupo de reflexión, también tenía una actividad externa, digamos, militante, de captación de posibles militantes, de adherentes, viste, era parecido todo ${ }^{1196}$.

Más allá de procurar el mantenimiento del vínculo eclesial por parte de los militantes cristianos comprometidos en agrupaciones políticas, la preocupación del asesor y de los compañeros residía en que los activistas continuaran participando de las reuniones de reflexión donde podían analizar los hechos cotidianos de militancia. Según Mónica, este aspecto fue recurrentemente planteado en la JEC, particularmente en los últimos meses: "Pepe ahí insistía MUCHO en que había que guardar, había que mantener esos espacios porque eran los que te daban la posibilidad de tener una distancia, y una mirada crítica ¿no?, tener otro, ese ámbito propio de discusión"1197.

\footnotetext{
${ }^{1193}$ Entrevista a Silvestre, vía e-mail, 29/10/2012.

${ }^{1194}$ Entrevista a Gabriel, Bahía Blanca, 27/10/2012.

${ }^{1195}$ Entrevista a Mirta y Jorge, Bahía Blanca, 11/4/2012.

${ }^{1196}$ Entrevista a Dante, Bahía Blanca, 15/3/2012.

${ }^{1197}$ Entrevista a Mónica, Buenos Aires, 9/11/2011.
} 
En este punto coincidía Gustavo, quien recordaba una conversación con el asesor al finalizar una de las últimas actividades jecistas en las que participó antes de abandonar el grupo y la ciudad, al calor de las exigencias de la militancia en UES-Montoneros:

Pepe tenía un citroen, veníamos del Seminario para el barrio -nosotros ya nos habíamos ido de casa, estábamos en la clandestinidad-, y él decía "pero mirá que si perdés contacto con la comunidad, perdés... " [...]

$V$ : Como que si perdés contacto con la comunidad...

Como que si perdés contacto con la comunidad, perdés claridad, perdés, perdés la posibilidad de...pero nosotros lo veíamos como el costo de la situación ${ }^{1198}$.

El interés del asesor porque los jóvenes que desarrollaban una militancia política contestataria no acabaran desatendiendo su presencia en las reuniones de revisión de vida o en otros ámbitos eclesiales, y en definitiva, su fe, estaba ligado a la atención puesta en esta cuestión por el MIEC-JECI a nivel latinoamericano. En efecto, según un documento de orientación del movimiento, la opción política y la acción que ella engendraba debían "estar constantemente criticadas por el militante al interior de un proceso de conocimiento cada vez más certero y riguroso de la realidad y de la experiencia de fe que le permitirá evaluar esta práctica, relativizarla y sobrepasar sus límites". Desde esta perspectiva, si el compromiso político era la manera privilegiada de encarnar el "mensaje del Señor", la experiencia de fe vivida a través de este compromiso no podía ser reducida al gesto. La exigencia de la comunicación de la fe obligaba a completarlo y a explicarlo "en todas sus dimensiones en la Palabra y en la celebración de Jesucristo resucitado". En suma, la reflexión teológica era pensada como necesaria para evitar una actitud dualista en los militantes, esto es, la separación entre la acción política y la expresión de la $\mathrm{fe}^{1199}$. Otras publicaciones del SLA volvían sobre este problema, al subrayar que la fe celebrada y vivida dentro de la comunidad constituía "una instancia crítica" que impulsaba "a la conversión y al amor eficaz al servicio de nuestros hermanos" y enriquecía el compromiso ${ }^{1200}$. Asimismo, al plantear las relaciones entre ideología y fe, el Servicio de Documentación postulaba que la participación de los cristianos en las ideologías se daba en la medida que ayudaran a la liberación y a la humanización. Así como la ideología depuraba la fe, la fe ayudaba a la depuración de las ideologías cuando valoraba lo positivo de aquellas y era crítica, dándole conciencia de sus límites. De ahí que la actitud de los creyentes en medio de la

\footnotetext{
${ }_{1198}$ Entrevista a Gustavo, 9/8/2012.

1199 “JECI: documento de orientación”, Spes, 26, septiembre de 1975.

1200 "Informe América Latina", Spes, 27-28, s/f.
} 
lucha ideológica implicara tanto la participación entusiasta como la constante crítica de la ideología para que ésta no se desviara de ese objetivo de humanización mencionado $^{1201}$.

\section{b) “Cristianuchis" en las agrupaciones políticas}

En las páginas anteriores he abordado la forma en que los jucistas que participaban en el PCR y el PRT-ERP vivieron esta doble militancia a partir de las afinidades y tensiones que su formación partidaria planteaba en relación a la religión y la pertenencia eclesial. También mencioné que estas trayectorias estuvieron marcadas por una temprana desvinculación de la comunidad cristiana, que, en el caso de Luis, estaba ligada a las dificultades de la JUC para tramitar la diversidad de opciones político-partidarias que convivían en su interior, y en el de Pablo -como desarrollaré luego- con la dinámica que fue adquiriendo el activismo político en una organización revolucionaria. En el corto tiempo en que Pablo estuvo en el espacio cristiano y en el político, no obstante, esta participación simultánea fue transitada sin contradicciones.

Por otra parte, he profundizado en las afinidades entre cristianismo y peronismo revolucionario. Ahora bien, ¿cómo vivieron concretamente la doble pertenencia los jóvenes que integraban agrupaciones de la izquierda peronista? ¿En qué medida la identidad cristiana y la participación en la Iglesia planteó tensiones al interior de esos espacios?, y en ese caso, ¿cuándo emergieron?, ¿cómo se explicitaron?

Los jocistas coinciden en que la intervención en el ámbito de reflexión cristiana no generaba cuestionamientos por parte de sus compañeros del Peronismo de Base. Por un lado, una parte del grupo político provenía de la JOC. Pero más allá de esta situación, los jocistas se sentían reconocidos por sus pares no cristianos en su espacio de militancia política. Así lo vivieron Mirta y Jorge: "se lo veía con mucho respeto al cristiano que se comprometía fuera de lo que fuera" ${ }^{1202}$; "aceptaban la posición nuestra, incluso lo decían 'está bien, vos creés. Yo, la verdad que no creo, pero... ' [...] nos respetaban ... la fe y la militancia politica" ${ }^{1203}$.

Como contrapartida, los peronistas de base católicos descubrieron en los no creyentes valores cristianos, ligados a la identificación con el pueblo, el compromiso

\footnotetext{
1201 “Fe cristiana e ideologías", Doc. 4, Servicio de Documentación, marzo de 1967.

1202 Entrevista a Mirta, Bahía Blanca, 18/6/2008.

${ }^{1203}$ Palabras de Jorge, entrevista a Mirta y Jorge, Bahía Blanca, 11/4/2012.
} 
con el proyecto de transformación social y la moral militante, que los llevaba a sentirlos hermanos y a vivir el encuentro con los otros en la acción como una experiencia de crecimiento y de apertura recíproca. Esto es, los jocistas constataron con su experiencia lo que habían aprendido con los teólogos de la liberación y que Paloma parafraseaba de la siguiente manera: "es posible que el que tengas al lado sea un cristiano no creyente, a tu derecha, y el que tengas a tu izquierda sea un marxista creyente porque acompaña

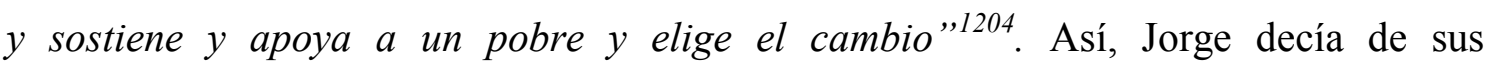
compañeros del PB: “demostraban que tenían más fe que muchos cristianos" "1205. Y Mirta explicaba:

el hecho de estar en politica en actitud de servicio, de entrega, de riesgo, entonces uno también valoraba esa gente que hiciera esas cosas sin decir que venía del cristianismo o que venía en mandato de Jesús y la Iglesia, porque uno le daba valor a eso, ellos lo hacían por convicción, por amor a la gente ${ }^{1206}$.

Los jóvenes de la JUC que integraron el PB concordaban con los jocistas en que los militantes cristianos, que constituían un grupo significativo de la agrupación universitaria basista "Movimiento 17 de octubre", eran valorados por sus compañeros, y en que las prácticas de cada uno de los dos ámbitos resultaban compatibles y complementarias. Al respecto, decían Roberto y María: "era una sola cosa ...las mismas caras, en general" "207; "los cristianos éramos respetados [...] Cada uno tenía sus reuniones, sus actividades...no teníamos problema" ${ }^{1208}$.

La participación de Manuel en la JUC tampoco era cuestionada por otros peronistas de base porque eran "las reglas de juego desde el principio". Sin embargo, las posibilidades que daba el movimiento eclesial para contactar e interactuar con militantes de trayectorias divergentes con el PB, ocasionó tensiones en el espacio político. Así, cuando Manuel volvió de su viaje por el país y contó en la organización su experiencia de trabajo con militantes cristianos que integraban la JP, sus compañeros "se enojan porque trabajé con gente que no era del Peronismo de Base (risas)...y me quedo desconcertado...como si fuera, no digo el enemigo, viste, pero como que estás compitiendo con ellos .Y poquito tiempo después me tuve que ir" ${ }^{\prime 1209}$.

\footnotetext{
${ }^{1204}$ Entrevista a Paloma, vía skype, 12/2/2013.

${ }^{1205}$ Entrevista a Mirta y Jorge, Bahía Blanca, 11/4/2012.

${ }^{1206}$ Entrevista a Mirta, Bahía Blanca, 18/6/2008.

${ }^{1207}$ Entrevista a Roberto, Bahía Blanca, 18/4/2013.

${ }^{1208}$ Entrevista a María, Bahía Blanca, 28/2/2013.

${ }^{1209}$ Entrevista a Manuel y Nancy, Neuquén, 21/3/2013.
} 
En la JP, los militantes utilizaban el calificativo “cristianuchis" para identificar a los compañeros católicos. Para algunos, se trataba de un modo afectuoso de nombrarlos, una expresión que suponía valoración y respeto, mientras para otros era una forma despectiva de referirse a ellos. De todas maneras, el nombre da cuenta de que los cristianos eran reconocidos en el espacio político como un grupo, con un cierto "estilo" de militancia. De modo similar, en la UES, el origen cristiano de los militantes los convertía en un "subgrupo" 1210 , al menos en los primeros tiempos, ya que, según explicaba Juan, más tarde el grupo político se fue haciendo más “compacto”"1211.

Para la UES, la JUP, la JP, la JTP y Montoneros, la continuidad de sus activistas cristianos en los ámbitos de reflexión semanal representaba una suerte de amenaza. La JUC y la JEC eran espacios de pertenencia paralelos y, fundamentalmente, estaban fuera del control de la organización política. Desde esta perspectiva, los militantes que participaban al mismo tiempo de los grupos de revisión de vida generaban dudas entre sus compañeros respecto de qué hablaban en aquel espacio, cómo manejaban la información y a qué ámbito obedecían en última instancia. En suma, se volvían poco confiables. De allí que algunos de ellos experimentaran ciertos "celos",1212 de parte de militantes no católicos respecto de su pertenencia eclesial. En este sentido, Rodolfo comentaba: “yo seguía participando en la JUC pero me sentía muy presionado porque del lado de la organización de Montoneros habia mucha desconfianza [...] respecto de los cristianos por eso de la doble fidelidad" ${ }^{213}$. En este punto, Mónica coincidía: “cada vez nos apretaban más para que dejáramos el espacio de los grupos cristianos $" 1214$. Sobre esta cuestión reflexionaba también Manuel:

todo el mundo sabía que estaba en la JUC pero ¿hasta dónde me confiaban?, yo creo que algunos me confiaban porque estaba en la JUC, algunos decían "este tipo va a hacer lo que dice que va a hacer porque tiene esa ética, cree en eso". Pero para otros, no podés estar en dos organizaciones, y de hecho es verdad, ¿hasta dónde algo que vos decís hasta podría comprometer otra cosa? ${ }^{1215}$.

De este modo, la tensión se agudizó con el recrudecimiento de la violencia política porque lo que estaba en juego era la seguridad de los compañeros. Así, según Gabriel, en la UES se mantenía una cierta prevención en torno a los militantes católicos

\footnotetext{
${ }^{1210}$ Entrevista a Inés, Bahía Blanca, 18/6/2011.

${ }^{1211}$ Entrevista a Juan, 24/8/2011.

1212 Entrevista a Gustavo, Bahía Blanca, 12/7/2011.

${ }^{1213}$ Entrevista a Rodolfo, Bahía Blanca, 2/4/2009.

1214 Entrevista a Mónica, Buenos Aires, 9/11/2011.

${ }^{1215}$ Entrevista a Manuel y Nancy, Neuquén, 21/3/2013.
} 
por la posibilidad de que éstos "abrieran el juego de la política" en su grupo, poniendo a los activistas en una situación de vulnerabilidad. Y lo ilustraba con una anécdota:

Yo estaba en una fiesta de 15 en el club Sportiva de alguna chica de La Pequeña Obra. Y estaban todos los de La Pequeña. Y 3 o 4 nos fuimos, aprovechamos la fiesta para poder ir a hacer una pintada [...] esto nos permitía volver al baile y entonces "aqui no ha pasado nada”, volvíamos a nuestras casas y "¿vos dónde estuviste?", "en la fiesta de 15 de coso". Cuando llegamos a la pintada, creo que el Ruso o alguno dice "¿le dijeron a alguien que venían acá?”, "y sí”. Vos imaginate, para nosotros militar políticamente era una cosa de orgullo y sentíamos que eso era un cobijo [...] Pero esto generaba mucha reserva en los compañeros. "¿Pero cómo, la gente sabe que estamos pintando? Si llega la cana y le pregunta a alguien, ustedes y nosotros estamos todos presos,"1216.

\section{c) Militantes católicos y/o activistas políticos}

Las experiencias de los laicos que profundizaron su participación en el PB, en la JP-Montoneros o en el PRT-ERP coincidían en que, con el tiempo, se tornó cada vez más difícil sostener su presencia en los dos ámbitos -el eclesial y el político-. En este proceso, lo que se ponía en cuestión no era necesariamente el sentimiento religioso sino la vivencia comunitaria de la fe y la revisión constante de las propias prácticas, incluidas las ejercidas desde la organización política, a la luz de la doctrina cristiana, que suponían los movimientos especializados de juventud.

En primer lugar, la militancia política demandaba una dedicación de tiempo completo, por lo que no quedaba espacio para otras ocupaciones. La urgencia e inminencia de la transformación social, tal como era pensada por los protagonistas, requería una entrega total, al menos durante el período que tomara su concreción. En este sentido, Dante explicaba que vivió la pertenencia simultánea a la JOC y al PB

casi naturalmente hasta que yo empecé a tener más responsabilidades dentro de la política y bueno...dejé mi pertenencia a la JOC, no a la fe ni a la Iglesia, pero no seguí juntándome, digamos. Eso a partir del '75...por ahí veníamos a la iglesia o en el barrio nos juntábamos siempre. Pero éramos dos o tres que nos dedicamos a full a la política...Y seguíamos laburando, no cobrábamos, pero digo, tuvimos que decidir. Y en esa época de turbulencia...era como un remolino, si vos estabas muy comprometido te llevaba con todo. Parecía que la revolución estaba a la vuelta de la esquina, entonces había que apurarse ${ }^{1217}$.

Permítaseme aquí un breve paréntesis para mencionar que el carácter integral que iba asumiendo la militancia, así como las concepciones políticas del PB, que

\footnotetext{
${ }^{1216}$ Entrevista a Gabriel, Bahía Blanca, 27/10/2011.

${ }^{1217}$ Entrevista a Dante, Bahía Blanca, 15/3/2012.
} 
sostenían el protagonismo de la clase trabajadora en la marcha hacia el socialismo, en detrimento de las clases medias y de cualquier alianza con estos sectores, sumieron a los militantes en otro tipo de tensiones. Paloma, por ejemplo, experimentó cuestionamientos derivados de la creencia de que la construcción política debía desarrollarse en el mundo obrero, relegando otros ámbitos de acción a un plano secundario. En ese momento su compañero le planteaba:

"tienes que ir a la fábrica a trabajar, en la fábrica de jean o en la textil" -donde trabajaba [la Rusa]-. Y "yo NO ESTOY PARA TRABAJAR ALLÍ, ESA NO ES MI FUNCIÓN, ese no es mi compromiso. Mi compromiso está en meterme en un aula y hacer reflexionar a los chicos sobre la historia, las circunstancias, el pasado, el presente y la actitud hacia el futuro, en hacerlos críticos ${ }^{1218}$.

Jorge también recordaba que cuando en el PB se empezó a plantear que "había que ser más obreros", Dante pasó de la administración de Sancor a la planta, mientras Silvestre renunció a la empresa donde trabajaba con Jorge para ingresar a una bodega: "no me lo decían directamente pero como que me lo daban a entender, que para militar realmente había que ir a un trabajo obrero, viste, cosa que yo me resistía" ${ }^{212}$.

El activismo en el PRT-ERP también regía la vida cotidiana de los militantes y los obligaba a darse exclusivamente a esa causa, obstaculizando su presencia en otros círculos sociales y actividades. Así, desde 1972, una vez que se "proletarizó", los días de Pablo comenzaron a estar abocados a las tareas del partido, que, a excepción del corto período de mayo-agosto de 1973, transcurrían en la ilegalidad (Giménez, 2008). En ese nuevo escenario, dejó de frecuentar las reuniones de la JUC:

era el concepto de militante profesional que vos tenías que estar las 24 horas, y la dinámica te llevaba a eso. Y eso fue también lo que me alejó [...] no tener vida propia, la vida familiar quedaba relegada, los amigos, el deporte, hasta el esparcimiento [...] porque vos trabajabas 8 horas, militabas, salias a pintar todas las noches, a repartir volantes en forma clandestina, cuidándote de la cana $^{1220}$.

Para los jecistas y jucistas que pasaron a tener niveles de responsabilidad importantes dentro de la estructura político-militar, la militancia política también se volvió una actividad "integral”"1221 . Gustavo definía como totalizadora la lógica de la participación en el espacio político:

\footnotetext{
${ }^{1218}$ Entrevista a Paloma, vía skype, 7/2/2013.

${ }^{1219}$ Entrevista a Mirta y Jorge, Bahía Blanca, 11/4/2012.

${ }^{1220}$ Entrevista a Pablo, Neuquén, 19/3/2013.

${ }^{1221}$ Entrevista a Mónica, Buenos Aries, 30/7/2008.
} 
la dinámica de la militancia era absorbente. El compromiso politico. Absorbente, total [...] toda mi vida era eso [...] la militancia me absorbía TODO. Es decir, yo comía, trabajaba o estudiaba, pero era en función de la militancia [...] la vida estaba absolutizada por la militancia ${ }^{1222}$.

Al mismo tiempo, en todo este proceso, Gustavo afirmaba: "nunca dejé de tener fe", pero la actividad política con esas características "no le dio espacio" a la participación simultánea en el grupo de revisión de vida ${ }^{1223}$. Así, la cuestión religiosa quedó reducida a una "identidad personal"1224, a una "cuestión privada"1225. En este punto coincidía Paloma para el caso de la JOC-PB: “cuando te metes en un grupo político la parte cristiana que te traía a comprometerte tiene que pasar a un plano diferente ${ }^{\prime 226}$. Es interesante destacar aquí la inversión de un proceso mediante el cual estos jóvenes habían experimentado, dentro de espacios y en la relación con personas ligadas al catolicismo liberacionista, un redescubrimiento de su fe que los llevó al compromiso "en el mundo", a "salir" del ámbito eclesial para asumir, como cristianos, una acción social y política en su medio cotidiano. Esto es, llegaron a la militancia desde una corriente eclesial que, en tanto variante del catolicismo integral, entendía que lo religioso, lejos de recluirse en la sacristía, debía penetrar en el espacio público, en este caso, para transformar la sociedad, e impregnar toda la vida del militante. Ahora, era la organización política la que expandía su influencia en todos los ámbitos donde se movía la persona, transformando también las prácticas de los actores que estaban vinculadas al espacio eclesial.

En segundo lugar, la actuación creciente de los grupos paraestatales, en particular de la Triple A, hizo de la acción política una actividad cada vez más clandestina. Siguiendo a Calveiro (2008), esta organización, dirigida por el ministro de Bienestar Social, José López Rega, protegida por el gobierno y vinculada con los organismos de seguridad, comenzó su accionar público en octubre de 1973 en un atentado contra el senador radical Hipólito Solari Yrigoyen. En su carácter de grupo paramilitar, se dedicó al asesinato de toda militancia de izquierda que tuviera una actividad política pública, aunque no estuviera directamente ligada a las organizaciones guerrilleras. A partir de la muerte de Perón, su accionar se aceleró. Entre julio y agosto de 1974 se contabilizó un asesinato de la Triple A cada 19 horas, y para septiembre de

\footnotetext{
${ }^{1222}$ Entrevista a Gustavo, Bahía Blanca, 12/7/2011.

${ }^{1223}$ Entrevista a Gustavo, Bahía Blanca, 12/7/2011.

${ }^{1224}$ Entrevista a Mónica, Buenos Aires, 30/7/2008.

1225 Entrevista a Juan, 24/8/2011.

${ }^{1226}$ Entrevista a Paloma, vía skype, 7/2/2013.
} 
1974 habían muerto, en atentados de esa organización alrededor de 200 personas. La Triple A fue el embrión del terrorismo de Estado y la "comunidad" represiva del Plan Cóndor. En este sentido, inauguró la práctica de la desaparición de personas, el secuestro de militantes latinoamericanos que eran trasladados ilegalmente a sus países y entregados a las fuerzas represivas, y realizó asesinatos masivos de familias de guerrilleros conocidos. La metodología de estos grupos era semejante a la que a partir de 1976 emplearon los grupos de tareas de las Fuerzas Armadas; también es significativo que aun desde entonces se propusieran, explícitamente, intimidar a la población. La noción de crear y diseminar el terror ya estaba presente.

En Bahía Blanca, la acción de la Triple A se volcó contra militantes de izquierda peronista y no peronista ${ }^{1227}$, referentes locales del catolicismo liberacionista, obreros y estudiantes de la UNS con algún tipo de participación en la política universitaria. Algunos fueron secuestrados de sus casas y luego encontrados con numerosos impactos de bala en sus cuerpos tirados mayormente en lugares comunes, todos en las afueras de Bahía Blanca como la zona de empalme de rutas, el paraje "Landa", el paraje "La Cueva de los leones" o el "Pibe de Oro". En otros casos, la violencia se tradujo en explosiones en locales partidarios o en las casas de los militantes perseguidos (Zapata, 2012). Estas amenazas, atentados, persecuciones, detenciones y asesinatos determinaron la desestructuración de grupos y organizaciones contestatarias, el abandono de los espacios y prácticas de acción política y la partida al exilio interno y externo de los militantes. Como mencionamos en el capítulo 5, a ello se sumaron, meses antes del golpe de Estado de 1976, las primeras desapariciones ocurridas en la ciudad.

En este marco, las medidas de seguridad se extremaron y ello implicó alejarse de los espacios cotidianos -en palabras de Juan, "cortar ciertos lazos" ${ }^{1228}$ - en los que estaban incluidos el grupo de reflexión y la comunidad cristiana, al igual que la escuela, la universidad, el trabajo, la familia, el barrio e incluso la ciudad. Con este tipo de iniciativas, se procuraba evitar la propia exposición, así como la de los familiares, amigos y compañeros. Así, Silvestre no podía precisar el momento en el que abandonó la JOC pero su participación terminó “cuando los acontecimientos de la represión la

\footnotetext{
${ }^{1227}$ Como ha analizado Giménez (2008), el recrudecimiento de la represión, que se volvía más sistemática a mediados de 1974, con la multiplicación de allanamientos policiales, detenciones en cadena, encarcelamientos y atentados, condujo al fin de las actividades de los "perros" bahienses. En este proceso, el secuestro del militante Luis Jesús García -"Negrito"- el 22/9/1974 de su casa del barrio Noroeste y su posterior asesinato en manos de la Triple A, constituyeron un antes y un después en el cambio de rutinas y espacios de los militantes, marcando la paulatina desarticulación del partido-ejército.

${ }^{1228}$ Entrevista a Juan, 24/8/2011.
} 
hacían inviable" ${ }^{1229}$. Lo mismo ocurrió con Dante y Paloma. El primero renunció a su trabajo en Sancor, empezó a evitar salir de noche o conservar objetos que pudieran comprometerlo en caso de ser detenido y sometido a tortura. Su compañera también dejó de trabajar en la escuela de Villa Nocito. Al mismo tiempo, se mudaron, e incluso, se fueron a vivir un tiempo a Mar del Plata. De esta etapa, Paloma recordaba: “empezamos un periplo de casas, apartamentos y lugares". Además, desde fines de 1974, el matrimonio frecuentó con menor regularidad los encuentros e iniciativas jocistas. Al respecto, Paloma decía: "con el asunto que teníamos que estar en la clandestinidad no podíamos estar en los lugares de siempre" ${ }^{1230}$. Esta situación "dificultaba ir a las reuniones...me dejó descolgada del mundo...ni mis padres sabían dónde estaba",1231. Y Dante explicaba: "el problema de seguridad es un problema serio, el problema de que los que teníamos más compromiso comprometíamos también a los demás, viste. Nunca nadie planteó eso, pero vos te das cuenta" ${ }^{\prime 1232}$.

De esta manera, algunos jóvenes vivieron la doble pertenencia cada vez con mayores dificultades y se plantearon la necesidad de elegir entre su participación en el ámbito de reflexión cristiana y su compromiso político. Tanto en la JUC, como en la JEC y en la JOC, un grupo de militantes privilegió entonces la acción política revolucionaria. En este marco, Paloma explicaba que para aquéllos, "la opción política representó la verdadera militancia y la JOC era como... una cosa light que allí quedaba atrás ${ }^{1233}$. Por su parte, Dante decía:

las aristas que tienen tanto el compromiso político para un cristiano tenía sus momentos que se tocaban y mutuamente se rechazaban por ahí. Para mí estaba claro que la cosa era ahi la política, no tenía ninguna duda. Pero por ahíotros sentían que se SUPERPONÍA y entraba EN COMPETENCIA el desarrollo del grupo de Iglesia con el grupo político. A qué le damos más pelota ${ }^{1234}$.

En cuanto a los jecistas, para algunos, la intervención en ambos espacios no era fuente de contradicciones porque estaban integrados, en parte, por las mismas personas. Juan señalaba: "nosotros estábamos en la conducción política [de la UES], es decir, yo me relacionaba en el grupo político con Alberto [Paira], con [Gustavo]", "mi jefe era

\footnotetext{
${ }^{1229}$ Entrevista a Silvestre, vía e-mail, 29/10/2012.

${ }^{1230}$ Entrevista a Paloma, vía skype, 12/2/2013.

${ }^{1231}$ Entrevista a Paloma, vía skype, 22/2/2013.

1232 Entrevista a Dante, Bahía Blanca, 15/3/2012.

${ }^{1233}$ Entrevista a Paloma, vía skype, 22/2/2013.

${ }^{1234}$ Entrevista a Dante, Bahía Blanca, 28/9/2011.
} 
Alberto" ${ }^{235}$. En el mismo sentido, Francisco afirmaba: "los responsables estaban en Sánchez Elía, eran parte de la comunidad. Lo que pasa es que ellos ya no eran Scouts ni nada [...] Pero ellos eran de allá, y de alguna manera, entendían de qué se trataba" ${ }^{236}$. Más allá de esta cuestión, estaba claro para ellos que lo prioritario era la acción política que, por otra parte, habían asumido desde sus principios cristianos. Una breve anécdota de Mónica ilustra esta cuestión: “[Gustavo] decía: '¿pero qué contradicciones, si el día que hay la revolución no vamos a ir a misa? Obvio' (risas). Y Pepe [Zamorano] decía: 'y capaz que si'",1237. El debate que involucró a los militantes de la JEC con motivo de la elección del delegado que los representaría en el encuentro mundial en Holanda, ponía de manifiesto esta visión:

para nosotros era fundamental la construcción política, es decir, sin desconocer la participación...Por eso el tema de darle preeminencia a Alberto para nosotros era importante porque Alberto tenía una capacidad política absolutamente infernal...convocante de gente, se relacionaba espectacularmente y siempre tenía el objetivo claro en ese sentido. Entonces para la edad que tenía era extraordinario. Por eso sentimos esa contradicción cuando lo nombran a Eduardo [Ricci], porque Eduardo de las dos cosas él priorizaba la cuestión de la Iglesia. Y para nosotros no había que dudar de que el compromiso político era la vía para hacer carne el compromiso cristiano ${ }^{1238}$.

La decisión de los militantes cristianos de volcarse de lleno a la actividad dentro de las organizaciones político-militares implicó el abandono primero de la militancia en la Iglesia -los Scouts-, luego del espacio de la parroquia o la comunidad cristiana y más tarde del grupo de reflexión. Así, al mencionar a los militantes de La Pequeña Obra desaparecidos en 1976 y 1977, Mario contaba: "no fue paralelo el compromiso político con el compromiso Scout. Los que estaban militando ya habian dejado el Scoutismo. Tienen vinculación afectiva e histórica con el grupo, pero no eran dirigentes activos en ese entonces" $" 1239$. Si bien en un primer momento los jóvenes mantuvieron la participación simultánea en la JEC, la JUC o la JOC y en la UES, la JP o el PB, a medida que crecía su compromiso político se resintió la práctica del culto y el grupo de referencia pasó de la comunidad de fe a "los compañeros", que, como vimos, en algunos casos eran la misma gente. De este modo, mientras otros jóvenes sostuvieron por más tiempo su pertenencia a las tres ramas, los equipos de revisión de vida sufrieron el éxodo de militantes asociada a la profundización de su compromiso político.

\footnotetext{
${ }^{1235}$ Entrevista a Juan, 24/8/2011.

${ }^{1236}$ Entrevista a Francisco, Buenos Aires, 16/11/2012.

${ }^{1237}$ Entrevista a Mónica, Buenos Aires, 30/7/2008.

1238 Entrevista a Juan, 24/8/2011.

${ }^{1239}$ Entrevista a Mario, Bahía Blanca, 5/1/2013.
} 
Eugenia se refería a la experiencia de la JEC en Sánchez Elía del siguiente modo: "otros chicos que habían optado por lo político...yo no sé si seguían concurriendo con tanta continuidad al grupo, era una época de toma de decisiones, entonces el grupo tal cual estaba conformado se fue separando" 1240 . Por su parte, Mario decía que el alejamiento de algunos amigos militantes de la UES había producido en la JEC, aunque de un modo más amplio, en el centro pastoral de La Pequeña Obra, "un sesgo en la comunidad”, y explicaba:

cuando es una reunión de JEC se puede participar, o una reunión Scout se puede participar, pero las reuniones de la UES, eran secretas. Entonces vos no podias saber lo que tu amigo, ni tu amiga pensaba. O sea es como que vos hasta entonces con tu amiga o tu amigo hablabas de cualquier tema pero después esos temas eran tabú y quien no participaba no podía compartirlo ${ }^{1241}$.

En los equipos de reflexión de los militantes más jóvenes, este proceso confluyó con la etapa de finalización de la escuela secundaria y la partida a otras ciudades -como Buenos Aires, La Plata, Neuquén o Viedma- para el inicio de los estudios terciarios o universitarios, que también contribuyó a la desarticulación del grupo. De modo similar, en este marco, la JUC asistió a la partida definitiva de algunos de sus integrantes. María describía así el escenario de la última etapa jucista: "venía gente, estaba un tiempo, tomaba su compromiso político y se iba. No por problemas, era su opción" ${ }^{\prime 1242}$. En el mismo sentido, Jorge decía de los grupos jocistas de Buenos Aires y Bahía Blanca: “al mezclarse con la actividad política un poco la JOC también se iba diluyendo, porque le dedicabas más tiempo a la parte política. No es que descuidabas lo otro pero..." ${ }^{1243}$. En este punto coincidía Silvestre, quien asociaba el fin de la JOC con "la dispersión por el compromiso político junto con el 'tsunami' de acontecimientos", 1244 .

Este tipo de crisis tampoco era privativa de las experiencias bahienses de mediados de la década de 1970 sino que había marcado a los movimientos de apostolado laico en las décadas anteriores. Según Mallimaci (1988), si la Acción Católica impulsaba al compromiso para restaurar, cambiar, transformar la sociedad, rápidamente surgía el problema de la "politización". Entonces, el esquema de funcionamiento típico era el siguiente: el compromiso del cristiano no podía quedar encerrado en el templo ni en sí mismo; debía manifestar en la sociedad el amor al

\footnotetext{
${ }^{1240}$ Entrevista a Eugenia, Bahía Blanca, 30/12/2012.

${ }^{1241}$ Entrevista a Mario, Bahía Blanca, 5/1/2013.

1242 Palabras de María durante la entrevista a Roberto, Bahía Blanca, 18/4/2013.

${ }^{1243}$ Entrevista a Mirta y Jorge, Bahía Blanca, 14/7/2012.

${ }^{1244}$ Entrevista a Silvestre, vía e-mail, 29/10/2012.
} 
hermano. Esa manifestación, revisada y criticada semanalmente en los círculos, parroquias, secciones, llevaba a cuestionarse sobre las causas sociales y políticas que impedían o dificultaban la expresión del amor de Dios a los hombres. Se llegaba así al compromiso político a partir de una profunda experiencia religiosa. Pero la crisis comenzaba cuando los tiempos de los militantes no eran los de la institución, cuando los momentos y lugares no coincidían, cuando se establecían prioridades. En suma, la inserción en movimientos sociales producía distanciamiento de la lógica institucional católica. Cuando se reconocía un contenido religioso a la participación en movimientos sociales, la actuación en la sociedad pasaba a ser considerado un deber moral, religioso, ético. La fuerza de esa integración era enorme como también la de las nuevas fidelidades y conflictos que se abrían.

Como plantea Cucchetti (2005), si históricamente el catolicismo vivido "integralmente" llevaba a preferir la participación en experiencias de "inspiración cristiana" a las experiencias "cristianas", al mismo tiempo, la acción de militantes católicos que se movían en espacios seculares de la cultura, la política y la sociedad planteaba el riesgo de la autonomía y un contacto con el "mundo" de consecuencias imprevisibles que escapaban al control eclesiástico. En los años cuarenta y cincuenta, por ejemplo, ello se tradujo en el riesgo de confusión o la absorción de la militancia católica por el peronismo.

El informe preparado por la JUC de Buenos Aires para el encuentro nacional de Ramos Mejía, que plasmaba el diagnóstico de la crisis del movimiento, resulta ilustrativo de este fenómeno general. En primer lugar, entre las causas de la situación se señalaba una suerte de "desacomodamiento" que sufrían los militantes comprometidos en partidos de izquierda, al querer entroncar sus nuevas experiencias en el campo político-ideológico con "un cristianismo en el que ahora encuentran carencias que ellos no logran cubrir ni el movimiento alcanza a solucionar”. Este desequilibrio se traducía en la imposibilidad de reflexionar su compromiso en los dos lugares, por lo cual, “creyendo que en una religión 'encarnada' lo religioso está en cada actitud, y que su reflexión en el movimiento político era también religiosa", optaban por hacerlo en sus propios partidos, alejándose en consecuencia del movimiento. Así, estos militantes mostraban a la comunidad sus problemas a la hora de asumir plenamente un compromiso como cristianos revolucionarios "en toda nuestra existencia", a saber: "los inconvenientes para vivir de manera interiormente unida lo religioso y lo humano", y "falta de sentido profundo de lo que significa vivir religiosamente", esto es, en relación 
directa con Dios, transformando la vida en una continua oración. En segundo lugar, se planteaba que el proceso que atravesaba el militante solía ser: a) ingreso; b) sensibilización ante la realidad que se le ayuda a descubrir; c) compromiso; d) contradicción entre su compromiso y su permanencia en JUC; e) salida del Movimiento, lo que abría una serie de interrogantes para la comunidad: “¿puede limitarse a JUC a ser sólo trampolín para el compromiso temporal de sus miembros? ¿No será eso una utilización instrumental de lo teológico?”. En tercer lugar, se observaba la ausencia de la reflexión evangélica del compromiso, así como la carencia de "una adecuada pedagogía para los nuevos militantes" que incorporara elementos teológicos a partir de la reflexión sobre la realidad, "a fin de conseguir una formulación más funcional, respecto de la problemática que vive el militante" (Armada, 1970: 310-312).

Así, la experiencia jucista bahiense de mediados de la década de 1960 -como vimos en el capítulo 2- y las que tenían lugar en diversos puntos del país a fines de aquella década y comienzos de la siguiente, habían puesto de manifiesto las contradicciones entre la pertenencia a los grupos de reflexión y la militancia en la izquierda. Manuel fue testigo de ese proceso en el viaje que en 1971 emprendió por Argentina como referente del movimiento. En su itinerario, el joven iba encontrando "las huellas" de la JUC pero no a los jóvenes, que se estaban "yendo a la militancia". En Santa Fe, el grupo acababa de desestructurarse: "hace 10 días que no se juntan" -le dijeron-, "no se juntan más, porque están en aquella cosa, en aquella y no quieren ser visibles". En Tucumán, no quedaban jucistas: "estaban todos pensando que la solución era la clandestinidad". En Buenos Aires, había un grupo de "gente suelta, desbandada, despistada" mientras otro había pasado a Montoneros o agrupaciones de izquierda no peronista. También estaba Alberto Carbone, quien ya no quería ser asesor del movimiento y compartió con Manuel sus reflexiones sobre este proceso:

decía que como muchos curas, los jóvenes, se habían ido acercando a la política y eso habia hecho que relativizáramos todo, la pareja, los padres, el trabajo, la fe...y, él decía "es como un árbol que las hojas se le empiezan a caer...y se le caen, y de golpe vos necesitás hojas y ya no tenés, de golpe matan a alguien, de golpe pasás un momento de peligro, y ya no tenés hojas, ya te peleaste con tus padres, ya te fuiste de los amigos del barrio, ya con tu novia no porque esa novia no era militante, no era no sé qué"...y perdimos esas dimensiones de la vida por concentrarnos en que éramos los que íbamos a hacer la revolución ${ }^{1245}$

${ }^{1245}$ Entrevista a Manuel y Nancy, Neuquén, 21/3/2013. 
En efecto, en esos años, las tensiones entre la fe y la política eran una de las preocupaciones centrales del MIEC-JECI en América Latina. En 1971, Gustavo Gutiérrez enmarcaba la crisis de los movimientos de apostolado laico en un contexto más general y señalaba entre sus causas las opciones cada vez más revolucionarias de los grupos cristianos. Si bien muchos descubrían en esos movimientos las exigencias evangélicas de un compromiso cada vez más resuelto con los oprimidos, la insuficiencia de los esquemas teológico-pastorales antes vigentes en esos grupos y las urgencias de la acción política hacían que en muchos casos el proyecto de la revolución sustituyese el del Reino o que la relación entre ambos se desdibujase. Asimismo, la situación política de América Latina y la subversión del orden que propugnaban estos grupos revolucionarios hacía que ellos se colocaran necesariamente en una cierta clandestinidad y frente a la violencia revolucionaria como una cuestión de eficacia política. Así, la idea de comunidades de cristianos con opciones políticas diferentes, que se reunían para una revisión a la luz de la fe resultaba inoperante, porque la "radicalización política" tendía a uniformar y a apasionar las opciones y porque el tipo de actividad que se desarrollaba no permitía expresarse con franqueza en esas reuniones (Gutiérrez, 1971).

El interés por dilucidar las causas, los síntomas, los matices, las consecuencias y las posibles soluciones a los conflictos entre la fe y la militancia contestataria de los jóvenes cristianos latinoamericanos, universitarios y secundarios, se ponía de manifiesto en los espacios de comunicación y encuentro del movimiento; por ejemplo, en el Comité Latinoamericano de Cali en 1970, el Encuentro Regional de la JUC del Cono Sur en 1969, el Encuentro de la JEC del Cono Sur en 1971, el Encuentro Zonal de la JEC del Caribe en 1972 o el Seminario Fe y Política de Lima en agosto de 1973. Así, los desafíos que la "politización" planteaba a las bases nacionales se convirtieron en una cuestión prioritaria de reflexión para el movimiento en los últimos años de la década de 1960 y primeros años de la siguiente, esto es, en el período en que los grupos bahienses se encontraban en pleno desarrollo, marchando así a contramano del proceso general.

En primer lugar, se constataba que la opción política de los militantes producía frecuentemente una crisis de fe o incluso su pérdida total ${ }^{1246}$. En este marco, el asesor de la JEC paraguaya, Gilberto Giménez, postulaba que los movimientos especializados de tipo profético en América Latina mostraban una tendencia a descalificar el signo sacramental por la dificultad de recrear su sentido a partir de una espiritualidad profética

1246 "Encuentro del Cono Sur. Informe”, JEC Boletín Secundario, 9, abril de 1969. 
del compromiso ${ }^{1247}$. Según explicaba un ex miembro del SLA al intentar dar cuenta de la evolución más frecuente en el medio universitario cristiano, el compromiso asumido absorbía de tal modo que la vivencia de fe se diluía más cada día y en ese estadio frecuentemente se daban tres opciones diferentes: los que negaban la fe, los que se embarcaban "en una búsqueda angustiosa", y por último, los que rompían a medias con la fe "o se aburguesan totalmente" 1248 . En este proceso, para algunos militantes, la fe era identificada con el compromiso con los hermanos, por lo que no había necesidad de explicitarla. Desde esta lógica, quien estaba comprometido tenía fe/ expresaba la fe/daba testimonio de la Iglesia. Por lo tanto, sus actos eran vistos como respuestas de fe. Así, si la fe había actuado como una motivación para el compromiso, una vez abrazado éste, ya no jugaba ningún papel ${ }^{1249}$. Con ello, según la perspectiva de los referentes del MIEC-JECI, se dejaba de lado el aporte de la fe como "relativizadora", “dinamizadora" y "radicalizadora" de ese compromiso ${ }^{1250}$. Al decir de Paul Blanquart -a quien había recurrido el movimiento para ayudar a esclarecer esta cuestión-, política y fe eran inseparables, aunque no confundibles. En cuanto se descubría la "politización" como algo propio de la historia, era imposible que estuviera separada de la fe. Lo que no era equivalente a decir que la fe se agotaba en la praxis política. La fe surgiría como el gran elemento crítico, es decir, lo que daba referencia al Cristo pleno ${ }^{1251}$.

En segundo lugar, se observaba que la acción en el medio, especialmente cuando era radical, planteaba serios cuestionamientos o la pérdida de sentido del movimiento ${ }^{1252}$. Si éste era el trampolín al compromiso, cuando cumplía este objetivo, otros grupos, gremiales o políticos, continuaban el proceso del militante y le proporcionaban más elementos para interpretar y actuar en la realidad. El hecho era que muchos jóvenes abandonaban entonces el movimiento por considerarlo ineficaz ${ }^{1253}$.

Desde la perspectiva de los militantes cristianos, estas tensiones revelaban una falta de una visión teológica que respaldara y explicara su acción comprometida en el medio, y de claridad en la pedagogía de evangelización dentro y fuera del

\footnotetext{
1247 "Introducción a una pedagogía de la pastoral universitaria”, Doc. 14, Servicio de Documentación, mayo de 1968.

1248 "Informe: la Iglesia de Medellín y el movimiento estudiantil en América Latina” de Carlos H. Urán, Spes, 6-7, abril-mayo de 1970.

${ }^{1249}$ Estudio de la JEC latinoamericana..., JEC Boletín Secundario, 14, agosto de 1970.

1250 "Encuentro de asesores de la zona andina", JEC Boletín Secundario, 17, junio de 1971.

1251 "Fe y Política", JEC Boletín Secundario, 17, junio de 1971.

1252 “Sesión Mundial 1970”, JEC Boletín Secundario, 11, noviembre de 1969.

${ }^{1253}$ Estudio de la JEC latinoamericana..., JEC Boletín Secundario, 14, agosto de 1970.
} 
movimiento ${ }^{1254}$, lo que planteaba la necesidad de reinterpretarla en los equipos de base, en especial, lo que se refería a la revisión de vida ${ }^{1255}$. El caso uruguayo permite ilustrar este diagnóstico. En 1971 y 1972 la JEC de Montevideo sufrió la desintegración de los equipos más antiguos, como consecuencia del alejamiento de los militantes que asumían la opción política, y de una aguda represión. En la caracterización de esta crisis, el movimiento remarcaba la carencia de instrumentos teológicos, científicos y pedagógicos. El primer aspecto se manifestaba en una no comprensión de la ubicación de la fe en relación al resto de la vida del militante (compromiso político, familia, afectividad, estudio), esto es, no se explicitaba la fe ni ésta intervenía en la revisión de vida aportando o cuestionando, y a la vez, no interesaba una relación con la Iglesia. La falta de elementos científicos se percibía en la escasa capacidad de "globalización" en las reuniones de equipo y en que no se llevaba la coherencia política a los demás campos de la vida. Además se notaba un "activismo despersonalizante", que pretendía dar respuesta a las "urgencias del medio". Por último, no había conciencia de movimiento y se daba escasa importancia a los encuentros, jornadas o publicaciones. Asimismo, la metodología no estaba exenta de espontaneísmo y rara vez se aplicaba en forma más o menos ortodoxa el esquema de revisión de vida ${ }^{1256}$.

Como respuesta, el secretariado regional definió algunas líneas de trabajo que fueron adoptadas por el Comité Latinoamericano de 1972. Entre ellas, figuraban: incrementar la reflexión teórica y científica sobre la realidad como modo de enriquecer y permitir mayor maduración en las opciones; profundizar la reflexión teológica, la experiencia de fe y la conciencia eclesial; trabajar de modo preferencial con los grupos que estuvieran llevando una experiencia más avanzada en el continente; tratar de que el movimiento se insertara lo mejor posible en el conjunto de la Iglesia, a través de la participación en encuentros e instancias de corresponsabilidad; extender cuantitativamente la experiencia para ser más significativos y eficaces en la Iglesia y en los espacios militantes; estructurar una pedagogía capaz de responder tanto a los sectores más politizados como a los que se incorporaban al movimiento, así como impulsar los aspectos comunitarios y organizativos del mismo para que la experiencia contara con la infraestructura de apoyo necesaria ${ }^{1257}$.

\footnotetext{
${ }^{1254}$ Estudio de la JEC latinoamericana..., JEC Boletín Secundario, 14, agosto de 1970.

1255 "Encuentro del Cono Sur", JEC Boletín Secundario, 16, mayo de 1971.

1256 "JEC de Montevideo: una experiencia a tener en cuenta" e "Informe. La pedagogía en la JEC uruguaya", Spes, 21, mayo de 1973.

1257 "Informe América Latina", Spes, 27-28, s/f.
} 
Más allá de lo que había ocurrido en el MIEC-JECI en el Cono Sur y en Argentina, fundamentalmente a fines de los años sesenta y principios de los setenta, y de las nuevas tensiones fe-política que se planteaban en Bahía Blanca a mediados de la década de 1970, existieron en las experiencias bahienses otras formas de vivir la participación en el grupo católico y en el político, y de resolver lo que para algunos constituía un dilema emergente. Hubo militantes cristianos que pudieron integrar con menos contradicciones la intervención en la comunidad cristiana y en el PB o en la JP. Mirta y la Rusa, por ejemplo, continuaron siendo catequistas mientras militaban en el $\mathrm{PB}$, y la primera nunca sintió que su activismo político transitara por un carril opuesto a su actividad en el ámbito eclesial; por el contrario, veía "que se insertaba, que tenía algo en común" 1258 . Paloma decía de estos compañeros: "tomaron el Peronismo de Base de otra manera, ellos NO LO PRIVILEGIARON",1259.

En el caso de los jucistas, la mayoría de los entrevistados mantuvo su pertenencia a ambos espacios hasta el comienzo de la represión. En cuanto a los jecistas, algunos de ellos, sobre todo aquellos que desarrollaban tareas de superficie, integraron los dos grupos hasta que se fueron a estudiar a otras ciudades una vez terminado el colegio secundario, o bien hasta que el recrudecimiento de la violencia política y la entrada en la clandestinidad de Montoneros marcó el alejamiento de la militancia política para una parte de este grupo. En estas trayectorias, la identidad cristiana y la pertenencia eclesial siguieron ocupando un lugar central en las definiciones personales de estos actores. Al respecto, Inés comentaba: “yo me sentía mucho más cómoda y con más 'sentido de pertenencia', como vos decís, en el ambiente de la JEC que en el de la UES. Aquello había sido como una consecuencia, pero era más fuerte la raíz"1260.

En estas formas diversas de vivir la participación simultánea en los grupos de revisión de vida y en los de la militancia revolucionaria intervinieron sus trayectorias religiosas previas, esto es, el tipo de inserción que estos militantes tenían en el espacio eclesial y el lugar que ocupaba su identidad cristiana en el conjunto de definiciones personales. Al respecto, Dante recordaba de los compañeros de la JOC: "el tipo que tenía más formación eclesial o venía de...ponía primero la Iglesia y después la

\footnotetext{
${ }^{1258}$ Entrevista a Mirta y Jorge, Bahía Blanca, 11/4/2012.

${ }^{1259}$ Entrevista a Paloma, vía skype, 22/2/2013.

${ }^{1260}$ Entrevista a Inés, Bahía Blanca, 18/6/2011.
} 
actividad política, y otros le daban más importancia a la actividad política y una menor importancia a la Iglesia"”1261.

A diferencia de lo que ocurre en otras trayectorias -como las analizadas por Donatello (2005) para el caso de Montoneros o las vinculadas a la crisis de la JUC a nivel nacional hacia fines de los años sesenta-, aquí no vemos un "desencanto" de las estructuras institucionales que planteara una ruptura con lo religioso y habilitara la búsqueda de alternativas seculares en el momento de ingreso a la militancia. La desvinculación del ámbito eclesial sólo se dio en algunos casos, tiempo después, motivada por la profundización del compromiso político y las características que fue tomando esta opción en un contexto de represión creciente. Pablo sintetizaba su experiencia de la siguiente manera: "nosotros cuestionábamos a la Iglesia en aquella época también, a la jerarquía de la Iglesia, no es que nosotros nos llevamos una desilusión...si ya sabíamos cómo era [...] el tema es que me absorbió tanto la militancia que me hizo alejar de eso" ${ }^{, 1262}$. El proceso de los militantes bahienses también marca una distancia respecto de los jocistas guatemaltecos. En aquellas trayectorias, la religión influyó en los jóvenes que fundaban sindicatos a través de un rico y ambiguo repertorio de política, ética y utopía, pero luego aquí como en otros países, estos actores se apartaron de la Iglesia como marco doctrinario en vez de tender un puente entre ésta y sus nuevas ideas, o lanzar un "contramovimiento" desde su interior. Cuando los militantes vieron que la Iglesia se había convertido en barrera para el protagonismo histórico pregonado por la JOC, abandonaron este movimiento para abocarse a la experiencia sindical, que era vista como "un paso más allá" (Levenson, 2007).

Los jóvenes que en 1974-1975 sintieron la necesidad de optar entre la continuidad de su militancia en la JEC, la JUC o la JOC, y el activismo político eran precisamente quienes habían alcanzado mayores niveles de responsabilidad en las organizaciones político-militares. Después de la entrada en clandestinidad de Montoneros y de las primeras acciones de la Triple A en la ciudad, esto suponía la acción en la clandestinidad o la semi-clandestinidad, lo cual -como hemos visto y profundizaremos en el próximo apartado-, sumía a los activistas en tensiones específicas. Así sucedió con Dante, quien era por entonces el responsable del PB en Bahía Blanca o de varios de los jecistas, tanto de la "loma" como de La Pequeña Obra,

\footnotetext{
${ }^{1261}$ Entrevista a Dante, Bahía Blanca, 28/9/2011.

1262 Entrevista a Pablo, Neuquén, 19/3/2013.
} 
que decidieron seguir militando en la UES/JP-Montoneros después de septiembre de 1974. Si los activistas políticos se alejaron del espacio de reflexión cristiana, en general, no abandonaron la fe ni la identidad católica. Como decía Marisa respecto de Horacio Russin: "se había corrido un poco de la Iglesia”, aunque "él su fe en Dios no la había perdido" ${ }^{263}$. Esto es, las razones de la ruptura con los movimientos especializados de juventud no residían en la incompatibilidad entre los principios y las prácticas de uno y otro ámbito sino en la dedicación exclusiva que les demandaba un proyecto que, por otra parte, entendían como venida del Reino de Dios, además de la dinámica que fueron adoptando las organizaciones político-militares en el contexto de persecución, atentados, amenazas, asesinatos y detenciones de los activistas contestatarios.

En este proceso, la trayectoria del asesor se distinguió de las de los jóvenes. Su posición como especialista religioso del catolicismo lo ubicaba en un lugar distinto dentro de la institución eclesial. A diferencia de los laicos, tenía con la Iglesia una relación de más largo plazo que posibilitaba/obligaba al mantenimiento de un compromiso exclusivo con ella. Así también lo percibían algunos jóvenes: "él era parte de la Iglesia y por ahí nosotros cuestionábamos algunas cosas de la Iglesia y él no. Si bien tenía una línea determinada dentro de la Iglesia por ahí defendía más la Iglesia institución que nosotros" ${ }^{1264}$. Este sostén institucional permite comprender que si "Pepe" tuvo un papel fundamental en el acercamiento de los jóvenes a la sociedad y a la política, a través de una propuesta de vivencia de la fe que asumía las novedades del Concilio y de Medellín, no transitó personalmente las opciones de compromiso "temporal"; su rol fue de acompañar críticamente a los laicos en sus derroteros de militancia que, incluso, los llevaron -a ellos sí- a abandonar la participación eclesial, en tiempos de efervescencia política y represión creciente. La insistencia del asesor en que los militantes no abandonaran la JOC, la JEC o la JUC puede leerse en esta clave. En la síntesis entre religión y política que marcó a los jecistas, jucistas y jocistas bahienses y los diferenció de las experiencias que habían sucumbido en el país durante los años anteriores, el asesor tuvo un papel significativo. Este aspecto era señalado por los jóvenes, entre ellos, Manuel, para quien los grupos locales pudieron integrar la militancia cristiana y el activismo contestatario, en parte gracias a la convicción de "Pepe" de que era posible y necesario participar políticamente sin perder la fe, y al acompañamiento dado a los jóvenes en este proceso: "a nosotros nos salva Pepe, -y

\footnotetext{
1263 Entrevista a Marisa, Neuquén, 19/3/2013.

${ }^{1264}$ Palabras de Mirta, entrevista a Mirta y Jorge, Bahía Blanca, 14/7/2012.
} 
Emilio, pero bueno, Pepe es el que va manteniendo la tradición-. Pepe nos hace pensar con mucha claridad que ser cristiano y vivir intensamente es un complemento, no es una contradicción $" 1265$.

De forma similar, el posicionamiento que asumió Kotska frente a la profundización de la militancia de los Scouts y Guías en las agrupaciones del peronismo revolucionario, resultaba coherente con su carácter de especialista religiosa. El planteo que le hizo a los jóvenes acerca de la incompatibilidad de la militancia católica y la política, y por lo tanto, de la necesidad de optar entre una u otra, así como su decisión de cerrar las ramas scouts mayores, obedeció a la priorización del objetivo de preservar a su comunidad cristiana.

\section{4) Debates y conflictos en torno a la vía armada}

La opción por la lucha armada que algunos miembros de los grupos de revisión de vida comenzaban a abrazar, a partir de sus convicciones religiosas, fue otra fuente de debate y conflicto. Como mencionamos en el capítulo anterior, para muchos era un camino legítimo, y si algunos eligieron transitarlo, otros no pudieron asumirlo a nivel personal por más que compartieran los objetivos revolucionarios, comprendieran el planteo de que la violencia "de arriba" no dejaba demasiadas alternativas, o incluso simpatizaran con quienes habían tomado las armas. Pero a la vez, había quienes la rechazaban de plano, y vivían con preocupación y temor las opciones de los demás. Las diferentes posturas, si bien no excluyeron el respeto por las decisiones de cada uno, el mantenimiento de los vínculos afectivos y los intentos de ayuda y protección a los más expuestos a la represión, también generaron cuestionamientos, presiones, distanciamientos. Por otra parte, la opción violenta resultaba compleja para los mismos militantes cristianos que estaban dispuestos a tomarla. Me interesa entonces explorar los diversos posicionamientos en torno a la violencia revolucionaria, los motivos esgrimidos y los debates y tensiones suscitadas en torno a la cuestión: ¿en qué medida las posturas frente a la violencia entraban en contradicción con las convicciones religiosas? ¿Qué implicancias tenía abrazar la lucha armada para un militante católico? ¿Cómo repercutió en los grupos cristianos la opción por las armas de sus integrantes?

\footnotetext{
${ }^{1265}$ Entrevista a Manuel y Nancy, Neuquén, 20/3/2013.
} 
Si para algunos de estos jóvenes el texto bíblico y la palabra de la Iglesia avalaban la "violencia de abajo", para otros inspiraban la "no violencia"1266. Así lo vivía Roberto, para quien, pensar la posibilidad de matar a otra persona, en el marco de su militancia en una Unidad Básica Revolucionaria, le generaba dudas y angustia, en cuanto ponía en cuestión sus principios religiosos:

traía otra visión de la revolución, algo del cristianismo también trabaja en ese sentido, lo que es la vida, el tema de la muerte o provocar la muerte no es fácil. Las guerras existen, pero si hacemos un análisis profundo de la vida de Cristo, no mandó a hacer ninguna guerra, al contrario, se entregó é $l^{1267}$.

En el caso de Ricardo, el debate en torno a la entrada en clandestinidad y la vía violenta decidió su salida de la UES, opción que a su entender respondía a su coherencia cristiana: "nunca estuve de acuerdo con las armas [...] eso es también parte de la Iglesia, era como una cuestión de pacifismo a ultranza" ${ }^{\text {1268 }}$. También para Pedro, que no tuvo militancia política pero participaba de las movilizaciones callejeras, la cuestión planteaba disonancias con su formación. De esta manera, cuando se encontró en una marcha escuchando consignas que celebraban la muerte de los otros, se planteó "esto no es lo que aprendi, o sea, no es ni lo que me dijo Pepe ni lo que me dijo Kotska, no es matar ni morir, es cambiar el mundo a través de cosas, gente comprometida, pero no ir a matar al otro por más que haya sido un militar, asesino" ${ }^{269}$.

La misma Populorum Progressio, retomada en Medellín, postulaba que "la revolución armada engendra nuevas injusticias, introduce nuevos desequilibrios y provoca nuevas ruinas. No se puede combatir un mal real al precio de un mal mayor". En otras palabras: aún cuando la violencia como respuesta a la injusticia aparecía comprensible moralmente, tal como expresaban algunos entrevistados, la violencia no resultaba una solución eficaz en cuanto generaba más violencia, alimentando una suerte de "espiral" sin solución de continuidad ${ }^{1270}$. En este sentido, se expresaba Liliana: "este te lo devuelve y se hace cada vez más grande la cosa, no sirve",1271.

Las organizaciones de izquierda peronista y no peronista compartieron un accionar militar guerrillero consistente en la realización de operativos de "expropiación" de armas, dinero y documentación (asalto a bancos, camiones blindados, cuarteles,

\footnotetext{
${ }^{1266}$ Entrevista a Nora, Bahía Blanca, 4/6/2008.

${ }^{1267}$ Entrevista a Roberto, Bahía Blanca, 18/4/2013.

1268 Entrevista a Ricardo, Bahía Blanca, 8/10/2011.

${ }^{1269}$ Entrevista a Pedro, Buenos Aires, 16/11/2012.

${ }^{1270}$ Entrevista a Hugo Segovia, Mar del Plata, 27/5/2010; a Paloma, vía skype, 22/2/2013.

${ }^{1271}$ Entrevista a Liliana, Bahía Blanca, 25/6/2008.
} 
comisarías, registros civiles), acciones de propaganda armada y las llamadas operaciones de "justicia popular" (asesinatos de personas comprometidas con la represión, en especial, la tortura y el fusilamiento de prisioneros). Al mismo tiempo que los asaltos y robos les permitían reunir dinero, armas y bienes necesarios para su funcionamiento, las acciones más "políticas" se orientaban a ganar la simpatía de la población. Se podía tratar de repartos de alimentos en zonas marginales, actos de propaganda de su propuesta en medios populares, y especialmente fabriles, operativos de apoyo a algún conflicto social o sindical y otros (Calveiro, 2008).

En el rechazo a esta estrategia guerrillera, eran esgrimidos argumentos tanto morales como políticos. En cuanto a los primeros, Norma Gorriarán decía: "siempre pensé que el Señor era dueño de la vida y de la muerte"1272. Por su parte, "Pepe" planteó seriamente sus objeciones a esta metodología en ocasión de la salida a la luz pública de Montoneros: “cuando mataron a Aramburu yo decía sin más análisis político ¡¿cómo un grupo de jóvenes se van a constituir en jueces...y entre ellos lo matan?!'. Por más que haya sido responsable de lo que sea"1273. Esta discusión también era evocada por Dante: "Pepe decía que era contrario a ese tipo de situaciones, de haber matado a alguien así ¿no? Y después estaban los otros que decían 'bueno, pero se lo merecía' y qué se yo, y entraba toda una cuestión ética y moral" 1274.

En el fondo, emergía el problema de que "ningún fin, en el terreno de la acción, podrá ya justificar a priori medios injustificables en ellos mismos" (Hilb, 2001: 55). Desde esta lógica, la liberación, la salvación histórica, el anuncio de un Hombre Nuevo no podría hacerse a través del uso de la violencia, que en parte implicaba seguir la lógica del enemigo. Al respecto, Paloma exponía sus contradicciones como militante del PB: para ella, la lucha armada "no era un camino o una metodología para llegar a un mundo más equitativo" ${ }^{1275}$. José coincidía en las razones de su rechazo a la lucha armada: "no entendía la muerte como medio para erradicar el mal”, "no justificaba la muerte de la otra persona por el cambio" "1276.

Tal como planteamos anteriormente, la militancia política en los años setenta tenía un contenido sacrificial. La disposición a morir daba cuenta de una ponderación particular de la vida, tanto propia como ajena. Al decir de los actores: "no había una

\footnotetext{
${ }^{1272}$ Entrevista a Norma Gorriarán, Bahía Blanca, 29/10/2008.

${ }^{1273}$ Entrevista a José Zamorano, Moreno, 19/9/2009.

${ }^{1274}$ Entrevista a Dante, Bahía Blanca, 28/9/2011.

1275 Entrevista a Paloma, vía skype, 1/3/2013; y apuntes de Paloma "Por qué y cómo milité en el PB", enviados vía e-mail, febrero de 2013.

${ }^{1276}$ Entrevista a José, Bahía Blanca, 19/6/2008.
} 
valoración como hay hoy de cuidar la vida",1277; "hubo una actitud... ‘si nos matan, que nos maten'",1278. Sobre esta cuestión, Gustavo explicaba que la convicción de que enarbolaban una causa justa, "trascendente", y el ejemplo de Jesús hacía que comprometerse con "el débil" implicara "jugarse hasta dar la vida”, enfrentarse a la persecución: "vimos el martirio", "vos sabías que podías morir”, "nunca es querido el sufrimiento pero sabiamos que podía pasar" ${ }^{1279}$. De forma similar se expresaba Juan cuando aludía a la certeza que sentía entonces de "estar en el camino" correcto y al "afán profético" ligado a aquélla, que implicaba "bancarte que te corten la cabeza" 1280 .

Esta visión de la persecución como consecuencia inevitable del compromiso cristiano trascendía a los bahienses y atravesaba a los militantes del MIEC-JECI en América Latina. Un documento publicado en Spes en 1970 reflexionaba sobre las implicancias de aceptar la invitación de seguir a Jesús "hasta las últimas consecuencias", tal como él mismo anticipó: "Si el mundo os odia sabed que a mí me ha odiado antes (Juan 15, 18)”, “os expulsarán de las sinagogas e incluso llegará la hora en que todo el que os mate piense que da culto a Dios (Juan 16, 1-4)", etc. De esta manera, según el texto, el cristiano no revelaba a Cristo a través de adherirse a una ideología concreta, por revolucionaria que fuera, ni por hacer tales o cuales acciones, en cuanto todo ello era compartido por los militantes no creyentes. Lo original del cristiano radicaba en conocer el sentido pascual de todo su esfuerzo: "la muerte, el sacrificio del yo de todo egoísmo, es semilla de resurrección de Cristo, nuestra y del mundo”. De ahí que al amor a los demás, al sacrificio, al esfuerzo, a la lucha, el cristianismo debía añadirle la alegría producida por la esperanza en el triunfo de Cristo "que ya es una realidad. Aunque sea una realidad que hay que estarla haciendo con dolor y sangre" ${ }^{\prime 281}$.

Esta disposición a dar la vida era compartida por los militantes católicos, tanto por aquellos que desempeñaban tareas "de superficie" como por los que tomaron las armas, pero no siempre ni necesariamente iba acompañada de una disposición a matar. Esto llevó a los primeros a rechazar las armas: "si estoy en esta prefiero que me maten y no matar a nadie" ${ }^{282}$. De modo similar, se expresaba Mirta: "antes de agarrar un

\footnotetext{
${ }^{1277}$ Entrevista a Nora, Bahía Blanca, 4/6/2008.

${ }^{1278}$ Entrevista a Rodolfo, Bahía Blanca, 23/6/2008.

${ }^{1279}$ Entrevista a Gustavo, 9/8/2012.

${ }^{1280}$ Entrevista a Juan, Bahía Blanca, 14/8/2012.

1281 "Pascua y evangelización", Spes, 6-7, abril-mayo de 1970.

1282 Entrevista a Marta, Bahía Blanca, 29/5/2008.
} 
revólver, no sé, me dejaba matar me parece"1283. Y luego: “cuando a él [su compañero] le propusieron de agarrar las armas, eso sí que yo dije `no, esto no va con mis principios, no va con nada', no me veía tirando un tiro" ${ }^{1284}$.

Incluso en los segundos, la mayor disposición a morir que a matar ponía de manifiesto la disyuntiva irresoluble entre este tipo de opciones y los principios cristianos. Rodolfo decía de su militancia en JP-Montoneros: “yo por suerte nunca maté a nadie ni tuve que poner bombas, que eso me hubiera creado algún conflicto serio" ${ }^{1285}$. De modo similar, Gustavo explicaba que la opción armada, lejos de ser buscada en sí misma o asumida sin contradicciones, era una alternativa vista como necesaria en aquel escenario y a partir de los valores que impulsaban a los militantes a la acción:

en el contexto que se daba, se dio así, pero no es porque a mí me gusta la guerra yo me metí a militar. A mí lo que me gusta es la transformación. Ese es el objetivo. Lo otro fue un medio...discutible, ahora no va, ponele todo lo que quieras, pero siempre fue un medio, nunca un fin [...] no es que es lo mismo. $O$ sea, para otro puede ser, pero el amor es el amor, y si vos estás en guerra y hay un conflicto y una pelea y hay una muerte, no es tan fácil de digerir ${ }^{1286}$.

Estos dilemas eran compartidos por los estudiantes católicos que en otros lugares del continente asumían "la lucha contra la injusticia". Así lo señalaba un documento del MIEC-JECI en 1970, cuando planteaba que la eficacia parecía exigir acciones reñidas con la moral. Se volvía entonces difícil compaginar la dureza de la lucha con la exigencia evangélica de amor universal, la urgencia del cambio con el respeto al desarrollo liberador de las personas: "es duro 'mancharse'. La violencia no es agradable para una persona 'sana' y sin embargo, la situación concreta parece exigirla" ${ }^{1287}$. Asimismo, un estudio de la JEC latinoamericana de 1970 incluía entre las grandes tensiones experimentadas al interior del movimiento estas cuestiones: ¿la fe podrá justificar el compromiso en acciones y grupos violentos? ¿El movimiento debe aceptar o evitar que los militantes se comprometan en acciones violentas? ${ }^{1288}$.

En cuanto a los militantes del PB, ya hemos visto que la forma particular en la que esta organización concebía la cuestión armada, fue una de las razones por las cuales los jocistas aceptaron integrarse a aquel espacio, entendiendo que dicho enfoque era

\footnotetext{
${ }^{1283}$ Entrevista a Mirta, Bahía Blanca, 18/6/2008.

${ }^{1284}$ Palabras de Mirta, entrevista a Mirta y Jorge, Bahía Blanca, 11/4/2012.

${ }^{1285}$ Entrevista a Rodolfo, Bahía Blanca, 23/6/2008.

${ }^{1286}$ Entrevista a Gustavo, Bahía Blanca, 12/7/2011.

1287 "Pascua y evangelización”, Spes, 6-7, abril-mayo de 1970.

${ }^{1288}$ Estudio de la JEC latinoamericana..., JEC Boletín Secundario, 14, agosto de 1970.
} 
más fácilmente compatible con su vivencia religiosa. De todos modos, entre los que profundizaron su acción militante también hubo quienes experimentaron tensiones frente a ciertas iniciativas políticas en tanto sentían que impugnaban su coherencia cristiana. Tal es el caso de Paloma, quien decía que la portación de armas le resultaba contradictoria con la "ética cristiana" en tanto suponía estar dispuesto a usarlas, con la consiguiente posibilidad de matar a otra persona; sin embargo, "tuvo que plegarse" a la vía violenta ${ }^{1289}$. En este sentido, recordaba una discusión con sus compañeros en oportunidad de la colocación de un "caño" en la puerta de una fábrica:

¡cómo he llorado ese día! Les dije "juegan, ustedes juegan a los soldaditos. ¿Qué logran con esto, a quién movilizan, a quién transforman, a quién le dan algo? Juegan” [...] [Dante] dijo "y, está muy impresionada por lo que acaba de hacer". ;Miércoles! No daba en mí misma del asco por mí misma y por estar con un grupo de gente adulta... ${ }^{1290}$.

En este sentido, robar, matar, secuestrar no dejaban de implicar rupturas muy profundas e inquietantes con la formación moral originaria (Calveiro, 2008). Y sin embargo, el rasgo más acusado que caracteriza a una "guerra" es la suspensión de la moral, mientras que el que la define es la condición dilemática de matar o morir. Si sólo es posible matar o morir, quien no esté dispuesto a morir, sólo podrá sobrevivir si mata y quien no está dispuesto a matar, deberá estar dispuesto a morir. Cuando esto último ocurre, se plantea una de las razones por las cuales las causas justas no pueden triunfar en el combate (Kaufman, 2005).

Por otra parte, la sensación de estar en medio de una confrontación límite, la ilusión triunfalista y el recrudecimiento de la represión del enemigo, obligaban a rechazar posiciones intermedias, a posponer la reflexión y la discusión en torno a los medios utilizados -en palabras de Rodolfo: "cuando haya terminado vemos qué hacemos" $" 1291$ - y a justificar las propias acciones, aún cuando pusieran en jaque los principios morales. Debe tenerse en cuenta, además, como afirma Calveiro (2008), que en Montoneros, la prevalencia de la lógica revolucionaria sobre el sentido de "realidad" o el contacto con el acontecer -que llevó al reemplazo del análisis político de circunstancias concretas por la lógica interna de un conjunto de principios revolucionarios-, ligado a la convicción del triunfo inexorable, llevó a asumir que toda

\footnotetext{
1289 Entrevista a Paloma, vía skype, 1/3/2013.

${ }^{1290}$ Entrevista a Paloma, vía skype, 1/3/2013.

${ }^{1291}$ Entrevista a Rodolfo, Bahía Blanca, 23/6/2008.
} 
acción del oponente era provocada por un avance del campo popular, distorsionando así en los militantes la visión de la situación política real.

Más allá de esos factores, sólo una convicción profunda podía justificar dar la vida y matar a un semejante, haciendo de la confrontación una "guerra justa": la idea de que "Dios está de nuestro lado"1292 o "Dios me protege" $" 1293$. Como afirma Touris (2011, 2012b), los símbolos del martirio cristiano habían signado siglos antes el lenguaje de la teoría de la "guerra justa" tornándola no sólo aceptable y loable sino hasta "santa" frente al enemigo pagano o hereje. En este sentido, se expresaba Gabriel:

me podía imaginar un Cristo armado [que] caminaba por Galilea con sus apóstoles, porque Cristo quería tomar el poder, digamos, tenía un mensaje del cual tenía absoluta convicción, y yo no creo que hubiera que permitir que el enemigo venciese. Y además, estaba seguro que -el creyente tenía otra mirada trascendente respecto de esto- cuando llegara el último momento lo iba a encontrar a Cristo. Esto no es lo mismo para un ateo. Para el ateo se termina ahí. Y yo creía que CREER te daba una doble carta de ciudadanía. Sos revolucionario y creyente, y entonces es mejor la lucha asi ${ }^{1294}$.

Es decir, como afirma Donatello (2005b, 2010), un cierto "aristocratismo de salvación" estaba en la base del hecho de que un grupo de personas en un momento determinado se sintiera elegido por un llamado divino -y con ello, distinto a los demás- para realizar una acción en el mundo que implicaba la salvación de sí mismos y de su colectividad. Una experiencia similar vivieron los jocistas guatemaltecos que resistían al terror estatal. En las entrevistas que los actores brindaron a Levenson (2007), muchos sindicalistas declararon que se hubieran retirado si no hubiera sido por sus convicciones religiosas que conferían al sacrificio un enorme estatus, y el consuelo que encontraban en el pensamiento de que había un ser supremo de su lado.

Así, la militancia armada planteó fuertes dilemas para algunos de estos militantes cristianos. Y más allá de ello, se convirtió en tema de debate en los grupos de reflexión. En este sentido, Lucy explicaba: "esa era la gran discusión, si sos cristiano

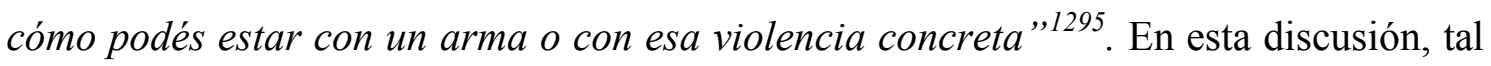
como se dio en la JEC, según Gabriel, para algunos, el compromiso armado era visto como una forma mayor de entrega, como un modo superior de canalizar las exigencias evangélicas, "el paso que hay que dar"; otros, en cambio, cuestionaban esta alternativa,

\footnotetext{
1292 Entrevista a Rodolfo, Bahía Blanca, 23/6/2008.

${ }^{1293}$ Entrevista a Gabriel, Bahía Blanca, 7/11/2012.

${ }^{1294}$ Entrevista a Gabriel, Bahía Blanca, 7/11/2012.

1295 Entrevista a Lucy, Neuquén, 18/3/2013.
} 
negando que la entrega que demandaba la construcción del Reino la involucrara necesariamente: “¿tenemos que reconocer que no hemos asumido el compromiso final, el más potente?, ¿esto lo exige Cristo o podemos seguir trabajando en nuestra lucha? [...] ¿hemos abandonado a Cristo porque no dimos el paso a la clandestinidad? ¿es necesario?, ¿no desmerece nuestra militancia?" "1296. Paloma ilustraba este tipo de debates con una anécdota de una reunión de la JOC y de la JEC en la que uno de los jóvenes de esta última rama, militante de la UES-Montoneros, apareció con un arma en el bolsillo: "Pepe hizo mención de eso como una barbaridad...él no juzgaba, ni aceptaba ni rechazaba pero lo dijo...y recuerdo también que considerábamos que los chiquillos de la ...JEC ...tomar la opción de Montoneros ...como algo terrible" ${ }^{\prime 1297}$.

Ahora bien, la certeza de que la guerrilla "no era el camino"1298 o "la salida"1299 -como decían los protagonistas- hacia una sociedad nueva, no iba acompañado necesariamente de la elaboración de otras alternativas políticas concretas. Rodolfo decía de sus compañeros jucistas: "los que no estaban de acuerdo con la lucha armada era, te diría, por una cuestión de principios, en contra de la violencia, no por una cuestión de estrategia, no es que estuvieran convencidos de que el camino era no violento" ${ }^{\prime 1300}$.

En cuanto al análisis político, las críticas se concentraban, fundamentalmente, en el enfoque de la lucha armada de Montoneros, y provenían no sólo de militantes de agrupaciones marxistas, sino también de los propios activistas de la JP con militancia "de superficie", así como de los integrantes del Peronismo de Base. Unos y otros defendían la idea de que no era el momento para enfrentar al poder con las armas, dado que ni era un contexto de auge de masas que la lucha armada viniera a apuntalar ni el pueblo estaba acompañando el crecimiento de la violencia política. Para Luis, el enfrentamiento sin la gente facilitaba la represión del enemigo, produciendo pérdidas inútiles sin alcanzar objetivo alguno ${ }^{1301}$. Asimismo, los peronistas de base cuestionaban, principalmente, la distancia entre dicho planteo y lo que le ocurría a quienes estaban llamados a ser los verdaderos protagonistas del proceso revolucionario. Para Silvestre, dicha estrategia era "producto de ciertas prisas políticas basadas en la inmadurez de la misma sin tener en cuenta el proceso del pueblo en su conjunto y en especial de la clase

\footnotetext{
${ }^{1296}$ Entrevista a Gabriel, Bahía Blanca, 27/10/2012.

1297 Entrevista a Paloma, vía skype, 1/3/2013.

1298 Entrevista a Patricia, Bahía Blanca, 19/5/2008.

${ }^{1299}$ Entrevista a Mirta, Bahía Blanca, 18/6/2008.

${ }^{1300}$ Entrevista a Rodolfo, Bahía Blanca, 23/6/2008.

${ }^{1301}$ Entrevista a Luis, Bahía Blanca, 18/12/2008.
} 
trabajadora", de allí que considerara "un error táctico la tarea foquista, al margen de la diaria lucha de los trabajadores en su puesto de trabajo y su vida personal, familiar y barrial" ${ }^{\prime 1302}$. En este punto coincidía el militante basista Julio Ruiz:

El tema era utilizar la fuerza en función de apoyo de un conflicto concreto y a requerimiento de la misma gente que estaba en el conflicto. Y no como una cosa aparte, como una aparateada, con un grado de autonomía del tipo "hay un conflicto en esta fábrica entonces vamos a hacer esta acción". Por eso habia una acusación respecto a las FAP de que habian abandonado la lucha armada. Porque no se creía que la cuestión armada tuviera que tener autonomía respecto de la lucha de masas. Para nada (David, 2006: 96).

Incluso, desde la perspectiva basista, la acción armada, tal como la concebía Montoneros, podía llegar a debilitar la lucha de los trabajadores en lugar de respaldarla/fortalecerla. Y Julio Ruiz ejemplificaba:

La huelga de la lechería Carlitos fue un despelote. Fue en el '74 y de alguna forma creo que fue el principio del fin. Fue una huelga que empezó con una asamblea, bien, con la gente, y se fue desvirtuando por la intervención militar de los Montos que hubo. Todo el mundo tiraba tiros, fue una cosa de locos. Nosotros le decíamos: "muchachos, paren. Esto es una huelga, ino es la tercera guerra mundial!”. Y no había caso. Y terminó como tenía que terminar: se perdió [...] Y había un grupo interesante adentro, que en vez de consolidarlo por abajo terminaron desvirtuándolo todo. Y la gente mirando, como siempre ocurre (David, 2006: 98).

En particular, la lectura que el PB hacía en 1975 de los acontecimientos políticos del momento subrayaba el "repliegue" del pueblo y la inminente llegada de un nuevo golpe de Estado con el consiguiente desencadenamiento de una represión feroz, lo que indicaba que los militantes revolucionarios debían adoptar la misma actitud que los trabajadores. Este planteo generaba discusiones con otros compañeros que eran evocadas por Dante:

Montoneros decía que había que acelerar las contradicciones. Yo digo "¿acelerar las contradicciones? ¡Nos van a hacer mierda! A todos. No es que si viene la dictadura va a estar todo más claro. Va a estar más claro que nos van a hacer mierda, viste. Es una locura, un delirio" ${ }^{1303}$.

En este punto coincidía Paloma: "me pareció en ese momento que era una tontería querer enfrentar un grupúsculo como los Montoneros contra un ejército organizado, entonces era un poco el juego para que la represión fuera más furibunda"1304.

\footnotetext{
${ }^{1302}$ Entrevista a Silvestre, vía e-mail, 29/10/2012.

${ }^{1303}$ Entrevista a Dante, Bahía Blanca, 28/9/2011.

${ }^{1304}$ Entrevista a Paloma, vía skype, 1/3/2013.
} 
Debe tenerse en cuenta que Montoneros argumentaba que si el enfrentamiento entre la organización y las Fuerzas Armadas se desviaba en confrontaciones menores y más numerosas, disminuiría la presión sobre la estructura de la guerrilla a la vez que incorporaría a su proyecto a los sectores populares. Esta idea llevó a "pensar como un todo la lucha armada y la lucha de masas", "contaminando" esta última y dificultando aún más el contacto político con una población renuente a identificarse con las acciones armadas, ya que era objeto de la política de terror generalizado que desplegaba el Estado (Calveiro, 2008: 114). En efecto, los ataques a las Fuerzas Armadas parecían hacer todo lo posible para precipitar el golpe; lejos de desearla, los cuadros montoneros veían en la intervención militar un inevitable paso que el enemigo emprendería cuando la guerra revolucionaria alcanzase cierto nivel de intensidad (Gillespie, 1987), constituyendo un nuevo escenario dentro de la lucha integral que llevaban a cabo, en el que se aprestaban a perder vidas. En este sentido, como afirma Donatello (2010), la ética de la convicción primaba sobre la ética de la responsabilidad. La responsabilidad política entendida como protección de las vidas humanas no era un planteo concebible para la conducción nacional. Para ella, la organización era un instrumento político, en un marco donde la política y la guerra se hallaban en el mismo plano.

Para los activistas de la Juventud Peronista, "un grupo armado no puede estar desvinculado del movimiento popular" $" 1305$ y lo que su experiencia en el barrio o en la universidad les decía era que "con esa alternativa nadie estaba de acuerdo"1306. En ese contexto, la lucha armada pasaba a ser un trabajo de "elites"1307 que exponía a sus integrantes a un aniquilamiento seguro ${ }^{1308}$. Y, aún más, para Calveiro (2008), este proceso explica, en parte, la derrota política de Montoneros. En efecto, la desinserción de los sectores populares se profundizó con el avance represivo de la Triple A y más tarde del gobierno militar, pero sus razones últimas deben buscarse en un trabajo de base muy reciente, poco asentado e interrumpido por la autoclandestinización, así como en una perspectiva política vanguardista -cuyas fuentes provenían del foquismo inicial y que la desinserción, a su vez, alimentó- que asumía una dudosa representación del "pueblo" e impulsaba como parte de su propuesta "popular" acciones que las bases del

\footnotetext{
${ }^{1305}$ Entrevista a Eduardo, Bahía Blanca, 16/10/2008.

${ }^{1306}$ Entrevista a Marta, Bahía Blanca, 29/5/2008.

${ }^{1307}$ Entrevistas a Eduardo, Bahía Blanca, 16/10/2012; a Ricardo, Bahía Blanca, 8/10/2011.

${ }^{1308}$ Estas críticas a la guerrilla, centradas en su estrategia ineficaz para debilitar al enemigo al tiempo que ponía en riesgo irresponsablemente otras vidas, en su elitismo/vanguardismo puesto de manifiesto en su marcha a contrapelo de la lucha de los pueblos, y la acusación de "hacerle el juego al golpismo", estuvieron presentes en los debates que tuvieron lugar en el exilio, y fueron puestos de relieve por Abós en su polémica con Bayer (Bayer, 1993).
} 
movimiento no asumían como viables ni deseables. A medida que aumentó el aislamiento, se incrementó la práctica "internista" y consecuentemente floreció una lógica cerrada, retroalimentada, autosostenida y sin instancias de confrontación política con otros sectores. Entonces, la organización “comenzó a girar en el vacío de su propia lógica, cada vez más desconectada y autosuficiente” (Calveiro, 2008: 105).

Por otra parte, se planteaba la tesis de que el aparato militar era necesario como autodefensa $^{1309}$ de la actividad política, que debía ser siempre la prioridad. Lo militar constituía, al decir de Eduardo, "una parte del desarrollo de la política"1310. Sin embargo, iniciativas como el asesinato de Rucci venían a mostrar el peso creciente de lo militar en detrimento de lo político en Montoneros. Y más allá de esto, como señala Donatello (2010), el operativo ponía de manifiesto la tensión que generaban las normas y decisiones que bajaban de la conducción nacional en el marco del "centralismo democrático" -o "centralismo burocrático" (Gillespie, 1987)-, dejando descolocados a los militantes de base. En efecto, son recurrentes los relatos que enfatizan las reacciones negativas que el atentado despertó en las bases ${ }^{1311}$. De fondo, entonces, había una tendencia común a los distintos movimientos sociales del siglo XX: el desarrollo organizacional implicaba la autonomización de las cúpulas. En términos sociorreligiosos, este conflicto expresaba un proceso de "inversión"1312 a partir del cual Montoneros empezaba a exacerbar su carácter de "comunidad de elegidos".

\footnotetext{
${ }^{1309}$ Entrevista a Juan Carlos, Buenos Aires, 1/8/2008.

${ }^{1310}$ Entrevista a Eduardo, Bahía Blanca, 20/5/2008.

${ }^{1311}$ El asesinato de Rucci tuvo repercusiones similares entre los cuadros montoneros y los activistas de la Tendencia en distintos lugares del país. Al analizar el caso de Moreno, Salcedo (2011) señala que los militantes juzgaron el hecho como una "barbaridad" y no podían creer que hubiera sido "gente nuestra" quien lo había llevado a cabo. Esta disidencia no estaba influida por factores ideológicos que avalaran a Rucci -considerado un burócrata- sino políticos: lo cuestionable era el momento político. La interpretación local, entonces, asociaba directamente la muerte de Rucci al enfrentamiento con Perón. Así, en aquella localidad -y en otras-, este acontecimiento fue uno de los varios hitos del conflicto de la militancia con la conducción montonera -entre ellos, la fusión formal de Montoneros y FAR, el documento interno conocido como "Mamotreto" o el ataque al cuartel del Ejército en Azul realizado por el ERP pero que Perón utilizó para señalar indirectamente a Montoneros como sus autores-, que acabó en la ruptura y la conformación posterior de la JP Lealtad. Según los entrevistados, a nivel local, no existió una escisión similar. La escasez de investigaciones sobre el peronismo revolucionario en Bahía Blanca nos impide, por el momento, confrontar/matizar/ confirmar/descartar dicha información.

1312 El término "inversión de sentido" es utilizado por Michel Wiewiorka para caracterizar experiencias análogas (Sendero Luminoso en Perú, Brigadas Rojas en Italia, ETA en España). Su significado, básicamente, es comprender el militarismo en los movimientos contestatarios como expresión de una alternativa, entre otras, en el desarrollo organizativo. Sus consecuencias, para el autor francés, son la autonomización de las ramas militares de los movimientos sociales, con respecto a aquellos a los cuales invoca como sectores portadores de sus reivindicaciones: la clase obrera, el pueblo, la nación, la etnia. Ello implica, asimismo, la copia degradada de los modelos, el lenguaje y las jerarquías de sus adversarios (Donatello, 2010).
} 
Por último, también estaba presente el supuesto de que con las elecciones de 1973 y el triunfo de Cámpora, la lucha armada perdía validez o el "fundamento ideológico" que había tenido previamente, con la sucesión de dictaduras y la proscripción del peronismo, cuando el pueblo no tenía posibilidades de expresarse ${ }^{1313}$. En efecto, enfrentar a las FFAA durante el gobierno democrático llevó a Montoneros a perder legitimidad política (Donatello, 2010). No obstante, este planteo dejaba de lado el crecimiento de las organizaciones armadas después de 1973 y olvidaba que éstas se definían revolucionarias y no reformistas electoralistas (Pozzi, 2006). Para la mayoría de los partidos de la izquierda revolucionaria, la política tenía un sentido puramente instrumental, por lo cual, las instituciones democráticas y las elecciones eran sólo un momento en el camino a la toma del poder dirigido por la organización armada (Hilb, 2001). En esta caracterización, no obstante, es posible marcar algunos matices. La influencia del peronismo en las organizaciones armadas peronistas, y su práctica de base creciente entre 1972 y 1974, habían llevado a una concepción necesariamente mestiza entre el foquismo y el populismo, más rica y compleja que la versión guevarista inicial. Pero esta apertura se fue desvirtuando y empobreciendo a medida que crecía el distanciamiento de Montoneros con el movimiento peronista y, con él, su aislamiento político general. En cambio, el PRT-ERP estuvo siempre más cerca de un foquismo "clásico" que incluía como parte esencial de su propuesta la formación de un ejército cuyo eje sería un foco de guerrilla rural; restringiendo su práctica política y seccionándose de la realidad nacional de modo más acelerado (Calveiro, 2008). En este marco, el partido-ejército manifestó su desconfianza frente al proceso electoral, hacia toda forma de institucionalidad burguesa y democrática, y hacia el peronismo como movimiento; de allí que el ERP suspendiera su accionar armado durante sólo dos meses, para retomarlo más tarde -lo que le valió que el gobierno lo declarara ilegal el 24 de septiembre de 1973-, y reforzarlo una vez que pasó a la clandestinidad, participando así en la intensificación de la violencia desatada en el país (Seoane, 1993).

Los posicionamientos y prácticas de los militantes bahienses frente a la acción violenta sufrieron un quiebre con la muerte de Perón, el recrudecimiento de la represión y la acción de los grupos parapoliciales, y el proceso de "reducción de lo político a la dimensión exclusivamente militar" que se operó en la guerrilla y en vastos sectores más allá de ella, llevando a una aceleración cada vez mayor de la violencia. Siguiendo a

${ }^{1313}$ Entrevista a Julio, Bahía Blanca, 22/5/2010. 
Calveiro (2008), si durante el período legal de las organizaciones, en virtud de su relación con otras formas de lo político -entre ellas la política de masas-, se buscó el equilibrio entre lo militar y lo político, a partir de la clandestinidad, aquél se fue rompiendo, a favor del primero. Una de las claves de esta militarización fue la idea de que lo militar era el pilar fundamental y prácticamente único del poder político, produciéndose una simplificación y desvirtuamiento de lo político hacia lo militar. En consecuencia, se convirtió la lucha política en guerra y el opositor en enemigo, incluyendo en esta noción un bloque amplio y arbitrario formado por el aparato represivo, la burocracia sindical, la derecha del peronismo y la burguesía, al menos la industrial. La actividad prioritaria pasó a ser el intento de construir un ejército popular que reuniera las mismas características del ejército regular, para poder enfrentarlo exitosamente. La estructura de Montoneros, hasta allí político-militar, comenzó entonces a especializarse. Todos los miembros plenos de la organización pasaron a ser “combatientes" y su práctica comprendía la participación en la actividad militar, mientras que los "milicianos" desempeñaban tareas de índole política, aunque estas también tendieron a ir militarizándose gradualmente ${ }^{1314}$.

El abandono del espacio político, ya de por sí bastante estrecho, por parte de Montoneros, y su priorización del accionar armado y clandestino, condenaban a las agrupaciones de base territoriales, sindicales, estudiantiles (Calveiro, 2008). Si Montoneros quería conservar una base legal en el sistema político, por lo que llevó a cabo el intento de mantener "en la superficie" a las organizaciones de masas, la reanudación de la lucha armada aumentó notablemente el riesgo que suponía participar en ellas. Se hizo evidente que las agrupaciones de la Tendencia estaban demasiado identificadas con Montoneros para servir de exponentes legales de su política. Así, JP, JUP, JTP y UES siguieron existiendo durante 1975, pero como organizaciones clandestinas. En consecuencia, la ligazón con las masas y la preeminencia de las tareas militares resultaban dos principios contradictorios en contexto de represión creciente: ésta comenzó por afectar con mucho más dureza a la periferia de la guerrilla que a los propios combatientes, provocando el paso de activistas "legales" a la clandestinidad,

\footnotetext{
${ }^{1314}$ Por su parte, el ERP hacía gala de un militarismo semejante, en particular en la llamada Compañía de Monte, en Tucumán: "La estratégica importancia de las unidades rurales radica en que el auxilio de la geografía hace posible construir velozmente poderosas unidades bien armadas y entrenadas, capacitadas para golpear duramente al enemigo...y hacer posible la construcción de bases de apoyo como sostén un poderoso Ejército Revolucionario de carácter regular, en condiciones de sostener victoriosamente con sus armas la insurrección general del pueblo argentino que llevará al triunfo de la revolución nacional y social en nuestra patria" (El Combatiente, 5/6/1974, citado en Calveiro, 2008: 94).
} 
pero impidiendo con ello el crecimiento de la periferia. Si la periferia era el medio de comunicación vital entre los combatientes y los movimientos de masas, su parálisis suponía una amenaza mortal para el porvenir de Montoneros en conjunto (Gillespie, 1987). En suma, como afirma Donatello (2010), desde el pasaje a la clandestinidad, Montoneros se vinculó de dos modos con las agrupaciones de masas: por un lado, intentaba sumarlas a la política de militarización, y por otro lado, las exponía ante los ataques perpetrados por la Triple A y los grupos paramilitares, como si hubieran asumido la lucha armada al igual que los militantes encuadrados, siendo así la protección de los activistas de base uno de los problemas claves de este período.

En este contexto, había indicios cada vez más evidentes de que no sólo la militancia armada sino el mismo activismo político eran opciones riesgosas, casi suicidas, "un camino sin salida"1315 -al decir de Julio- que no conducían sino a la muerte. Así lo vivieron los actores bahienses: “cuando en el '74 estando nosotros en Holanda llega la noticia de que los Montoneros han pasado a la clandestinidad, yo pregunto: ¿qué pasa ahora con los que están en la superficie?" ${ }^{1316}$. En consecuencia, la profundización de las opciones de otros fue vivida con preocupación, temor, impotencia y dolor por lo que pudiera ocurrir. "Pepe" recordaba: "un día peleando con María Clara [Ciocchini]... '; Chicos, esto es una locura!', en ese contexto, y no entendían ¿eh? Estaban tan enchufados. ;Salir a volantear en la noche!, ; con el nivel de violencia que había! ¡Una inconsciencia!",1317. En este marco, mientras algunos jóvenes cristianos, al sentirse interpelados a asumir lo que entendían era un "compromiso total con el hermano", entraron en la clandestinidad, otros decidieron rechazar la propuesta de tomar las armas y abandonar la militancia política como una opción deliberada por preservar la vida y posponer la lucha.

Por otro lado, muchos de los jucistas que militaban en la JP o en Montoneros, que hasta ese momento habían aceptado el planteo de la lucha armada, comenzaron a expresar sus objeciones frente al énfasis que adquiría lo militar en la organización. Estas diferencias políticas implicaron, en algunos casos, el alejamiento de la agrupación política y el desplazamiento hacia un lugar cada vez más marginal dentro de la estructura, en otros. Así lo vivieron Graciela y Rodolfo respectivamente: "no era fácil entenderlo y seguirlo [...] no trabajo más a nivel político...porque ahí ya no estaba de

\footnotetext{
1315 Entrevista a Julio, Bahía Blanca, 22/5/2010.

${ }^{1316}$ Entrevista a José Zamorano, Moreno, 19/9/2009.

${ }^{1317}$ Entrevista a José Zamorano, Moreno, 19/9/2009.
} 
acuerdo"1318; "no tuve un gran protagonismo en la última etapa, antes del golpe, en Montoneros precisamente por esas críticas, porque eran calificadas como 'debilidad ideológica",1319. En efecto, para los cuadros medios, el año 1975 y principios de 1976 fue un período de cuestionamientos, que precisamente tuvieron como epicentro las columnas norte y sur de la provincia de Buenos Aires, y eran síntoma de la desconfianza con respecto a las ambivalencias de la conducción nacional. Para los militantes del nivel más bajo, tal vez, el punto en el cual el disenso era más amplio era el temor a descuidar el trabajo de base. Sin embargo, la tensión entre militarismo y trabajo de base se solapaba con el problema de la autoridad (Donatello, 2010). Así, se destacan una creciente falta de participación en los mecanismos de promoción, en la toma de decisiones y en la definición de la línea política -que recayó de manera creciente en conducciones vitalicias, inamovibles y burocráticas-, y el disciplinamiento del desacuerdo, ambas consecuencias de la militarización de lo político. Desde 1974 se incrementó la centralización de las decisiones, desapareciendo toda instancia que pudiera limitar o cuestionar a la conducción nacional. Paralelamente, si en la promoción y el ascenso había intervenido cierto grado de democracia interna, luego se definían por estricta decisión jerárquica, en virtud de las aptitudes bélicas y disciplinarias, cundiendo un desinterés por el militante en tanto individuo y cierta despersonalización propia de las instituciones militares. Entonces la disciplina reemplazó a la participación y las condiciones represivas "justificaron" la imposibilidad de ampliar la discusión. La conducción se dedicó primero a disimular el desacuerdo restándole importancia, boicoteando la discusión y luego ahogándolo, al tiempo que reivindicaba el principio de obediencia y castigaba la disidencia. El desacuerdo ameritaba entonces la expulsión y la identificación con el enemigo (Calveiro, 2008). De esta manera, siguiendo a Donatello (2010), Montoneros invertía su rol de secta, presentándose como Iglesia. El salto organizativo para la lucha armada implicaba lógicas de diferenciación que sólo podían coordinarse desde una autoridad centralizada, jerárquica y, análogamente al mundo católico, infalible.

Por último, la percepción de una diferencia entre una época en la que predominaba la propaganda armada y otra en la que la violencia se volvió más indiscriminada (Calveiro, 2005) hizo que los jóvenes que no estaban involucrados con la militancia en esas organizaciones pero que habían visto con simpatía esas acciones -

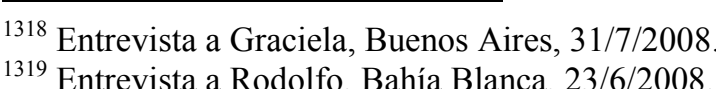


que Héctor definía como "del que le roba a los ricos para repartir a los pobres"-, luego les resultara cada vez más difícil sostener ese apoyo ${ }^{1320}$. Si las primeras iniciativas aparecían marcadas por un espíritu "romántico-justiciero" (Calveiro, 2008), un estilo "Robin Hood" (Gillespie, 1987), como una "violencia que procura la justicia" (Kaufman, 2010), como reparación, costaba ver en los atentados a los referentes "contrarrevolucionarios" otra cosa que no fuera, al decir de Héctor, la "eliminación -lisa y llana- de personas" $" 1321$.

En efecto, entre 1970 y 1974, la guerrilla había seleccionado de manera muy política los blancos del accionar armado, pero con la entrada en clandestinidad se intensificó la práctica militar, y el valor efectista de la violencia multiplicó engañosamente su peso político real (Calveiro, 2008). En esta nueva fase de la lucha armada de Montoneros, los atentados no siempre eran suficientemente selectivos como para que el público apreciara su significado, además de favorecer la representación de los guerrilleros como únicos responsables de la represión. Una mayor discriminación de objetivos y métodos operativos iba en contra del creciente ímpetu de la lucha guerrillera y de la progresiva tendencia a equiparar la lucha revolucionaria con una guerra regular. De esta manera, se erosionaba la imagen de la organización. Se incrementaron entonces las operaciones de guerrilla industrial, los ajustes de cuentas con los "traidores" peronistas, los atentados contra personajes vinculados a la Triple A y la represión paraestatal, así como los ataques a los miembros del aparato de seguridad y las FFAA $^{1322}$, incluidos los soldados, como ocurrió en Bahía Blanca a fines de 1975 (Gillespie, 1987; Donatello, 2010). En este marco, quienes desarrollaban su militancia en otras organizaciones, arreciaban sus críticas contra estos atentados. Como expresaba Paloma: "me repelía la acción de Montoneros, ir a tomar un destacamento o ir a robar armas a alguien y llegar a matar a unos pobres conscriptos,"1323.

\footnotetext{
${ }^{1320}$ Entrevista a Héctor, Bahía Blanca, 1/5/2010.

${ }^{1321}$ Entrevista a Héctor, Bahía Blanca, 1/5/2010.

${ }^{1322}$ Después de haber llegado con el ERP a una cuerdo táctico que dejaba los ataques contra los militares exclusivamente en manos de los guevaristas, Montoneros concentró su potencial bélico, hasta agosto de 1975, en la policía, los monopolios y la derecha peronista. Si bien el ERP veía en las Fuerzas Armadas un monolito reaccionario, Montoneros seguía abogando por un programa de liberación nacional que sería apoyado por un amplio frente del que participarían la pequeña burguesía y los sectores progresistas de las Fuerzas Armadas. Además, Montoneros consideraba que el "foquismo rural" del ERP era anticuado e inapropiado (Gillespie, 1987).

${ }^{1323}$ Entrevista a Paloma, vía skype, 22/2/2013. A nivel local, también se visualizaba un cambio en las modalidades de acción del ERP. Si hasta allí primaba el trabajo político sobre el militar, basándose este último en iniciativas propagandísticas o reivindicativas -consistentes en colocar "caños", desarmar policías o repartir alimentos-, a mediados de 1974 la actividad apuntaba a atacar al enemigo en sus bases. En este marco, se produjo el copamiento del puesto de Prefectura de Galván, con robo de uniformes y
} 
Sin embargo, más allá de los cambios de opinión que pudieron haberse planteado en 1974, como mencionamos, la misma aparición pública de la organización de la mano del asesinato de Aramburu, había provocado ya fuertes debates en la JUC. En este sentido, uno podría preguntarse, ¿hasta qué punto la militarización no era el resultado inevitable de una lógica de guerra revolucionaria en la que las organizaciones político-militares encontraban su razón de ser? Desde el momento en que el escenario del conflicto es concebido como una guerra, es el ejército lo que termina prevaleciendo (Vezzetti, 2009: 64). Como afirma Donatello (2010), si bien tanto la conducción como los militantes de Montoneros iban adecuándose a la vertiginosa velocidad de los acontecimientos, y el pase a la clandestinidad les dejó las manos libres para desarrollar su accionar militar, gran parte de los elementos originales de la organización prevalecían o se fueron afianzando. El militarismo, el aparatismo o el burocratismo estaban estrechamente vinculados a un hecho originario: la necesidad de construir una organización político-militar clandestina, que se planteaba como horizonte una guerra integral a los poderes establecidos. En el mismo sentido, Calveiro (2008) señala que la concepción foquista de las organizaciones armadas, al suponer que del accionar militar nacería la conciencia necesaria para desatar la revolución social, las llevaba a dar prioridad a lo militar sobre lo político, y esta preeminencia contribuyó a desarrollar una práctica y una concepción militarista y autoritaria en el seno de las organizaciones.

En todo este debate en torno a la "opción violenta", la gradualidad o la "zona gris" se destacaba sobre las posturas concluyentes. Descubrimos un proceso cargado de complejidades, no reductibles a una oposición entre dos polos extremos, lucha armada y lucha no armada. Como afirma Kaufman:

La descripción abstracta [que podemos hacer desde el presente] de los acontecimientos conflictivos con el recurso a una distinción binaria entre violencia y no violencia, como si todo lo heterogéneo que determina los conflictos pudiera simplemente instalarse bajo esa denominación, y la institucionalidad democrática como su contrario, es una forma de congelar la comprensión de lo sucedido y reducirla a fórmulas de legitimación y deslegitimación de categorías sociopolíticas que merecen discusiones mucho más matizadas [...] Y lo que vuelve mucho más complejo este panorama es la enorme diversidad de enfoques y concepciones con que se abordaba la lucha armada (en foro de clase Kaufman, 2010). 
En el capítulo anterior, hemos visto que fue menos en el terreno de las nociones generales sobre la violencia insurgente que en el de las elecciones personales, donde aparecieron los desacuerdos y se manifestaron las tensiones. Pasemos lista y analicemos entonces esos conflictos. En primer lugar, estaban los suscitados al interior de los grupos cristianos a partir del debate en torno a la opción por la lucha armada. Marta explicaba que con el pase a la clandestinidad de Montoneros, "se dividen las aguas entre los jóvenes, hay quienes dicen 'bueno, es la única manera' y hay quienes dicen 'no, somos un mosquito contra un elefante y más vale dar un paso atrás ",1324. Si bien los lazos de amistad se mantenían y se procuraba comprender las elecciones de los otros, las rupturas entre los jóvenes se profundizaron al calor de la aceleración del proceso de militarización de Montoneros. Marta recordaba “compañeros que nos decían 'cuídenme a los chicos porque este noche nosotros tenemos que salir'. 'No te los cuidamos porque en lo que no estamos de acuerdo es con el proyecto [...] no vamos a ser retaguardia',"1325. Al respecto, Lucy contaba que las discusiones en torno a la opción armada cristalizaron en un encuentro en el Seminario, después del cual los jóvenes tomaron distintos caminos, ahondándose la distancia entre ellos. Ésta significó perder el contacto cotidiano, dejar de ver o hacerlo con menor frecuencia a aquellos amigos que habían decidido asumir la lucha armada, o bien quedar excluidos de sus conversaciones, reuniones e iniciativas: “cuando ya llega ese momento hay muchos que si habian decidido agarrar las armas y vos habías optado por no, medio que te hacían a un lado. O sea, empiezan las separaciones". Esta segregación, sin embargo, no fue vivida por Lucy y su esposo en todos los grupos sino en la rama universitaria y en relación a las trayectorias políticas en Montoneros: "sentí más el `no estás en la misma que yo' [en] los intelectuales [...] parejas con las que vos te tratabas siempre de repente dejaban de venir o hablaban en secreto" ${ }^{\prime 326}$.

En la JEC este debate tampoco excluyó, según Gabriel, “reproches recíprocos ${ }{ }^{1327}$. Inés y Juan, quienes hicieron opciones diferentes frente a la entrada en clandestinidad de la organización, coincidían en señalar que los jecistas militantes de la UES que no estaban dispuestos a continuar su activismo en ese escenario eran juzgados

\footnotetext{
${ }^{1324}$ Entrevista a Marta, Bahía Blanca, 29/5/2008.

${ }^{1325}$ Entrevista a Marta, Bahía Blanca, 29/5/2008.

${ }^{1326}$ Entrevista a Lucy, Neuquén, 18/3/2013.

${ }^{1327}$ Entrevista a Gabriel, Bahía Blanca, 27/10/2012.
} 
por sus compañeros: "no te lo decían directamente, pero eras como que ‘como la cosa se puso fea vos te borrás'... Y vos tenías un sentimiento de culpa"1328;

nosotros éramos súper fanáticos. En ese sentido, a mí me habían criado así, y no le iba a aflojar...Entonces, de alguna manera, actitudes de gente que se trataba de preservar o hacía críticas "no, por este lado no va", que "no al militarismo", que esto que lo otro, nosotros obviamente, desde nuestra posición de más tiernitos -vos pensá que teníamos 17 años en ese momento-, los veíamos mal, a la gente que se iba, “ ¿cómo te vas a ir?"1329.

En efecto, en muchos casos, como afirma Donatello (2010), la disciplina militante permitía superar la desconfianza en las líneas que bajaban de la conducción y las tensiones inherentes al desarrollo que estaba tomando la organización. Sus vidas habían girado en torno a la búsqueda de un proyecto. Y la inversión de las afinidades con el catolicismo contestatario había conducido a la rutinización de las prácticas en torno a la lucha armada: Montoneros era a la vez un ejército, una iglesia, un partido y para muchos, parte de sus familias. De allí que muchos militantes hayan decidido permanecer en la organización hasta el final. Siguiendo a Calveiro (2008), la fidelidad a los principios enunciados y la sensación de haber emprendido un camino sin retorno favorecían ese proceso. Este camino estaba pactado por un pacto de sangre, sellado por la sangre propia y ajena; con los compañeros muertos, con la responsabilidad colectiva en la espiral de violencia, con las secretas complicidades que unían a un grupo estructurado alrededor de la transgresión a la legalidad y las normas sociales vigentes; también con la sangre de los "otros", fueran militares, policías o cualquier otra víctima. La ruptura con su formación moral originaria que implicaban las acciones armadas -a la que hemos aludido- profundizó la impresión de no retorno. De esta manera, los cuadros quedaban "atrapados" entre una sensación de deuda moral o culpa, una construcción artificial de convicciones que sólo se sostenía en la dinámica interna de la organización, la situación represiva externa que no reconocía deserciones ni "arrepentimientos" y la propia represión de la organización que castigaba con la muerte a los desertores.

En los testimonios bahienses, también se destaca el malestar generado por quienes, atrapados entre esa lógica militar y la represión, presionaban a amigos y familiares que adherían al proyecto revolucionario, empujándolos a asumir compromisos que les significaban riesgos. En efecto, siguiendo a Donatello (2010), la "inversión de sentido" había producido una realidad en la cual era difícil adoptar

\footnotetext{
${ }^{1328}$ Entrevista a Inés, Bahía Blanca, 18/6/2011.
}

${ }^{1329}$ Entrevista a Juan, 31/5/2011. 
estrategias de supervivencia más allá de la organización. Lucy decía, por ejemplo, que mientras estaba viviendo en Neuquén -después de 1972- viajó a Bahía Blanca, visitó el que había sido su barrio, el Rosendo López, y una ex vecina le advirtió que en su casa, que se encontraba desocupada pero amueblada, se reunían algunos jóvenes:

como sabian que yo había dejado la llave en la casa de mi mamá...Son conclusiones que sacás vos después...si esta vecina a mí no me hubiese dicho nada y me hubiesen denunciado...Pero claro, había Montos, digamos, ¿cuál era su objetivo? Su objetivo era la lucha armada por la liberación, todo bárbaro...el tema es que vos participabas de algo que no te habian preguntado nada ${ }^{1330}$.

Guardar armas o publicaciones y alojar a compañeros perseguidos eran otras formas en las que se involucraba a los demás, entre ellos, a personas que formando parte de los ámbitos de sociabilidad del catolicismo liberacionista estaban lejos del activismo contestatario, colocándolos en la disyuntiva de brindar su ayuda a quienes se encontraban en dificultades -como mandaba el Evangelio- o protegerse a sí mismos del peligro que estas acciones implicaban. En este sentido, Gabriel explicaba:

Necesitabas dejarle las cosas o pedirle asilo al que no tenía militancia política. Te daba como cierta garantía. Y el tipo también decía "loco, pero escuchame, me ponés en riesgo a mi". Y ahi empezaba a haber una fractura. El que uno veía como "me estás poniendo en riesgo a mí sin decirmelo", el otro lo veía "¿cómo vos sos un cristiano y ahora me estás negando el cobijo que necesito?",133i.

Por su parte, Rodolfo reflexionaba sobre estas demandas que también se planteaban a los militantes "de superficie", enfrentándolos a la paradoja de resultar expuestos a pesar de haber rechazado la participación en acciones armadas, mientras los cuadros militares, que actuaban en clandestinidad, quedaban a salvo de los operativos de las fuerzas de seguridad:

el que se banca usar las armas por razones de seguridad no las tenía...entonces las tenía otro que no se bancaba o no estaba de acuerdo con usarlas, simpatizaba con los objetivos generales pero aceptaba a regañadientes la violencia, y justo esa franja que aceptaba a regañadientes la violencia era la que se veía obligada por ahí a colaborar en cosas de mayor exposición ${ }^{1332}$.

Y dada la lógica vertical y jerárquica de Montoneros, los activistas con menores niveles de responsabilidad se veían obligados a responder a los requerimientos de los jefes, sin posibilidad de elegir sobre acciones que los comprometían, y ello a pesar de que sus cuestionamientos políticos o su escasa/nula disposición a tomar las armas los

\footnotetext{
${ }^{1330}$ Entrevista a Lucy, Neuquén, 18/3/2013.

${ }^{1331}$ Entrevista a Gabriel, Bahía Blanca, 27/10/2012.

1332 Entrevista a Rodolfo, Bahía Blanca, 23/6/2008.
} 
convertía en poco confiables. Roberto, quien escondió en su casa a algunos compañeros, decía al respecto: "no lo asumíamos como un hecho que nosotros participábamos libremente" ${ }^{1333}$. Y Nora y Rodolfo contaban cómo vivieron el hecho de tener que prestar su auto para actividades de la organización

N: 10 días-15-20, lo que lo necesitara, no podías decir "yo con esto no estoy de acuerdo, no". Eso, digamos, en la vida cotidiana a nosotros nos trajo

$R$ : estás o no estás, estás o no estás

$N$ : muchas tensiones porque

$R$ : te imaginás que te agarren un auto con armas en Comodoro Rivadavia

$N$ : a tu nombre, decís "no, se lo presté a este amiguito" (risas) $)^{1334}$.

En este sentido, estaban los conflictos que resultaban de adherir a un proyecto político que asumía la guerra revolucionaria, y pretender, al mismo tiempo, mantenerse ajeno a las manifestaciones de violencia. Un militante podía disentir con el planteo del recurso a violencia o bien haber elegido quedar al margen de la lucha armada, pero a la vez estar involucrado en el dispositivo armado, a partir del compromiso en tareas "de superficie" que facilitaran los operativos de la organización. Y en definitiva, esto significaba convalidar los métodos violentos para la consecución de una meta compartida. Secundar los objetivos de las organizaciones armadas sin aceptar tomar las armas, generaba contradicciones, al tiempo que implicaba convertirse en blanco de la represión. Otra anécdota de Nora y Rodolfo permiten ilustrar este punto. La misma transcurrió durante los días siguientes al asesinato del jefe de la policía federal, ligado a la Tripla A, Alberto Villar -perpetrado el $1^{\circ}$ de noviembre en el Tigre a través de la explosión de la lancha en la que navegaba ${ }^{1335}$-, y tuvo como protagonista a Nora, militante de la JP, quien estaba a poco de dar a luz a su primer hijo:

R: Ella fue a buscar unos volantes que eran parte de Montoneros, el parte de guerra que habian liquidado a Villar, los fue a buscar no sé si a la universidady los llevaba a casa, y cruzó la Plaza Rivadavia tirando volantes, estaba sola.

$N$ : No me acordaba de eso (risas)

R: sí, vos viniste con el paquete abierto, dije “¿qué hiciste?”. "Lo fui tirando en la Plaza Rivadavia” [...] Venía con la panza así tirando volantes, contentos

\footnotetext{
${ }^{1333}$ Entrevista a Roberto, Bahía Blanca, 18/4/2013.

${ }^{1334}$ Entrevista a Nora y Rodolfo, Bahía Blanca, 2/4/2009.

${ }^{1335}$ La acción que le quitó la vida a Villar fue uno de los más significativos asesinatos vindicativos o de represalia que multiplicó Montoneros en 1974 y 1975, y, en particular, de la persistente campaña contra la Triple A que afectó a policías y a personal del Ministerio de Bienestar Social. Estos atentados no estaban exentos de legitimidad en el ánimo de muchos observadores. Por otra parte, estimularon la violencia de la derecha, que a partir del asesinato de Villar se volvió cada vez más indiscriminada (Gillespie, 1987; Calveiro, 2008).
} 
Montoneros que habian matado a Villar (risas)...viste, y era ella, digamos, no era una persona que lo había matado a Villar ni nada... ${ }^{1336 .}$

El problema de la violencia insurgente se vuelve más complejo y los matices se multiplican si consideramos los grados de violencia que cada uno estaba dispuesto a ejercer personalmente. Muchos de los jóvenes cristianos con militancia política decían aceptar una violencia que adjetivaban como "defensiva" mientras rechazaban otro tipo de manifestaciones violentas. Así, Gabriel afirmaba que si bien nunca portó armas sabía que cuando iban a hacer pintadas con la UES había compañeros armados que los custodiaban $^{1337}$. En forma similar, Mirta explicaba que durante su participación en el PB: "no me veía tirando un tiro, en todo caso tener un arma para defenderte, pero de ir a hacer un atentado...ni ahí. Cuando salíamos a pintar yo sabía que venía un chico atrás con un arma, pero era por si nos llegaba a pasar algo"1338. En este sentido, Mirta recordaba reuniones de la JOC en Buenos Aires, a las que asistió Jorge, donde una parte de los militantes iban armados como una forma de protegerse: "se sentaban en la mesa y cada uno dejaba el arma como si ahora dejás los celulares...y estaban en un movimiento católico, viste, tenían que ir a los barrios, que era necesario, defensa "1339.

Más allá de los diversos posicionamientos respecto de la lucha armada, en aquel universo de sentido donde la confrontación y la violencia eran formas válidas de hacer política y el espacio político era concebido como un campo de guerra, los militantes desarrollaban prácticas violentas en forma cotidiana, como parte constitutiva de su acción política. Éstas consistían, por ejemplo, en romper vidrios, arrojar bombas molotov o miguelitos, tirar piedras a la policía montada en una manifestación, ir armado a hacer pintadas o a repartir volantes, recibir instrucción militar para defenderse de la represión. En este sentido, Mónica contaba que una parte de los jecistas bahienses que militaban en la UES si bien no participaba de la lucha armada, estaba enmarcada en la organización político-militar y desarrollaba acciones que involucraban riesgo:

ninguno de nuestro grupo se encontró ante la disyuntiva de tener un arma. Otra gente sí, pero nosotros no. Lo que nosotros sí participamos de algunas acciones de propaganda casi te diría con un cierto nivel de ejercicio de la violencia, pero que no era violencia contra personas sino contra cosas ${ }^{1340}$.

\footnotetext{
${ }^{1336}$ Entrevista a Nora y Rodolfo, Bahía Blanca, 2/4/2009.

${ }^{1337}$ Entrevista a Gabriel, Bahía Blanca, 7/11/2012.

${ }^{1338}$ Entrevista a Mirta y Jorge, Bahía Blanca, 11/4/2012.

${ }^{1339}$ Entrevista a Mirta, Bahía Blanca, 18/6/2008.

${ }^{1340}$ Entrevista a Mónica, Buenos Aires, 9/11/2011.
} 
Por su parte, Nora y de Rodolfo se referían a las complejidades presentes en ese tipo de situaciones:

$\mathrm{N}$ : vos cuando ibas a una manifestación y llevabas unas bolitas por si te corría...los caballos, vos no pensabas que esas bolitas en el bolsillo eran violencia. Vos pensabas "me estoy defendiendo" [...] Y vos decís tirar una piedra a un milico es violencia, pero el milico te está apuntando o te está persiguiendo o te tira el caballo encima...es como MUY gradual

R: muy gradual, después llega un momento que estás adentro de un bolonqui de mucha violencia y estás como preso de una lógica ${ }^{1341}$.

Estas últimas palabras habilitan la reflexión en torno a -al menos- dos cuestiones. En primer lugar, si es posible distinguir entre una violencia puramente reactiva, que brota inmediata ante la impotencia, y una violencia instrumentalizada, que se racionaliza como un medio para un fin, ¿de qué tipo de violencia estamos hablando cuando pensamos en las prácticas de los militantes políticos, incluidos los cristianos, entre 1969 y 1976 ? ¿Cómo se da el paso de una a otra y cuáles son sus implicancias? (Hilb, 2001). Luego, ¿cómo se comprende el proceso por el cual un sector importante de la generación setentista se integró o adhirió a la acción política en organizaciones revolucionarias "por una cuestión de sensibilidad social y política, de producir una transformación social y la justicia” -al decir de Rodolfo- pero luego quedaron atrapados en una lógica militarista que "no tiene nada que ver con lo que nos llevó a eso",1342 (Hilb, 2001)?

${ }^{1341}$ Entrevista a Nora y Rodolfo, Bahía Blanca, 2/4/2009.

${ }^{1342}$ Palabras de Rodolfo, entrevista a Nora y Rodolfo, Bahía Blanca, 2/4/2009. 


\section{CONCLUSIONES}

Esta tesis se propuso abordar las afinidades y tensiones entre catolicismo liberacionista y política en el marco de efervescencia social y política que conmovió a Bahía Blanca, Argentina y América Latina en los años sesenta y setenta. En relación a la primera cuestión, en confluencia con otros autores, hemos optado por el concepto de "afinidad electiva" para elucidar la relación entre religión y política en el movimiento liberacionista, basada en una matriz común de creencias religiosas y políticas en torno a las prácticas de transformación social, matriz que otorga significado y coherencia a la experiencia subjetiva de los protagonistas. Este concepto, lejos de hacer referencia a una relación causal, nos ha permitido comprender las interacciones entre fenómenos sociales desde una perspectiva que rescata su carácter dinámico.

Si otros trabajos en los que abreva esta investigación han planteado dicha afinidad tanto en el contexto latinoamericano como argentino, o han elucidado el marco político-religioso para comprender esta relación, esta tesis avanza en aspectos o enfoques no abordados por las interpretaciones existentes, penetrando entonces en las singularidades de dicha afinidad y siguiéndola desde su origen hasta su culminación. Esto es, hemos profundizado con minuciosidad en las trayectorias individuales y grupales de un colectivo de hombres y mujeres católicos particular en un escenario local y un marco histórico específico.

En este sentido, este estudio también contribuye a llenar el vacío de trabajos empíricos sobre los movimientos especializados de juventud en nuestro país, en las décadas de 1960 y 1970. Así, hemos analizado de qué se trataba la JUC, la JOC y la JEC, cómo se constituyeron en Bahía Blanca, cómo funcionaban, cuáles eran sus espacios de encuentro, quiénes las integraban, cómo y por qué se desestructuraron. Y si varios trabajos coinciden en señalar la relación entre las ramas especializadas de Acción Católica y Montoneros, o el catolicismo liberacionista y la lucha armada, esta tesis se detiene en el proceso mediante el cual los jóvenes católicos asumieron la acción contestataria en general, abonando la comprensión de las maneras concretas mediante las cuales dichos grupos influyeron en sus itinerarios militantes.

Así, el análisis de diversas trayectorias jucistas, jocistas y jecistas en Bahía Blanca da cuenta del papel central que desempeñaron los ámbitos de sociabilidad ligados al catolicismo liberacionista en la intervención social y política de sus integrantes. Hemos mostrado las múltiples dimensiones involucradas en este proceso, 
destacando tanto los aspectos ideológicos como relacionales, afectivos, éticos y ligados a las prácticas cotidianas. Como plantean Donatello y Catoggio (2010), la formación en una matriz católica común proveyó a los militantes de una serie de disposiciones para la acción, prácticas, modelos a seguir, un universo de relaciones personales e instancias de socialización que fueron claves.

En primer lugar, los equipos de la JUC, la JOC y la JEC, en continuidad con otras experiencias familiares, escolares y de la constelación liberacionista local o en ruptura con espacios católicos tradicionales, representaron un hito en la maduración de una forma de vivir la fe y una visión de Iglesia y su relación con el mundo marcada por la idea del compromiso del cristiano en la sociedad, orientado a la construcción de un orden social más justo. Dicha concepción estaba estrechamente vinculada a la influencia de los documentos del Concilio Vaticano II, de Medellín y de las elaboraciones de la teología de la liberación, así como a una matriz católica integral de larga data.

Las trayectorias de los actores -de los laicos aunque también de algunos referentes consagrados- mostraron que, en muchos casos, la formación religiosa tradicional o la participación en grupos eclesiales alejados o incluso renuentes a abrazar el aggiornamento de la institución, actuó como base de la militancia católica posterior, marcando una continuidad en la búsqueda de intervención social "desde la fe" religiosa. Luego, la lectura de los nuevos documentos del Papa y los obispos latinoamericanos y argentinos, $\mathrm{y}$, fundamentalmente, la interpretación que los actores liberacionistas le dieron a aquellos -que en ocasiones iban más allá de los planteos originales-, decidieron a los jucistas, jocistas y jecistas bahienses a involucrarse en la historia, considerada escenario del plan divino y anticipo de su Reino. De allí que encontraran apremiante la tarea de identificar, denunciar y cambiar las situaciones sociales, políticas y económicas que contradecían el Evangélico, abrazaran la “opción por los pobres” y asumieran un rol protagónico en cuanto laicos y jóvenes en la empresa liberadora, complemento indisociable de la conversión personal según el modelo de un Hombre Nuevo. Así, los actores descubrieron la política y su relación con la fe, encontrando en ella una dimensión teológica. De este modo, los referentes y grupos locales del catolicismo liberacionista, al igual que sus pares de otras latitudes, entendieron el compromiso político del cristiano como un compromiso revolucionario que los llevaba a la opción por el socialismo, en unión con otros "hombres de buena voluntad", y que podía asumirse desde diversos ámbitos de acción, reservando a los “oprimidos” el lugar privilegiado en el proceso de su propia liberación. 
En este marco, la "pedagogía" de la revisión de vida, practicada semanalmente en los equipos jucistas, jocistas y jecistas, tuvo una significación clave en términos de su vivencia religiosa. En este sentido, en esta tesis, intentamos brindar, a partir del caso bahiense, un aporte al estudio de las características de la "revisión de vida" y sus implicancias no sólo en la vida cotidiana de los militantes, sino también en el compromiso cristiano. A pesar de su relevancia como instancia de transformación personal no ha sido suficientemente considerada en los trabajos existentes. En consecuencia, exploramos las singularidades del método aplicado en comunidades específicas, esto es, cómo se llevó a cabo, sobre qué tipo de cuestiones giraba -qué se "veía", qué juicios se emitían y qué acciones se tomaban en consecuencia, en el marco de una sociedad y una época determinadas- y con qué dificultades se enfrentaba su ejercicio, así como su vinculación con las opciones que los jucistas, jocistas y jecistas fueron realizando en el contexto en el que se encontraban.

En efecto, Ver, Juzgar y Actuar, planteaba novedades en la articulación de la escritura y el dogma en cuanto partía, no ya de verdades establecidas por la institución eclesial que debían ser aprendidas para luego ser llevadas a la práctica, sino de la realidad misma del militante para luego interpretarla desde el Evangelio. En estas cuestiones se incluían las situaciones propias de los ambientes laboral y estudiantil, los temas de la coyuntura social, política y económica local, nacional e internacional, y problemas de la vida familiar de los jóvenes, siendo su acción concreta, su "compromiso", el nudo central de la revisión de vida; se trataba así de una reflexión sobre la praxis, que encontraba su punto de partida y de llegada, y su razón de ser en el Actuar. Por otra parte, suponía una forma particular de relación con Dios -un Dios que ahora aparecía como cercano y amoroso-, consumada en el devenir histórico, en la acción, en el amor eficaz al prójimo y, en especial, al "oprimido". Asimismo, implicaba una vivencia de la fe comunitaria, cotidiana e integral, en cuanto atravesaba todas las dimensiones, espacios y momentos de la vida del militante. Al mismo tiempo, la fe aparecía como una opción personal libre, que interpelaba a la participación, otorgando un papel activo en las prácticas religiosas, y empezaba a hacer sentido en la propia historia.

En relación con la anterior, la revisión de vida favoreció el discernimiento de los procesos sociales, económicos y políticos del momento, la "toma de conciencia" de la realidad, la asunción de una postura crítica frente a la misma y la reflexión del lugar del militante en ella. Y partir de este "descubrimiento", la fe se volvió indisociable del 
“compromiso". Éste asumía la forma de una intervención transformadora, en vistas a la "liberación", la construcción de un Hombre y mundo nuevos, siendo los “oprimidos" los destinatarios y protagonistas del proceso. Esta empresa significaba hacer presente el Reino de los Cielos y abarcaba tanto la denuncia de las situaciones sociales consideradas contradictorias con el espíritu evangélico, como toda acción orientada al cambio del orden vigente.

Además de la identificación con estas concepciones sobre el "ser cristiano" e ideas sobre la Iglesia y su relación con el mundo, los movimientos especializados de juventud proveyeron a sus integrantes de otros elementos que influyeron en su acercamiento a la sociedad y a la política. En este sentido, hemos constatado que la JUC, la JOC y la JEC se constituyeron en espacios de formación donde los jóvenes adquirieron/construyeron/ejercitaron una multiplicidad de saberes que, parafraseando a los pedagogos, podemos identificar no sólo como "conceptuales", sino también como "procedimentales" y “actitudinales".

Los saberes "procedimentales" se pusieron en juego en las herramientas organizativas y relacionales recreadas en las reuniones semanales así como en los demás ámbitos de encuentro del movimiento. Cuando los jóvenes se decidieron a encarnar su compromiso cristiano en espacios concretos de inserción, se encontraron con que, al calor de su militancia eclesial y como consecuencia del rol activo que los jóvenes habían asumido en las actividades jucistas, jocistas y jecistas, habían interiorizado una serie de habilidades, destrezas, capacidades, estrategias, procesos vinculados con el "saber hacer"; esto es, habían construido y ejercitado un conocimiento vinculado al trabajo colectivo. Un conjunto de acciones reiteradas de manera sistemática en las instancias grupales constituían una suerte de "capital” que facilitaba su participación en las agrupaciones estudiantiles, las unidades básicas, los sindicatos o las células de las organizaciones revolucionarias, a saber: le lectura y la interpretación de textos; el análisis de información, de noticias o de situaciones cotidianas; la comunicación de pareceres o información a través de declaraciones, exposiciones, debates; la toma de postura, el ejercicio crítico, la fundamentación de una opinión; la elaboración de síntesis y conclusiones; la búsqueda de consenso; la organización, planificación y coordinación de actividades; o la reflexión. Al mismo tiempo, la familiaridad construida en los movimientos católicos con ciertos repertorios de acción, como la lectura y discusión en pequeños grupos, la participación en asambleas, la elaboración de informes y documentos públicos donde se hacía un diagnóstico y se denunciaban situaciones 
consideradas injustas, la distribución de volantes o la organización de campamentos de estudio y trabajo, contribuía a que las prácticas del espacio político fueran vividas en continuidad con aquéllas.

Por otra parte, el paso por la JUC, la JOC y la JEC imprimió en los jóvenes una serie de valores, actitudes y normas que fueron modelando sus conductas, hábitos, decisiones y expectativas ante las personas y los fenómenos que los rodeaban. Entre ellas, se encontraban: la sencillez, la humildad, la austeridad, el ascetismo, el despojo de lo material, el rechazo al consumismo; el compromiso, la responsabilidad, la disciplina, la puntualidad, el trabajo, el esfuerzo, la exigencia, la disponibilidad absoluta/la entrega/estar "siempre listo", en detrimento del ocio o la diversión; la coherencia, ser "bueno", incluso, "el mejor" y practicar los valores evangélicos en todos los ámbitos de la vida -la familia, la pareja, los amigos, el estudio, el trabajo, la militancia-; la valoración de la persona sobre todas las cosas, lo que llevaba a vincularse con los otros desde la honestidad, la lealtad, la generosidad y el respeto, y a condenar las actitudes pragmáticas, interesadas, individualistas o egoístas. Este conjunto de rasgos fueron dando forma a una sensibilidad y un estilo de vida que tenía que ver con la identidad y fe cristiana de los actores, pero que al mismo tiempo la trascendía. Por un lado, resultaba de la voluntad de seguimiento de Jesús, que había nacido en un pesebre, había elegido a sus amigos entre los pescadores, había enseñado que el mandamiento más importante era el amor al prójimo $\mathrm{y}$, entre otras cosas, que Dios y el dinero se encontraban en dos caminos irreconciliables. Asimismo, y en relación con el ejemplo de Jesús, la "opción por los pobres" obligaba a vivir y sentir como ellos, a identificarse con su suerte y con sus luchas. Ý al mismo tiempo, se trataba de dar forma al Hombre Nuevo, que cargado de virtudes de resonancia cristiana y encarnado en la figura del "Che" Guevara, se convertía en el modelo a seguir por todos los activistas revolucionarios, en cuanto anunciaba otro mundo cimentado en una nueva ética y moral.

De allí que cuando los jóvenes católicos se integraron a las organizaciones político-militares sintieron que hablaban un mismo lenguaje y se regían por similares pautas de conducta. Aún más, en el caso de Montoneros, Donatello (2010) ha postulado que la conexión entre la disciplina ascética adquirida en la vida socio-religiosa constituyó una da las marcas genéticas de la organización, y que más tarde el disciplinamiento interno profundizó los contenidos ascéticos pero en clave secular.

Asimismo, las ramas especializadas de Acción Católica forjaron lazos con personas, grupos e instituciones que jugaron un papel esencial en la articulación de 
denuncias públicas, la generación de iniciativas políticas, el paso de la militancia eclesial a otra social o político-partidaria y el ingreso a las organización revolucionarias.

El origen mismo de la JUC, la JOC y la JEC, y la integración de los militantes a esos espacios da cuenta de la importancia de las redes sociales. El contacto previo entre dos militantes jucistas y los misioneros españoles, a partir de sus tareas pastorales en Coronel Suárez, facilitó su encuentro en Bahía Blanca y la elaboración de la propuesta de refundar la JUC en la ciudad. El fenómeno de los "acercados" como modo común de ingreso a los grupos de revisión de vida también da cuenta de la importancia de los vínculos tejidos en distintos ámbitos en la conformación de estos círculos sociales. Así, entre los primeros jucistas y jocistas se encontraban alumnos de colegios secundarios e institutos terciarios donde "Pepe" y Emilio daban clases, integrantes de los grupos juveniles del Movimiento Familiar Cristiano, que los sacerdotes habían acompañado en 1967-1968, y vecinos de Nuestra Señora del Carmen. Luego, los equipos de universitarios y trabajadores católicos se fueron haciendo más numerosos con la llegada de jóvenes contactados por los militantes en la capilla, el centro pastoral, el movimiento Guía-Scout, la universidad, el Pensionado Católico, las agrupaciones políticas, el lugar de trabajo, el barrio o la parada de colectivo. Por otra parte, el surgimiento de la JEC también está ligado a las relaciones personales establecidas a partir de la participación en Nuestra Señora del Carmen y La Pequeña Obra.

De modo similar, la conformación de otros espacios identificados con el catolicismo liberacionista en Bahía Blanca y Punta Alta se explica atendiendo a los contactos previos entre sacerdotes, religiosas y laicos. Por otro lado, la vinculación entre estos círculos sociales estaba basada, fundamentalmente, en los lazos personales que unían a sus integrantes, antes que en intercambios regulares o en una coordinación formalizada entre los grupos. Las relaciones de familiaridad y amistad construidas en la escuela, en el barrio, en la parroquia, en la universidad mediaron en la incorporación de nuevos militantes a las organizaciones laicales y marcaron las conexiones entre ellas. En estos intercambios, predominaban vínculos informales, alimentados de ámbitos y prácticas comunes, así como de espacios festivos y de celebración que ampliaban el tejido de relaciones interpersonales. Los militantes católicos se cruzaban en La Pequeña Obra, en la "loma", en Villa Nocito, en Cáritas, en la UES, en la JUP, etc. Esto tiene sentido en el marco de las dimensiones medianas de esta ciudad, lo que delimita una trama de interrelaciones sociales relativamente estrecha y espacios de vecindad construidos a partir de contactos cotidianos. 
Sin embargo, las instancias de encuentro y de puesta en común de experiencias también existieron y jugaron un rol importante en la articulación de la red social de la renovación católica en Bahía Blanca, así como en la construcción de una identidad compartida, cimentada en una forma de vivir la fe encarnada en la realidad cotidiana. En este proceso, los referentes consagrados, especialmente los sacerdotes -que, por su parte, constituían un grupo- tuvieron un papel fundamental.

Los límites de este amplio espacio de interacción social se vuelven difíciles de determinar si tenemos en cuenta la construcción de puentes de comunicación y lazos de solidaridad con referentes de la corriente liberacionista a nivel nacional y latinoamericano, como así también con pastores y jóvenes de otras Iglesias cristianas, sin olvidar, la cercanía y participación ocasional en los grupos católicos de militantes políticos, compañeros de trabajo o de estudio no creyentes. La extensión de esta red más allá del ámbito local tenía que ver con la integración de algunos sacerdotes "bahienses" al MSTM; la pertenencia de la JUC, la JEC y la JOC a movimientos latinoamericanos e internacionales y el protagonismo de los militantes en las actividades de los mismos; la actuación de los jucistas en los Campamentos Universitarios de Trabajo; la intervención de los grupos locales en iniciativas que congregaban a la región Comahue; la distribución y lectura de la revista Cristianismo y Revolución, así como el recurso a la misma para difundir documentos conjuntos; y los cruces que establecían los actores locales con los referentes de la teología de la liberación, a partir de las instancias de coordinación y encuentro, y las publicaciones del MIEC-JECI, y del estudio de sus escritos fundamentales.

Las relaciones de los grupos católicos liberacionistas bahienses y puntaltenses con la jerarquía fueron complejas. En general, estos grupos mantuvieron una actitud crítica frente al arzobispo y le reclamaron el aggiornamento de la Iglesia local, así como un mayor compromiso de ésta hacia los sectores desfavorecidos. La propia estructura del MIEC-JECI y de la JOC, y la relativa indiferencia de los referentes eclesiales respecto de los movimientos especializados de juventud, permitió además que éstos funcionaran con relativa autonomía respecto de aquél. Sin embargo, pueden distinguirse dos etapas, según fuera Esorto o Mayer quien estuviera a cargo de la Arquidiócesis. Si el primero resultaba más accesible a los sectores renovadores, el segundo no ocultaba su oposición hacia ellos. Así, mientras Esorto protegió y avaló las iniciativas de los sacerdotes y laicos liberacionistas, Mayer confrontó con ellos y les quitó su respaldo. Por otra parte, las tensiones entre la red de renovación católica local y otros sectores 
eclesiales se visualizaron a lo largo de todo el período, aunque adquirieron otro cariz e intensidad con el recrudecimiento de la violencia represiva, tal como hemos podido mostrar a partir de la reconstrucción de las repercusiones locales de la consagración del país a la Virgen María por parte de Onganía, las interrupciones de las homilías de Duilio Biancucci y Oscar Barreto en la Catedral por integrantes de las Fuerzas Armadas, la volanteada anónima contra Miguel Sarmiento y Hugo Segovia en Punta Alta, el allanamiento de la casa parroquial de la "loma" y la detención de "Pepe" Zamorano, o la serie de atentados perpetrados por la Triple A en marzo y abril de 1975 contra la comunidad salesiana del Instituto Juan XXIII, la hermana Norma Gorriarán y la escuela de Villa Nocito, y el capellán de Nuestra Señora del Carmen.

La reconstrucción de estos conflictos y de otras iniciativas comunes de los sectores liberacionistas también permitió dar cuenta de la función política de los vínculos de sociabilidad. Entre aquellas iniciativas analizamos aquellas que buscaban responder a los ataques que recibían estos sectores -incluidos los mediáticos, protagonizados, fundamentalmente, por La Nueva Provincia-, o dejar sentada su posición respecto de las políticas sociales, económicas y culturales del gobierno dictatorial -tanto a nivel nacional como local-, las medidas represivas que sufrían los grupos contestatarios -entre ellos, los eclesiales- de la mano de las fuerzas armadas y de seguridad, y las decisiones de la jerarquía. El entretejido de lazos sociales existente entre laicos, sacerdotes y religiosas facilitó la articulación conjunta del discurso de la revisión de vida y el profético en vistas a denunciar las situaciones consideradas de injusticia. Como han señalado otros autores y nos han mostrado las fuentes referidas al MIEC-JECI, no eran sólo los bahienses sino diversos referentes y grupos identificados con el catolicismo liberacionista en el país y en América Latina quienes asumían, tal como planteaban los nuevos documentos del magisterio católico y recuperando la tradición profética del Antiguo Testamento, la tarea de identificar e impugnar los hechos que contradecían el espíritu evangélico y lo hacían a través de repertorios de acción similares. Entonces la palabra se convertía en un importante gesto comprometido, adquiriendo, así, una dimensión política, que además multiplicaba su impacto al ser pronunciada de modo colectivo. En efecto, este tipo de prácticas era la única forma de intervención social que los grupos de revisión de vida emprendieron en conjunto, en cuanto la JUC, la JOC y la JEC se definían como espacios de reflexión que movía a sus integrantes a la acción pero concibiendo a ésta fuera del grupo y como elección personal de cada joven. 
Los contactos entre las ramas especializadas de Acción Católica, el Grupo Misionero, la Comunidad Universitaria Bahiense, Cáritas, la escuela Nuestra Señora de la Paz, la JAC de Punta Alta, y los referentes consagrados que los acompañaban posibilitaron entonces la redacción de informes y declaraciones públicas, la organización de volanteadas en las puertas de las iglesias, de misas concelebradas y de reuniones con la jerarquía eclesiástica, y la elaboración de pautas consensuadas para las homilías que se replicaban -con matices, según las peculiaridades de las distintas comunidades- en diversos puntos de la ciudad y de Punta Alta. Los actores también echaron mano a las redes sociales construidas en torno al catolicismo liberacionista en el espacio local y nacional para darle mayor eficacia a sus iniciativas cuando eligieron difundir sus comunicados en las publicaciones que actuaban como voceras de estos sectores -Cristianismo y Revolución o Pablo-.

El papel de la materialidad constitutiva de las relaciones sociales en el impulso y la concreción de la acción contestataria no sólo se recreó en las prácticas de impugnación al orden vigente sino en las opciones de compromiso de los actores orientadas a la construcción de un mundo nuevo. Ya en la primera experiencia jucista bahiense, los lazos personales habían jugado un rol significativo en el compromiso de los militantes en diversos espacios de acción, favoreciendo no sólo la conformación de la Liga Humanista y la Democracia Cristiana en la ciudad o la colaboración en algunas de sus actividades, sino también en la participación de los jóvenes en diversas iniciativas vinculadas con la recientemente creada UNS, como la fundación del Club Universitario.

En el período 1968-1975, vimos las redes sociales del catolicismo liberacionista actuando de diversas maneras. Por un lado, hemos mencionado cómo el Pensionado de Zapiola 428 actuó como punto de encuentro de las agrupaciones universitarias y centro de distribución de publicaciones de izquierda, mientras la escuela Nuestra Señora de la Paz funcionó como espacio de referencia, e incluso de reunión -como lo fue en ocasión de la lucha contra el proyecto del Camino de Cintura- entre los vecinos y los diversos grupos políticos que hicieron de Villa Nocito su lugar de militancia.

Por otro lado, las relaciones entre los actores facilitaron el paso a la acción pastoral y barrial, y de un tipo y espacio de militancia a otro. Como mencionamos en el capítulo 6, muchas maestras de la escuela de Villa Nocito fueron reclutadas en la JUC, la JOC o el grupo Guía-Scout de La Pequeña Obra. Y "Pepe" consiguió armar un equipo de catequistas y responsables de las comunidades en Harding Green y Grünbein, 
convocando a jóvenes de la JOC. De modo similar, los voluntariados de Cáritas se consolidaron con el aporte de jóvenes integrantes de diversos grupos laicales.

Asimismo, los vínculos de confianza construidos en los movimientos especializados de juventud, o de modo más amplio, en la red de renovación católica local, favorecieron la integración de los militantes católicos a las organizaciones revolucionarias. Así como, una vez convencido de la necesidad de abrazar la política como alternativa privilegiada para el cambio social, Pablo se decidió por la agrupación universitaria ligada al PRT en virtud de la militancia previa de sus amigos del Pensionado, Mirta, Jorge o Paloma se acercaron al PB a partir de la invitación de Dante $\mathrm{y}$, de modo similar, lo hicieron los jucistas y jecistas a las agrupaciones de la Tendencia Revolucionaria del Peronismo. En el proceso de conformación de la UES, por ejemplo, es posible visualizar el rol de los lazos personales y el elemento afectivo. Los cruces entre los grupos de la "loma" y de La Pequeña Obra favorecieron la iniciativa común de algunos de ellos de fundar la UES en la ciudad, y la cercanía de la JUC y la JEC facilitó el reclutamiento de militantes católicos para la nueva organización por parte de los compañeros universitarios que entonces actuaban como referentes de la JP. Luego, la organización estudiantil se amplió con la llegada de otros jecistas que siguieron los pasos de compañeros o referentes del ámbito eclesial. Asimismo, la fundación de "la Sabino Navarro" en Sánchez Elía estuvo estrechamente ligada a los contactos entre miembros de los equipos de revisión de vida de la "loma". Una vez integrados a los grupos políticos, el conocimiento y confianza mutua construidos en el mundo eclesial, posibilitaron la adaptación de los actores al nuevo espacio y allanaron las tareas propias del activismo revolucionario, al tiempo que éstas fortalecieron aquellos lazos.

En relación con lo anterior, hemos visto que la dimensión afectiva fue un componente de la interacción que condicionó la acción y las decisiones individuales de los militantes, así como las prácticas colectivas, dentro del ámbito eclesial y más allá de éste. Así, la conformación de nuevos grupos laicales y el paso por los diversos movimientos de Iglesia y desde éstos a la acción social y política fueron vividos como un proceso colectivo/grupal. La comunidad era el espacio de vivencia de la fe y el sostén de la reflexión que llevó a "tomar conciencia" de las injusticias y a involucrarse para erradicarlas, y más tarde, de la revisión crítica de las propias prácticas militantes. Además, la experiencia comunitaria les había enseñado que había que unirse a proyectos colectivos para lograr el cambio del orden vigente. 
Por otra parte, ir a misa a Nuestra Señora del Carmen o a La Pequeña Obra, integrar el núcleo de dirigentes Guías y Scouts -lo que conllevaba reuniones, campamentos o actividades de servicio-, o participar de los encuentros de la JUC, la JOC y JEC eran una oportunidad, no sólo para vivir la fe y desarrollar un trabajo que en sí mismo hacía sentido para los actores, sino también -o incluso fundamentalmentepara encontrarse, compartir y divertirse con los referentes de vida, los amigos, y chicos y chicas de la misma edad. Estas convivencias establecían un tipo de sociabilidad en la que los compañeros eran también los amigos, las parejas, los hermanos, la familia.

Los grupos cristianos fueron al mismo tiempo, para los jóvenes, un refugio afectivo, un ámbito donde iban definiendo y fortaleciendo su personalidad, la confianza en sí mismos, donde podían hablar, expresarse, manifestar sus pareceres, sentimientos e ideas, a la vez ampliaban el horizonte de la vida social cotidiana que, en muchos casos, hasta entonces no había trascendido los límites de la familia, la escuela o el barrio, o bien, debía recrearse con nuevos vínculos ante la distancia geográfica, en los casos de los jóvenes que se habían venido a vivir a la ciudad para iniciar sus estudios terciarios o universitarios.

Así, el espacio religioso otorgaba un sentido de pertenencia y una identidad colectiva, y las prácticas ligadas a aquél ocupaban un lugar central en la vida diaria de los militantes. Vividos como "totalidad”, los grupos laicales respondían de una sola vez a diversas necesidades, inquietudes o demandas de los jóvenes, vinculadas a la práctica de fe, el compromiso, la formación, la diversión, la relación con los pares y con jóvenes del otro sexo. De allí, que las opciones vinculadas a distintas dimensiones personales estuvieran condicionadas por esa participación, por los valores y actitudes allí impresos y la dimensión afectiva puesta en juego, como es el caso de la elección del/la compañero/a, de la carrera o el trabajo. La colaboración que brindaban quienes no tenían militancia política a los activistas también se comprende en esa clave. Distribuir volantes o publicaciones partidarias, relevar paredones para futuras pintadas, guardar materiales o esconder compañeros perseguidos sin coincidir con las líneas políticas de las organizaciones político-militares encontraban sentido en la intención de brindar ayuda a los amigos.

Ahora bien, esta investigación muestra, como afirman Donatello y Catoggio (2010), que si la convicción en torno a un compromiso con el cambio del mundo motivó un camino ascendente en las carreras militantes, que en muchos casos llevó a los actores a proseguir su acción fuera del campo religioso, la socialización católica no condujo a 
un sendero unívoco sino que habilitó una diversidad de opciones político-religiosas. En este sentido, este trabajo intentó explorar un amplio abanico de formas y espacios de militancia que se han visto opacados por la centralidad que ocupó el fenómeno insurreccional tanto en los estudios sobre catolicismo liberacionista y política en los años setenta -a excepción de algunos abordajes-, como en los trabajos que en el campo de la historia reciente han hecho de la militancia "setentista" su objeto de investigación. Así, esta tesis reconstruyó experiencias diversas de acción, que no excluyeron la vía político-militar pero que la trascendieron, y que encontraron en el catolicismo liberacionista un origen e impulso particular. Entre ellas, se encuentran la participación en tareas pastorales, como referentes del MIEC-JECI y de la JOC, catequistas, animadores de la liturgia, responsables de comunidades dependientes de la capilla, dirigentes Scouts y Guías; el trabajo social y la presencia en los barrios periféricos, desde el voluntariado de Cáritas, la labor docente (en la escuela Nuestra Señora de la Paz) y las experiencias de "servicio" Scout (colectas de alimentos, campañas de ayuda a los inundados, asistencia a personas humildes puntuales, apoyo escolar y actividades de recreación para los niños de Villa Nocito, Villa Serra y Villa Quilmes, y asistencia a sus familias); la militancia en el lugar de trabajo, que incluía desde charlas personales con los compañeros hasta múltiples maneras de inserción en el espacio gremial (presencia en las asambleas, participación en el equipo de fútbol del sindicato, formación de listas y ocupación de cargos directivos), pasando por la formación de agrupaciones de base en las fábricas; la militancia universitaria, que comprendía la participación en asambleas, reuniones de las agrupaciones, actos relámpago, movilizaciones, tomas, y más tarde, cambio de autoridades, juicios académicos, iniciativas de vinculación de la universidad con el medio; el compromiso en la escuela secundaria, que abarcaba un amplio abanico de intervenciones con los compañeros, los profesores, a nivel de curso y de la institución, la promoción de actividades deportivas y culturales, la participación en las luchas estudiantiles (organización de los centros de estudiantes, asambleas, tomas de la escuela, etc.); y, por último, el activismo en agrupaciones políticas o político-militares, que englobaba diversos espacios (no sólo la universidad o la escuela sino también el barrio, el gremio, la fábrica) y prácticas (distribución de publicaciones y volantes, pintadas, movilizaciones, campamentos de trabajo, reuniones de lectura y discusión, etc.).

Estas múltiples formas de acción y construcción social y política incluyeron un tipo de militancia de carácter contestatario, que se explicitaba en el cuestionamiento al 
orden vigente y en la búsqueda de su transformación. Si la a denuncia de las injusticias en tanto situaciones de "pecado" se materializaban en documentos públicos, el anuncio de otro mundo posible, como crecimiento del Reino de Dios, era la contracara y la consecuencia inevitable de la actitud profética.

Los que asumieron el compromiso político entendieron que se trataba de una herramienta privilegiada para emprender la tarea transformadora, el camino más "eficaz" del amor cristiano. A partir de esta certeza, no obstante, se abrieron una diversidad de alternativas de participación concreta, que además en ocasiones fueron cambiando a lo largo del período 1968-1975. En este sentido, hemos intentado enriquecer y complejizar la mirada sobre las afinidades entre catolicismo liberacionista y la política contestataria atendiendo a los matices y vaivenes que los actores experimentaron en sus adscripciones político-partidarias. El análisis de trayectorias nos ha mostrado que muchos de estos jóvenes iniciaron su militancia en agrupaciones ubicadas en distintas vertientes de la izquierda (PRT, PCR), que parte de ellos mantuvo su activismo en esos espacios a lo largo de esos años, mientras otra "descubrió" el peronismo, constituyéndose en el posicionamiento político mayoritario de los jucistas, jocistas y jecistas bahienses desde 1972-1973. Sin embargo, esta identificación tampoco fue unívoca; por el contrario, los militantes se dividieron entre los que se unían a las organizaciones de la Tendencia, lideradas por Montoneros, y quienes se sumaban al Peronismo de Base, encontrándose también entre ellos militantes que transitaron por ambos, siendo las elecciones de 1973 un punto de inflexión en este proceso.

Además de las redes personales, las concepciones ideológicas y los repertorios de acción comunes, favorecieron el acercamiento de los jóvenes a la izquierda peronista. En el marco de una serie de afinidades previas entre peronismo y catolicismo, los actores bahienses, al igual que los Sacerdotes para el Tercer Mundo y el grupo de Cristianismo y Revolución, encontraron en el peronismo, en cuanto constituía un movimiento popular, el camino hacia la construcción del socialismo, la vía hacia la revolución en nuestro país. Su "opción por los pobres" llevó a estos jóvenes laicos a acercarse a los sectores desfavorecidos y a descubrir que éstos se identificaban, en su mayoría, con el movimiento liderado por Perón, y a entender entonces que si querían estar con el pueblo debían abrazar la identidad peronista.

Sin embargo, la identificación con los pobres y "oprimidos" y la necesidad de "inserción en la masa" también fueron relevantes en las trayectorias militantes que desembocaron en la izquierda no peronista. Si acercarse al "pueblo" o, mejor, al 
"proletariado" era una preocupación en la que confluían con sus compañeros no cristianos empujándolos a una mayor presencia territorial y a asumir modalidades de vida -a través del llamado a la "proletarización", por ejemplo-, para ellos, era un aspecto estrechamente ligado a su adscripción cristiana liberacionista.

Así, quienes decidieron encarnar su compromiso cristiano en las filas del PRTERP también encontraron afinidades entre su identidad católica y su pertenencia partidaria. Además de que el paso por grupos religiosos era común en las trayectorias de compañeros y dirigentes, un conjunto de formulaciones teórico-ideológicas y el entrecruzamiento de imaginario político, prácticas y postulados morales con elementos propios de la cultura religiosa cristiana favorecieron la "doble pertenencia" de los militantes en los dos espacios. En cuanto a los posicionamientos teóricos del partido, éstos estaban influidos por la postura de Santucho, quien compartía la concepción integral del catolicismo y le reservaba al cristianismo un papel central en el proceso revolucionario.

En el marco de la integración de los militantes a diversas organizaciones revolucionarias, la lucha armada emergió como una forma de hacer política. ¿Qué relación encontramos entre catolicismo liberacionista y lucha armada? Si bien no está a nuestro alcance aportar una respuesta acabada a este interrogante, podemos, en cambio, formular algunas reflexiones. En este sentido, creemos pertinente la afirmación de Donatello (2010), respecto de la existencia de una relación de "afinidad electiva" entre ambos fenómenos. A partir de ella, el autor caracterizó a Montoneros como una "comunidad de elegidos" y postuló el concepto de "aristocratismo de salvación" para dar cuenta de experiencias donde lo religioso se desplaza a la guerra. Este concepto alude a la representación existente en un grupo de sentirse elegidos para una causa sagrada, representación cuyas bases se gestaron al calor de los "procesos de selección" que los militantes católicos que se hicieron montoneros pasaron en distintos momentos de su vida, sumado al imaginario de ascenso social permanente arraigado en las capas medias argentinas.

Esta idea de que "Dios está de nuestro lado", en cuanto la causa por la que se luchaba era la instauración de una sociedad más justa, que no se agotaba en el Reino de Dios pero que lo acercaba, justificaba cualquier sacrificio, e incluso más, le daba a éste un lugar cargado de significado. Así, el militante estaba dispuesto a una entrega absoluta para el triunfo del proyecto revolucionario. Esa entrega implicaba no sólo vivir en función del activismo político con las consiguientes renuncias a los espacios 
cotidianos y afectos más cercanos -de la mano de la "proletarización", el abandono de los estudios universitarios o secundarios, la mudanza de barrio o de ciudad, la disminución del contacto con la familia, los amigos o el grupo eclesial-, sino también tomar la opción armada. De allí que el compañero de Rodolfo expresara que la forma superior de ser católico era ser montonero. Esto conllevaba abrazar el dilema de matar o morir. En estos militantes, la disposición a morir, que tenía raíz en la fe y en el ejemplo de Cristo, era mayor a la de matar, que entraba en contradicción con los principios morales, pero en la guerra -aún en una "guerra santa"-, matar era una posibilidad siempre presente, un sacrificio que se imponía. Al mismo tiempo, morir, dar la propia vida, los acercaba a Jesús. En palabras de Carlos Mugica: "Nada ni nadie me impedirá servir a Jesucristo y a su Iglesia, luchando junto a los pobres por su liberación. Si el Señor me concede el privilegio, que no merezco, de perder la vida en esta empresa, estoy a su disposición”. En la concepción revolucionaria, el encuentro con la muerte en el camino de la justicia convertía a sus protagonistas en mártires, a la vez que en héroes, más allá de que tuvieran un origen religioso u otras trayectorias. El martirio, resignificado así con un acento fuertemente político, bendecía/validaba/ habilitaba la construcción de un mundo y Hombre nuevos. De esta manera, la acción violenta estaba legitimada por este sentido sacrificial. En la concepción del sacrificio, entonces, encontramos una ligazón entre catolicismo liberacionista y lucha armada.

Ahora bien, en el cruce entre religión y política en las experiencias de los jóvenes laicos bahienses, es posible reconocer particularidades asociadas a cada una de las tres ramas especializadas. Por ejemplo, los militantes jocistas, en mayor medida que los estudiantes, hicieron de la acción pastoral parroquial un espacio privilegiado de su compromiso cristiano. Esta práctica estaba estrechamente ligada al arraigo de estos jóvenes en Nuestra Señora del Carmen o en las comunidades ligadas a aquélla, y se centró en la catequesis y la animación de la liturgia. En este campo de intervención, los jecistas de La Pequeña Obra tenían en la comunidad Guía-Scout su ámbito de trabajo pastoral privilegiado e, incluso, su lugar de pertenencia primordial.

Por otra parte, la JUC presentó mayor diversidad y movilidad interna en cuanto a las trayectorias político-ideológicas. Es decir, ni en la JOC ni en la JEC la opción política fue el camino de compromiso cristiano transitado por todos los militantes, pero quienes eligieron esa vía en la rama obrera se integraron al $\mathrm{PB}$, mientras los secundarios lo hicieron en la UES. Por el contrario, en la JUC convivieron militantes del PRT, del PCR, del PB, de la JP. La mayor profundidad temporal de la historia jucista respecto de 
la jecista hace que sea posible distinguir diversas etapas a lo largo del período respecto de las adscripciones partidarias, coincidiendo entre 1972 y 1975 ambos movimientos en su identificación con las organizaciones lideradas por Montoneros.

En este sentido, en la breve historia de la JEC bahiense -si comparamos los tres años de su desarrollo con los siete años de la JUC o la JOC- el proceso mediante el cual los militantes "descubrieron la realidad", la necesidad de comprometerse como cristianos para cambiarla y la política como alternativa posible -o incluso, la mejor- para ello, se presenta como más corto y acelerado que en las otras ramas especializadas de juventud. Esta "aceleración" en un contexto marcado no sólo por la efervescencia social sino por el avance de la violencia represiva, era justamente lo que estaba en el centro de las preocupaciones del asesor y los compañeros no activistas. Debe tenerse en cuenta, sin embargo, que una parte de este grupo, a pesar de su corta edad, tenía una larga militancia en el movimiento Scout y Guía, esto es, en otro espacio del cristianismo liberacionista local, lo que los fue familiarizando con las nuevas concepciones de la Iglesia y su relación con el mundo, así como con experiencias de acción pastoral, social y barrial, que se constituyeron en una plataforma significativa para el posterior "salto" a la política. De modo similar, actuaron sus experiencias previas y contemporáneas de participación estudiantil y de trabajo social, ligadas a las Escuelas Medias dependientes de la UNS.

Ahora bien, hemos visto que las relaciones entre catolicismo liberacionista y militancias contestatarias no estuvieron exentas de tensiones. En este sentido, esta tesis procuró avanzar sobre otro aspecto poco trabajado en los estudios existentes: el conflicto del militante que transita desde la perspectiva de un catolicismo integral que le da un sentido total a su vida a una opción vital que agudiza dramáticamente sus opciones.

Hemos constatado que las tensiones se manifestaron tanto a interior de los grupos de revisión de vida, o bien, en ciertos espacios de la red católica renovadora, como en los espacios de acción de los militantes, especialmente, en las organizaciones político-militares. Las primeras guardaban relación con las heterogeneidades de los equipos, que a su vez resultaban de los tipos y espacios de militancias asumidos por los jóvenes y de sus opciones ideológico-políticas. Esto es, por un lado, con la construcción de una suerte de jerarquía que colocaba al activismo político como estadio superior de compromiso cristiano, en tanto constituía el camino más “eficaz" para la construcción del Hombre Nuevo, mientras las otras maneras de encarnar el compromiso cristiano, y 
concretamente el trabajo asistencial y social, ocupaban un lugar secundario, si bien habían sido fundamentales en la "toma de conciencia" de la situación de los marginados y la identificación con su condición y su causa; y por el otro, con el hecho de que el auténtico encuentro de militantes con diversas concepciones políticas resultaba un desafío. De esta manera, el pluralismo de la JUC, la JOC y la JEC fue difícil de asimilar y, en la práctica, fue opacándose al calor de un lento proceso de homogeneización en torno a las concepciones políticas predominantes.

Por otra parte, se plantearon conflictos en el cruce del mundo católico con el que lo rodeaba y llegó un momento que la "doble pertenencia" resultó difícil de transitar en la práctica. En primer lugar, la comunidad del centro pastoral La Pequeña Obra -a la que pertenecía parte de los jucistas y jecistas- se partió ante el creciente compromiso político de los jóvenes y su opción por el peronismo. En segundo lugar, el ejercicio de la revisión de vida fue perdiendo profundidad en los equipos de la JUC, la JOC y la JEC en la medida en que el carácter contestatario del activismo político de sus integrantes en un escenario de clandestinidad y de avance de la represión, restringía los temas de reflexión. En tercer lugar, mientras se replicaron los encuentros semanales y la política se convertía en una opción cada vez más significativa para los jóvenes, la práctica de los militantes en las organizaciones revolucionarias fue frecuentemente cuestionada, poniéndose en conflicto la dinámica de funcionamiento de ambos espacios.

En cuarto lugar, existían reservas de distinto tipo en las agrupaciones políticas respecto de la militancia cristiana de estos jóvenes. Por un lado, para algunos militantes de la izquierda no peronista (PCR, PC) resultaba compleja la tarea de conciliar su fe católica y/o su pertenencia eclesial con su participación partidaria y el postulado marxista que rezaba que la religión era el "opio de los pueblos". En las trayectorias de izquierda (PCR, PRT), distintos factores -como crisis de fe y concepciones ideológicas contradictorias, sumadas a las diferencias políticas en el caso de Luis, y dinámica "integral"/ "total" del activismo político, en el de Pablo- se combinaron para hacer que la experiencia en los grupos de revisión de vida culminara tempranamente. Por otro lado, en la Tendencia Revolucionaria del Peronismo la pertenencia de sus activistas al ámbito eclesial despertaba desconfianza porque se trataba de un espacio que quedaba fuera de control de la organización y planteaba el interrogante de en qué medida aquél comprometía la clandestinidad de ciertas iniciativas políticas o la seguridad de los compañeros. 
Por otra parte, la participación en organizaciones políticas donde el ejercicio de la violencia era una posibilidad cotidiana planteaba dilemas particulares a los actores. Primero, en los propios militantes surgían cuestionamientos morales a las acciones violentas. Si había una común disposición a la entrega absoluta para el triunfo del Reino de Dios, incluso dejando la propia vida, la posibilidad de matar no dejaba de resultar problemática a la luz del ejemplo de Cristo y los documentos del magisterio de la Iglesia. Segundo, quienes estaban convencidos del camino revolucionario implicaba sacrificios -incluso la aceptación de prácticas reñidas con la moral- contribuían a construir otra jerarquía de formas de acción contestataria que se superponía con aquella que colocaba a la política como opción superior, ubicando la lucha armada en la cima de las alternativas, lo que generaba reproches al interior de los grupos cristianos y, en no pocas ocasiones, una sensación de "culpa" en quienes no estaban dispuestos a dar el paso hacia las armas. Tercero, la cuestión despertaba fuertes diferencias políticas entre los militantes, acrecentándose las rupturas con el pase a la clandestinidad de Montoneros y el recrudecimiento de la represión. Cuarto, estaban los conflictos que se le presentaban a los militantes de "superficie" que adherían al proyecto revolucionario y pretendían, al mismo tiempo, quedar al margen de la lucha armada, pero resultaban involucrados en los operativos de la organización guardando armas o publicaciones, escondiendo compañeros, prestando el auto o la casa o repartiendo partes de guerra, lo que los exponía, de todos modos, a la represión. Por último, y ligado a lo anterior, para estos activistas, no abrazar la lucha armada pero estar dispuesto a ejercer la violencia en grados menores, era fuente de contradicciones.

En la introducción planteamos que, en la medida en que este trabajo hacía foco en lo local, aspiraba a aportar a la construcción de la historia de este período y su comprensión desde diferentes dimensiones, complejizando la mirada y poniendo en cuestión evidencias aceptadas en otros estudios sobre los procesos y actores estudiados. En este sentido, al analizar cómo un grupo de hombres y mujeres con rostros concretos experimentaron localmente el cruce entre religión y política durante los años de efervescencia social y política, la presente investigación pretendía mostrar aspectos nuevos, matizar explicaciones construidas desde una mirada nacional -o, más bien, centradas en la realidad porteña y proyectadas como explicación general-, y poner entre paréntesis periodizaciones consagradas.

En efecto, como también adelantamos entonces, esta tesis muestra asincronías o velocidades diferentes, planteando una distancia respecto de los hitos y cesuras de la 
cronología nacional y alumbrando una temporalidad diferente en el desarrollo de las ramas especializadas de juventud. Como ocurre con otras investigaciones inscriptas en el espacio local ${ }^{1343}$, las presentes páginas relativizan las concepciones y dataciones sobre el desarrollo y crisis -en este caso- de la JUC, la JOC y la JEC que entiendo más ajustadas a las experiencias de otras ciudades. Sin disputar la validez de esas interpretaciones en su propia inscripción regional, el análisis de los grupos de revisión de vida bahienses cuestiona su validez general. Como nos muestran los derroteros del caso que nos ocupa, en primer lugar, hubo una experiencia jucista que se desarrolló en la ciudad en los primeros años sesenta y que encontró su ocaso hacia 1966-1967 como consecuencia de dos procesos que afectaban simultáneamente a la conducción nacional: por un lado, la "politización" de los cuadros y, por otro, el abandono del ministerio sacerdotal por parte de los asesores. Es decir, ya fuera que los jóvenes optaran por alguna forma de marxismo o que comenzaran a descubrir al peronismo, lo político fue viéndose, cada vez más, como el cauce del compromiso histórico. Y la situación de los sacerdotes les trajo serios cuestionamientos, acelerando su conflicto al interior de la Iglesia. El ingreso masivo a lo político no fue acompañado entonces por una reflexión teológica y un apoyo espiritual. La institución no llegaba a contener las inquietudes de los jucistas. Así, llegó el éxodo de los militantes, ligado a una crisis de pertenencia a la Iglesia e, incluso, a una crisis de fe. El viaje de Manuel por el país, en 1971, confirmó este panorama de la JUC en distintos lugares del interior, asociado a la opción políticomilitar de sus integrantes. Por otra parte, las publicaciones del MIEC-JECI y las reflexiones de los asesores en otros puntos del continente daban cuenta de que las dificultades de los movimientos de apostolado laico planteadas por los desafíos de su compromiso político constituían un problema común a los diversos equipos latinoamericanos en el período 1969-1973.

En segundo lugar, se desarrolló una nueva experiencia jucista en Bahía Blanca entre 1967 y 1975, que fue objeto de las reflexiones de esta tesis. Si la datación y las causas del fin de la primera JUC bahiense se inscribe plenamente en el proceso general, esta segunda JUC local marchó entonces a contramano de lo que ocurría en otras ciudades del país e incluso del continente. Las agrupaciones universitarias de izquierda, que antaño habían recibido el flujo de jucistas que abrazando la política abandonaban el espacio eclesial, ahora se convertían en uno de los espacios de reclutamiento de nuevos

$\overline{{ }^{1343} \text { Por ejemplo, la de Alonso (2010) }}$ referida al movimiento de derechos humanos en Santa Fe. 
militantes de la JUC. Este grupo bahiense nació y alcanzó pleno auge -lo que se puso de manifiesto en el protagonismo que tuvo entonces en el secretariado nacional y latinoamericano del MIEC-JECI o en la representación del país en los encuentros mundiales- en el momento en que otros movimientos de jóvenes universitarios habían dejado de existir o entraban en decadencia. Esto marca, en consecuencia, un desfase temporal en la constitución de este movimiento respecto del de Buenos Aires y otras regiones del interior, y unido a ello, su relativa soledad, a excepción de algunos otros grupos que, incluso, debían su formación a la iniciativa de los bahienses, como el de Mar del Plata o Santa Rosa.

La desestructuración de los equipos de revisión de vida locales, formados por universitarios y secundarios, se inscribe, como hemos visto, en las tensiones femilitancia que habían atravesado al MIEC-JECI. Sin embargo, al mismo tiempo, las trayectorias bahienses muestran, por un lado, que a diferencia de otras experiencias, los militantes no experimentaron tanto una pérdida de sentido de su fe religiosa y un "desencanto" con la Iglesia que los llevara a una necesidad de trascender sus límites, rompiendo con ella, sino la dificultad de abrazar dos proyectos "integrales" -dos espacios de pertenencia que demandaban una dedicación intensa- en momentos de represión creciente. Es decir, no se trataba tanto de un problema de crisis de fe, de desgaste de la identidad católica, de la aparición de cuestionamientos novedosos respecto de la institución eclesial/el movimiento de estudiantes u obreros católicos, o de la constatación de que sus dinámicas constituían una suerte de obstáculo para "hacer carne" el compromiso cristiano, sino de que la presencia concreta de los activistas revolucionarios en el mundo religioso -así como en otros ámbitos como la familia, el barrio, la escuela, la universidad, la fábrica, etc.- resultaba cada vez más problemática a medida que la militancia impregnaba íntegramente la cotidianeidad de los jóvenes y se volvía una actividad secreta y riesgosa. Y aquí se plantean matices divergentes respecto de interpretaciones como las de Donatello (2005), construidas en base a otras trayectorias y escenarios, que hacen foco en la ruptura de la pertenencia eclesial de los militantes al momento de concretarse la inserción en el espacio político-partidario, ligada a las limitaciones de la institución eclesial para satisfacer el impulso a la acción contestataria de los jóvenes. Si tomamos el esquema típico de funcionamiento de los movimientos de apostolado laico frente a la cuestión de la "politización", propuesto por Mallimaci (1988) -al que hemos hecho referencia en el capítulo 7-, la partida de los bahienses de la JUC, la JOC o la JEC tuvo más que ver, en todo caso, con el 
“establecimiento de prioridades" en un escenario muy concreto de clandestinización de las prácticas políticas y de persecución, que con desencuentros entre "tiempos y lugares" de la institución eclesial y los movimientos sociales.

Por otro lado, el foco que hemos intentado colocar en un vasto abanico de experiencias de militancia cristiana nos permite identificar los dilemas de la "doble pertenencia" entre el ámbito de participación eclesial y el espacio de concreción del compromiso, como un asunto emergente de un tipo particular de alternativa de acción la política-, vinculado a la pertenencia a determinadas organizaciones más que a otras y en los que se pueden reconocer diferentes etapas y matices a lo largo del período estudiado. Al mismo tiempo, muestra una diversidad de formas de convivencia, complementariedad, de síntesis entre participación en los equipos de revisión de vida y construcción "temporal", que se mantuvo hasta el final del período en cuestión, existentes en las formas de militancia social, barrial, eclesial e incluso política en los casos de los activistas con menores niveles de responsabilidad en las organizaciones revolucionarias. De allí que lejos de encontrar un modo unívoco de integrar la pertenencia eclesial y la militancia, los actores tuvieron múltiples experiencias, en relación con los tipos y ámbitos de acción, el nivel de encuadramiento en las agrupaciones político-militares, las adscripciones partidarias, el contexto político inmediato y las trayectorias religiosas previas. Estos cruces, complejos y variados, entre identidad católica, o más específicamente jucista/jecista/jocista, y acción contestataria ya se habían evidenciado entre los primeros jucistas bahienses: si bien muchos jóvenes plantearon un quiebre con la comunidad cristiana cuando se sumaron a organizaciones de izquierda, otros, como Ángel, se mantuvieron en los dos espacios.

La experiencia bahiense también contribuyó a complejizar la mirada respecto de los modos en que las teologías de la liberación han influido en los grupos católicos renovadores en nuestro país. Donatello $(2005,2010)$ ha destacado la importancia de la teología de la cultura en el caso argentino, dándole singularidad al mismo, en detrimento de la teología de la liberación. Según el autor, fue fundamentalmente la primera corriente la que brindó elementos y sembró las bases éticas para modalidades de acción de los actores. Según hemos visto en este trabajo, sin embargo, tanto el asesor como los jóvenes de las ramas estudiantiles y obreras de Acción Católica, si bien no dejaban de consultar autores como Lucio Gera, Rafael Tello o Juan Carlos Scannone, recibían los lineamientos teológicos fundamentales de las obras de Gustavo Gutiérrez. Los mismos materiales de formación que el Secretariado Latinoamericano del MIEC- 
JECI ofrecía a los equipos de estudiantes católicos del continente, incluido los bahienses, incluían un abanico amplio de temas y enfoques que podrían ubicarse, siguiendo la clasificación propuesta por Scannone, en distintas corrientes de las teologías de la liberación. No obstante, se destaca la incidencia de los planteos de Gutiérrez a partir de su actuación como asesor de la UNEC y de los contactos personales establecidos por los militantes y miembros del SLA de origen local con el teólogo en los encuentros celebrados por el movimiento en Lima. Laicos y sacerdotes, además, explicitaron entonces sus discrepancias teóricas con los partidarios de la teología de la cultura, tanto en el movimiento juvenil como al interior del MSTM.

Una visión más abarcadora y matizada de los movimientos especializados de juventud en los años sesenta y setenta en el cruce con la política, que permita dar cuenta del fenómeno en su conjunto como de sus especificidades locales y regionales, requerirá de nuevos estudios, así como de comparaciones sistemáticas.

Por último, este trabajo abre una serie de caminos posibles de indagación. Avanzar sobre el análisis de las sociabilidades y las trayectorias político-religiosas de los grupos laicales liberacionistas en Bahía Blanca y Punta Alta del período 1967-1975, el abordaje de las trayectorias, experiencias e identidades de los ex integrantes de la JUC, la JOC y la JEC bahienses desde la desestructuración de estos grupos en 1975 en adelante, o el estudio de las identidades, las formas de objetivación y las huellas de las memorias sobre el pasado reciente de los sectores católicos renovadores en Bahía Blanca desde la transición democrática hasta la actualidad, son algunas de ellas. 


\section{FUENTES Y BIBLIOGRAFÍA}

\section{FUENTES}

\section{Fuentes orales}

\section{a. Entrevistas realizadas por la autora a:}

i. Integrantes de la JUC bahiense

Aída, Buenos Aires, 17/5/2013.

Ángel, Buenos Aires, 8/10/2009.

Eduardo, Bahía Blanca, 20/5/2008 y 16/10/2008.

Elena, Bahía Blanca, 17/6/2010.

Elsa, Bahía Blanca, 9/3/2012.

Graciela, Buenos Aires, 31/7/2008.

Héctor, Bahía Blanca, 1/5/2010.

José Zamorano, Moreno, 19/9/2009 y 2/9/2011.

Juan Carlos, Buenos Aires, 19/7/2008 y 1/8/2010.

Julio, Bahía Blanca, 22/5/2010.

Luis, Bahía Blanca, 18/12/2008.

Manuel y Nancy, Neuquén, 20/3/2013 y 21/3/2013.

María, Bahía Blanca, 21/2/2013 y 28/2/2013.

Marta, Bahía Blanca, 29/5/2008.

Nora, Bahía Blanca, 4/6/2008.

Nora y Rodolfo, Bahía Blanca, 2/4/2009.

Pablo, Neuquén, 19/3/2013.

Patricia, Bahía Blanca, 26/10/2008 y 19/5/2008.

Patricia y Eduardo, Bahía Blanca, 21/3/2008.

Roberto, Bahía Blanca, 18/4/2013.

Rodolfo, Bahía Blanca, 23/6/2008.

Susana, Bahía Blanca, 1/4/2009.

\section{ii. Integrantes de la JOC bahiense}

Angélica, Bahía Blanca, 25/4/2012.

Bruno, Bahía Blanca, 4/8/2012. 
Clara, Bahía Blanca, 10/10/2012.

Dante, Bahía Blanca, 28/9/2011 y 15/3/2012.

Ema, Bahía Blanca, 27/9/2012.

José, Bahía Blanca, 19/6/2008.

Liliana, Bahía Blanca, 25/6/2008.

Lucy, Neuquén, 18/3/2013.

Mirta, Bahía Blanca, 18/6/2008.

Mirta y Jorge, Bahía Blanca, 11/4/2012 y 14/7/2012.

Paloma, vía skype Bahía Blanca-Orrefors, 7/2/2013, 11/2/2013, 12/2/2013, 2/2/2013, 1/3/2013.

Silvestre, vía e-mail, 29/10/2012.

\section{iii. Integrantes de la JEC bahiense}

Alicia, Bahía Blanca, 9/7/2011.

Ana, Bahía Blanca, 17/10/2012.

Carlos, Bahía Blanca, 4/5/2011.

Cecilia, Bahía Blanca, 2/6/2011.

Eugenia, Bahía Blanca, 30/12/2012.

Francisco, Buenos Aires, 16/11/2012.

Gabriel, Bahía Blanca, 27/10/2012 y 7/11/2012.

Gustavo, Bahía Blanca, 12/7/2011 y 9/8/2012.

Inés, Bahía Blanca, 18/6/2011.

Juan, 31/5/2011, 24/8/2011 y Bahía Blanca, 14/8/2012.

María del Carmen, Bahía Blanca, 18/5/2011.

Mario, Bahía Blanca, 5/1/2013.

Marisa, Neuquén, 19/3/2013.

Mónica, Buenos Aires, 30/7/2008 y 9/11/2011.

Norma, Bahía Blanca, 8/4/2011 y 6/8/2011.

Pedro, Buenos Aires, 15/11/2012 y 16/11/2012.

Ricardo, Bahía Blanca, 8/10/2011.

iv. Referentes e integrantes de otros grupos católicos liberacionistas locales.

Alberto, Bahía Blanca, 29/8/2012. 
Benjamín Stocchetti, vía e-mail, 25/7/2012, 13/8/2012, 8/1/2013, 10/1/2013, 8/3/2013.

Ester, Bahía Blanca, 14/12/2010.

Fernando, Bahía Blanca, 16/11/2010 y 30/11/2010.

Hugo Segovia, Mar del Plata, 27/5/2010.

Miguel Sarmiento, Punta Alta, 29/11/2010 y 11/2/2011.

Néstor Navarro, Bahía Blanca, 18/11/2010.

Norma Gorriarán, Bahía Blanca, 29/10/2008.

Rosita Rodríguez, Bahía Blanca, 29/4/2009.

Zulma, Bahía Blanca, 25/8/2010.

v. Compañeros de militancia política de los jucistas y/o "acercados" a la JUC.

Diana, Buenos Aires, 18/9/2009.

Julia, Buenos Aires, 17/9/2009.

Beatriz, Bahía Blanca, 23/4/2009.

b. Entrevistas realizadas por los integrantes del Taller literario "Relatar" de los Abuelos Relatores por la Identidad, la Memoria y la Inclusión Social, en compañía de la autora, a ex residentes del Pensionado Católico:

Alberto Monge, Beto Migliorisi y Miguel Ponce de León, Bahía Blanca, 21/8/2012.

Beto Migliorisi, Bahía Blanca, 16/8/2012.

Miguel Ponce de León, Bahía Blanca, 30/7/2012.

c. Entrevistas realizadas durante el 2010 por los alumnos de la Escuela Normal Superior en el marco del Proyecto "Jóvenes y Memoria" a (ex) miembros de la comunidad Guía-Scout de La Pequeña Obra:

José Zamorano, Moreno.

María Laura Barral, Bahía Blanca.

Lilia Real, Bahía Blanca.

Daniel Bedetti, Bahía Blanca.

Susana Garbiero, Susana López y Graciela Gallego, Bahía Blanca. 


\section{d. Audios radiales}

Entrevistas a Julio Ruiz, ex integrante de la JOC, realizadas por el periodista Mauro Llaneza para el programa "El Juicio desde la calle", 9 y 11 , octubre y noviembre de 2011, transmitidos por FM de la Calle, Bahía Blanca.

\section{Fuentes escritas}

a. Testimoniales de ex miembros de la JUC, la JEC o la JOC o de otros espacios de la renovación católica bahiense

“Julio Ruiz. Las formas del destino", en: David, 2006.

"Historia de la JOC", "El por qué de mi militancia en la JOC" y "Por qué y cómo milité en el PB", apuntes no publicados de Paloma elaborados en paralelo a la serie de entrevistas que compartimos por skype y enviados a la autora vía e-mail, febrero y marzo de 2013.

"Era cura pero su elección de vida fue tener hijos. Miguel Sarmiento, ex párroco del movimiento tercermundista, en un retrato realizado por su hijo Gustavo, periodista de este diario", Tiempo Argentino, 20/6/2010.

"Testimonio del Padre Néstor H. Navarro, actual Obispo de la diócesis del Alto Valle de Río Negro", Horizontes. Publicación periódica de Cáritas Bahía Blanca, 36, agosto-septiembre de 2009.

"Biancucci, Duilio", en: Diana, 2013.

"Stochetti, Benjamín”, en: Diana, 2013.

“Zamorano, José”, en: Diana, 2013.

"Entrevista: Santecchia, Benito. 15 de diciembre de 1990 en el Instituto Salesiano de Estudios Teológicos, Buenos Aires", en: Martín, 2013.

Santecchia, Benito (2008). Carta al Padre José Juan del Col SBD, sábado 12 de abril de 1975, en: AA.VV. Homenaje a Benito Ángel Santecchia. Testimonios, crónicas, documentos, escritos, estudios. Bahía Blanca-Buenos Aires: Instituto Superior Juan XXIII, Proyecto, Centro de estudios salesianos. 
Santecchia, Benito (2008) Notas sobre una “Publicación” aparecida en Bahía Blanca (1972-1973), 15 de junio de 1975, citado en Vanzini, 2008: 62.

Segovia, Hugo (2008). La palabra provocadora, en: AA.VV. Homenaje a Benito Ángel Santecchia. Testimonios, crónicas, documentos, escritos, estudios. Instituto Superior Juan XXIII de Bahía Blanca, Proyecto, Centro de estudios salesianos de Buenos Aires.

"Entrevista con Emma Vila, Canciller del Arzobispado de Bahía Blanca", Horizontes. Publicación periódica de Cáritas Bahía Blanca, 36, agosto-septiembre de 2009.

"La justicia llega y con ella la paz a los corazones" (testimonio de Lilí Real, quien trabajó en la escuela de Cáritas en Villa Nocito), Anuario 2011 Cáritas Bahía Blanca.

“1970”, en: Esapi de Oro. Publicación de la Comunidad Guía-Scout de La Pequeña Obra de Bahía Blanca, 7, octubre de 2011.

Lince Observador, "Nosotros cuatro", en: Esapi de Oro. Publicación de la Comunidad Guía-Scout de La Pequeña Obra de Bahía Blanca, 7, octubre de 2011.

María Laura Barral, “Por qué recordarlos?”, en: Esapi de Oro. Publicación de la Comunidad Guía-Scout de La Pequeña Obra de Bahía Blanca, 7, octubre de 2011.

Susana Garbiero y Alejandro "Chicho" Cantaro, "Diáspora", en: Esapi de Oro. Publicación de la Comunidad Guía-Scout de La Pequeña Obra de Bahía Blanca, 7, octubre de 2011.

Susana Garbiero, "A corazón abierto", en: Esapi de Oro. Publicación de la Comunidad Guía-Scout de La Pequeña Obra de Bahía Blanca, 7, octubre de 2011.

Tato (Castor Leal), "Carta a María Clara", en: Esapi de Oro. Publicación de la Comunidad Guía-Scout de La Pequeña Obra de Bahía Blanca, 7, octubre de 2011.

Emilio Flores, "Un saludo", en: Esapi de Oro. Publicación de la Comunidad Guía-Scout de La Pequeña Obra de Bahía Blanca, 7, octubre de 2011 . 
María Inés Vila, “¿Por qué GUÍA?”, en: 50 Ruca Hueney. "Nuestra forma de ser". 1963-2013.

\section{b. Producción literaria de los protagonistas}

Anónimo (1999). "Hecubú-Mapú, país del diablo. Cuentos Argentinos". Archivo personal de Juan.

Julio Ruiz (2010). "La lección de geografía", "El Panzazo", "Canillita", "Bicicletas", "El avión”, en: Abuelas Relatoras por la Identidad, la Memoria y la Inclusión Social, Recuerdos y Presencias. Bahía Blanca: Mussini Industria Gráfica.

Julio Ruiz (2011). "Nos vemos a la salida", en: Abuelos Relatores por la Identidad, la Memoria y la Inclusión Social, Caminando la Memoria. Bahía Blanca: PAMI.

\section{c. Correspondencia y textos personales}

Cartas y postales enviadas por Eduardo a su familia, así como las enviadas a él o a su familia, durante su viaje por América Latina como integrante del SLA del MIEC-JECI, 1971 y 1972.

Carta de Duilio Biancucci a Monseñor Jorge Mayer, 27/12/1972, Legajo de Duilio Biancucci, Archivo Histórico Salesiano Patagónico.

Carta de Duilio Biancucci dirigida a Jorge Mayer, 3/5/1975, Legajo de Duilio Biancucci, Archivo Histórico Salesiano Patagónico.

Apuntes de una reunión de la JUC, durante un campamento de verano en Pehuen-có, 16/1/1970. Archivo personal de Julio e Irene.

Apuntes de Benito Santecchia, Legajo de Benito Santecchia, Archivo Histórico Salesiano Patagónico.

\section{d. Declaraciones de la JUC, la JOC y la JEC, y otros grupos laicales liberacionistas locales:}

Declaración (volante) de la Juventud Universitaria Católica de Bahía Blanca, sobre la "Revolución Argentina", sin fecha. Archivo DIPPBA, Mesa A, Estudiantil, Juventud Universitaria Católica, Localidad Bahía Blanca, Legajo No 111. 
Declaración (volante) de la comunidad de la parroquia María Auxiliadora de Punta Alta, de octubre de 1970, Archivo DIPPBA, Mesa "Referencia", Legajo No 15281, Tomo V.

Declaración (volante) de la JUC, la JOC, la Comunidad Universitaria Bahiense y el Grupo Misionero Bahiense, titulada "Medios de comunicación social en Bahía Blanca. ¿Qué persigue La Nueva Provincia?", sin fecha (hacia diciembre de 1970). Archivo DIPPBA, Mesa "Referencia”, Legajo No 15281, Tomo V.

Carta de un grupo de laicos bahienses dirigida a Diana Julio de Massot, titulada "Nuestro dolor y nuestra protesta", Cristianismo y Revolución, 28, abril 1971.

Declaración de la Juventud Universitaria Católica, el Grupo Misionero Bahiense, la Juventud Obrera Católica, la Comunidad Universitaria Bahiense y la Juventud de Acción Católica de Punta Alta, titulada "Militante cristiano secuestrado y torturado en Punta Alta", Cristianismo y Revolución, 30, septiembre de 1971.

Declaración (volante) de la JUC en ocasión de la Masacre de Trelew, de agosto de 1972, titulado "A los compañeros estudiantes", Mesa "D(s)", Carpeta Varios, Legajo 383, Tomo 1. FONDO DIPPBA División Central de Documentación, Registro y Archivo.

Declaración de la JUC sobre el proyecto del Camino de Cintura, en: "Bahía Blanca ¿polo de crecimiento?”, Revista Graphos, 11, noviembre de 1972.

Declaración (volante) de la CUB, la JUC, la JOC, la JEC y Cáritas, del 23/12/1973. Archivo personal de Mirta y Jorge.

"Los militantes de la JUC y su inserción en las agrupaciones universitarias", documento extractado de un informe presentado al encuentro nacional de la JUC en Bahía Blanca, en enero de 1965, por JUC de la Arquidiócesis de Buenos Aires, incluido en: Armada, 1970.

"El conflicto entre la comunidad religiosa y la militancia política", del informe preparado por JUC de Buenos Aires para el encuentro de dirigentes nacionales de la JUC en Ramos Mejía, realizado del 4 al 7 de febrero de 1967, incluido en: Armada, 1970. 


\section{d. Fuentes periodísticas locales y nacionales}

Diario La Nueva Provincia (Biblioteca Popular Bernardino Rivadavia).

Diario El Eco (Biblioteca Popular Bernardino Rivadavia).

Diario El Sureño (Biblioteca Popular Bernardino Rivadavia).

Diario La Nación

Diario La Opinión (Archivo DIPPBA).

Diario Página 12 (disponible en:

http://www.pagina12.com.ar/usuarios/anteriores.php).

Revista Graphos (Biblioteca Popular Bernardino Rivadavia).

Revista Reporte. La revista puntaltense (Archivo personal de Miguel Sarmiento).

Revista Nuevo Hombre (Archivo de Julia Giménez).

Revista Así (Archivo de Julia Giménez).

e. Publicaciones confesionales y católicas oficiales locales, nacionales y latinoamericanas

Revista Pablo (Archivo DIPPBA).

Boletín El Mensajero de la Juventud Obrera Católica de Grünbein (Archivo personal de Mirta y Jorge).

Revista Cristianismo y Revolución (colección completa editada en versión facsimilar por el Centro de Documentación e Investigación de la Cultura de Izquierdas en Argentina-CEDINCI).

Publicaciones del Secretariado Latinoamericano del MIEC-JECI (Biblioteca del Colegio Máximo de San Miguel y archivos personales de Mónica y Juan Carlos, Nora y Rodolfo, y María y Roberto):

América Latina Boletín

Boletin Spes

Servicio de Documentación

JEC. Boletin Secundario 
Boletín eclesiástico. Boletín oficial del Arzobispado de Bahía Blanca, correspondiente a los años 1939-1976 (Archivo del Arzobispado de Bahía Blanca).

\section{f. Documentos de los Papas y obispos:}

Concilio Vaticano II. Constitución Pastoral "Gadium et Spes". La Iglesia en el mundo contemporáneo, 1965. Buenos Aires: Ediciones Paulinas, 1979.

Documento de San Miguel: declaración del Episcopado Argentino sobre la adaptación a la realidad actual del país de las conclusiones de la II Conferencia General del Episcopado Latinoamericano (Medellín), 1969. En: Documentos del Episcopado Argentino (19651981). Buenos Aires: Editorial Claretiana, 1982.

Mater et Magistra. Encíclica de S. S. Juan XXIII sobre el reciente desarrollo de la cuestión social, 1961. Buenos Aires: Ediciones Paulinas, 1966.

Mensaje de 18 obispos del Tercer Mundo, 15/8/1967. En: Bresci, 1994.

Pacem in Terris. Carta encíclica de su santidad el Papa Juan XXIII, 1963. Buenos Aires: Ediciones Paulinas, 1967.

Populorum Progressio. Carta encíclica de su santidad Pablo VI, 1967. Buenos Aires, Ediciones Paulinas, 1977.

Segunda Conferencia General del Episcopado Latinoamericano. Medellín. Septiembre de 1968. Documentos Finales. III Edición. Córdoba, Talleres Tipográficos de la Pía Sociedad de San Pablo, 1969.

\section{g. Documentos del MSTM y sus integrantes:}

Carta del Secretariado proponiendo realización de 'hechos significativos' en ocasión de la Navidad, 3/12/1969.

Coincidencias Básicas, 3/5/1969.

Comunicado del Tercer Encuentro Nacional, 2/5/1970.

Comunicado de los 60 sacerdotes que se entrevistaron con Perón, 9/12/1972. 
Crónica sobre los hechos de Navidad, diciembre de 1968.

Declaración Compromiso de Navidad, diciembre de 1968.

Declaración de Coordinadores, Secretario y Secretariado sobre el retorno de Perón al país, 4/12/1972.

Documento de trabajo preparado por los grupos que proponen un nuevo encuentro nacional, 22/8/1974.

Documento del Cuarto Encuentro Nacional, 9/7/1971.

Documento en el que se repudia la iniciativa del General Onganía de consagrar el país a la Virgen, noviembre de 1969.

Documento final del Quinto Encuentro Nacional, 19/10/1972.

Informe del secretariado para discutir en los grupos del movimiento sobre "Peronismo y Socialismo" y "conflictos eclesiásticos", $10 / 12 / 1970$.

Nuestra Reflexión, 11/10/1970.

Política y Pastoral, 4/1969.

Síntesis de la encuesta enviada a los miembros del movimiento sobre "Peronismo-socialismo" en preparación del Cuarto Encuentro Nacional, 7/8/1971.

Síntesis de las Conclusiones de los equipos regionales, 3/5/1969.

En: Bresci, 1994.

Concatti, Rolando (1972). Nuestra opción por el peronismo. Buenos Aires.

Mugica, Carlos (1973). Peronismo y cristianismo. Buenos Aires: Merlín.

\section{h. Documentos de Inteligencia}

Archivo DIPPBA (documentos solicitados como investigadora a la Comisión Provincial por la Memoria o correspondientes a las fichas personales de Norma Gorriarán y Pablo, facilitados por los propios protagonistas).

"El Movimiento Sacerdotal para el Tercer Mundo". Comando de Operaciones Navales de la Base Naval Puerto Belgrano. Archivo del Área Cultura, Sociedad y Religión, CEIL-PIETTE, CONICET. 


\section{i. Varios}

Volante firmado por la "Asamblea estudiantes el Juan XXIII". Mesa “D(s)", Carpeta Varios, Legajo 383, Tomo 1. FONDO DIPPBA

División Central de Documentación, Registro y Archivo.

Volante titulado "Asamblea estudiantil". Mesa A, Estudiantil, Localidad Bahía Blanca, Legajo $N^{\circ}$ 47. FONDO DIPPBA División Central de Documentación, Registro y Archivo.

Volante firmado por la "Asamblea estudiantil Guillermo López" del 7/9/1972. Mesa "D(s)", Carpeta Varios, Legajo 383, Tomo 1. FONDO DIPPBA División Central de Documentación, Registro y Archivo.

Volante titulado "La mentira de patas cortas" del 25/8/1972. Mesa A, Estudiantil, Localidad Bahía Blanca, Legajo $\mathrm{N}^{\circ}$ 47. FONDO DIPPBA División Central de Documentación, Registro y Archivo.

Libro de designaciones de la Escuela Nuestra Señora de la Paz de Villa Nocito. Archivo del Arzobispado de Bahía Blanca.

Arzobispado de Bahía Blanca, Guía Arquidiocesana. 1997. Bahía Blanca: Talleres gráficos de la obra salesiana "La Piedad".

Plan de desarrollo de Bahía Blanca. Publicación de la Municipalidad de Bahía Blanca. Bahía Blanca, 1971.

Reformulación del Plan de Desarrollo Urbano de Bahía Blanca. Plan Director. Departamento Planeamiento Urbano, Dirección de Ordenamiento Urbano y Planificación, Secretaría de Obras y Servicios, Municipalidad de Bahía Blanca, 1983.

Cancionero utilizado en misas y celebraciones de los grupos católicos liberacionistas en 1973. Archivo personal de Nora y Rodolfo.

"Historia de la JOC en Bahía Blanca", apuntes s/f (probablemente de comienzos de la década de 1980) elaborados por la JOC de Grünbein a partir de los relatos de Mirta y Jorge. Archivo personal de Mirta y Jorge.

"Campamento Universitario de Trabajo", volante s/f (probablemente de 1966), Archivo personal de Julio e Irene. 
Agrupación Ignacio Rucci, "Iglesia Cristo Rey", volante arrojado en las calles del barrio Nueva Bahía de Punta Alta en el otoño de 1974. Archivo personal de Miguel Sarmiento.

Estatuto aprobado en Buenos Aires el 23 de agosto de 1966; Carta al jefe Batallón 181 de Comunicaciones y al intendente municipal, del 8 de marzo de 1966; Carta a la dirección de promoción y desarrollo de la comunidad, 19 de febrero de 1973; Memorias de los ejercicios 1970-1972 y 1973-1974; Carta al comandante del V Cuerpo de Ejército, 23 de mayo de 1974; "Una obra piloto una magnífica lección. Villa Rosario. Bahía Blanca”, Cultura Popular, 25, marzo abril, mayo junio 1974, en: Carpeta "Comisión Mundial de Lucha Contra el Hambre" (Archivo Cáritas Bahía Blanca).

Legajos de los salesianos Duilio Biancucci, Benito Santecchia y Carlos Dorñak (Archivo Histórico Salesiano Patagónico).

Pasaporte de Eduardo. Archivo personal de Eduardo.

\section{Fuentes audiovisuales}

\section{a. Fotografías}

Sobre el Pensionado Católico, los Scouts y Guías de La Pequeña Obra y de Nuestra Señora del Carmen, campamentos de la JUC, encuentros, ordenaciones sacerdotales, cumpleaños, casamientos, actividades del MIEC-JECI, pertenecientes a la comunidad GuíaScout de La Pequeña Obra; Cáritas; los Abuelos Relatores por la Identidad, la Memoria y la Inclusión Social; Miguel Sarmiento, Julia Pizá, Eduardo, Liliana, Juan y Héctor (Archivo personal).

\section{b. Filmación de la comunidad Guía-Scout de La Pequeña Obra, a principios de los '70.}

\section{Fuentes virtuales}

http://juiciobahiablanca.wordpress.com, cobertura periodística de los juicios orales por delitos de lesa humanidad cometidos bajo control operacional del Comando V Cuerpo de Ejército y la Armada 
Argentina desde la Base Naval de Puerto Belgrano y las causas en instrucción contra el Terrorismo de Estado y la Triple A.

http://www.arsomos.org.ar/itlp/q/, micrositio de Don Bosco Argentina Sur (ARS).

http://m.aciprensa.com/noticia.php? $\mathrm{n}=6535$, portal católico. Noticias, recursos, controversias, información de la Iglesia en América, España y el mundo.

http://bahiagris.blogspot.com.ar/, memorias sobre el terrorismo de Estado en Bahía Blanca y Punta Alta. Trabajo colectivo de reconstrucción de la historia local del genocidio, abierto por el periodista Diego Martínez. Su objetivo es "enfrentar al silencio cómplice con la difusión de la verdad y la exigencia de justicia”.

http://radiofuturalaplata.blogspot.com.br/2011/05/nuevo-impulsopara-el-enjuiciamiento-de.html, página de Radio Futura, donde se puede escuchar el audio de la entrevista realizada a Alicia Leichuk el $16 / 5 / 2011$.

http://www.comisionporlamemoria.org/archivo/?page $\mathrm{id}=3$, página del Archivo de la Dirección de Inteligencia de la Policía de la Provincia de Buenos Aires, que está bajo custodia y gestión de la Comisión Provincial por la Memoria. 


\section{BIBLIOGRAFÍA}

Abuelos Relatores por la Identidad, la Memoria y la Inclusión Social (2012). Voces de la memoria. Pensionado de Zapiola 428, Bahía Blanca. Bahía Blanca: PAMI.

Agesta, Nieves (2009). Proyecciones en imágenes: prensa ilustrada y cultura visual en el proceso de modernización de Bahía Blanca (1909-1910). Tesis de Magíster en Sociología de la Cultura y Análisis Cultural, IDAES, UNSAM.

Agesta, Nieves (2013). Mundos de papel. Las revistas en el proceso de modernización cultural de Bahía Blanca (1902-1927). Tesis de Doctorado en Historia, Departamento de Humanidades, Universidad Nacional del Sur, Bahía Blanca.

Águila, Gabriela (2008). Dictadura, represión y sociedad en Rosario (1976/1983). Un estudio sobre la represión y los comportamientos y actitudes sociales en dictadura. Buenos Aires: Prometeo.

Águila, Gabriela (2012). La Historia Reciente en la Argentina: un balance. Historiografías, 3, 62-76.

Águila, Gabriela (2013). La represión en la historia reciente argentina: perspectivas de abordaje, conceptualizaciones y matrices explicativas. Contenciosa, 1, 13pp.

Agulhon, Maurice (1966). La sociabilité méridionale. Confréries et associations en Provence orientale dans la deuxième moitié du XVIIIe siècle. Aix-en-Provence: La Pensée Universitaire.

Agulhon, Maurice (2009). El círculo burgués. Buenos Aires: Siglo Veintiuno Editores. Alonso, Luciano (2010). Integración e impacto del movimiento por los derechos humanos en una ciudad del litoral argentino, en: Bohoslavsky, Ernesto et al. Problemas de Historia Reciente en el Cono Sur. Buenos Aires: UNGS-Prometeo.

Altamirano, Carlos (2001a). Bajo el signo de las masas (1943-1973). Buenos Aires: Ariel.

Altamirano, Carlos (2001b). Peronismo y cultura de izquierda. Buenos Aires: Temas Grupo Editorial.

Amaral, Samuel (1993). Introducción. Perón en el exilio: la legitimidad perdida, en: Amaral, Samuel y Plotkin, Mariano, Perón: del exilio al poder. Buenos Aires: Cántaro. Ameigeiras, Aldo (2006). El abordaje etnográfico en la investigación social, en: Vasilachis de Gialdino, Irene (coord.), Estrategias de Investigación Cualitativa. Barcelona: Gedisa. 
Ameigeiras, Aldo (2008). Catolicismo y pluralidad religiosa o pluralidad de catolicismos, en: Mallimaci, Fortunato (comp.), Modernidad, religión y memoria. Buenos Aires: Colihue.

Ameigeiras, Aldo (2014). La Iglesia católica y los DDHH en la Argentina; de la dictadura militar a la consolidación democrática, en $V$ Coloquio Internacional Religión y símbolo - Religión y DDHH, México.

Anguita, Eduardo y Caparrós, Martín (1997). La Voluntad. Una historia de la militancia revolucionaria en la Argentina. Tomo 1/ 1966-1973. Buenos Aires: Grupo Editorial Norma.

Ansaldi, Waldo (2004). Matriuskas de terror. Algunos elementos para analizar la dictadura argentina dentro de las dictaduras del Cono Sur, en: Pucciarelli, Alfredo (coord.), Empresarios, tecnócratas y militares. La trama corporativa de la última dictadura militar. Buenos Aires: Siglo XXI.

Ansaldi, Waldo (2010). Las dictaduras del Cono Sur y las transiciones a la democracia hasta la actualidad (1964-2005), en: La historia reciente como desafío a la investigación y pensamiento en Ciencias Sociales, CAICYT CONICET (http://ecursos.caicyt.gov.ar), Argentina.

Archetti, Eduardo (1988). Ideología y Organización Sindical: las Ligas Agrarias del norte de Santa Fe. Desarrollo Económico, 111, 447-461.

Armada, Arturo (1970). Los documentos del proceso, en: Mayol, Alejandro, Habegger, Norberto y Armada, Arturo, Los católicos posconciliares en la Argentina. Buenos Aires: Editorial Galerna.

Aróstegui, Julio (1998). Historia y Tiempo Presente. Un nuevo horizonte de la historiografía contemporaneista/ Conclusión, Cuadernos de historia contemporánea, 20.

Barletta, Ana María y Tortti, María Cristina (2002). Desperonización y peronización en la universidad en los comienzos de la partidización de la vida universitaria, en: Krotsch, Pedro, La universidad cautiva. La Plata: Ediciones Al margen.

Bayer, Osvaldo (1993). Di Giovanni y la teoría de los dos demonios. La polémica Abós-Bayer, en: Rebeldía y Esperanza. Buenos Aires: Grupo Editorial Zeta.

Bazcko, Bronslaw (1984). Los imaginarios sociales. Memorias y esperanzas colectivas. Buenos Aires: Nueva Visión. 
Beigel, Fernanda (2005). Vida, muerte y resurrección de las "teorías de la dependencia", en: AA.VV., Crítica y teoría en el pensamiento social latinoamericano. Buenos Aires: CLACSO.

Bertaux, D. (1996). Historias de casos de familias como método para la investigación de la pobreza. Revista de Sociedad, Cultura y Política, 1, 3-32.

Bianchi, Susana (1990). La Iglesia Católica en los orígenes del peronismo, Anuario IEHS, 5, 71-90.

Bidegain, Ana María (1979). La organización de movimientos de Juventud de Acción Católica en América Latina. El caso de obreros y estudiantes en Brasil y Colombia. 1930-1955. Tesis doctoral en Ciencias Históricas. Universidad Católica de Lovaina, Lovaina.

Bidegain, Ana María (2009). Participación y protagonismo de las mujeres en la historia del catolicismo latinoamericano. Buenos Aires: San Benito.

Blanco, Jessica (2008). Componentes identitarios del imaginario de la Juventud Obrera Católica. Cuadernos de Historia. Serie Economía y Sociedad, (Área de Historia del CIFFyH-Universidad Nacional de Córdoba), 10, 1-40 pp.

Blanco, Jessica (2010). Los diversos orígenes de la Juventud Obrera Católica en Argentina y su inserción en el campo católico, en: Vidal, Gardenia y Blanco, Jessica (comps.), Catolicismo y política en Córdoba, siglos XIX y XX. Córdoba: Ferreyra editor. Blanco, Jessica (2011). Mundo sindical, esfera política y catolicismo en Córdoba, 19401955. La Juventud Obrera Católica durante el peronismo. Tesis de Doctorado en Historia. Universidad Nacional de Córdoba, Córdoba.

Blanco, Jessica (2012) La Juventud Obrera Católica y la política: entre la lealtad peronista y la identidad católica. Prohistoria, 17, 101-128.

Boff, Clodovis (1990). Epistemología y método de la teología de la liberación, en: Ellacuría, Ignacio, Sobrino, Jon et al., Mysterium Liberationis. Conceptos fundamentales de la teología de la liberación. Madrid: Editorial Trotta.

Bohoslavsky, Ernesto et al. (2010). Problemas de Historia Reciente en el Cono Sur. Buenos Aires: UNGS-Prometeo, 2 tomos.

Bonavena, Pablo (2010). Notas sobre el movimiento estudiantil de Bahía Blanca (19661973), en: Buchbinder, Pablo, Bonavena, Pablo, Califa, Sebastián, Millán, Mariano, Vega, Natalia y Yuszczyk, Erica, Apuntes sobre la formación del movimiento estudiantil argentino (1943-1973). Buenos Aires: Final Abierto. 
Bonavena, Pablo (2012). El movimiento estudiantil secundario: del golpe de Onganía al Cordobazo, en: Actas de las VII Jornadas de Sociología de la UNLP, La Plata. Disponible en: http://jornadassociologia.fahce.unlp.edu.ar

Borja, J. (1998). Ciudadanía y seguridad urbana. (Una reflexión europea). Barcelona (mimeo).

Bottinelli, Leandro et al. (2001). La JOC. El retorno de Cristo Obrero, en: Mallimaci, Fortunato y Di Stefano, Roberto (comps.), Religión e imaginario social. Buenos Aires: Manantial.

Bozza, Juan Alberto (2001). El peronismo revolucionario. Itinerario y vertientes de la radicalización, 1959-1969. Sociohistórica, Cuadernos del CISH, 9/10,135-169.

Bracamonte, Lucía (2011). Feminismo y derechos de las mujeres: representaciones de género en la prensa católica bahiense a principios del siglo XX. La Aljaba. Revista de Estudios de La Mujer, 15, 29-56.

Bracamonte, Lucía (2012). Mujeres benefactoras en el sudoeste bonaerense argentino: el caso del Patronato de la Infancia de Bahía Blanca (1906-1931). Historelo. Revista de historia regional y local, 7, 48-84.

Bracamonte, Lucía, Torre, Elena y Vila, Emma (2004). Misión Escuela Nuestra Señora de la Paz, en: Dulcísimo Recuerdo de mi vida. 90 años del Colegio La Inmaculada. Bahía Blanca 1913-2003. Buenos Aires: Colegio Inmaculada.

Brennan, James (1996). El Cordobazo. Las guerras obreras en Córdoba.1955-1976. Buenos Aires: Editorial Sudamericana.

Bresci, Domingo (1994). Movimiento de Sacerdotes para el Tercer Mundo. Documentos para la memoria histórica. Buenos Aires: Centro Salesiano de Estudios San Juan Bosco, Centro Nazaret, Comisión de Estudios de Historia de la Iglesia en Latinoamérica (CEHILA).

Buchbinder, Pablo (2005). Historia de las universidades argentinas. Buenos Aires: Sudameriana.

Buffa, Norma (1994). Inmigración y movimiento obrero en Bahía Blanca durante la primera década del siglo XX. Sus ideologías, en: Felix Weiberg (dir.), Estudios sobre inmigración II. Bahía Blanca: Departamento de Humanidades (UNS).

Burkart, Mara (2007). La dictadura militar y su proyecto de transformación cultural, en: Actas de las XI Jornadas Interescuelas/Departamentos de Historia, Tucumán.

Cabezas, Gonzalo (2012). Representaciones sobre la industria metalúrgica bahiense en los testimonios orales de antiguos trabajadores del rubro, en: Cernadas, Mabel y 
Marcilese, José (comp.), Mundo del Trabajo, organizaciones sindicales y conflictividad. Memorias obreras en Bahía Blanca durante el siglo XX. Bahía Blanca: Universidad Nacional del Sur.

Caimari, Lila (1994). Perón y la Iglesia Católica. Buenos Aires: Ariel.

Calveiro, Pilar (2005). Antiguos y nuevos sentidos de la política y la violencia. Lucha Armada en la Argentina, 4, 4-19.

Calveiro, Pilar (2008). Política y/o violencia. Una aproximación a la guerrilla de los años 70. Buenos Aires: Verticales de bolsillo.

Campos, Esteban (2010). Salidos del guetto. Del diálogo entre cristianos y marxistas al Comando Camilo Torres (1965-1971). Lucha Armada en la Argentina, Anuario 2010, 130-147.

Carassai, Sebastián, (2010). Antes de que anochezca. Derechos humanos y clases medias en Argentina antes y en los inicios del golpe de Estado de 1976. América Latina Hoy, 54, 69-96.

Carnovale, Vera (2005). "Jugarse al Cristo": mandatos y construcción identitaria en el Partido Revolucionario de los Trabajadores-Ejército Revolucionario del Pueblo (PRTERP). Entrepasados, 28, 11-26.

Carnovale, Vera (2007). Memorias, espacio público y Estado: la construcción del Museo de la Memoria, en: Stabili, María Rosaria (coord.), Entre historias y memorias. Los desafios metodológicos del legado reciente de América Latina, Colección Estudios AHILA de Historia Latinoamericana, 2, Madrid/Frankfurt: Iberoamericana/ Verveurt.

Carnovale, Vera (2012). Lazos de sangre. Afectividad y totalidad en el Partido Revolucionario de los Trabajadores-Ejército Revolucionario del Pueblo (PRT-ERP). Páginas. Revista Digital de la Escuela de Historia. Universidad Nacional de Rosario, 6, 81-99.

Catoggio, Soledad (2010a). Contestatarios, Mártires y Herederos. Sociabilidades político-religiosas y ascesis altruista del catolicismo argentino en la dictadura y posdictadura, Tesis doctoral, Facultad de Ciencias Sociales, Universidad de Buenos Aires, Buenos Aires.

Catoggio, Soledad (2010b). Cambio de hábito. Trayectorias de religiosas durante la última dictadura militar argentina. Latin American Research Review, Vol. 45, 2, 27-48. Catoggio, Soledad (2011). Mártires y sobrevivientes: figuras de la violencia política en los años sesenta y setenta. Lucha Armada en la Argentina, Anuario 2011, 100-110. 
Cattaruzza, Alejandro (1997). El mundo por hacer. Una propuesta para el análisis de la cultura juvenil en la Argentina de los años setenta. Entrepasados, 13, 103-114.

Cavarozzi, Marcelo (2004). Autoritarismo y democracia. Buenos Aires: Eudeba.

Caviglia, Jorgelina (1993). Ingeniero White. La huelga de 1907. Bahía Blanca:

Ediciones de la Cocina del Museo del Puerto de Ingeniero White.

Caviglia, Jorgelina (2003). Inmigrantes en Bahía Blanca, 1880-1914. Unitec, 13. Accesible en http://www.frbb.utn.edu.ar/utec/utec/13/n03.html.

Cernadas de Bulnes, Mabel (1999). Apuntes para la caracterización de la cultura política socialista en Bahía Blanca: Nuevos tiempos 1930-1936. Buenos Aires: Academia Nacional de la Historia.

Cernadas de Bulnes, Mabel (comp.) (2001). Historia, politica y sociedad en el Sudoeste bonaerense. Bahía Blanca: Universidad Nacional del Sur.

Cernadas de Bulnes, Mabel (2003). La construcción de la ciudadanía en un espacio provincial: Bahía Blanca en la época del Centenario (1928). Disponible en http://historiapolitica.com/datos/biblioteca/Mabel_Bulnes.pdf.

Cernadas de Bulnes, Mabel y Marcilese, José (compiladores) (2012). Mundo del Trabajo, organizaciones sindicales y conflictividad: memorias obreras en Bahía Blanca durante el siglo XX. Bahía Blanca: Universidad Nacional del Sur.

Cernadas de Bulnes, Mabel (dir.) (2006). Universidad Nacional del Sur. 1956-2006. Bahía Blanca: Universidad Nacional del Sur.

Chama, Mauricio (2007). Movilización y politización: abogados de Buenos Aires entre 1968 y 1973, en: Perotin-Dumon, Anne, (dir.), Historizar el pasado vivo en América Latina. Libro electrónico, disponible en: http://www.historizarelpasadovivo.cl/

Colectivo Viceversa (2009). Plan de estudio Licenciatura en Economía (UNS) de 1972, documento de trabajo presentado como material de discusión en las II Jornadas de Economía Crítica. Crisis Mundial y Nacional: alternativas teóricas y políticas frente a la ortodoxia, Bahía Blanca.

Crespi Valls, Antonio (1955). Primer centenario de la Legión agrícola militar: 18561956. Bahía Blanca: Municipalidad, Museo histórico.

Cruz Feliciano, Héctor (2012). El nuevo sandinismo y el hombre nuevo: ideología y formación de cuadros en el FSLN, en: Fernández Hellmund, Paula Daniela (comp.), Nicaragua: problemas, estudios y debates de la historia reciente, 1979-2011. Bahía Blanca: Ediciones del CEISO; Centro de Estudios de América Latina Contemporánea. 
Cucchetti, Humberto (2005). Religión y Política en Argentina y en Mendoza (19431955): lo religioso en el primer peronismo. Documento de trabajo. Buenos Aires: CEIL-PIETTE.

Cucchetti, Humberto (2007). Articulaciones religiosas y politicas en experiencias peronistas: memoria política e imaginario religioso en trayectorias de la Organización Única del Trasvasamiento Generacional, Tesis doctoral en co-tutela entre la Universidad de Buenos Aires y la École des hautes études en sciences sociales, Buenos Aires.

Cucchetti, Humberto (2010). Combatientes de Perón, herederos de Cristo. Peronismo, religión secular y organizaciones de cuadros. Buenos Aires: Prometeo.

David, Guillermo (2006). Perón en la chacra asfaltada, Figuras del peronismo bahiense. Punta Alta: Ediciones de Barricada.

De Riz, Liliana (1987). Retorno y derrumbe. El último gobierno peronista. Buenos Aires: Hyspamérica.

Deaux, Kay y Martin, Daniela (2003). Interpersonal networks and social categories: specifying levels of context in identity processes. Social Psychology Quarterly, Volumen 66, N², pp. 101-117.

Del Pino, Ponciano y Jelin, Elizabeth (comps.). (2003) Luchas locales, comunidades e identidades. Madrid: Siglo XXI.

Devés Valdés, Eduardo (2003). El pensamiento latinoamericano en el siglo XX. Tomo II. Desde la CEPAL al neoliberalismo (1950-1990). Santiago: Biblos, DIBAM.

Di Stefano, Roberto y Zanatta, Loris (2000). Historia de la Iglesia Argentina. Desde la conquista hasta fines del siglo XX. Buenos Aires: Grijalbo-Mondadori.

Di Stefano, Roberto y Mallimaci, Fortunato (2001). Los grupos religiosos frente a un mundo que se derrumba. Los imaginarios cristianos de la década del treinta, en: Mallimaci, Fortunato y Di Stefano, Roberto (compiladores), Religión e imaginario social. Buenos Aires: Manantial.

Diana, Marta (2013). Buscando el Reino. Buenos Aires: Planeta.

Diburzi, Nélida (2005). La huelga de hambre del '68 en la Universidad Católica de Santa Fe. Entre la protesta reivindicativa y el cuestionamiento social, en: Actas de las $X$ Jornadas Interescuelas/Departamentos de Historia, Rosario.

Diburzi, Nélida (2007). El movimiento estudiantil universitario santafesino en la segunda mitad de los '60. Discurso posconciliar y radicalización ideológica, en: Actas de las XI Jornadas Interescuelas/Departamentos de Historia, Tucumán. 
Dominella, Virginia (2008). Memorias y experiencias del exilio de los militantes cristianos en Bahía Blanca, 1974-1976, en: XI Congreso Solar Desde nuestro sur mirando nuestra América, Bahía Blanca.

Dominella, Virginia (2010a). Espacios y prácticas de la militancia católica en Bahía Blanca (Argentina) a fines de los '60 y principios de los '70. Ánfora, 29, 29-44.

Dominella, Virginia (2010b). ¿Qué persigue La Nueva Provincia? El diario bahiense y el catolicismo post-conciliar en la primera mitad de la década de 1970, en: Actas de las V Jornadas de Trabajo sobre Historia Reciente, Los Polvorines.

Dominella, Virginia (2010c). Afinidades y tensiones entre religión y política en las trayectorias militantes de los integrantes de la Juventud Universitaria Católica en Bahía Blanca (1968-1975), en: Actas de las II Jornadas Catolicismo y Sociedad de masas, Buenos Aires.

Dominella, Virginia (2011). Las redes sociales del catolicismo post-conciliar en Bahía Blanca (1968-1975), en: Actas de las II Jornadas de Religión y Sociedad en la Argentina Contemporánea y países del Cono Sur (RELIGAR-SUR)- IV Jornadas de Religión y Sociedad en Argentina, Buenos Aires.

Dominella, Virginia (2012a). Memorias de la militancia y la violencia política de integrantes de la Juventud Universitaria Católica en Bahía Blanca (1968-1975). Sociedad y Religión. Sociología, Antropología e Historia de la Religión en el Cono Sur, $37,12-54$

Dominella, Virginia (2012b). Catolicismo y política en Argentina en los años '60 y '70. Apuntes sobre las implicancias políticas del aggiornamento eclesial y la opción por el peronismo, en: Actas de las VII Jornadas de Sociología de la Universidad Nacional de La Plata, La Plata. Disponible en:

http://jornadassociologia.fahce.unlp.edu.ar/search?Subject\%3Alist=Mesa11

Dominella, Virginia (2013). Chicos comunes, militantes, mártires. La rememoración de víctimas católicas bahienses del terrorismo de Estado en los homenajes de 2011. Aletheia, 7. Disponible en: http://www.aletheia.fahce.unlp.edu.ar/front page.

Dominella, Virginia (2014a). "Hacer el Reino de Dios presente". Acción social y política contestataria de los integrantes de la Juventud Estudiantil Católica en Bahía Blanca (1972-1975), en: Fernández Hellmund, Paula y Millán, Mariano (comps.), Organizaciones y movimientos sociales en la Argentina reciente (1966-2012). Buenos 
Aires: Ediciones del CEISO, Instituto de Investigaciones Gino Germani (Facultad de Ciencias Sociales, Universidad de Buenos Aires), 65-104.

Dominella, Virginia (2014b). Las repercusiones de la "Masacre de Trelew" en Bahía Blanca y Punta Alta, en: Actas de las VII Jornadas de Trabajo sobre Historia Reciente, Ensenada [en prensa].

Dominella, Virginia (2014c). Afinidades y tensiones entre religión y política en las trayectorias de los militantes de la Juventud Obrera Católica en Bahía Blanca, (19681975). Ciencias Sociales y Religión/Ciências Sociais e Religiao, 20, 39-57.

Dominella, Virginia, Fernández Albanesi, Florencia, Montero, María Lorena, Rodríguez, Andrea Belén, Seitz, Ana Inés, Vidal, Ana, Zapata, Belén (2009). Marcas locales de la dictadura en Bahía Blanca, en: II Seminario Internacional Políticas de la Memoria “Vivir en dictadura. La vida de los argentinos entre 1976 y 1983 ”, Buenos Aires.

Dominella, Virginia, Giménez, María Julia, Montero, María Lorena, Seitz, Ana Inés, Vidal, Ana (2010). Pensar "La Escuelita" como un espacio de memoria. Boletín del Núcleo Memoria, 18.

Dominella, Virginia y Montero, Lorena (2007). La Historia intervenida: Rupturas y continuidades en las materias de la carrera de historia de la UNS (1973-1976), en: Actas del XI Congreso de Historia de los Pueblos de la provincia de Buenos Aires, Bahía Blanca.

Donatello, Luis (2002). Ética católica y acción política. Los Montoneros: 1966-1976, Tesis de Maestría de la Facultad de Ciencias Sociales, Universidad de Buenos Aires, Buenos Aires.

Donatello, Luis (2003). Religión y política: las redes sociales del catolicismo postconciliar y los Montoneros 1966-1973, Estudios Sociales, 24, 89-112.

Donatello, Luis (2005). El catolicismo liberacionista en la Argentina y sus opciones político-religiosas. De la efervescencia social de los sesenta a las impugnaciones al neoliberalismo en los noventa, Tesis en co-tutela entre la Facultad de Ciencias Sociales de la Universidad de Buenos Aires y la École des hautes études en sciences sociales, Buenos Aires.

Donatello, Luis (2005a). Catolicismo liberacionista y política en la Argentina: de la política insurreccional en los setenta a la resistencia al neoliberalismo en los noventa. América Latina Hoy, 41, 77-97. 
Donatello, Luis (2005b). Aristocratismo de la Salvación. El catolicismo "liberacionista" y los Montoneros. Prismas. Revista de Historia Intelectual, 9, 241-258.

Donatello, Luis (2008). La última dictadura militar como problema teológico político, en: Mallimaci, Fortunato (comp.), Modernidad, religión y memoria. Buenos Aires: Colihue.

Donatello, Luis (2010). Catolicismo y Montoneros. Religión, política y desencanto. Buenos Aires: Manantial.

Donatello, Luis y Catoggio, Soledad (2010). Sociabilidades católicas y carreras militantes. Lucha Armada en la Argentina, Anuario 2010, 148-155.

Dri, Rubén (2011). La hegemonía de los cruzados. La Iglesia Católica y la dictadura militar. Buenos Aires: Biblos.

Dussel, Enrique (1990). Teología de la liberación y marxismo, en: Ellacuría, Ignacio, Sobrino, Jon et al., Mysterium Liberationis. Conceptos fundamentales de la teología de la liberación. Madrid: Editorial Trotta.

Ellacuría, Ignacio (1990a). La Iglesia de los pobres, sacramento histórico de liberación, en: Ellacuría, Ignacio, Sobrino, Jon et al., Mysterium Liberationis. Conceptos fundamentales de la teología de la liberación. Madrid: Editorial Trotta.

Ellacuría, Ignacio (1990b). Historicidad de la salvación cristiana, en: Ellacuría, Ignacio, Sobrino, Jon et al., Mysterium Liberationis. Conceptos fundamentales de la teología de la liberación. Madrid: Editorial Trotta.

Ellacuría, Ignacio (1990c). Utopía y profetismo, en: Ellacuría, Ignacio, Sobrino, Jon, et al., Mysterium Liberationis. Conceptos fundamentales de la teología de la liberación. Madrid: Editorial Trotta.

Errazu de Mendiburu, Delia, Rey, María y Abraham, Norma (1970). La industria en Bahía Blanca, 1900-1914. Bahía Blanca: Universidad Nacional del Sur.

Fanduzzi, Natalia (2007). Embestidas y contragolpes: la definición del trabajo en el puerto de Ingeniero White a principios del siglo XX, en: Cernadas, Mabel y Marcilece, José (comp.), Cuestiones políticas, socioculturales y económicas del Sudoeste Bonaerense: actas de las IV Jornadas interdisciplinarias del sudoeste bonaerense. Bahía Blanca: Universidad Nacional del Sur, 377-384.

Feierstein, Daniel (2000). Seis estudios sobre genocidio. Análisis de las relaciones sociales: otredad, exclusión y exterminio. Buenos Aires: EUDEBA.

Fernández, Sandra (comp.) (2007). Más allá del territorio. La historia regional y local como problema. Discusiones, balances y proyecciones. Rosario: Prohistoria. 
Fernández, Bruno Leonardo (2007). Legalización de la prostitución en la región de Bahía Blanca, en: Cernadas, Mabel y Marcilese, José (eds.), Cuestiones políticas, socioculturales y económicas del Sudoeste Bonaerense: actas de las IV Jornadas interdisciplinarias del sudoeste bonaerense. Bahía Blanca: Universidad Nacional del Sur, 259-264.

Formiga, Nidia y Marenco, Silvia (coord.) (2000). La dinámica urbana. El proceso de desarrollo vertical y la problemática de la marginalidad urbana en Bahía Blanca. Bahía Blanca: Editorial de la Universidad Nacional del Sur.

Forni, Floreal (1987). Catolicismo y peronismo. Revista Unidos, 14, 211-226; 17; 18, $120-144$

Franco, Marina y Levín, Florencia (comps.) (2007). Historia Reciente. Perspectivas y desafios para un campo en construcción. Buenos Aires: Paidos.

Freytes, Nadia (2008). Mujeres que hicieron historia. Un acercamiento a la militancia estudiantil y política de los años '70 desde la historia oral, en: Actas de las $I V$ Jornadas de Trabajo sobre Historia Reciente, Rosario.

Gera, Lucio y Rodríguez Melgarejo, Guillermo (1970). Apuntes para una interpretación de la iglesia argentina. Montevideo: Ediciones del Centro de Documentación MIECJECI.

Gillespie, Richard (1987). Soldados de Perón. Los Montoneros. Buenos Aires: Grijalbo. Gilman, Claudia (2003). Entre la pluma y el fusil. Debates y dilemas del escritor revolucionario en América Latina. Buenos Aires: Siglo XXI.

Giménez, María Julia (2008). Ciudad de "Perros". Historias de militancia y recorridos del PRT-ERP por la ciudad de Bahía Blanca. Tesis de Licenciatura en Historia, Departamento de Humanidades, Universidad Nacional del Sur, Bahía Blanca.

Giménez, María Julia (2009). Revista Graphos, tribuna del movimiento estudiantil en Bahía Blanca (1970-1973), en: Romero, Fernando Gabriel (comp.), Los estudiantes. Organizaciones y luchas en Argentina y Chile. Bahía Blanca: Libros en Colectivo.

Giménez, María Julia (2014). Las políticas penitenciarias al servicio de la lucha antisubversiva: la cárcel de Bahía Blanca y los presos políticos entre 1973 y 1976. Tesis de Maestría en Historia y Memoria, Facultad de Humanidades y Ciencias de la Educación, Universidad Nacional de La Plata.

Giménez Béliveau, Verónica (2005). Sociabilidades de los laicos en el catolicismo en la Argentina. Un recorrido socio-histórico. Prismas. Revista de Historia Intelectual, 9, 217-227. 
Gómez De Souza, Luis Alberto (1984). A JUC: Os Estudantes Católicos e a Política. Petrópolis: Vozes.

González Bernaldo de Quirós, Pilar (2008). La “sociabilidad” y la historia política. Mundo Mundos Nuevos, BAC -Biblioteca de Autores del Centro, [En línea], puesto en línea el 17 de febrero de 2009. URL: http://nuevomundo.revues.org/24082. Consultado el 19 de abril de 2012.

Gordillo, Mónica (2003). Protesta, rebelión y movilización: de la resistencia a la lucha armada, en: James, Daniel (comp.), Violencia, proscripción y autoritarismo (19551976), Nueva Historia Argentina, Tomo 9. Buenos Aires: Editorial Sudamericana.

Grammático, Karin (2005). Las mujeres políticas y las feministas en los tempranos setenta. ¿Un diálogo (im)posible?, en: Andujar, Andrea y otras (comp.), Historia, género y política en los '70. Buenos Aires: Feminaria Editora.

Guerra, Francois Xavier (1985). México, del Antiguo Régimen a la Revolución. París: L'Harmattan.

Guglielmucci, Ana (2006). Dar la vida y la muerte por la revolución. Moral y política en la praxis militante. Lucha Armada en la Argentina, 5, 72-91.

Gutiérrez, Gustavo (1971). Teología de la liberación. Perspectivas. Lima: Editorial universitaria, CEP.

Gutiérrez, Gustavo (1990). Pobres y opción fundamental, en: Ellacuría, Ignacio, Sobrino, Jon et al., Mysterium Liberationis. Conceptos fundamentales de la teología de la liberación. Madrid: Editorial Trotta.

Habegger, Norberto (1970). Apuntes para una historia, en: Mayol, Alejandro, Habegger, Norberto y Armada, Arturo, Los católicos posconciliares en la Argentina. Buenos Aires: Editorial Galerna.

Healey, Mark (2003). El interior en disputa: proyectos de desarrollo y movimientos de protesta en las regiones extrapampeanas, en: James, Daniel (comp.), Violencia, proscripción y autoritarismo (1955-1976), Nueva Historia Argentina, Tomo 9. Buenos Aires: Sudamericana.

Hilb, Claudia (2001). La responsabilidad como legado. Puentes, 5, 50-61.

James, Daniel (1990). Resistencia e Integración. El peronismo y la clase trabajadora argentina. 1946-1976. Buenos Aires: Editorial Sudamericana.

Jensen, Silvina (2010). Diálogos entre la historia local y la historia reciente en Argentina. Bahía blanca durante la última dictadura militar, en: XIV Encuentro de 
Latinoamericanistas Españoles. Santiago de Compostela. Disponible en http://hal.archivesouvertes.fr/docs/00/53/11/87/PDF/AT10_Jensen.pdf.

Kaufman, Alejandro (2005). Legado paradójico de un tesoro perdido. Confines, 17, 6572 .

Kaufman, Alejandro (2010). Memoria, identidad y representación. Elementos para el análisis cultural del pasado argentino reciente, en: La historia reciente como desafio a la investigación y pensamiento en Ciencias Sociales, curso CAICYT CONICET (http://ecursos.caicyt.gov.ar), Argentina.

Kohn, Laura (1999). Historia de Política Obrera, artículo presentado a la cátedra de "Historia del Periodismo y las Comunicaciones en Argentina" de la Facultad de Periodismo y Comunicación Social de la Universidad Nacional de La Plata. Disponible en: http://es.scribd.com/doc/239328420/Historia-de-Politica-Obrera\#scribd

Kowaric, L. (1991). Ciudad y ciudadanía. Nueva Sociedad, 141.

Lanusse, Lucas (2007a). Montoneros. El mito de sus 12 fundadores. Buenos Aires: Vergara.

Lanusse, Lucas (2007b). Cristo Revolucionario. La Iglesia militante. Buenos Aires: Vergara.

Lasa, Claudio (1987). Un proceso de mediación política: Movimiento Rural y las Ligas Agrarias Chaqueñas. Sociedad y Religión, 7,12 pp.

Lenci, María Laura (1998). La radicalización de los católicos en la Argentina. Peronismo, Cristianismo y Revolución (1966-1971). Cuadernos del CISH, 4, 175-200.

Lenci, María Laura (2000). Católicos militantes en "la hora de la acción". Todo es Historia, 401, 62-69.

Levenson, Deborah (2007). Sindicalistas contra el terror. Ciudad de Guatemala, 19541985. Guatemala: AVANCSO.

Levi, Giovanni (1991). Sobre Microhistoria, en: Burke, Peter, Formas de hacer Historia. Madrid: Ed. Alianza.

Levín, Florencia (2010). Violencia, trauma y el fenómeno de la memoria. El pasado reciente entre la historia y la memoria, en: La historia reciente como desafío a la investigación y pensamiento en Ciencias Sociales, CAICYT CONICET (http://ecursos.caicyt.gov.ar), Argentina.

Levine, Daniel (1996). Voces populares en el catolicismo latinoamericano. Lima: CEP. Levine, Daniel (2006). Religión y política en América Latina. La nueva cara pública de la religión. Sociedad y Religión, 26/27, 7-29. 
Levine, Daniel (2011). Camilo Torres: fe, política y violencia, Sociedad y Religión, 34/35, 59-91.

Levine, Daniel (2012). Politics, Religion and Society in Latin America. Londres: Rienner.

Lois, Julio (1990). Cristología en la teología de la liberación, en: Ellacuría, Ignacio, Sobrino, Jon et al., Mysterium Liberationis. Conceptos fundamentales de la teología de la liberación. Madrid: Editorial Trotta.

López Pascual, Juliana (2009). “Trincheras” el campo cultural en Bahía Blanca entre 1963 y 1968. Tesis de licenciatura en Historia, Departamento de Humanidades, Universidad Nacional del Sur.

López Pascual, Juliana (2014). Representaciones, prácticas y tensiones en la institucionalización de las actividades culturales. Bahía Blanca, 1940-1969. Tesis de Doctorado en Historia. Departamento de Humanidades, Universidad Nacional del Sur. Löwy, Michael (1999). Guerra de dioses. Religión y Política en América Latina. México: Siglo XXI Editores.

Llull, Laura (2005). Prensa y política en Bahía Blanca: La Nueva Provincia en las presidencias radicales, 1916-1930. Bahía Blanca: Universidad Nacional del SurEdiuns.

Mallimaci, Fortunato (1988). El catolicismo integral en la Argentina. Buenos Aires: Biblos.

Mallimaci, Fortunato (1991). Movimientos laicales y sociedad en el período de entreguerras. La experiencia de la Acción Católica Argentina. Cristianismo y Sociedad, 108.

Mallimaci, Fortunato (1992). El catolicismo argentino desde el liberalismo integral a la hegemonía militar, en: AA.VV., 500 años de cristianismo en Argentina. Buenos Aires: CEHILA-Centro Nueva Tierra.

Mallimaci, Fortunato (1995). Catolicismo y militarismo en Argentina (1930-1983). De la Argentina liberal a la Argentina Católica, en: AA.VV., La Iglesia de Quilmes durante la dictadura militar, 1976-1983. Derechos Humanos y la cuestión de los desaparecidos. Universidad Nacional de Quilmes.

Mallimaci, Fortunato, Cucchetti, Humberto y Donatello, Luis (2006). Caminos sinuosos: nacionalismo y catolicismo en la Argentina Contemporánea, en: Colom, Francisco y Rivero, Ángel (edit), El altar y el trono. Ensayos sobre el catolicismo politico latinoamericano. Barcelona: ANTROPHOS/ UNIBIBLOS. 
Mallimaci, Fortunato y Donatello, Luis (2012). El catolicismo liberacionista en Argentina: 'praxis liberadora' y 'opción por os pobres'. Acción y presencia en las masas, en: Renold, Juan (comp.), Miradas antropológicas sobre la vida religiosa III. Buenos Aires: CICCUS.

Mallimaci, Fortunato y Giménez Béliveau, Verónica (2006). Historias de vida y método biográfico, en: Vasilachis de Gialdino, I. (coord.), Estrategias de Investigación cualitativa. Barcelona: Gedisa.

Marcilese, José (2006). Los antecedentes de la Universidad Nacional del Sur, en: Cernadas de Bulnes, Mabel (dir.), Universidad Nacional del Sur. 1956-2006. Bahía Blanca: Universidad Nacional del Sur.

Marcilese, José (2008). El primer peronismo en Bahía Blanca, de la génesis a la hegemonía (1943-1955). Tesis de Doctorado, Departamento de Humanidades, Universidad Nacional del Sur, Bahía Blanca.

Marcilese, José (2009). El movimiento obrero bahiense en vísperas del peronismo. Documento de Trabajo $N^{o}$, Centro de estudios para el desarrollo de políticas regionales (CEDPRE).

Markarian, Vania (2009). Una mirada desde los derechos humanos a las relaciones internacionales de la dictadura uruguaya, en: Demasi, Carlos, Marchesi, Aldo, Markarian, Vania, Rico, Álvaro y Yaffé, Jaime, La dictadura cívico-militar. Uruguay 1973-1985. Montevideo: Ediciones de la Banda Oriental.

Martín, José Pablo (2010). El Movimiento de Sacerdotes para el Tercer Mundo. Un debate argentino. Los Polvorines: Universidad Nacional de General Sarmiento.

Martín, José Pablo (2013). Ruptura ideológica del catolicismo argentino: 36 entrevistas entre 1988 y 1992. Los Polvorines: Universidad Nacional de General Sarmiento.

Maxwell, Joseph (1996). Qualitative resarch design. An interactive approach. London: Sage Publications.

Mayol, Alejandro (1970). Apuntes para la interpretación del proceso (De Trento a Cañada de Gómez), en: Mayol, Alejandro, Habegger, Norberto y Armada, Arturo, Los católicos posconciliares en la Argentina. Buenos Aires: Editorial Galerna.

Mignone, Emilio (1998). Política y Universidad. El estado legislador. Buenos Aires: Lugar editorial.

Mignone, Emilio (2006). Iglesia y dictadura. El papel de la Iglesia a la luz de sus relaciones con el régimen militar. Buenos Aires: Colihue. 
Miravalles, Ana (2013). Los Talleres invisibles. Una historia de los Talleres ferroviarios Bahía Blanca Noroeste. Bahía Blanca: FerroWhite.

Montserrat, Carina (2013). La iglesia metodista y la defensa de los derechos humanos en Bahía Blanca (1974-1983), en: Hernández, Graciela (comp.), Lo dicho y los hechos. Investigación y debates de historia oral y etnografía en Bahía Blanca y la región del suroeste bonaerense. Bahía Blanca: Libros en Colectivo.

Montero, Carolina (2009). Gigantes de hormigón. La plaza de los lápices: espacio público y memoria de la última dictadura. Bahía Blanca 1993-2007”. En: $1^{\circ}$ Seminario Internacional sobre Arte Público en Latinoamérica, Buenos Aires.

Montero, Lorena (2006). Memorias del golpe en La Nueva Provincia, en: Cernadas, Mabel y Marcilese, José (ed.), Cuestiones politicas, socio-culturales y económicas del Sudoeste Bonaerense. Bahía Blanca: Archivo de la memoria, UNS.

Montero, Lorena (2010). Prensa y dictadura: La Nueva Provincia frente a la persecución ideológica en la Universidad Nacional del Sur, en: IX Jornadas Nacionales- VI Latinoamericanas "El pensar y el hacer en nuestra América, a doscientos años de las guerras de la independencia”, Bahía Blanca.

Montero, Lorena (2014). La construcción de sentidos sobre "guerra" y "subversión" a escala local. La prensa bahiense y la corporación militar en la definición de un “enemigo" común, en: VI Jornadas de Historia de la Patagonia, Cipolletti.

Montero García, Feliciano (2006). La Iglesia y el catolicismo en el final del franquismo. El "despegue" de la Iglesia en la pretransición. 1960-1975, en: Mateos López, Abdón y Herrerín López, Ángel (coord.), La España del presente: de la dictadura a la democracia. España: Asociación Historiadores del Presente.

Morello, Gustavo (2003). Cristianismo y Revolución: los orígenes intelectuales de la guerrilla argentina. Córdoba: Universidad Católica de Córdoba.

Morello, Gustavo (2007). El Concilio Vaticano II y la radicalización de los católicos, en: Lida, Clara, Crespo, Horacio y Yankelevich, Pablo (comps.), Argentina, 1976. Estudios en torno al golpe de Estado. Buenos Aires: Fondo de Cultura Económica, El Colegio de México.

Morello, Gustavo (2011). Víctimas y victimarios. Catolicismo argentino en los Setenta, en: XVI Jornadas sobre Alternativas religiosas en América Latina, Punta del este.

Mounier, Emmanuel (1956). Qué es el personalismo. Buenos Aires: Ediciones Criterio. Mounier, Emmanuel (1962). El personalismo. Buenos Aires: Eudeba. 
Moyano, Mercedes (1992). La década del '60. Organización popular y conciencia cristiana, en: AA.VV., 500 años de cristianismo en Argentina. Buenos Aires: CEHILACentro Nueva Tierra.

Mugica, G. (1985). Trayectoria de la teología de la liberación (1970-1985). Iglesia Viva, 116/117, 144-148.

Nievas, Flavián (1999). Cámpora: primavera - otoño. Las tomas, en: Pucciarelli, Alfredo, La Primacía de la Política. Lanusse, Perón y la Nueva Izquierda en tiempos del GAN. Buenos Aires: EUDEBA.

O'Donnell, Guillermo (1982). El Estado burocrático autoritario. Triunfos, derrotas y crisis. Buenos Aires: Editorial de Belgrano.

Oberlin Molina, Matías (s/f). Acción Sindical Argentina. El sindicalismo cristiano y su relación con la formación de la guerrilla urbana (1955-1976), disponible en: https://es.scribd.com/

Oliveros, Roberto (1990). Historia de la teología de la liberación, en: Ellacuría, Ignacio, Sobrino, Jon et al., Mysterium Liberationis. Conceptos fundamentales de la teología de la liberación. Madrid: Editorial Trotta.

Orbe, Patricia (2006). El surgimiento y la consolidación de una Universidad nueva, en: Cernadas de Bulnes, Mabel (dir.), Universidad Nacional del Sur. 1956-2006. Bahía Blanca: Universidad Nacional del Sur.

Orbe, Patricia (2007). La política y lo político en torno a la comunidad universitaria bahiense (1955-1976). Estudio de grupos, ideologías y producción de discursos. Tesis doctoral, Universidad Nacional del Sur, Bahía Blanca.

Partnoy, Alicia (2006). La Escuelita: relatos testimoniales. Buenos Aires: La Bohemia. Pittaluga, Roberto (2006). La memoria según Trelew. Sociohistórica, 19/20, 81-111.

Pittaluga, Roberto (2010). Notas sobre la historia del pasado reciente, en: Cernadas, Jorge y Lvovich, Daniel (eds.), Historia, ¿para qué? Revisitas a una vieja pregunta. Buenos Aires, Prometeo.

Politi, Sebastián (1992). Teología del Pueblo. Una propuesta argentina a la teología latinoamericana. 1967-1975. Buenos Aires, San Antonio de Padua: Editorial Guadalupe/ Ediciones Castañeda.

Pontoriero, Gustavo (1991). Sacerdotes para el tercer mundo. El fermento en la masa. Buenos Aires: CEAL.

Portantiero, Juan Carlos (1977). Economía y política en la crisis argentina: 1958-1973. Revista mexicana de sociología, 2, 531-565. 
Pozzi, Pablo (2006). Para continuar con la polémica sobre la lucha armada. Lucha Armada en la Argentina, 5, 44-53.

Pujol, Sergio (2003). Rebeldes y modernos. Una cultura de los jóvenes, en: James, Daniel (comp.), Violencia, proscripción y autoritarismo (1955-1976), Nueva Historia Argentina, Tomo 9. Buenos Aires: Editorial Sudamericana.

Pupio, Alejandra y Dominella, Virginia (2013). La recuperación arqueológica del CCD La Escuelita. Articulación entre la investigación y el peritaje judicial, en: Resúmenes de las V Jornadas de Investigación en Humanidades, Bahía Blanca.

Raimundo, Marcelo (2004). Izquierda peronista, clase obrera y violencia armada: una experiencia alternativa. Sociohistórica, 15-16, 99-128.

Randazzo, Federico (2007). Las grietas del relato histórico. Apuntes sobre los orígenes del anarquismo en Bahía Blanca y la matanza de obreros en Ingeniero White en 1907. Buenos Aires: Ediciones CCC del Instituto Movilizador de Fondos Cooperativos.

Ribas, Diana Itatí (2008). Del fuerte a la ciudad moderna: imagen y autoimagen de Bahía Blanca. Tesis de doctorado en Historia. Departamento de Humanidades, Universidad Nacional del Sur.

Richard, Pablo (1990). Teología en la teología de la liberación, en: Ellacuría, Ignacio, Sobrino, Jon et al., Mysterium Liberationis. Conceptos fundamentales de la teología de la liberación. Madrid: Editorial Trotta.

Rico, Álvaro (2009). Sobre el autoritarismo y el golpe de Estado. La dictadura y el dictador, en: Demasi, Carlos, Marchesi, Aldo, Markarian, Vania, Rico, Álvaro y Yaffé, Jaime, La dictadura cívico-militar. Uruguay 1973-1985. Montevideo: Ediciones de la Banda Oriental.

Ridenti, Marcelo (2002). Ação Popular: cristianismo e marxismo, en: Reis Filho, Daniel e Ridenti, Marcelo (orgs.), História do marxismo no Brasil, 5. Partidos e organizaçaoes dos anos 20 aos 60. Campinas: ed. da UNICAMP.

Robles, Horacio (2012). "Los fortines montoneros": aproximación a la conformación y localización de las unidades básicas montoneras en la ciudad de La Plata (1972/74), en: Actas de las VII Jornadas de Sociología de la UNLP, La Plata. Disponible en: http://jornadassociologia.fahce.unlp.edu.ar

Roze, Jorge Próspero (2011). Conflictos agrarios en la Argentina. El proceso liguista (1970-1976). Buenos Aires: Ediciones R y R.

Salcedo, Javier (2011). Los Montoneros del barrio. Caseros: Editorial de la Universidad Nacional de Tres de Febrero. 
Scannone, Juan Carlos (1987). La teología de la liberación. Caracterización, corrientes, etapas, en: Teología de la liberación y Doctrina social de la Iglesia. Madrid-Buenos Aires: Ediciones Cristiandad-Editorial Guadalupe.

Segundo, Juan Luis (1990a). Libertad y liberación, en: Ellacuría, Ignacio, Sobrino, Jon et al., Mysterium Liberationis. Conceptos fundamentales de la teología de la liberación. Madrid: Editorial Trotta.

Segundo, Juan Luis (1990b). Revelación, fe, signo de los tiempos, en: Ellacuría, Ignacio, Sobrino, Jon et al., Mysterium Liberationis. Conceptos fundamentales de la teología de la liberación. Madrid: Editorial Trotta.

Seitz, Ana Inés (2010). Dictadura, sociedad y espacio escolar en Bahía Blanca. El caso de los estudiantes de la ENET. Tesis de Licenciatura en Historia, Universidad Nacional del Sur, Bahía Blanca.

Seitz, Ana Inés (2011). Repensando los trabajos de la memoria sobre la última dictadura militar en una escala local. El 'caso de los chicos de la ENET', en: I Jornadas de Investigadores en Formación: "Reflexiones en torno al proceso de investigación", Ciudad Autónoma de Buenos Aires.

Seitz, Ana Inés (2013). Actitudes y comportamientos sociales en regímenes dictatoriales. Aportes para una reflexión metodológica, en: V Jornadas de Investigación en Humanidades, Bahía Blanca.

Seitz, Ana Inés (2014). Juventud y participación política. Una exploración de los "modos de ser joven" en los '70 a partir de un estudio de caso, en: XI Encuentro Nacional y $V$ Congreso Internacional de Historia Oral de la República Argentina. AHORA, Córdoba.

Seoane, María (1993). Todo o nada. Buenos Aires: Planeta.

Serna, Justo y Pons, Anaclet (2001). En su lugar. Una reflexión sobre la historia local y el microanálisis, en: C. Frías y M.A. Carnicer (eds.), Nuevas tendencias historiográficas e historia local en España. Huesca: IEA-Universidad de Zaragoza.

Sidicaro, Ricardo (1993). La política mirada desde arriba: las ideas del diario La Nación. 1909-1989. Buenos Aires: Sudamericana.

Sigal, Silvia (2002). Intelectuales y poder en Argentina. La década del sesenta. Buenos Aires: Siglo Veintiuno de Argentina Editores.

Silva, Hernán (1987). El transporte cerealero en la región de Bahía Blanca: auge y decadencia del monopolio ferroviario. Buenos Aires: Academia Nacional de la Historia. 
Sobrino, Jon (1990). Cristología sistemática. Jesucristo, el mediador absoluto del Reino de Dios, en: Ellacuría, Ignacio, Sobrino, Jon et al., Mysterium Liberationis. Conceptos fundamentales de la teología de la liberación. Madrid: Editorial Trotta.

Soneira, Abelardo (1989a). Las estrategias institucionales de la Iglesia Católica (18801976). Buenos Aires: CEAL.

Soneira, Abelardo (1989b). La Juventud Obrera Católica en la Argentina: de la secularización a la justicia social, Justicia Social, 8, 76-88.

Soneira, Abelardo (2002). La Juventud Obrera Católica en la Argentina (y notas comparativas con su desarrollo en Brasil y México), en: Puente Lutteroth, María Alicia Innovaciones y tensiones en los procesos socio-eclesiales. De la Acción Católica a las Comunidades Eclesiales de Base. México: Universidad Autónoma del Estado de Morelos.

Soneira, Abelardo (2008). Trayectorias creyentes/trayectorias sociales, en: Zalpa, Genaro y Offerdal, Hans Egil (comps.), ¿El reino de Dios es de este mundo?: el papel ambiguo de las religiones en la lucha contra la pobreza. Bogotá: Siglo del Hombre Editores-CLACSO.

Suasnábar, Claudio (2004). Universidad e intelectuales. Educación y política en Argentina (1955-1976). Buenos Aires: FLACSO Manantial.

Svampa, Maristella (2003). El populismo imposible y sus actores, 1973-1976, en: James, Daniel (comp.), Violencia, proscripción y autoritarismo (1955-1976), Nueva Historia Argentina, Tomo 9. Buenos Aires: Editorial Sudamericana.

Tamayo Acosta, Juan José (1989). Para comprender la teología de la liberación. Navarra: Editorial Verbo Divino.

Terán, Oscar (1991). Nuestros años sesentas. La formación de la nueva izquierda intelectual en la Argentina 1956-1966. Buenos Aires: Puntosur editores.

Terán, Oscar (2006). La década del 70: la violencia de las ideas. Lucha Armada en la Argentina, 5, 20-28.

Torre, Juan Carlos (dir.) (2002). Los años peronistas (1943-1955). Nueva Historia Argentina. Tomo 8. Buenos Aires: Sudamericana.

Tortti, María Cristina (1999a). Protesta social y nueva izquierda en la Argentina del Gran Acuerdo Nacional, en: Pucciarelli, Alfredo (editor), La primacía de la política. Lanusse, Perón y la Nueva Izquierda en tiempos del GAN. Buenos Aires: EUDEBA.

Tortti, María Cristina (1999b). Izquierda y "Nueva Izquierda" en la Argentina. El caso del Partido Comunista. Cuadernos del CISH, 6, 221-232. 
Tortti, María Cristina (2002). Debates y rupturas en los partidos Comunista y Socialista durante el frondizismo. Primas, 6, 265-274.

Touris, Claudia (2005). Neointegralismo, denuncia profética y revolución en la trayectoria del Movimiento de Sacerdotes para el Tercer Mundo. Prismas, Revista de historia intelectual, 9, 229-239.

Touris, Claudia (2008). Sociabilidad e identidad político-religiosa de los grupos católicos tercermundistas en la Argentina (1966-1976), en: Moreyra, Beatriz y Mallo, Silvia (edit.), Miradas sobre la historia social argentina en los comienzos del siglo XXI. Centro de Estudios Históricos "Prof. Carlos Segreti”. Córdoba-La Plata: CEHAC, FaHCE-UNLP.

Touris, Claudia (2011). Integrismos y profecía utópica en los imaginarios católicos de los años setenta, en: Ceva, Mariela y Touris, Claudia (coords.), Nuevos aportes a los estudios de la religión en las sociedades contemporáneas del Cono Sur. Buenos Aires: Lumiere.

Touris, Claudia (2012a). Catolicismo y cultura política en la Argentina. La constelación tercermundista (1955-1976), Tesis de doctorado en Historia, Universidad de Buenos Aires, Buenos Aires.

Touris, Claudia (2012b). Profecía, Política y clericalismo popular en el Movimiento de Sacerdotes para el Tercer Mundo (MSTM): 1967-1973. PROHAL MONOGRÁFICO, Revista del Programa de Historia de América Latina, Vol. 3, Primera Sección: Vitral Monográfico, 3, 251- 283.

Trincheri, Alcira (2003). Las tinieblas en la Universidad: el "adelantado proceso" en el Comahue, en: Kaufmann, Carolina (dir.), Dictadura y Educación. Depuraciones y vigilancia en las universidades nacionales argentinas. Buenos Aires: Miño y Dávila editores.

Vanzini, Marcos (2008). La violencia irracional y la palabra lúcida, en: AA.VV. Homenaje a Benito Ángel Santecchia. Testimonios, crónicas, documentos, escritos, estudios. Bahía Blanca-Buenos Aires: Instituto Superior Juan XXIII, Proyecto, Centro de estudios salesianos.

Vasilachis de Gialdino, Irene (coord.) (2006). Estrategias de investigación cualitativa. Barcelona: Gedisa.

Verbitsky, Horacio (2009). Vigilia de armas. Historia política de la Iglesia Católica. Tomo III: Del Cordobazo de 1969 al 23 de marzo de 1976. Buenos Aires: Sudamericana. 
Vezzetti, Hugo (2009). Sobre la violencia revolucionaria. Memorias y olvidos. Buenos Aires: Siglo Veintiuno Editores.

Vidal, Ana (2010). Arte y memoria colectiva. Representaciones de la militancia política y la represión de la década del '70 en Bahía Blanca (Argentina), 1995- 2009. Revista Antiteses, 5. Disponible en: http://www.uel.br/revistas.

Vidal, Ana (2013a). Bahía Blanca, teatro y dictadura. Afuera. Estudios de crítica cultural, 13, pp. 1-19.

Vidal, Ana (2013b). Los artistas y las organizaciones políticas revolucionarias: la articulación entre las agrupaciones de teatro, el Partido Comunista Revolucionario y la Juventud Peronista (1972-1979), en: Actas de las VI Jornadas de Trabajo sobre Historia Reciente / Marina Franco et al., coordinado por Luciano Alonso y otros. Santa Fe: Ediciones UNL. E-Book. Disponible en: http://www.riehr.com.ar/archivos/Investigacion/JTHR2012Eje6.pdf. ISBN 978-987657-842-4.

Vidal, Ana (2013c). Teatro y radicalización: Bahía Blanca en los primeros años de la década del setenta, en: Jornadas AINCRIT, Buenos Aires, mayo (en prensa).

Vidal, Ana (2013d). Imágenes inquietas. Arte, política y memoria en Bahía Blanca, en: Ribas, Diana (coord.), Los Límites de las imágenes. Bahía Blanca: 17 Grises.

Vidal, Ana (2014a). El teatro militante en Bahía Blanca, la agrupación Alianza: experiencias, memorias, reverberaciones: ganador del $1^{\circ}$ Concurso AINCRIT Historia Oral del teatro en Argentina. DVD Audiolibro. Buenos Aires: AINCRIT Ediciones.

Vidal, Ana (2014b). Arte, violencia y política en la Cantata Santa María de Iquique. Grupo de Teatro Popular Eva Perón, Bahía Blanca, septiembre de 1973, en: Zubieta, Ana María (comp.), Mapas de la violencia. Filosofía, teoría literaria, arte y literatura. Bahía Blanca: Ediuns.

Vilanova, Mercedes (1998). La historia presente y la historia oral. Relaciones, balance y perspectivas. Cuadernos de historia contemporánea, 20.

Visotsky, Jessica y Gattari, Verónica (2004). Rescate de un olvido, treinta años después...Luchas por la hegemonía, luchas por la pedagogía, en: 3ras. Jornadas de Innovación Pedagógica en el Aula Universitaria, Bahía Blanca, Departamento de Humanidades, Universidad Nacional del Sur.

Weber, Max (1967). The Protestant ethic and the spirit of Capitalism. Londres: Unwin. Weinberg, Félix (1988). Historia del Sudoeste bonaerense. Buenos Aires: Plus Ultra. 
Weinberg, Félix (1978). Manual de Historia de Bahía Blanca. Bahía Blanca: Universidad nacional del Sur.

Zanatta, Loris (1996). Del Estado liberal a la Nación Católica. Iglesia y ejército en los orígenes del peronismo. 1930-1943. Buenos Aires: Universidad Nacional de Quilmes.

Zanatta, Loris (1999). Perón y el mito de la nación católica. Iglesia y ejército en los orígenes del peronismo (1943-1946). Buenos Aires: Sudamericana.

Zanatta, Loris (2008). El precio de la nación católica. El Vaticano y el golpe de Estado de 1976. Puentes, 23, 83-98.

Zanetto, Rocío (2014). El proceso de normalización universitaria en el Departamento de Humanidades de la Universidad Nacional del Sur (1983-1986). Cuadernos del Sur.

Zapata, Ana Belén (2008). Páginas Manchadas. Conflictividad laboral entre los gráficos y La Nueva Provincia en vísperas de la dictadura de 1976. Tesis de Licenciatura en Historia, Universidad Nacional del Sur, Bahía Blanca.

Zapata, Ana Belén (2012). Violencia parapolicial en Bahía Blanca, 1974-1976. Delgados límites entre lo institucional y lo ilegal en la lucha contra la "subversión apátrida". Anos 90, 19, 108 - 136.

Zapata, Ana Belén (2014a). Andamios de experiencias: Conflictividad obrera, vigilancia y represión en Argentina. Bahía Blanca, 1966-1976. Tesis de Doctorado en Historia, Universidad Nacional de La Plata, La Plata.

Zapata, Ana Belén (2014b). 'Como el herrero que machaca sobre el yunque hasta moldear la forma ideal' La Nueva Provincia y su construcción del llamado "delincuente subversivo" (1975-1977). ReHiMe - Red de Historia de los Medios, 144 - 169. 